\title{
Rodrigo Archangelo
}

\section{UM BANDEIRANTE NAS TELAS DE SÃO PAULO O DISCURSO ADHEMARISTA EM CINEJORNAIS}

(1947 - 1956)

Dissertação apresentada ao Depto. de História da Faculdade de Filosofia, Letras e Ciências Humanas da Universidade de São Paulo, para obtenção do título de Mestre em História.

Área de concentração: História Social

Orientadora: Profa. Dra. Maria Luiza Tucci Carneiro

São Paulo 


\section{Rodrigo Archangelo}

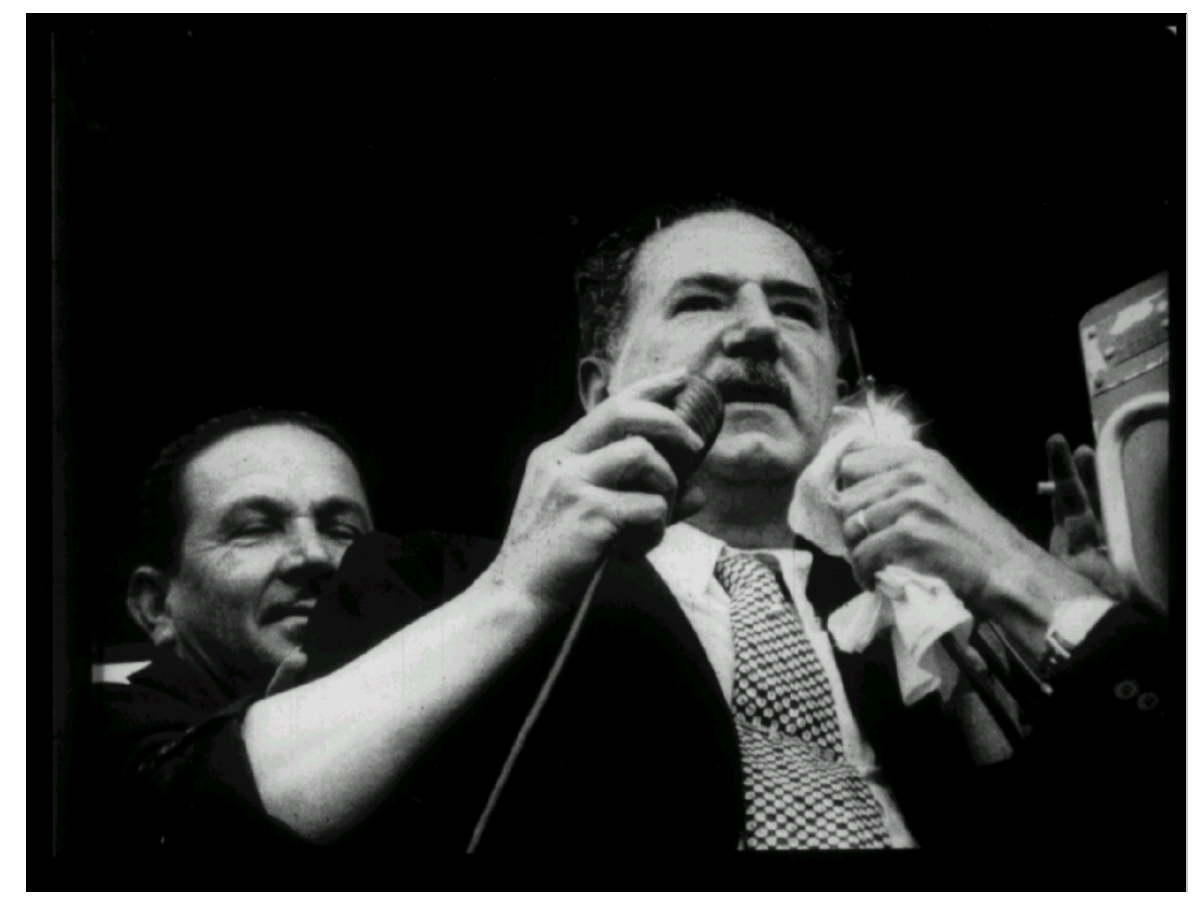

\section{UM BANDEIRANTE NAS TELAS DE SÃO PAULO O DISCURSO ADHEMARISTA EM CINEJORNAIS}

(1947 - 1956)

Dissertação apresentada ao Depto. de História da Faculdade de Filosofia, Letras e Ciências Humanas da Universidade de São Paulo, para obtenção do título de Mestre em História.

Área de concentração: História Social Orientadora: Profa. Dra. Maria Luiza Tucci Carneiro 


\section{RESUMO}

A democratização da participação política a partir de 1946 caminhou por estratégias que visaram, sobretudo, um maior alcance da mensagem ao eleitorado. Dentre elas, tomamos como exemplo a visualidade das campanhas políticas de Adhemar de Barros em São Paulo, trabalhadas no formato de um veículo inspirado e testado numa experiência ditatorial (então recente) e capaz de "dar vida" ao seu o discurso: o cinejornal. Neste caso, o cinejornal Bandeirante da Tela, da Divulgação Cinematográfica Bandeirante. Seu conteúdo propagandístico - apresentado em meios a notícias de "atualidades" - carrega signos e valores latentes na sociedade em questão. E nos possibilita investir, analisando a representação adhemarista pela linguagem cinematográfica, na releitura de um momento político ainda pouco visitado pelo viés da História Cultural. Neste caso, por uma História Cultural da Política.

Palavras-chave: cinema; política; cinejornal; populismo; adhemarismo; bandeirantismo. 


\begin{abstract}
Since 1946 the democratization of political participation has aimed reaching the electors in a wider way. As an example of this we have studied the visibility of the political campaigns of Adhemar Barros in São Paulo. The media vehicle was inspired and tested in a dictatorial context (that was recent at the time) and it gave life to his speech: the newsreel. In this case it was the newsreel Bandeirante da Tela of the Divulgação Cinematográfica Bandeirante. Its propaganda content - which was presented as news - bears signs and latent values of the society in question. This makes it is possible for us to study and read again, analyzing the "adhemarista" representation through the cinematographic language, a political moment still unknown to the Cultural History. In this case a Cultural History of the Politics.
\end{abstract}

Keywords: cinema; politic; newsreel; populism ; adhemarismo; bandeirantismo. 


\section{SUMÁRIO}

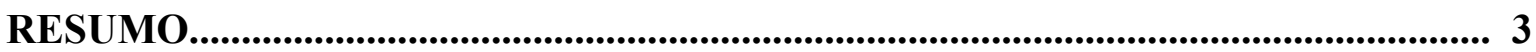

ABSTRACT ...................................................................................................................... 4

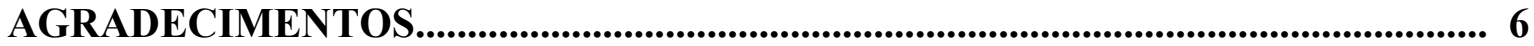

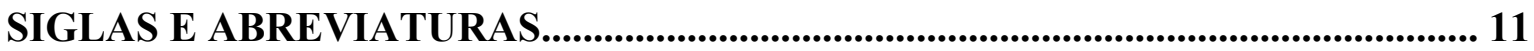

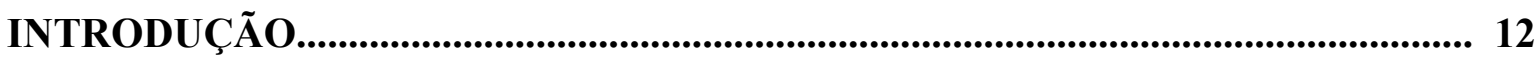

I - A POLÍTICA EM CINEJORNAIS............................................................................ 24

1.1 - Imagem, política e uma História Cultural da Política................................................. 24

1.2 - A imagem em cinejornais e a busca em outros suportes............................................ 33

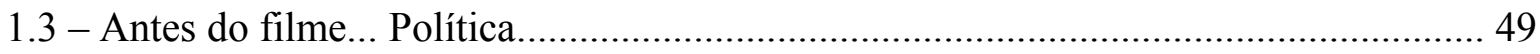

II - EM CENA, A POLÍTICA QUE ENCENA............................................................ 55

2.1 - $\mathrm{O}$ cinejornalismo na cinematografia nacional....................................................... 55

2.2 - O cinejornal: entre críticas e tensões no campo cinematográfico................................. 66

2.3 - Adhemarismo: uma força em marcha?...................................................................... 77

III - O ADHEMARISMO EM “QUADROS",................................................................. 93

3.1 - Construindo realidades, fortalecendo o mito........................................................... 95

3.2 - Um interlocutor para vários desejos: o "Bandeirante" na tela.....................................165

CONSIDERAÇÕES FINAIS............................................................................................. 175

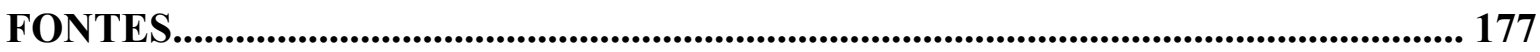

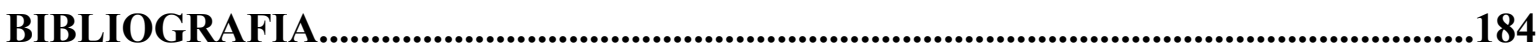

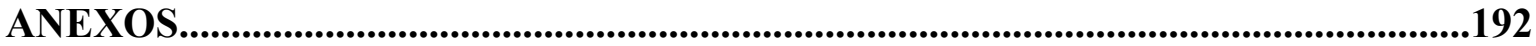




\section{AGRADECIMENTOS}

Talvez o resultado dessa pesquisa não reflita o tamanho esforço desprendido por este que escreve, assim como por aqueles que contribuíram em diferentes etapas. Tirante o eventual sucesso e as lacunas (certamente as temos), quando uma caminhada termina e o trabalho é entregue à prestação de contas perante uma banca acadêmica, agradecer é mais do que cumprir um protocolo. É quase um desabafo, poder dizer daquelas pessoas seriamente compromissadas com o trabalho e em ajudar quem trabalha.

Primeiramente agradeço a toda minha família, especialmente minha mãe, dona Lúcia, e os meus irmãos Márcio (e esposa) e Renato. Mais do que ninguém, essas pessoas acompanharam com uma compreensão incomum o dia-a-dia quase insano de alguém que tenta, com o que pode, conciliar o mundo acadêmico das pesquisas em arquivos e investidas teórico-metodológicas com o ofício do professorado na rede pública estadual de ensino. Devo aos meus familiares, sobretudo, a vontade de seguir em frente. Transitar por estas realidades incrivelmente (e infelizmente) distantes me fez perceber o quanto ainda há por caminhar no sentido de aproximá-las. E que este trabalho, quem sabe, contribua para a construção de um olhar crítico do cidadão comum - um aluno meu, por exemplo - sobre a retórica política em imagens e os seus efeitos na sociedade.

Agradeço a grande aceitação da professora Maria Luiza Tucci Carneiro, com quem compartilho desde 2001 os enfrentamentos da minha inserção no mundo acadêmico. Ser seu orientando é muito mais que corrigir textos lidos, cumprir tarefas ou coisas do tipo. É ser convidado a participar efetivamente de um grupo, e com ele enfrentar desafios que envolvem os ofícios da História, tanto na prática como na teoria. Falo especificamente do PROIN - Projeto Integrado Arquivo-Universidade, que há mais de dez anos vem promovendo discussões e realizando pesquisas em parceria com Arquivo Estado de São Paulo (AESP) sobre os prontuários da polícia do Departamento Estadual de Ordem Política e Social de SP (DEOPS/SP). Meu aprendizado no trato com as fontes, sejam textuais, iconográficas ou audiovisuais obtidos desde a minha Iniciação Científica ${ }^{2}$; a paciência na

${ }^{1}$ Com a orientação da professora Dra. Maria Luiza Tucci Carneiro que, com o professor Dr. Boris Kossoy, são idealizadores e coordenadores do PROIN desde o seu início, há mais de dez anos.

${ }^{2}$ Rodrigo Archangelo, As Luzes Dentro e Fora das Fábricas: aspectos do cotidiano urbano em São Paulo (1937-1945). 2003. Iniciação Científica. Faculdade de Filosofia, Letras e Ciências Humanas da Universidade 
organização e no arranjo das evidências, bem como a busca pelas conexões possíveis e plausíveis das informações obtidas; e, o mais importante, o "respeito ao documento" e para com aquilo e aqueles que dele emergem mediante a investigação histórica foram aprendidos nesta vivência junto ao PROIN. Obrigado a todos os colegas desta "família". Também não poderia esquecer a maneira com que a professora aceitou o desafio - que foi para ambos - de orientar um trabalho com imagens em movimento, algo inédito em seu grupo de pesquisa. Assim como também agradeço a paciência e a "paz de espírito" nos momentos difíceis em relação aos prazos com que me debati, para que assim pudesse colocar com certa calma as idéias no papel. Nesse sentido, compartilho nossos acertos e reconheço os meus erros, muitos poderiam ser evitados se cumprisse com mais afinco a minha parte nos prazos. Obrigado, professora.

Ao professor Boris Kossoy, o agradecimento daquele que aprendeu com suas aulas no curso de 2005 (turma inesquecível!); com as conversas e a argüição na minha qualificação sobre o maior rigor e organização das questões teóricas; assim como acurar o olhar para as diferentes realidades presentes no documento com imagens em movimento. Obrigado, professor, pela amizade e a receptividade com que me recebeu.

Da mesma forma, agradeço ao professor Eduardo Morettin pela oportunidade de têlo em minha qualificação. A maneira respeitosa com que procedeu em suas análises e avaliações; o convite para participar de congressos, mesas e grupos de discussões; e a compreensão e disposição diante das minhas necessidades, sobretudo acerca da relação entre Cinema e História me revelaram o caráter e o tamanho respeito com que procedeu diante das minhas carências. Pude vencer algumas, outras redimensionar para um embate futuro. Obrigado, sobretudo, por entendê-las.

Aos professores Maria Aparecida Aquino e Marcos A. Silva, meus agradecimentos. À professora pelos esclarecimentos, em seu curso, sobre as questões mais recentes acerca de um fenômeno controverso na historiografia política brasileira: o populismo. Ao professor por me auxiliar, também no seu curso, em questões acerca da retórica da imagem. Da mesma forma, não poderia deixar de agradecer aos professores Marcos Napolitano pelas intervenções na exposição do meu trabalho e Carlos Eduardo J. Machado pela gentileza em

de São Paulo. Parte desse trabalho resultou no texto ainda inédito "Um bonde chamado utopia" In A Utopia da Metrópole. São Paulo: Editora Lazurri, 2007, no prelo. 
me ceder um texto, ainda inédito no Brasil, sobre cinejornais. Contribuição esta sentida nas várias linhas que seguem.

A José Inácio de Melo Souza agradeço por ter me atendido nas dúvidas iniciais deste trabalho e esclarecido, com seus escritos e em conversas pessoais, quanto às dificuldades inerentes em lidar com cinejornais. E ao professor Máximo Barro por ter me atendido gentilmente em seu local de trabalho e ter confessado, em entrevista, detalhes do cinema paulista dos anos de 1950.

Quanto a Cinemateca Brasileira, a pausa para agradecimento será prolongada... O que está escrito nas páginas deste trabalho simplesmente não existiria sem ela. Nesta casa, que me acolheu de forma tão incomum em 2001, estão pessoas com as quais contraí uma dívida de gratidão cujo débito reconheço com enorme prazer. No setor da Documentação, a minha porta de entrada, conheci amigos. E ali Olga Futemma foi, sem dúvida, quem me deu acesso ao restante da Cinemateca. Desde o início, sua amizade nunca faltou, tendo sido uma das primeiras pessoas a acreditar e incentivar a pesquisa com cinejornais. Indicou caminhos e pessoas dentro da Cinemateca para "cercar" o material; agilizou acessos ao artefato fílmico e contatos com outros setores; e soube compreender, como ninguém, as agruras diárias que envolvem o cotidiano de quem pesquisa, leciona e estuda em pontos distintos e distantes da grande São Paulo. Olga, só tenho a agradecer. Ainda entre amigos, Francisco Mattos (Catalogação), sempre cordial, me ajudou a tatear o que havia disponível para consulta imediata do material, inclusive telecinando o que fosse possível. Também nessa investida inicial, foi Carlos Roberto de Souza (Sibia - Sistema Brasileiro de Informações Audiovisuais) quem me explicou detalhes importantes quanto ao histórico do material depositado na própria Cinemateca. Por tudo isso, agradeço a ambos. Fernanda Coelho (Preservação), Ana Viegas e Fernando Fortes (Laboratório Fotográfico) demonstraram uma paciência incrível ao separar os rolos de filmes, dispor de uma mesa enroladeira e digitalizar os fotogramas selecionados para compor este trabalho. Igualmente, Vivian e Kátia (Pesquisa de Imagens) e o pessoal do Laboratório de Vídeo, sempre dispostos a me atender, principalmente às vésperas de alguma apresentação ou aula, em que as imagens eram imprescindíveis. Fernanda, Ana, Fernando, Vivian, Kátia e a equipe do Laboratório de Vídeo, muito obrigado a todos. 
Voltando à Documentação, agradeço a oportunidade do convívio com todos os colegas que "habitam" aquele espaço. Seria injusto, contudo, não mencionar Anna Paula Nunes. Uma amiga sempre presente e predisposta a ajudar no que fosse preciso. E para além da ajuda nas referencias de livros ou informações de acervos e documentação, esteve disposta a conversar, ouvir lamúrias e reclamações. Obrigado Anna Paula. Também não poderia esquecer os amigos que participam das reuniões de estudo na Cinemateca, e com quem pude trocar idéias, refletir, conhecer dimensões e dilemas teóricos da imagem, principalmente o cinema e a fotografia. Pedro, Marina, Fábio e os demais, o nosso grupo continuará!

Não poderia deixar de registrar, ainda que em poucas linhas, a contribuição de dois grandes amigos. Um deles conhecido de longa data e presente em esquinas importantes, nunca faltando quando solicitado. Seja para opinar determinado aspecto do tema da pesquisa, reler o texto, dar uns "toques" acerca das recentes discussões sobre o cinema em suas várias vertentes, ou mesmo ouvir desabafos. Obrigado meu caro Adilson Inácio Mendes, agora é daqui para frente.

Da mesma forma, alguém que aprendi a respeitar pela sua aversão ao "menor esforço". Entre os colegas e amigos pesquisadores, Marcelo Augusto Morais Gomes é o exemplo mais próximo de dedicação e seriedade, desde os tempos da nossa graduação no departamento de História da FFLCH. Mais que revisões e leituras preliminares desta pesquisa - que me foram de extrema valia, nunca vou esquecer - nossas conversas foram, e continuam sendo, indispensáveis. Continuemos, meu caro, e muito obrigado até aqui.

Agradeço também ao Arquivo Público do Estado de São Paulo e todo o seu setor de atendimento, na figura de Lauro Ávila, por entender o drama de uma "reta final", garantindo fácil acesso aos fundos DEOPS/SP e Adhemar de Barros. Também ao Instituto de Estudos Brasileiros, o IEB, pela gentileza em permitir a reprodução digital de algumas obras ali existentes. Assim como o Arquivo Nacional, no Rio de Janeiro, pela liberação de alguns números do Cine Jornal Informativo da Agência Nacional.

Esta pesquisa contou com apoio parcial do Programa Bolsa Mestrado, patrocinado pela Secretaria de Educação do Estado de São Paulo. 
Para

Pasqual Archangelo, Osvaldo Archangelo e Mário Archangelo

(belos exemplos)

e para

Maria Eduarda

(que inaugurou, com muita alegria, uma nova edição na família). 


\section{SIGLAS E ABREVIATURAS}

APESP

AIB

AN

BT

CB

CCB

CJB

CJI

DCB

DEIP

DEOPS/APESP

DIP

FAB/AEPSP

PCB

PSD

PRP

PSP

PTB

SDC

UDN
Arquivo Público do Estado de São Paulo Ação Integralista Brasileira Agência Nacional Bandeirante da Tela Cinemateca Brasileira Censo Cinematográfico Brasileiro Cine Jornal Brasileiro Cine Jornal Informativo Divulgação Cinematográfica Bandeirante Departamento Estadual de Imprensa e Propaganda Departamento Estadual de Ordem Política e Social de SP

Departamento de Imprensa e Propaganda Fundo Adhemar de Barros/Arquivo Público do Estado de SP Partido Comunista Brasileiro, fundado em 1922 Partido Social Democrático, fundado em 1945 Partido Republicano Paulista, fundado em 1873 Partido Social Progressista, fundado em 1946 Partido Trabalhista Brasileiro, fundado em 1945 Serviço de Divulgação Cinematográfica União Democrática Nacional, fundada em 1945 


\section{INTRODUÇÃO}

$\mathrm{Na}$ complexa senda da construção de um discurso político, conselho valioso é aquele em que "o novo não está no que é dito, mas no acontecimento em sua volta" ${ }^{3}$. Nesse sentido, para se pensar a falência de uma política populista ocorrida num intervalo democrático entre duas experiências ditatoriais na República; ou a aposta desenvolvimentista que permeou projetos durante essas quase três décadas de democracia; ou ainda a sempre presente proposta de um Estado autoritário, sustentado por um discurso legitimador da "ordem"; é necessário um esforço de observação crítica sobre os discursos de representação política inseridos em seus respectivos contextos, e mesmo sobre a memória que eles vingaram. Estas, muitas vezes portadoras de um "idealismo vulgar" 4 em que abstrações teóricas, invariavelmente, relegaram às camadas mais amplas da sociedade civil, geralmente as populares, o papel de simples receptoras, algo "submissas", sem, contudo, considerar as tramas das relações sociais ${ }^{5}$.

O que propomos, no decurso das próximas páginas, possivelmente se insere no âmbito da construção discursiva e dos usos da representação para fins políticos, e mesmo da memória histórica. Mas o que está na base das nossas investigações teóricas e metodológicas é tentar entender a elaboração de um discurso representativo - portanto político - numa sociedade que vivia a descoberta da democracia porque recém-saída de um longo período de exceção política. E como ele se processou nos marcos de uma proposta tida por muitos como populista simplesmente. Porém, a tarefa empreendida à compreensão de uma estratégia política permeada por uma mitologia com seus signos e valores - e que remetem a uma tradição e cultura à sua volta - será feita decupando filmes.

Partiremos de dois temas. Um deles muito pouco visitado nos estudos históricos sobre política: o adhemarismo, que como tantos outros "ismos" é comumente diluído na apreensão teórica pelo conceito do populismo, uma espécie de lugar-comum nas abordagens sobre a forma de se fazer e entender a política entre 1930 e 1964 . O segundo

\footnotetext{
${ }^{3}$ Michel Foucault. A Ordem do Discurso - aula inaugural no Collége de France, pronunciada a 2 de dezembro de 1970; 4 ed.; tradução Laura Fraga de Almeida Sampaio. São Paulo: Edições Loyola, 1998, p.26. ${ }^{4}$ Maria Sylvia Carvalho Franco. "O tempo das ilusões" In Marilena Chauí e Maria Sylvia Carvalho Franco. Ideologia e Mobilização Popular. Rio de Janeiro: Paz e Terra: Centro de Estudos de Cultura Contemporânea, 1978, pp. 151-209.

${ }^{5}$ Idem, p.167.
} 
tema, inserido na relação entre política e cinema é o cinejornal, um formato cinematográfico utilizado para divulgar a política adhemarista no contexto democrático pós 1946. Temas que se unem, portanto, na aposta de Adhemar Pereira de Barros ao se valer do cinejornal Bandeirante da Tela (BT), produzido entre 1947 e 1956, para divulgar sua imagem na cena política do final dos anos de 1940 até meados da década seguinte.

Analisar a construção de um discurso político e a sua desconstrução no formato em cinejornal consistem num trabalho em níveis diferenciados. Significa buscar subsídios nas discussões que envolvem a imagem e o imaginário coletivo inseridos na mentalidade e na cultura de um determinado contexto sócio-histórico. Mas, antes, alçar o cinema ao estatuto de fonte histórica, “aceitá-lo" nesse sentido. Realizando, assim, um esforço de compreensão da potencialidade existente na relação "história e imagem" pelas possíveis imbricações entre cinema e política, detendo-se na historicidade e nas discussões específicas que cercam os principais flancos desta relação. Sendo eles, neste trabalho: Adhemar de Barros em sua trajetória política em São Paulo durante os anos de 1940 e 1950 - considerando os necessários recuos e avanços explicativos nestas balizas cronológicas; e o BT - nossa principal fonte aqui analisada - compreendido no meio cinematográfico ao qual pertenceu, bem como analisado pelo viés da decupagem cinematográfica e no diálogo com outras fontes. É, portanto, partindo do cinema enquanto fonte para o ofício do historiador que buscamos nosso principal objetivo: entender como um veículo de massas no formato cinejornal encerrou uma proposta política, a de Adhemar de Barros, e nos possibilita um olhar - a partir das suas próprias opções de representação - sobre a sociedade para a qual ele foi produzido e pensado: a sociedade paulista em meio à redemocratização política e uma forte promessa de progresso em fins dos anos de 1940 e na década seguinte.

Como em toda pesquisa, um esclarecimento sobre o trajeto percorrido do seu início à conclusão do trabalho é necessário para situar o terreno em que se pisa. Além de expor, de maneira franca, as dificuldades enfrentadas e as opções encontradas diante das mesmas. Embora realizado dentro do período da Pós-Graduação, entre 2004 e 2007, este trabalho possui, digamos, uma "gestação" anterior. Quando em 2001 iniciei minhas atividades como estagiário na Cinemateca Brasileira $(\mathrm{CB})$ e lá ficando pelo período de quinze meses; e o meu retorno a esta casa entre setembro de 2003 e março de 2004, já como colaborador. Foi durante a primeira passagem pela $\mathrm{CB}$ que tomei contato com a sistematização de 
cinejornais para o Censo Cinematográfico Brasileiro 6 , junto à alimentação, indexação e revisão das informações do Cine Jornal Informativo (CJI), da Agência Nacional (AN), na base de dados da CB. Em meio a este trabalho, nos deparamos com o BT como uma das coleções de cinejornais ali existentes ${ }^{7}$. Depositado no início dos anos de 1970 na CB, o BT possui uma trajetória comum a das várias películas que lá se encontram. Na sua chegada ao acervo, a preocupação inicial foi com o seu estado de preservação e a manutenção de uma certa ordem do lote a partir das anotações contidas nas latas e nos próprios rolos, bem como a reunião das informações constantes em fichas que acompanhavam o material. Nesta primeira aproximação, foi possível identificar cerca de duzentos e trinta edições, entre 1951 e 1955, das quais setenta e cinco estavam completas e menos afetadas pela deterioração ${ }^{8}$. O inventário que resultou deste levantamento serviu para uma nova triagem, realizada no início dos anos de 1980. Nela foi realizada uma prospecção mais detalhada sobre o material: confronto das bandas de som e de imagem; sinopses criadas a partir de uma decupagem do conteúdo resgatado; investigação das datas, mediante a pesquisa - quando possível - dos fatos ocorridos no período; e a indexação dos dados alcançados. Investidas que resultaram na elaboração do catálogo hoje existente do $\mathrm{BT}^{9}$, composto por cento $e$ oitenta e um registros distribuídos entre os anos de 1949 e $1956^{10}$. Desses, cerca de um terço encontra-se disponível para consulta em vídeo na CB.

\footnotetext{
${ }^{6}$ Com o objetivo de preservar a memória do cinema nacional, o Censo Cinematográfico Brasileiro vem sistematizando desde 2001 os dados da nossa filmografia. Concluído em dezembro de 2006, este trabalho já catalogou 39.362 registros brasileiros, ou com participações brasileiras mundo a fora (dados fornecidos pela própria CB em 07 de agosto de 2007). Atualmente, o esforço consiste em manter atualizada a sua base de dados, revisando registros, agregando informações advindas de novas fontes, incorporando a produção cinematográfica recente e disponibilizando periodicamente tais informações pelo site $<$ www.cinemateca.org.br $>$.

${ }^{7}$ É importante lembrar que a CB, enquanto mantenedora de várias coleções de filmes, há cerca de trinta anos vem sistematizando as coleções de jornais cinematográficos ali existentes, tais como o Cine Jornal Brasileiro, o Cine Jornal Informativo, o cinejornal Carriço, o cinejornal Brasil Hoje, entre outros.

${ }^{8}$ Estas duzentos e trinta edições identificadas pertenciam a um lote formado por trezentos e oitenta rolos, onde uma pequena parcela era formada por filmes de nitrato. No geral, eram abundantes sobras, materiais não-editados, pontas, cortes e edições incompletas. Todas estas informações foram cedidas por Carlos Roberto de Souza, então responsável pela curadoria do acervo fílmico da CB na entrevista realizada em 22 de outubro de 2004.

${ }^{9}$ Cinemateca Brasileira. Bandeirante da Tela. Introdução de Carlos Roberto de Souza; apresentação de José Inácio de Melo Souza. São Paulo: Cinemateca Brasileira / IPHAN, 1991.

${ }^{10}$ Embora haja indícios da existência de números referentes aos anos de 1946 (1), 1947 (2) e 1948 (1). Cf. idem.
} 
No início do nosso trabalho vislumbramos um cenário difícil para a pesquisa, pois tínhamos acesso a uma parcela por demais reduzida de uma série iniciada em $1947^{11}$, que alcançou a casa dos quinhentos registros em 1952 e dos setecentos em $1955^{12}$. Dados estes que sustentam a hipótese da periodicidade de dois números semanais, em média. E com o lançamento em salas de grande freqüentação como o Ipiranga e o Marabá ${ }^{13}$ situados na "cinelândia paulista" dos anos quarenta e cinqüenta ${ }^{14}$. Somam-se a esta dificuldade primeira, as limitações do material disponível, onde praticamente inexistem dados sobre a equipe técnica (produtor, editor, diretor, montador...), restando apenas poucas informações quanto à companhia produtora, narração e distribuição. Além do que, alguns filmes não possuem mais a sua informação sonora ou tampouco se encontram completos. Mas apesar das limitações referenciais tanto quanto físicas do artefato fílmico - também parte do desafio $^{15}$ - as próprias imagens contidas no BT nos ofereceram, logo nos passos iniciais da pesquisa, possibilidades de entendimento. Portanto, partimos de um universo de cinqüenta e cinco números do $\mathrm{BT}$ - alguns analisados neste trabalho - disponíveis à consulta bem como algumas referências a outros números hoje inexistentes (irremediáveis já na chegada a CB). Com esse recorte traçamos nossas primeiras aproximações acerca dos interesses e estratégias que envolveram a sua produção e difusão, bem como visualizamos a necessidade de expandir este corpus documental através de um diálogo com outras fontes e uma bibliografia específica, como veremos.

Na primeira aproximação com dados coletados e reunidos pela $\mathrm{CB}$, uma conexão foi bastante óbvia: na incidência dos assuntos indexados em todos os números catalogados, cerca de um terço diz respeito a Adhemar de Barros e os correligionários do seu partido, o

${ }^{11}$ Baseamo-nos em pesquisa realizada por José Inácio de Melo Souza sobre as sessões de cinema publicadas no jornal O Estado de S. Paulo, onde constam aparições, em janeiro de 1947, do "N.01" do BT em sessões do Cine Piratininga. Cf. José Inácio de Melo Souza. Filmografia do cinema brasileiro: O Estado de S. Paulo 1947-1949. São Paulo: Cinemateca Brasileira, 1994.

${ }^{12}$ Cf. Cinemateca Brasileira, op. cit,

${ }^{13}$ Idem, p.3.

${ }^{14}$ Respectivamente a terceira e segunda salas mais freqüentadas em meados dos anos de 1950, e pertencentes às dez mais freqüentadas em toda a cidade de São Paulo. Cf. Inimá Ferreira Simões. Salas de cinema em São Paulo. Col. João Abdalla Saad Neto et. al.. São Paulo: PW/ Sec. Mun. de Cultura/ Sec. Est. da Cultura, 1990, p. 89.

${ }^{15}$ Como propõe José Inácio de Melo Souza, quando "na maior parte dos casos os cinejornais ou documentários chegam de forma precária aos arquivos, isso quando são recuperados. Faltam fichas técnicas, documentação escrita sobre as condições de filmagem, quais foram os redatores do texto de locução", Cf José Inácio de Melo Souza. "Trabalhando com Cinejornais: relato de uma experiência" In História: Questões e Debates n. 38, ano 20. Paraná: Associação Paranaense de História / UFPR, jan-jun 2003, pp. 43-62, 61. 
Partido Social Progressista (PSP) ${ }^{16}$. Como se vê, o resultado exibido nas telas dos cinemas indicava a grande presença de Adhemar de Barros e respondia aos interesses do partido que este liderava. Ainda assim, algo que precisaríamos entender era a ligação entre o político Adhemar de Barros e o cinejornal BT. Embora confusamente apontada em alguns trabalhos ${ }^{17}$ e mais claramente em outros ${ }^{18}$, tal relação carecia de esclarecimentos no sentido de aferir em que nível, efetivamente, ocorreu uma participação, ou não, de Adhemar de Barros na idealização do produto. Pois diferente dos modelos de cinejornais como o Cine Jornal Brasileiro (CJB) dos tempos do Departamento de Imprensa e Propaganda (DIP), e o Cine Jornal Informativo (CJI) da Agência Nacional (AN), o BT não possuía o apoio da máquina estatal. De modo que a Divulgação Cinematográfica Bandeirante (DCB), sua produtora, lançava mão de um certo tipo de cavação $o^{19}$. O que explica a presença dos mais variados assuntos como coberturas de casamentos e reuniões da alta sociedade, eventos religiosos e civis com autoridades do poder municipal e estadual, divulgação de cidades interioranas e de outros estados brasileiros, esportes que vão do futebol ao pólo, festividades no Jóquei Clube e reuniões de clubes filantrópicos, e novidades do próprio meio cinematográfico. Mas qual seria o envolvimento de Adhemar de Barros com o BT?

${ }^{16}$ Além de 39 ocorrências envolvendo conteúdos políticos, contabilizamos um total de 62 ocorrências para Adhemar de Barros e 61 para Lucas Nogueira Garcez, os dois principais nomes do PSP, como veremos mais adiante. Cf. Cinemateca Brasileira, op. cit.

${ }^{17} \mathrm{Em}$ um trabalho importante sobre o adhemarismo, o BT encontra-se de maneira um tanto deslocada: "É dessa fase [a interventoria] a série de documentários jornalísticos cujo título dá bem a idéia de uma das facetas com que Adhemar pretendia se apresentar: 'O Bandeirante da Tela"'. Cf. Regina Sampaio. Adhemar de Barros e o PSP. São Paulo: Global, 1982, p.45 (nota de rodapé). Grifo nosso. Seguindo os mesmos passos: "Sua imagem era cuidadosamente alimentada através da utilização da máquina administrativa do Estado, dos prefeitos nomeados e de uma ativa política de propaganda que chegou a utilizar o cinema, como na série de documentários intitulada 'O Bandeirante da Tela'". Cf. Marli Guimarães Hayashi. A Gênese do Adhemarismo. 1996. Dissertação (mestrado em História Social) Faculdade de Filosofia, Letras e Ciências Humanas da Universidade de São Paulo. Além de não informar a fonte para tais conclusões, as autoras sequer mencionam a palavra "cinejornal". Também the atribuem, equivocadamente, uma roupagem de propaganda oficial do Estado. Como veremos adiante, trata-se de um contexto posterior à interventoria, em que o BT não contou com o financiamento da máquina administrativa do Estado.

${ }^{18}$ Cf. José Inácio de Melo Souza. "Eleições e Cinema Brasileiro: Do Fósforo Eleitoral aos Santinhos Eletrônicos" In Revista da USP $n^{\circ} 22$ - Dossiê Futebol. São Paulo: USP, jun/jul/ago 1994, pp. 155-65; Publicado posteriormente em ___. Congressos, Patriotas e Outros Ensaios de Cinema. São Paulo: Linear B, 2005, pp.223-41.

${ }^{19} \mathrm{O}$ que, em linhas gerais, se resume na forma de pagar o filme antes dele chegar às telas. Numa atuação em certa "área livre", fora da concorrência com a fita estrangeira: a produção de documentários e cinejornais, os chamados "naturais" das primeiras décadas do século XX. Ou seja, algumas produtoras, a fim de conseguir subsídios para lançarem-se à produção de filmes de enredo ou para simplesmente manterem abertas as suas portas, recorriam a produção de filmes curtos, geralmente "cavados" entre aqueles que detinham o "poder": a elite ávida em promover seu nome a burguesia e seus empreendimentos e negócio, e até os partidos políticos. Cf. Jean-Claude Bernardet, Cinema Brasileiro: Propostas para uma História. Rio de Janeiro: Paz e Terra, 1979, p. 27. 
Não é por acaso que o período de sua produção, 1947 a 1956, corresponde igualmente ao percurso de "ascensão e queda" do adhemarismo em SP: a DCB, mais que adhemarista, era do próprio Adhemar de Barros, como veremos no decorrer deste trabalho. Pois se em março de 1947 ele tomou posse em SP, como o primeiro governador eleito na democracia restabelecida após a ditadura do Estado Novo, e em janeiro de 1951 entregava a faixa a Lucas Nogueira Garcez, seu sucessor pelo PSP, numa clara demonstração do poder político, a partir de 1953 o cenário mudou, com o "racha" entre o governador Garcez e o PSP, e com o surgimento de Jânio Quadros na cena política para as eleições municipais daquele ano. Nos anos seguintes, tratava-se de "buscar" novamente o eleitorado para as eleições estaduais em 1954 e presidenciais em 1955 - pleitos em que Adhemar de Barros foi derrotado; e sair estrategicamente da cena política em $1956^{20}$. Dois momentos, portanto, de uma estratégia política cujo discurso representativo primeiro conseguiu vencer, depois precisou convencer. E para isso contou com o cinema como aliado.

Ainda que o BT não tenha sido uma produção governamental, mas resultado de uma iniciativa política particular ligada a um partido, é notável a correspondência que possuía com cinejornais governamentais como o CJB do então extinto DIP, e o CJI da AN, seu contemporâneo. Nesse sentido, a semelhança de formato com um cinejornal que havia sido produzido por uma ditadura então recente ${ }^{21}$, e que se estendia nos seguintes ${ }^{22}$, não deixa de refletir a prática de uma experiência adquirida pelo chefe pessepista na interventoria de São Paulo (entre 1938 e 1941), bem como a aproximação de Adhemar de Barros e Getúlio Vargas, no seu segundo mandato (1951-1954). Essa adesão, entretanto, não nos impede de aferir como a experiência em cinejornais brasileiros foi aprimorada pelo teatro adhemarista em relação ao que havia sido trabalhado por Getúlio Vargas - durante o

\footnotetext{
${ }^{20}$ As derrotas nas eleições estaduais de 1954 para Jânio Quadros, o terceiro lugar "conquistado" nas eleições presidenciais em 1955 (ficando atrás de Juarez Távora e Juscelino Kubitschek), e o "exílio” para o Paraguai, a fim de se livrar de um processo judicial movido pelo então governador Jânio Quadros. Voltaremos mais atentamente a estes episódios no capítulo 2 deste trabalho.

21 Apesar de haver na década de 1920 uma certa "estandartização" na produção de cinejornais. Cf. “Cinejornal”, José Inácio de Melo Souza In Fernão Ramos e Luiz Felipe Miranda (orgs). Enciclopédia do cinema brasileiro. Colaboração de Afrânio Mendes Catani et al. São Paulo: SENAC, 2000. p. 134.

${ }^{22}$ Considerando que dos cento e oitenta e um registros atualmente catalogados pela CB, cinqüenta e um apresentam notícias que transitaram nas telas do CJI, vinculadas a AN. Cf. Cinemateca Brasileira, op. cit..
} 
Estado Novo $^{23}$ e retomado a partir de 1951. E mais: como o conteúdo do BT reflete um esforço próprio à construção de um discurso palatável à sociedade paulista.

Analisar um discurso político para cinejornais consiste num trabalho em níveis diferenciados, como já dissemos. Com base no trabalho realizado pela $\mathrm{CB}$ sobre o BT, resolvemos montar um ferramental de pesquisa nos mesmos moldes, agregando etapas inerentes às nossas necessidades e incorporando a "receita" fornecida em trabalhos já realizados ${ }^{24}$. De modo que a nossa "pesquisa de campo" consistiu, fundamentalmente, em quatro etapas: primeiro assistir o material, etapa em que foi marcado o tempo do cinejornal, bem como o dos assuntos que o compõe; em seguida, assistimos novamente o material e gravamos em fitas microcassetes o som, quando existente é claro; o terceiro passo consistiu na decupagem das imagens e do som com base numa metodologia que tentou incorporar as sistematizações anteriores do BT, a experiência do nosso trabalho junto à $\mathrm{CB}$, e um ferramental teórico-metodológico sobre cinema - como veremos mais adiante. Por último, alimentamos, com os dados obtidos nos passos anteriores, fichas individuais (em formato Access) para cada filme assistido - que se encontram disponíveis no final deste trabalho -, criando assim um inventário com informações para podermos iniciar a análise dos cinqüenta e cinco números do BT. Após todos esses passos, começamos a traçar nossas primeiras abordagens.

E para entender a mensagem do BT, analisamos a sua "desconstrução" em compasso com um contexto e um universo cultural mais amplo. Portanto, ao conjecturar o conteúdo decupado do discurso adhemarista no BT, ficamos atentos às representações nele contidas, bem como as apostas em certas imagens para a montagem de uma mensagem política que dialogasse com um universo de aspirações daqueles a quem o discurso se dirigiu - o espectador paulista principalmente. É nesse diálogo do discurso cinematográfico com o espectador, no viés da mensagem política, que verificamos resquícios de uma sintonia de valores socialmente aceitos, culturais por assim dizer. Mais claramente, rastros de uma representatividade que num dado momento foi aceita pela sociedade. E é nesse sentido, acreditamos, que vislumbramos a sociedade espectadora exercendo o papel que lhe cabe no conjunto "das relações de forças legitimadoras, [...] de um conjunto de

${ }^{23}$ Como analisado por Maria Helena Rolim Capelato em Multidões em Cena. Propaganda Política no Varguismo e no Peronismo. Campinas: Papirus, 1998; E José Inácio de Melo Souza, O Estado Contra os Meios de Comunicação (1889 - 1945). São Paulo: Annablumme: Fapesp: 2003.

${ }^{24}$ Especialmente o artigo de José Inácio de Melo Souza, op. cit. 
transfigurações de que é, ao mesmo tempo, o objeto e realizadora" ${ }^{25}$. Ou melhor, uma função compensatória no jogo político.

Portanto, acreditamos que o cálculo e as estratégias de convencimento da opinião pública tornam-se um tanto mais evidentes e pronunciados nas campanhas políticas, principalmente em períodos eleitoreiros, que configuram um "ato primeiro" no processo de decisão na sociedade política, cujos signos circundantes que apontam para uma dada visualidade, indicam um caminho útil ao entendimento das mentalidades ${ }^{26}$. E nos oferecem a chance de compreender, pelo cinema, uma certa representação aceita, ou não, pela sociedade política sob certas circunstancias históricas. E na visualidade que entendemos possuir o BT, uma vasta gama de temas está presente, idéias-força que perpassam, inclusive, os mais variados tipos de suportes iconográficos de propaganda adhemarista. E se já foi dito que o historiador é o "mais bem equipado" à tarefa de analisar o "material visual" ${ }^{27}$, também se sabe da necessidade em cercar de cuidados o corpus documental que o traz à tona ${ }^{28}$. Mais que um dever de ofício para quem lida com a fonte iconográfica, tratase de um procedimento valioso para aquele que lida com o cinejornal. Uma vez que, ao articular signos diversos, desfilar na tela diferentes camadas sociais e repercutir um discurso político reinventado em formas materiais distintas, ele põe em cena uma pluralidade de códigos partilhados, situados justamente num espaço social cuja recepção assume tonalidades diversas, matizando uma apropriação de sentidos ${ }^{29}$. Mediante uma visualidade que, para além do conteúdo político, evidencia estratégias simbólicas que de certa forma determinaram posições e relações, construindo para cada camada participante do jogo político um "ser percebido de sua identidade" ${ }^{30}$.

E é neste ponto, por assim dizer, que o BT carece ser cotejado com outras fontes e formar um corpus centrado em questões tanto políticas e sócio-culturais como específicas

${ }^{25}$ Georges Balandier. O Poder em Cena. Brasília: Universidade de Brasília, 1982, p. 21.

${ }^{26}$ Cf. René Rémond. “As Eleições” In René Rémond.(org.). Por uma História Política. Trad. Dora Rocha. Rio de Janeiro: FVG, 2003, pp. 37-55.

${ }^{27}$ Sendo que em relação a esse "material visual", o historiador não deve esquecer a "discussão de sua produção e de seu consumo como atividades sociais, econômicas e políticas". Ivan Gaskell. "História das Imagens" In A Escrita da História: novas perspectivas. Peter Burke (org.). Tradução Magda Lopes. São Paulo: Editora da Universidade Estadual Paulista, 1992, pp. 199-256, 268.

${ }^{28}$ Michel Vovelle, Imagens e Imaginário da História - fantasmas e certezas nas mentalidades desde a Idade Média até o séc. XX. Trad. Maria Júlia Goldwasser. São Paulo: Ática, 1977, pp. 20-1.

${ }^{29}$ Como propõe Roger Chartier, ao mencionar a tentativa de apreender um contexto histórico pelo traçado da área social em que acontece a recepção de um objeto. Cf. Roger Chartier. "O Mundo Como Representação" In Estudos Avançados no 11, vol.5. São Paulo, jan/abr.1991, pp. 173-191.

${ }^{30}$ Cf. Michel Vovelle, op. cit., p. 184. Grifo nosso. 
do campo cinematográfico. $\mathrm{Na}$ análise iconológica do material fílmico, notamos uma recorrência a certos mitos e valores colhidos na tradição e na cultura do espaço sóciohistórico em que circulou. Incidência que também ocorreu em outros suportes, mostrando que, se o cinejornal não foi o principal, muito menos o único componente utilizado na estratégia de convencimento nas campanhas adhemaristas, ele foi capaz de pôr em movimento toda a simbologia presente em marchinhas, programas de rádio ou materiais panfletários, fontes circundantes disponíveis no Fundo Adhemar de Barros (FAB/APESP) depositado no APESP ${ }^{31}$; editar notícias, privilegiando a imagem do PSP e de seu líder, ajudando a alçar Adhemar de Barros ao cenário nacional - algo perceptível, por exemplo, num cotejamento com alguns números do CJI disponíveis no Arquivo Nacional (AN-RJ); ofuscar enfrentamentos cotidianos e choques de valores presentes em sua relação com as diversas camadas da sociedade - no que contribui tanto a documentação do DEOPS/SP também depositada no APESP ${ }^{32}$; como uma literatura sobre Adhemar de Barros composta por livros de época ${ }^{33}$, memórias pessoal e institucional ${ }^{34}$, e até mesmo "passagens pitorescas" e estórias sobre o comportamento do mito político e de seu eleitorado ${ }^{35}$. Assim sendo, a composição de um corpus documental (com fontes escritas, iconográficas e audiovisuais dispostas ao longo desse trabalho ou reproduzidas em anexo) visa ampliar os parâmetros para a abordagem da mensagem de Adhemar de Barros nos cinemas e verificar

31 Depositado pela própria família em 2001, composto por comunicados, correspondências, diplomas, panfletos, cartazes, livros, fotos, etc. Limitamos o uso do material textual e iconográfico às necessidades da nossa própria pesquisa, não lançando mão das fotografias, por considerarmos um flanco investigativo extenso, além dos limites deste trabalho.

${ }^{32}$ A documentação do DEOPS/APESP composta por prontuários gerados pela atividade desta polícia contém registros de investigações, comunicados, relatórios informativos, processos judiciais, etc., envolvendo tanto pessoas como associações que ajudam a compor o universo da prática eleitoral e algumas nuanças circundantes ao período abordado, assim como as tensões existentes na relação de Adhemar de Barros com o eleitorado paulista, algo inexistente no discurso contido no BT.

${ }^{33}$ Livros críticos sobre Adhemar de Barros: João Ramalho. A Administração Calamitosa do Snr. Adhemar de Barros em SP. Rio de Janeiro: 1941; e Francisco Rodrigues Alves Filho. Um Homem Ameaça o Brasil: A História Secreta e Espantosa da "Caixinha" de Adhemar de Barros. São Paulo: 1954.

${ }^{34}$ Como o depoimento do amigo e correligionário Mário Beni. Adhemar. São Paulo: Grafikor, 1973/4; e o recente livro de Paulo Cannabrava Filho. Adhemar de Barros: trajetórias e realizações. São Paulo: Terceiro Nome, 2004. Fruto da sistematização do arquivo da família de Adhemar de Barros e publicado com o propósito de preservar o "mito" político em sua trajetória de realizações.

${ }^{35}$ A exemplo dos "episódios pitorescos" envolvendo Adhemar de Barros, coletados no livro de Carlos Laranjeira. Histórias de Adhemar. São Paulo: Carlos Laranjeira, 1990; assim como o conto "O Adhemarista" de Marcos Rey, cujo personagem principal, o taxista e militante pessepista "Moa" (Moacyr), canaliza suas energias fazendo "boca de urna" e enfrentando os janistas dias antes do pleito. In Roniwalter Jatobá (org.). Trabalhadores do Brasil: histórias cotidianas do povo brasileiro. São Paulo: Geração Editorial, 1998, pp. 205-17. 
como ela soou familiar à sociedade paulista. Ou melhor, em que medida o discurso exibido na tela aproximou o político e o espectador.

As apostas adhemaristas em temas que procurassem a empatia no eleitor demonstram o esforço gasto na construção de uma realidade para o seu discurso. Nesse sentido, o nosso personagem principal - Adhemar de Barros - encenou vários papéis: o empreendedor progressista e moderno; o político paternal, chefe de família e solícito às iniciativas assistenciais da figura maternal da sua esposa, dona Leonor; o "doutor", médico incumbido de diagnosticar as mazelas do povo; o homem franco que nada tem a esconder, pois sua casa está de portas abertas; o homem querido pelas massas, como nas manifestações de prestígio de São Paulo e "de todo o Brasil"; o fiel devoto cristão; e, enfim, o que o próprio título do cinejornal indica: o bandeirante da tela, ou seja, o dos tempos modernos, mas igualmente estandarte de uma unidade paulista e daquela verve que todos que habitam e trabalham em São Paulo "tendem a oferecer" ${ }^{36}$ em proveito de um bem coletivo, comumente transfigurado na idéia do progresso.

O político, o empreendedor, o paternal, o assistencialista, o médico, o homem sensibilizado, o chefe de família. Enfim, uma variedade de representações numa unidade merecedora de crédito: o bandeirantismo. Idéia cara a Adhemar de Barros, pois investida não sem conflitos e enfrentamentos com os inimigos políticos, como veremos na terceira parte deste trabalho, mas bastante difundida quando vinculada a um tipo de cinema que noticiava o cotidiano, convidando o espectador a partilhar símbolos e valores tomados de um caldo cultural que lhe era próprio.

É nesse sentido que o aspecto ritualístico do cinejornal nos ofereceu subsídios para uma história cultural da política que analise o peso das imagens no discurso político pensado para o formato cinematográfico. E promova, assim, uma aproximação entre cinema e história ou, no mínimo, realize uma parcela da potencialidade do cinema enquanto fonte histórica.

Optamos por dividir este trabalho em três partes. Inicialmente, traçamos algumas aproximações teóricas da nossa problemática com autores que estabeleceram conexões do político e o uso da imagem, em todo o seu aspecto ritualístico e com o universo de práticas

${ }^{36}$ Cf. Elias Thomé Saliba, "Histórias, Memórias, Tramas e Dramas da Identidade Paulistana" In Paulo Porta (org.). História da Cidade de São Paulo: a cidade na primeira metade do século XX. Vol. 3. São Paulo: Ministério da Cultura / Paz e Terra. 2004, pp. 555-87, 575. 
culturais em que ele ocorre. $\mathrm{O}$ que remete às discussões sobre a representação e representatividade numa sociedade espectadora de imagens inseridas na construção de realidades que delas faz uso - independente do suporte em que se encontram. Na parte cinematográfica especificamente, o auxílio maior veio de estudiosos do cinema que promoveram pesquisa com cinejornais, discussões sobre obras cinematográficas, bem como o olhar crítico sobre o cinema.

$\mathrm{Na}$ segunda parte, a discussão perpassa os principais flancos da pesquisa: o adhemarismo e como ele foi apreendido e estudado ao longo dos anos pelo viés do populismo e quais complicações existem neste tipo de análise, e o cinejornal, inserido nas polêmicas envolvendo este tipo de cinema tanto na perspectiva historiográfica como no meio cinematográfico em que circulou. Por último, na terceira parte, tentamos aplicar o ferramental teórico-metodológico desenvolvido anteriormente, analisando alguns números do BT. Mostramos como alguns temas de propaganda "ganharam vida" no discurso cinematográfico, ao mesmo tempo demonstrando seus limites em revelar uma construção pensada para o convencimento do espectador. Construção essa que levou para o cinema a mitologia bandeirante, retomada numa chave inédita por Adhemar de Barros.

São essas as linhas-mestras deste trabalho que buscou na mise-en-scène adhemarista uma certa mitificação da modernidade e dos valores tradicionais através de cenários, gestos atenciosos, acenos à população, obras inauguradas ou realizadas em outras gestões, certas atitudes assistencialistas ou qualquer outra ação dirigida às massas que, de uma forma ou outra, sentiam-se tocadas pelo que viam nas telas. Por tais motivos, o BT se apresentou como um poderoso aliado no "fazer" da política adhemarista. Portanto, a partir da análise de um discurso político que articulou um repertório de imagens e com a devida atenção à especificidade do cinejornal enquanto fonte é que repousam, assim acreditamos, as nossas chances de analisar historicamente tais imagens em movimento. Porém, por ser a história política irreversivelmente interdisciplinar, uma "ciência da encruzilhada", porque impraticável se isolada das outras áreas do conhecimento, um mergulho num contexto político-cultural obriga o pesquisador a transitar pelas idéias políticas com um espírito necessariamente interdisciplinar ${ }^{37}$, admitindo arriscar-se ao fazer julgamentos. E é dessa maneira que caminhamos no sentido de propor um conhecimento histórico novo e não

${ }^{37}$ René Remond. "Uma História Presente" In René Rémond (org.). Por uma História Política. Trad. Dora Rocha. Rio de Janeiro: FVG, 2003, pp. 13-6, 29. 
justificado apenas por ir contra uma variedade de outros julgamentos distintos ${ }^{38}$. E para isso nos valemos, inclusive, dos conselhos de quem sempre questionou a pouca importância dada ao potencial do cinema brasileiro (ficcional ou não) enquanto registro cultural, pois

A gente encontra tanto de nós num mau filme que pode ser revelador em tanta coisa de nossa problemática, da nossa cultura, do nosso subdesenvolvimento, da nossa boçalidade inseparável de nossa humanidade que em última análise é muito mais estimulante para o espírito e para a cultura cuidar dessas coisas do que ficar consumindo no maior conforto intelectual e na maior satisfação estática os produtos estrangeiros. ${ }^{39}$

Tentamos, enfim, contribuir para que o conhecimento da nossa cultura política seja esclarecido por uma percepção mais crítica sobre o mundo das imagens. E que o passado novamente visitado traga subsídios para tornar o presente inteligível, realizando o que talvez seja a finalidade da inserção numa história política ${ }^{40}$ : tornar a nossa ação presente mais enriquecedora, como já dizia o mestre ${ }^{41}$.

\footnotetext{
${ }^{38}$ Richard Tuck. "História do Pensamento Político” In Peter Burke (org.), op. cit., pp. 273-89, 289.

${ }^{39}$ Paulo Emilio Salles Gomes em entrevista concedida a Carlos Reichenbach, Inácio Araújo e Eder Manzini In Revista Cinema n. 01. Uma publicação do Centro Acadêmico Armando Salles Oliveira. Campos de São Carlos - USP, julho /1974, p. 7.

${ }^{40}$ Michel Winock, “As Idéias Políticas” In René Remond, op. cit., pp. 271-94, 290.

${ }^{41}$ Marc Bloch. Apologia da História. Rio de Janeiro: Zahar, 2002, p. 63.
} 


\title{
I - A POLÍTICA EM CINEJORNAIS
}

\subsection{Imagens, política e uma História Cultural da Política}

\begin{abstract}
Porque é muito necessário conhecer os costumes dos ouvintes, $e$ as opiniões que entre eles correm, para assim regularmos o discurso, (...) Se assim fizermos, antes mesmo de pronunciarmos o nosso discurso, poderemos saber o juízo que dele hão de formar os nossos ouvintes.
\end{abstract}

Quintiliano. Instituições Oratórias ${ }^{42}$.

Escritos há mais de mil e quinhentos anos, tais conselhos nunca pareceram tão atuais... Para o autor, a elaboração de um discurso, com toda eloqüência que procurou ensinar, deve corresponder a certas exigências. Pode-se falar de tudo. Mas existem precauções na escolha de um repertório que é algo dificilmente universal, pois há lugares onde a sua "eficiência" é maior. Portanto, para que a coisa seja convincente, decente e até mesmo conveniente como na pintura de Antígono feita por Apeles, que foi pintado de perfil para encobrir a deformidade da falta de um olho ${ }^{43}$, ele necessita estar minimamente situado para que seja compreendido e cause o efeito esperado. Por outro lado, o discurso, em todo seu processo de elaboração, tenta não demonstrar os cuidados tomados. Pretende-se "leve" e espontâneo independente da linguagem empregada. Seja então falado, escrito, pintado, fotografado ou filmado, muito de sua credibilidade está em não deixar transparecer a construção que o sustenta, ou melhor, a sua espontaneidade construída.

Nesta espontaneidade, contudo, tenta-se justificar e preservar um certo veredicto sobre determinada questão, ou mesmo um conjunto delas. A pretensão de verdade, ou uma "vontade de verdade" como aborda Michel Foucault ${ }^{44}$, parece rondar a retórica discursiva. E, respeitando convenções e estabelecendo distinções, o discurso mostra-se representativo

\footnotetext{
${ }^{42}$ Marco Fábio Quintiliano. Instituições Oratórias. Tradução por Jerônimo Soares Barbosa. São Paulo: Cultura, 1944, p118. (Clássica Universal).

${ }^{43}$ Idem p. 53.

${ }^{44}$ Em que "[...] através de nossos discursos, essa vontade de verdade [...] atravessou tanto séculos de nossa história", Michel Foucault, op. cit., p. 14.
} 
do assunto em pauta, busca ser a "última palavra" ${ }^{45}$. Tal representatividade, no campo da política propriamente dita, revela a intenção de “dominar” um grupo, ou melhor, controlálo mostrando-se representativo dele. O que torna a busca pela representatividade algo central na análise do discurso político. E, neste trabalho, numa chave em que o uso da imagem assume um papel central.

Todos os cuidados, as apostas e as opções observadas na construção de uma proposta política dizem respeito, em muito, às opiniões e costumes dos ouvintes como dizia Quintiliano em tempos idos. Ou do público espectador, como no caso da sociedade contemporânea. Lembrando Pierre Francastel, os diversos modos de expressão que recorrem ao uso da imagem "não servem aos homens para vestir pensamentos fora de seu espírito" "46. Desta forma, investigar imagens é tentar chegar em até que ponto certas representações tocaram o espírito, pois as artes visuais, e nelas o cinema, não constituem um duplo reduzido ou limitado no tempo de um "real estável" que, aliás, não existe ${ }^{47}$. Tanto o "real" como o percebido e o imaginário estão presentes na imagem, mas nenhum é exclusivo $^{48}$, de modo que a imagem simplesmente não "apresenta", e sim "re-apresenta". Não se trata, também, de pensar o espírito apenas no sentido do autor, do artista, mas de toda uma coletividade e caminhar pelas representações que se pautam no imaginário que paira sobre ela. Pois se "a obra está no imaginário" ${ }^{49}$, as imagens colhidas no imaginário coletivo dizem mais respeito ao espírito daqueles que são os seus usuários, toda a coletividade por assim dizer. Elas permeiam o contexto homem-sociedade e são capazes de fornecer um testemunho relativo a um ou vários objetos desta $\operatorname{sociedade}^{50}$, e independente da forma como ocorre a sua veiculação, as imagens na pesquisa histórica contribuem ao refletir as agitações de um tempo curto, assim como o peso de uma herança longa ${ }^{51}$. Sendo capaz, também segundo Michel Vovelle, de articular múltiplas expressões do imaginário coletivo, compondo com temas e signos - idéias-força - comuns às mais variadas camadas

${ }^{45}$ Cf. Ibdem, pp. 21-36.

${ }^{46}$ Pierre Francastel, A Realidade Figurativa; tradução: Mary Amazonas Leite de Barros. 2 ed. São Paulo: Perspectiva, 1993 (coleção estudos, 21), p. 13. Grifo nosso.

${ }^{47}$ Ibidem, pp. 88-9.

${ }^{48}$ Ibidem, p. 92.

${ }^{49}$ Ibidem, p. 17.

${ }^{50}$ Pierre Francastel, op. cit, p.96.

${ }^{51}$ Michel Vovelle. Imagens e Imaginário da História, op. cit. p. 31. 
da sociedade ${ }^{52}$. E não podemos esquecer que tal propriedade das imagens, que é a de representar, coloca um eixo central à tarefa do historiador que se vê diante das representações do passado "que se constroem como fonte através do seu olhar" ${ }^{53}$, nos mais diversos tipos de suportes iconográficos, fotográficos e audiovisuais. As representações aproximam, de uma só vez, elementos para se pensar as construções discursivas dos objetos que delas fazem uso, como o cinema que nos servirá de fonte para este trabalho.

Vale dizer que o filme - e assim o cinema - é uma obra figurativa que carrega em si valores situados para além do objeto figurativo (o próprio filme). Remetendo, em última instância, à sua própria matéria-prima: as imagens ${ }^{54}$. Por outro lado, as imagens contidas no cinema são mais que um repositório especular de informações, são representações que avançam para desvelar dimensões da vida social, cultural e política. Falamos de arte, a sétima arte, que também é representação. Deste modo, o representado na película se valeu de elementos do já simbolizado e "socializado em cada parte" ${ }^{55}$ e é nessa complicada trilha que o cinema servirá de abrigo para uma análise histórica, muito embora desafiando o historiador que terá de ir fundo nesta prática cultural voltada em todo o seu potencial à sociedade de massas, como nos lembra Walter Benjamin ${ }^{56}$.

Portanto, sendo o cinema um produto cultural inserido numa prática, ele se apresenta enquanto representação do e no passado. Ou, no que é mais que um jogo de palavras para Sandra Pesavento, "fonte como representação do passado, meio para o historiador chegar às representações construídas no passado" ${ }^{57}$. Assim, o cinema é uma das várias portas de entrada existentes para uma História Cultural, cuja característica principal é a tentativa de se aproximar do passado por meio das próprias representações nele criadas. O registro cinematográfico realiza tal empreendimento porque também encerra questões colhidas no imaginário coletivo bem como a tradução, em imagens, dos valores pertencentes ao caldo cultural de onde saiu. Valores estes que permeiam os vários

${ }^{52}$ Cf. Michel Vovelle. Ideologias e Mentalidades. Trad. Maria Julia Cottvasser. São Paulo: Brasiliense, 2004, p. 71.

${ }^{53}$ Sandra Jatahy Pesavento. História e História Cultural, 2 ed. Belo Horizonte: Autêntica, 2005, p. 42. (História \&... Reflexões), p. 42.

${ }^{54}$ Ibidem, pp. 106-7.

55 Jean-Louis Leutrat. "Uma relação de diversos andares: cinema e história" In Revista Imagens $n^{\circ} 5$. São Paulo: Campinas: Unicamp, ago/dez. 1995, pp.28-32, 31.

${ }^{56}$ Cujo sucesso depende da quantidade de cópias que faz de si mesmo, de sua reprodutibilidade. Cf. "A Obra de Arte na Época de sua Reprodutibilidade" in Walter Benjamin, Magia e Técnica, Arte e Política. Tradução por Sérgio Paulo Rouanet. São Paulo: Brasiliense, 1985, pp. 165-196. (Obras Escolhidas 1).

${ }^{57}$ Sandra Jatahy Pesavento, op. cit., p. 42. Grifo nosso. 
tipos de representação que já foram transpostas à grande tela, a despeito da pretensão de verdade em alguns gêneros cinematográficos como, por exemplo, o documentário ${ }^{58}$. E como em outros meios de comunicação em massa (rádio, televisão, etc.), a representação no discurso cinematográfico também convida à tarefa de se pensar o universo da política e as estratégias de busca pela representatividade de um grupo - em especial as formulações retóricas precavidas na escolha de um "repertório" e dos "lugares" onde a eficiência do discurso é maior. Como expõe René Rémond, tendo em conta o político como ponto para onde conflui a maioria das atividades e que recapitula os outros aspectos do social ${ }^{59}$, inclusive porque no "fazer política" encontram-se outros níveis da coletividade, pois se trata de

[...] uma das expressões mais altas da identidade coletiva: um povo se exprime tanto pela sua maneira de conceber, de praticar, de viver a política tanto quanto por sua literatura, seu cinema e sua cozinha. Sua relação com a política revela-o da mesma forma que seus outros comportamentos coletivos. ${ }^{60}$

Ou como esclarece Pesavento na constatação de uma História Cultural do Político

[...] mobilizada pelos estudos que se centram em torno do imaginário do poder, sobre a performance de atores, sobre a eficácia simbólica de ritos $e$ imagens produzidas segundo fins $e$ usos do político [...] sobre mitos $e$ crenças que levam os homens a acreditar em alguém ou algo, pautando a ação e a percepção da realidade sobre mecanismos pelos quais se constroem identidades dotadas do poder simbólico de coesão social. ${ }^{61}$

Nesse sentido, o cinema se apresenta como um novo aporte para se pensar o político pelo cultural. Em que, por exemplo, a história das idéias políticas, por todas as camadas da sociedade, faz fronteira com a história da propaganda, na chave da influência recíproca sobre o comportamento dos atores e dos espectadores ${ }^{62}$, abrindo espaço para o potencial de novas fontes ${ }^{63}$, como no caso da nossa escolha pelo cinema. E esta porta de entrada, como

${ }^{58}$ Cássio Tomaim alerta sobre os cuidados que o analista (historiador no caso) deve tomar em suas formulações acerca do gênero documentário. Não se deixar levar pela objetividade e pretensão de verdade que o gênero abriga. Cf. "O filme documentário entre a realidade e a ficção: uma proposta de desmistificação" In Revista Olhar, ano 6, $n^{\circ} 10-11$; jan-jul e ago-dez, 2004, p. 27-47.

${ }^{59}$ René Rémond. "Do Político" In René Rémond, op. cit.,pp. 441-450, 447.

${ }^{60}$ Idem, p. 449. Grifo nosso.

${ }^{61}$ Sandra Jatahy Pesavento, op. cit., p. 75. Grifo nosso.

${ }^{62}$ Cf. Jean-Noel Jeanneney. "A Mídia” In René Rémond, op. cit., pp. 213-230.

${ }^{63} \mathrm{Ou}$, como coloca Michel Winock, "a curiosidade a fontes antes inusitadas". "As Idéias Políticas" In René Rémond, op. cit., p. 278-9. Grifo nosso. 
dissemos há pouco, também dá acesso aos traços da representação política, se considerarmos o "ritualismo" na performance dos atores, permeado de imagens, crenças e mitos que dizem respeito ao lugar em que se encontram e mesmo a tessitura da sociedade em que orbitam identidades dotadas do poder simbólico de coesão social.

Para os elementos circundantes à prática política, bem como o seu ritualismo e o comportamento dos atores e dos espectadores, Georges Balandier propõe pensar a sociedade como uma entidade reguladora do "poder em cena", cuja encenação foi direcionada às necessidades da coletividade que lhe deu suporte. E esta, muito mais que uma mera espectadora, ao mesmo tempo ensina e cobra o político das suas responsabilidades, como numa espécie de pedagogia coletiva ${ }^{64}$. Desta forma, o ritual político, em sua eterna busca e manutenção do poder, colhe seus elementos discursivos justamente do público que o assiste - já dizia Quintiliano -, das suas aspirações sociais, culturais e até psicológicas - como bem observou Theodor W. Adorno ao notar uma certa ambivalência na imagem do líder que, no limite, suscita no público um duplo da identificação: obedecer e querer parecer-se com ele ${ }^{65}$.

Mas a sociedade receptora de um determinado discurso político deve ser investigada no maior número possível dos meandros que compõe a sua trama social. Por esse caminho, Pierre Bourdieu apresenta contribuições importantes quando discute o mundo social apresentado num sistema simbólico que traduz, em última instância, as representações como dimensão fundamental dos embates sociais ${ }^{66}$, verificados em diferentes níveis. Como a diferença simbólica representada nos próprios corpos e comportamentos, em que a condescendência traduziria uma negação estratégia da distância social ${ }^{67}$. Um "sistema de produção de práticas" que exprime, em suas representações, posições sociais e juízo de valores $^{68}$ dentro de um determinado espaço social. O que nos ajuda a pensar as representações que tiram da popularidade a sua força e entender o alarde daqueles que arvoram representatividade sobre o "popular" e o "povo", dada a rentabilidade e a

\footnotetext{
${ }^{64}$ Como nas palavras do autor quando a "pedagogia coletiva ensina ao soberano, requerendo a sua fidelidade". Georges Balandier, op. cit., p. 20.

${ }^{65}$ Cf. Theodor W. Adorno. "A Teoria Freudiana e o Padrão da propaganda Fascista” In Margem Esquerda, n. 7. São Paulo: Boitempo, maio de 2006, pp. 164-89, 177.

${ }^{66}$ Pierre Bourdieu. Coisas Ditas. Tradução: Cássia R. da Silveira e Denise Moreno Pegorim. São Paulo: Brasiliense, 2004, pp. 163, 184.

${ }^{67}$ Idem, p. 155.

${ }^{68}$ Ibidem, pp. 158-159.
} 
eficiência simbólica que gozam estes conceitos no jogo político ${ }^{69}$. E, ainda neste caso, o carisma que provém, na raiz, da idolatria à personagem política, mas que aparece como uma misteriosa propriedade objetiva da pessoa, um encanto ou um poder que parece ter origem em si mesmo ${ }^{70}$. Quando na verdade resulta de um imbricado jogo de representações e mesmo da alienação no ato da delegação, naquilo que o autor qualifica de fetichismo político. Que, no seu limite, autoriza uma "ventriloquia política", um efeito de oráculo, em que o porta-voz de um grupo - que é o autorizado - autoriza-se perante a coletividade que o autorizara a exercer certa função reconhecida ${ }^{71}$. Com estas considerações, Bourdieu contribui no sentido de desmistificar representações que se valem de uma complexidade simbólica que habita a própria valoração do grupo que as sustentam e as alimentam. Seja criando regras de distinção social ${ }^{72}$, baseada no status que cada um carrega, seja alimentando os mitos criados nas frestas das próprias diferenças (sociais, culturais, econômicas) que a sociedade apresenta.

Seguindo este raciocínio sobre as imbricações contidas na prática política e suas representações, vale a máxima de Girardet em que o mito político contém em si uma "visão global e estruturada do presente e do futuro coletivos" ${ }^{73}$, cabendo ao historiador enxergar nas representações da narrativa mítica, como esta se valeu de um imaginário mítico para tornar o mundo coerente em seu discurso. Estar atento aos traços marcantes de uma dada mitologia política no que lhe é peculiar, tendo como exemplos o que o próprio autor sugere: a imagem do "salvador" que carrega em si elementos de convencimento por exercer liderança e ao mesmo tempo apresentar a qualidade de homem comum - em síntese, aquele "a quem recorrer"; Um passado ideal - a tal "idade de ouro" - retomado como objetivo a ser reconquistado pelo empreendimento de toda uma coletividade; Ou mesmo uma "unidade" (uma crença, uma coletividade, uma cidade ou uma pátria) enquanto poderosa força irradiadora de harmonia e de pertencimento. Desta forma, ainda que a investigação

\footnotetext{
${ }^{69}$ Ibidem, p. 184.

${ }^{70}$ Como se fossem "pessoas, coisas, seres que parecem não dever senão a si mesmos uma existência que lhes foi dada pelos agentes sociais". Idbem, p. 190.

${ }^{71}$ Ibidem, p. 197.

${ }^{72}$ Que para Bourdieu é permeada pelo capital simbólico ao tramitar relações sociais que determinam o próprio poder simbólico. Em outras palavras, esta forma "reconhecimento" está na base das relações sociais, inclusive políticas, cuja força do homem público provém da "confiança que um grupo põe nele". Pierre Bourdieu. O Poder Simbólico. Trad. Fernando Tomaz (Portugal). Rio de Janeiro: Bertrand Brasil, 1998, pp. 187-8. Grifo nosso.

${ }^{73}$ Raoul Girardet. Mitos e Mitologias Políticas. São Paulo: Cia. das Letras, 1987, p. 182.
} 
histórica se dê nos meandros de uma interpretação deformada da narrativa mítica, "fabulação do real vivido" nas palavras do autor, é esta que encerra as chaves explicativas de seu surgimento, da construção que lhe deu força ao longo do tempo e, sobretudo, a respeito da figura central em que se baseia. Uma espécie de criptografia que requer bastante atenção aos símbolos, imagens e arquétipos que fundamentam a sua mística ${ }^{74}$.

$\mathrm{Na}$ tarefa de desvendar esta criptografia mítica, é extremamente necessário ater-se aos elementos que a constrói e a reconstrói, atualizando as representações que fortalecem o mito e realizando, de fato, o empreendimento de uma história que opte pelo cultural, porque é deste universo que é retirada a essência das representações. É aonde devemos estar atentos, ou como já disse Michel de Certeau sobre toda reflexão acerca da sociedade e sua(s) cultura(s): "com uma atenção preparada para a surpresa" ${ }^{75}$. Também do mesmo autor, alguns conselhos são valiosos para medirmos até que ponto as "referências" colhidas do universo cultural, e formuladoras de representações, não estão a serviço de um utilitarismo, da necessidade de um grupo - um partido político, por exemplo -, de interesses ou crenças sem uma realidade correspondente, a não ser a do próprio discurso ${ }^{76}$. Neste sentido, aquilo que é trazido para o discurso como conseqüência da experiência concreta, e que pode ser identificado pelo que Certeau chamou de "signos críveis" 77, é um termômetro para a avaliação da representatividade de certas autoridades. No exercício da aceitação há também um julgamento, na medida em que a autoridade aceita repousa sobre uma adesão, sobretudo numa democracia. E no exercício do poder, tal adesão pressupõe uma legitimidade que possui, nas suas representações, signos críveis levados ao "público" por meio de uma "comunicação parcimoniosa [cautelosa] e necessária credibilidade" ${ }^{78}$. A exemplo da promessa de felicidade colhida no imaginário da cidade, principalmente no cenário das grandes cidades, onde uma certa mitologia - unificando a "idade de ouro" à "unidade" - prolifera em compasso com o desenvolvimento técnico das formas de veiculação das representações, como o cinema. A comunicação de massa transforma a sociedade em público espectador que assiste, e que espera das representações, principalmente nos discursos políticos, a "concretização" em imagens de algo que a cidade

\footnotetext{
${ }^{74}$ Idem, p. 13.

${ }^{75}$ Michel de Certeau. A Cultura no Plural. Tradução Enid Abreu Dobránszky. Campinas: Papirus, 1995. (Coleção Travessia do Século), p. 35.

${ }^{76}$ Cf. Idem, p. 27.

77 Ibidem, p. 35.

${ }^{78}$ Ibidem.
} 
não mais oferece ${ }^{79}$. No limite, isso permite a interlocução do mito e suas representações colhidas no imaginário coletivo com um clima psicológico e social de incerteza, de temor ou de angústias coletivos, chegando até a classificar a mais ampla diversidade de atores sociais como sendo agentes sociológicos causadores deste "medo coletivo" 80 - prática afeita aos regimes autoritários. Ou ainda, se valer de um ressentimento disfarçado de indignação social disseminado nas camadas do todo social ${ }^{81}$, até não mais poder sustentar a realidade do seu discurso, ou seja, não se manter crível perante a realidade concreta do diaa-dia e, assim, perder a eficiência por já não dizer muito ao "lugar", à realidade da sociedade que o assiste.

Enfim, são várias as contribuições para se pensar o político pelo viés de uma abordagem cultural. Como a questão do mito político e suas identidades dotadas de poder simbólico e coesão social. Assim como sua representação em imagens, que por sua vez traduzem uma promessa que toca a sociedade, ou setores dela, pela forma com que é levada ao público. Contudo, tal forma pensada em termos de cinema nos transporta às questões sobre a visualidade no seu discurso específico, o da linguagem cinematográfica. Nesse sentido, existe algo que Paulo Emílio Salles Gomes constatou nas primeiras décadas do século XX no cinema - do cinema brasileiro no caso - e que parece contemplar o que já foi discutido até aqui. No ritualismo visto nas telas, algo de político permeia a contemplação e a exaltação do "berço esplêndido" em algumas películas nacionais, enquanto o político está totalmente presente num "ritual do poder" que eventualmente elas apresentam ${ }^{82}$. Deste modo, na pretensão de se mostrar leve e espontâneo como um elogio, ou verdadeiro por "comprovar" com imagens o poder político de homens públicos, a credibilidade do discurso cinematográfico ligado àqueles que detém o poder está em não deixar que o receptor - o espectador numa sessão de cinema - perceba o esforço gasto na sua construção, tampouco o comportamento invariavelmente ensaiado dos seus atores. Como no caso do cinejornal

\footnotetext{
${ }^{79}$ Ibidem., pp. 42, 44.

${ }^{80}$ Raoul Girardet, op. cit., pp.53-34.

${ }^{81}$ Pierre Bourdieu. A Economia das Trocas Simbólicas. Introdução, organização e seleção: Sérgio Miceli, $6{ }^{\mathrm{a}}$ ed. São Paulo: Perspectiva, 2005. (Coleção Estudos), p. 7.

${ }^{82}$ O texto “A Expressão Social dos Filmes Documentais no Cinema Mudo Brasileiro (1898 - 1930)" é de 1974, mas se encontra, na íntegra, em Carlos Augusto Calil e Maria Teresa Machado (orgs.). Paulo Emílio: Um Intelectual na Linha de Frente - Coletânea de Textos de Paulo Emilio Salles Gomes. São Paulo: Brasiliense: Rio de Janeiro: Embrafilme, 1986, pp. 323-328.
} 
BT que atendeu aos interesses de Adhemar de Barros durante os anos de 1940 e 1950, e que veremos com detalhes mais adiante.

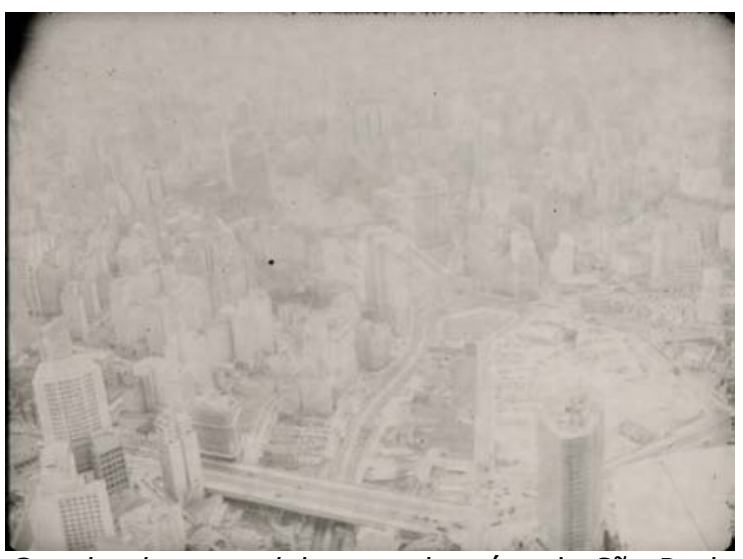

Grande plano geral dos arranha-céus de São Paulo (capital): a pujança do "berço esplendido" bandeirante. Bandeirante da Tela no 591, 1954. Acervo Cinemateca Brasileira.

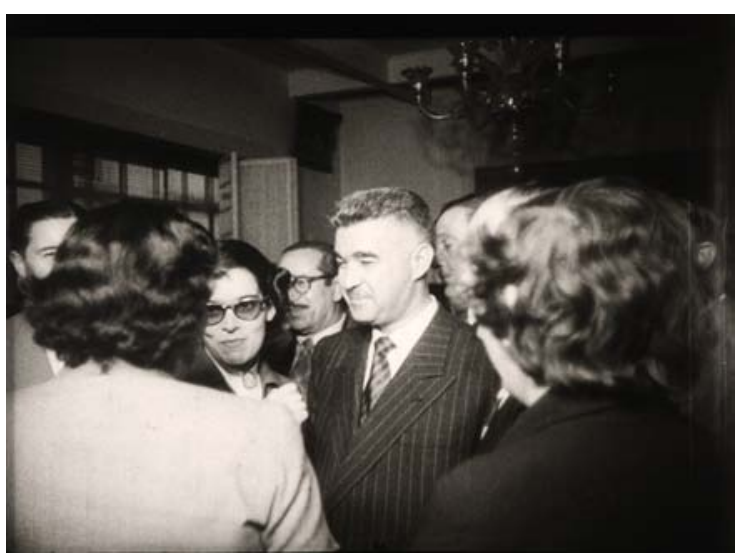

O "ritual do poder" nas telas: O "iniciante" Lucas Nogueira Garcez e esposa em recepção ao então "padrinho político" Adhemar de Barros. Bandeirante da Tela no 501, 1952. Acervo Cinemateca Brasileira.

Como disse Siegfried Kracauer, por detrás da representação "pura e simples" no discurso cinematográfico, a exibição de certos aspectos de um dado assunto em detrimento de outros traduz interesses na aproximação com o público ${ }^{83}$. Da mesma forma, Giradet nos lembra que o mito político jamais deixa de "enraizar-se em uma certa forma de realidade histórica" pois não foge ao fato dele surgir a partir de

um ser de carne e osso, historicamente definível, e cujo processo de heroificação poderia fazer esquecer os traços particulares que são os de uma personalidade e de um destino. ${ }^{84}$

Para Leif Furhammar e Folke Isaksson, tal “processo de heroificação” é identificável na linguagem cinematográfica, na encenação do jogo político onde a

demonstração de naturalidade do ídolo, e mesmo sua qualidade de ser comum, torna-se parte importante da apoteose; ele pode ser qualquer um, mas ao mesmo tempo é algo mais

\footnotetext{
${ }^{83}$ Siegfried Kracauer. "O espectador" In Filme e Cultura n. 1, v. 1. São Paulo, out. 1966, pp. 27-38, 30.

${ }^{84}$ Raoul Girardet, op. cit., p. 81. Grifo nosso.
} 
[...] Para que uma personalidade se transforme num ídolo tem que se estabelecer um elemento de identificação [...] nas respostas emocionais de um amplo público. ${ }^{85}$

Algo, inclusive, já apontado por Adorno quando analisa o emocional como resposta psicológica à imagem representativa do líder - no caso da propaganda fascista - capaz de despertar um alto grau de satisfação, um duplo desejo do seguidor em estar submisso e se sentir, ao mesmo tempo, a própria autoridade, tamanha a empatia existente na relação ${ }^{86}$.

Da mesma forma, o próprio olhar da população captada em sua espontaneidade, em qualquer manifestação pública, acrescenta à análise da construção de realidades para veiculação em massa. As faces na tela, por si só, oferecem conclusões por mais que se pretenda dar um outro sentido ${ }^{87}$. E, deste modo, as convenções políticas passam a ter gestos e rostos que vão além das bandeiras, dísticos e canções e invariavelmente deixam rastros na película. Ou melhor, momentos de uma espontaneidade ainda que ensaiada, mas inestimáveis à compreensão e releitura de uma dada memória política na medida em que os entes políticos, estando expostos ao olhar público, personificam a política em gestos e trejeitos, isto é, em sinais corporais que passam a ter uma função política mesclada à particularidade de quem a encena ${ }^{88}$.

\section{2 - A imagem em cinejornais e a busca em outros suportes}

Entendemos que a opção pelo cinema enquanto fonte comporta especificidades e cuidados. Seguir por um caminho que nos auxilie a desvendar as entrelinhas, ou os lapsos do documento filmográfico ${ }^{89}$, é ter em vista todo o processo de sua construção, em que as condições de produção são de fundamental importância, e tudo o mais que contribua para

\footnotetext{
${ }^{85}$ Leif Furhammar e Folke Isaksson. Cinema \& Política. Rio de Janeiro: Paz e Terra, 1976, p. 160. Grifo nosso.

${ }^{86}$ Cf. Theodor W. Adorno, op. cit., p. 177.

87 Siegfried Kracauer. "The Conquest of Europe on the Screen. The Nazi Newsreel (1939-1940)". Nova Iorque, mimeo, 1947. Agradeço ao professor Carlos Eduardo Jordão Machado pela cessão desse artigo.

${ }^{88}$ Assim como nos comportamentos, nas expressões corporais, na fala, na religião e até mesmo na sexualidade. Cf. Thomas Mergel. "Algumas Considerações a Favor de Uma História Cultural da Política" In História - Unisinos: Revista do Programa de Pós-Graduação em História da Universidade do Vale do Rio dos Sinos Vol. 7, $N^{o}$ 8. São Leopoldo: 2003, pp. 11-55, 40.

89 Como propõe Marc Ferro em seu célebre ensaio sobre a importância do cinema enquanto fonte historiográfica. "O filme: uma contra-análise da sociedade?" In Jacques Le Goff e Pierre Nora (orgs.) História: novos objetos. Rio de Janeiro: Francisco Alves, 1976, pp. 202-230.
} 
uma contra-análise da sociedade ${ }^{90}$. Mas para Marc Ferro, a contra-análise da sociedade pelo cinema consiste numa busca, principalmente, dos "lapsos" deixados pelo diretor no filme que realizou. Em outras palavras, no que podemos perceber de latente através do aparente. Uma contribuição importante, porém, impossível de abarcar com profundidade a linguagem cinematográfica em seus diversos gêneros e formatos.

Como questiona Eduardo Morettin, analisar a obra cinematográfica não é se limitar em trazer à tona a informação que "sem querer [...] vai contra as intenções daquele que filma, ou da firma que mandou filmar" ${ }^{91}$. É, antes disso, assumir o cinema como documento de fato, atribuindo-lhe o estatuto de fonte já adquirido em outros suportes. Ou melhor, "livrá-lo" da comparação - ainda presente no célebre texto de Ferro - com a fonte escrita enquanto paradigma de sucesso para o resgate do passado daqueles que a produziram $^{92}$. Portanto, pretende-se assumir o cinema num patamar acima daquele em que o seu sucesso enquanto fonte significaria corroborar um saber já consolidado. Entendemos que a contra-análise da sociedade proposta no trabalho com cinema seja um tanto mais viável não somente pelos "lapsos" verificáveis na polissemia de suas imagens - que também são indispensáveis -, mas pela desconstrução do seu discurso na linguagem cinematográfica de cada categoria específica, através de um mergulho em todo o processo cinematográfico considerando os meios para a sua produção, os interesses em jogo e o gênero ao qual pertence - o cinejornal no caso, bem como a composição com outras fontes para melhor situá-lo na análise. Vislumbramos serem estas, no mínimo, as etapas para se buscar respostas na própria película, e não algo que precise ser corroborado por um saber preexistente, num sentido que desmereça o cinema enquanto chave explicativa para diversos fenômenos, inclusive políticos, como o adhemarismo nas salas de cinema em São Paulo por meio do seu cinejornal, o BT.

Como já dissemos anteriormente, o cinema é uma arte da imagem que trabalha com representações. Neste sentido ele não apresenta, e sim re-apresenta um espaço e um tempo

\footnotetext{
${ }^{90} \mathrm{Cf}$. Idem.

91 Eduardo Victorio Morettin, "O Cinema Como Fonte Histórica na Obra de Marc Ferro" In História: Questões e Debates, ano 20, n.38. Paraná: Associação Paranaense de História (APAH) / UFPR, jan/jun, 2003. pp. 11-42, 14 .

${ }_{92}$ Segundo Morettin, para Marc Ferro o “documento fílmico produzido pelo Estado ou por outras instituições difere do documento escrito que possui a mesma origem”, "não que não haja 'lapsos' nos documentos escritos, 'mas no filme há lapsos a todo momento, porque a realidade que se quer representar não chega a esconder uma realidade independente da vontade do operador"'. Ibidem.
} 
reinventado e redimensionado de acordo com as opções e os interesses envolvidos, de maneira que é preciso tentar enxergar a construção que ele comporta. Ainda que não se trate de cinema, a compreensão do processo fotográfico proposta por Boris Kossoy oferece uma base para se pensar as construções, ou melhor, as realidades contidas no processo de representação. Divididas em quatro, as realidades da fotografia remetem às diferentes dimensões da composição imagética. A "primeira realidade” é a do assunto em si da qual a fotografia participa por um único instante no momento de sua geração, ou como o próprio autor coloca, uma "dimensão da vida passada [...] a história particular do assunto independentemente da representação" ${ }^{93}$. Intrínseca à própria imagem fotográfica, há uma "realidade interior" oculta e interna, invisível e inacessível fisicamente ${ }^{94}$. E no campo da própria representação, a "segunda realidade", a que corre na dimensão da imagem fotografada, ou melhor, a realidade fotográfica do documento, "referência sempre presente de um passado inacessível" 95 . O último passo do percurso teórico-metodológico proposto pelo autor consiste no próprio assunto representado, numa pequena face do passado "cristalizada expressivamente" e que se realiza como "realidade exterior" 96 , ou seja, o aspecto visível da imagem tornada documento. Resumindo, a fotografia implica numa transposição de realidades, num paralelo bastante próximo ao processo de produção cinematográfico, no sentido em que ambos não traduzem, em suas realidades, a verdade histórica, e sim o "registro expressivo da aparência..." ${ }^{97}$. Desta forma temos, tal como na fotografia, o discurso cinematográfico selecionando do real (da "primeira realidade") o registro tornado visível na película (segunda realidade) enquanto dimensão representada do passado "real". E acessível na sua exterioridade (realidade exterior), enquanto documento para o historiador.

Teóricos do cinema e da fotografia traçaram paralelos entre estas duas linguagens. Sobre uma espécie de linha evolutiva nos fala André Bazin, quando coloca o cinema como multiplicador das "interpretações estáticas da fotografia por aquelas que surgem da aproximação de planos" 98 e que tanto pelo conteúdo das imagens como pelos recursos da montagem (aproximação de planos) o cinema dispõe de "todo um arsenal de procedimentos

\footnotetext{
${ }^{93}$ Boris Kossoy, Realidades e Ficções na Trama Fotográfica. São Paulo: Ateliê Editorial, 2000, p.36.

${ }^{94}$ Ibidem.

${ }^{95}$ Idem, p. 37.

96 Ibidem.

${ }^{97}$ Idem, p. 38.

${ }^{98}$ André Bazin. O Cinema: ensaios. São Paulo: Brasiliense, 1991, p. 56. Grifo nosso.
} 
para impor aos espectadores sua interpretação ao acontecimento representado" 99 . Contudo, há de se ter o cuidado proposto por Susan Sontag, ao aproximar a imagem estática da fotografia à imagem em movimento do cinema na chave da evolução de uma linguagem para a outra pura e simplesmente. No limite desta comparação, o mundo fotografado mantém com o mundo real "a mesma relação essencialmente errônea que se verifica entre as fotos de filmes e os filmes" ${ }^{100}$. Trata-se, portanto, de uma outra linguagem a do cinema, com os seus dispositivos e meios, na medida em que o tempo de leitura de um livro (ou uma foto) depende do leitor e o "tempo de assistir a um filme é determinado pelo cineasta", assim como as imagens "são percebidas como rápidas ou vagarosas apenas de acordo com sua edição" ${ }^{101}$. Não compactuamos com Bazin quanto à "imposição de interpretação" ao espectador pelo cinema - assim como deve ser matizado o que Sontag propõe como “imagens percebidas”. O cinema, como a fotografia, nunca estará livre da percepção dos seus receptores, ou seja, do referencial cultural daqueles que o percebe. Na exterioridade do registro cinematográfico - na representação em imagens que chegam até nós - a mensagem deve ser analisada na chave da receptividade não perdendo de vista a sua construção e, sobretudo, considerando o "processo de construção da interpretação" 102 . Há de se pensar sobretudo num discurso cinematográfico a serviço do político - em que medida o repertório de imagens, crenças e mitos e a performance dos atores dialogam, através de representações diversas, com o repertório de convicções culturais, morais, éticas, religiosas e mesmo os mitos que dizem respeito ao imaginário coletivo dos receptores, da sociedade para a qual ele (o registro cinematográfico) foi produzido e pensado. Em outras palavras, qual a informação e a mensagem ali presentes na complexa trama de "criação / construção de realidades" 103 ?

Portanto, se pretendemos entender a construção no registro cinematográfico, e suas realidades, não há como não enveredar pela própria linguagem do cinema. Mas, além disso,

\footnotetext{
${ }^{99}$ Idem, p. 68. Grifo nosso.

${ }^{100}$ Susan Sontag. Sobre Fotografia. Tradução Rubens Figueiredo. São Paulo: Cia. das Letras, 2004, p. 96.

${ }^{101}$ No raciocínio da autora, "a relação de uma foto de filme com um filme é intrinsecamente enganosa. Citar de um filme não é o mesmo que citar de um livro", pois "uma foto de um filme, que nos permite observar um único momento pelo tempo que quisermos, contradiz a própria forma do filme, assim como um conjunto de fotos que congela os momentos de uma vida ou de uma sociedade contradiz as formas destas, que é um processo, um fluxo no tempo". Ibidem. Grifo nosso.

${ }^{102}$ Cf. Boris Kossoy, op. cit. p. 44.

${ }^{103}$ Boris Kossoy. "O relógio de Hiroshima: reflexões sobre os diálogos e silêncios das imagens" In Revista Brasileira de História vol. 25, $n^{\circ}$ 49, Dossiê: História e manifestações visuais. São Paulo: ANPUH, jan-jun, 2005, pp. 35-42, 38-9.
} 
atentar às especificidades do filme em questão: o cinejornal. Entender, por exemplo, a natureza de um gênero que difere em muito dos outros formatos fílmicos, cuja especificidade está no universo fragmentado que apresenta ${ }^{104}$. Newsreels ingleses e norteamericanos, noticiarios espanhóis, actualités franceses, cinegiornali italianos, wochenshau alemães, o jornal cinematográfico, ou simplesmente cinejornal, marcou presença, principalmente na primeira metade do século passado, em diversos cantos do planeta ${ }^{105}$, e no Brasil não foi diferente ${ }^{106}$. Numa rápida definição, o cinejornal consiste num registro em curta metragem, seriado, com uma periodicidade semanal para apresentação ilustrada de eventos $^{107}$, exibido no espaço das sessões cinematográficas antes do longa-metragem - aqui conhecido como o espaço do "complemento nacional". Uma certa estabilização na produção desse gênero em terras brasileiras ocorreu a partir da década de 1920, devido a grande quantidade de títulos no mercado exibidor brasileiro ${ }^{108}$, padronizando, aos poucos, a duração e o formato de apresentação com os letreiros iniciais (conhecidos também por cartela de apresentação ou simplesmente título) e intertítulos que anunciam os assuntos dentro do mesmo número ${ }^{109}$. A partir dos anos de 1930, passou a contar com uma legislação que garantia sua presença nas salas cinematográficas e institucionalizando, inclusive, o seu patrocínio na esfera governamental, pois em geral eram filmados por pequenas empresas e cinegrafistas independentes que viviam da cavação ${ }^{110}$. E o que o caracteriza, de uma maneira bem geral, é a defasagem de "tempo" em relação aos demais veículos de comunicação à época (muito mais “ágeis” como o rádio e a imprensa escrita, antes do invento da televisão). De modo que o cinejornal ao chegar às telas dos cinemas raramente

${ }^{104}$ De modo que eles podem ser "uma série de catástrofes seguidas por um show de moda", ou mesmo uma "coleção de saltitantes cartões postais". Raymond Fielding apud José Inácio de Melo Souza, "Trabalhando com Cinejornais: relato de uma experiência", op. cit., p.46.

${ }^{105}$ Cf. Jacques A. Wainberg "A voz de Deus: um estudo da narração de cinejornais em tempos de guerra - a persuasão audiovisual de um povo" In Intercom - Revista Brasileira de Comunicação n. 2, vol. XV. São Paulo: jul/dez, 1992, pp. 144-66, 154-5.

106 Dos 39.362 registros brasileiros reunidos pela CB, no Censo Cinematográfico Brasileiro como mencionado em nota anterior, 11.887 são cinejornais (conforme informações colhidas em agosto de 2007). Ou seja, uma impressionante marca de quase um terço do que foi realizado em nossa cinematografia.

${ }^{107}$ Cf. Karel Reisz e Gavin Millar. A Técnica da Montagem Cinematográfica; Tradução: Marcos Maguliés, apresentação: Alberto Cavalcanti; Rio de Janeiro: Embrafilme / Civilização Brasileira, 1977, (Cinebiblioteca Embrafilme), p. 188.

${ }^{108}$ Cf. Enciclopédia do cinema brasileiro, op. cit., pp. 133-135.

${ }^{109}$ Seria impossível aferir um tempo de duração para "os cinejornais". O que podemos informar é que em nossa sistematização do BT, verificamos uma duração que varia entre seis até dez minutos, em média. Quanto aos títulos e intertítulos, nos números aqui analisados identificaremos a sua importância.

${ }^{110}$ Discutida com mais detalhes na segunda parte deste trabalho. 
apresentava um conteúdo inédito, seus acontecimentos não eram mais uma novidade ${ }^{111}$. Porém, novos aspectos das notícias veiculadas apresentaram uma outra dimensão no jornal cinematográfico, como explicam Karel Reisz e Gavin Millar:

Quando se apresenta uma conferência internacional de estadistas, por exemplo, o público poderá encontrar interesse nos sorrisos dos diplomatas que trocam cumprimentos [...] um cine-jornal (sic) sobre corridas de cavalo [...] pode dedicar tanta metragem à moda feminina quanto à própria corrida, porque a platéia, se tiver algum interesse, já saberá qual o cavalo que venceu, mas talvez não tenha visto os últimos modelos apresentados pelas senhoras $^{112}$.

Sejam os sorrisos e os cumprimentos dos diplomatas ou os modelos da última moda, tais detalhes são significativos porque traduzem uma seleção de "aspectos humanos" "113 que eram, digamos, o atrativo nas imagens do cinejornal. Ele "dava à ver" ao espectador a notícia, o que não se tinha em outros meios antes da televisão. Portanto, retomar a questão do ritualismo no cinema é extremamente importante, pois é nela que verificamos em que medida foi possível desfilar nas telas valores culturais e míticos representados no espetáculo cinematográfico de atualidades. E que necessita ser analisado, inicialmente, nas fronteiras da linguagem cinematográfica em seus dispositivos mais essenciais como a montagem, os enquadramentos e movimentos de câmera e a parte sonora.

É na montagem que o filme adquire a sua "unidade", e no cinejornal ela se apresenta basicamente em dois momentos. No encadeamento das imagens, das cenas por assim dizer, com a atmosfera sonora e especialmente a figura do narrador. E na aproximação de assuntos que compõem um número de cinejornal. Neste caso, Kracauer nos lembra que a “junção" de assuntos também implica uma associação de temas, criando certa continuidade de sentido entre eles ${ }^{114}$. Na construção da realidade cinematográfica em cinejornais, como no caso do BT, podemos aventar ser este um elemento "ordenador" do universo fragmentado de notícias, principalmente quando associa temas afins em assuntos separados

\footnotetext{
${ }^{111}$ Karel Reisz e Gavin Millar, op. cit., p. 188.

112 Ibdem, pp. 188-189.

${ }^{113}$ Ibdem.

${ }^{114} \mathrm{O}$ autor tece suas considerações com base em dezoito cinejornais nazistas lançados entre 1939 e 1940 , e que cobrem a campanha da Alemanha na Polônia até o evento da Batalha na Inglaterra. Nesse contexto, a associação de duas estórias, uma noticiando a realeza inglesa e a outra mostrando Hitler visitando jovens soldados mostra, por exemplo, que "[...] the contents of the stories which it connects, the transition implies that England is in complete decay, whereas Germany is young and virile". Cf. Siegfried Kracauer, op. cit., p. 25.
} 
como, por exemplo, política e religião. Por outro lado, pode despertar no espectador a atenção para as disparidades existentes na representação do seu próprio "lugar", como no caso de uma mesma seqüência de assuntos, em que aparecem uma partida de pólo e algumas famílias nordestinas pobres chegando a São Paulo.

É claro, outros dispositivos participaram, mas coube ao montador um papel proeminente $^{115}$ diante da limitação de tempo que parecia rondar a confecção dos cinejornais. Os eventos filmados in loco, ainda que ensaiados ou direcionados por um roteiro, dificilmente poderiam ser re-filmados por se tratar se tratar de ocasiões e eventos únicos trazidos à tela como "notícias". Além disso, "noticiar" implicava levar o quanto antes o material finalizado às sessões. Nesse sentido, é bastante provável que a montagem não fosse contemplada com refinamento técnico, tampouco com um cuidado estético ou artístico como bem observam Reisz e Millar ${ }^{116}$. O que se agravava diante da carência técnica, resumida na falta de pessoal, baixa qualidade e pouca quantidade do material virgem e a precariedade dos equipamentos disponíveis com que seus realizadores, em se tratando de uma firma pequena, tinham que lidar. Não havia tempo, e o "toque de caixa" refletia a qualidade final do que era levado ao espectador ${ }^{117}$.

Mas é no encadeamento das cenas numa dada multiplicidade de pontos de vista, nos enquadramentos e angulações de câmera, e numa continuidade de planos que podemos esmiuçar a realidade cinematográfica, seguindo uma "decupagem clássica". Por mais que existam descontinuidades visuais para a representação de eventos separados no tempo e espaço, ordenados por uma montagem que ofereça continuidade lógica ${ }^{118}$, um importante trabalho vem das várias tomadas efetivas pela câmera. Nisso, Ismail Xavier nos ajuda, com sua sucinta descrição de como os movimentos de câmera contribuem para se pensar as opções de representação das imagens captadas da primeira realidade. Para além das básicas definições do que sejam cenas, planos e seqüências ${ }^{119}$, as noções de enquadramentos,

\footnotetext{
115 Ou mesmo uma posição "privilegiada”, como assume Vicente Sanchéz-Biosca logo nas primeiras páginas de Teoria Del Montaje Cinematográfico. Valência: Filmoteca Generalitat Valenciana / IVAECM, 1991 (Coleção Textos), p.21.

${ }^{116}$ Karel Reisz e Gavin Millar, op. cit., p. 198.

117 Problema este que pode não ter afetado tão diretamente os cinejornais governamentais, que geralmente dispunham de melhores condições técnicas e assim cercavam-se de maiores cuidados.

${ }^{118}$ Cf. Ismail Xavier. O discurso cinematográfico: a opacidade e a transparência. São Paulo: Paz e Terra: 2005, p. 28.

119 Resumidamente, cena constitui "cada uma das partes dotadas de unidade espaço-temporal"; estas, por sua vez, constituem a seqüência ou seqüências, que são "unidades menores dentro do filme, marcadas por sua função dramática e/ou posição na narrativa"; já a denominação plano corresponde a cada tomada de cena, ou
} 
ângulos e movimentos de câmera ${ }^{120}$ nos ajudam a ler os códigos da linguagem cinematográfica, no sentido mesmo de buscar o que se pretendeu com tais representações do real sob a perspectiva diferenciada - se comparada com a percepção humana - oferecida pelo olhar da câmera cinematográfica ${ }^{121}$.

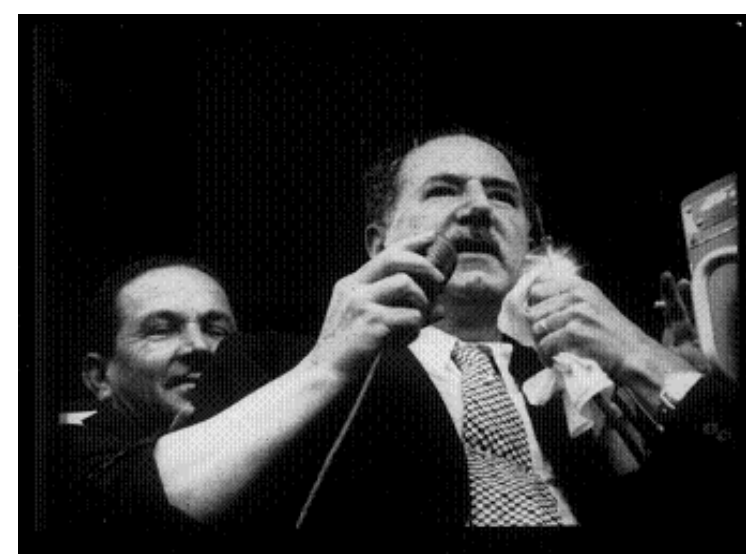

Câmera baixa (ou contra plongée), uma tomada efetiva pela câmera no sentido de enaltecer a figura do político que fala à multidão. Bandeirante da Tela no 501, 1952. Acervo Cinemateca Brasileira.

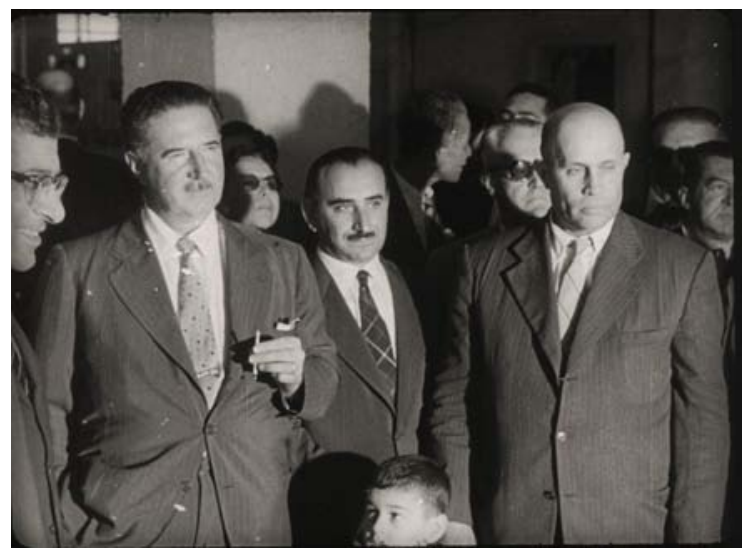

Plano americano corresponde ao ponto de vista em que as figuras humanas são mostradas até a cintura, aproximadamente. Bandeirante da Tela no 588, 1954. Acervo Cinemateca Brasileira.

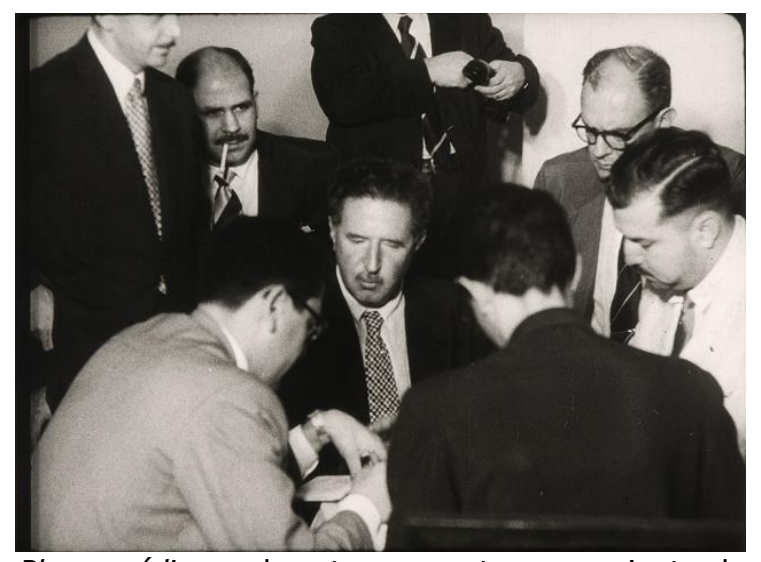

Plano médio geralmente apresenta um conjunto de elementos (figuras humanas e cenários) numa dada ação, principalmente em interiores. Bandeirante da Tela no 501, 1952. Acervo Cinemateca Brasileira.

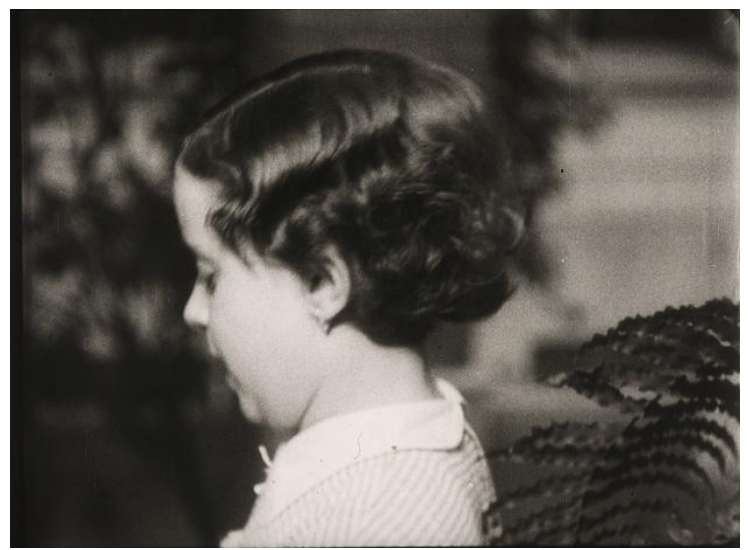

Primeiro plano (ou close-up). A figura humana em detalhes - principalmente o rosto. Assim como a proximidade com objetos numa cena. Bandeirante da Tela no 501, 1952. Acervo Cinemateca Brasileira.

seja, "à extensão de filme compreendida entre dois cortes". Cf. Ismail Xavier, op. cit., p. 27. Na análise dos cinejornais, eventualmente estaremos usando o termo plano-seqüencia, no sentido de descrever um plano ininterrupto, sem corte, geralmente longo e que compreende toda uma seqüência de ação. Cf. Karel Reisz e Gavin Millar, op. cit., p. 418.

${ }^{120}$ Plano geral, plano médio, plano americano (ou meia figura), primeiro plano (close-up), câmera alta (plongée), câmera baixa (contra plongée) e os movimentos de panorâmica, travelling e mesmo vista aérea. Ismail Xavier, op. cit., pp. 27, 32. São as nomenclaturas utilizadas na decupagem dos cinejornais estudados. ${ }^{121}$ Cf. Siegfried Kracauer, op. cit., p. 15. 


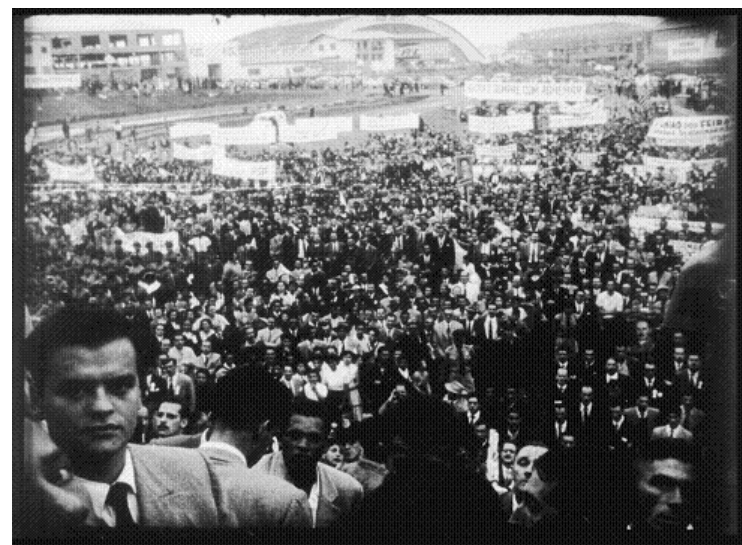

Panorâmica em plano geral. Movimento no sentido de informar ao espectador a grandiosidade da cena "varrendo", geralmente na horizontal, o espaço representado. Bandeirante da Tela no 501, 1952. Acervo Cinemateca Brasileira.

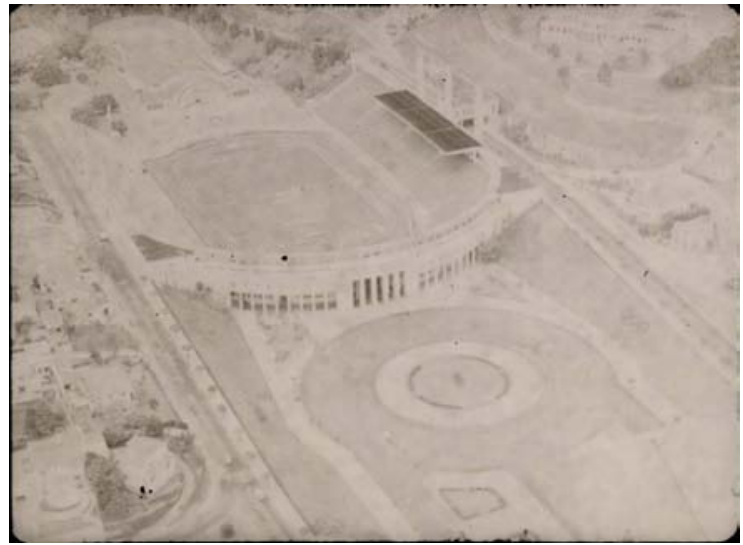

Grande plano geral ou vista aérea. Também no sentido de informar o espaço representado, mas numa chave de exaltação e contemplação. Bandeirante da Tela no 591, 1954. Acervo Cinemateca Brasileira.

Desta forma, os interesses e julgamentos dos realizadores sobre "como" e "o que" mostrar aos espectadores ficam mais claros. Por mais que esteja ausente uma concepção artística mais elaborada no cinejornal ${ }^{122}$, uma certa topografia dos espaços representados e escolhas de enquadramento indicam a intenção de mostrar ou esconder, exaltar ou diminuir elementos na cena. Se "certas imagens transmitem todo o seu significado em pouco tempo, enquanto outras requerem mais tempo" ${ }^{123}$, devido à forma com que foram registradas pela câmera, ou por mais que exista continuidade com cortes abruptos, elas se "encontram" no ritmo e no sentido de direção ${ }^{124}$ atribuído pela montagem. É isso que nos orienta sobre o que poderia ser conotado e denotado nas imagens e mensagens da trama do cinejornal, como sugere Anthony Aldgate ${ }^{125}$. E como o dispositivo de movimentação, angulação e a multiplicidades de pontos de vista para focalizar acontecimentos, a dita "expressividade" da câmera $^{126}$, pode expandir o espaço mostrado na tela, como nas varreduras em panorâmicas,

\footnotetext{
${ }^{122}$ Muito embora S. Kracauer consiga nos mostrar o oposto, ao analisar a estética dos cinejornais nazistas. Cf. Siegfried Kracauer. "The Conquest of Europe on the Screen...", op. cit.

${ }^{123}$ Karel Reisz e Gavin Millar, op. cit., p. 223.

${ }^{124}$ Idem, p. 250.

${ }^{125}$ Anthony Aldgate. Cinema and History - British Newsreels and the Spanish Civil War. Lodon: Solar Press, 1979, p. 12.

${ }^{126}$ Ismail Xavier, op. cit., p. 21.
} 
ou nos enquadramentos e recortes visuais, quando, por exemplo, um plano médio denota a existência de um plano geral, pela composição de uma panorâmica em plano médio sobre um pequeno grupo de pessoas que corta para um plano geral de uma multidão, sugerindo uma continuidade nos diferentes espaços registrados. E, ainda nesse caminho, considerar como o retângulo da imagem, a tela de projeção, sugere uma espécie de janela "que [se] abre para um universo que existe em si e por si, embora separado do nosso mundo pela superfície da tela" ${ }^{127}$. Algo que, no limite da análise do cinejornal, sugere a intenção de convidar o espectador a "mergulhar" nas representações que dialogam com os seus filtros culturais, no mesmo sentido proposto por Christian Metz, ou seja, pela aproximação com os atores ou a participação efetiva na representação ${ }^{128}$, dado o potencial de identificação que certos símbolos e ícones despertam no espírito humano ${ }^{129}$ ao lembrar as qualidades de algo ausente, mas latente no imaginário coletivo. Como a valoração contida numa dada iconografia ou lugar, ou na provável empatia com certas atitudes representadas na tela quando trazidas por um político cordial que cumprimenta, aperta mãos, acena, Ou carinhosamente afaga uma criança, abraça a massa e entrega presentes aos pobres.

A desconstrução das realidades no cinema não estaria cercada de consideráveis cuidados se esquecêssemos um aspecto importante da narrativa fílmica e mesmo essencial nos cinejornais: a função do narrador e a atmosfera sonora. Esta, como analisa Kracauer, se bem trabalhada com a imagem, pode afetar os sentidos da representação com maior ou menor intensidade ${ }^{130}$. Pode criar uma atmosfera inexistente no ato do registro ou mesmo reforçá-la ${ }^{131}$, adicionando um som ambiente para determinados interesses como, por exemplo, aplausos ou ovações. Intensificar ou mesmo subverter a narrativa com a adição de uma música alegre para um tema não tão festivo, ou ainda, como também coloca Kracauer: "transformar um tanque [de guerra] num brinquedo" ${ }^{132}$. Porém, está na narração um aporte valiosíssimo à mensagem que se pretende transmitir nos cinejornais. Para Jacques

\footnotetext{
${ }^{127}$ Como o autor coloca, uma "noção de janela (ou às vezes de espelho)". Idem, p. 22.

${ }^{128}$ Christian Metz apud Ismail Xavier, op. cit., p. 23

129 Tomando emprestado o conhecimento em questões bastante pontuais acerca das idéias de ícone, símbolo, signo e representação, desenvolvidas na semiótica discutida por Charles Sanders Pierce. Cf. Charles Sanders Pierce. Semiótica e Filosofia. Octanny Silveira Mota e Leônidas Hegenberg (trad., sel. e org.). São Paulo: Cutrix, 1993, pp. 114, 129 e 131.

${ }^{130}$ Siegfried Kracauer. De Caligari a Hitler - Uma História Psicológica do Cinema Alemão. Tradução Tereza Ottoni. Rio de Janeiro: Jorge Zahar Editor, 1988, p. 324.

${ }^{131}$ Karel Reisz e Gavin Millar, op. cit., p. 191.

132 Idem, 323.
} 
Wainberg a voz do narrador, muito mais que um "mestre de cerimônias", era uma fazedora de imagens, no sentido que "o comentário vocal podia acrescentar e alargar a imagem e não só explicá-la" ${ }^{133}$. E é esse "alargar" que contribui à continuidade visual do cinejornal, pois enquanto se ouve a voz do narrador, cria-se a "impressão de que muita coisa rápida está acontecendo na tela" ${ }^{134}$. Nesse sentido, o uso da elipse, dado o pouco tempo de que dispõe uma notícia no cinejornal, é um dos recursos utilizados e que melhor ilustra a convergência entre a montagem e o comentário verbal. O anúncio de uma ação pelo narrador, por exemplo, é imediatamente seguido por seu resultado que também é comentado verbalmente, e nisso, supõe-se que ocorreu um certo desenvolvimento entre as duas unidades $^{135}$. Nesse contraponto entre a imagem e a declaração verbal, a tendência é aumentar o peso da imagem, pois valoriza-se o resultado de uma ação "explicada" ao espectador pelo narrador ${ }^{136}$. Ou seja, a narração consiste em mais que uma mera e simples descrição de cena, ela acrescenta dados e informações de background, marcando o sentido das imagens ${ }^{137}$, cadenciado-as até. Contudo, por vezes ocorre o contrário e a narração pode servir como um elemento revelador da intenção que não se confirma na imagem, ou mesmo que não se quer transmitir ao público.

Deixamos claro o nosso objetivo de enveredar por uma história do político, ou melhor, uma história cultural do político e tentar tal empreendimento no âmbito das representações, ao investigar o passado através de um suporte ao mesmo tempo discursivo e imagético. Sendo o cinema um suporte com este perfil, acreditamos no conselho de Raymond Fielding sobre o cinejornal conter as "intenções informacionais ou de propaganda e técnicas de uma organização ou governo" ${ }^{138}$ - tendo em mente a primeira opção: a de estar a serviço de uma organização, no caso o próprio político Adhemar de Barros e o seu partido. À tarefa do historiador em lidar com cinejornais, Aldgate aconselha buscar as conexões e interesses que envolveram a sua produção. Afinal, como também coloca o autor, filme é business tanto quanto uma arte em conjunto ${ }^{139}$, inserido no entretenimento de massa e por isso a necessidade de recorrer, durante a investigação, a outras fontes para

\footnotetext{
133 Jacques A. Wainberg, op. cit., p. 159.

${ }^{134}$ Karel Reis e Gavin Millar, op. cit., p. 191.

${ }^{135}$ Siegfried Kracauer, op. cit, p. 322.

${ }^{136}$ Idem, p. 323.

137 Jacques A. Wainberg, op. cit., p. 163.

${ }^{138}$ Raymond Fielding apud Jacques A. Wainberg, op. cit., p. 161.

${ }^{139}$ Cf. Anthony Aldgate, op. cit., p. 14.
} 
melhor aferir o seu conteúdo e o meio em que circulou ${ }^{140}$. Nesse sentido, para a visualidade que buscamos compreender pela análise do BT foi necessário, pelo menos, expandir o corpus documental na tentativa de conectar o seu conteúdo imagético ao trânsito das práticas culturais ao seu redor. Tivemos que ir além de uma análise puramente circunscrita ao BT para tentar esclarecer os "mundos mal conhecidos" ${ }^{141}$ que o circundavam.

Seguimos o exemplo de quem enfrentou semelhante tarefa e prosseguimos com a pesquisa para além das fronteiras da própria película ${ }^{142}$. Porém, a etapa inicial não teve como ser outra: enfrentamos o tédio e assistimos "incansavelmente" ${ }^{143}$, por repetidas vezes, o que estava ao nosso alcance ${ }^{144}$. Feito isso, estabelecemos algumas normas tanto para as análises a serem escritas, como para a identificação e transposição das imagens com as quais teceríamos as considerações mais significativas ${ }^{145}$. E nestas escolhas tentamos, sobretudo, manter a "honestidade" com a fonte e com os possíveis leitores - com a História enfim - fornecendo as imagens possíveis, bem como as localizações de arquivo ${ }^{146}$.

\footnotetext{
${ }^{140}$ Idem, p. 15.

${ }^{141}$ Michel Vovelle. Imagens e Imaginário da História, op. cit., p. 17.

${ }^{142}$ Como Vicente Sánchez-Biosca em seu estudo sobre o cinejornal franquista NO-DO, quando assume para este uma "posição fronteiriça" com outras fontes documentais. Rafael R. Trache e Vicente Sánchez-Biosca. NO-DO: el tiempo y la memoria. Presentación José María Otero. 3. ed. Madrid: Cátedra/Filmoteca Española, 2001, p. 247.

${ }^{143}$ Assim como Vicente Sánchez-Biosca, que também "enfrentou o tédio" ao assistir incansavelmente os cinejornais de Franco. Cf. Rafael R. Trache e Vicente Sánchez-Biosca, op. cit., p. 277.

${ }^{144}$ Foram cinqüenta e cinco números do BT, cujas fichas sistematizadas contendo a decupagem das imagens, o tempo dos assuntos e a localização no acervo da CB se encontram no anexo deste trabalho.

${ }^{145}$ Escolhemos compor as análises dos cinejornais com as imagens fixadas no corpo do texto e com a fala do narrador àquela imagem comentada. Contudo, as explicações se completam com as legendas de cada imagem (que também fazem referência às instituições mantenedoras do respectivo acervo), que por sua vez estarão reproduzidas rigorosamente no sentido da sua seqüência original (não respeitar este princípio, assim como atribuir uma outra fala do narrador à seqüência correspondente, seria ir contra a própria natureza da fonte). Ainda sobre as reproduções, cabe dizer que três tipos de imagens aparecerão: o fotograma digitalizado a partir da própria película em 16 e $35 \mathrm{~mm}$; e a imagem congelada do DVD fornecido pela CB. As imagens do CJB foram, basicamente, retiradas do catálogo organizado pela CB (Cine Jornal Brasileiro: Departamento de Imprensa e Propaganda, 1938-1946. São Paulo: Cinemateca Brasileira / Imprensa Oficial do Estado, 1982). Quanto à descrição propriamente dita, utilizaremos o itálico para certos dispositivos da linguagem cinematográfica como montagem e definição de planos e movimentos de câmera (plano médio, plano geral, panorâmica, etc.), assim como para as falas do narrador que estarão entre " $<>$ " para diferenciá-las das aspas nas citações de texto e entrevistas.

${ }^{146}$ Rafael R. Trache e Vicente Sánchez-Biosca, op. cit., p. 244.
} 

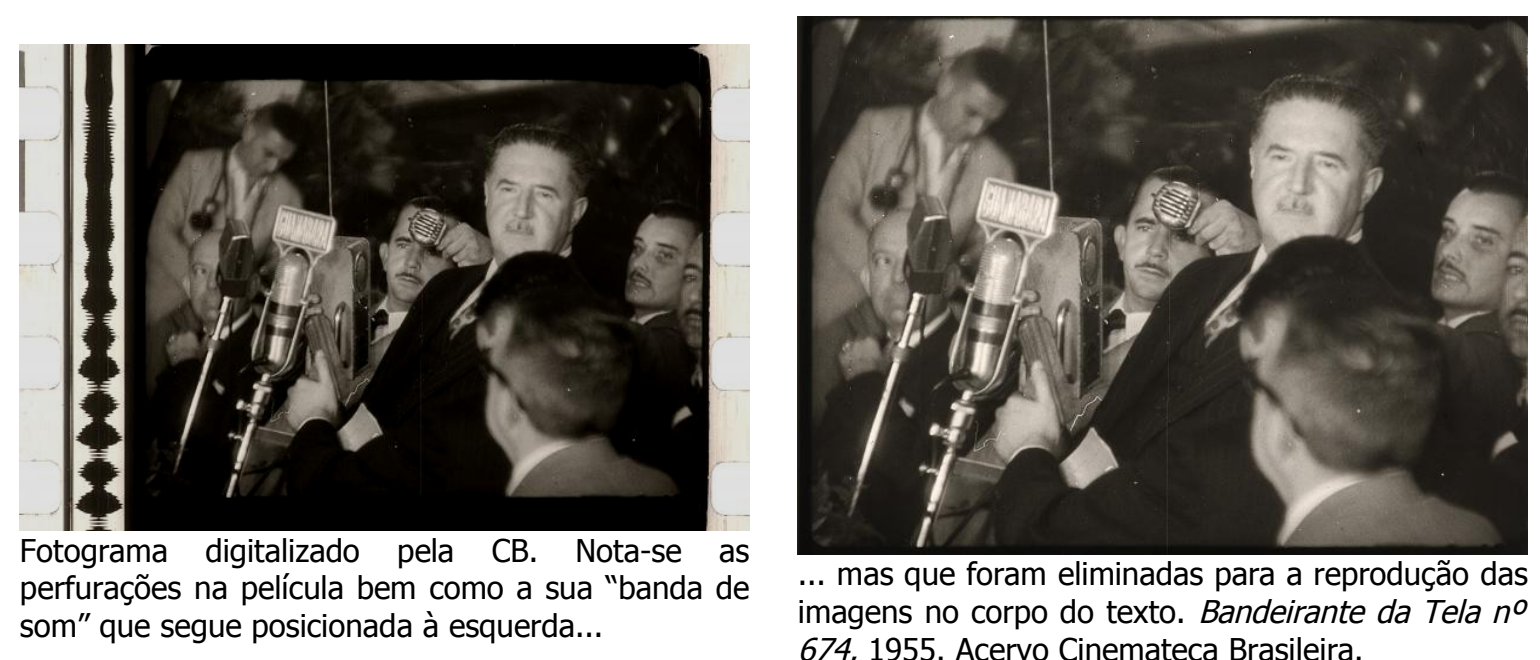

... mas que foram eliminadas para a reprodução das imagens no corpo do texto. Bandeirante da Tela $n^{\circ}$ 674, 1955. Acervo Cinemateca Brasileira.

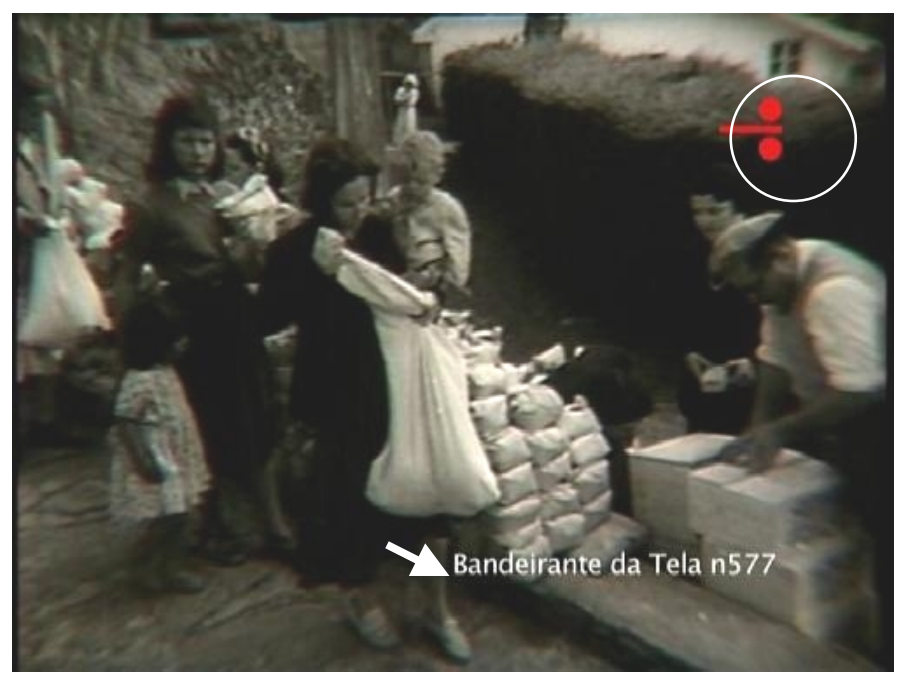

Imagem congelada do DVD. Com uma definição inferior ao fotograma digitalizado, as imagens ainda apresentam legendas do número ao qual pertencem (abaixo à direita) e a logomarca da CB (acima à direita). Bandeirante da Tela no 577, 1954. Acervo Cinemateca Brasileira

Inicialmente, nos detivemos sobre os números disponíveis do BT que traziam à tela o próprio Adhemar de Barros e as principais figuras a ele ligadas: sua esposa dona Leonor Mendes de Barros (ou simplesmente dona Leonor) e os correligionários do PSP, entre eles o mais importante no período, o seu sucessor no governo do estado de São Paulo, Lucas Nogueira Garcez. Mas durante a pesquisa em outros suportes - que corria em paralelo à sistematização do BT - pudemos cercar de maneira mais segura as ligações do político com o meio cinematográfico. Balanços da DCB oficialmente publicados, por exemplo, nos levaram à conclusão de que não só esta empresa correspondia aos interesses de Adhemar de 
Barros, como a mesma era propriedade sua ou de familiares ${ }^{147}$. Provavelmente foi "moeda de troca" nos cálculos da estratégia política adhemarista, influenciando, nesse sentido, direta ou indiretamente o conteúdo veiculado no BT, dependendo dos acordos cavados. Livros, depoimentos e recortes de jornal nos forneceram informações que vão da “ocupação" das instalações do antigo Departamento Estadual de Imprensa e Propaganda de São Paulo (DEIP) ${ }^{148}$ - criado em 1941 durante a interventoria de Adhemar de Barros; passando pelas acusações de um patrimônio alcançado de forma duvidosa na sua segunda passagem pelo poder executivo estadual ${ }^{149}$, até reclames sobre o uso indevido, para fins políticos, do espaço destinado exclusivamente ao cinema nacional ${ }^{150}$. Mediante a todas estas questões, percebemos a inevitável necessidade de assistir, no mínimo, todos os números que estavam disponíveis para consulta.

A partir daí, a pesquisa foi direcionada sobre outros suportes de propaganda política, no sentido de ampliar o nosso horizonte a respeito do que assistíamos naquele ritualismo adhemarista. Ou melhor, como a mensagem contida em outros meios de divulgação dialogavam com o suporte cinematográfico que pretendia atingir um elevado número de espectadores nas salas de cinema - potenciais eleitores. E como a própria linguagem do cinejornal, eventualmente, tensionou as representações contidas nas apostas adhemaristas para se aproximar do eleitorado.

${ }^{147}$ Talvez a mais concreta prova da ligação de Adhemar com a produtora do BT seja o balanço da DCB publicado em 1962, cuja assinatura é a de Adhemar de Barros Filho, na qualidade de "diretor-presidente". "Divulgação Cinematográfica Bandeirante S.A. - relatório da diretoria". Diário Oficial de São Paulo, 23 de fevereiro de 1962. Hemeroteca - Cinemateca Brasileira, pasta 997, doc. 73 (ver anexo 1).

${ }^{148}$ Máximo Barro, professor aposentado no Curso de Cinema da Fundação Armando Álvares Penteado (FAAP); montador de filmes em São Paulo nos anos de 1950 e 1960; e autor de livros como Caminhos e Descaminhos do Cinema Paulista: a década de 50. São Paulo: Máximo Barro, 1997; e A Primeira Sessão de Cinema em São Paulo. São Paulo: Tanz do Brasil, 1996; gentilmente concedeu entrevista para esta pesquisa. Sua história pessoal como espectador e profissional do meio cinematográfico paulista revelam uma experiência enriquecedora de alguém que viveu aquela época. Nesse sentido, comenta que Adhemar de Barros utilizou as próprias instalações do antigo DEIP para montar, no mesmo espaço, a DCB "[...] com os técnicos e tudo (informação verbal)". Entrevista de Máximo Barro, concedida na Biblioteca Faculdade de Comunicação da FAAP, em São Paulo, em 19 de maio de 2005. Fita cassete (45min).

${ }^{149}$ Segundo uma lista de bens materiais "reunidos" durante a sua segunda passagem pelo governo paulista, onde consta a DCB, uma "Empresa cinematográfica que produz jornais e películas de curta metragem" com equipamentos moderníssimos furtados do antigo DEIP. Cf. Francisco Rodrigues Alves Filho. Um Homem Ameaça o Brasil, op. cit., p. 140.

${ }^{150} \mathrm{Em}$ que se pede "Um jornal mais variado, com noticiário de diversos esportes e informações do que vai pelo mundo. Evidentemente não é o da Cinematográfica São Luiz, Campos Filme, Bandeirante da Tela e outras "maravilhas"". "Os jornais cinematográficos não acompanharam a evolução do cinema". A Rua, São Paulo, 05 de outubro de 1955. Hemeroteca - Cinemateca Brasileira, pasta 78, doc. 6. Grifo nosso. 
É interessante notar que alguns trabalhos sobre Adhemar de Barros parecem concordar quanto ao investimento na imagem do político realizador, progressista e filantropo. Como no período da interventoria em que, segundo Marli G. Hayashi,

[...] Adhemar de Barros queria associar sua imagem à de um administrador dinâmico $e$ realizador de grandes obras. Daí a ampla divulgação de empreendimentos como Hospital das Clínicas, as vias Anchieta e Anhanguera e a eletrificação da estrada de ferro Sorocabana. ${ }^{151}$

E como demonstra Regina Sampaio, ao expor as linhas-mestra da propaganda de Adhemar de Barros que se seguiu durante toda sua atuação pelo PSP:

Começava a se criar o mito Adhemar de Barros: de um lado a imagem do administrador ousado e dinâmico e, de outro, a imagem, com ele identificada personalisticamente, do Estado como responsável direto pelo amparo aos mais humildes e sem acesso às estruturas formais do poder. Reforçando esta imagem, surgia a figura de Dna. Leonor como 'símbolo da bondade da mulher brasileira', encabeçando iniciativas de assistência social amplamente divulgadas. ${ }^{152}$

Tais aspectos refletem tanto as apostas adhemaristas representadas no seu cinejornal, como fazem coro com um vasto arsenal de propaganda utilizado para veicular a imagem do político "realizador" e "dinâmico"; assistencialista enquanto o duplo das ações de dona Leonor; o médico de formação, preocupado com a saúde da população; o homem próximo às massas; e o representante uterino do estado paulista: o "bandeirante moderno". Quanto a este e os demais temas, são vários os documentos como "marchinhas" de propaganda política, panfletos, esquetes de rádio (e até televisão) e cédulas partidárias que trabalham este arsenal de representações. Nas campanhas presidências de 1955, por exemplo, Adhemar de Barros assim se dirigia aos ouvintes, no seu programa radiofônico Palestras ao Pé do Fogo:

Caro Patrício,

[...] quem lhe escreve é um homem que costuma levar avante os seus empreendimentos $e$ concretizar suas promessas.

Você conhece, meu caro patrício, o Hospital das Clínicas, por mim construído na capital paulista? Reflita que muitos desses hospitais podem ser construidos nos nossos Estados irmãos, como sentinelas avançadas zelando pela saúde do povo.

${ }^{151}$ Marli Guimarães Hayashi, op. cit., pp. 4-5. Grifo nosso.

${ }^{152}$ Regina Sampaio, op. cit. pp.45-6. Grifo nosso. 
Você já viajou pela Via Anchieta, por nós construida, estrada de concreto, comparável às melhores da Europa e dos Estados Unidos? Rodovia que prorrogamos, depois, para o interior do Estado e do Brasil, com a Via Anhanguera, que já tem perto de cem quilômetros de via calçada? [...] quantas Vias Anchieta e Anhanguera poderão ser construidas por todo este imenso Brasil? Quantas estradas poderão ser rasgadas? Pergunto: o que se fez em São Paulo não pode ser feito para todo o nosso país mudandolhe radicalmente a fisionomia, dando-lhe um novo destino? ${ }^{153}$

Um homem que realiza, "que costuma levar avante os seus empreendimentos", constrói hospitais e rasga estradas enfim, um "bandeirante de uma nova geração" 154 . Hinos, marchas e até baião ${ }^{155}$ de Adhemar de Barros eram cantados exaltando tais feitos, inclusive satirizando as acusações de que era alvo, ao enunciar alguns "crimes do grande líder Adhemar":

Este Bandeirante moderno / Simples e de bom coração! / Não sabe guardar rancor / A todos estende a mão!!! [...] Esquece toda calúnia/ Dele mesmo, ele esquece! / Só não esquece a angústia / Deste povo que padece!!!

“Crimes" como ser esposo da elogiada e respeitável dona Leonor:

[...] Os grandes homens do mundo / Tem grandes companheiras! / Que na hora da borrascal Também sabem ser timoneiras!!! / Entre as damas adoradas / Da história brasileira!/ Leonor Mendes de Barros / Nossa grande pioneira!!!

Ou ser um digno representante da pátria paulista:

[...] São Paulo, locomotiva / Deste pais, céu cor de anil! / Seu filho Adhemar de Barros / Fará um grande Brasil.

Ou mesmo por ser o homem que "põe o paletó de lado" e realiza. E que pode provar tal atitude com seus feitos:

[...] Pôs de lado o paletó / Como só faz o Adhemar / Vendo que já podia / Seu trabalho começar / Vou falar pouca coisa / Do muito que ele fez! / Se não terei que falar / Por muito

\footnotetext{
${ }^{153}$ Texto para locução do programa Palestra ao Pé do Fogo. São Paulo, 1955. Caixa 634, pasta 02, doc. 014 Fundo Adhemar de Barros/APESP. Grifo nosso.

${ }^{154}$ Livreto de músicas "Adhemar de Barros - Bandeirante de uma nova geração", por Jaconias Cristosomo da Silva. São Paulo, s/d. Caixa 631, pasta 02, doc. 016. Fundo Adhemar de Barros/APESP.

155 Livreto de músicas "Parada Musical" pelo Depto. Musical do Comitê Nacional do Partido Social Progressista. Rio de Janeiro, s/d, Caixa 631, pasta 02, doc. 6. Fundo Adhemar de Barros/APESP.
} 
mais que um mês / O Hospital das Clínicas / Um dos maiores do mundo! / Adhemar, idealizou / E fez tudo num segundo!!! / A Rodovia Anchieta / O que há de perfeição! / Vá até lá, veja só!! / Causa admiração!!! / E Campos de Jordão / A Suíça Brasileira! / Adhemar idealizou! / E fez tudo de primeira!!! ${ }^{156}$

Casado com uma mulher exemplar, idealizador e realizador de um dos maiores hospitais do mundo, construtor de estradas que beiram à perfeição... Tais temas, "lugares comuns" no discurso adhemarista, podem ter angariado votos e mesmo soado harmonicamente em marchinhas e panfletos. Porém, até aonde um "novo destino" baseado nas realizações feitas em São Paulo ${ }^{157}$ poderia ser atrativo na encenação de um discurso político que se orgulhava de dar esmolas ${ }^{158}$ e ao mesmo tempo ter construído a "Suíça brasileira" ? O BT traduziu em planos, tomadas efetivas, textos de locução e outros elementos da linguagem do cinema as disparidades da encenação política de Adhemar de Barros. E é uma outra dimensão das tensões desse ritualismo que o cinejornal nos dá a ver.

\section{3 - Antes do filme... Política}

Sobre os anos de 1930, o depoimento de um destacado produtor paulista de cinejornais acerca dos princípios que pautaram a sua relação com a política e com os políticos, nos chama a atenção:

Sai um governo eu estou lá, vendo o que posso fazer com o outro. [...] Com Adhemar de Barros, eu fazia quase um jornal por dia. [...] Político que não acredita em cine-jornal (sic) está destruído [...], pois nós vivemos num país onde as pessoas quase não lêem jornal, nem tem acesso a outros meios de comunicação. Por isso, seja em política seja em publicidade comercial, o cine-jornal é muito importante. ${ }^{159}$

Ainda que deixemos de avaliar a veracidade do depoimento de Primo Carbonari quanto à importância da veiculação cinematográfica frente à imprensa escrita e o rádio

\footnotetext{
${ }^{156}$ Livreto de músicas "Patrícios e patrícias, para vocês eu vou contar! Alguns dos crimes, do grande 'líder Adhemar'!!!”. São Paulo, s/d. Caixa 631, pasta 02, doc. 006. Fundo Adhemar de Barros/APESP. Grifo nosso. (ver anexo 2).

${ }^{157}$ Texto para locução do programa Palestra ao Pé do Fogo. São Paulo, op. cit.

${ }^{158}$ Como nas passagens desta marchinha adhemarista infantil: "Quem é que deu aos pobres tanta esmola? Adhemar! Então se foi Adhemar... é em Adhemar de Barros que vamos votar!". Livreto de marchas "Adhemar - Marcha", Clube infantil Adhemar de Barros. São Paulo, S/d. Caixa 631, pasta 02, doc. 006. Fundo Adhemar de Barros/APESP.

${ }^{159}$ Primo Carbonari, Câmara do Poder. Jornal da Tela, Folha de São Paulo, 29 agosto 1977. pasta 316, doc. 4. Hemeroteca da Cinemateca Brasileira. Grifo nosso.
} 
naquele período ${ }^{160}$, com a abertura democrática em 1946, o mesmo Adhemar de Barros, que fazia "quase um jornal por dia", pareceu se lembrar da importante contribuição do cinema à cena política. A propósito, foi no final da interventoria adhemarista, ocorrida entre 26 de abril de 1938 e 04 de junho de 1941, que se deu a criação do DEIP concebido à imagem e semelhança do DIP - que já possuía o seu cinejornal, o CJB - com o intuito de estender a São Paulo as idéias do Estado Novo ${ }^{161}$. São destes anos, enquanto interventor, o que parece ter sido as primeiras aparições de Adhemar de Barros nas telas de cinema, filmes como Primeiro Aniversário do Estado Novo - São Paulo ${ }^{162}$ e Getúlio Vargas e Adhemar de Barros - Visita a Goodyear ${ }^{163}$, realizado durante a ocasião de uma visita oficial do presidente Getúlio Vargas a São Paulo. Além disso, inúmeros outros registros fílmicos do mesmo período $^{164}$,

${ }^{160}$ Embora algumas considerações nesse sentido sejam necessárias. Sobre o lugar do cinema nacional nos anos trinta e quarenta, Jean-Claude Bernardet nos diz que "[...] Nessa época, o veículo principal era o rádio, o qual não cedeu seu papel para o cinema, mas para a televisão". E continua, "[...] o cinema brasileiro nunca teve um papel preponderante na construção de uma hegemonia ideológica", muito embora o autor não aprofunde o que significa, para ele, "hegemonia ideológica", op. cit., p. 64. Contudo, à "hegemonia ideológica" buscada pela ditadura, por exemplo, não faltaram projetos. E, entre eles, o cinema foi preterido em relação à imprensa escrita e o rádio, como nos mostra José Inácio de Melo Souza. Cf. O Estado Contra os Meios de Comunicação (1889 - 1945). São Paulo: Annablumme: Fapesp, 2003. Por outro lado, não deixa de ser interessante perceber que algumas pesquisas em países como os EUA revelam que $83 \%$ da população preferiu cinemas onde os cinejornais eram mostrados, apesar da enorme onda crítica contra sua superficialidade. Além do quê, este formato possuía um bom alcance sobre a porção semi-alfabetizada da população, dada a capacidade de despertar uma resposta emocional maior que a palavra impressa. Cf. Jacques A. Weinberg, op. cit., pp. 155, 157.

${ }^{161}$ Cumprindo os dispositivos legais do Decreto $\mathrm{n}^{\circ} 11.849$ de 13 de fevereiro de 1941, o DEIP imediatamente passou a controlar os seguintes serviços já existentes na administração estatal: a Diretoria da Propaganda e Publicidade (organizado pelo próprio Adhemar de Barros); o Serviço de Censura e Fiscalização de Teatros e Divertimentos Públicos; o Registro de Jornais, Revistas e Empresas de Publicidade; o Serviço de Turismo. Cf. Silvana Goulart. Sob a Verdade Oficial - Ideologia, Propaganda e Censura no Estado Novo. São Paulo: Marco Zero, 1990, p. 77-8.

${ }^{162}$ Primeiro aniversário do Estado Novo. São Paulo: Garnier Film, 1938. Fita de vídeo (6min32seg), VHS, mudo, p\&b. VV00097. Cinemateca Brasileira.

${ }^{163}$ Getúlio Vargas e Adhemar de Barros - visita a Goodyear. São Paulo: Rossi - Rex Film, 1938-1941. Fita de vídeo (6min14seg), VHS, mudo, p\&b. VV01581N. Cinemateca Brasileira.

${ }^{164}$ Existe, ainda, um terceiro registro composto por um trecho de aproximadamente três minutos, onde Adhemar de Barros recebe a atenção das câmeras numa solenidade em que é anfitrião, seguido da leitura de um discurso pelo mesmo. Apesar de não haver um título específico, nem som, provavelmente seja o discurso de posse da interventoria. [Adhemar de Barros]. São Paulo: 193?. Fita de vídeo (3min), VHS, mudo, p\&b. VV 01560N. Cinemateca Brasileira. Outras informações de títulos (com a existência do material fílmico em verificação) estão disponíveis no site da CB. São eles: A Posse do Novo Interventor Paulista. São Paulo: Garnier Filme Ltda. 1938. Curta-metragem, sonoro, b\&p; A Posse do Novo Interventor em São Paulo. São Paulo: Victor Filme. 1938. Curta-metragem, sonoro, p\&b; O Dr. Ademar de Barros em São Miguel. São Paulo: Garnier Filme Ltda. 1938. Curta-metragem, p\&b; Recepção ao Dr. Adhemar de Barros. São Paulo: Garnier Filme Ltda. 1938. Curta-metragem, sonoro, p\&b; Obras do Hospital de Clínicas de São Paulo. São Paulo: Garnier Filme. 1938. Curta-metragem, sonoro, p\&b; O Interventor em Batatais (São Paulo). São Paulo: Campos, J. Francisco. 1939. Curta-metragem, sonoro, p\&b; Homenagem ao Interventor Federal em São Paulo das Cidades Araraquara e Mirassol. São Paulo: Garnier Filme Ltda. 1939. Curta-metragem, 
produzidos inclusive pelos mecanismos institucionais ${ }^{165}$ como o próprio $\mathrm{CJB}^{166} \mathrm{e} \mathrm{o}$ DEIP jornal ${ }^{167}$, ilustram a atenção que o “jovem” político dispensou à publicidade das suas realizações e a sua imagem pública no cinema. Deste modo, compreendendo a necessidade dos meios de propaganda e conhecendo os seus mecanismos internamente, Adhemar de Barros lançou mão do seu próprio cinejornal no período democrático seguinte, produzindo o BT entre 1947 e 1956.

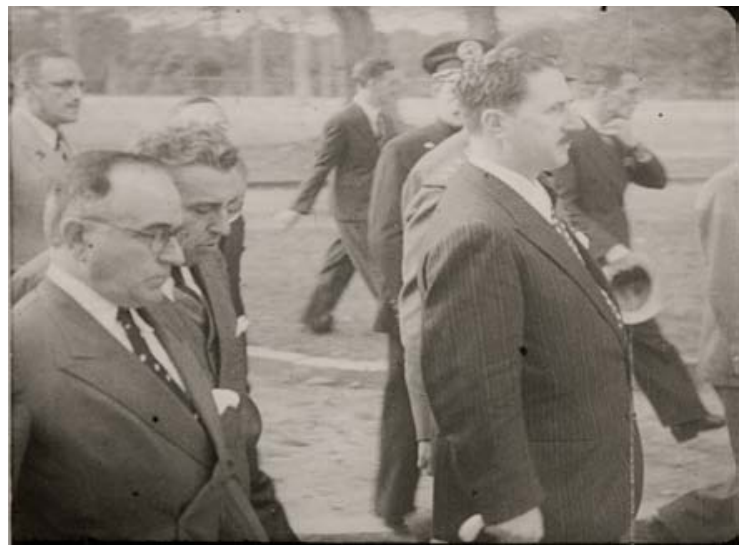

Adhemar de Barros apresenta ao presidente Getúlio Vargas as instalações da Goodyear em São Paulo. Getúlio Vargas e Adhemar de Barros - Visita a Goodyear, 1938. Acervo Cinemateca Brasileira.

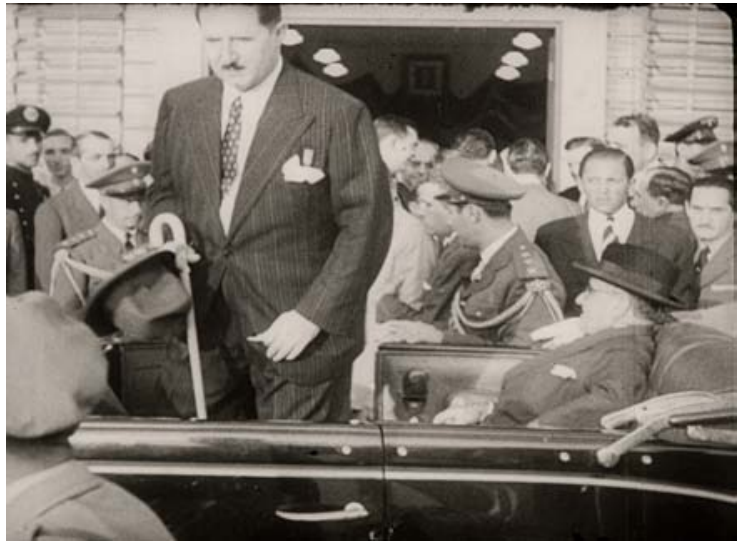

$\mathrm{Na}$ mesma ocasião, Adhemar de Barros e o presidente Getúlio Vargas em carro aberto, Getúlio Vargas e Adhemar de Barros - Visita a Goodyear 1938. Acervo Cinemateca Brasileira.

sonoro, p\&b; Homenagem ao Interventor Ademar de Barros em Santos. São Paulo: Guarani Filme. 1939. Curta-metragem, sonoro, p\&b; Primeiro Aniversário do Governo do Dr. Adhemar de Barros. São Paulo: Garnier Filme Ltda. 1939. Curta-metragem, sonoro, p\&b; Segundo Aniversário do Governo Ademar de Barros. São Paulo: J. F. Campos. 1940. Curta-metragem, p\&b; A Visita do Interventor Adhemar de Barros ao Litoral Norte de São Paulo. Rio de Janeiro: Aurora Filmes. 1941. Curta-metragem, sonoro, p\&b. Cf. $<$ http://www.cinemateca.com.br/>, Acesso em: 16 de ago. 2007.

165 Dois títulos constam no site da CB: Dois Anos de Governo. São Paulo: Diretoria de Propaganda e Publicidade. 1940. Curta-metragem, p\&b; Três Anos de Governo. São Paulo: Departamento Estadual de Imprensa e Propaganda. 1941. Curta-metragem, sonoro, p\&b. Cf. <http://www.cinemateca.com.br/>, Acesso em: 16 de ago. 2007.

${ }^{166}$ Em que Adhemar de Barros, ao lado de Getúlio Vargas, figurou em algumas edições. A exemplo do "Lançamento da Pedra Fundamental do Hospital para Tuberculosos" e "A Primeira Estaca da Ponte das Bandeiras", Cine Jornal Brasileiro $n^{\circ}$ 55, 1939; e "Pacaembu - São Paulo: os trabalhos de construção de um grande estádio", Cine Jornal Brasileiro $n^{\circ} 83$, 1940. Cf. Cinemateca Brasileira. Cine Jornal Brasileiro: Departamento de Imprensa e Propaganda, 1938-1946., op. cit., pp. 9, 98-9.

${ }_{167}$ A respeito deste cinejornal sabe-se, até o momento, que dos 121 títulos informados na base de dados da $\mathrm{CB}$ todos dizem respeito a um período posterior da interventoria adhemarista. Além da inexistência do material para pesquisa. Cf. <http://www.cinemateca.com.br/>, Acesso: 16 de ago. 2007. Também sobre o DEIP Jornal, cf. Fernão Ramos e Luiz Felipe Miranda, op. cit., p. 134. 


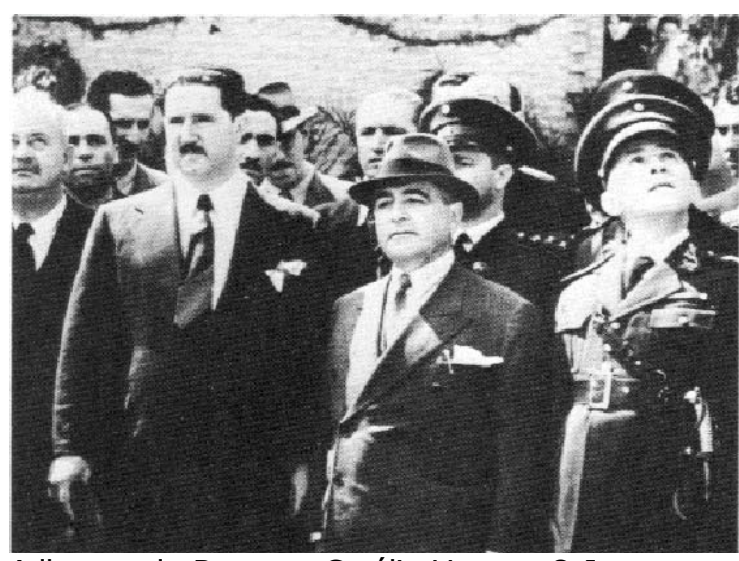

Adhemar de Barros e Getúlio Vargas. O Interventor e o presidente posam para as câmeras do CJB, na ocasião da "Primeira Estaca da Ponte das Bandeiras" em São Paulo. Cine Jornal Brasileiro no 55, 1939. Acervo Cinemateca Brasileira.

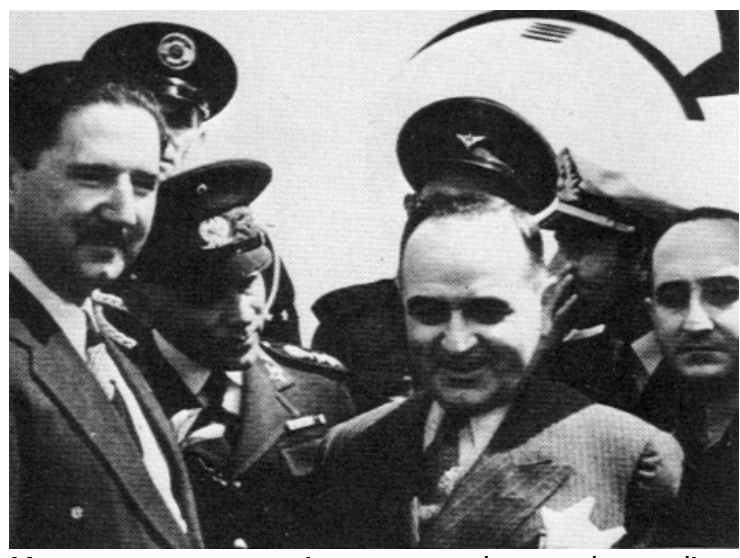

Momentos antes, o interventor do estado paulista recepciona o presidente da República no então "Campo de Congonhas", na cidade de São Paulo. Cine Jornal Brasileiro no 55, 1939. Acervo Cinemateca Brasileira.

Após a interventoria, Adhemar de Barros conduziu sua carreira política pautando-se pela montagem e manutenção de sua própria máquina partidária, o PSP, assim como o constante investimento em propaganda, buscando contribuições em contextos distantes, a exemplo das suas conversas radiofônicas "Palestra ao Pé do Fogo" 168, evidentemente inspiradas na "Conversa ao Pé da Lareira" do presidente norte-americano Franklin Roosevelt ${ }^{169}$. Aliás, consta numa delas a definição por Adhemar de Barros, no penúltimo ano do mandato como governador, sobre o que significava ser "populista":

[...] ser populista, para nós, é dar à função social do estado uma amplitude que não teve até agora. É governar dando oportunidade a todos e procurando elevar cada um de acordo com suas possibilidades, porém, amparando cada um de acordo com suas necessidades. ${ }^{170}$

\footnotetext{
${ }^{168}$ Que eram transmitidas diariamente para todo o estado paulista, segundo Mário Beni, correligionário e amigo de Adhemar de Barros. Por mais saudosista e maniqueísta que pareça, seu depoimento nos dá uma idéia do que tenham sido tais transmissões: "[...] naquela época não havia televisão, havia apenas transmissões pelo rádio. Todas as noites, às sete horas, ele tinha uma palestra com o povo de São Paulo, uma conversação íntima, todas as noites, inclusive sábado e domingo. Chamava 'Palestra ao Pé do Fogo' e os que tinham rádio, de qualquer maneira, em todo o interior, ouviam aquela conversa muito amigável dele. Isto fez a época, ele tinha aquela conversa de caboclo franco, não um discurso inflamado não... falava a linguagem deles... falava errado até. Era uma novidade, nunca houve isto, foi dai que surgiu o termo populismo, quer dizer, nós descermos à linguagem do povo para que ele entendesse. E ele foi um pioneiro neste sentido, por isso criou esse carisma". Mario Beni apud Regina Sampaio, op. cit. p. 45. Grifo nosso. Essa versão de Mário Beni também é contada numa chave "pitoresca" sobre a trajetória de Adhemar, em Carlos Laranjeira. Histórias de Adhemar, op. cit., p. 27.

169 Jacques A. Weinberg, op. cit., p.153.

${ }^{170}$ Palestra radiofônica transcrita do jornal $O$ dia, de 13 de maio de 1949 apud Regina Sampaio, op. cit. p. 68.
} 
Para alguém que se julgava "populista" porque que atendia a população de acordo com as "possibilidades" de cada cidadão, o cinejornal de Adhemar de Barros oferece subsídios para se pensar como um discurso político, pelo cinema, uniu essa proposta populista às imbricações de interesses políticos e privados, mexendo com os ânimos do meio cinematográfico.

Adhemar de Barros assumiu, de fato, o exemplo de Getúlio Vargas quanto à necessidade de uma forte propaganda ${ }^{171}$, inclusive pela proximidade no formato do BT com o CJI e o CJI, onde tanto as notícias da Agência Nacional como o próprio presidente da República estiveram presentes nas telas do cinejornal adhemarista. Porém, o líder do PSP, por mais que alianças fossem feitas e desfeitas ${ }^{172}$, nunca chegou próximo da força varguista. Pois o seu projeto nacional - se é que tinha um - nunca se realizou, quando muito a promessa de um futuro no âmbito regional - dado os reveses que tanto o político como o partido sofreu durante a década de 1950. Desta forma, acreditamos ser impossível esgotar o adhemarismo pela análise dos seus cinejornais ${ }^{173}$, mas confiamos numa análise reveladora das representações políticas que, através do cinema, dialogaram com o espectador correspondendo ou tensionando as aspirações do momento. Numa chave em que a política e o cinema estiveram

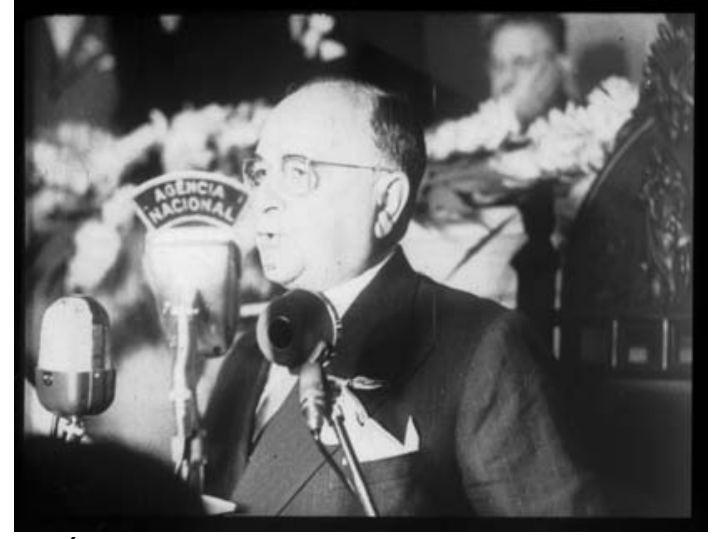

Getúlio Vargas numa solenidade registrada pelo BT. as telas do BT. Bandeirante da Tela no 501, 1952. Acervo Cinemateca Brasileira.

\footnotetext{
${ }^{171}$ Não estamos, neste trabalho, promovendo uma análise sobre as películas getulistas, suas referências são pontuais e servem apenas para balizar algumas análises desenvolvidas exclusivamente para o BT. Ao contrário, existem trabalhos como o de José Inácio de Melo Souza. O Estado Contra os Meios de Comunicação, op. cit., que promovem este tipo de abordagem. E outros mais recentes, como nos parece ser a proposta de Cássio dos Santos Tomain. Janela da alma: cinejornal e Estado Novo, fragmentos de um discurso totalitário. Franca, 2004. Dissertação apresentada ao Departamento de História da Faculdade de História, Direito e Serviço Social da UNESP.

${ }^{172}$ Lembrando que uma aparente "contradição" verificada nas apostas e nos discursos políticos pode refletir as incoerências ou ambigüidades "postas pelo real". Cf. Pedro César Dutra Fonseca. Vargas: O Capitalismo em Construção. São Paulo: Brasiliense, 1999, p. 325.

${ }^{173} \mathrm{O}$ que prescindiria um trabalho de muito mais fôlego. Com uma prospecção mais detalhada e realizada por uma equipe de profissionais num tempo bem maior. Como o trabalho realizado pela $\mathrm{CB}$ que resultou no catálogo publicado em 1991 (Cinemateca Brasileira. Bandeirante da Tela., op. cit.) e que está na base das nossas incidências temáticas e ocorrências para determinados eventos, visto nossa sistematização estar por demais reduzida pelo fato de ter sido feita sobre apenas cinqüenta e cinco números do BT.
} 
efetivamente ligados, participando ativamente da recém democracia. Tais incursões investigativas parecem deixar bem claro o fato de que em 1962, após recente gestão como prefeito da capital paulista, e há doze anos afastado do Palácio dos Campos Elíseos ${ }^{174}$, Adhemar Pereira de Barros ser homenageado em seu retorno ao executivo do Estado por cerca de quarenta empresas paulistas do ramo de cinema. Talvez uma manifestação de "boas vindas" publicada em um jornal de considerável circulação ${ }^{175}$ teria sido apenas deferência àquele com quem uma certa categoria de profissionais trataria suas questões nos próximos anos. Por outro lado, e considerando a trajetória política de Adhemar de Barros, teria sido o reflexo de uma aproximação anterior, existente entre este político e o meio cinematográfico?

\footnotetext{
${ }^{174}$ No período entre 08.04.1957 e 07.04.1961 exerceu o cargo de prefeito da capital; sua última gestão como governador, até então, havia sido entre 14.03.1947 e 31.01.1951.

175 "Nossas homenagens ao governador eleito". Diário de São Paulo, 24.11.1962, p. 5. Hemeroteca Cinemateca Brasileira, pasta 106, doc.1. (ver anexo 3).
} 


\section{II - EM CENA, A POLÍTICA QUE ENCENA}

\section{1 - O cinejornalismo na cinematografia nacional}

Por não ser filme de enredo, um provável "lugar" para o cinejornal na historiografia do cinema brasileiro estaria no que já foi escrito acerca dos "complementos nacionais" onde se inserem também documentários institucionais e os curtas-metragens propagandísticos. Portanto, um possível ponto de partida para este tema podem ser algumas poucas, e boas, reflexões realizadas na década de 1970.

Autores como Paulo Emílio externaram sua preocupação com a carência de discussões sobre os filmes documentais, existentes desde os primórdios do cinema brasileiro $^{176}$. Numa tentativa de resgatá-los enquanto matéria-prima para eventuais interpretações da nossa sociedade, o autor verifica que duas categorias de discursos sobressaem, como já sugerido na primeira parte deste trabalho. Primeiramente, o culto das belezas naturais de várias regiões do Brasil, principalmente a então capital federal, Rio de Janeiro, numa espécie de elogio ao "berço esplêndido". E, em segundo lugar, um outro tipo de elogio envolvendo autoridades e grandes personalidades (notadamente o presidente da República) e que posteriormente se estendeu às datas comemorativas, configurando uma espécie de "ritual do poder". Num recorte bibliográfico a respeito dos complementos nacionais, identificamos serem estes os primeiros apontamentos sobre uma lacuna na história do cinema no Brasil.

Tal "descaso" para com o complemento nacional também foi discutido por outros autores. Jean-Claude Bernardet ${ }^{177}$, ao propor algumas linhas de pesquisa para uma história do cinema nacional, atenta para as práticas que circundaram a produção de filmes em determinados períodos. Entre elas, uma forma particular e muito comum de angariar recursos com a produção de documentários e cinejornais voltados aos interesses de quem os patrocinava: a cavação, um modelo de produção que permeou o meio cinematográfico das primeiras décadas do século passado ${ }^{178}$. Nesse sentido, o autor conclui que a ausência de

\footnotetext{
${ }^{176}$ Cf. Paulo Emílio. “A Expressão Social dos Filmes Documentais no Cinema Mudo Brasileiro (1898 1930)", op. cit., pp. 323-328.

177 Cf. Jean-Claude Bernardet, Cinema Brasileiro..., op. cit.

${ }^{178}$ Em que, segundo o próprio autor, Primo Carbonari, o Canal 100, e os documentários de Jean Manzon: "são simples prolongamento dessa fase", seguidos nas décadas de 1940, 50 e 60. Ibidem, p. 26.
} 
estudos mais calcados na realidade concreta do cinema no Brasil é a causa direta do desprezo às cavações. $\mathrm{O}$ que também se verifica nos livros de história do cinema brasileiro: mais preocupados em contar a história do filme de ficção ${ }^{179}$. Contrário a um certo tipo de discurso histórico, Bernardet coloca em xeque toda uma historiografia cuja tendência foi aplicar, sem crítica, um modelo de história elaborado para os países industrializados, com uma produção cinematográfica efetivamente sustentada pelo cinema de ficção. Trata-se da crítica a uma certa historiografia, idealizada, do cinema nacional e que o autor retoma em outros trabalhos ${ }^{180}$. Dentre as suas principais preocupações, está a urgência em se pensar uma história fora da periodização por ciclos, distante dos marcos estabelecidos pela realização dos cineastas, e que se relacione com as etapas do processo de produção do nosso cinema (a difusão, a exibição, o relacionamento com o Estado e a participação do público). Tais críticas recaem, sobretudo, no estabelecimento de uma periodização construída por colapsos, por quedas, que se coadunam "com a Idade de Ouro e a utopia" ${ }^{181}$.

No entanto, para além da crítica epistemológica, é com o trabalho de Maria Rita Galvão que avançamos numa "visão de dentro" do processo de produção do cinema em São Paulo, ocorrido nas primeiras décadas do século passado. Baseando-se em depoimentos de antigos profissionais do meio ${ }^{182}$, a autora contribuiu em níveis diferenciados. Metodologicamente, a autora é pioneira em lançar mão das fontes orais à história do cinema brasileiro, delimitando tanto o objeto quanto o alcance de suas análises logo nas primeiras páginas do seu trabalho:

O cinema que se tem é de uma mediocridade atroz - mediocre nos meios, na forma, no conteúdo, na repercussão (ou na ausência dela). No entanto, o que é extraordinário, este cinema existiu. Importa pouco o mérito da questão, e entrar em considerações estéticas não teria o menor sentido. Parece-me que a única coisa que tem sentido é constatar esta existência, e tentar compreender as circunstancias em que ela se tornou possível $^{183}$.

\footnotetext{
179 "Com exceção de Maria Rita Galvão [...] e Paulo Emílio [...], os historiadores não reconhecem que o que sustentou a produção local não foi o filme de ficção", mas (seguindo o raciocínio do autor) os documentários e os cinejornais. Ibidem, p. 28.

${ }^{180}$ Cf. Jean-Claude Bernardet. Historiografia Clássica do Cinema Brasileiro. São Paulo: Annablume: Fapesp, 1995.

${ }^{181} \mathrm{Cf}$. Ibidem.

182 "Procurava obter uma visão 'de dentro' do cinema paulista, durante o período considerado. Buscava informações que ajudassem a melhorar a nossa compreensão do processo e das pessoas", Maria Rita Galvão. Crônica do Cinema Paulistano. São Paulo: Ática, 1975, p. 9. Grifo nosso.

${ }^{183}$ Ibidem, p. 11. Grifo nosso.
} 
Na geração de um conhecimento histórico novo, seus resultados foram igualmente valiosos, pois descerraram um meio cinematográfico paulista reconstituído, principalmente, pelos caminhos seguidos por pioneiros como Francisco Serrador (espanhol e cinegrafista ambulante, dono da primeira sala de exibição fixa em São Paulo); Gilberto Rossi (italiano e o primeiro cinegrafista profissional surgido em São Paulo - conforme a própria autora) e José Medina (brasileiro descendente de espanhóis e fundador, juntamente com Gilberto Rossi, da Rossi Film). Da mesma forma, a autora discorre sobre as primeiras projeções e exibições em São Paulo - esporádicas e sempre acompanhadas de outro tipo de diversões. Além de informar sobre as primeiras investidas de filmes de enredo e esclarecer alguns pontos sobre o desenvolvimento do mercado cinematográfico, bem como a relação do público com o espetáculo - precário nos primeiros tempos, mas aos poucos se generalizando por todo o conjunto da população e entrando, definitivamente, nos hábitos da cidade ao assumir o posto de diversão mais importante, desbancando circos, cafés-concerto, teatros, serões, etc.

Quanto aos recursos possíveis à produção cinematográfica deste período, sobressaise a prática da cavação ${ }^{184}$, inserida que estava num meio cinematográfico pouco voltado ao filme de enredo e tomado por documentários, jornais cinematográficos e um cinema de propaganda - constituído quase que exclusivamente de propaganda política e comercial ${ }^{185}$. Ou seja, na constatação de uma certa produção cinematográfica nos anos vinte, já se verificam as raízes de um mercado cinematográfico paulista propício, no mínimo, aos complementos nacionais que circularam décadas depois. E a respeito desse cenário dos cinejornais cavados nas primeiras décadas do século XX, também nos fala José Inácio de Melo Souza:

Destituidos de mercado interno, a circulação dos filmes era restrita ao local de produção, com rendimento financeiro mediocre. À falta de amplidão nos negócios desembocava na cavação como forma de escape à existência calamitosa [...] A cavação cinematográfica acompanha o perfil baixo do cinema brasileiro. Era miúda, simplória. Fazendeiros e suas posses, cidades do interior, tornaram-se alvos diretos [...] Entretanto, o dinheiro pingava

\footnotetext{
${ }^{184}$ Ibidem, pp. 20-6, 37-8, 4-5.

${ }^{185}$ Ibidem, p. 29.
} 
certo e constante quando se conseguia uma subvenção do governo. Um conto de réis por mês [...] para uma produção de quatro números de cinejornal, era algo fabuloso. ${ }^{186}$

Um período posterior na produção paulista também foi o foco de Galvão ${ }^{187}$. A década de 1950, anos de extraordinária animação na prática e no pensamento cinematográfico esteve, de início, "sob o estímulo da produção industrial, e em seguida na tentativa de compreensão do seu fracasso", ${ }^{188}$. Nesse período de efervescência sobre o que se pretendia para um cinema brasileiro "de qualidade", opiniões transitavam entre a industrialização em padrões internacionais (leia-se hollywoodiano) e um modelo "independente", arraigado numa ideologia nacionalista e desenvolvimentista com o incentivo e proteção do Estado ${ }^{189}$. Tratava-se, segundo a autora, de um "período de gestação de temas", com mesas redondas e congressos no início dos anos de $1950^{190}$, primeiramente realizados em São Paulo, depois estendidos ao Rio de Janeiro ${ }^{191}$. Apesar de toda a discussão em torno de um "cinema ideal", calcado na idéia de um "nacional" e um "popular" 192 capaz de alçá-lo à categoria de manifestação artística condizente com uma imagem de progresso, compensando e ocultando o nosso subdesenvolvimento ${ }^{193}$, ou numa coloração mais ideológica de um nacionalismo à esquerda, pretendendo uma manifestação representativa crítica de nossa realidade histórica, intervindo nela mesma ${ }^{194}$. Fato era que o cinema brasileiro, àquela altura, "além de estar à procura de sua forma e sua verdade, estava ainda à procura de seu público, de um mercado que não lhe pertencia" ${ }^{195}$, pois estava dominado pelo cinema estrangeiro.

\footnotetext{
${ }^{186}$ José Inácio de Melo Souza. O Estado contra os meios de comunicação (1889 - 1945), op. cit., p. 29. Cf. também _. Ação e o Imaginário de uma Ditadura: controle, coerção e propaganda política nos meios de comunicação durante o Estado Novo. 1990. Dissertação (mestrado em Comunicações) Escola de Comunicações e Artes, USP, São Paulo. As citações e referências utilizadas estão baseadas na publicação recente.

187 Maria Rita Galvão. "O desenvolvimento das idéias sobre cinema independente" In: Cinemateca Brasileira. Trinta anos de cinema paulista: 1950-1980. São Paulo, 1980. pp. 13-23.

${ }^{188}$ Ibidem, p. 13.

${ }^{189}$ Ibidem, p. 21.

${ }^{190}$ Ibidem, p. 14.

191 Cf. José Inácio de Melo Souza. "Os Congressos de Cinema" In Congressos, Patriotas e Ilusões e Outros Ensaios de Cinema. São Paulo: Linear B, pp. 9-121.

${ }^{192}$ Maria Rita Galvão e Jean-Claude Bernardet. Cinema, Repercussões em Caixa de Eco Ideológica: as idéias de "nacional" e "popular" no pensamento cinematográfico brasileiro. São Paulo: Brasiliense, 1983. (O Nacional e o Popular na Cultura Brasileira, Cinema), p. 36.

${ }^{193}$ Ibidem, pp.38-9.

${ }^{194}$ Maria Rita Galvão, O desenvolvimento..., op. cit., p.23.

${ }^{195}$ Ibidem, p. 23.
} 
Não entender esse problema parece ter sido umas das causas, senão a principal, do malogro da única tentativa de concretização do mito da indústria cinematográfica pela elite paulista no início dos anos de 1950, com a criação da Companhia Cinematográfica Vera Cruz $^{196}$. Algo sintomático de uma necessidade muito mais voltada ao consumo de padrões culturais dos países desenvolvidos, do que pelo amadurecimento de uma consciência cinematográfica dentro das limitações do campo cinematográfico nacional. Nesse sentido buscou-se, antes,

O pleno domínio de uma atividade industrial tão complexa [que] seria ao mesmo tempo a demonstração de desenvolvimento paulista, e um meio de divulgar à nação $e$ ao mundo a nossa capacidade, o nosso dinamismo e a nossa cultura. ${ }^{197}$

Não podendo romper, ao menos fazer algo totalmente diferente do que julgavam existir de mais degradante na produção cinematográfica nacional: os complementos nacionais e a produção de rápida realização e de retorno financeiro relativamente fácil, as chanchadas produzidas no Rio de Janeiro. Ou seja, romper com a baixa qualidade nem que para isso fosse necessário recomeçar do zero ${ }^{198}$.

Porém, ao buscar soluções e horizontes com os olhos para o exterior, o resultado foi a indiferença às conquistas obtidas junto ao Estado, fruto da continuidade de uma produção cinematográfica tida de "baixa qualidade". Pois como nos lembra a autora:

[...] foi graças à produção carioca que se conseguiu um volume de filmes suficientemente grande para pressionar uma legislação cinematográfica. O decreto-lei $n^{\circ} 1949$, que estabelece a obrigatoriedade de exibição de longas-metragens nacionais durante sete dias por ano, entra em vigor no início dos anos 40, e em 46 a obrigatoriedade de exibição é triplicada. Com todos os problemas de distribuição e exibição que a Vera Cruz possa ter enfrentado depois, assim mesmo ela já contava com uma legislação mínima que obrigava todos os cinemas do território nacional a exibirem filmes brasileiros durante 21 dias por ano (assim como no próximo aumento, o célebre 'um em oito' de 1952, a pressão da própria produção paulista seria fundamental). ${ }^{199}$

Além do que, a primeira lei para o cinema nacional foi promulgada em 1932 (decreto 21.240/32) - entrando em vigor apenas em 1934 - e tinha como objetivo a

\footnotetext{
${ }^{196}$ Cf. Maria Rita Galvão. Burguesia e Cinema: O Caso Vera Cruz. Rio de Janeiro: Civilização Brasileira, 1981.

${ }^{197}$ Ibidem, p. 13. Grifo nosso.

${ }^{198}$ Ibidem, p. 42.

${ }^{199}$ Ibidem p. 43..
} 
obrigatoriedade de exibição de complementos nacionais ${ }^{200}$. Retomamos aqui a crítica de Bernardet, em que a forma de se encarar o cinema nacional apenas focando o estágio da produção, ou melhor, "as realizações do autor", impediu um olhar crítico sobre as dificuldades da estruturação de um mercado que absorva tais produções. E por esse caminho, o discurso histórico parece ter reproduzido essa visão:

[...] chegando à primeira cópia, considera-se que o essencial está feito. O discurso histórico está calcado nesta filosofia, que parece esgotada. Por estar grandemente dependente dela, se vê na impossibilidade de analisá-la e de compreender por que se esgotou. [...] A crise da produção leva de roldão o discurso histórico. ${ }^{201}$

Acreditamos que esse rápido "passeio" pelas discussões de P.E.S. Gomes e JC. Bernardet e a visita aos textos de Galvão contribuem no esclarecimento de um contexto cinematográfico carente em vários aspectos: como a competição com a fita estrangeira, a briga do cinema nacional com os distribuidores e exibidores, a fragilidade e a pouca receptividade do mercado interno, e a falta de uma melhor legislação.

Contudo, raros trabalhos investigaram questões ligadas à estrutura do mercado cinematográfico brasileiro, bem como o espaço nele existente para a fita nacional. E da mesma forma, o potencial de análise histórica que o cinejornal oferece - um tipo de complemento fartamente presente no espaço dedicado aos curtas-metragens nacionais. Nestes flancos destacam-se, respectivamente, os trabalhos de Anita Simis ${ }^{202}$ e de Melo Souza ${ }^{203}$.

Em seu livro, Simis estuda as aproximações entre o cinema e a esfera estatal num paralelo com a nossa história política, indo da Era Vargas (1930 a 1945) ao contexto da redemocratização pós-1946, do pré-golpe de 1964 ao início do regime militar, até a criação do Instituto Nacional do Cinema em 1966. Com o enfoque sobre tópicos que influenciaram as leis de cinema e os seus desdobramentos, a autora se baseou em dados oficiais (atas de congressos, documentos institucionais, anais da Câmara dos Deputados e da Câmara Municipal de São Paulo), assim como em jornais e revistas para aprofundar a pesquisa ${ }^{200}$ Cf. Maria Rita Galvão e Carlos Roberto de Souza em "Cinema Brasileiro: 1930 - 1964" In Boris Fausto (org.). O Brasil republicano, v. 3: economia e cultura (1930-1964). São Paulo: Difel, 1984. (História Geral da Civilização Brasileira; t. 3, v. 3.), pp. 463-500

${ }^{201}$ Jean-Claude Bernardet. "Acreditam os Brasileiros nos seus mitos? - O Cinema Brasileiro e Suas Origens" In Jean-Claude Bernardet. Historiografia Clárssica do Cinema Brasileiro, op. cit., p. 22.

${ }^{202}$ Anita Simis. Estado e Cinema no Brasil. São Paulo: Annablume/Fapesp, 1996.

${ }^{203}$ José Inácio de Melo Souza, O Estado contra os meios de comunicação, op. cit.. 
sobre o monopólio do produto estrangeiro no mercado distribuidor; sobre a prática da cavação; e até mesmo a assiduidade do público em geral, aferida pela quantificação das salas e o tabelamento das entradas.

Resumindo, a autora traça um panorama para além da constatação do cinema como o mais freqüentado meio de diversão popular $^{204}$ e se detém num estudo sobre o espetáculo cinematográfico no Brasil. Em que o filme, juntamente com a distribuição, a exibição e o seu público, compõe uma prática cultural voltada às massas. Trata-se, também, de uma análise sobre como essa prática cultural, encarada como propaganda pelo Estado Novo, havia sido investida de um potencial "pedagógico" pelos projetos governamentais nos anos trinta, haja vista a criação do Instituto Nacional do Cinema Educativo. E que, no limite, impulsionou uma legislação pouco correspondente às necessidades do cinema nacional ${ }^{205}$, deixando resquícios para além da reabertura democrática, marcando profundamente os caminhos seguidos pela prática cinematográfica brasileira, onde persistiu um paternalismo traduzido na

[...] fiscalização quanto ao cumprimento da obrigatoriedade de exibição, regulamentação do comércio dos filmes brasileiros no mercado nacional com a instituição do pagamento mínimo para os produtores brasileiros e para os distribuidores, obrigatoriedade de exibição de um longa-metragem por ano e até barateamento e facilidades de transporte para os filmes ${ }^{206}$.

Ou seja, uma série de "paliativos possíveis conquistados pelos produtores" 207 que legitimaram a intervenção estatal ao criarem um mercado cinematográfico cada vez mais assistido e dependente.

No período entre 1930 até 1966, verificado pela autora, foram os complementos nacionais - principalmente os cinejornais - quem mais mantiveram uma continuidade segura, apesar das oscilações em relação a sua produção e exibição, pois transitaram num

\footnotetext{
${ }^{204}$ Anita Simis, op. cit. p. 195.

${ }^{205}$ Com o desinteresse das produtoras privadas, o cinema educativo, "[...] utilizado como fonte de transmissão de conhecimento e formação de mentalidade [...] passou a ser apresentado como proposta alheia aos problemas da produção privada". Posteriormente ao ano 1937, quando criado o INCE, delineou-se um novo arranjo institucional na política cultural com o a criação do DIP, em 1939: "[...] a política cinematográfica separou-se da esfera educativa e canalizou as reivindicações corporativas para o Conselho Nacional de Cinematografia, consolidando o Estado como árbitro". Conselho este que, congregando a categoria de produtores de cinema, buscava concessões legais e medidas protecionistas, confiando plenamente ao Estado a regulamentação e solução dos problemas. Ibidem p. 280-81. Grifo nosso

${ }^{206}$ Ibidem, p. 281.

${ }^{207}$ Ibidem.
} 
nicho que não era dominado pela fita estrangeira. A exemplo de São Paulo, que durante a existência do DIP e o seu CJB obteve uma exibição superior de cinejornais privados em relação aos oficiais $^{208}$. Dado este importante, pois no mínimo corrobora com a grande produção e circulação deste gênero cinematográfico, como levantado por Galvão no início do século $\mathrm{XX}$, e a sua continuidade nas décadas posteriores. Vale ainda observar que o próprio Estado, com os seus cinejornais, foi forte concorrente pelas cotas de exibição do complemento nacional:

O DIP começa a produzir documentários e jornais cinematográficos, e com a produção oficial institucionalizada, as produtoras independentes perdem boa parte do seu mercado. Além da concorrência desigual, têm de enfrentar censura sistemática. Alguns produtores e cinegrafistas conseguem transformar-se em funcionários públicos, filmando diretamente para o DIP, ou para suas agências estaduais, mas a maior parte é marginalizada. ${ }^{209}$

As relações entre o Estado e os meios de comunicação também estão contempladas nas análises de Melo Souza, num período que se estende da primeira república até o Estado $\mathrm{Novo}^{210}$. Resumidamente, podemos dizer que o autor promove um raio-x do DIP ao delinear a importância das divisões que o constituía ${ }^{211}$, bem como avaliar os enfrentamentos nele ocorridos ${ }^{212}$. Além deste enfoque central, neste mesmo trabalho o autor apresenta inovações no resgate histórico ao lançar mão de cinejornais, trabalhando diretamente o artefato fílmico ${ }^{213}$ e elaborando um ferramental metodológico de pesquisa ${ }^{214}$.

\footnotetext{
${ }^{208}$ Ibidem, pp. 308-10.

${ }^{209}$ Maria Rita Galvão e Carlos Roberto de Souza, op. cit., pp.472-3.

${ }^{210}$ Cf. José Inácio de Melo Souza. O Estado contra os meios de comunicação (1889 - 1945), op. cit. .

${ }^{211}$ São elas, as Divisões de Divulgação, de Rádio, de Turismo, de Imprensa, e de Cinema e Teatro.

212 Se a incumbência deste órgão foi divulgar uma nação una, dentro do governo ele sofreu, e também promoveu, enfrentamentos por busca de espaço com outros ministérios, a exemplo da disputa entre o ministro da Educação e Saúde Gustavo Capanema e Lourival Fontes (diretor do DIP em 1940). O primeiro, defensor do Instituto Nacional do Cinema Educativo (INCE, idealizado em 1936 e oficializado em 1937) e da proposta de filmes educativos como elemento de aprendizado e integração nacional. Para o diretor do DIP, o mesmo objetivo seria alcançado com cinema pela propaganda claramente inspirada no exemplo nazista. Cf. José Inácio de Melo Souza, op. cit.

${ }^{213}$ Como pesquisador da CB, José Inácio de Melo Souza colaborou na catalogação e sistematização não só do CJB do DIP, mas também de outros cinejornais como o próprio BT e o CJI da AN. Cf. Cinemateca Brasileira, Cine Jornal Brasileiro: Departamento de Imprensa e Propaganda, 1938-1946, op. cit.; __. Catálogo do Acervo de Filmes: Longas-metragens Nacionais, Cine Jornal Informativo, Curtas-metragens Nacionais produzidos entre 1934-40. São Paulo: Cinemateca Brasileira, 1987; Bandeirante da Tela... op. cit.; Cinejornal Brasil Hoje. São Paulo: Cinemateca Brasileira, 1994.

${ }^{214} \mathrm{Em}$ que o próprio autor reconhece os limites do material fílmico que se tem em mãos, justamente pela fragilidade do estado em que se encontra o suporte sobrevivente: “[...] certamente foram filmados mais do que os 146.184 metros lineares de película computados até agora, dos quais a Cinemateca Brasileira salvou
} 
Ao estudar detidamente a Divisão de Cinema e Teatro do DIP, Melo Souza verifica que a principal incumbência deste órgão, além da censura cinematográfica, foi a produção do CJB, cuja mensagem levada ao público comportou temas como o "trabalhador brasileiro", o "líder nacional" entre outros. Representações que contribuíram à "manipulação dos trabalhadores pelo regime e a transformação de Vargas no homem providencial / pai dos pobres", conclui o autor ${ }^{215}$. Nesse sentido, "manipulação" e o uso de uma certa "mitologia" foram as principais linhas de força num mundo criado (realidade construída) pelo Estado Novo. Um verdadeiro cenário para o desenvolvimento de um "ritual" característico do governo estadonovista, onde desfilaram tanto Getúlio Vargas, o chefe supremo, como as Forças Armadas (Exército, Marinha, Aeronáutica e as forças auxiliares: Forças Públicas Estaduais e Corpo de Bombeiros, por exemplo), “dois poderes territoriais e encontráveis em todos os quadrantes da nação", exprimindo a vontade de abarcar por duas vias a unidade, em que

A representação desta busca é dada pelas imagens da presença das Forças Armadas em todo o território nacional, freqüentemente combinadas com a presença de Vargas. Enquanto aquelas exibiam a manutenção, segurança e tranqüilidade da possessão territorial, Vargas faria da sua presença física, atenciosa e decidida, um signo para os habitantes das regiões mais distantes do país de que finalmente o corpo da nação era um só. $^{216}$

Nesse ritualismo verificado nas telas, contribuíram tanto as comemorações festivas ${ }^{217}$ quanto as mais diversas ações de Getúlio Vargas que

[...] visita, recebe, preside, assiste, discursa, excursiona, veraneia, embarca, retoma, parte, passeia, inicia, encerra, exorta, soluciona. [...] um recurso semelhante trilhado pelos chefes militares que também visitam, recebem, etc., onde o Sete de Setembro, com a sua magnífica parada militar, joga papel idêntico ao aniversário do ditador. ${ }^{218}$

91.495 metros, em 414 cinejornais (67\% sobre o total)”. José Inácio de Melo Souza, op. cit., p. 207.

${ }^{215}$ José Inácio de Melo Souza, op. cit, p. 207. Grifo nosso.

${ }^{216}$ Ibidem, p. 211. Grifo nosso.

${ }^{217}$ Como a "posse de políticos nos ministérios [...], viagens de interventores, visitantes estrangeiros". Ibidem, p. 213.

${ }^{218}$ Zulmira Tavares, apud ibidem p. 211. 
Desta forma, o objetivo maior foi a criação de uma personalidade nacional, subjacente a uma série de outros temas como "economia", "agricultura", "indústria", "segurança", "progresso", etc. Sempre abordados de forma grandiloqüente ${ }^{219}$.

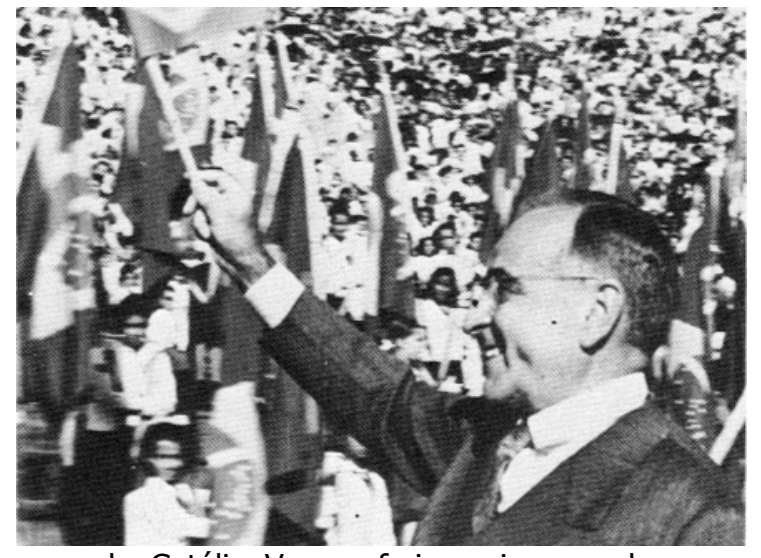

... onde Getúlio Vargas faria mais uma das suas aparições. A presença física, atenciosa e decidida do líder completava o ritualismo nas telas. Cine Jornal Brasileiro no 48, 1945. Acervo Cinemateca Brasileira.

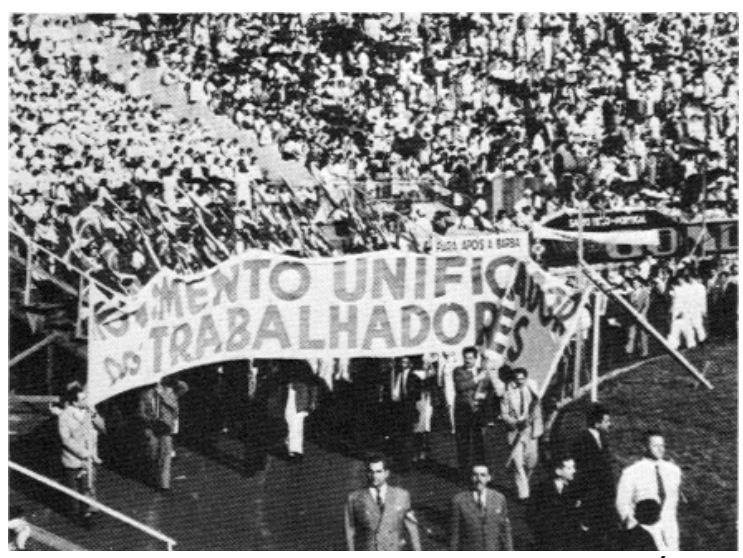

De forma grandiloqüente e em espaços estratégicos como nos estádios de futebol, o presidente podia "concentrar a massa" em festividades. A exemplo do Primeiro de Maio ocorrido no Estádio do Pacaembu em São Paulo...

A temática dos cinejornais foi retomada por Melo Souza em artigo posterior ${ }^{220} \mathrm{e}$ de maneira inovadora. Nesta abordagem, o autor consegue visualizar uma certa "tradição" de cinejornais unificada pelo continuísmo político retratado de forma ritual - um "ritual do poder", por assim dizer - transposto às telas dos cinemas. São cinejornais e curtasmetragens ligados às campanhas eleitorais de figuras políticas "presidenciáveis" como Venceslau Brás, Arthur Bernardes, Washington Luiz, Júlio Prestes, o próprio Getúlio Vargas e Eurico Gaspar Dutra ${ }^{221}$. E políticos de grande expressão em contextos regionais, como Adhemar de Barros e Lucas Nogueira Garcez em São Paulo. Tal abordagem nos pareceu pioneira, por exemplo, em relação ao o BT, pois ainda que cinejornal adhemarista não seja o foco do artigo, e esteja reduzido a um universo de três números ${ }^{222}$, ele é colocado

219 Por outro lado, o tema "trabalho", obteve uma freqüência menor em relação aos demais, até porque os trabalhadores eram apresentados em assuntos sobre assistencialismo, comemorações e festejos como o Primeiro de Maio, o Sete de Setembro e o aniversário do presidente, sempre organizados em massa. Ibidem, p. 215-16.

220 "Eleições e Cinema Brasileiro: Do Fósforo Eleitoral aos Santinhos Eletrônicos", op. cit.

${ }^{221}$ Sobre Venceslau Brás, Brasil Ilustrado (edição de março), Nacional Filmes, 1918; Arthur Bernardes, Para Ler a sua Plataforma Chega ao Rio de janeiro o Futuro Presidente da República Dr. Arthur Bernardes, Carioca Filme, 1921; Washington Luiz, Rossi Actualidades nº101, Rossi Filme; sobre Júlio Prestes, são dois: Era da Renascença Nacional, Botelho e Neto, 1929, e Recepção Apoteótica ao Presidente Júlio Prestes, Rossi Filme, 1929; sobre Getúlio Vargas, alguns números do CJB; assim como alguns números do CJI para o Eurico Gaspar Dutra. Ibidem, p. 165.

${ }^{222}$ Faz uso de apenas três "números relativos a eleições" do Bandeirante da Tela: Um Homem Capaz; Campanha à Presidência de Ademar; e Campanha contra Jânio Quadros. Idem, p. 165. 
na perspectiva desta "tradição" existente no cinema brasileiro, fruto da junção de interesses políticos e de pessoas ligadas ao campo cinematográfico. Quanto a uma metodologia para o manuseio de cinejornais em pesquisas históricas, Melo Souza expõe sua experiência em artigo mais recente ${ }^{223}$. Detalhando etapas do seu trabalho com este tipo de fonte, o autor considera que os resultados obtidos surgem após um longo curso de arranjo e organização da documentação, da análise cuidadosa da imagem e do som; da confrontação com outras fontes escritas e outros arquivos de imagem, e, até mesmo, o estabelecimento da veracidade do documento. E reconhece, por fim, que muito há para ser feito, dado que cada empreitada traduz novas preocupações e um "padrão" formado para este trabalho é algo impensável, uma vez que a pesquisa em cinejornais resultará, em boa parte, do estado do material quase sempre precário -, da bagagem teórica do pesquisador, bem como as suas preocupações e seus objetos ${ }^{224}$.

Consideramos, portanto, que o espaço dedicado ao complemento nacional, especialmente os cinejornais, na história do cinema no Brasil foi pouco visitado, talvez pelas dificuldades de informações e de acesso que rondam esse tipo de material. Mas ao mesmo tempo "em aberto" para ser preenchido por publicações recentes e pesquisas em desenvolvimento 225 . Contudo, convém reconhecer que pouco foi feito no sentido de preencher as ausências apontadas pelos trabalhos de Paulo Emílio e Bernardet. A falta de um maior número de trabalhos dedicados a este gênero cinematográfico produzido, por aqui em grande quantidade ${ }^{226}$, parece sugerir uma estratégia própria do cinema, se lembrarmos que muito da sua linguagem se apreende no que não é mostrado ${ }^{227}$. Ou seja,

\footnotetext{
${ }^{223}$ José Inácio de Melo Souza. “Trabalhando com Cinejornais: relato de uma experiência”, op. cit.

${ }^{224}$ Ibidem, p. 61.

${ }^{225}$ Como o recente lançamento de Cássio dos Santos Tomain. "Janela da Alma": Cinejornal e Estado Novo fragmentos de um discurso totalitário. São Paulo: Annablume \& FAPESP, 2006. E as pesquisas concluídas e/ou em andamento, conferenciadas em encontro ocorrido neste ano: Renata Vellozo Gomes. "As possibilidades de pesquisa histórica em arquivos audiovisuais: um estudo das imagens do Rio de janeiro nos cinejornais da Agência Nacional dos anos 50"; Maria Leandra Bizello. "Cinejornais nos anos dourados: JK e Brasília em imagens em movimento"; Daniela Giovana Siqueira, "Cenas de um horizonte político - o ano de 1963 e a produção de cinejornais a serviço de uma administração municipal na capital de Minas Gerais" In História e multidisciplinaridade: territórios e deslocamentos: anais do XXIV Simpósio Nacional de História / XXIV Simpósio Nacional de História; Associação Nacional de História - ANPUH. - São Leopoldo: Unisinos, 2007. CD-Rom.

${ }^{226}$ Além dos "quase um terço" que os cinejornais representam dentro da produção cinematográfica brasileira - segundo os dados da CB mencionados em nota anterior - confira Carlos Roberto de Souza, "Newsreels and newsreels cataloguing at the Cinemateca Brasileira" In Roger Smither, Wolfgang Klaue. Newsreels in Film Archive: a survey based on the FIAF Newsreels Symposium. Wiltshire: Flicks Books, 1998, pp. 98-105.

${ }^{227}$ Cf. Paulo Emílio Salles Gomes. "A arte de não mostrar" In Paulo Emílio Salles Gomes. Crítica de Cinema no Suplemento Literário, vol. 1. Rio de Janeiro: Paz e Terra, 1981, pp. 284-87.
} 
não se importar com um gênero cinematográfico por ele não representar um "cinema ideal”. Ou porque discuti-lo significaria ter que investigar um feixe de interesses tanto políticos quanto comerciais repudiados pela crítica contemporânea em detrimento das prazerosas questões artísticas e estéticas, debatidas também por aqueles que propuseram um cinema nacional independente das imposições de um mercado dominado pela fita estrangeira ${ }^{228}$. Nesse sentido, estaríamos falando de um "ritual do poder", sobre a escolha do que é digno ou não de ser resgatado.

\section{2 - O cinejornal: entre críticas e tensões no campo cinematográfico}

No mais recente trabalho sobre Adhemar de Barros, a imagem do homem progressista assume um tom elogioso. A ratificação da sua figura visionária corrobora a iniciativa daquele que "introduziu no Brasil o marketing eleitoral" na política, fruto das inovações trazidas dos Estados Unidos e da Europa $^{229}$ e aplicadas na década de 1950, quando surgiu a prática da "caixinha":

Foi nas campanhas dos anos 1950 que surgiu a prática da 'caixinha' [...]. A 'caixinha', dizia a imprensa na época, arrecadava dinheiro do jogo, que naquele tempo não era proibido, e dos empresários, particularmente fornecedores ou empreiteiros, para financiar as campanhas. Era sabido também que Adhemar, homem de grande fortuna pessoal, herdada de sua família, gastava a granel para atingir seu sonho de ser presidente. Muitos dos seus colaboradores diretos se aproveitavam do dinheiro das campanhas para enriquecimento pessoal. Adhemar ficou com a fama de 'homem da caixinha', mas a prática generalizou-se, e até hoje todas as campanhas eleitorais, praticamente em todo o mundo, têm sido realizadas à custa da arrecadação de dinheiro de grupos de interesses. ${ }^{230}$

Típico da intenção de preservar uma certa memória do político - manter o mito - é apoiar-se no jogo de palavras (“dizia a imprensa da época”, "naquele tempo não era proibido", "homem de grande fortuna pessoal" ou "ficou com fama"...) para diluir uma questão grave e bastante presente em nossa história política. Não questionar algo polêmico na trajetória política de Adhemar de Barros, para manter sua imagem positiva, pode nos dar indício sobre outras questões de fundo, como, por exemplo, um toma-lá-dá-cá que resvalou

\footnotetext{
${ }^{228}$ Em congressos realizados no início dos anos de 1950, em especial o I Congresso Paulista do Cinema Brasileiro (1952) e o I Congresso Nacional do Cinema Brasileiro (1953). Cf. José Inácio de Melo Souza. “Os Congressos de Cinema" In Congressos, Patriotas e Ilusões e Outros Ensaios de Cinema, op. cit.

${ }^{229}$ Paulo Cannabrava Filho, op. cit., p. 89.

${ }^{230}$ Ibidem, p. 89-90. Grifo nosso.
} 
nos acordos que sustentaram a produção do BT dentro do esquema da cavação. Algo sintomático, inclusive, do mal-estar que o cinejornal adhemarista pareceu ter despertado na crítica cinematográfica dos anos de 1950.

Também não podemos esquecer que o "inovador" Adhemar de Barros havia sido um aprendiz bastante dedicado em como "promover" a própria imagem. Assemelhando-se em muito, quando ainda interventor, ao seu "mestre" Getúlio Vargas, antecipando-se ao presidente em relação ao cuidado com a propaganda em diversas ocasiões. No mês de abril, por exemplo, onde coincidentemente eram comemorados os aniversários de Getúlio Vargas, o de Adhemar de Barros e o de sua interventoria, "a imprensa paulista muitas vezes deu mais destaque ao interventor, principalmente antes de 1940, quando o aniversário do presidente era pouquíssimo divulgado" ${ }^{231}$. E mesmo as visitas oficias, onde

[...] Adhemar com o intuito de divulgar São Paulo [e o seu governo] para o exterior, habituou-se a convidar embaixadores sediados no Rio de Janeiro, recebendo-os oficialmente, com direito a revista de tropas e continências oficiais [o que] trouxe-lhe muitas críticas, chegando a ser advertido pelo Ministério das Relações Exteriores do Estado Novo. Diziam até que estava transformando São Paulo em nação, dentro da Nação. $^{232}$

Assim sendo, o investimento numa propaganda inspirada na ditadura recente, certamente provocou tensões com a crítica de cinema, descontente com o que os interesses políticos e privados eram capazes de gerar no seio da realidade cinematográfica nacional. Por isso, convém tentar enxergar os cinejornais envoltos à repercussão que provocaram no campo cinematográfico, assim como o estranhamento que a película adhemarista causou durante os anos 1950, uma vez que é neste período que encontramos a maioria dos números do $\mathrm{BT}^{233}$.

Em 1949, um mal-estar patente foi relatado pelo crítico de cinema Carlos Ortiz, ao questionar o abuso de certos complementos, cuja propaganda comercial soava aberta e de forma escancarada. Protegidos por decreto e tidos "automaticamente" pela censura como filmes de "boa qualidade", exibidores e o público eram praticamente obrigados a aceitar o

${ }^{231}$ Marli Guimarães Hayashi, op. cit., pp. 4-5. Grifo nosso.

${ }^{232}$ Ibidem, p. 112.

${ }^{233} \mathrm{Em}$ cerca de cento e oitenta registros catalogados pela $\mathrm{CB}$, verificamos uma proporção quase ínfima de números realizados nos anos quarenta: apenas quatro. Dos outros cento e setenta e seis, quatro são de 1950; quarenta e sete de 1951, vinte e cinco de 1952, dezoito de 1953, vinte e sete de 1954, trinta e sete de 1955 e os dezoito restantes da década de cinqüenta, porém sem identificação exata quanto ao ano. 
complemento nas telas em todo o Brasil, como nos conta Máximo Barro: "você não ia ao cinema sem ver o cinejornal porque era obrigado (informação verbal)" ${ }^{234}$. Tal crítica, por exemplo, recaía ao Serviço de Divulgação Cinematográfica (SDC), cuja produção parecia enveredar cada vez mais para o complemento de pura propaganda política e com uma péssima seleção de temas e assuntos, como informa Carlos Ortiz, antigo crítico de cinema, em um dos seus artigos publicados no jornal O Estado de S. Paulo, em julho de 1949:

Em São Paulo, fazem jornais a Rossi Filmes, a Campos Filmes e o Serviço de Divulgação. [...] ultimamente o Serviço de Divulgação enveredou para o complemento de pura propaganda pessoal e política. Suas produções, pelo menos as últimas que temos visto na tela do Ipiranga, primam pelo desleixo no trabalho de laboratório, e revelam péssimo gosto na seleção de temas e assuntos. Continuará nesse rumo errado o Serviço de Divulgação? ${ }^{235}$

Nas cartelas iniciais de alguns números do BT, em 1952, estão presentes os créditos referentes ao SDC. Tal fato nos permite pensar a ligação dessa instituição com os interesses adhemaristas sugerindo até uma rede de divulgação entre empresas do meio cinematográfico, ainda que fosse a DCB a produtora do BT. E essa mesma relação, eventualmente tendo os interesses adhemaristas à frente, parece ter sido alvo de críticas anos depois, conforme reclames sobre uma empresa cinematográfica paulista que se valeu do cinejornal para "fazer propaganda política do seu dono e do partido [...] de sua propriedade" ${ }^{236}$. Tais críticas recaíam também sobre a facilidade com que certos “abusosnas sessões de filmes" eram inexplicavelmente liberados pela censura, inclusive em todo o Brasi ${ }^{237}$.Questionava-se o desagrado do público nas salas diante da propaganda política que assumia proporções "fora do permissível e do tolerável [causando] assuadas e as vaias $[\ldots]$ perturbando sempre a platéia" ${ }^{238}$.

\footnotetext{
${ }^{234}$ Entrevista de Máximo Barro, op. cit.

${ }^{235}$ Centro de Documentação e Informação sobre Arte Brasileira Contemporânea. Carlos Ortiz e o Cinema Brasileiro na década de 50. Carlos E. O. Berriel (coord.). São Paulo: Idart, 1981, p. 39. Grifo nosso.

236 Política nos jornais cinematográficos. A Gazeta, 11 de junho de 1954. Hemeroteca - Cinemateca Brasileira, pasta 78, doc.8. Grifo nosso.

237 "À censura federal cabe a obrigação de acabar com tal abuso, aliás, praticado em todo o Brasil, por uma única empresa, e daqui, ligada às conveniências de campanhas políticas".Ibidem, grifo nosso.

${ }^{238}$ Ibidem. Grifo nosso.
} 


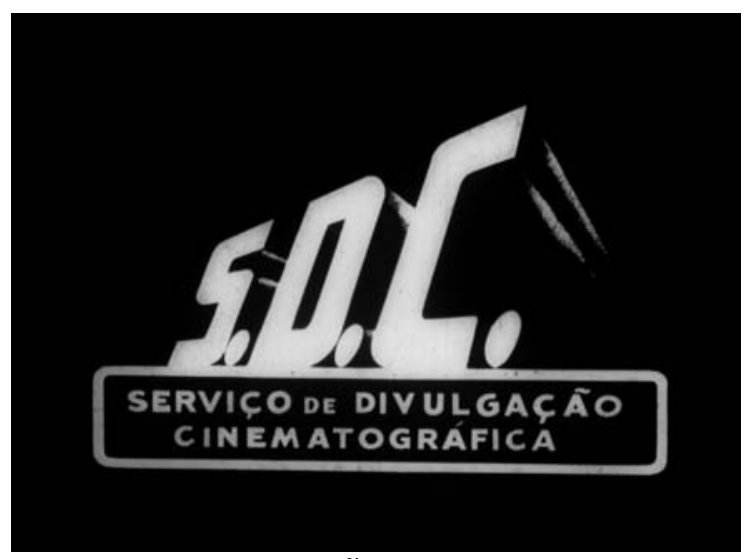

Cartela de apresentação com o logo do SDC. Bandeirante da Tela no 501, 1952. Acervo Cinemateca Brasileira.

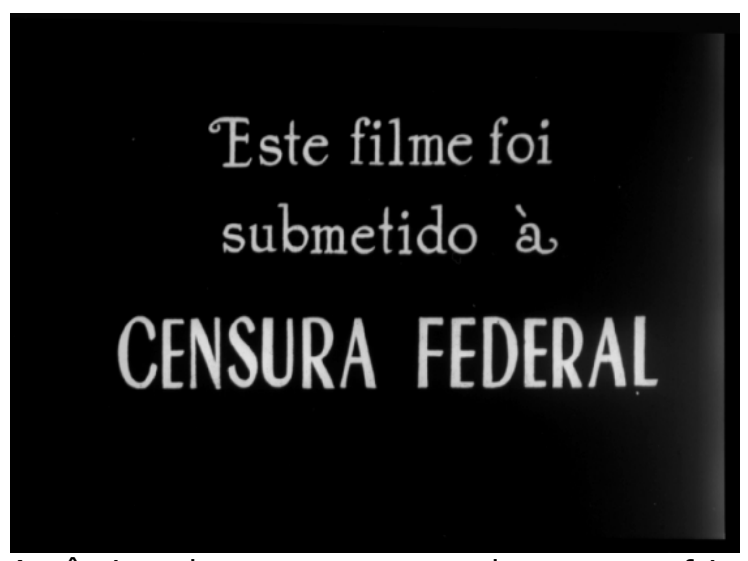

Anuência da censura em letras garrafais. Bandeirante da Tela no 501, 1952. Acervo Cinemateca Brasileira.

Nota-se, entretanto, que não está claro se a platéia era perturbada em ver Adhemar de Barros na tela do cinejornal ou pelas "assuadas e vaias" vindas de uma parte do público, que incomodava o restante. $\mathrm{O}$ fato é que um investimento sem o mínimo de retorno político e financeiro - dificilmente teria gerado um número considerável de cinejornais, a ponto deles inflamarem opiniões contrárias na imprensa. Contudo, não deixa de ter razão o artigo (que não está assinado), ao sugerir que tais complementos nacionais contavam com o "fator surpresa", em que o espectador que "sofre verdadeira burla, quando lhe impingem a encenação filmada em benefício das esperanças candidatícias de um cidadão qualquer" ${ }^{239}$. O "cúmulo", para aqueles que iam ao cinema esquecer da política e se deparavam como o próprio Adhemar de Barros:

[...] mas é o cúmulo! Vamos ao cinema esquecer da confusão e dos incitamentos açulados pelos choques dos partidos, e eis senão quando menos se espera lá surge na tela o teimoso e avantajado paredro, fazendo praça de suas... qualidades de pretendente a postos de supremas investiduras ${ }^{240}$

De fato, o "teimoso e avantajado paredro", que passava a imagem de conhecido nacionalmente por divulgar tanto as belezas do Brasil como a sua propaganda política

\footnotetext{
${ }^{239}$ Ibidem. Grifo nosso.

${ }^{240}$ Ibidem. Grifo nosso.
} 
através do cinejornal produzido pela sua própria produtora cinematográfica, se cercava de cuidados e acordos, como nos lembra Barro:

Nunca iria aparecer nada contrário à política dele. Dele e daqueles que poderiam ser os seus aliados naquele determinado momento [...] Em todo jornal, em todo Bandeirante da Tela, tinha algo, alguma inauguração, alguém que tinha passado pelo palácio, alguma coisa... Ele era lembrado oficialmente (informação verbal). ${ }^{241}$

Em meio às discussões sobre os cinejornais, acusações também pesaram sobre os realizadores, culpados pelo retrocesso de um espaço "subaproveitado", destinado aos complementos nacionais, posto que ocupado por cinejornais em detrimento dos demais gêneros cinematográficos:

Esta situação acabou por condenar a verdadeira escola de cinema, justamente a curtametragem, que tanto poderia ser o drama, a comédia, o natural, os diversos ângulos pelos quais se mostraria em poucos metros de celulóide, motivos de agrado, de diversão e, principalmente, educacionais. ${ }^{242}$

Porém, tal culpa também recaía aos exibidores, pois quem se aventuraria a produzir "filmezinhos" se de "antemão sabe que eles não terão exibição devido aos cinejornais de pura cavação?" ${ }^{243}$. Tratava-se, portanto, de um problema estrutural, como enfoca o artigo que não está assinado:

Mesmo no caso do pagamento estatuído por lei, é tão irrisório, que não daria nem para pagar a celulóide da cópia. Deste modo, o verdadeiro filme que deve merecer a atenção do Governo e o apoio do público, ficou condenado, sendo substituído pelos jornalecos da tela, pasquins sem nenhuma qualidade e que vivem de mostrar banquetes, inaugurações e tudo quanto se presta à mais descarada das propagandas e dos interesses particulares dos seus produtores. $^{244}$

Banquetes, inaugurações, festinhas íntimas e até solenidades de entrega de diplomas a alunas de corte e costura ${ }^{245}$, ou mesmo a formatura de uma turma de cabeleireiras como

\footnotetext{
${ }^{241}$ Entrevista de Máximo Barro, op. cit..

${ }^{242}$ Lei contra nosso cinema. O Cruzeiro, São Paulo, 16 de abril de 1955. Hemeroteca - Cinemateca Brasileira, pasta 155-1, doc. 9. Grifo nosso.

${ }^{243}$ Ibidem. Grifo nosso.

244 Ibidem. Grifo nosso.

${ }^{245}$ Ibidem.
} 
registrado no $\mathrm{BT}^{246}$, são algumas queixas decorrentes da "vulgaridade" do conteúdo exibido: matéria paga e em grande quantidade, patrocinada por homens que queriam aparecer ou políticos em véspera de campanha eleitoral. Recado direto para os cinejornais cavados, entre eles, o BT, que deveriam ser substituídos por

Um jornal mais variado, com noticiário de diversos esportes e informações do que vai pelo mundo. Evidentemente não é o [...] Bandeirante da Tela e outras 'maravilhas' informativas. ${ }^{247}$

E também uma crítica aos cavadores que, após a redemocratização, a volta da liberdade de imprensa e o decreto de leis - ao menos em São Paulo, que proibiam a propaganda comercial em complementos exibidos em sessões pagas $^{248}$-, levaram os cinejornais para uma caminho obscuro, em que o oportunismo e o lucro fácil fortalecia um "truste" de produtores e exibidores, responsáveis por uma situação em que os cinejornais apresentavam-se "quase todos de exclusiva matéria paga", uma vez que

a facilidade de produção de filmes desta espécie, serviu para formar um truste de exibição, pela renda que produz. Tanto assim que para furar esta quase exclusividade, chegam alguns produtores a se oferecer para pagar exibidores, em vez de receber o que manda a lei, porque o lucro está justamente no 'assunto' apresentado, ou seja, no anúncio projetado. ${ }^{249}$

Uma prática que, pouco a pouco, minava o potencial de um gênero cinematográfico, uma “poderosa arma de combate" em todo o país que

Durante muito tempo, os produtores nacionais relegaram a um plano secundário [...] Usado a princípio como um veículo de propaganda estatal (vide o tempo da ditadura), os espectadores viam-se obrigados a assistir repetidos 'clichês' de endeusamento, não só ao governo, como de toda a sua corte. Com o advento da democracia em 1945, e a volta da liberdade da imprensa escrita, os cinejornais começaram a larear por um caminho incerto,

\footnotetext{
${ }^{246}$ Bandeirante da Tela n. 521. São Paulo: Divulgação Cinematográfica Bandeirante, 1953. Fita de vídeo (8min), VHS, sonoro, p\&b, VV00098. Cinemateca Brasileira.

${ }^{247}$ Os jornais cinematográficos não acompanharam a evolução do cinema. A Rua, São Paulo, 05 de outubro de 1955. Hemeroteca - Cinemateca Brasileira, pasta 78, doc. 6. Grifo nosso.

${ }^{248}$ Trata-se, no caso de São Paulo, da lei n.4.412 apresentada à Câmara Municipal de São Paulo em 08 de fevereiro de 1953 e efetivada em outubro daquele ano, quando foi aceita pela Câmara dos Vereadores. Mas regulamentada só em 30 de junho de 1956, com o decreto 3.157, que a colocou em vigor. Cf. Complemento Nacional ou Publicidade?, A Crítica de São Paulo de 16 a 23 de abril de 1959. Hemeroteca - Cinemateca Brasileira, pasta 995, doc. 2.

${ }^{249}$ Lei contra nosso cinema. op. cit. Grifo nosso.
} 
do que se aproveitaram oportunistas em busca do lucro fácil, filmando banquetes, homenagens, inaugurações duvidosas $e$ ridículas demonstrações de solidariedade a figurões. Entretanto, os cinejornais, têm o dever de noticiar e, através de críticas construtivas, orientar o público que acorre às bilheterias das casas de exibição [...] não se pode compreender, que sendo uma poderosa arma de combate, de elucidação, de educação [...] se limitassem a uma 'água açucarada'. ${ }^{250}$

A crítica, portanto, da ação nociva de produtores e exibidores nos permite refletir como estes estavam de mãos dadas com os interesses políticos que noticiavam "ridículas demonstrações de solidariedade a figurões”. Vale lembrar que o artigo é de 1955, período em que Adhemar de Barros (há quase cinco afastado de um cargo político) saía derrotado de uma campanha para governador e entrava numa outra para presidente, viajando por todo o Brasil. Nesse sentido, poderíamos questionar, inclusive, se a manutenção dos baixos preços das entradas "contrárias à indústria cinematográfica nacional" não seria uma medida que atenderia os próprios políticos "com fins populistas, dada a preferência do público por esta diversão?" 251

A idéia de fortalecer o complemento nacional marcou presença em importantes discussões, envolvendo grupos de interesse que atuavam no campo cinematográfico: produtores, distribuidores, exibidores, trabalhadores e técnicos do cinema. No I Congresso Paulista do Cinema Brasileiro (1952) e no I Congresso Nacional do Cinema Brasileiro $(1953)^{252}$, tentou-se estabelecer algumas diretrizes para o uso do espaço destinado ao complemento nacional, salvaguardado pela legislação brasileira e distanciado da concorrência com a fita estrangeira. Houve propostas que visavam tal espaço circunscrito ao trânsito e o incremento da produção documental, ligando estes à produção de longasmetragens para fortalecer o "treinamento e eficiente capacitação dos assistentes [...] tornando-os profissionais aptos à indústria cinematográfica" ${ }^{253}$.

Outras "teses" propunham soluções específicas quanto aos cinejornais, a exemplo da intitulada "Faixas de cinejornais" em que se pretendia ocupar um espaço deixado livre pelos americanos, ingleses e franceses - já que em maio de 1952 o Estado, por meio da Censura, fazia revigorar a lei que impunha a reciprocidade na compra de $10 \%$ de

\footnotetext{
${ }^{250}$ Waldemar Paiva, "Cine jornais". O Mundo, 01 de janeiro de 1955. Hemeroteca - Cinemateca Brasileira, pasta 78, doc. 7. Grifo nosso.

${ }^{251}$ Anita Simis, op. cit., p. 195

${ }^{252}$ Ocorridos, respectivamente, em São Paulo e no Rio de Janeiro. Cf. José Inácio de Melo Souza, "Os Congressos de Cinema", op. cit.

${ }^{253}$ Ibidem, pp. 38-9.
} 
cinejornais brasileiros pelas distribuidoras estrangeiras ${ }^{254}$-, mas atrelando tais faixas aos maiores produtores e longas-metragens. Uma idéia coerente que afetaria, porém, produtoras pequenas como a DCB que, assim nos pareceu, atuou mais como laboratório e estúdio, nada muito além das suas atribuições para com a produção do $\mathrm{BT}^{255}$. Existiram também disposições pela suspensão dos cinejornais da $\mathrm{AN}$, como o CJI, e a obrigatoriedade da inclusão de uma reportagem diferente da $\mathrm{AN}$, como o BT já vinha fazendo ${ }^{256}$, bem como a concessão de "10 cadeiras por sessão ao complemento nacional". Resumindo, tais propostas visavam romper uma barreira imposta, principalmente pelos exibidores, "estruturados em seus sindicatos e federações, atuando de forma eficiente como barreira aos avanços da legislação protecionista do cinema brasileiro" ${ }^{257}$. Ou seja, buscavam-se saídas sob a tutela do Estado "como fonte suprema de recursos", a exemplo do cinema europeu onde o financiamento pelo Estado acontecia como na Itália, "que tinha, desde o período fascista (1935), uma carteira de ajuda cinematográfica aberta na Banca Nacionale Del Lavoro" ${ }^{258}$. Aliás, foi este o foco de tais discussões que persistiram durante os anos de 1950, pois ainda pairava, em 1959, como "bons exemplos" de curtas-metragens subvencionados por uma legislação que preservasse o cinema nacional, experiências recorrentes como

Na Itália, [onde] a 'Oliveti' financiou um magnifico ciclo de filmes de arte, coloridos, sobre os grandes vultos da pintura peninsular, que são anunciados oficialmente nos programas dos cinemas, atraindo, por si só, singular massa de público interessado nesse gênero. $O$ que não é possível são essas intermináveis sucessões de anúncios camuflados projetados nas nossas salas como 'atualidades' dentro de um noticiário cinematográfico ${ }^{259}$

O "ideal" seria, assim, uma situação em que todos os envolvidos (produtores, exibidores e políticos) se esforçassem para produzir algo verdadeiro sobre o próprio país, ao invés de propalar ao público intermináveis sucessões de anúncios camuflados em "atualidades", utilizando o cinema enquanto "veículo publicitário para seus melhores clientes, que são os

\footnotetext{
${ }^{254}$ Ibidem, p. 46.

255 "Eu fiz muitos trabalhos lá de anúncios publicitários e fiz dois longas-metragens durante dois anos, 57 e 58 , eu trabalhava com uma equipe [...] inclusive revelávamos dentro daquele laboratório e tudo o mais... (informação verbal)". Entrevista de Máximo Barro, op. cit..

256 José Inácio de Melo Souza, op. cit., p.47.

${ }^{257}$ Ibidem, p. 29. Grifo nosso.

258 Ibidem, p. 22.

${ }^{259}$ Complemento Nacional ou Publicidade?, op. cit.. Grifo nosso.
} 
políticos em véspera de eleições, fazendo alarde de suas ações 'em benefício' (?) da coletividade" ${ }^{260}$.

Também é curioso notar que em 1959, mesmo com a televisão, o cinejornal continuava sendo uma questão pertinente. Entre o "complemento nacional e a publicidade" ainda era o dilema que se arrastava, especialmente sobre a publicidade de políticos como Adhemar de Barros, provavelmente num formato menos periódico ${ }^{261}$, que incomodavam os críticos de cinema:

Como impedir que [...] a Divulgação Cinematográfica Bandeirante deixe de propalar aos quatro ventos, para um publico indefeso, que pagou até 100 cruzeiros na porta de um cinema, as virtudes administrativas do Sr. Adhemar de Barros. ${ }^{262}$

"Injustificável para uns, justificável para outros" seria esse o impasse comentado em 1959 por Marcos Marguliés (um dos organizadores dos congressos de cinema ocorridos no início dos anos de 1950) no jornal O Estado de S. Paulo. Ao escrever sobre a crônica realidade dos cinejornais cavados, ele defende que a mudança de tal quadro independe simplesmente dos cavadores, pois mesmo sendo as críticas procedentes:

o produtor dos jornais filmados e a publicidade cinematográfica vêm sendo acusados como os únicos culpados pela insustentável atmosfera reinante na sala de cinema durante os dez minutos de exibição do complemento nacional. Na realidade, porém, ambos - produtor e publicidade - são as maiores vítimas. ${ }^{263}$

Ou seja, a culpa recaía muito mais sobre as leis de obrigatoriedade de exibição, criadas nos anos trinta e regulamentadas décadas após, e cujos dispositivos obrigavam os realizadores a manter uma certa periodicidade nas salas de cinema. O que os obrigava a cumprir uma meta com jornais antigos e desatualizados, desagradando tanto o público como o exibidor. Nesse sentido, tornava-se inevitável recorrer à publicidade, caso contrário o lucro do produtor não

\footnotetext{
${ }^{260}$ Ibidem.

${ }^{261}$ Considerando o fato de não se ter notícias do BT para além de 1956, pois como veremos adiante, a carreira política de Adhemar de Barros passou por um momento conturbado em que o melhor para sua imagem foi o arrefecimento dos holofotes da mídia. Nesse sentido, Máximo Barro nos lembrar que sendo a DCB uma empresa de Adhemar de Barros, “[...] a saída física dele do país [1956] faz com que os jornais não tenham a necessidade de antigamente, então a Bandeirante (DCB) continua, mas agora sendo uma locadora [de serviços] (informação verbal)". Entrevista de Máximo Barro, op. cit..

${ }^{262}$ Complemento Nacional ou Publicidade?, op. cit. Grifo nosso.

263 Marcos Maguliés, Justificando o injustificável, O Estado de S. Paulo, 20 de setembro de 1959. Hemeroteca - Cinemateca Brasileira, pasta 995, doc. 3. Grifo nosso.
} 
compensaria nem a película virgem ${ }^{264}$. Ou seja, a propaganda se apresentava como um mal necessário à produção de curtas, enquanto a "legislação arcaica", a principal culpada por subverter uma arte - ou um formato fílmico cujo principal compromisso seria com a notícia jornalística - em anúncios particulares.

Acompanhando os desdobramentos do artigo de Marguliés, na semana seguinte J. Pereira, diretor da Divisão de Diversões Públicas da Secretaria da Segurança de SP, responsável pela censura cinematográfica em São Paulo, rebateu as críticas feitas à legislação vigente, muito mais no sentido de defender o governo, que propriamente propor soluções. Porém, numa curiosa inversão de papéis, o diretor "rompe" com aquilo que o próprio governo criou para o cinema e se aproxima do que fora preconizado pelos congressistas do início da década: evoca o cinema como arte e espetáculo e condena a sua utilização enquanto órgão de divulgação, pois

justificar a exposição da propaganda nos cinemas - ainda que através de jornais cinematográficos - lembrando a imprensa, o rádio e a TV é laborar em equívoco imperdoável [...] o espectador que ingressa num cinema objetiva assistir a uma forma de manifestação artística, tal qual o público freqüentador dos teatros e das galerias de arte. [de maneira que] o público que paga ingresso para ver Arte Cinematográfica, é obrigado a ver propaganda, porque é, sem a sua autorização e sem receber nada por isso, alugado, o que constitui, afinal de contas, uma ilegalidade. ${ }^{265}$

O fato é que as tensões verificadas neste breve passeio pelos anos cinqüenta, deixam à mostra um cenário cinematográfico brasileiro em que o único espaço destinado à fita nacional, e livre da ameaça estrangeira, foi bastante "disputado" por críticos, políticos, produtores, distribuidores e exibidores. Muitas vezes divergentes e conflitantes, mas praticamente unânimes quanto ao potencial dessa "poderosa arma de combate". Que vinha sendo utilizada muito mais no sentido de ocupar as salas veiculando e divulgando interesses políticos e particulares, do que propriamente agradando o público enquanto arte exibida nas telas.

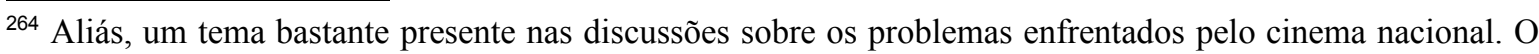
alto custo da película virgem, sobretudo, motivou propostas - "teses" - nos fóruns de discussão ocorridos nos Congressos no início da década de 1950. Cf. José Inácio de Melo Souza, op. cit., p. 37.

265 J. Pereira, diretor da Divisão de Diversões Públicas da Secretaria da Segurança de SP, "Justificando o injustificável", O Estado de S. Paulo, 27 de setembro de 1959. Hemeroteca - Cinemateca Brasileira, pasta 995, doc. 4. Grifo nosso.
} 
Porém, o fato é que o complemento nacional - por onde transitavam grandes quantidades de cinejornais - atravessou os anos de 1950 não apenas causando polêmica. Mas sendo utilizado de forma estratégica, justamente por estar inserido num divertimento público, cujas pesquisas daquela época apontavam para um "período de ouro": o cinema era a maior diversão ${ }^{266}$. E foi justamente essa presença

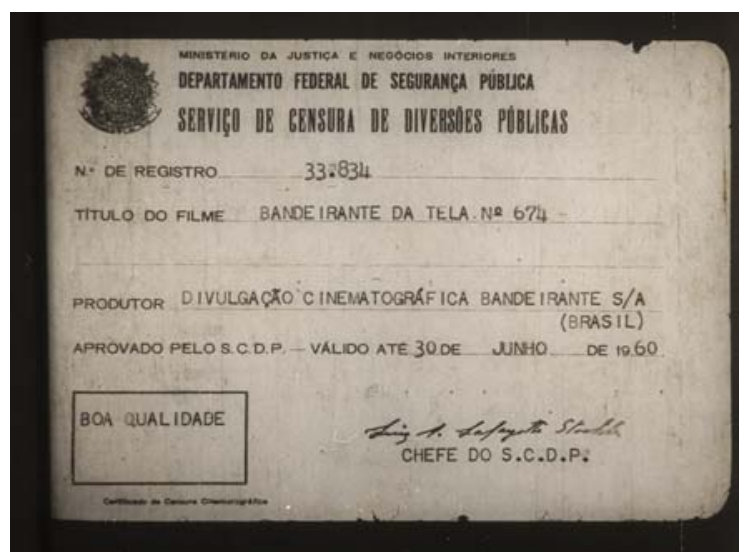

Certificado de Censura pela Divisão de Diversões Públicas adicionado à película. Bandeirante da Tela no 674, 1955. Acervo Cinemateca Brasileira.

do público que buscava no cinema uma diversão acessível com entradas em níveis populares $^{267}$, como nos lembra Máximo Barro ${ }^{268}$, que esteve na mira de vários políticos reconhecidamente populares, em que tanto o adhemarismo, como pessoas ligadas a ele continuaram a encontrar no espetáculo cinematográfico a tradução dos seus interesses. Assim como os casos de Marino Netto, narrador e, em alguns números, apresentador do $\mathrm{BT}$, que seguiu com o seu próprio cinejornal ${ }^{269}$, Hermantino Coelho, responsável pela distribuição do BT e outros complementos nacionais, e que continuou com suas atividades nesse nicho durante os anos sessenta, distribuindo para conhecidos produtores como Primo Carbonari ${ }^{270}$ e o próprio Adhemar de Barros, que em sua terceira e homenageada ${ }^{271}$ passagem pelo governo paulista, não dispensou a ajuda do cinema ${ }^{272}$ que tanto contribuiu para a proliferação da sua popularidade, ou melhor, do seu populismo.

\footnotetext{
${ }^{266}$ Cf. Inimá Ferreira Simões. Salas de cinema em São Paulo, op. cit., pp. 82; 89.

${ }^{267}$ Cf. Anita Simis, op. cit., p. 195.

268 "[...] um divertimento muito, muito barato. Eu era mecânico naquele momento, eu ia todas as noites no cinema, todas as noites. Como se fosse uma obrigação religiosa. Segunda-feira no Cine Bandeirantes, terçafeira no Art-Palácio, quarta-feira no Gazeta [...] era muito barato, nunca me faltou dinheiro para ir ao cinema (informação verbal)”. Entrevista de Máximo Barro, op. cit.. Grifo nosso.

269 "Programação do circuito de salas de cinema de S. Paulo" Suplemento de Cine Revista, São Paulo, de 13 a 19 de março de 1957, Hemeroteca - Cinemateca Brasileira, documentação diversa 1395, doc. 4. (ver anexo 4). ${ }^{270}$ Notícias n$^{\circ}$ 532. São Paulo: Primo Carbonari, 1964. Ficha Cens/I - Cinemateca Brasileira. (ver anexo 5).

271 "Nossas homenagens ao governador eleito", op. cit.

${ }^{272}$ Notícias n$^{\circ}$ 547. São Paulo: Primo Carbonari, 1964. Ficha Cens/I - Cinemateca Brasileira. (ver anexo 6).
} 


\section{3 - Adhemarismo: uma força em marcha?}

Se escrever sobre o populismo ou os políticos tidos como populistas é uma tarefa arriscada, como constatou Ângela de Castro Gomes, pois seja por

[...] incapacidade ou por má compreensão, por adesão ou por rejeição, o texto será alvo de críticas de todas as espécies. Nesse sentido, o destino de qualquer reflexão que trate do tema reproduz, em certa medida, o próprio destino de seu objeto de estudo. ${ }^{273}$

A nossa abordagem não será diferente, assumiremos os riscos sabendo que não estaremos livres de praticar exclusões e simplificações em nosso recorte. Porém, a nossa proposta ancora-se numa aposta bastante sólida, ao menos para nós: o populismo não é um dado concreto, uma categoria teórica disponível, tampouco um fenômeno que se manifesta igualmente em diferentes contextos, sobretudo subdesenvolvidos. Ele é, antes, uma construção que explica uma relação política resultante, principalmente, de especificidades sócio-históricas irredutíveis a modelos teóricos, porém suscetíveis a recortes investigativos sobre as suas práticas culturais em compasso com o contexto imediato e um universo cultural mais amplo da sociedade em questão. Nesse sentido, o cinema e a política, unidos numa mesma prática cultural, parecem estar no cerne desta confluência. Mas num tema tão amplo, admitimos que as escolha dos textos e reflexões próximas ao nosso trabalho implicam algumas exclusões e até simplificações, talvez inaceitáveis sob outros pontos de vista.

Todavia, assim como fizemos com o cinejornal tentando entendê-lo enquanto resultante de interesses políticos e inserido no contexto de uma atividade cultural de massas como é o cinema, é necessário, também nos determos sobre a trajetória política de Adhemar de Barros, com o auxílio de outras abordagens já realizadas. Assim, verificamos alguns contornos da sua política, o que nos dará subsídios para analisar a representação contida no discurso cinematográfico.

Antes, é importante recuarmos ao ano de 1941, quando Adhemar de Barros deixa a interventoria paulista com um saldo positivo, apesar das acusações que iam desde o caráter perdulário da administração, denúncias de desvios do erário público, favorecimento pessoal

273 Ângela de Castro Gomes, "O populismo e as ciências sociais no Brasil: notas sobre a trajetória de um conceito" In Jorge Ferreira (org.). O Populismo e sua História: debate e crítica. Rio de Janeiro: Civilização Brasileira, 2001, pp. 17-57, 19. 
em licitações de obras governamentais, insinuações de suborno, etc. Assim como as acusações de ordem política que também não foram esquecidas ${ }^{274}$. Mas é igualmente

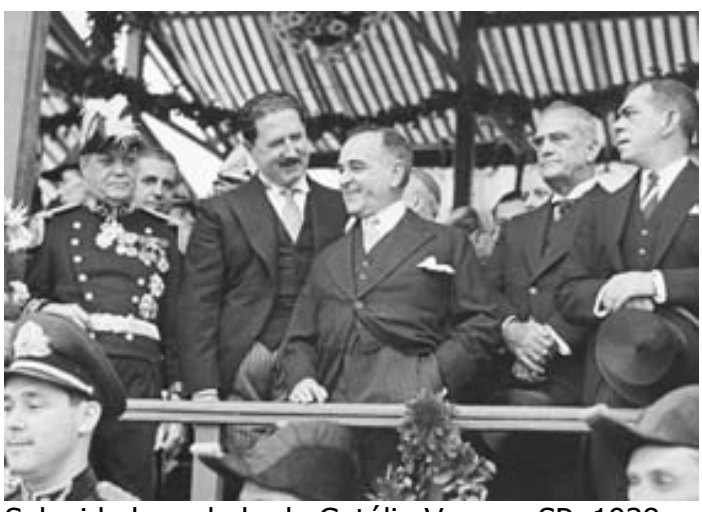

Solenidade ao lado de Getúlio Vargas, SP, 1938. Site:<.www.adhemar.debarros.nom.br>. Acesso em: 14 de jul. 2004. fruto dessa passagem a configuração de um certo capital político ${ }^{275}$, algo que estaria na base das suas futuras relações políticas, bem como no trato com sua imagem pública, e que logo seria colocada em prática para sustentar uma carreira que já havia ensaiado o uso da propaganda, reunido e fortalecido as suas bases políticas.

É no período entre a saída da interventoria e a reabertura democrática, em 1946, que Adhemar de Barros articula uma futura máquina partidária, o PSP, cujo objetivo imediato foi ampliar as bases políticas e eleitorais para as eleições estaduais que se aproximavam. Surgido da fusão com partidos menores ${ }^{276}$, este partido nasce um tanto controverso, dada a disposição do seu líder em compor alianças nada condizentes com o seu passado político de antigo deputado federal pelo então conservador Partido Republicano Paulista (PRP), entre 1935 e 1937, e interventor na ditadura do Estado Novo. E que nesse momento flertava com a esquerda, haja vista que o então líder pessepista,

[...] se posicionara à esquerda do centro logo após o término da guerra. Quando os comunistas do $A B C$ [paulista] e outros lugares foram presos logo após o golpe de 29 de outubro contra Vargas, Adhemar declarou seu apoio à manutenção da legalidade do PCB. No correr do ano seguinte, o PSP de Adhemar seria também co-patrocinador $e$ participante de muitas atividades com o $P C B{ }^{277}$

\footnotetext{
${ }^{274}$ Regina Sampaio, op. cit., p. 48.

275 Que para Pierre Bourdieu também é um capital simbólico, uma espécie de "distinção", determinada e determinante de relações sociais que se configuram de acordo com o próprio poder simbólico que carregam, como dito em nota anterior. Cf. Pierre Bourdieu. O Poder Simbólico, op. cit., pp. 188.

${ }^{276}$ Fundado em 2 de dezembro de 1945, o Partido Republicano Progressista (nome estrategicamente escolhido por Adhemar pela proximidade com a sigla do então extinto Partido Republicano Paulista) se une a outros dois menores: o Partido Popular Sindicalista e o Partido Agrário Nacional, também surgidos em 1945, nascendo assim o Partido Social Progressista em junho de 1946.

277 Cf. John French. $O A B C$ dos Operários: Conflitos e Alianças de Classe em São Paulo, 1900-1950. São Paulo: São Caetano do Sul: Hucitec, 1995, p. 198.
} 


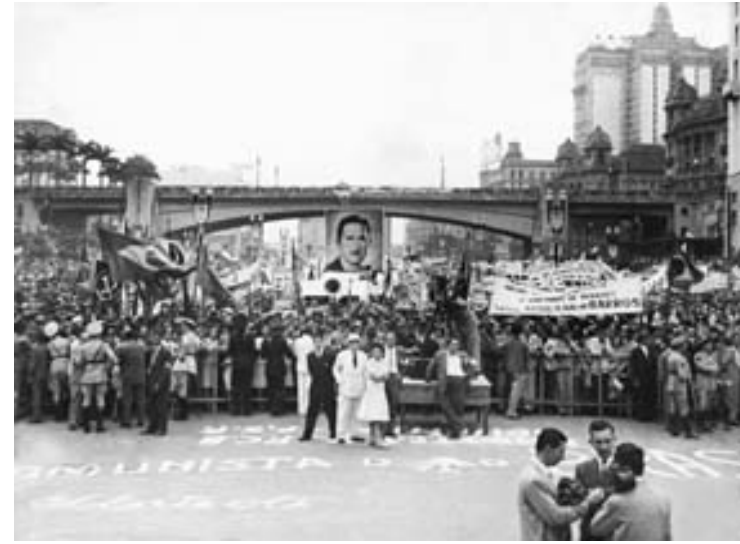

"Comício Monstro" no Vale do Anhangabaú, 1947. Site: <www.adhemar.debarros.nom.br>. Acesso em: 14 de jul. 2004.

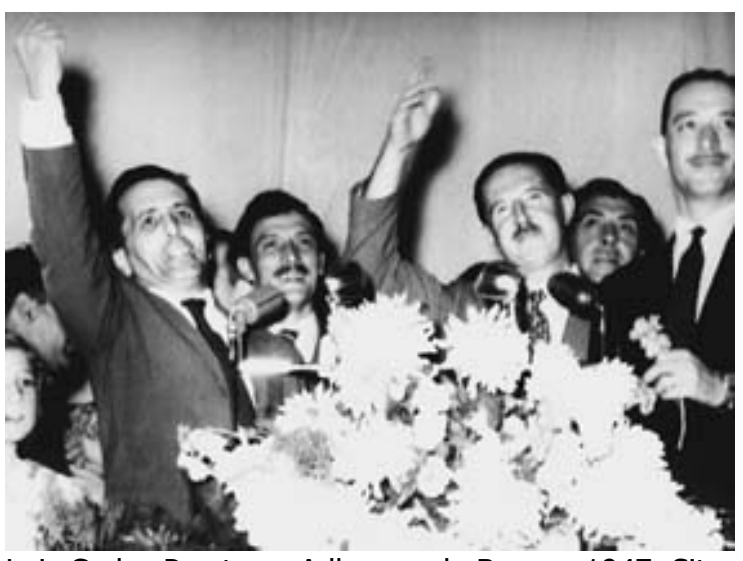

Luiz Carlos Prestes e Adhemar de Barros, 1947. Site: $<$ www.adhemar.debarros.nom.br>. Acesso em: 14 de jul. 2004.

Eleito governador em 1947, Adhemar de Barros parecia ter posto fim à supremacia de partidos conservadores como o Partido Social Democrático (PSD), do então interventor Macedo Soares, e a União Democrática Nacional (UDN), que saíra das eleições para a governança estadual com um saldo extremamente negativo, atrás ainda do rival Partido Trabalhista Brasileiro (PTB), fundado por Getúlio Vargas. Fato era que os seus quase quatrocentos mil votos se estenderam ao PSP, cujo prestígio ficou patente pelas nove cadeiras conquistadas na Assembléia Constituinte estadual - número igual ao da UDN, mas ficando atrás do PCB, do PTB e do $\mathrm{PSD}^{278}$. O estado mais populoso da nação estava agora nas mãos de um partido regional e sem vínculos com os nacionalmente estruturados PSD e UDN, e com um governador que conseguira angariar um pouco mais de um terço dos votos válidos na região metropolitana de São $\mathrm{Paulo}^{279}$ e que, ainda por cima, contava com o apoio do Partido Comunista Brasileiro (PCB).

No início do seu governo, o líder pessepista demonstrou enorme vocação para coligações, ao associar os dois mundos da política paulista: empenhou-se em ampliar e consolidar sua base de apoio nas áreas rurais e urbanas. No interior, seu corpo correligionário foi bastante fortalecido ao "conquistar" máquinas políticas locais através da

${ }^{278}$ Que ficaram, respectivamente, com 11, 14 e 26 cadeiras. Cf. Dicionário Histórico-Biográfico Brasileiro pós-30. 2. ed. ver. amp. Coordenação: Alzira Alves de Abreu et. al. Rio de Janeiro: FGV; CPDOC, 2001, 5v., p. 543.

${ }^{279}$ Considerando os 393.637 votos para Adhemar de Barros num total de 1.116 .883 votos válidos. Apud Dicionário Histórico-Biográfico Brasileiro, op. cit., p. 543. Para um contexto de aproximadamente 1.701.694 habitantes na região metropolitana, conforme dados do SEADE (ex-Departamento de Estatística de São Paulo) apud Inimá Simões, op. cit., p. 89. 
prática clientelística, ganhando terreno onde o PSD era forte. A esse respeito, é esclarecedor o depoimento de Mário Beni, um dos líderes do PSP e amigo de Adhemar de Barros:

[...] é claro que o PSP quando elegeu o governador, não tinha a totalidade do estado de São Paulo [...], mas depois de 47, o governador [...] foi substituindo os prefeitos, por decretos, porque as eleições de prefeito só viriam no fim de 48 [...] Ele (Adhemar) destituía os prefeitos e nomeava para prefeitos correligionários seus e foi se fortalecendo. Quando vieram as eleições, as municipais, esses que comandaram o executivo dos municípios, lideraram as eleições e deu ao PSP uma vitória fabulosa. Dai começou a ascensão (informação verbal). ${ }^{280}$

Simultaneamente, manteve proximidade com o PTB de Getúlio Vargas e com o PCB nas áreas urbanas. $\mathrm{O}$ que durou até a investida do PSD e da UDN, no sentido de destituir Adhemar de Barros do governo estadual, dada a coligação com o PCB posto na ilegalidade em maio de 1947. Situação que faz o PSP e seu líder assumirem uma posição de "neutralidade" frente à cassação daquele partido. Trata-se de um momento em que o governador é, então, tido pelos comunistas como um traidor. E não sem motivos, pois

[...] dois dias após a decisão de tornar ilegal o Partido Comunista, a polícia estadual de Adhemar passou a invadir, por todo o estado, centenas de escritórios do PCB e organizações a ele aliadas - medida essa reproduzida em âmbito nacional. $O$ seqüestro pelo governo dos registros do PCB foi seguido de intervenções levadas a cabo pelo Departamento Estadual do Trabalho de Adhemar, que depôs dirigentes de centro-esquerda em trinta e seis sindicatos paulistas ${ }^{281}$.

Mas o mandato de que durou até 31 de janeiro de 1951 alavancou a imagem de Adhemar de Barros e do PSP, conquistando notoriedade para ambos no cenário político paulista e nacional. E ainda que o líder pessepista não tivesse sido candidato à presidência nas eleições de 1950, em São Paulo tanto o PTB de Getúlio Vargas ou qualquer outra máquina partidária não chegou a possuir uma forte penetração no estado ${ }^{282}$. Inversamente, o PSP ainda conseguira, para o governo federal, emplacar a candidatura de João Café Filho à vice-presidência. Portanto, as eleições de 1950 mostraram um adhemarismo e um

\footnotetext{
${ }^{280}$ Mario Beni apud Bolívar Lamounier e Fernando Henrique Cardoso (coord.). Os Partidos e as Eleições no Brasil. Rio de Janeiro: Paz e Terra, 1978, p. 51. Grifo nosso.

${ }^{281}$ John French, op. cit, p. 213.

282 Por exemplo, em novembro de 1947, quando o PSP elegeu cerca de $27 \%$ dos prefeitos paulistas, mais do qualquer outro partido. Na capital, o mesmo cargo ainda era por indicação do governador. Dicionário Histórico-Biográfico Brasileiro pós-30, op. cit., p. 544.
} 
“pessepismo" em alta, cujo êxito foi alçar o partido ao posto de grande máquina partidária, fazendo a sucessão para governador com o então desconhecido (na política) candidato Lucas Nogueira Garcez, alcançando a vice-presidência da República com João Café Filho e ajudando Getúlio Vargas a se eleger. E se tornando a maior força da bancada de São Paulo na Câmara Federal, conquistando doze cadeiras $^{283}$.

Começava então, nesse curto panorama político da trajetória adhemarista, a sedimentar-se os elementos que motivariam a primeira análise teórica, de que temos conhecimento, sobre um fenômeno político considerado uma "força em marcha". No artigo “O que é adhemarismo?”, de 1954, Hélio Jaguaribe procurou responder qual o tipo de manifestação política que, desde algum tempo, estaria ocorrendo em São Paulo. $\mathrm{O}$ autor caracteriza a atuação adhemarista como um "fenômeno" caracterizado por uma política ao largo da sustentação ideológico-partidária, onde quem lhe dava substância era uma liderança de enorme apelo carismático. Tratava-se de populismo, em sentido lato ${ }^{284}$, uma espécie de desvio se comparado à clássica evolução política dos países capitalistas desenvolvidos.

Nestas formulações dos ibespianos $^{285}$, o populismo era fruto do rápido processo de urbanização e modernização pelo qual o país passava. Numa perspectiva evolutiva, que ia de uma sociedade tradicional para uma sociedade moderna, tendo a rápida proletarização dos trabalhadores como uma das variáveis histórico-sociais desse esquema explicativo. Portanto, nessa teoria da modernização, o contingente das áreas rurais ao se inserir no mundo urbano não estaria organizado politicamente de forma consciente, constituindo-se, dessa forma, em massas. Soma-se a isso a necessidade de se impor um comando dirigente a esse novo quadro nacional-desenvolvimentista - de industrialização voltada ao mercado interno. Tarefa que caberia à nova burguesia industrial, se ela não estivesse politicamente

\footnotetext{
${ }^{283}$ Enquanto o PTB elevou sua representação para nove deputados em detrimento das bancadas do PSD e da UDN. Ibidem, p.545.

${ }^{284}$ Hélio Jaguaribe et. al. "O que é o Adhemarismo?” In Câmara dos Deputados. O Pensamento Nacionalista e os "Cadernos do Nosso Tempo". Seleção e introdução por Simon Schwartzman. Distrito Federal: Universidade de Brasília, 1981, p. 23-30.

285 Também conhecidos como o Grupo de Itatiaia, este mesmo grupo fundado em 1953 iniciou, neste mesmo ano, a publicação dos "Cadernos do Nosso Tempo". Como observou Ângela de Castro Gomes, esta publicação seria considerada o berço de uma ideologia nacional-desenvolvimentista para o atraso que representava a crise nacional em curso nos anos 50. Participaram do IBESP, intelectuais como Alberto Guerreiro Ramos, Cândido Mendes de Almeida, Hermes Lima, Inácio Rangel, João Paulo de Almeida Magalhães, Hélio Jaguaribe, entre outros. Núcleo este que posteriormente fundaria o Instituto Superior de Estudos Brasileiro (ISEB). Cf. Ângela de Castro Gomes, op. cit., pp. 22-3.
} 
carente de meios e valores para impor sua ideologia à coletividade, às massas. Da necessidade de conquistar apoio político das massas emergentes surgia, assim, a figura do líder carismático, com capacidade para mobilizá-las.

Nesse modelo explicativo dos "anos cinqüenta", nota-se que a evolução política e social do Brasil consistia num "desvio" da evolução clássica do modelo capitalista europeu. Em que, teoricamente, a burguesia industrial, condizente com a sociedade moderna, deveria substituir a oligarquia agrária, resquício de uma sociedade tradicional, nos rumos políticos nacionais. É nesse “desvio", portanto, que se encontrava o populismo, transitando enquanto chave explicativa, tendo em vista o que lhe era exterior e não as suas próprias especificidades. Nesse sentido, Maria Sylvia Carvalho Franco verificou um tipo de "idealismo vulgar" contido nas análises empreendidas pelo viés de uma teoria da modernização, pois elas preconizavam o subdesenvolvimento das camadas populares como algo a ser conquistado e submetido ao comando de uma burguesia industrial progressista, para que a sociedade brasileira se desenvolvesse segundo a ótica do trabalho capitalista ${ }^{286}$.

$\mathrm{Na}$ década de 1960 o populismo foi revisitado, ainda nas bases de um "fenômeno político”. E dentre as análises mais interessantes, destacam-se os trabalhos de Francisco Weffort ${ }^{287}$ e Octávio Ianni ${ }^{288}$. Na tentativa de explicar a relação das massas e o Estado no populismo, F. Weffort sugere a Revolução de 30 como um divisor de águas na política brasileira, observando que o vazio de poder ocasionado com esse episódio impossibilitou a hegemonia política de um só grupo dirigente ${ }^{289}$, assim como gerou a ampliação da participação democrática das camadas populares. Resumidamente, seriam estas as condições para a ascensão de políticos como Getúlio Vargas, tendo em vista a política de massas para lhe dar com a massa - composta, sobretudo, pelo contingente migratório das áreas rurais com uma mentalidade individualista, carentes de uma consciência de classe.

\footnotetext{
${ }^{286}$ Maria Sylvia Carvalho Franco. “O tempo das ilusões”, op. cit. pp.163, 172, 181.

287 Especialmente seu artigo "Política de Massas" In Francisco C. Weffort, O Populismo na Política Brasileira. Rio de Janeiro: Paz e Terra, 1980, pp.15-44.

${ }^{288}$ Sobretudo os trabalhos O populismo na América Latina. Rio de Janeiro: Civilização Brasileira, 1975 e $O$ colapso do populismo no Brasil. Rio de Janeiro: Civilização Brasileira, 1978.

289 "Encontramos, com efeito, uma situação em que nenhum dos grupos (classes médias, setor cafeeiro, setores agrários menos vinculados à exportação) detém com exclusividade o poder político [...] a legitimidade acha-se limitada pelos horizontes políticos abertos por estes interesses". Francisco Weffort, op. cit., p.50.
} 
É nessa relação, entre o político e a massa, que se encontra a idéia de manipulação na análise de Weffort. Ou seja, a forma de governar abrindo concessões às certas demandas ${ }^{290}$. Mas mesmo pela aparente rigidez dessa idéia de manipulação e de concessões aos grupos de interesses, as possibilidades de entendimento se tornam um tanto mais "flexíveis". Aliás, é de Weffort uma definição bastante coerente do populismo, ao analisar suas "ramificações" em São Paulo, traduzidas nas forças adhemaristas e janistas:

[...] o populismo nestas formas espontâneas [o adhemarismo e o janismo] é sempre uma forma popular de exaltação de uma pessoa na qual esta aparece como uma imagem desejada para o Estado. ${ }^{291}$

Com base em algumas considerações deste autor, nos parece que o cenário político internacional desenvolvido ainda era o modelo no qual o Brasil precisava se inserir. Porém, dentro do nosso subdesenvolvimento, o contexto político paulista apresentou características únicas. Segundo Weffort, por ser o estado economicamente mais desenvolvido em relação ao restante do país, São Paulo foi capaz de gerar nas frestas de sua sociedade uma "marginalidade pequeno-burguesa", afeita à classe média premida por uma situação de fronteira entre "ricos" e "pobres", e por isso portadora de um sentimento de "desamparo" e uma ânsia por estabilidade e ascenso social. No que se verificava a identificação destas camadas com o discurso das "realizações adhemaristas" mesclado à figura apaziguante e paternal de Adhemar de Barros, como imagem capaz de evitar o descenso social mediante a crescente "ameaça" de proletarização - geralmente tingida com as colorações de um trabalhismo à esquerda ${ }^{292}$. Tal "ressentimento social adhemarista" se expandiu pelo viés paternalista, e é por esta porta que outras camadas da sociedade participam, como o "assalariado marginal" de baixa qualificação.

Estas considerações, num primeiro momento, parecem tramitar no espaço teórico da política de massa baseada numa manipulação pensada em termos de exploração de uma das partes na relação política. Em que o líder, o populista, tirava proveito da massa passiva e

${ }^{290}$ Como também sugere Boris Fausto, quando fala em um Estado de compromisso compondo com grupos dominantes para garantir o poder pessoal da liderança política - no caso Getúlio Vargas - e no compromisso com as classes populares, que passariam a integrar, de forma subordinada, o cenário político nacional. Cf. Boris Fausto. A Revolução de 30: história e historiografia. São Paulo: Brasiliense, 1970; Ver também Ângela de Castro Gomes, op. cit. pp. 32-34.

${ }^{291}$ Francisco C. Weffort, op. cit., p. 36. Grifo nosso.

${ }^{292}$ Francisco C. Weffort. "Razões sociais do populismo em São Paulo" In Revista Civilização Brasileira n. 2. Rio de Janeiro: Civilização Brasileira, 1965, pp. 39-60, 57. 
desprovida de consciência, ou melhor, esclarecimento sobre a sua própria condição. Assim, a participação alienada das camadas populares oferecia condições à ascensão de políticos como Getúlio Vargas, Adhemar de Barros, entre outros. Curiosamente, são dessas mesmas reflexões acerca de um populismo algo manipulador - que, quase automaticamente, é atribuído ao adhemarismo - que surgem os questionamentos acerca da possível e provável idéia de interlocução entre o político e as camadas populares, configurando uma relação de mão dupla e não apenas de cima para baixo.

Ao comparar o adhemarismo e o janismo, Weffort analisa a existência de uma certa interlocução que dialoga com as camadas sociais, ainda que para o autor estas estejam desprovidas de uma perspectiva para o conjunto da sociedade. A exemplo das eleições ocorridas para governador do estado em 1962, o autor identifica no adhemarismo vitorioso a retomada de um discurso calcado na imagem construída durante as primeiras passagens de Adhemar de Barros pelo governo paulista. Duas vertentes: uma fase "progressista", que compactua com as obras e as realizações do político e uma conservadora, calcada no bordão "paz e tranqüilidade". Dois aspectos de uma proposta que surtiu efeito junto às camadas médias da sociedade, em que

O viver tranqüilo [era] uma aspiração permanente deste pequeno-burguês que, mesmo nos momentos de ascensão, busca assegurar garantias de estabilidade contra as perspectivas, obscuras mas inevitáveis, da decadência. ${ }^{293}$

Para Weffort, tais "massas pequeno-burguesas" não negam o seu conservadorismo justamente por estarem ressentidas ante à ameaça de queda iminente do padrão de vida. Ou seja, externam uma expectativa bem típica de setores marginalizados que dialogam com o poder na medida em que este promete livrá-los do infortúnio. Por outro lado, o desafortunado, o "assalariado marginal" de baixa qualificação, também se aproxima do discurso de um Estado protetor que olhe para os pobres. Deste modo, a atividade filantrópica desenvolvida por dona Leonor assume grande importância aos olhos tanto da "massa pequeno burguesa" como do pobre "assalariado marginal": no primeiro caso, menos porque já os tenha servido em circunstâncias difíceis, mas em ambos, porque constitui a expressão do tipo de generosidade que imaginam para o Estado ${ }^{294}$.

${ }^{293}$ Francisco C. Weffort, O Populismo na Política Brasileira, op. cit., p. 31.

${ }^{294}$ Idem, pp. 31-32. 
Nesse sentido, pesava a imagem do "chefe patriarcal" que, na sua generosidade, prometia um "viver tranqüilo" para atender tais setores que apoiavam o adhemarismo: menos esperançosos de uma política específica do que um poder que "olhe pelos pobres" ${ }^{295}$. No estilo mesmo de um populismo de Luís Bonaparte analisado por Karl Marx, cujo representante tem, ao mesmo tempo, que parecer o seu senhor com um poder governamental ilimitado e que do alto lhes mandasse o sol ou a chuva ${ }^{296}$.

Já o janismo, na perspectiva de Weffort, expressava setores sociais mais "estáveis" que aqueles contemplados pelo discurso adhemarista. A partir de meados dos anos de 1950, o crescimento econômico do estado cria um cenário cuja grande maioria do eleitorado de Jânio Quadros, operários e classe média proletarizada ou em vias de proletarização, se inserem sem tantas dificuldades no desenvolvimento capitalista. Pois ao contrário do adhemarista típico,

Na medida em que o sistema [capitalista] se desenvolve, eles sentem-se menos como pequena burguesia em crise de decadência do que como operários com situação estabilizada ou em ascensão. Nesta mesma medida, chegaram ao limite da escala social urbana, seja decaindo como pequena burguesia que passa a viver do salário, seja ascendendo como homens de campo e do interior que engrossam as fileiras do proletariado. ${ }^{297}$

No sentido proposto pelo autor, o que conta para estes setores é a capacidade de trabalho e não a expectativa de favores. É no horizonte de um Estado impessoal (algo inconcebível no adhemarismo), que garanta justiça e o propalado moralismo - o "tostão contra o milhão" quando do seu surgimento em 1953, e a vassoura para varrer a sujeira - que se encontram as aspirações do eleitorado janista. Que se sentiu traído, contudo, pela renúncia de Jânio Quadros à presidência em 1961.

Portanto, o que nos parece inovador nas análises de Weffort é a medida da interlocução dos agentes sociais, transfigurados em classes sociais que buscam a representação dos seus interesses na exaltação de uma pessoa, de um líder carismático, enquanto imagem desejada para o Estado. E que o remédio para tais angústias sociais

\footnotetext{
${ }^{295}$ Francisco C. Weffort. "Razões sociais do populismo em São Paulo", op. cit., p. 58.

${ }^{296}$ Karl Marx. O 18 Brumário e Cartas a Kugelmann, 7.ed. Tradução Leandro Konder e Renato Guimarães. Rio de Janeiro: Paz e Terra, 1997, p.128. Grifo nosso.

${ }^{297}$ Ibidem, pp. 34-35.
} 
aparece representado seja em Adhemar de Barros, na figura do realizador e do patriarca ou em Jânio Quadros na figura do político impessoal e supostamente justo. De modo que resta, a saber, em que medida tais representações dialogaram, de fato, com as aspirações do eleitorado em geral, pois não se pode assumir a categoria de classe social (classe média, operariado, assalariado marginalizado, etc.) como açambarcadora das nuanças da sociedade $^{298}$. Há muito mais nas representações do jogo político, a exemplo do adhemarismo que, mesmo com o discurso de realizador e progressista afeito a uma cidade que se desenvolvia rapidamente, só conseguiu retornar ao poder em 1962 mudando a sintonia do seu discurso em "ondas" mais conservadoras.

Octávio Ianni também oferece contribuições para se pensar o populismo na política brasileira, na medida em que estabelece a relação entre as esferas econômica e social da política enquanto fruto de um projeto de desenvolvimento basicamente apoiado na incorporação das camadas populares ao jogo político. Com Ianni, a interlocução entre o Estado e a classe trabalhadora é analisada num contexto de crise do populismo, dado o esgotamento da democracia populista, ou o que ele chama de "modelo getuliano". O autor analisa tal processo dentro da falência de um projeto nacional-desenvolvimentista pertinente durante o período de 1930 e $1964^{299}$.

A saber, um projeto econômico de substituição das importações - sem o exclusivismo agrário do período oligárquico e com uma industrialização voltada para o desenvolvimento interno e independente - que não consegue resistir ao capital estrangeiro, ou melhor, à internacionalização da economia. Acarretando a perda de alguns centros de decisões importantes à formulação e à execução da política econômica. E junto à derrocada desse modelo nacional-desenvolvimentista, cairia também a democracia populista que tinha nas camadas populares e no apelo nacionalista o seu suporte ${ }^{300}$.

Resumindo, tanto Ianni como especialmente Weffort apresentaram importantes contribuições ao tema do populismo na política brasileira na medida em que estabeleceram novas bases para esta discussão. Para o segundo, a presença do conceito de interlocução, que mesmo através da questionável manipulação das massas, pressupõe um diálogo entre o

\footnotetext{
${ }^{298}$ Pois como nos lembra Pierre Bourdieu ao retomar E. P. Thompson, grupos sociais estão por fazer, não estão dados na "realidade social, aliás, esta também é um objeto de percepções". Cf. Pierre Bourdieu, Coisas Ditas, op. cit., p.156.

${ }^{299}$ Cf. Octávio Ianni, O colapso do populismo no Brasil, op. cit., pp 53-55.

${ }^{300}$ Ibidem.
} 
Estado e as camadas populares. E da mesma forma, mas na chave de uma "macro-análise", Ianni estabelece a relação entre as esferas econômica e social da política, mostrando existir um projeto de desenvolvimento que se apoiava na incorporação das camadas populares ao jogo político. Mesmo assim, a via explicativa pela chave do populismo acabou perdendo sua aplicabilidade justamente por sua capciosa abrangência para retratar fenômenos políticos distintos ocorridos no mesmo período. E, da mesma forma, por se tratar de um pressuposto teórico bastante "datado", ligado à experiência de Getúlio Vargas, que quando aplicado acaba por diluir as práticas e as atitudes dos entes envolvidos. Homogeneizando especificidades de diferentes contextos políticos, a exemplo do trabalho de Guita Grin Debert $^{301}$.

Tal autora, propondo estudar as especificidades nos discursos de quatro "líderes populistas" em diferentes cenários políticos - os estados da Guanabara, Recife, Rio Grande do Sul e São Paulo -, detém-se ao estudo específico dos respectivos discursos, porém, deslocando-os do contexto onde eles acontecem e restringindo-se ao processo de elaboração lingüística de cada um. Ao homogeneizar no nível da análise os discursos em questão a autora enquadra, antecipadamente, os discursos num arcabouço de idéias que habitam o conceito populismo. E com isso acaba reafirmando o que pretende questionar no início: idéias como manipulação, líder carismático, massas, etc. A abordagem fica presa ao conceito, o reafirma, ao "forçar" a igualdade nos discursos. E não alcança, a não ser muito difusamente, as características ideológicas que explicariam os diferentes estilos de mobilização política que apareceram no "período populista” da política brasileira.

Como não considerarmos, por exemplo, que a partir de 1953 Adhemar de Barros e o PSP tiveram que lidar com uma série de reveses políticos. E que, nesse sentido, a figura de um líder carismático, populista por excelência, resultou de uma construção bastante cautelosa e sujeita a infortúnios. Entre estes, um importante correligionário como Lucas Nogueira Garcez que, em prol da governabilidade de seu mandato como governador, compôs com outros quadros partidários na câmara de deputados contrariando os interesses do líder pessepista. O adhemarismo, corrente até então praticamente unânime no PSP, sofreu tensões dentro do próprio partido.

${ }^{301}$ Guita Grin Debert. Ideologia e Populismo: A.de Barros, M. Arraes, C. Lacerda e L. Brizola. São Paulo: T.A.Queiroz, 1979. 
Indicado pelo próprio Adhemar de Barros, o então governador passou a ser o maior problema entre os seus correligionários e os anos seguintes marcaram o rompimento entre estas duas figuras importantes no PSP. O que dificultou a sucessão do executivo estadual, pois em 1954 a candidatura de Adhemar de Barros

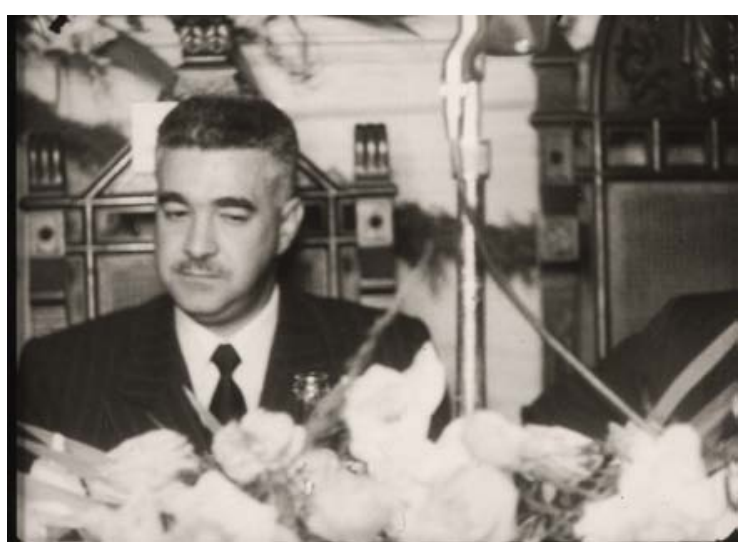

Lucas Nogueira Garcez, recorrente presença no cinejornal adhemarista. Bandeirante da Tela $n^{\circ} 674$, 1955. Acervo Cinemateca Brasileira. às eleições estaduais ficou "fragilizada" e acabou derrotada. Já não se tratava de dar continuidade ao projeto pessepista, pois Lucas Nogueira Garcez havia se desligado do partido no ano anterior.

Adhemar de Barros e o PSP se encontravam em grande desvantagem, uma vez que não possuíam mais ligações com a máquina governamental de São Paulo. Além do que, estas mesmas eleições marcaram o início da polarização entre Adhemar de Barros com o seu maior rival: Jânio Quadros, ainda que este houvesse vencido o pleito por uma pequena margem $^{302}$. Nas eleições presidenciais de 1955 o mesmo aconteceu, com Adhemar de Barros ficando em terceiro lugar ${ }^{303}$, apesar de uma incansável propaganda pelo BT, como veremos adiante.

Em 1956, o PSP iniciou o ano com sua queda em progressão: distanciado que estava do executivo do Estado, sofreu com ameaças e perseguições sob a bandeira da moralidade de Jânio Quadros. E perdia também a possibilidade do controle da máquina municipal, dada as pressões janistas no Senado para suspender a licença concedida a Lino de Matos, do PSP, para assumir a Prefeitura. Este, temendo a perda de imunidade parlamentar que o

${ }^{302}$ Foram 660.264 votos para Jânio Quadros, 641.960 para Adhemar de Barros, 492.518 para Prestes Maia e 79.783 para Toledo Piza num total de 1.874 .525 votos válidos. Apud Dicionário Histórico-Biográfico Brasileiro, op. cit., p. 546. Para uma população de aproximadamente 2.2870.258 de habitantes na capital, conforme os dados do SEADE (ex-Departamento de Estatística de São Paulo) apud. Inimá Simões, op. cit., p. 89 .

${ }^{303}$ Sendo 3.077.411 para Juscelino Kubitschek (PSD-PTB), 2.610.462 para Juarez Távora (UDN) e 2.222.725 para Adhemar de Barros (PSP). Apud Dicionário Histórico-Biográfico Brasileiro, op. cit., p. 546. 
tornaria mais vulnerável às pressões janistas, renuncia à Prefeitura em abril de 1956, assumindo, então, o vice-prefeito Wladimir Toledo Pizza, do PTB ${ }^{304}$. Já o líder pessepista, julgado culpado em processos judiciais, foi obrigado a um "exílio" no Paraguai, o que lhe serviu para arrefecer a conturbada crise em que estava envolvido. Trata-se do "Caso dos Chevrolets" em que Adhemar de Barros fora condenado a dois anos de reclusão. Contudo, sua absolvição naquele mesmo ano foi habilmente explorada, inclusive, com o intuito de recuperar o seu prestígio. Ao retornar à cena política em 1957, explora a imagem de vítima de perseguições políticas, vencendo o pleito para prefeito da capital paulista naquele mesmo ano.

Nesse contexto de ascensão e queda do adhemarismo, a estratégia utilizada por Adhemar de Barros para preservar a sua imagem foi bastante clara: manter-se em constante evidência. Certamente, o seu carisma não passou imune aos conflitos vividos nesse período e a força do "seu" populismo provavelmente não teria sobrevivido sem uma estrutura partidária forte. Ainda que a preocupação com a sua imagem fosse uma constante, ele não se apoiou apenas em seu carisma. Nos momento onde sua imagem saíra arranhada de certos confrontos, o partido era quem lhe dava sustentação a partir da troca de favores com outras correntes políticas. Assim, temos que o adhemarismo e o "pessepismo" não se misturaram, mas deram sustentação um ao outro. E na mais pura desmistificação da supervalorização do adhemarismo enquanto uma "força em marcha", por mais carismático que Adhemar de Barros tenha sido, ele dependeu do seu partido ${ }^{305}$.

Bem como o constante retorno à certas alianças - entre elas, indiscutivelmente a figura de Getúlio Vargas ${ }^{306}$ - e, sobretudo, muita propaganda política. No que os diretórios distritais, veiculação em programas radiofônicos e o cinema parecem ter sido bastante significativos. Vale lembrar que a maioria dos números disponíveis do BT é do período em que Adhemar de Barros governa, e nesse sentido refletem o esforço com que a imagem do líder populista foi trabalhada. Seja noticiando a sua agenda de compromissos políticos, seja registrando a rotina do PSP e dos seus correligionários mais ilustres, ou mesmo cobrindo

\footnotetext{
${ }^{304}$ Regina Sampaio, op. cit., p. 88.

305 Ibidem.

306 "O abraço que uniu as forças populares contra a espoliação do povo", panfleto do Partido Social Progressista e Partido Trabalhista Brasileiro. Caixa 638, pasta 03, doc. 001. Fundo Adhemar de Barros/APESP.
} 
fatos marcantes como, por exemplo, o suicídio de Getúlio $\operatorname{Vargas}^{307}$ e datas comemorativas $^{308}$.

Portanto, é sintomática a inexistência de informações sobre o BT para além de 1956, indicando, talvez, o esgotamento que um esquema de propaganda montado por Adhemar de Barros e o PSP não tivesse resistido ao desgaste da imagem política do líder pessepista, principalmente com a condenação de Adhemar de Barros em 1956. Algo que teria se estendido aos acordos comerciais que sustentavam a produção, a circulação e a exibição do BT. E colocando fim a esta propaganda política, mas que logo seria retomada em outros veículos de comunicação como a televisão ${ }^{309}$.

Diante das reflexões até aqui desenvolvidas cabe perguntar: quais estratégias, traduzidas para o discurso do cinejornal foram utilizadas por Adhemar de Barros? Se num primeiro momento criou-se um discurso para sedimentar uma representatividade conquistada nas urnas, quais pontos foram acentuados posteriormente à preservação do seu carisma, do seu capital político? Mais que buscar as raízes daquilo que foi visto como um fenômeno político ${ }^{310}$, é preciso desmistificar um discurso que inevitavelmente dialogou com os valores e as aspirações do espectador paulista, seu potencial eleitorado. E quais signos e temas foram "tirados" do que estava social e culturalmente sedimentado na sociedade daquela época. Uma investida que, se não deu certo para vôos políticos mais altos - como a presidência da República -, ao menos ajudou Adhemar de Barros a atravessar o tempo e as dificuldades em sua trajetória política numa sociedade que ainda lhe daria um terceiro mandato estadual.

Se há rastros de uma dimensão social na película do BT, e acreditamos nisso, resta saber em que medida eles nos servirão para explicar o fenômeno político, "descobrir" aspectos do mito, e melhor entender como um político fez uso do cinema para estender o alcance do seu discurso. Verificar como o adhemarismo, analisado pelo viés da linguagem

\footnotetext{
${ }^{307}$ Bandeirante da Tela s/n (Morte de Getúlio Vargas). São Paulo: Divulgação Cinematográfica Bandeirante, 1954, Fita de Vídeo (6min37seg), VHS, sonoro, p\&b, VV00683. Cinemateca Brasileira.

${ }^{308}$ Bandeirante da Tela, Ed. Especial. São Paulo: Divulgação Cinematográfica Bandeirante, 1954, Fita de Vídeo (10min54seg), VHS, sonoro, p\&b, VV00206. Cinemateca Brasileira.

${ }^{309}$ A exemplos dos textos de locução para programas de televisão, existente no FAB. Cf. "Texto de locução para televisão, campanha eleitoral para presidente". São Paulo, 1960. Caixa 634, pasta 002, doc 004 - Fundo Adhemar de Barros/APESP.

${ }^{310}$ Marli Guimarães Hayashi. A Gênese do Adhemarismo, op. cit., promove uma busca pelas raízes do fenômeno adhemarista, promovendo um inventário da sua passagem pela interventoria paulista e dos recursos que utilizou à construção de sua imagem política neste período.
} 
cinematográfica, se apresenta inovador, algo inusitado em termos de registro histórico. E porque este cinejornal, curiosamente, sequer aparece na mais recente compilação de realizações e feitos de Adhemar de Barros ${ }^{311}$. Provavelmente, suas imagens revelem mais do que se pretende para conservar uma certa memória do adhemarismo e/ou a manutenção do mito Adhemar de Barros.

Numa conjuntura delimitada entre os anos de 1946 e 1964, em que desfilaram tantas propostas e projetos políticos, é preciso entender que além do tão estudado trabalhismo brasileiro, surgido com Getúlio Vargas, e suas vertentes petebistas pragmáticas, doutrinárias e reformistas ${ }^{312}$, ou mesmo o desenvolvimentismo iconizado na imagem de Juscelino Kubitschek, outros projetos e propostas surgiram nesse "caldeirão populista". Muito resta saber, por exemplo, a respeito do janismo e do adhemarismo ${ }^{313}$, ainda que tenhamos que voltar ao "provincianismo" dos seus contextos regionais, e talvez por lá ficar - paráfrase tanto irônica da trajetória de Adhemar de Barros que jamais conseguiu ultrapassar as fronteiras da sua província. Mas ainda sim uma tentativa de análise que talvez colabore no que, só recentemente, historiadores vêem se ocupando para melhor compreender: os usos do termo populista ${ }^{314}$. Palavra esta que, seja em uso corrente, quase sempre com um significado voltado à imagem estigmatizada da política em nosso país ${ }^{315}$, seja na datação do termo, que certamente correspondeu a outras carências - tanto acadêmicas, como da opinião pública - de décadas atrás. E que, considerando o tempo decorrido, a sua (re)utilização talvez tenha perdido o significado ${ }^{316}$, pois não custa lembrar que antes de relacionar adhemarismo, ou qualquer outro "ismo" político, a um populismo algo sinônimo de atitudes pouco éticas à nossa percepção atual de mundo, ser um populista

${ }^{311}$ Cf. Paulo Cannabrava Filho. Adhemar de Barros: trajetórias e realizações, op. cit..

${ }^{312}$ Cf. Lucilia de Almeida Neves. "Trabalhismo, nacionalismo e desenvolvimentismo: um projeto para o Brasil (1945-1964)" In Jorge Ferreira (org.).O Populismo e sua história: debate e crítica, op. cit., pp. 167-203, pp. 177-178.

${ }^{313}$ Fernando Teixeira da Silva e Hélio da Costa. "Trabalhos urbanos e populismo: um balanço dos estudos recentes" In Jorge Ferreira (org.).O Populismo e sua história: debate e crítica, op. cit., pp. 205-271, 269.

${ }^{314}$ Jorge Ferreira. "O nome e a coisa: o populismo na política brasileira" In Jorge Ferreira (org.).O Populismo e sua história: debate e crítica, op. cit., pp. 59-124.

315 "São populistas os políticos que enganam o povo com promessas nunca cumpridas ou, pior ainda, os que articulam retórica com falta de caráter em nome de interesses pessoais. É o populismo, afinal, que demonstra como o "o povo não sabe votar" ou, em versão mais otimista, "ainda não aprendeu a votar". Ângela de Castro Gomes, ibidem, p. 21.

${ }^{316}$ Ibidem, p.54. 
nos anos quarenta e cinqüenta não significava o que para o nosso senso comum atual isso representa: uma necessidade em dizer que o populista é, invariavelmente, o outro ${ }^{317}$.

317 "Mas, afinal, quem são os populistas? Difícil saber, pois depende do lugar político em que o personagem que acusa se encontra. [...] O populista, portanto, é o outro, é o adversário, o concorrente, o desafeto". Jorge Ferreira, op. cit., p.124. 


\section{III - O ADHEMARISMO EM “QUADROS”}

[...] e se mandou para sede do partido pra pegar mais propaganda. Ia lá, na Duque, quase todas as tardes apanhar material (retratos do candidato, bandeirinhas, flâmulas, dísticos, cédulas) que distribuía aos passageiros, no ponto, no bar, no puteiro da Lilá e na vila onde morava. Os retratões, de mais de um metro, costumava guardar no porta-malas pra colar nas paredes durante a noite.

[...] - O fogo cerrado tem que ser no lombo dos indecisos. Pra que gastar saliva com os janistas? É com eles que eu converso, eles que trago pro meu lado. Assim que vocês devem trabalhar. Falem na Via Anchieta, falem no Hospital das Clínicas, em dona Leonor. Nos tuberculosos. Os indecisos é que vão nos levar pros Campos Elísios.

O Adhemarista, Marcos Rey ${ }^{318}$.

Além dos cuidados casuais com a fonte histórica, o historiador deve atentar para os traços marcantes de uma dada mitologia política. É nela que se encontram as portas para os caminhos que explicam o seu surgimento e a construção no tempo, em torno da figura central em que se baseia. Consiste num exercício, portanto, que requer bastante atenção às imagens que fundamentam a sua mística ${ }^{319}$. Como na epígrafe acima, ao descrever as estratégias e as apostas de um adhemarista - o taxista "Moa" (Moacyr) - em temas vinculados à imagem de seu ídolo, ela reflete o próprio discurso que Adhemar de Barros plantou naquele momento político. Nesse sentido, a opção de Marcos Rey, narrando tais passagens, sugere os ecos criados na memória coletiva.

Esses contornos do discurso adhemarista - a idéia de progresso, o trato com a saúde pública, o assistencialismo, além de outros - também estão representados no BT. E analisados quadro a quadro, colocam em xeque a idéia de um eleitorado passivo porque traduzem o esforço gasto na construção de um diálogo que precisava convencer o público, que na comunicação em massa tomou o lugar da noção de sociedade ${ }^{320}$. Desta forma, podemos entender que a popularidade de Adhemar de Barros foi sendo construída na medida em que se tentou compor com os anseios da sociedade que pretendia representar. $\mathrm{O}$ que implica pensar a dimensão das apostas realizadas pelo político numa chave de

\footnotetext{
${ }^{318}$ Marcos Rey , “O Adhemarista”, op. cit., p. 206-7. Grifo nosso.

${ }^{319}$ Raoul Girardet, op. cit., p. 20.

320 Michel de Certeau. A Cultura no Plural. Tradução Abreu Dobránszky. Campinas: Papirus, 1995, (Travessia do Século), p. 52.
} 
entendimento bastante distante da idéia, por vezes cômoda, de manipulação das massas. Até porque, a partir de 1954, o seu discurso dá sinas de esgotamento, mediante a dificuldade de representatividade política num cenário submetido a outras propostas políticas. Principalmente uma bastante inovadora: a do "tostão contra o milhão", cujo candidato com "ternos desalinhados, jeito desengonçado e discurso vibrante, salvacionista e moralizador" ${ }^{\prime 21}$, jurava varrer

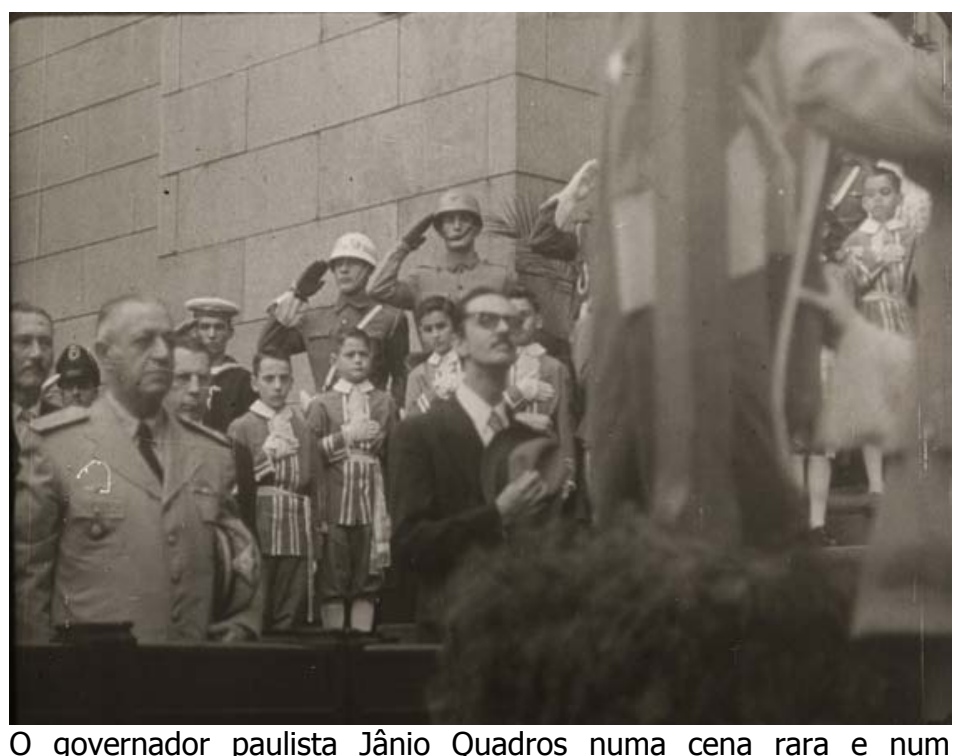
governador paulista Jânio Quadros numa cena rara e num enquadramento bastante desfavorável no cinejornal adhemarista. Bandeirante da Tela no 674, 1955. Acervo Cinemateca Brasileira. a sujeira do cenário paulista: Jânio da Silva Quadros, nada bem-vindo nas notícias do BT.

Trata-se, portanto, da estratégia adhemarista de convencimento que se completou com o investimento em propaganda no cinema. Visionando-o enquanto um meio tão moderno como o ideal de progresso que Adhemar de Barros tentou encenar no seu cinejornal e encerrando, desta forma, política e cinema num produto assistido nas salas de cinema em São Paulo.

\footnotetext{
${ }^{321}$ Ângela de Castro Gomes. "A política brasileira em busca da modernidade: na fronteira entre o público e o privado" In História da Vida Privada no Brasil: Contrastes da Intimidade Contemporânea. Fernando Novais (coordenador-geral da coleção); Lilia Moritz Schwarcz (organizadora do volume). São Paulo: Cia. das Letras, 1998, pp. 489-558, 547.
} 


\section{1 - Construindo realidades, fortalecendo o mito}

A mentalidade progressista fez a sua estréia com Getúlio Vargas, trazendo consigo a consolidação dos princípios burgueses ${ }^{322}$. Esse mesmo contexto gerou uma série de aspirações em agentes sociais da classe média e das camadas mais populares, participantes agora do jogo político e que passaram a pesar na balança eleitoral após o Estado Novo. Nesse sentido, a observação detalhada do BT revela uma série de símbolos e temas ligados à pluralidade da sociedade paulista, cujo corpo social, inserido no progresso de uma cidade "que não para", se reconheceu nas diversas formas de desenvolvimento e modernidade que pairava nos discursos políticos das mais variadas tonalidades, entre eles o de Adhemar de Barros. Assim, passagens características no discurso adhemarista estavam voltadas para algumas aspirações daquela sociedade e, do imaginário coletivo, ganharam vida na miseen-scène exibida pelo BT. Mais claramente: do arcabouço da modernidade, do progresso e dos valores tradicionais daquele contexto, alguns temas foram iconizados no sentido de despertar uma empatia no público pela representação de papéis respeitáveis na estrutura e mobilidade social daquela época.

$\mathrm{Na}$ senda de uma representação "convincente", o paternalismo no discurso adhemarista foi patente, num apelo que ocorreu indiretamente quando vinculado aos compromissos de dona Leonor. Nas manifestações de carinho registradas no BT para com ela, o discurso cinematográfico enveredou pela figura por vezes maternal, com ações assistencialistas, noutras matriarcal, com representações de uma pessoa central no seio do lar e da família. Comumente filmadas no âmbito das ações assistencialistas, seja no "Natal em São Paulo" ou nas "Notícias Sociais". Um tipo de aposta no discurso político que já havia tido suas aparições nos cinejornais de Getúlio Vargas, inclusive em sua experiência contemporânea do CJI, com a ação social de Darcy Vargas ${ }^{323}$. E mesmo em outros exemplos conhecidos de valorização da primeira-dama, como nos cinejornais da Espanha de Franco com as atividades sociais de sua esposa, dona Carmen Pólo ${ }^{324}$, ou mesmo na

\footnotetext{
${ }^{322}$ Cf. Pedro Cezar Dutra Fonseca. op. cit., p. 298.

${ }^{323}$ Cine Jornal Informativo vol. 2, n..52. Rio de Janeiro: Agência Nacional, 1951. Fita de vídeo (9min23seg), VHS, sonoro, p\&b, Arquivo Nacional, Rio de Janeiro - RJ.

${ }^{324}$ Sáncez-Biosca. Cine de Historia Cine de Memória - la representación y sus límites. Madrid: Cátedra, 2006, p. 49 (Sigo e Imagem).
} 
Argentina, com o exemplo mais lapidar da ex-atriz de rádio-novela Evita Perón, praticamente um duplo do carisma de seu marido ${ }^{325}$.

Em dois exemplos, podemos constatar o cuidado com a imagem de dona Leonor. No BT $415^{326}$ (1951), o registro reporta à entrega de presentes no "Natal em São Paulo". O cinejornal começa com várias imagens de bonecos de Papai Noel que enfeitam a cidade e, ao fundo, ouve-se uma música com motivos natalinos. Após esta breve introdução, o BT registra a ação dos postos de entrega dos tíquetes para retirada dos presentes junto a dona Leonor.

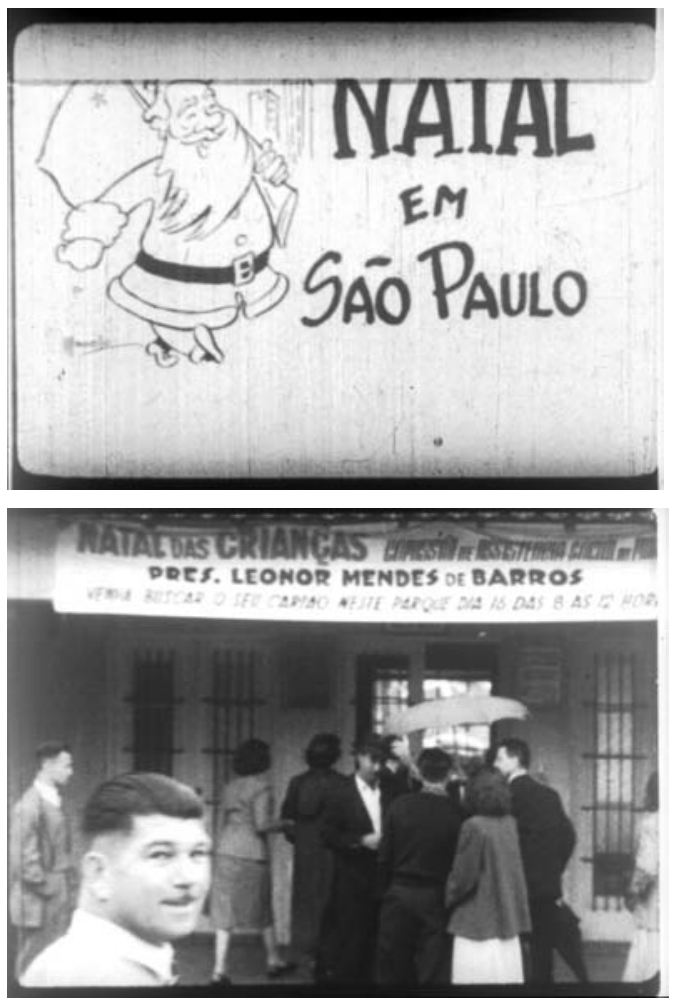

Cartela de apresentação do Natal em São Paulo Bandeirante da Tela no 415, 1951. Acervo Cinemateca Brasileira.

Fachada de um posto de distribuição de tíquetes Bandeirante da Tela $n^{\circ}$ 415, 1951. Acervo Cinemateca Brasileira.

Após esta primeira parte, em que o narrador faz questão de lembrar a iniciativa caridosa de dona Leonor, <em São Paulo, porém, há pessoas que se incumbem de lembrar a Papai Noel a infância desprotegida>, começam as entregas dos presentes. Pelo dispositivo da montagem, dilui-se uma temporalidade real para a criação de um espaço cinematográfico completamente visitado por dona Leonor, lhe atribuindo uma onipresença digna de Papai Noel: ela está em todos os postos de entrega. Como enfatiza o narrador ao lembrar o espectador do <trabalho de percorrer a cidade em todos os quadrantes, a fim de que os pais pobres possam ver felizes seus filhos no natal>. Durante todo momento, o discurso destila elementos para que se crie um clima bastante harmônico, algo que é anunciado nas cenas das entregas dos tíquetes, cartões, segundo o narrador, com panorâmicas em plano geral das pessoas que aguardam em longas filas indianas $<a$

\footnotetext{
${ }^{325}$ Cf. Prado, Maria Lígia C.O Populismo na América Latina, 6.ed. São Paulo: Brasiliense, 1981, pp. 37-65, 60 (Tudo é História, 4); Cf. Maria Helena Rolim Capelato. Multidões em Cena, op. cit., p. 95.

${ }^{326}$ Bandeirante da Tela n. 415. São Paulo: Divulgação Cinematográfica Bandeirante, 1955. Fita de vídeo (5min40seg), VHS, sonoro, p\&b, VV00098. Cinemateca Brasileira.
} 
entrega dos cartões [que] evitam atropelos e possibilita aproveitar melhor, os milhares de presentes de antemão preparados $>$.

No ato da entrega, as câmeras do BT estão postas estrategicamente para captar toda a ação de dona Leonor. São tomadas em plano médio, numa posição superior ao evento filmado, quase um plongée, com a intenção de captar o que parece ter sido ensaiado: as crianças vão passando e pegam seus presentes, algumas são advertidas com sinais para que avancem, enquanto outras ganham "tapinhas" nas costas por dona Leonor e suas assistentes, provavelmente, para que se apressem a fim de que a câmera capte o maior número possível de crianças assistidas. Pois <é preciso passar depressa ou não haverá tempo para todos $>$, justifica o narrador.

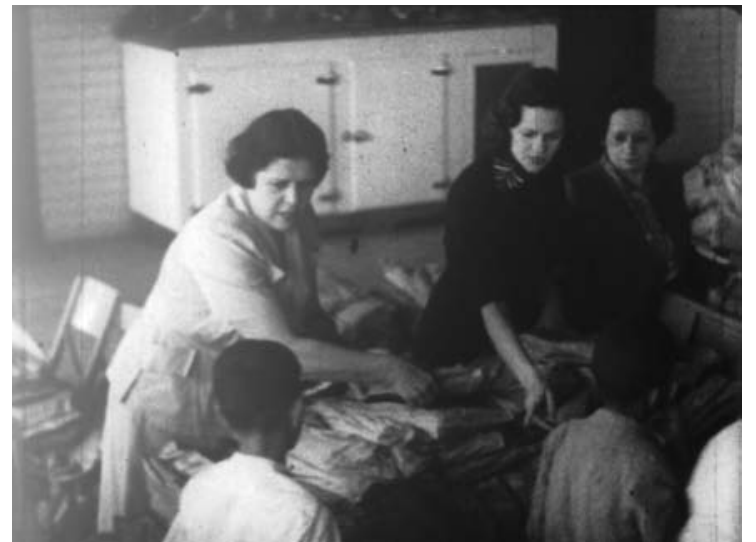

$<0$ altruísmo e as virtudes cristãs de amor ao próximo e caridade multiplicam as forças dos soldados desta campanha>...

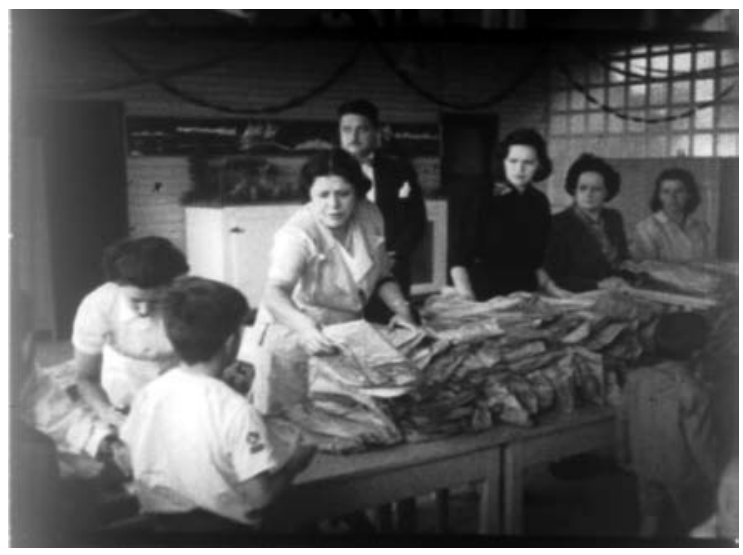

... dona Leonor e a entrega dos presentes. Bandeirante da Tela no 415, 1951. Acervo Cinemateca Brasileira.

Após várias seqüências de entregas, para "selar" o compromisso da ação social, as câmeras do BT "fecham" em plano geral dona Leonor caminhado com cerca de dezoito crianças à sua frente, quase todas sorridentes segurando seus presentes, e tendo ao seu lado outras mulheres, provavelmente suas assistentes nas distribuições, <os soldados desta campanha>. O movimento se prolonga numa panorâmica que reafirma a imagem da mulher protetora e responsável por toda a ação social, a mãe dos paulistas pobres, aquela que acolhe no "Natal em São Paulo". Mas ao narrar um assistencialismo ocorrido no cenário de uma grande cidade, o discurso cinematográfico, tanto pela intenção como pelo lapso de quem organizou a cena, tensiona uma fronteira social: entre todas as crianças escolhidas para "posar" junto a dona Leonor, curiosamente, nenhuma delas é negra. 
Pelo espaço cinematográfico, delimitam-se posições na sociedade, embora as crianças brancas no enquadramento com dona Leonor também indiquem carência. Para as crianças negras e suas famílias, os espaços representados neste BT são outros: não ao lado de dona Leonor, mas sentadas na calçada, por exemplo. Estabelecem-se, assim, lugares, e entre eles, uns mais marginais que outros. Onde dona Leonor, representante do $<$ altruísmo e das virtudes cristãs de amor ao próximo $e$ caridade $>$, mesmo sendo a mãe de todos os paulistas, está mais próxima fisicamente de uns que de outros. Destes, se aproxima enquanto entidade, pela idolatria que procurar granjear.

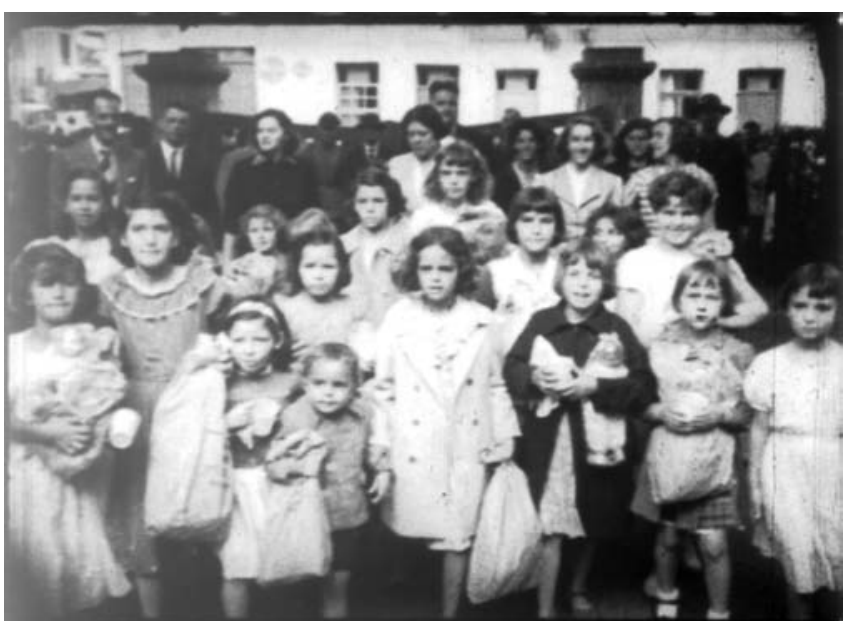

Dona Leonor ao centro do enquadramento: as crianças vão à frente. Bandeirante da Tela no 415, 1951. Acervo Cinemateca Brasileira.

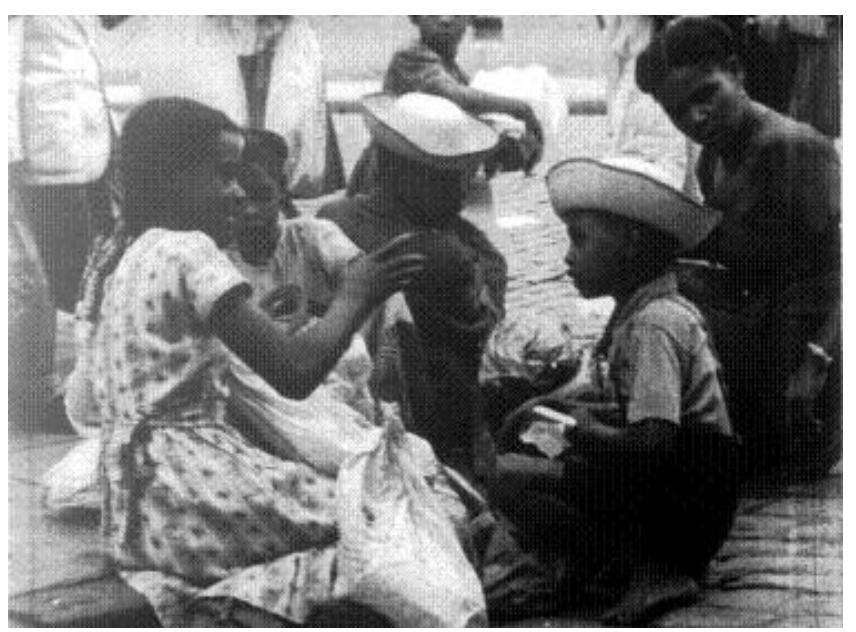

Crianças sentadas no meio-fio abrindo os pacotes recebidos por dona Leonor. Bandeirante da Tela no 415, 1951. Acervo Cinemateca Brasileira.

E a constatação da grandeza do gesto promovido por dona Leonor em benefício dos humildes prossegue, pois <até junto de Papai Noel, os pobres precisam de alguém que interceda por eles $>$. E a conclusão, menos pelo que se vê na tela (conforme a cena abaixo) e mais pelo que diz o narrador, é o resultado de uma ação social que tenta sensibilizar o espectador paulista pelo assistencialismo aos mais humildes, que estão < milionários de satisfação e alegria, apesar de papai e mamãe serem pobres, por isso eles acreditam que exista mesmo o Papai Noel, ou alguém que toma o seu lugar no Natal>. Trata-se, nesse ano de 1951, de uma aposta que vem somar força ao adhemarismo em ascensão, posto que acabava de fazer a sucessão no cargo mais importante do Estado. 


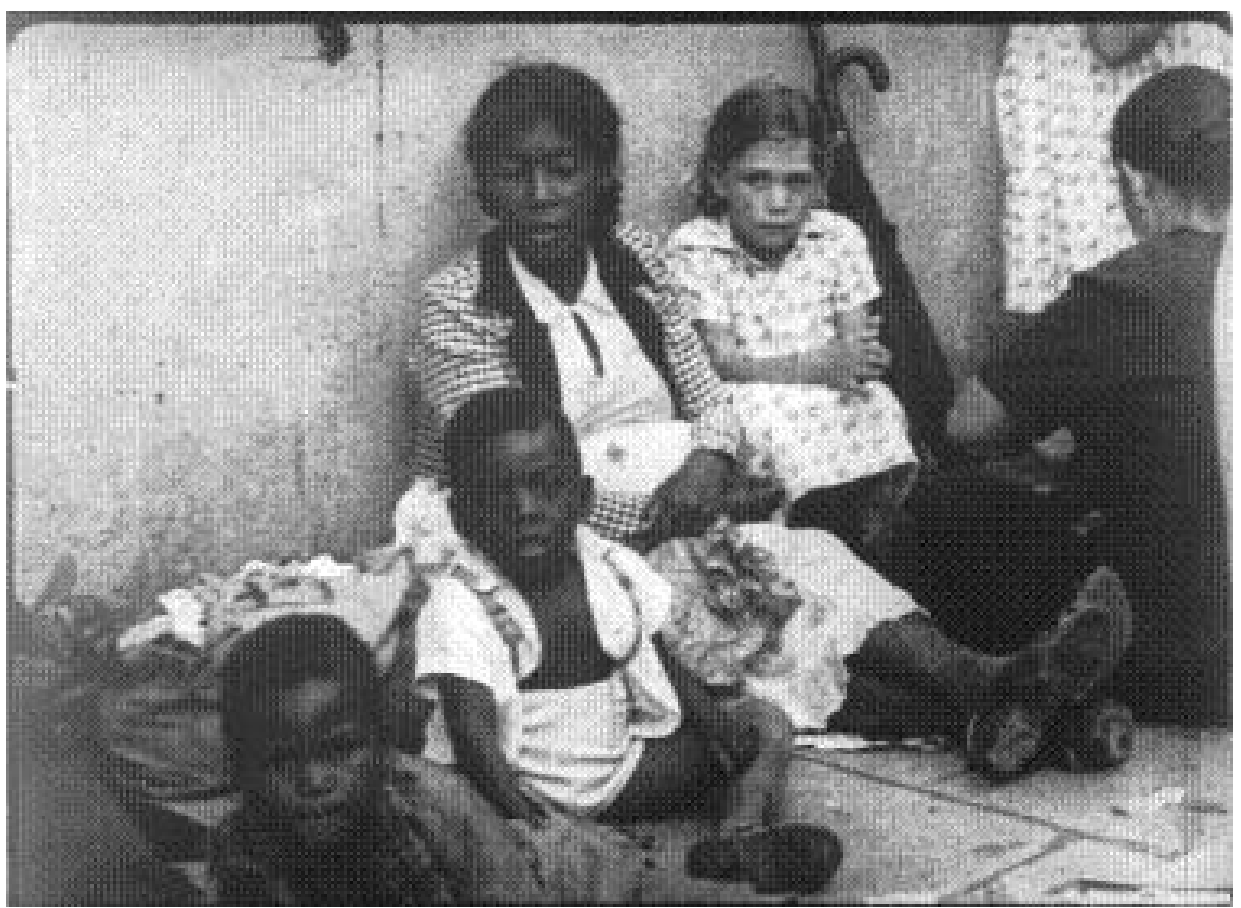

<... milionários de satisfação e alegria >: mulher e crianças após serem contemplados por aquela que intercedeu por eles. Bandeirante da Tela $n^{0}$ 415, 1951. Acervo Cinemateca Brasileira.

Vejamos outro exemplo de como a figura de dona Leonor foi trabalhada no cinejornal adhemarista. No BT $577^{327}$ (1954) temos indícios da outra face dessa representação assistencialista: o papel da matriarca. Apesar da perda de informação sonora deste registro - algo que realmente limita a análise de um discurso pensado para acompanhamento da fala -, ainda assim temos a dimensão do ritual que prossegue. $\mathrm{O}$ cenário não é mais a cidade de São Paulo, mas uma cidade do interior paulista (talvez Campos de Jordão, a "Suíça brasileira" ${ }^{328}$ ?), onde as pessoas se aglomeram para também receber presentes. $\mathrm{O}$ ritual da entrega segue nos moldes do BT 415: enquadramento com dois planos fixos que se alternam sem deslocamentos de câmera, tentando mostrar o todo da ação de pessoas que passam diante da câmera, apanham seu pacote e saem do enquadramento. Dona Leonor realiza a tarefa com o auxílio de ajudantes:

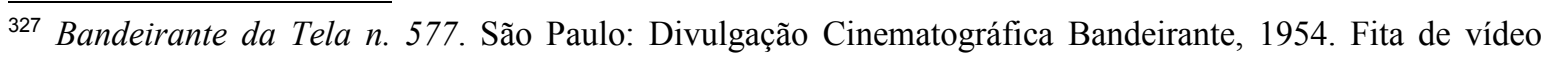
(6min45seg), VHS, mudo, p\&b, VV00099. Cinemateca Brasileira.

${ }^{328}$ Livreto de músicas "Patrícios e patrícias, para vocês eu vou contar! Alguns dos crimes, do grande 'líder Adhemar'!!!", op. cit.. 


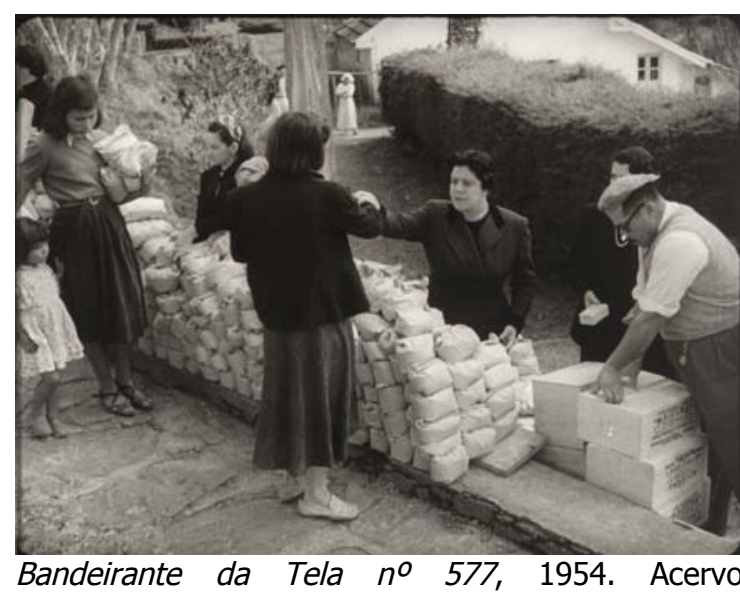

Cinemateca Brasileira.

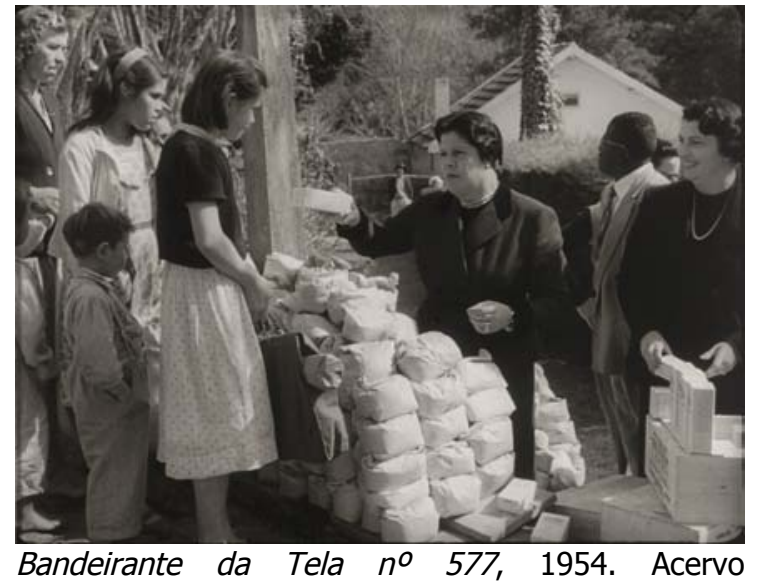

Cinemateca Brasileira.

Abruptamente, há um corte que desloca a ação para outro contexto. Duas seqüências com pequenas panorâmicas em plano americano mostram pessoas "chegando" (amigos, familiares?) para o que parece ser uma pequena confraternização. Há mais um corte, que nos leva para um plano geral, em que as pessoas reunidas compõem o seguinte enquadramento: dona Leonor, ao centro, está cercada por amigos que a brindam. Congratulações pelo seu aniversário ou um brinde pela iniciativa de mais uma ação pelos pobres? Não sabemos, mas é possível que sejam as duas coisas. Pois a montagem dos planos-seqüencia tenta estabelecer um jogo de cenas que se inicia com uma ação social, pois se trata de "Notícias Sociais" como a cartela de apresentação informa, e termina com uma homenagem à esposa de Adhemar de Barros, que também está presente nestas últimas cenas. Filantropa e matriarca se mesclam: todos centram atenção em Leonor.

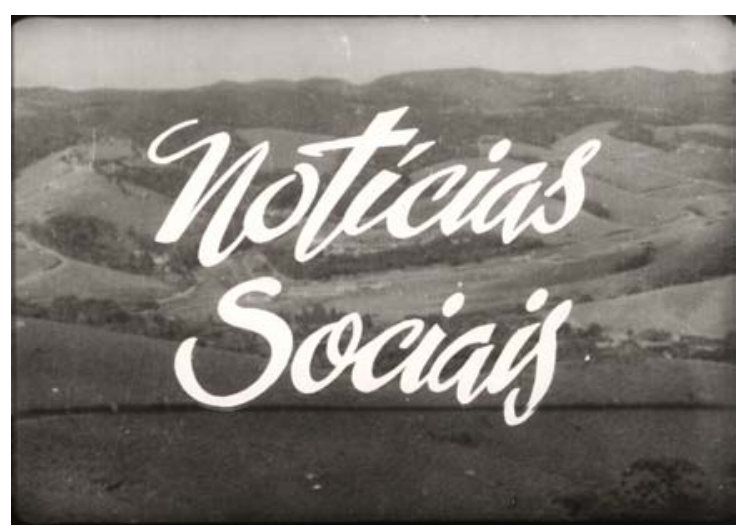

Cartela de apresentação do assunto Notícias Sociais. Bandeirante da Tela no 577, 1954. Acervo Cinemateca Brasileira. 


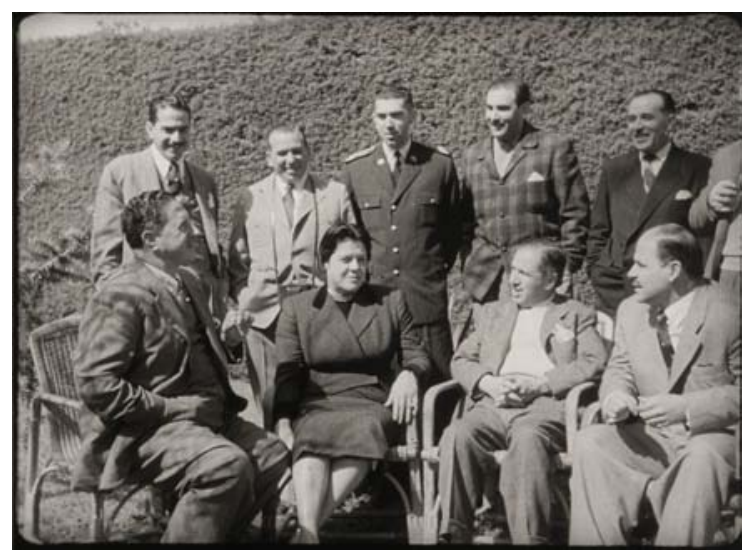

Adhemar e amigos homenageiam dona Leonor que é "brindada" estando durante todo o registro no...

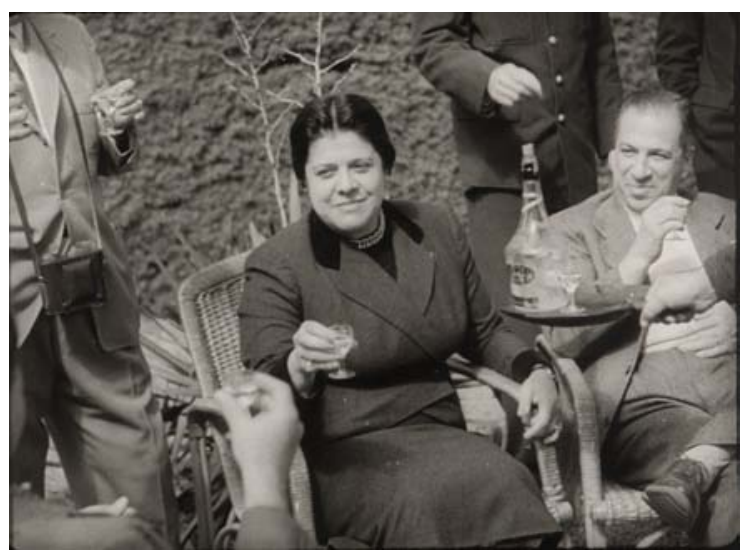

...centro do enquadramento. Bandeirante da Tela $n^{\circ}$ 577, 1954. Acervo Cinemateca Brasileira.

Em mais um exemplo, o BT $416^{329}$ (1951, também sem som), a imagem de dona Leonor enquanto mulher dedicada ao zelo da família aparece de maneira bastante clara. $\mathrm{O}$ cenário é uma reunião entre amigos e familiares numa determinada casa (de Adhemar de Barros?). Entre cortes bruscos (chicotes) assistimos algumas cenas em primeiro plano de Adhemar de Barros recebendo cumprimentos, pessoas no interior da casa e dona Leonor conversando com algumas delas, além de moças reunidas na sala. Tais tomadas estabelecem para o espectador as pessoas presentes naquele recinto, para depois concluir com uma cena de dona Leonor sentada num sofá, em plano médio, tendo à sua direita uma árvore de Natal, ocupando quase todo o enquadramento. A "Homeagem", como apresentado na cartela inicial, termina com uma panorâmica que se inicia em dona Leonor acompanhando pessoas (seus os convidados?) e que se desloca verticalmente para cima, fixandose num quadro da Virgem Maria com o menino Jesus, num primeiro plano que se mantém por sete segundos. As imagens abaixo seguem a ordem descrita:

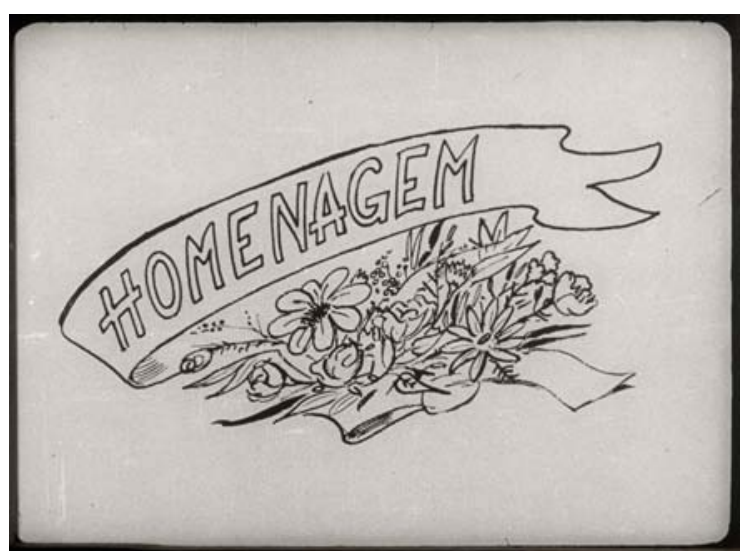

Cartela inicial. Bandeirante da Tela no 416, 1951. Acervo Cinemateca Brasileira.

${ }^{329}$ Bandeirante da Tela n. 416. São Paulo: Divulgação Cinematográfica Bandeirante, 1951. Fita de vídeo (6min47seg), VHS, mudo, p\&b, VV00048. Cinemateca Brasileira. 


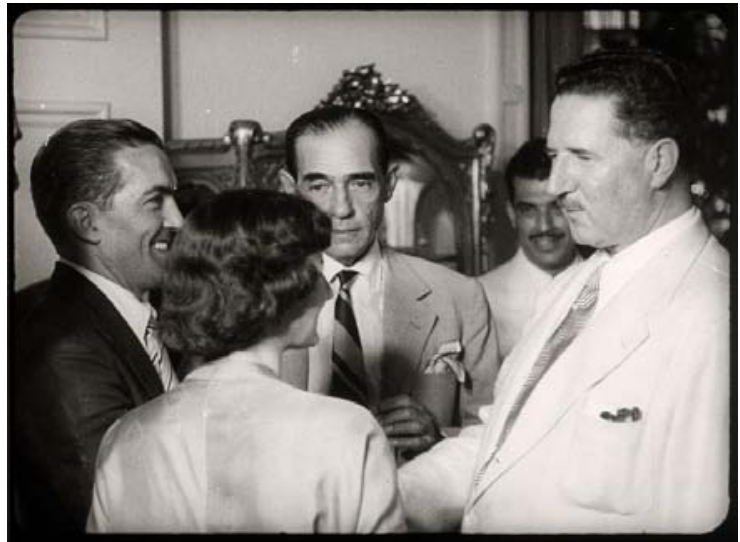

Adhemar de Barros sendo cumprimentado enquanto...

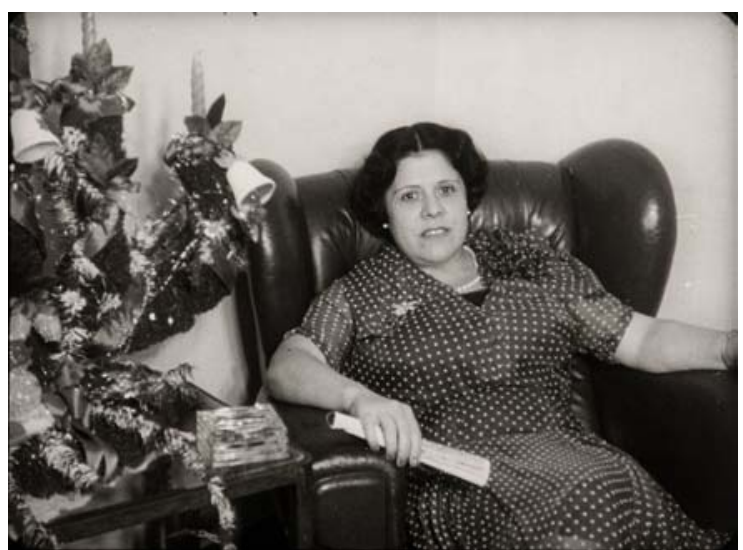

Plano médio de dona Leonor no sofá e a árvore de Natal à sua direita, seguido por um...

Apesar da dúvida se o acontecimento ocorreu ou não na casa de Adhemar de Barros - uma vez que não temos o som e nenhuma outra indicação a respeito nos foi possível -, o fato de como a notícia se encerra é indicativo da associação que se pretendeu alcançar: Adhemar de Barros e dona Leonor carregam valores católicocristãos, ou então, participam de uma comunhão familiar em que se prezam tais valores. Mais ainda, com base na linguagem

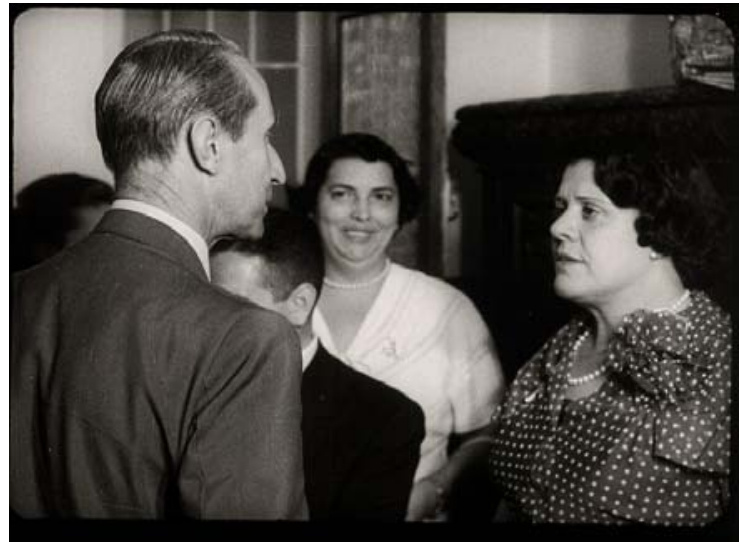

... dona Leonor conversa com os demais presentes. Bandeirante da Tela $n^{\circ}$ 416, 1951. Acervo Cinemateca Brasileira

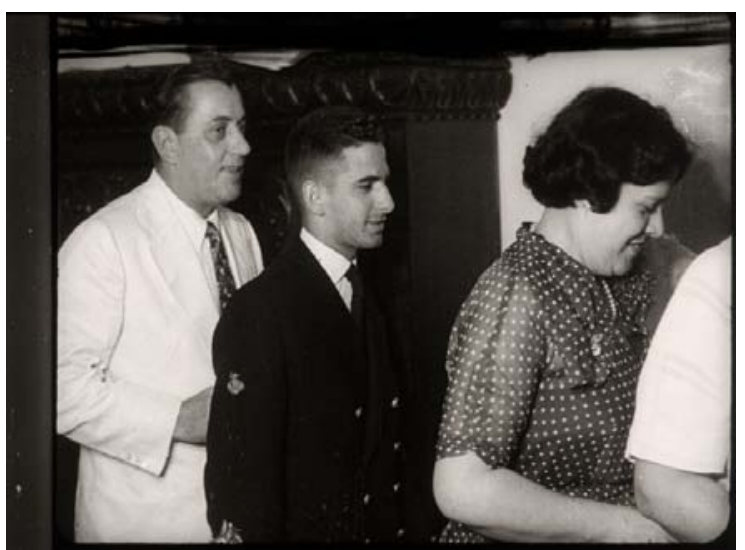

... corte à cena de dona Leonor acompanhando as pessoas presentes no recinto, numa panorâmica que termina...

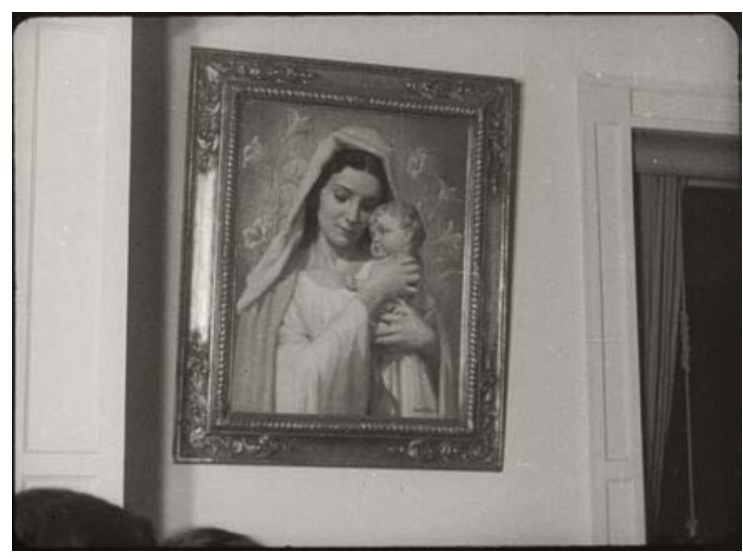

... num registro de sete segundos, em primeiro plano, da imagem católica Virgem Maria com o menino Jesus. Bandeirante da Tela no 416, 1951. Acervo Cinemateca Brasileira 
do cinema, pela montagem e os movimentos de câmera, criou-se uma continuidade visual, dona Leonor com o quadro na parede, e o que parece persistir é o indicativo bem claro da associação entre duas "entidades" que prezam pela santidade do lar e da família: dona Leonor e a Virgem Maria. A primeira como força política, a segunda enquanto "adorável criatura", muitas vezes evocada por Adhemar de Barros ${ }^{330}$.

A contrapartida, portanto, dessa representação de dona Leonor certamente fortaleceu um certo paternalismo do líder pessepista, associado que estava - enquanto o duplo de sua esposa - com as qualidades inerentes ao grande pai. E ao participar de inaugurações, visitações a hospitais, escolas e centros de puericultura, dona Leonor fortaleceu a imagem de um "protagonismo" feminino duplamente positivo. Ou seja, no melhor sentido pequeno-burguês ${ }^{331}$, ligado à dedicação ao lar e ao marido, mas também mesclado à disposição política de uma eterna "primeira-dama".

O próprio líder pessepista esteve presente nos atos de caridade de sua esposa, como consta no BT $679^{332}$ (1954), numa celebração do aniversário de dona Leonor em Campos do Jordão. Em alguns momentos deste cinejornal, é Adhemar de Barros quem aparece distribuindo presentes, como explica o narrador: $<$ Doutor Adhemar colabora nessa tarefa humanitária e filantrópica>, em que a <alma dos adultos também sabe notar as demonstrações de solidariedade humana dos bons> (caberia perguntar se não se quer dizer da alma do eleitor saber notar as manifestações de solidariedade “dos bons"...).

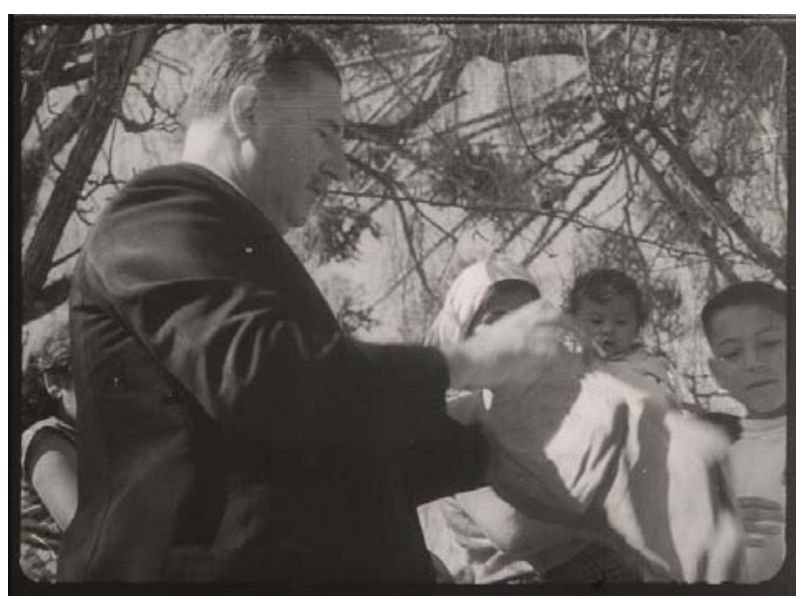

Adhemar participando da caridade promovida por sua esposa. Bandeirante da Tela no 679, 1954. Acervo Cinemateca Brasileira

${ }^{330}$ Roberto Schwarz. "Cultura e política, 1964-1969" in Cultura e Política. São Paulo: Paz e Terra, 2005, pp. 7-58, 23.

${ }^{331}$ Ou melhor, de uma pequena burguesia afeita ao adhemarismo, segundo F. Weffort. Cf. O Populismo na Política Brasileira, op. cit., p. 31.

332 Bandeirante da Tela n. 679. São Paulo: Divulgação Cinematográfica Bandeirante, 1955. Fita de vídeo (7min), VHS, mudo, p\&b, VV00099. Cinemateca Brasileira. 
Constrói-se, pouco a pouco, pelos detalhes, uma proximidade do tipo em que se valoriza o "homem honrado" e a "moça direita" cujo devir é a instituição do lar e da família ${ }^{333}$. É a transposição de hábitos privados e cristãos para o discurso político, baseado no homem público e na sua eterna companheira, primeira-dama, muito embora, naquela ocasião, Adhemar de Barros não fosse governador.

Voltemos ao BT $\mathrm{n}^{\circ} 679$ (1954), em que Adhemar de Barros acompanha dona Leonor que aniversaria, em visitas aos hospitais para tuberculosos para se dedicar às ações assistencialistas pelo interior paulista, naquele momento, ainda em Campos do Jordão. Após algumas tomadas de dona Leonor acompanhada de outras mulheres carregando presentes, ela parece percorrer vários corredores, adentrar e sair de vários leitos, numa clara continuidade visual criada pelo dispositivo da montagem cinematográfica. Tais "entradas" e "saídas" dos quartos, passadas repetidamente, dão a impressão de agilidade na visitação dos pacientes que, pelo arranjo das seqüências, não foram poucos os "contemplados" pela visita. Além disso, a montagem sugere claramente que aquelas imagens se somam a todas as outras visitações. Para dar "sentido" àquelas cenas, anuncia o locutor que < como todos os anos doutor Adhemar e dona Leonor visitaram os hospitais da Bandeira Paulista, contra tuberculose e outros nosocômios e maternidades distribuindo presentes $>$, ainda que nestas cenas iniciais a presença de Adhemar de Barros inexista, e seja sustentada pela fala do narrador. Entretanto, a mensagem foi comunicada ao espectador: o político participa ao lado da esposa nas várias visitas realizadas aos doentes.

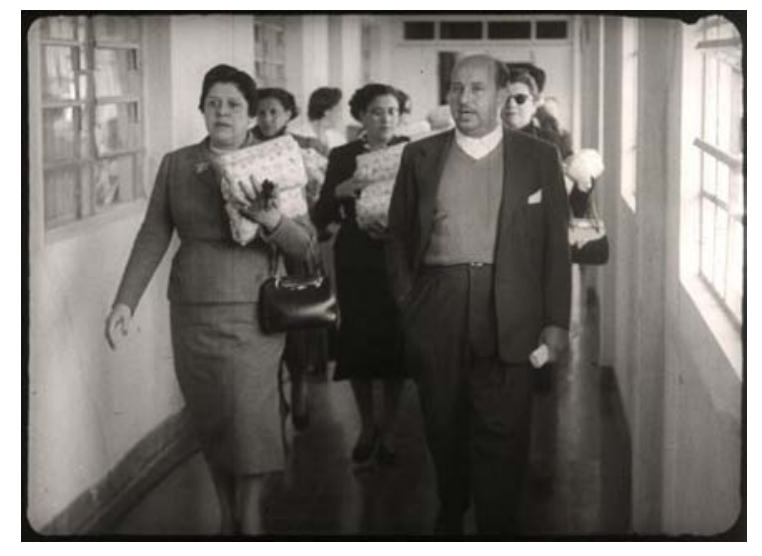

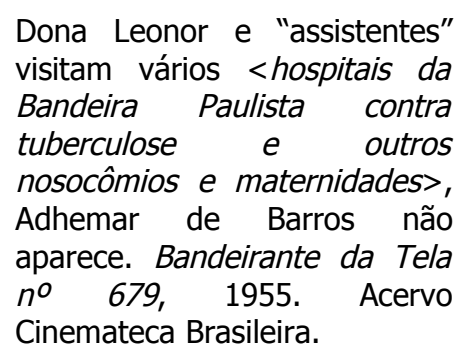

Dona Leonor e "assistentes" visitam vários < hospitais da Bandeira Paulista contra tuberculose e outros nosocômios e maternidades>, Adhemar de Barros não aparece. Bandeirante da Tela no 679, $1955 . \quad$ Acervo Cinemateca Brasileira.

\footnotetext{
${ }^{333}$ Segundo estereótipos trabalhados pelo cinema narrativo clássico e em especial pelo paulista, do início do século XX, conforme já apontado por Rubens Machado, em que “'homem honrado' encontra na 'moça direita' o tipo complementar, cujo devir é a instituição do lar e da família”. Rubens L. R Machado Jr. São Paulo em Movimento - a representação cinematográfica da metrópole nos anos 20. 1989. Dissertação (Mestrado na área de Artes). Departamento de Cinema, Rádio e Televisão da Escola de Comunicações e Artes da Universidade de São Paulo, p. 91.
} 
$\mathrm{Na}$ cena seguinte, a ação acontece no interior de um leito hospitalar. Adentram o recinto Adhemar de Barros, acompanhado de "autoridades" masculinas, tendo à sua frente mulheres, num plano americano que valoriza a presença física do político na composição espacial dos elementos dispostos no enquadramento. As mulheres, cujas estaturas e a própria condição feminina oferecem proeminência à figura masculina de Adhemar de Barros, reforçam, digamos, uma valorização paternal e protetora. O político que adentra o recinto solene, pois se trata de um leito hospitalar, o faz num gesto protetor de quem "olha" por aquelas mulheres, que ao mesmo tempo parecem "anunciá-lo" ao abrir passagem para ele. Nisso, o crucifixo pregado na parede, ao fundo, reforça a aura daquele momento em que alguém - Adhemar de Barros no caso - chega para praticar o bem.

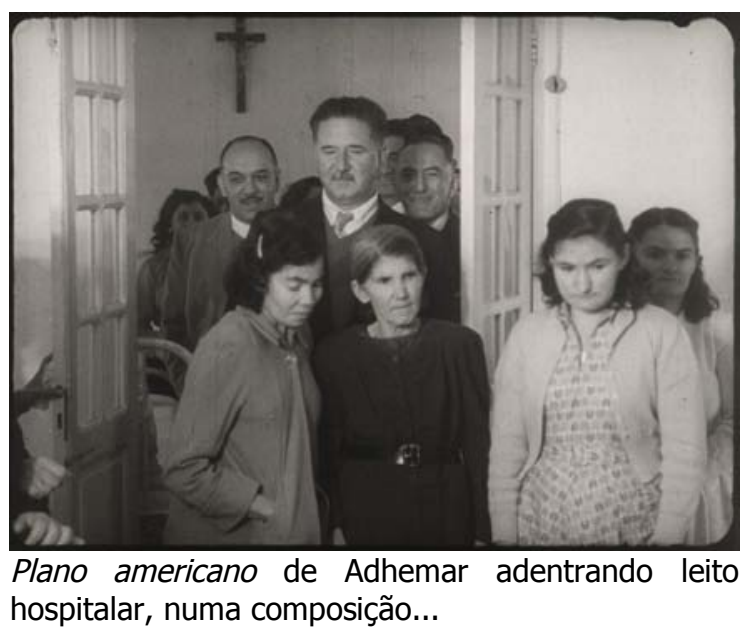

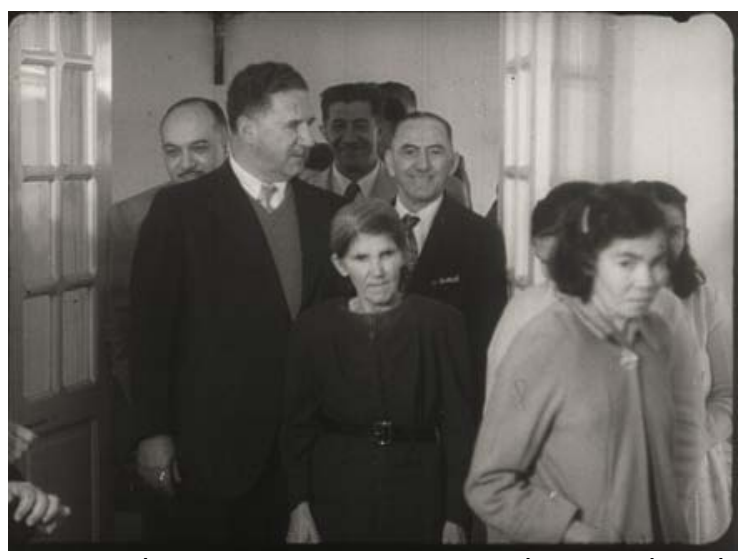

... que valoriza a sua presença. Bandeirante da Tela no 679, 1955. Acervo Cinemateca Brasileira.

Ali, supõe-se, o casal dedica especial atenção aos pacientes que se encontram internados. Entre enquadramentos em plano médio e plano americano, Adhemar de Barros aparece em pé, ao lado esquerdo da cama com a paciente, numa postura de quem a observa - sugerindo mais do que um simples acompanhante naquela visita. Ao lado direito do enquadramento, dona Leonor oferece um afago carinhoso à moça que está na cama, e que parece pouco confortável com a situação, encabulada, talvez, na medida em que ela quase não olha para Adhemar de Barros. Num corte para outra cena, segue uma ação num sentido claro de indicar uma continuidade em que dona Leonor dedica especial atenção a mais uma paciente: 


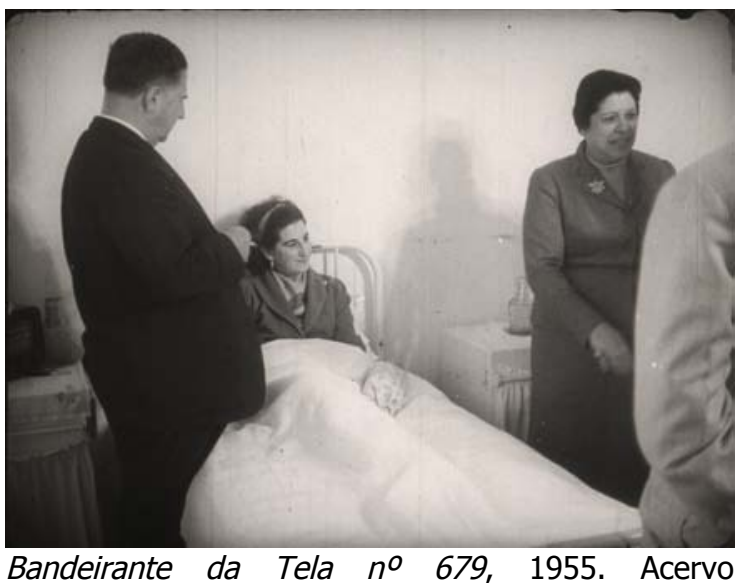
Cinemateca Brasileira.

Mais que um mero coadjuvante nas atividades sociais de sua esposa, Adhemar de Barros significa algo a mais. $\mathrm{O}$ fato de ser médico parece compor com a construção discursiva em que o político ali presente não se esquece, jamais, das tarefas condizentes à sua formação primeira: a missão de “clinicar". Outro precioso apelo à aposta de criar mais laços de afetividades com público. Não estaria a moça encabulada diante do doutor Adhemar, que se manifesta humana e solidariamente pelos ambientes em que passa?

Figura importante, o médico era crucial para a família. Dos cuidados com a manutenção do corpo e da vida, aos conselhos sobre a vida conjugal, a educação dos filhos e a orientação psicológica ${ }^{334}$, a imagem do doutor transmitia, no mínimo, uma postura de alguém confiável e ético. Tanto para aqueles que tinham acesso a esse profissional, classes média e alta, como aqueles que raramente o consultavam, as camadas mais populares, e que

${ }^{334}$ Fernando Novais e João Manuel Cardoso de Mello. "Capitalismo tardio e sociabilidade moderna" In História da vida privada no Brasil: contrastes da intimidade contemporânea. Fernando Novais (coordenadorgeral da coleção); Lilia Moritz Schwarcz (organizadora do volume). São Paulo: Cia. das Letras, 1998, pp. 559-658, 588.

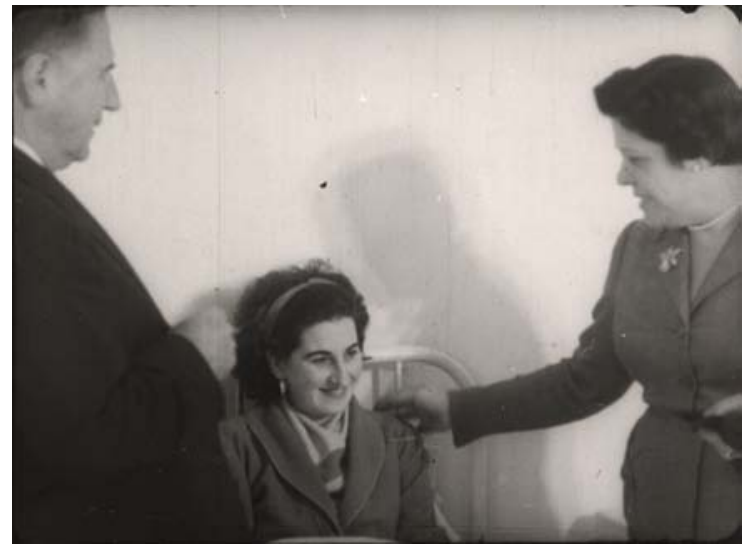

Continuação da seqüência: Adhemar e Leonor dedicam atenção e solidariedade. Bandeirante da Tela no 679, 1955. Acervo Cinemateca Brasileira.

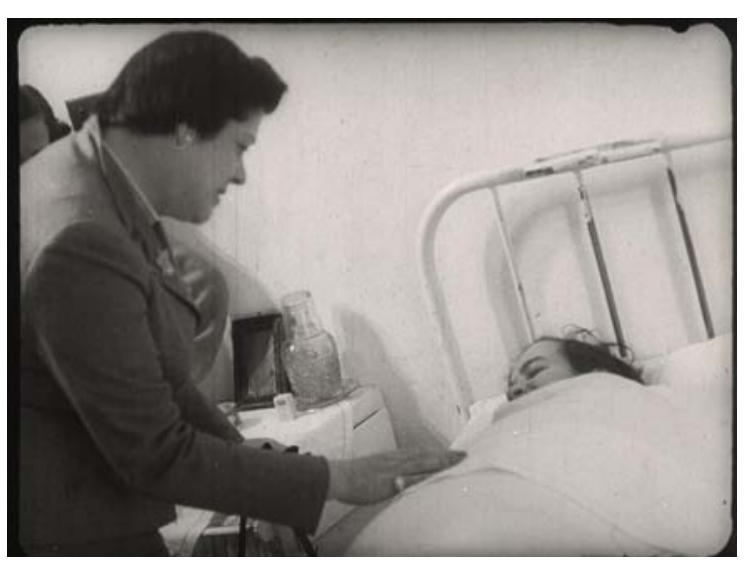

Continuação do mesmo plano: "doutor Adhemar" examina a paciente. BT, 1955. Bandeirante da Tela no 679, 1955. Acervo Cinemateca Brasileira. 
por esta mesma razão o respeitava ${ }^{335}$. Portanto, numa sociedade mediada por uma hierarquia de níveis profissionais, as distinções - diferença inscrita na própria estrutura do espaço social - atribuídas ao papel de médico, colocava Adhemar de Barros no topo de uma pirâmide de valores socialmente aceitos ${ }^{336}$. Um outro exemplo, portanto, de uma chave discursiva presente no adhemarismo: "Doutor Adhemar", médico preocupado com a saúde do povo paulista, que nas das visitas aos doentes tuberculosos em leitos hospitalares buscava a "conexão" com suas realizações nessa área como, a exemplo da maior de todas, o Hospital das Clínicas, "um dos maiores do mundo" 337.

Outros caminhos foram tentados para uma aproximação com o público paulista, como nas manifestações de carisma enquanto tentativa de convencimento do espectador pela demonstração da "força" do adhemarismo. O BT $501^{338}$ (1952) é exemplar neste aspecto, ao registrar o retorno de Adhemar de Barros e dona Leonor a São Paulo, após quatro meses de viagem pela Europa. Em pouco menos de seis minutos, temos o registro de um percurso nesta ordem: o desembarque no Rio de Janeiro, a recepção em São Paulo, no aeroporto de Congonhas, o discurso em palanque montado no mesmo local e o seu deslocamento e recepção por amigos, correligionários e familiares em sua residência. Quatro "blocos", por nós assim divididos, que articulam claramente a construção de um discurso cujo objetivo primeiro foi manter em evidência a figura do político, ou melhor, o capital político daquele que o Brasil <recebe com alegria $>e<\ldots$ que regressa de uma viagem de vários meses da Europa>.

$\mathrm{Na}$ aterrissagem no Rio de Janeiro, o narrador prepara o cenário, como na fala acima, para o longo percurso de uma rara manifestação de popularidade que veremos a seguir. Num ambiente reservado, uma tomada em plano médio mostra Adhemar de Barros cercado por sete pessoas que tomam nota da sua fala. Tal cena realmente demonstra uma entrevista, mas nada comparado a algo maior, como sugere o narrador que nos informa se tratar de uma <entrevista concedida à imprensa brasileira na capital federal>. Soma-se a

\footnotetext{
335 Ibidem.

${ }^{336}$ Numa comparação, segundo Pierre Bourdieu, do valor da distinção com o stand webweriano. Cf. Pierre Bourdieu. O Poder Simbólico, op. cit., p. 144-5.

${ }^{337}$ Livreto de músicas "Patrícios e patrícias, para vocês eu vou contar! Alguns dos crimes, do grande 'líder Adhemar'!!!"”, op. cit..

${ }^{338}$ Bandeirante da Tela n. 501. São Paulo: Divulgação Cinematográfica Bandeirante, 1952. Fita de vídeo (7min56seg), VHS, sonoro, p\&b, VV00098. Cinemateca.
} 
isso a própria composição do enquadramento de câmera que, ao dispor sete pessoas em volta do político, indica o recorte para um número provavelmente bem maior de pessoas da "imprensa brasileira" que o cercam. Igualmente interessante é o uso da fala para "criar" imagens que não vemos na tela, enquanto um claro reforço à composição de uma atmosfera de comoção, pois somos informados sobre um <vedado acesso a todas as pessoas $>$ que vêm trazer os cumprimentos ao político que retornara, no instante em que não há imagens que corroborem tais palavras. Nesse sentido, "todas as pessoas" provavelmente existam apenas na fala do narrador, numa interpretação do evento bem ao sabor dos interesses de quem o produziu 339 .

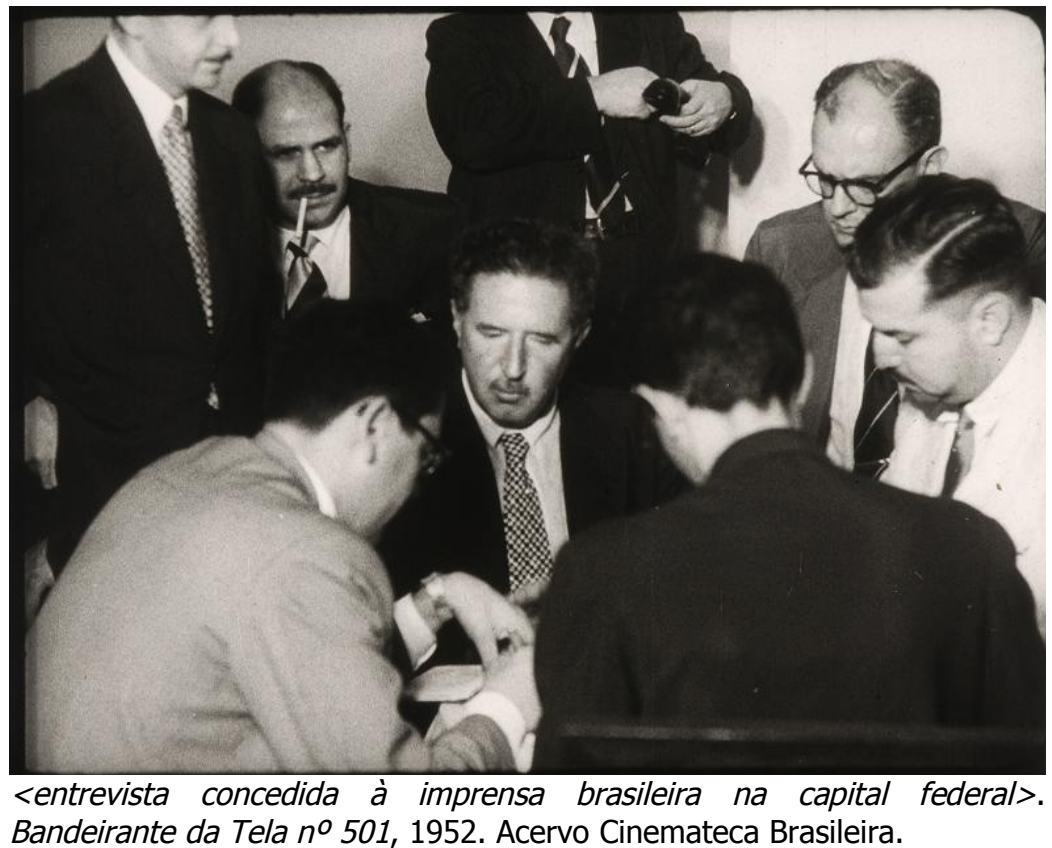

Num segundo momento - o da sua chegada em São Paulo - temos a maior manifestação de prestígio registrada nos números do BT ainda existente na $\mathrm{CB}$. O ano é 1952 e considerando a trajetória política de Adhemar de Barros, trata-se de um momento de ascensão, que ainda não havia sofrido seus maiores reveses políticos e tampouco se deparado com a figura de Jânio Quadros, que só despontaria no ano seguinte. Contudo, a euforia anunciada pelo narrador sobre uma <paulicéia [que] já se preparava para receber o grande líder populista $>$ apresenta pontos importantes para se pensar a construção de uma

${ }^{339}$ Algo usual ao papel da locução em cinejornais. Cf. Karel Reisz e Gavin Millar. A Técnica da Montagem Cinematográfica; op. cit., p. 195. 
proposta de convencimento pelas imagens, no discurso cinematográfico. Várias cenas mostram uma São Paulo imersa numa verdadeira mobilização, caracterizada por ruas com filas de carros sugerindo trânsito intenso e viadutos com muitas pessoas escoradas em parapeitos, supostamente aguardando a passagem de Adhemar de Barros. Mais uma vez, cabe inferir se a composição dos planos garante a verossimilhança das cenas, ou mesmo se elas tenham ocorrido em virtude da chagada do <líder populista $>$. Embora não nos foi possível checar a veracidade do evento mediante ao confronto com outras fontes principalmente jornais - é interessante notar os elementos selecionados pela montagem para compor a objetividade cinematográfica de um registro captado in loco.

Balões em formato de zepelim, carros com bandeiras do estado de São Paulo, ônibus com motivos adhemaristas, caminhão com a caçamba enfeitada de faixas, entre outras coisas. Nestas cenas, quase o "desvelar" de um acordo prévio à captação daquelas imagens se estabelece, se considerarmos as circunstâncias que comumente cercaram a produção de cinejornais como, por exemplo, o uso de um roteiro pré-estabelecido para poupar tempo e metragem ${ }^{340}$. Desta forma, a escassez de tempo, variante que provavelmente acompanhou diferentes etapas da produção ${ }^{341}$, inevitavelmente deixou rastros no discurso visto na tela. A falta de uma melhor revisão de conteúdo ou mesmo um retoque estético e a obtenção de "transições suaves" entre os planos ${ }^{342}$, comprometeu a representação ilustrada das "atualidades".

A pretensa naturalidade ficou exposta justamente na busca de efetividade com os signos do cotidiano. Como nos ônibus enfeitados e no caminhão adhemarista com faixas seguras por pessoas que parecem estar mais interessadas na câmera, pois inevitavelmente olham para ela. Pode-se questionar o real sentido daqueles cidadãos presentes na película: talvez interessados em simplesmente aparecer no cinema, pois esperaram o momento da

\footnotetext{
${ }^{340}$ Ibidem, p.189.

${ }^{341}$ Nesse sentido, é esclarecedora a fala de Maximo Barro, que viveu profissionalmente o cinema nos anos de 1950, ao descrever as condições de uma, dentre várias, produtoras de cinejornais paulistas: "[...] nessa época [...] a Campos Filmes só vivia do jornal [cinejornal]. O laboratório, o 'estudiozinho' dela, era uma coisa diminuta num primeiro andar de um prédio que ainda existe hoje, do mesmo jeito, na Rua do Triunfo. E era tão precário que, às vezes, você passava por volta do meio-dia lá e eles estavam secando os filmes na calçada por causa do sol. O equipamento dele não tinha a velocidade para secar e às $14 \mathrm{~h} 00 \mathrm{o}$ filme tinha que estrear no Cine Marrocos (informação verbal)". Entrevista de Máximo Barro, op. cit.. Grifo nosso. Um cenário precário que muito provavelmente esteve presente na realidade de outras empresas como a DBC que, após 1956, atuou como laboratório ou estúdio. Um indicativo, talvez, das suas limitações por não mais contar com a continuidade de sua principal fonte financeira, o cinejornal BT.

${ }^{342}$ Karel Reisz e Gavin Millar, op. cit., pp. 190, 199.
} 
captação da câmera, do registro pelo cinegrafista ali estrategicamente posicionado conforme ensaiado previamente ou preestabelecido em roteiro. Deste modo, o próprio processo cinematográfico utilizado no BT coloca em xeque a proximidade destes "populares" com Adhemar de Barros e pairam dúvidas se realmente as pessoas partiram do Anhangabaú em <conduções de toda espécie> até o aeroporto de Congonhas, ou que na $<$ na nova ponte do Ibirapuera $>$ as filas de automóveis foram aumentando com o crescente tráfego que < desde meio-dia levava gente a Congonhas > :

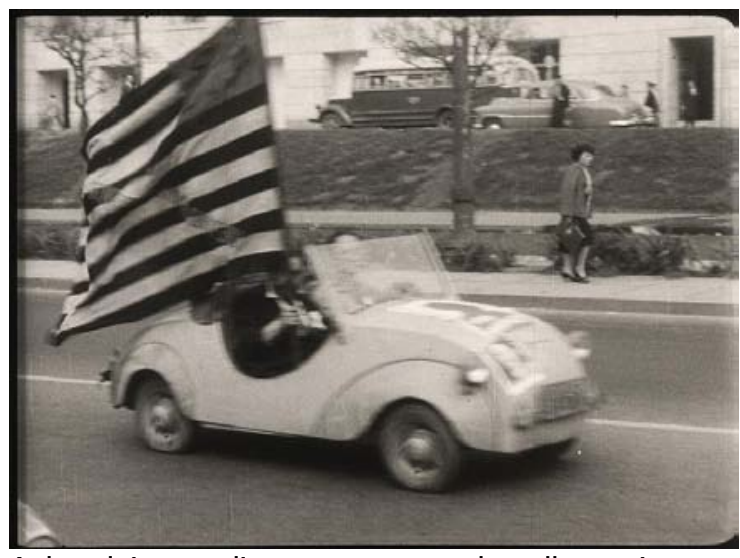

A bandeira paulista e propaganda adhemarista no capô. Carro preparado para receber Adhemar. Embora a seqüência seguinte não comprove o transito intenso em razão da homenagem, uma vez que os carros caracterizados aparecem isolados, em ruas sem muito movimento...

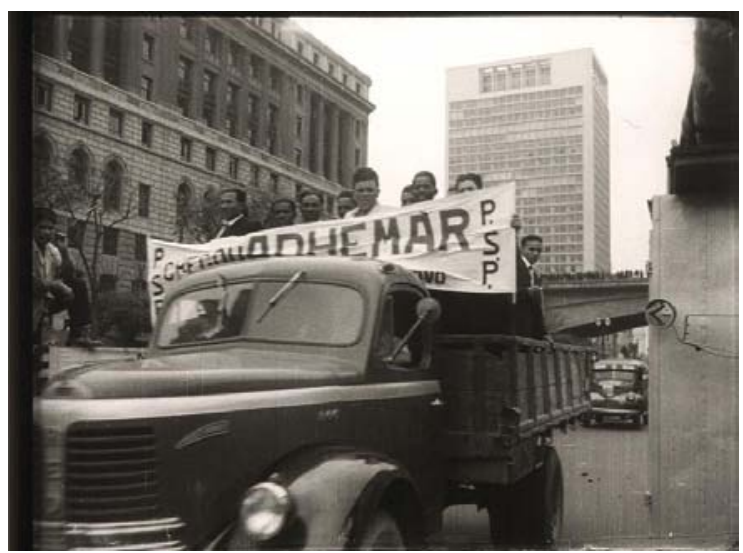

Pessoas na caçamba de um caminhão segurando faixa: participação em um grande evento ou pose para câmera? Bandeirante da Tela no 501, 1952. Acervo Cinemateca Brasileira.

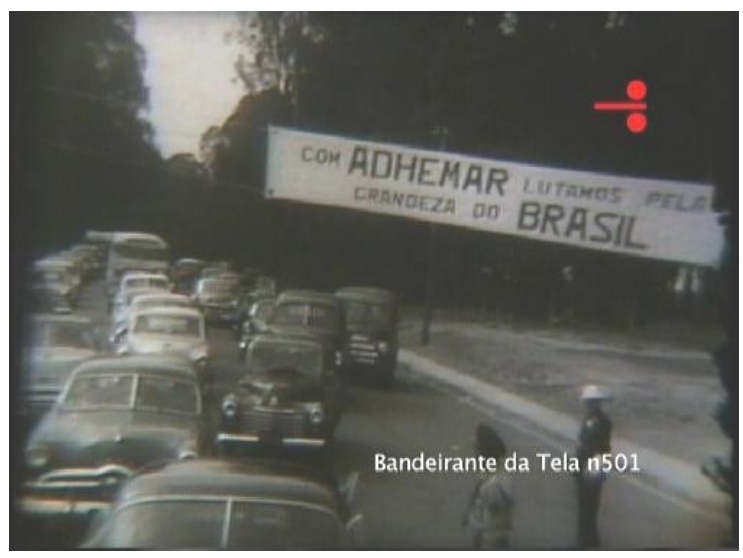

... enquanto a panorâmica sobre o trânsito não revela carros enfeitados. O "dado verossímil" para o convencimento vem de uma faixa estrategicamente colocada no término do movimento da câmera que mostrou automóveis reunidos. Bandeirante da Tela no 501, 1952. Acervo Cinemateca Brasileira.

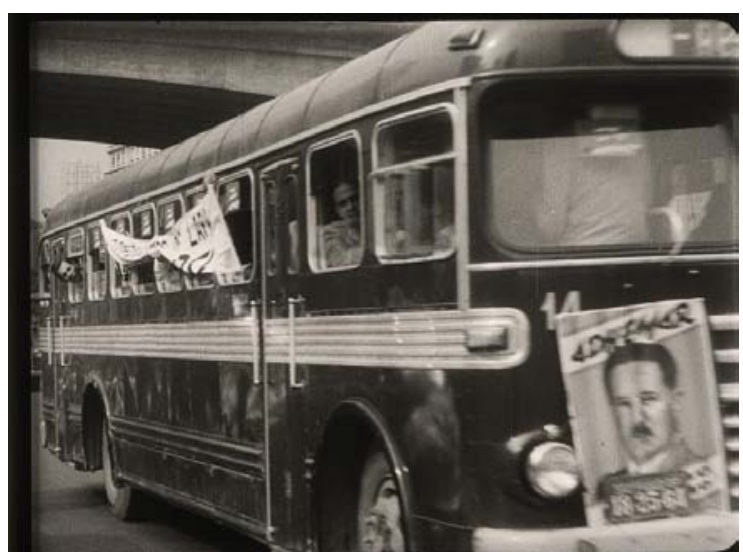

Mais do cotidiano? Populares em coletivos "participando" de uma grande homenagem. Bandeirante da Tela no 501, 1952. Acervo Cinemateca Brasileira. 


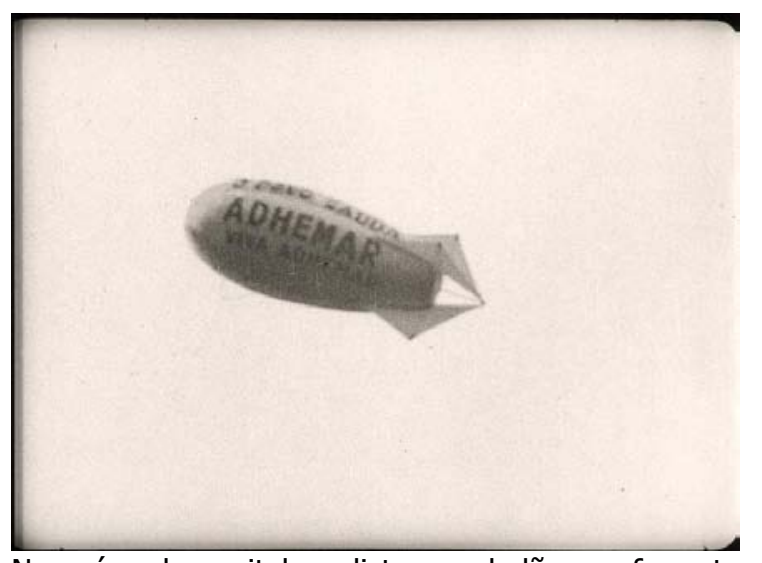

Nos céus da capital paulista, um balão em formato zepelim saudando Adhemar, enquanto nas ruas, 0 povo "improvisa", segundo o BT, para festejar o...

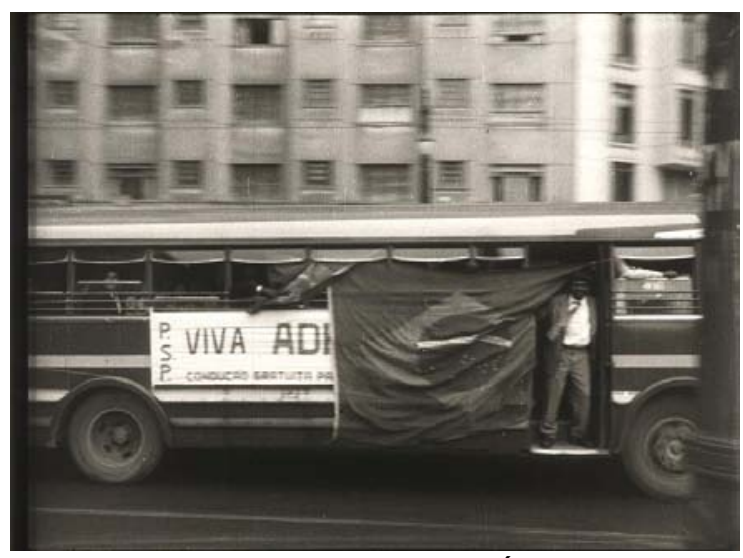

... 0 retorno do grande <líder populista>. Bandeirante da Tela no 501, 1952. Acervo Cinemateca Brasileira.

À mescla da política com o cotidiano pelo uso da imagem e do som, temos uma montagem com cenas de coletivos, automóveis, ruas, avenidas e locais conhecidos pelo público, bem como uma narração estabelecendo lugares para estes elementos dentro do evento. Uma realidade construída para as telas com ingredientes do que é próprio ao cotidiano.

$$
\text { No aeroporto de }
$$

Congonhas, as imagens mostram

o governador Lucas Nogueira

Garcez e esposa a espera de Adhemar de Barros e dona Leonor, que aterrissam às $<16 h 30>$. Um ritual que se inicia com bastante proximidade ao das películas getulistas como no CJB e no CJI, em que uma comitiva aguarda o líder que chega num avião e acena ao povo em solo firme. Mas a partir daí, o BT caminha por uma outra chave de relacionamento do líder com as massas.

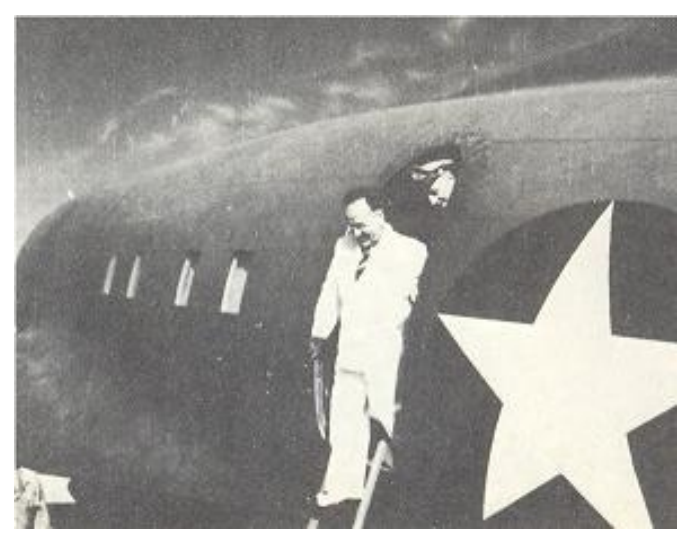

Presidente Getúlio Vargas em suas visitas a bordo do avião presidencial da FAB. Cine Jornal Brasileiro no 180, 1943.

Acervo Cinemateca Brasileira

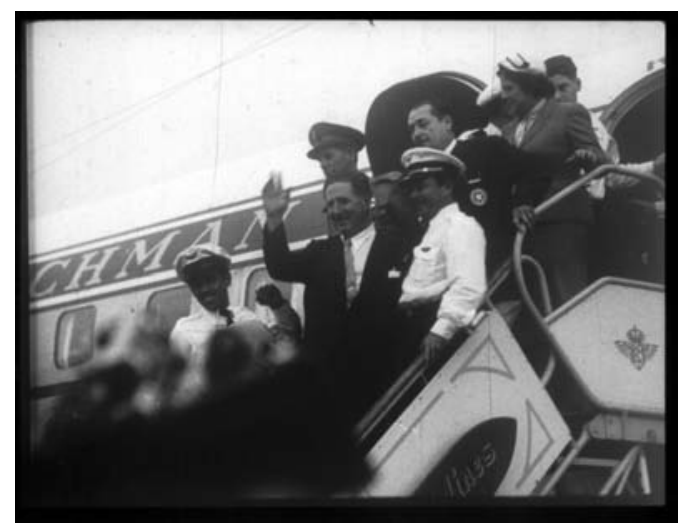

Nos moldes

getulistas,Adhem ar <voa no seu catalina rumo a São Paulo>. 0 político que regressa também tem o seu avião.

Bandeirante da Tela no 501, 1952. Acervo 
$<$ Restringiu-se o acesso a pista > nos informa a locução, porém, <para abraçar o amigo, elevado número de autoridades, pessoas da família e elementos destacados da política e da administração estadual, acercam-se do avião $>$. Enquanto uma panorâmica em plano geral "varre" o espaço ocupado no aeroporto, informando o espectador da massa ali presente, a seqüência prossegue com inserções do governador Lucas Nogueira Garcez e demais pessoas (impossível de identificarmos) envolvidas num "tumulto" algo reforçado pela câmera, que se movimenta bruscamente cercada e posicionada à altura das pessoas filmadas. Enquanto o próprio governador parece demonstrar desconforto ao ser empurrado pelas pessoas que <esquecendo-se da calma> diante do <júbilo que de todos se apossa> ao rever Adhemar de Barros, assim procedem. Não sabemos se, de fato, a panorâmica da multidão corresponde à grandiosidade do evento, tampouco o plano geral demonstra um enorme número de pessoas reunidas espontaneamente, sem quaisquer motivos que não o de homenagear o líder pessepista.

A continuidade no discurso cinematográfico, com tomadas favorecidas pela disposição da massa num dado instante, dá corpo a uma surpreendente

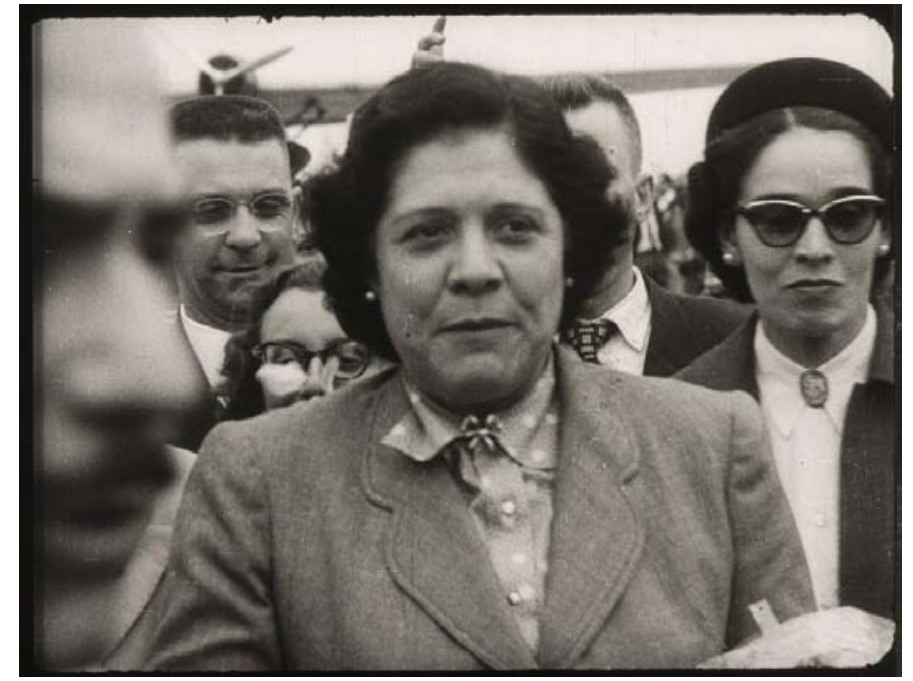

$<$ Dona Leonor é cumulada por respeitosa admiração por dona Carmelita Garcez [atrás, à sua esquerda] e todos os presentes>. Bandeirante da Tela $n^{\circ}$ 501, 1952. Acervo Cinemateca Brasileira

demonstração de carisma. Nesse ponto, o ritual adhemarista se distancia, por exemplo, das manifestações getulistas ocorridas em datas comemorativas e em cenários estratégicos, como nos estádios de futebol, com arquibancadas lotadas, onde era possível "conter" a massa de forma a pré-estabelecer o melhor a ser registrado pelas câmeras, ou os espaços das fachadas dos prédios públicos igualmente cheios. No BT, assim nos parece, a perspectiva de convencimento político na mise-en-scène é outra, pois Adhemar de Barros não está acenando de um palanque num estádio ou da sacada de um prédio oficial. Ele está, 
como quer as câmeras do seu cinejornal, literalmente no meio da massa. E em meio a ela tenta chegar até o palanque onde fará um <colóquio amigo com a multidão que o recebia>.

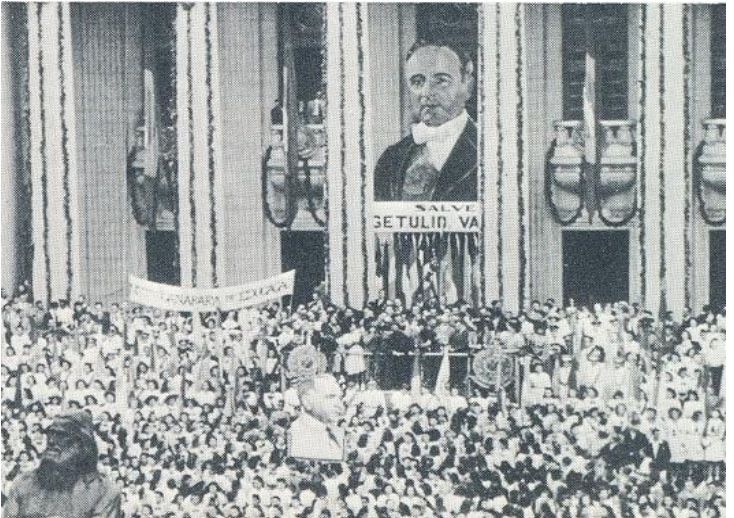

Lugares estratégicos como a fachada de algum prédio oficial. Getúlio Vargas acima e sobre a massa no Palácio Tiradentes, no Rio. Cine Jornal Brasileiro $n^{\circ} 25,1943$. Acervo Cinemateca Brasileira

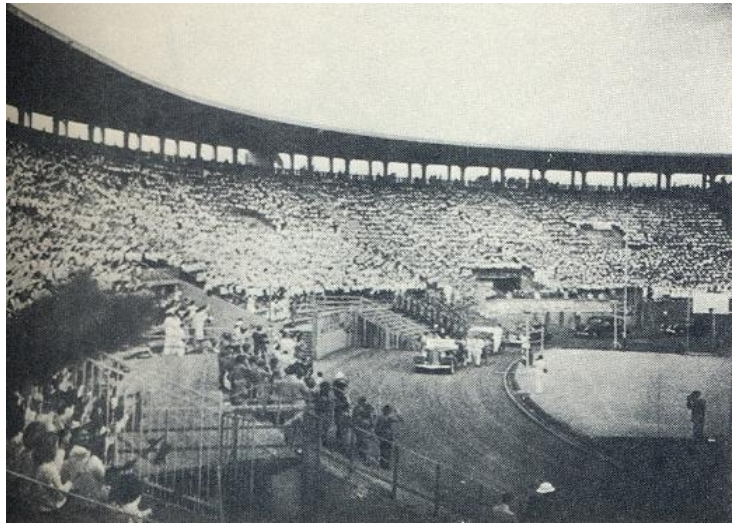

Ou espaços "controladores" da massa como estádios de futebol, com grande concentração. Estádio São Januário, Rio. Cine Jornal Brasileiro $n^{\circ}$ 121, 1942. Acervo Cinemateca Brasileira

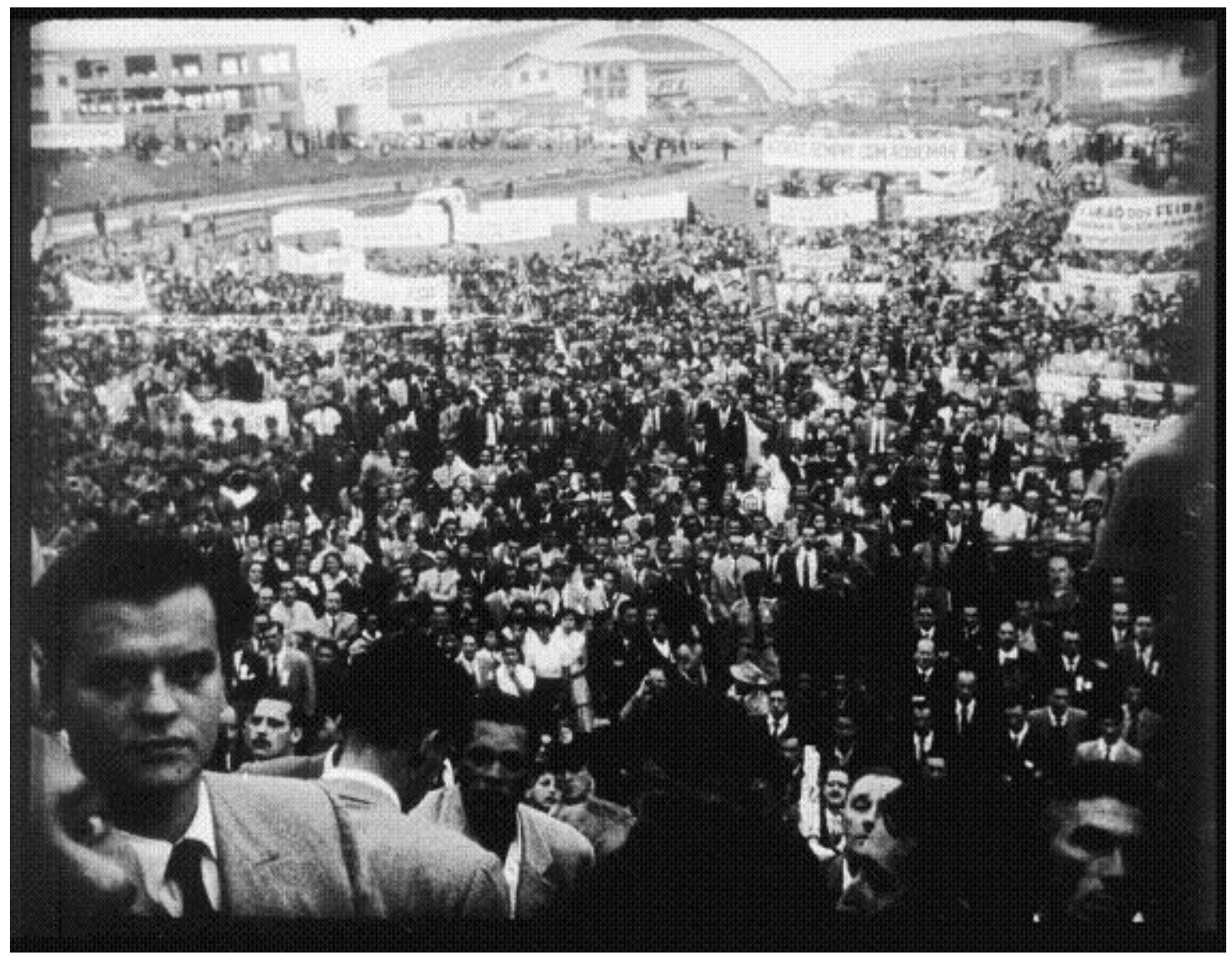

A câmera do BT, numa panorâmica em grande plano geral da esquerda para a direita, "varre" o espaço dando ao espectador uma dimensão do evento numa continuidade visual, pela montagem, estendida até Adhemar de Barros ... 


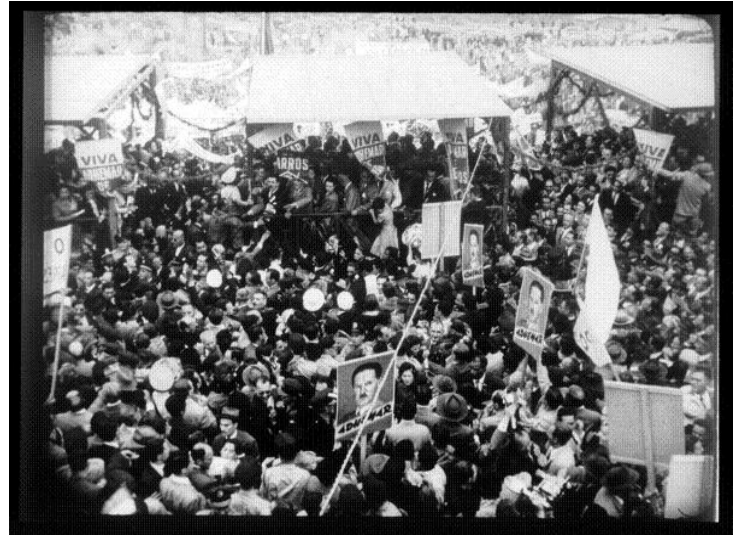

... que, no caminho ao palanque, é completamente envolvido pela massa a ponto de não o identificarmos nas imagens: <uma prova de sua popularidade que o povo transmite em suas aclamações e vivas>. Bandeirante da Tela no 501, 1952. Acervo Cinemateca Brasileira

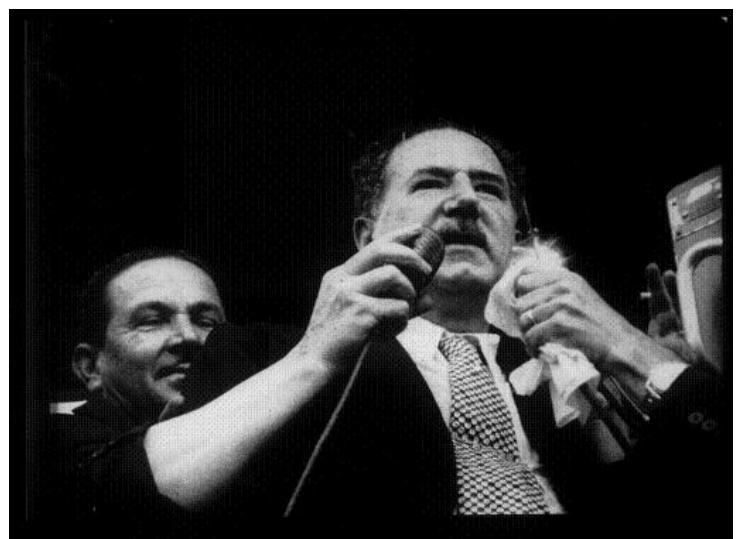

< Visitei uma dúzia de países na Europa em viagem de estudos e tive a oportunidade de verificar 0 muito que aí se faz e que pode interessar à nossa terra>. Bandeirante da Tela no 501, 1952. Acervo Cinemateca Brasileira

No melhor estilo de quem goza de uma <popularidade que o povo transmite em suas aclamações e vivas $>$, Adhemar de Barros vai até à massa, numa seqüência composta por imagens que o mostram sendo levado por uma correnteza de pessoas, algo intensificado por uma simplória aceleração da projeção e o uso do som adicional de aclamações ao fundo, do tipo <Adhemar! Adhemar!>, provavelmente adicionados na montagem do registro, para criar um reforço à atmosfera predominante no trecho ${ }^{343}$. Quase não conseguimos identificar o político, que é engolido pelas pessoas que o cercam. Porém, mais uma vez, cabe questionar se esse ritual do líder que a massa carrega não seria possível apenas no BT. Nada garante, por exemplo, que aquelas pessoas que o envolvem e quase o impedem de chegar ao carro, que o conduzirá à sua residência, não são correligionários seus. E, da mesma forma, haverá real continuidade com a concentração de pessoas anteriormente mostrada nas imagens em plano geral e a $<$ multidão e milhares de pessoas $>$ que o aguarda na saída do aeroporto?

Adhemar de Barros sobe até o palanque, discursa, desce e só encontra dificuldades para se locomover. E numa clara construção cinematográfica para conduzir o espectador naquele ritual, continuam os "vivas" ao político que, em meio a toda aquela comoção, ainda encontra disposição para um <colóquio amigo> com a massa que continua gritando $<$ Adhemar! Adhemar!>, como nos informa o narrador ao fazer suas as palavras de Adhemar de Barros: <Visitei uma dúzia de países na Europa em viagem de estudos e tive a

${ }^{343}$ Ibidem, p. 191. 
oportunidade de verificar o muito que aí se faz e que pode interessar à nossa terra>. Seguem, novamente, seqüências do político empurrado pela "multidão", mas numa composição de imagens que tensiona a veracidade pretendida, pois são takes idênticos aos anteriormente mostrados na chegada ao Rio de Janeiro. O que, para um olhar mais atento talvez não aquele dispensado pelo espectador na sala de cinema -, é um claro indicativo de uma realidade existente apenas no artefato fílmico, uma "segunda realidade" por assim dizer $^{344}$. Soma-se a isso um campo visual delimitado pelo enquadramento em plano geral, restrito à ação que corre naquele espaço pré-estabelecido no roteiro de um ritual a ser filmado e exibido no cinema. Cria-se, enfim, o discurso sobre alguém bastante querido, aguardado por muitos, que desce <para junto do povo >. E a partir de uma viagem particular, tem-se o mote para articular a idéia do político popular, empreendedor e esclarecido, que vai buscar soluções em outros contextos porque quer investir em sua terra.

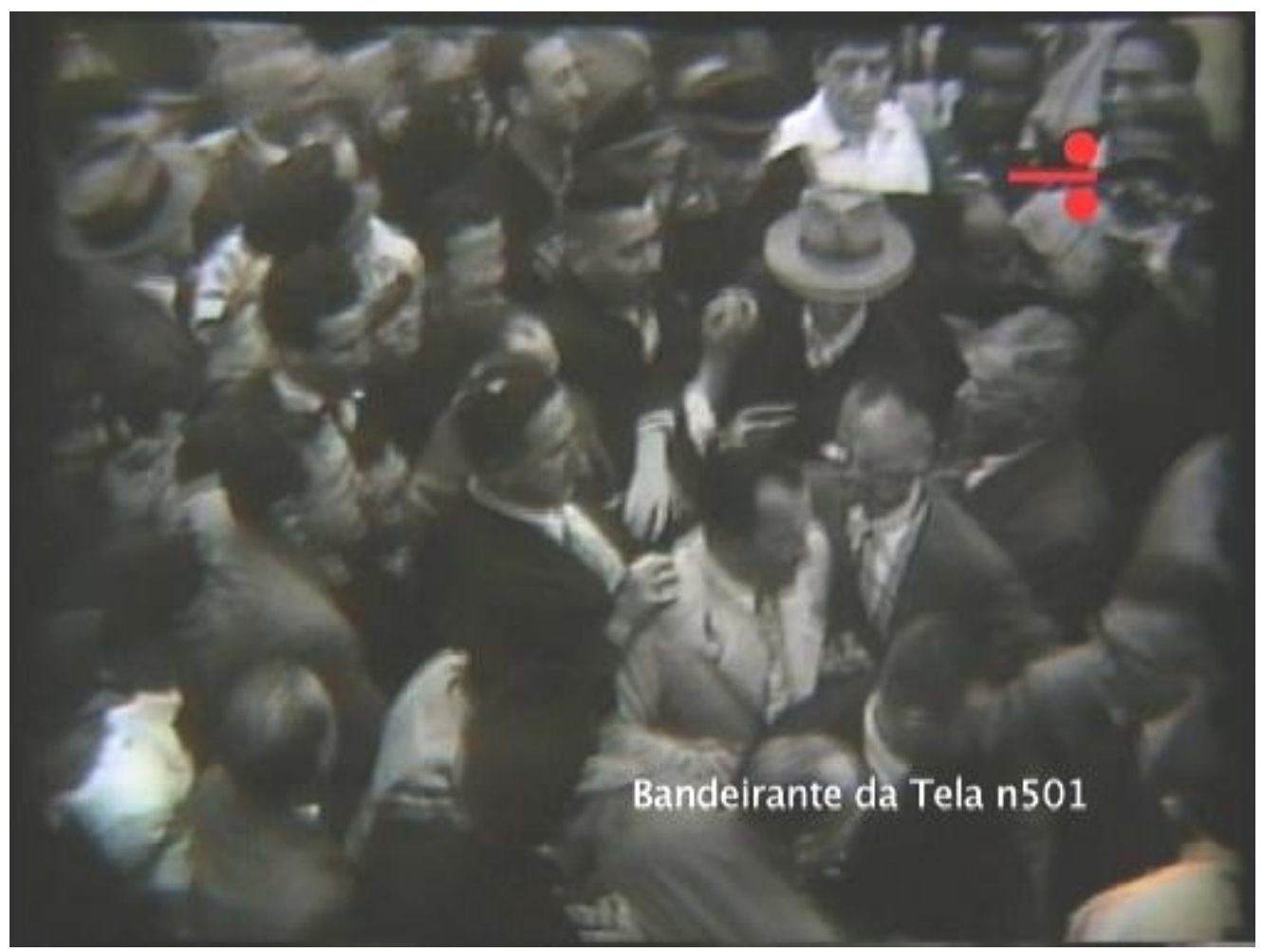

Uma panorâmica em ritmo acelerado de projeção mostra Adhemar que desce <para junto do povo >. A câmera delimita um trajeto pelo seu enquadramento, mostrando somente aqueles que 0 "carregam". Seriam correligionários? Bandeirante da Tela no 501, 1952. Acervo Cinemateca Brasileira

${ }^{344}$ Algo próxima à chave trabalhada por Boris Kossoy, ao desnudar a trama do registro fotográfico. Cf. Realidades e Ficções na Trama Fotográfica, op. cit., p. 37. 


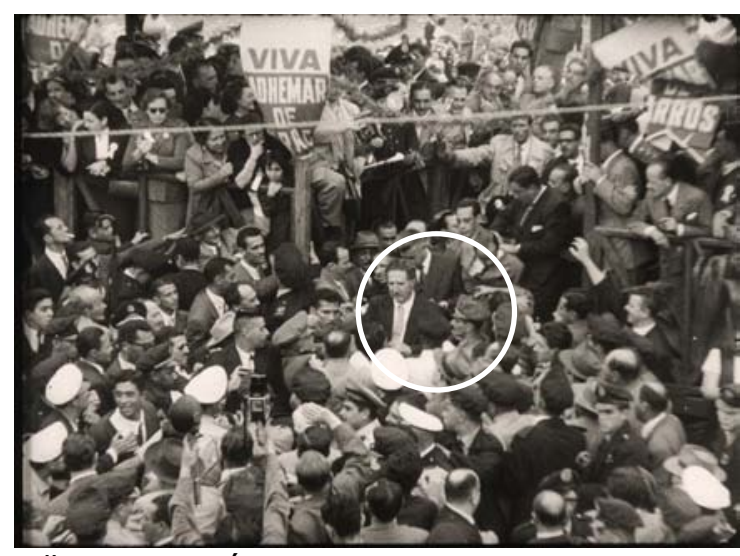

Adhemar vai até as massas...

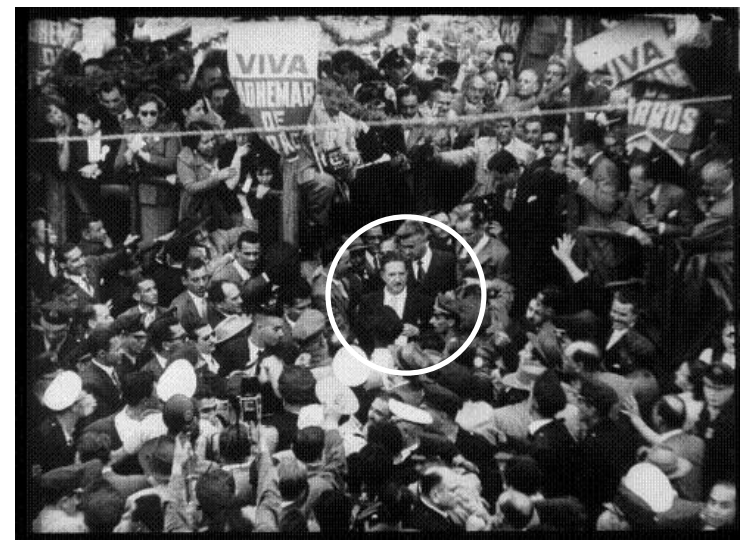

... que o envolve em <milhares de abraços>, porém dificultando o caminho até o carro...

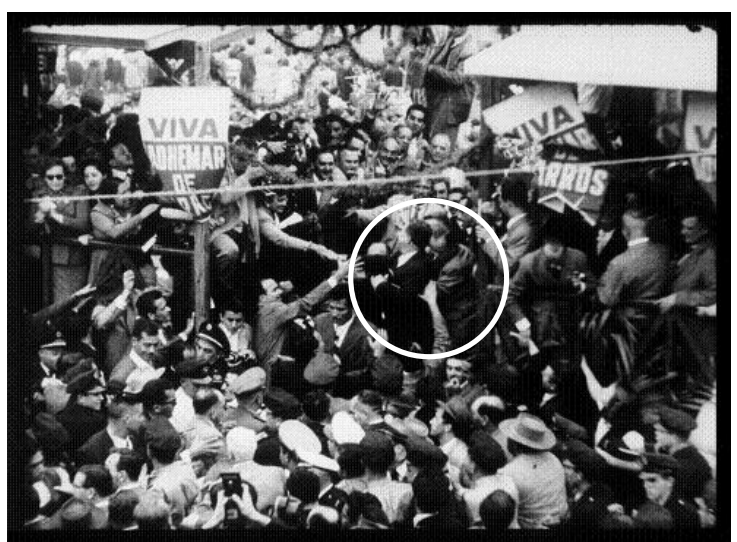

... e num esforço quase hercúleo, tenta abrir caminho entre aqueles que o idolatram...

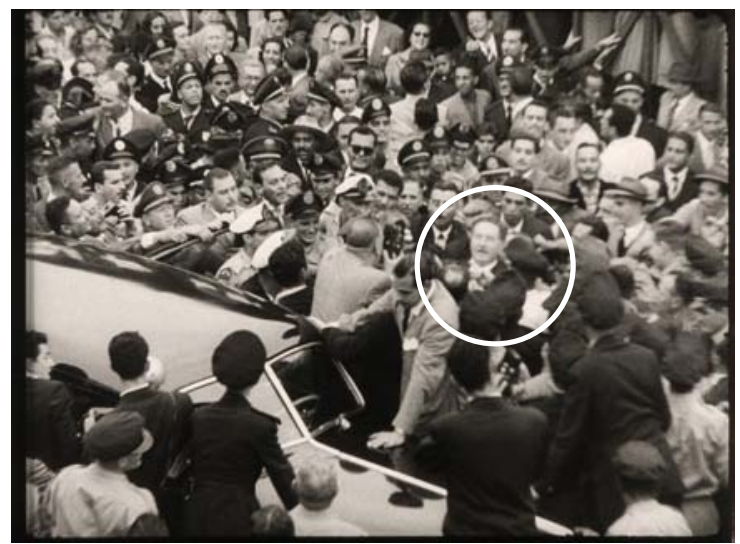

... que o levará à sua residência. Bandeirante da Tela no 501, 1952. Acervo Cinemateca Brasileira

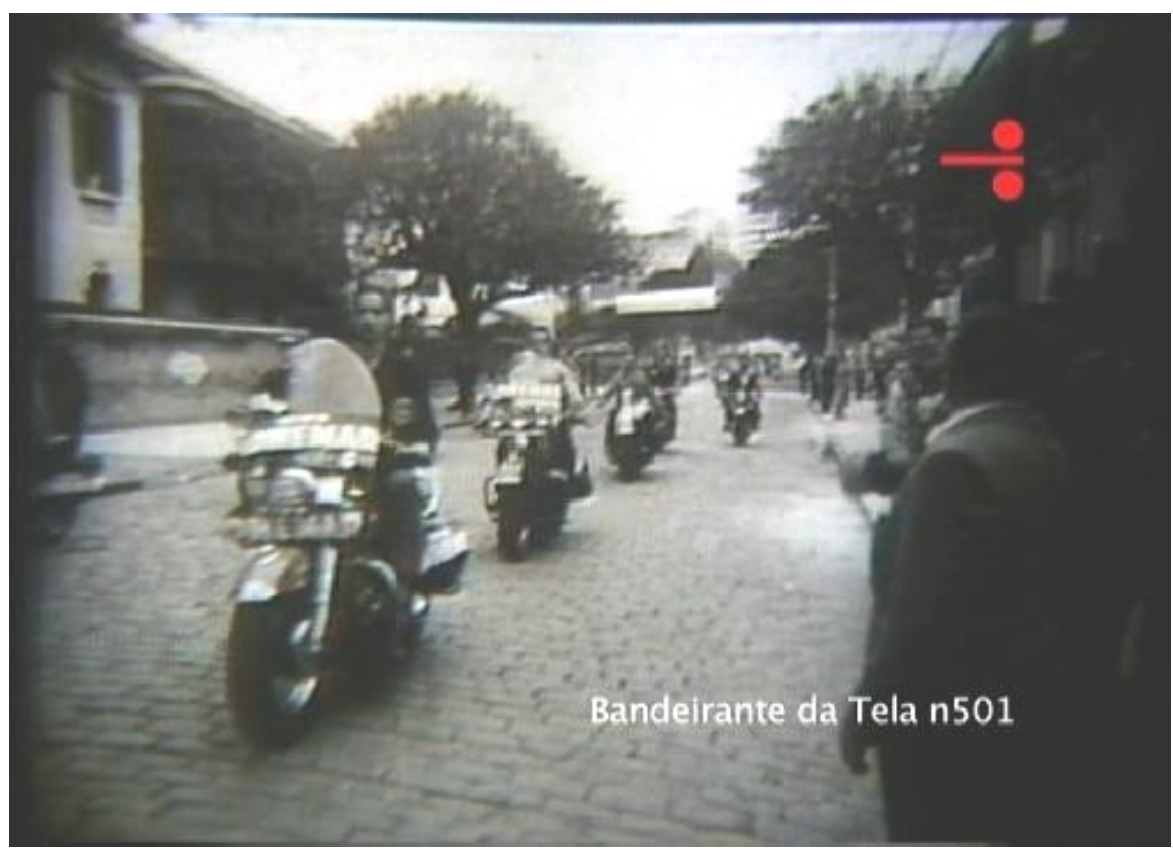

Ao estilo das autoridades oficiais, <as sereias abrem caminho>. Um olhar mais detido revela não ser uma escolta oficial e sim motocicletas com propagandas adhemaristas. Um elemento a mais para representar uma convenção digna de chefe de estado. Bandeirante da Tela no 501, 1952. Acervo Cinemateca Brasileira. 
Num último momento, digamos, do BT 501, temos no discurso a parte que envereda por uma estratégia de convencimento baseada na legitimidade e no compromisso que os laços afetivos, subtendidos em valores como a família, representam. Nesse sentido, a harmonia que rondava o lar de Adhemar de Barros, e que por várias vezes foi mostrada ao espectador do BT, sugere um convite para, da sala escura do cinema, "adentrar" a residência do homem público ${ }^{345}$. Um reforço ao aspecto de sinceridade no discurso adhemarista, algo caro mediante as acusações de conduta ilícita que o líder pessepista lidou durante sua vida política.

As manifestações de carinho e afeto começam antes mesmo de "adentrarmos" ao lar do homem público. No quintal de sua residência, já nos deparamos com demonstrações de respeito e devoção extremas ao <casal que despertou saudades durante os quatro meses em que esteve ausente do país>. Atitudes como uma criança <graciosa e adorável> de seis ou sete anos, que em toda a sua <espontaneidade> recita uma <feliz saudação> a $<$ Doutor Adhemar>. E que só não é superada pelo exagero de um político "taumaturgo" que o olhar mais atento revela, na rápida tomada de uma mulher que beija a mão de Adhemar de Barros.

O carinho "espontâneo" de uma criança que recita com dedo em riste algo certamente decorado, da pilastra de um muro em que foi colocada e uma deferência digna de autoridade episcopal ou paterna que concede a benção e a aprovação. Tais passagens tentam corresponder a um imaginário coletivo que preza, por exemplo, a espontaneidade infantil dos pequeninos enquanto uma das poucas manifestações verdadeiras existentes (tanto quanto a reciprocidade de Adhemar de Barros para com as crianças), assim como a demonstração de respeito incondicional, na proporção merecida por aquele que a recebe. Elementos que não foram esquecidos e sim incorporados ao teatro adhemarista compactuando com a atmosfera de veracidade que se pretendeu ao momento registrado pelas câmeras do BT.

\footnotetext{
${ }^{345}$ No sentido mesmo de uma "metáfora" proporcionada pela linguagem cinematográfica em que a "dimensão temporal define um novo sentido para as bordas do quadro" juntamente com os movimentos e a expressividade da câmera que reforçam a "impressão de que há um mundo ao lado de lá, que existe independente da câmera em continuidade ao espaço da imagem percebida". Ismail N. Xavier, op. cit., pp. $21-2$.
} 


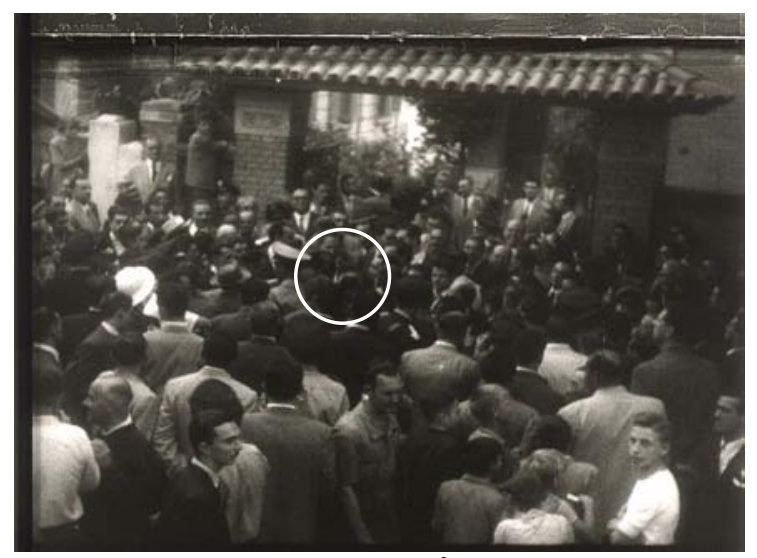

No quintal de casa, Adhemar é recebido por amigos e correligionários...

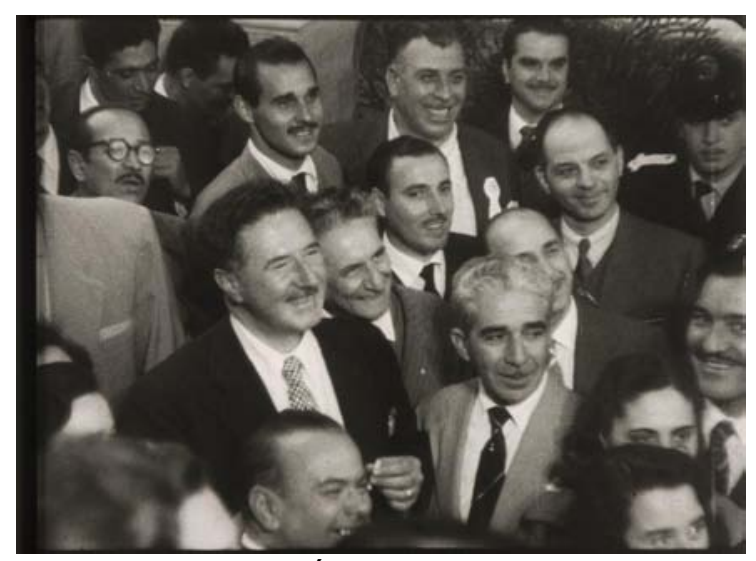

... para alegria do político e os demais presentes...

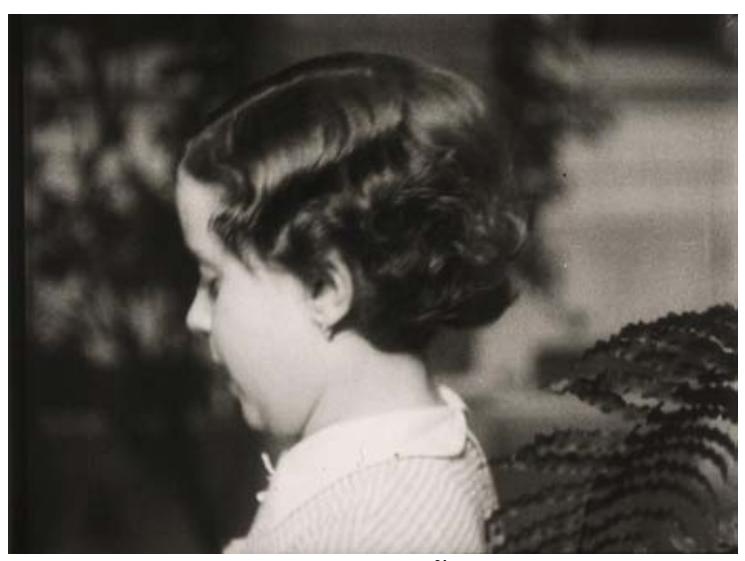

... e entre tantas manifestações de carinho, uma criança <graciosa e adorável na sua espontaneidade $>$...

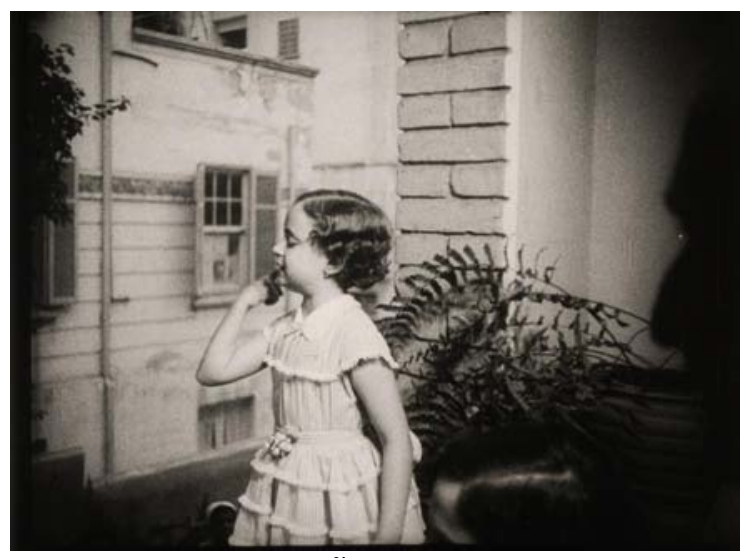

... <recita feliz saudação a Doutor Adhemar e dona Leonor>. Bandeirante da Tela no 501, 1952. Acervo Cinemateca Brasileira.

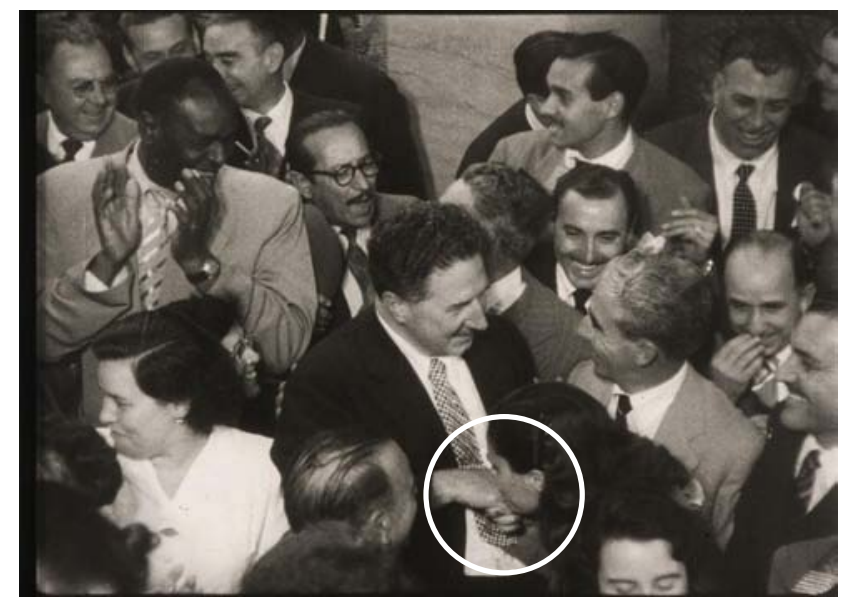

Deferência e respeitabi-lidade em proporções exageradas? Mas, nas imagens do BT, algo merecido por aquele que a recebe. Adhemar é reverenciado com algumas demonstrações de respeito e obediência extremas. Bandeirante da Tela no 501, 1952. Acervo Cinemateca Brasileira. 
E os cumprimentos continuam, mais uma vez, na composição estabelecida pela mescla do público (o político) com o privado (laços de família e amizade). Elementos de convencimento pela linguagem do cinema são destilados, por exemplo, numa tomada em primeiro plano de Adhemar de Barros abraçado com os netos. $\mathrm{O}$ registro destas ações nas telas em si é

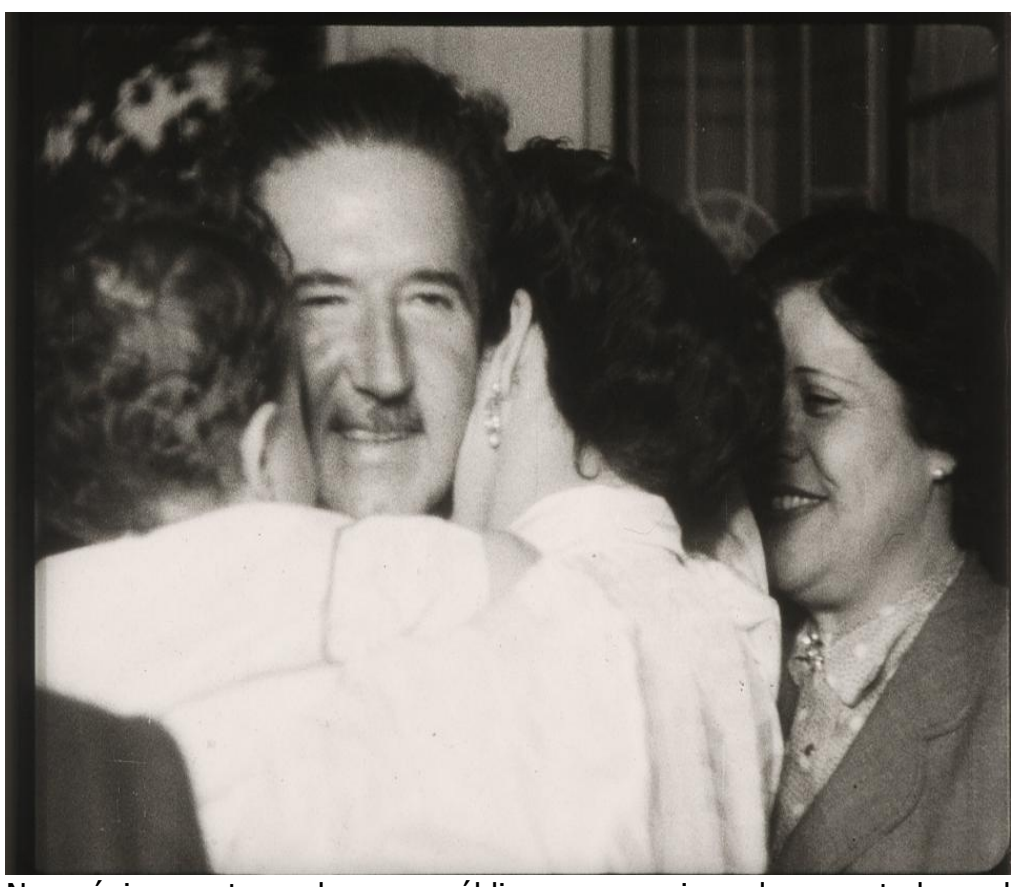
Num único gesto, o homem público se aproxima do espectador pela exposição de sua face privada: Adhemar abraçado aos seus netos. Bandeirante da Tela no 501, 1952. Acervo Cinemateca Brasileira.

notícia $^{346}$, pois aglutina num único gesto o homem do lar, da família, pai e avô, revelando a face privada de um homem público, o político, aproximando-o assim das pessoas comuns, do eleitor por assim dizer.

$\mathrm{Na}$ mesma medida, a política se traduz em relações de compadrio quando vemos o “casal Garcez”, governador e primeira-dama, no interior da residência de Adhemar de Barros e dona Leonor, cumprimentando-os. Mais do que uma amizade ou aproximação entre correligionários, tem-se um "ritual do poder" , como na ocasião da transmissão de cargo e posse de Lucas Nogueira Garcez por Adhemar de Barros, ocorrida quase que nos moldes de uma investidura ${ }^{347}$. Mas no BT 501, parece estar presente muito mais que a idéia de continuísmo de um projeto político: temos o apadrinhado e esposa que acompanham, por respeito ou por dívida, o homem que os colocou na política, desde as cenas no aeroporto de Congonhas até a sua sala de estar.

${ }^{346}$ A exemplo dos cinejornais espanhóis da série No-Do, em que o próprio Franco procurou trabalhar as vertentes do homem poderoso, chefe de Estado com a figura bonachona do avô com seus netos e o homem do lar. Sánchez-Biosca. Cine de Historia Cine de Memória, op. cit., p. 50.

${ }^{347}$ Como já apontado por José Inácio de Melo Souza, na ocasião da transmissão de cargo e posse de Lucas Nogueira Garcez por Adhemar de Barros, nos moldes quase de uma investidura. Cf. "Eleições e Cinema Brasileiro...", op. cit, p. 161. 


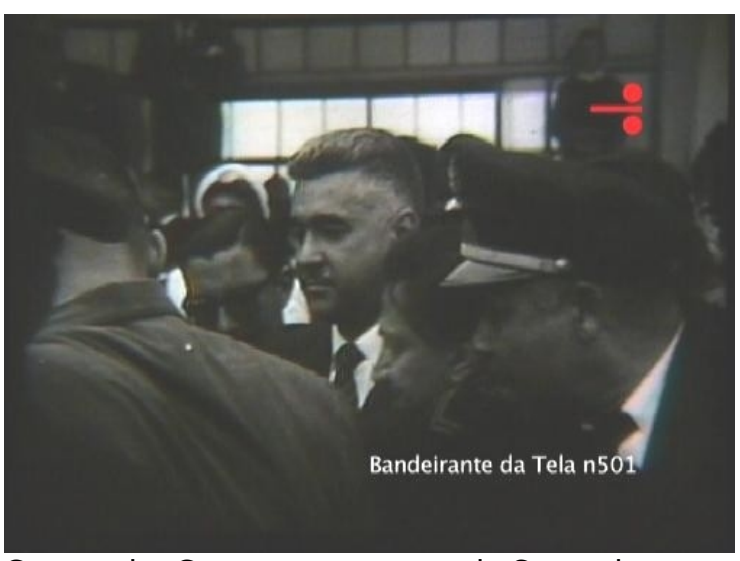

Governador Garcez no aeroporto de Congonhas para recepcionar Adhemar num "ritual de poder" em que o chefe do executivo estadual e a primeira-dama...

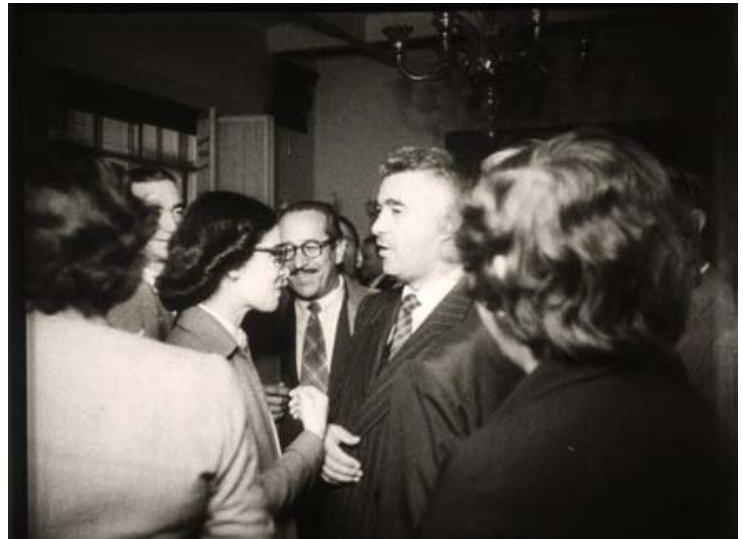

... demonstram reverência e amizade ao freqüentar a casa daquele que os trouxe à cena política. Bandeirante da Tela no 501, 1952. Acervo Cinemateca Brasileira.

Para finalizar o percurso desta surpreendente manifestação de carisma, o BT registra várias tomadas em plano médio dos anfitriões recebendo várias felicitações no interior da casa, entremeando tomadas de Adhemar de Barros no lado de fora, pois sua presença foi $<$ solicitada novamente no exterior de sua residência $>$, onde <manifestações se renovam intercalando-se aos cumprimentos dos amigos $>$. Assim termina o cinejornal que começou com o retorno de uma viagem particular à Europa, passando pela comoção que mobilizou uma cidade inteira para a recepção preparada por correligionários e amigos, e chegando à concentração num espaço familiar, onde é dado ao espectador conhecer um pouco mais da privacidade do <líder populista $>$. Neste sentido, as câmeras do BT incorporaram cenários distintos à política, ao enfatizar tanto características do cotidiano (como vimos acima), quanto detalhes do espaço privado de um homem público que,

da sacada de uma janela em sua casa, como que um vizinho que fala aos amigos, ainda recebe homenagens dos partidários que carregam retratos "gigantes", bastante parecidos com aqueles carregados pelo fanático adhemarista "Moa", no conto de Marcos Rey ${ }^{348}$.

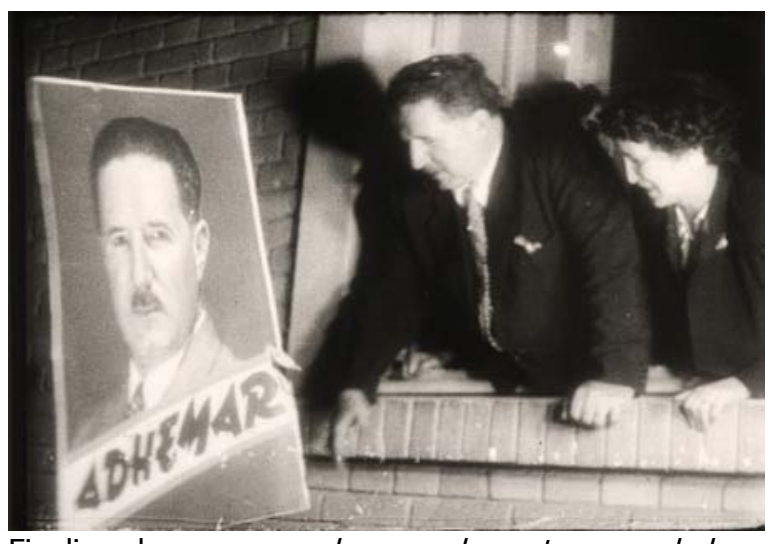

Finalizando, o <casal que despertou saudades> agradece da janela de sua casa. Bandeirante da Tela $n^{\circ}$ 501, 1952. Acervo Cinemateca Brasileira.

${ }^{348}$ Op. cit., p. 206. 
As apostas contidas no discurso adhemarista, como verificamos até aqui nas imagens do BT, comportam uma estrutura montada, obviamente, para sustentar a imagem do líder pessepista colocando-a em evidência dentro de uma variedade de possibilidades. Ora tentando ocultar inimigos políticos ${ }^{349}$, ora colocando-a como figura atuante na cena política, ainda que não estivesse exercendo cargos eletivos. E até mesmo "forçando" uma importância para Adhemar de Barros nas ocasiões em que o mesmo havia sido um mero convidado $^{350}$, como no exemplo, também registrado no BT 501 (1952), do "II Congresso dos Municípios Brasileiros", realizado em São Vicente, SP. Neste evento, figuras importantes do cenário político paulista e nacional estão presentes, como Lucas Nogueira Garcez e o próprio Getúlio Vargas. Numa rara oportunidade em confrontar as mesmas notícias, este episódio registrado pelo CJI possui enfoques distintos dos que foram dados no BT. Neste, Adhemar de Barros é personalidade ilustre que compõe, em grau de importância, com o presidente da República e o governador do Estado. No CJI, embora sem a informação sonora, ele aparece numa rápida tomada e um tanto controverso, rindo para a câmera.

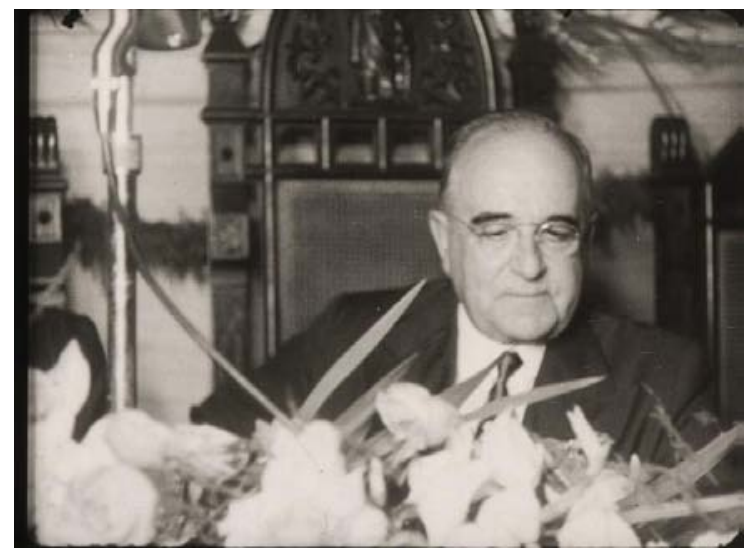

Da direita para esquerda, uma panorâmica se inicia com o presidente Getúlio Vargas...

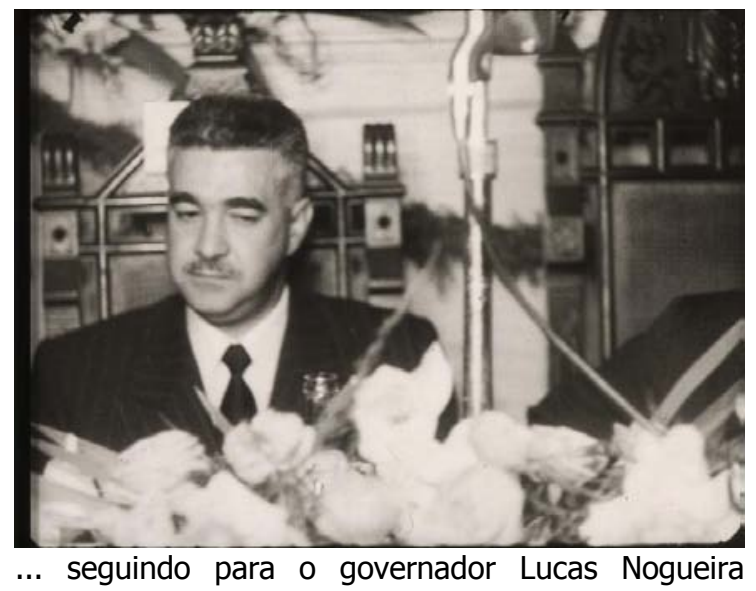
Garcez e cortando para a inserção de uma platéia...

${ }^{349}$ A exemplo de Jânio Quadros que aparece uma única vez em nossas sistematizações (no BT 674 de 1955). Para alguém que ocupou o palácio dos Campos Elíseos em 1955, sua presença é bastante reduzida. No catálogo da $\mathrm{CB}$, há quatro ocorrências para Jânio, muito embora não haja confirmação de sua presença física nelas. Há também a indicação de um BT com a atribuição de título "Campanha contra Jânio Quadros", porém, esse inexiste para a pesquisa. Veja imagem na página 93.

350 Bandeirante da Tela $n$ 501. São Paulo: Divulgação Cinematográfica Bandeirante, 1952. Fita de vídeo (7min56seg), VHS, sonoro, p\&b, VV00098. Cinemateca Brasileira; Cine Jornal Informativo vol. 3, n..35. Rio de Janeiro: Agência Nacional, 1951. Fita de vídeo (8min40seg), VHS, sonoro, p\&b, Arquivo Nacional, Rio de Janeiro - RJ. 


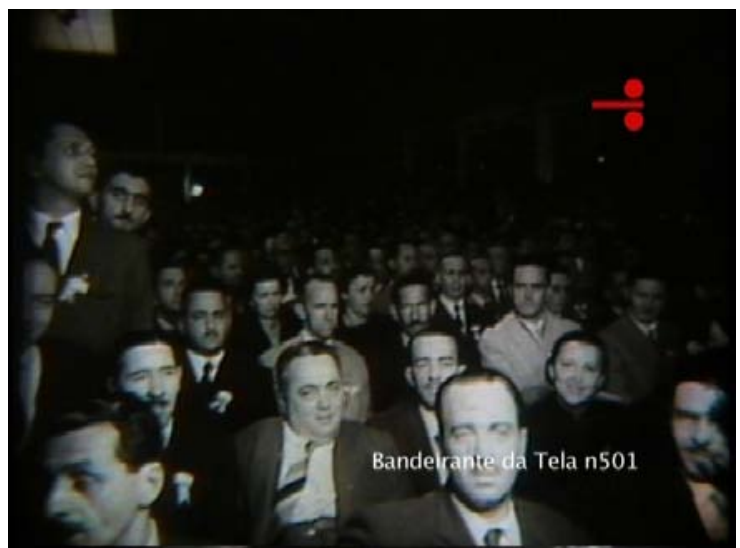

... composta por < deputados, senadores, representantes de vinte estados e dois mil e quinhentos delegados credenciados, [que] tomam parte do conclave $>$...

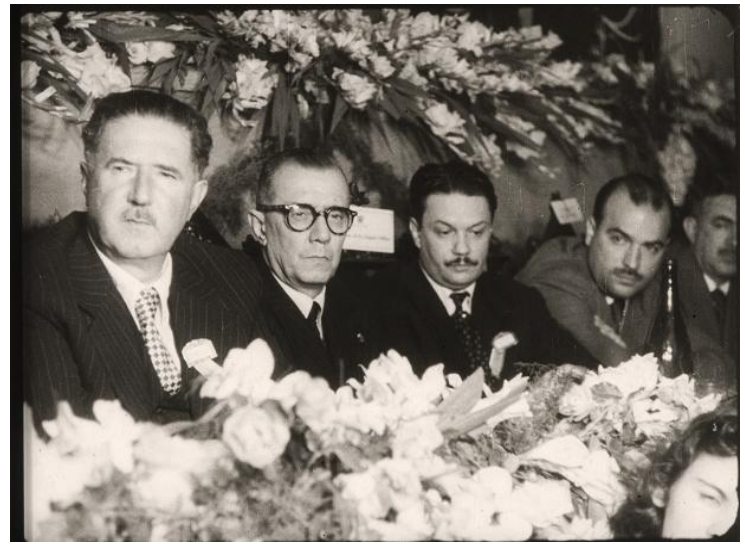

... <ao qual comparece também o senhor Adhemar de Barros> que "finaliza" as apresentações importantes. Bandeirante da Tela no 501, 1952. Acervo Cinemateca Brasileira.

Outro fator presente à composição da mensagem adhemarista criada para o cinema foi o trato com a religiosidade, na perspectiva da "vida religiosa" traduzida em valores cristãos-católicos. Os BT $669^{351}$ e $674^{352}$, ambos de 1955, oferecem exemplos a esse respeito. Em "Fatos do Momento" (BT 669) a notícia começa com dois enquadramentos, um em plano médio com quatro senhoras e, em seguida, um plano mais "fechado" com três crianças. Nos dois planos, mulheres e crianças exibem para a câmera souvenirs religiosos: garrafinhas com as imagens de N. S. Aparecida e "medalhinhas" do $<$ Padre Lima $>$, que o próprio BT não oferece maiores detalhes - por certo, uma "notícia" corrente -, exceto que os <milagres de Tambaú [foram] conseguidos com a interseção do Padre Lima à Virgem Maria $>$. O narrador anuncia que tal fato <repercutiu no Brasil inteiro $>$ e, em seguida, nos deparamos com cenas de uma fila < diante da Rádio Nacional de São Paulo>. Somos informados dos fiéis que ali estavam para receber as garrafinhas mostradas anteriormente e que são especiais porque revelam, às vezes nitidamente, a imagem da Virgem Maria em seu interior. As próximas seqüências mostram outras filas que se estabeleceram em algumas < casas comerciais>, para que nelas fossem entregues aos fiéis imagens benzidas da $<$ Padroeira do Brasil $>$ e do Padre Lima. Tais tomadas são registradas em planos fixos, compostos por uma alternância entre plano geral e cenas rápidas em primeiro plano. Algo muito parecido com a ensaiada entrega de presentes por dona Leonor, como vimos

${ }^{351}$ Bandeirante da Tela n. 669. São Paulo: Divulgação Cinematográfica Bandeirante, 1955. Fita de vídeo (7min), VHS, sonoro, p\&b, VV00099. Cinemateca Brasileira.

${ }^{352}$ Bandeirante da Tela n. 674. São Paulo: Divulgação Cinematográfica Bandeirante, 1955. Fita de vídeo (5min24seg), VHS, sonoro, p\&b, VV00099. Cinemateca Brasileira. 
anteriormente: a pessoa recebe e sai do campo de visão da câmera. E como habitual no BT, a voz em off reforça a montagem integrando seqüências num vínculo de continuidade e sentido ao espectador: $<A$ distribuição formou filas extensas, mostrando que o sentimento de religião dos paulistanos ainda está desperto>.

$\mathrm{Na}$ elaboração de um registro que aproxima religiosidade às pessoas, são vários os "tipos" que aparecem na entrega dos objetos. Cria-se assim, a sugestão de uma "galeria" de cidadãos paulistanos, diferentes camadas sociais, representadas por cada devoto que passa pelo campo visual da câmera. Sejam eles senhoras com pacotes, mães com criança de colo, rapazes engravatados, moças de tailleur, pessoas "simples", adolescentes de calças-curtas, crianças acompanhadas dos pais e homens e mulheres de meia idade, etc.. Todos ali unidos pela fé cristã e católica. Ou seja, um traço latente da cidadania paulista e que um simples "fato" (cartela inicial) é capaz de trazer a tona. Algo propício num discurso que lida com toda uma coletividade de pessoas em ano de eleições presidenciais. E que pelas imagens veiculadas num cinejornal reconhecidamente ligado ao candidato

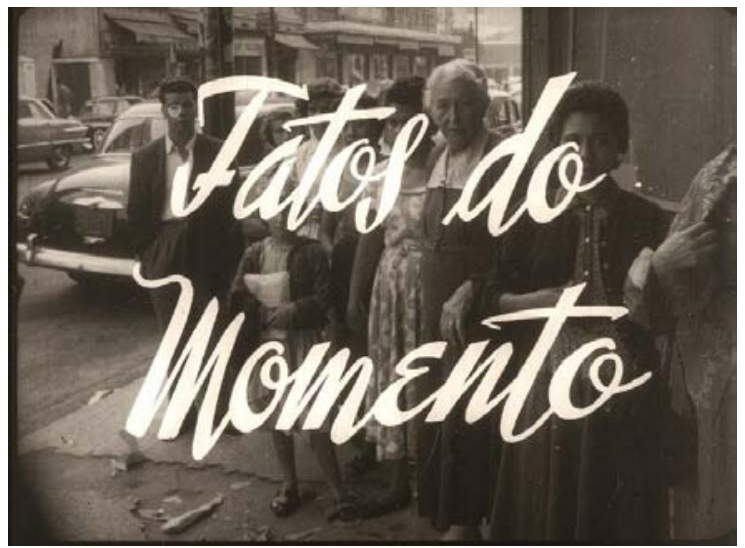
Cartela inicial "noticia" um fato do momento...

Adhemar de Barros, tenta atrair essa mesma coletividade com caras e rostos tirados do seu cotidiano. Na provável intenção de alimentar a esperança do eleitorado potencialmente descrente no PSP e em seu líder ${ }^{353}$, apostando na fé quando <são muitos que acreditam em milagre, mesmo nos dias de hoje>, termina o narrador a "notícia".

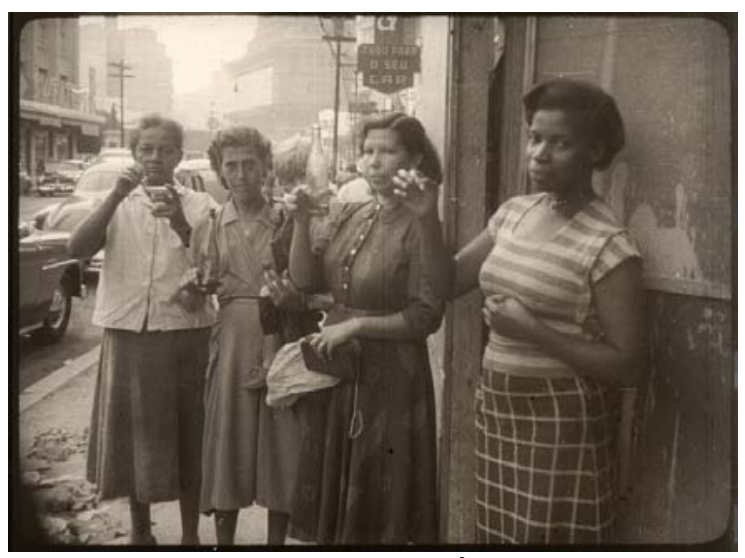

... começando por um plano médio com mulheres e crianças que...

353 Ambos, em 1955, não viviam um bom momento dadas as circunstâncias políticas, como vimos anteriormente. 


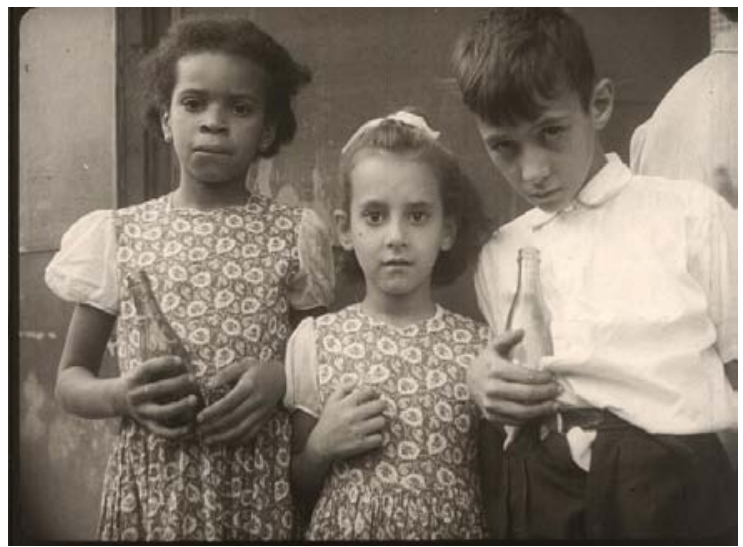

... exibem para as câmeras a sua devoção católica...

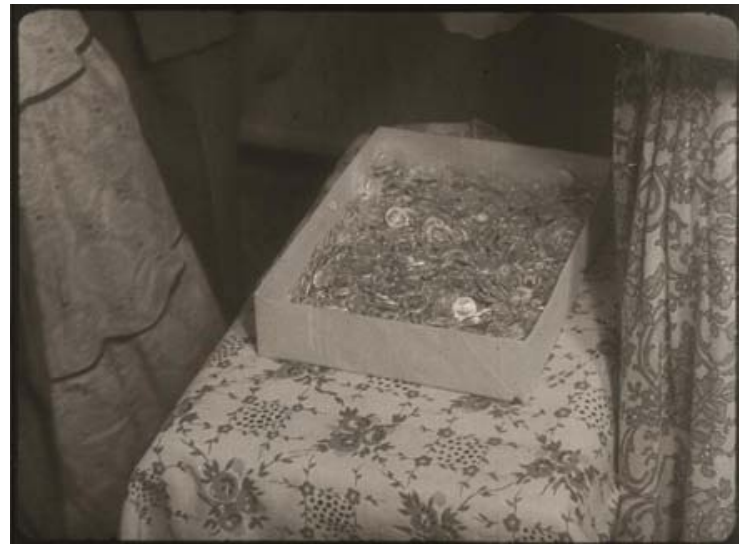

... dos objetos benzidos que serão entregues e...

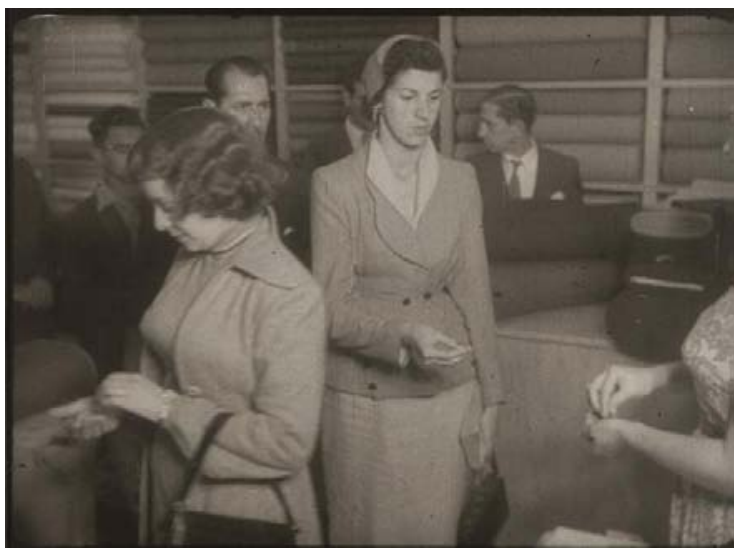

... que aparece nas imagens do BT desfilando...

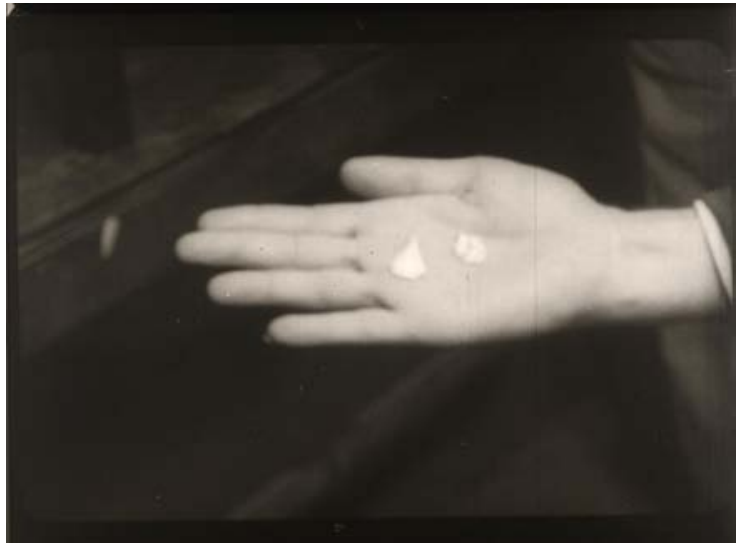

... seguido pelo detalhe em primeiro-plano...

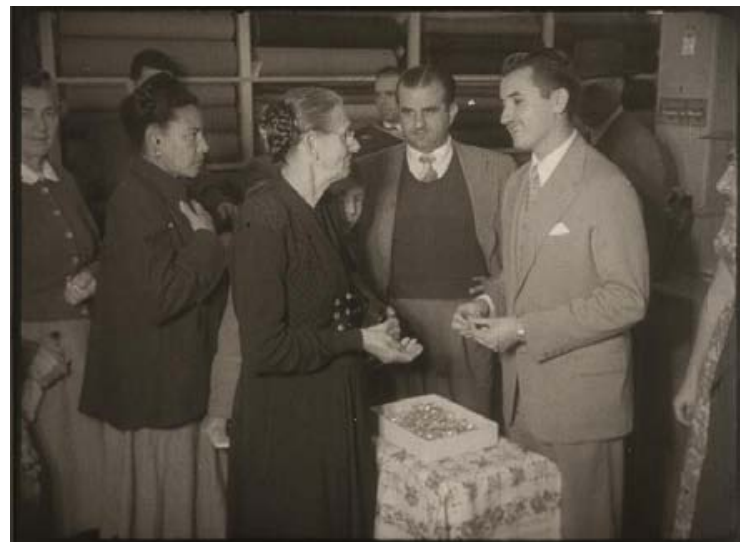

... que marcam a religiosidade de uma sociedade...

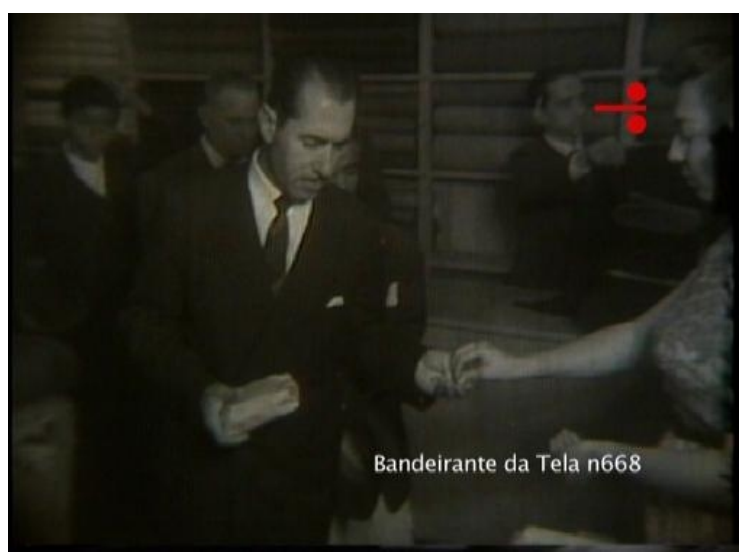

... uma galeria paulistana de tipos Bandeirante da Tela no 669, 1955. Acervo Cinemateca Brasileira. 
A composição das cenas, e mesmo os espaços usados para a captação das imagens, deixam pistas sobre a estratégia utilizada para a montagem do discurso adhemarista no cinema. Nos levam a pensar, por exemplo, se tais registros não foram realizados com base no movimento diário daquelas lojas de roupas e tecidos, que notamos pelas prateleiras dispostas ao fundo, bem como o trânsito típico das ruas movimentadas, provavelmente centrais porque abrigam casas comerciais. Produzir um registro cinematográfico em meio a pontos de muita concentração de pessoas talvez tenha sido a solução para a possível ausência de devotos para compor o teatro filmado. E é esclarecedor da ensaiada entrega dos objetos religiosos, dada a "curiosidade" com que os "fiéeis" olham para a câmera. Fé, curiosidade diante da câmera cinematográfica, ou mesmo vontade de se ver no cinema? Fica a dúvida mediante a devolução do olhar das pessoas antes de deixar o campo visual do cinegrafista, como nas cenas abaixo reproduzidas em imagens do próprio BT 669:
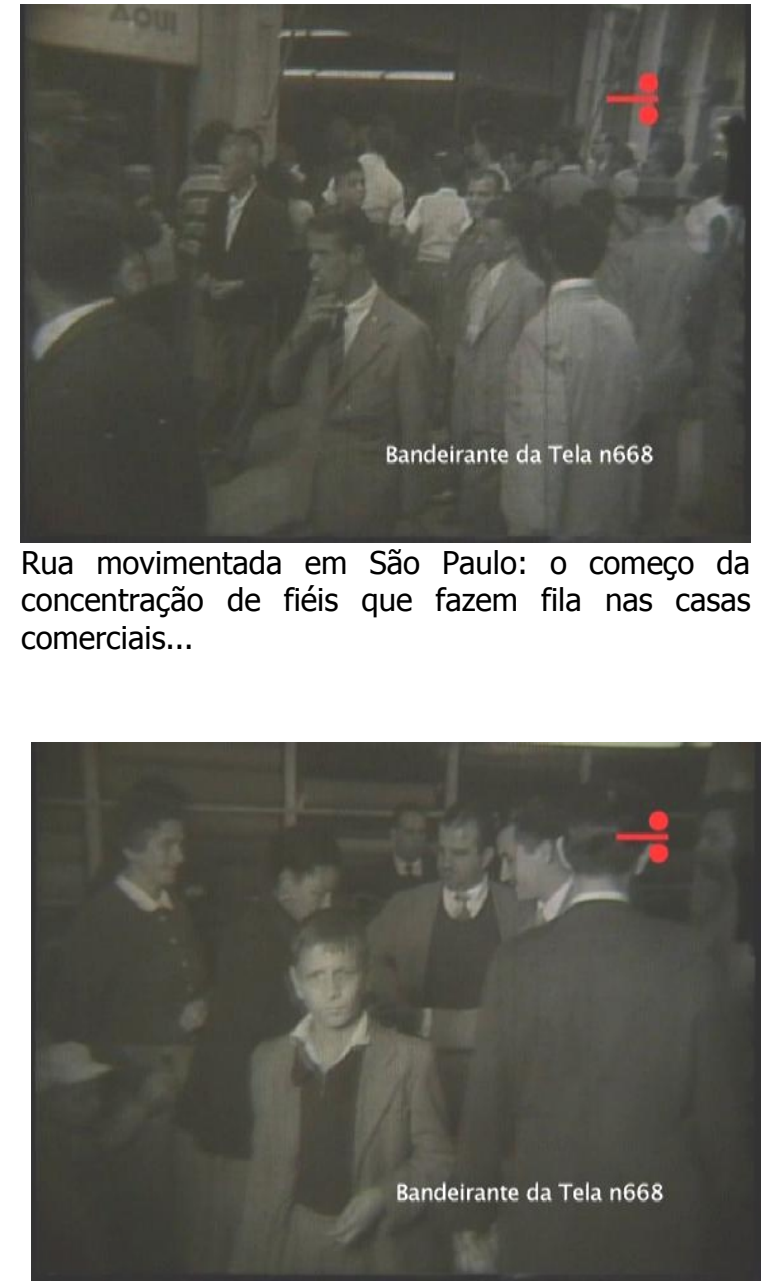

Pessoas retiram suas imagens...

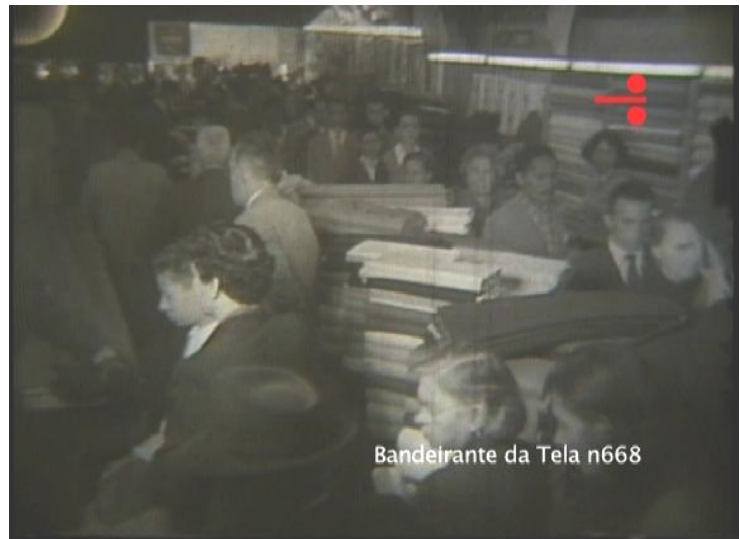

... para conseguir uma imagem milagrosa de N. S. Aparecida. Bandeirante da Tela no 669, 1955. Acervo Cinemateca Brasileira.

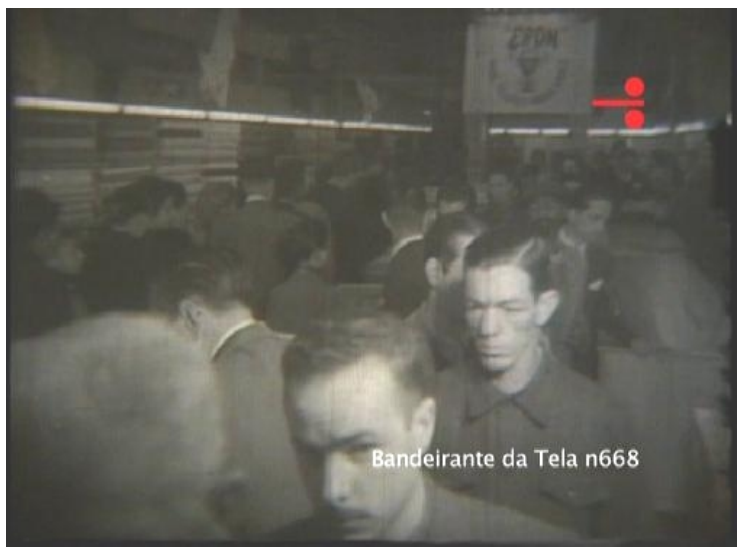

... e olham para câmera... 


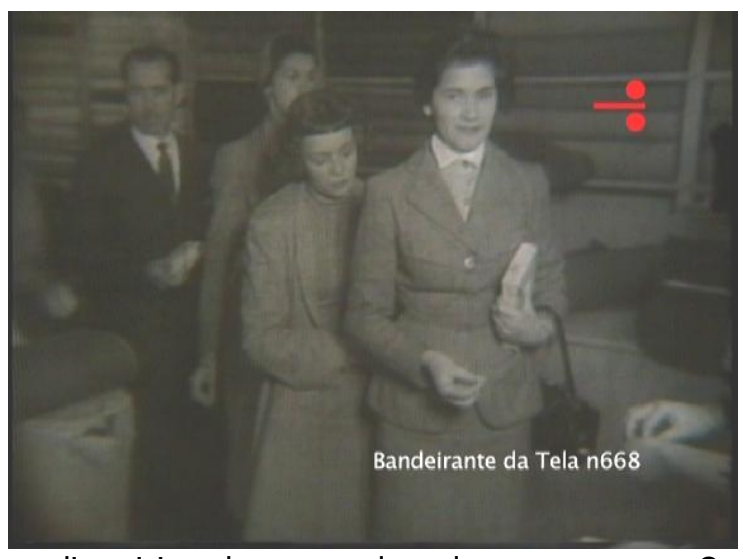

... ali posicionada esperando cada um que passa. Ou cada um que passa...

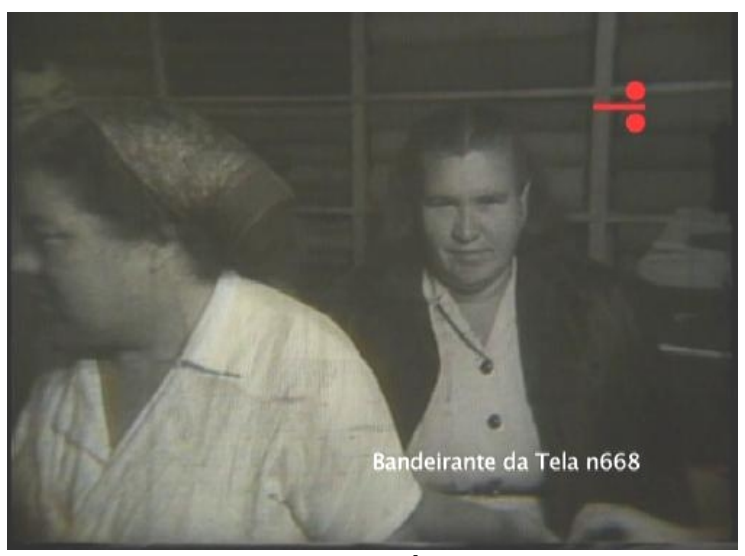

... espera ser filmado pela câmera? Bandeirante da Tela no 669, 1955. Acervo Cinemateca Brasileira.

Ainda na esfera da religiosidade, o BT 674 (1955) registra outro evento, vinculado ao mostrado no BT 669. Em "Vida Religiosa", o narrador informa que <depois dos milagres de Tambaú $>$, que repercutiram no $<$ Brasil inteiro $>$, Nossa Senhora continua a fazer pelos bairros paulistanos e cidades do litoral paulista como Praia Grande e Santos. O que vemos, inicialmente, é uma tomada em primeiro plano da imagem de Nossa Senhora coberta por faixas e rodeada de ex-votos e pessoas (mulheres, homens, civis e militares) que a tocam. Segue-se uma seqüência em plano médio da população, em especial uma senhora que, numa demonstração inconteste de sua fé, quase desmaia e é amparada. Apesar de mencionar bairros paulistanos como Vila Prudente, Água Rasa, Vila Isabel e cidades litorâneas, não nos é informado pelo BT o local onde tais imagens foram captadas. O que é patente numa estratégia de universalizar tais cenas para além dos locais mencionados, estendendo, dessa forma, a religiosidade na proposta adhemarista para outros lugares, certamente com intenções políticas de atingir o eleitorado de várias regiões dado o momento da corrida eleitoral em 1955.

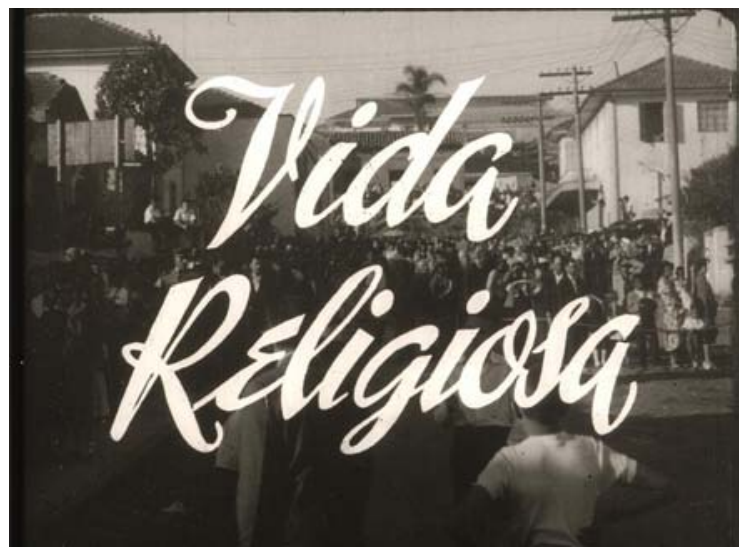

Em São Paulo, a vida religiosa é retratada nas telas do BT, com...

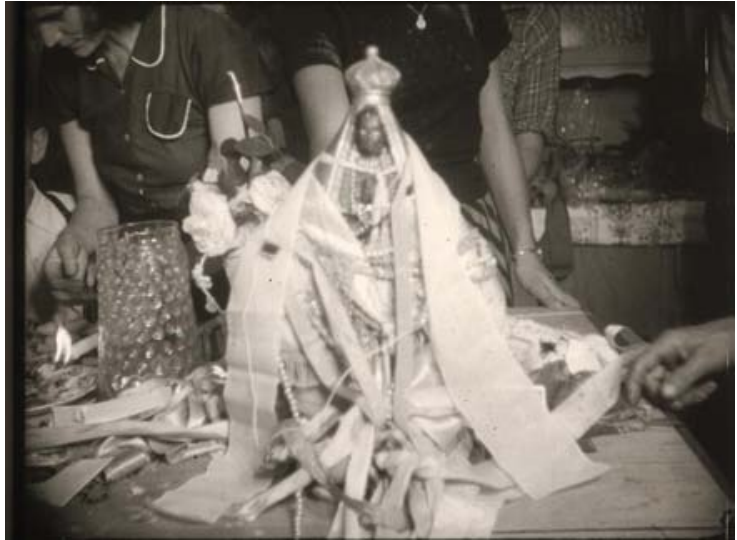

... tomadas em primeiro plano da imagem de Nossa Senhora... 


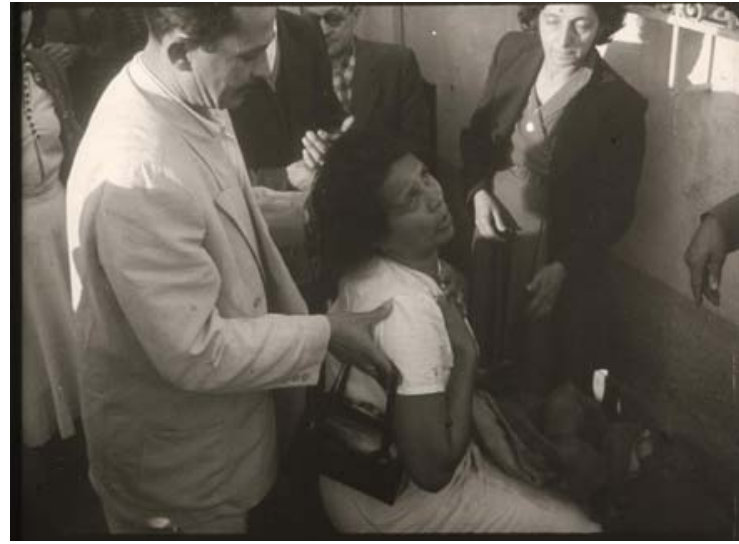

... e marcantes manifestações públicas de fé numa chave religiosa bastante trabalhada...

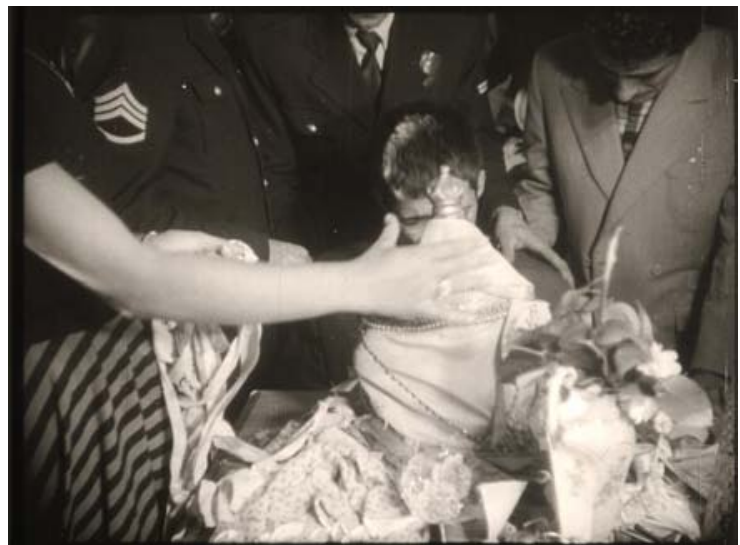

... no cinejornal adhemarista. Bandeirante da Tela no 674, 1955. Acervo Cinemateca Brasileira.

Nesse sentido, a aproximação entre política e religião saiu-se fortalecida pelo próprio formato do cinejornal (dividido em assuntos) e mais especificamente pelo dispositivo de montagem. Não apenas pela aproximação de planos numa mesma notícia, mas pela associação entre o que era noticiado. No BT 669, ao assistirmos a entrega de medalhas milagrosas nos deparamos anteriormente com Adhemar de Barros sendo bem recebido numa cidade do nordeste. Já na "Vida Religiosa", antes de aparecer ao espectador no BT 674, temos uma convenção do PSP na capital federal onde Adhemar de Barros foi $<$ recebido com palmas prolongadas $>$ e chuva de papel picado na ocasião da homologação de sua candidatura para presidente.

O encontro dos temas políticos e religiosos pela disposição dos assuntos em meio ao universo fragmentado das diversas notícias ${ }^{354}$, nos remete a toda estratégia tentada com outros temas, para compor uma imagem representativa de Adhemar de Barros, onipresente até. Uma imagem portadora de um elo sócio-cultural que envolve não só valores cristãos, como nesses dois cinejornais, mas que soma, no "noticiário" exibido semanalmente, a moral ética do assistencialismo, o saber científico de um médico, o paternalismo e a família, como vimos até aqui. Uma estratégia que se reforça ao lançar mão de um caleidoscópio de signos do cotidiano do próprio espectador, tomados numa dimensão inusitada pela câmera cinematográfica ${ }^{355}$.

${ }^{354}$ Tendo em vista o BT como cinejornal cavado, fruto de interesses comerciais e particulares.

${ }^{355}$ Cf. Siegfried Kracauer. "The Conquest of Europe on the Screen...”. op. cit., pp. 15-16. 
Por tratar destes assuntos, o BT acaba apresentando o seu dono como aquele "há quem recorrer" ${ }^{356}$, quem comporta condições de apaziguar uma certa angústia colhida no próprio imaginário coletivo da sociedade ${ }^{357}$. Num vínculo um tanto tênue, valores culturais mesclam-se à esfera política, revelando como esta se estende às práticas que permeiam toda a sociedade. Como no exemplo do estado de São Paulo onde uma tradição cristã-católica apresenta valores fortemente arraigados em sua formação histórica: do surgimento ligado à fundação por um padre, até o fato de abrigar em seu território o maior centro de peregrinação católica do país ${ }^{358}$.

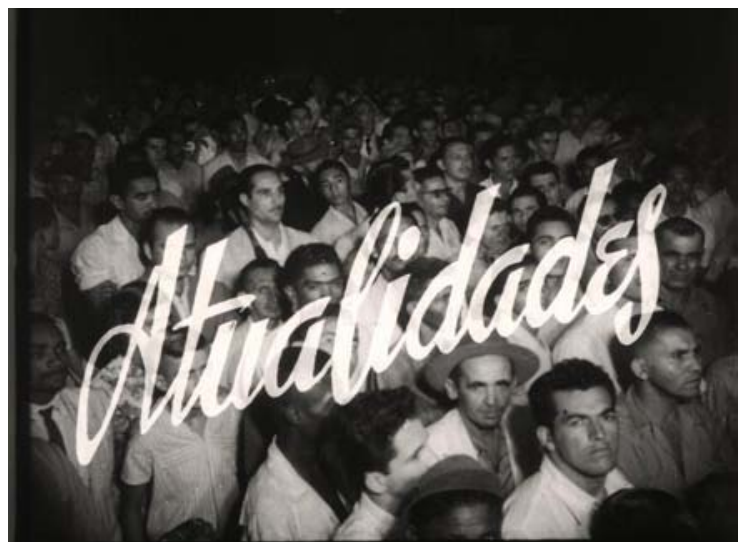

"Atualidades" no sentido manter o espectador atualizado de que...

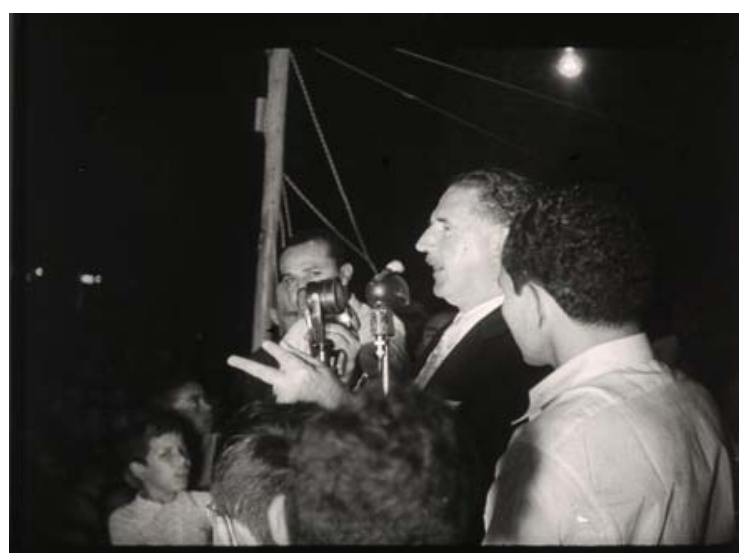

... em Aracajú, Adhemar também goza de extrema popularidade. Bandeirante da Tela no 669, 1955. Acervo Cinemateca Brasileira.

\footnotetext{
${ }^{356}$ A exemplo do homem providencial nas formulações de Raoul Girardet. Em que uma narrativa de caracteres comuns atua no sentido de "banalizar o grande homem, para permitir que cada um de seus concidadãos se reconheça nele". Op. cit. p. 65.

${ }^{357}$ Aproximando-se ao que Raoul Girardet aborda como "sociologia da angústia" numa sociedade "doente" cujas inquietações, desnorteamentos, incertezas e os ressentimentos cristalizam-se em torno de uma imagem negativa, como no mito da "conspiração" ou do "complô", estigmatizando um determinado seguimento da sociedade (como o anti-semitismo, segundo o autor); ou cristalizar-se positivamente, como na imagem de uma unidade (lugar, cidade ou nacionalidade) ou àquele a quem recorrer. Cf. idem, pp. 49-57.

${ }^{358}$ Trata-se da cidade de Aparecida, fundada em 1928. Nesse sentido, é interessante o dado levantado por Joseph Love em que, no ano de 1940 , pouco mais de $2 \%$ da população paulista era protestante. Cf. $A$ Locomotiva: São Paulo na Federação Brasileira (1889 - 1937). Tradução Vera Alice Cardoso da Silva. Rio de Janeiro: Paz e Terra, 1982, p.137.
} 


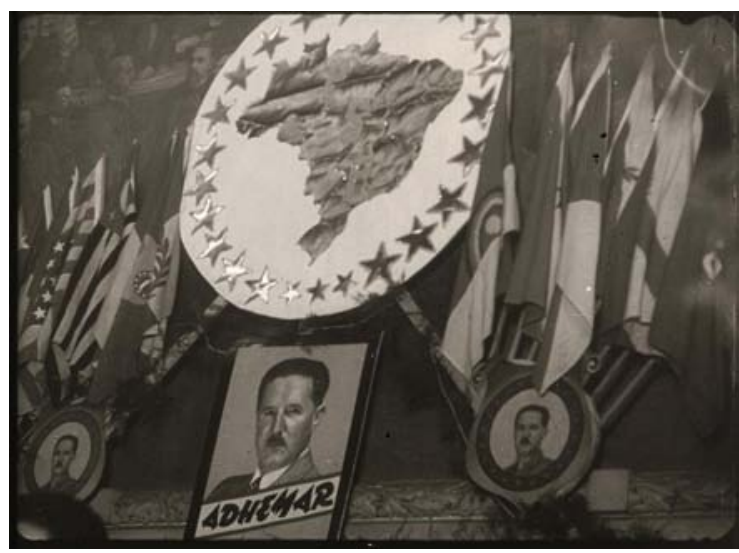

Dísticos bandeiras estaduais e cartazes de Adhemar na convenção nacional do PSP, no Rio, onde é celebrada com festa a homologação...

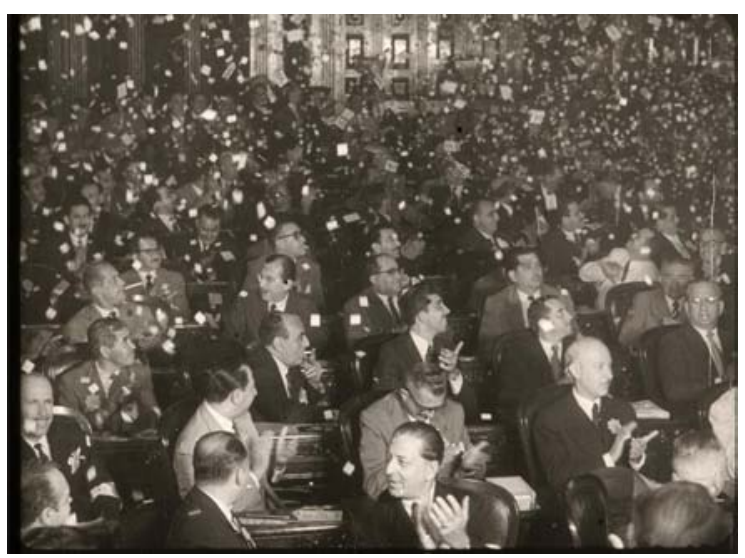

... da candidatura adhemarista para presidente. Bandeirante da Tela no 674, 1955. Acervo Cinemateca Brasileira.

Porém, a "onipresença” de Adhemar de Barros nas imagens do BT, baseada na representatividade sustentada em imagens, apresenta-se em momentos dos mais diversos no teatro de atualidades do cinejornal. Como no exemplo do BT $585^{359}$ (1954), em que após um desfile de modelos em trajes de banho bastante sensuais, temos na seqüência Adhemar de Barros num contato com eleitores pelo "Norte do Brasil".

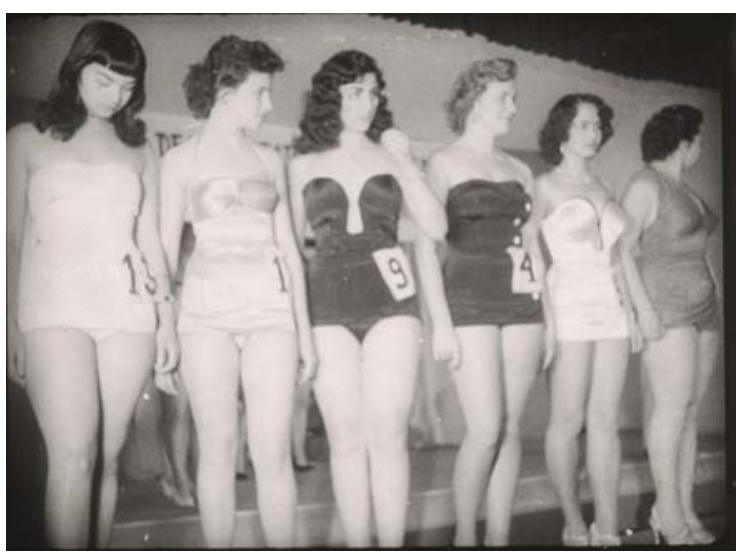

"Saúde e Beleza": desfile de modelos em trajes de banho antecedendo...

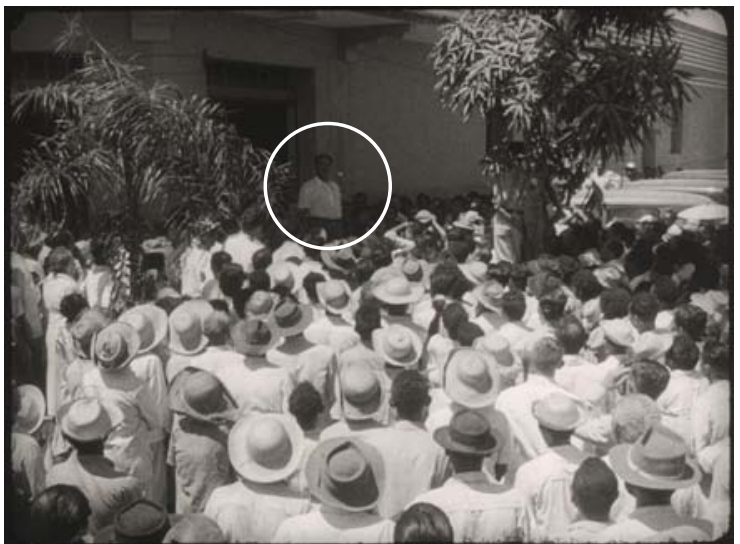

... Adhemar no "Norte do Brasil". Bandeirante da Tela no 585, 1954. Acervo Cinemateca Brasileira.

Nesse sentido, a presença de Adhemar de Barros inserida em diversas notícias foi a estratégia utilizada, num grande veículo de massa como o cinema, para difundir a imagem

359 Bandeirante da Tela n. 585. São Paulo: Divulgação Cinematográfica Bandeirante, 1954. Fita de vídeo (6min40seg), VHS, sonoro, p\&b, VV00048. Cinemateca Brasileira. 
do líder pessepista ${ }^{360}$. Inserido numa rede de eventos corriqueiros anunciados como "Conheça sua Terra", "Atualidades", "Norte do Brasil”, etc., o político "visitava" o público ao dar as caras semanalmente em salas de grande freqüentação em São Paulo, compondo com notícias de esporte, beleza, convenções sociais, datas comemorativas, e por aí vai. Era essa a saída, num cinejornal cavado, para atender interesses diversos: comerciais, privados, institucionais e, inclusive, inter-regionais. Como acontece no BT $372^{361}$ (1951), ao registrar uma viagem a Belém do Pará, porém realizando uma divulgação turística daquele estado cujas autoridades são mostradas como "queridas" dado o trabalho que por lá promovem.

Apresentado como "Conheça sua Terra", o assunto pode ter surpreendido o espectador que, mediante um convite para conhecer mais do seu país, se viu naquele instante diante de uma propaganda política. Num ritual já conhecido, Adhemar de Barros chega de avião e é recepcionado por uma comitiva que o espera no aeroporto. Após receber os cumprimentos do prefeito e do governador, assistimos o político paulista e autoridades locais num passeio em carro aberto, numa determinada rua. Num travelling em plano médio - captado por uma câmera num veículo à frente - enquadra-se Adhemar de Barros acenando à população que quase não aparece nas extremidades do campo visual da câmera. Somos informados, neste momento, que as <ruas e os lugares mais interessantes de Belém do Pará são percorridos por Adhemar de Barros em companhia dos principais homens da administração paraense > e que <espontânea e cordial [é] a homenagem que o povo presta durante o trajeto pelas ruas da cidade>. Não vemos o político paulista e as autoridades daquele estado percorrendo as "ruas" e os "lugares", tampouco algo que nos convença, pelas imagens mostradas, que tenham sido agraciados pela mostra de <simpatia e prestígio que desfrutam eles no seio dos habitantes de lá>.

\footnotetext{
${ }^{360}$ Podemos lembrar aqui, em composição com o conceito de idéias-força desenvolvido por Michel Vovelle, que a representação em imagens - tanto escritas como audiovisuais - tende a obscurecer a força explicativa de conceitos que pedem uma reflexão maior por parte do receptor (ainda que este possua o seu próprio arcabouço empírico) pela diluição em imagens facilmente reconhecíveis na experiência cotidiana. Este pode ser o princípio da "função propagandística" que tenta criar uma realidade através da justaposição de palavras e imagens, Cf. Jacques A. Weinberg, op. cit. 157; Assim como se aproxima das "palavras encantatórias", na análise de Marilena Chaú, se pensarmos a noção de pertencimento ou "classe social" e o seu "esvaziamento" pelo discurso conservador integralista que tenta abolir "a distância entre o mundo e o discurso" com imagens que "soldam o real e a palavra". Cf. Marilena Chaú "Apontamentos para uma crítica da Ação Integralista Brasileira" In Marilena Chaú e Maria Sylvia Carvalho Franco. Ideologia e Mobilização Popular, op. cit., pp. 17-149, 44, 47.

${ }^{361}$ Bandeirante da Tela $n$. 372. São Paulo: Divulgação Cinematográfica Bandeirante, 1951. Fita de vídeo (8min55seg), VHS, sonoro, p\&b, VV00098. Cinemateca Brasileira.
} 


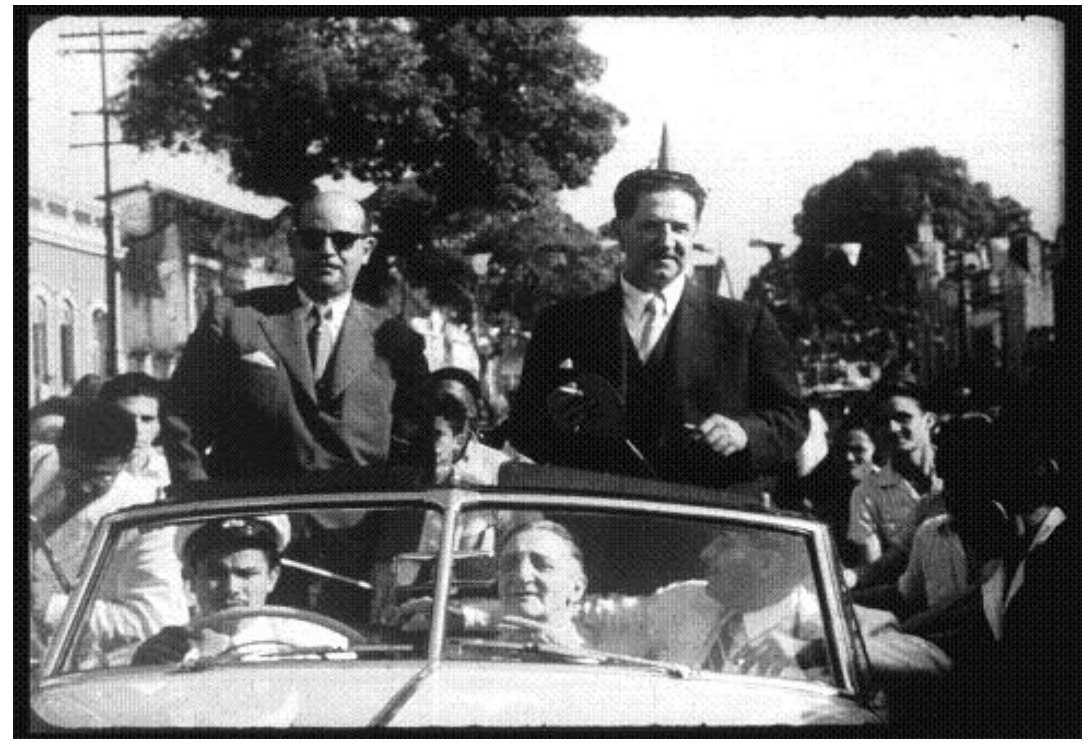

Nesta única tomada, somos informados que Adhemar de Barros percorreu os lugares mais interessantes de Belém do Pará, sendo espontane-amente e cordial-mente homenageado pelo povo paraense. Bandeirante da Tela no 372, 1951. Acervo Cinemateca Brasileira.

Para além destas cenas, temos a aparição de Adhemar de Barros visitando moradores carentes num bairro pobre. Oportunidade criada no BT para esclarecer os propósitos do político paulista que visita os "habitantes de lá": <uma visita se impõe aos bairros pobres, preocupação constante dos governos esclarecidos $>$. Ao chegar no local, crianças cercam o automóvel - o mesmo mostrado no passeio em carro aberto - como que surpresas com a visita. Mais um enquadramento é realizado para mostrar o contato de um político "esclarecido" que quer tomar nota de como <os mocambos e favelas vem sendo substituídos por habitações mais confortáveis $>$ para aquela gente.

Uma tomada em plano geral é realizada com Adhemar de Barros ao centro, com alguns homens ao lado e cercado por crianças. A cena demonstra, claramente, a preocupação em registrar o contato do político com os "humildes de Belém”. Mas também nos dá uma idéia do distanciamento, falta de tato até, do político e seus assessores com aquela situação, dado o esforço para atrair a atenção das crianças que, insistentemente, não param de acenar e fazer gestos para a câmera. Esta sim, nos parece, a real novidade naquela circunstância, e não Adhemar de Barros que se interessa < vivamente pelo assunto que visa beneficiar os humildes de Belém>. 


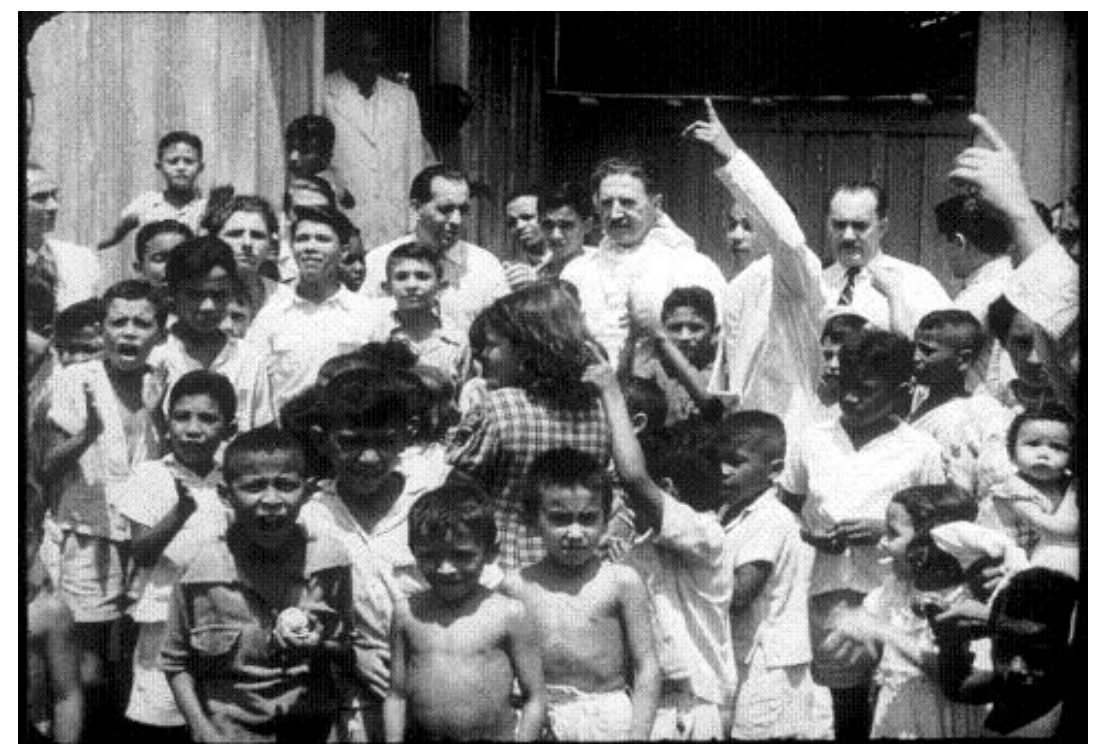

Adhemar visita a periferia de Belém: <uma preocupação constante dos gover-nos esclarecidos $>$.

Dificuldades para compor uma cena em que as crianças estão muito mais interessadas na câmera que as filma, que no político que as visita. Bandeirante da Tela no 372, 1951. Acervo Cinemateca Brasileira.

Em meio a algumas seqüências da Igreja de Belém, do forte e do entreposto de pesca, do Mercado Ver-o-Peso, da feira-livre e comidas típicas, da praça central da cidade e algumas tomadas aéreas em grande plano geral do centro urbano, numa alusão ao progresso e pujança alcançados pela cidade, o espectador é levado a acompanhar os espaços visitados pelo político. Considerando que em pouco mais de sete minutos de assunto o líder pessepista aparece em menos de dois minutos ${ }^{362}$. Mesmo quando não o vemos, sua presença é garantida pelo narrador que sustenta a continuidade visual de sua imagem $^{363}$ até o momento em que Adhemar de Barros aparece se despedindo da comitiva no aeroporto. Ao final, ele esteve "presente" em todo o registro, pois é a sua visita que assegura uma unidade orgânica do assunto, mostrando ao espectador um pouco do Brasil que cada vez mais o político conhece e se interessa: <depois de demorado contacto com este pedaço de Brasil setentrional, despede-se o doutor Adhemar>.

\footnotetext{
${ }^{362}$ De exatos 7'19' de assunto, Adhemar de Barros aparece em apenas 1'89'".

${ }^{363}$ Como apontado por Gerard Betton sobre o som - e como entendemos também estar presente na voz em off do narrador do cinejornal - que "assegura uma continuidade da percepção e da unidade orgânica do filme". Estética do Cinema. São Paulo: Martins Fontes, 1987. (Coleção Opus 86), p. 38. Grifo nosso.
} 
Embora 1951 tenha sido o primeiro ano de Adhemar de Barros após sua saída do governo paulista (1947 a 1950), vale lembrar que o projeto político, mais do que nunca, estava presente nesse momento, pois o PSP conseguiu perpetuar o poder por mais quatro anos com Lucas Nogueira Garcez ${ }^{364}$. Assim sendo, a recente gestão do político paulista ainda lhe conferia uma apresentação enquanto governo, "esclarecido" como informa a narração do BT 372. E esperava cultivar essa imagem para vôos mais altos, para as próximas eleições presidenciais, por exemplo. É nesse sentido que podemos entender a necessidade de uma evidência constante, da onipresença de Adhemar de Barros no artefato fílmico criado para ele mesmo. E que o apresenta ora viajando pelo mundo, como vimos no BT 501, ora em várias regiões do Brasil, como identificamos em vários números do BT. E é necessário ressaltar que se o PSP lhe deu sustentação partidária nos momentos em que esteve distante do poder executivo (seja municipal ou estadual) ${ }^{365}$, o seu cinejornal parece ter completado esta estratégia, cumprido papel semelhante na divulgação de sua imagem ${ }^{366}$.

E na alimentação constante de uma imagem pública que poderia esvaecer, sobretudo em períodos eleitorais, as aparições adhemaristas no cinema insistiram repetidamente em transitar por duas chaves representativas, à primeira vista contraditórias, - que bem articularam no discurso político um elo sócio-cultural importante para angariar popularidade: a imagem do homem empreendedor, realizador, moderno ${ }^{367}$ e portador de grande prestígio político e ao mesmo tempo a do "homem comum", acessível à massa, como vimos no BT 501.

A imagem da modernidade vinculada ao homem que realiza, a princípio, nos remete a uma tradição bastante clara nos cinejornais getulistas com recepções nos aeroportos, cumprimento das autoridades locais, desfiles em carro aberto, visitas

\footnotetext{
${ }^{364} \mathrm{O}$ que de fato não ocorreu dado o seu rompimento com partido em 1954, como vimos na segunda parte deste trabalho.

${ }^{365}$ Cf. Regina Sampaio, op. cit. 155.

${ }^{366} \mathrm{O}$ que responde a indagação de Francisco C. Weffort, quanto à manutenção do populismo de Adhemar de Barros apesar do duro ostracismo que sofreu depois de 1950. Além da estrutura partidária, como levanta o autor, acreditamos que a propaganda e o investimento no cinema foi um forte elemento propagador da sua imagem e alimentadora, também, da "máquina populista" (Weffort) que se baseia, sobretudo, na própria imagem do chefe. Cf. Francisco C. Weffort, O Populismo na Política Brasileira, op. cit., p. 32.

367 O mais próximo possível do que foi dito por Freud, em que "[...] a fim de permitir a identificação narcisista, o líder tem de aparecer como absolutamente narcisista". Cf. Theodor W. Adorno. "A teoria freudiana e o padrão da propaganda fascista", op. cit., p. 175.
} 
em instalações fabris

ou obras públicas,

participações em eventos

sociais com grande

presença das massas, etc. ${ }^{368}$.

Tudo isso somado a

onipresença do

presidente em todos os

quadrantes do país. Sem

dúvida, Getúlio Vargas foi

um apelo constante na

trajetória de Adhemar de

Barros e do PSP durante a

década de $1950^{369}$.

No entanto, a

modernidade, presente em

todo o arsenal de campanha

adhemarista $^{370}, \quad$ assumiu

contornos do que Adhemar

de Barros foi em carne

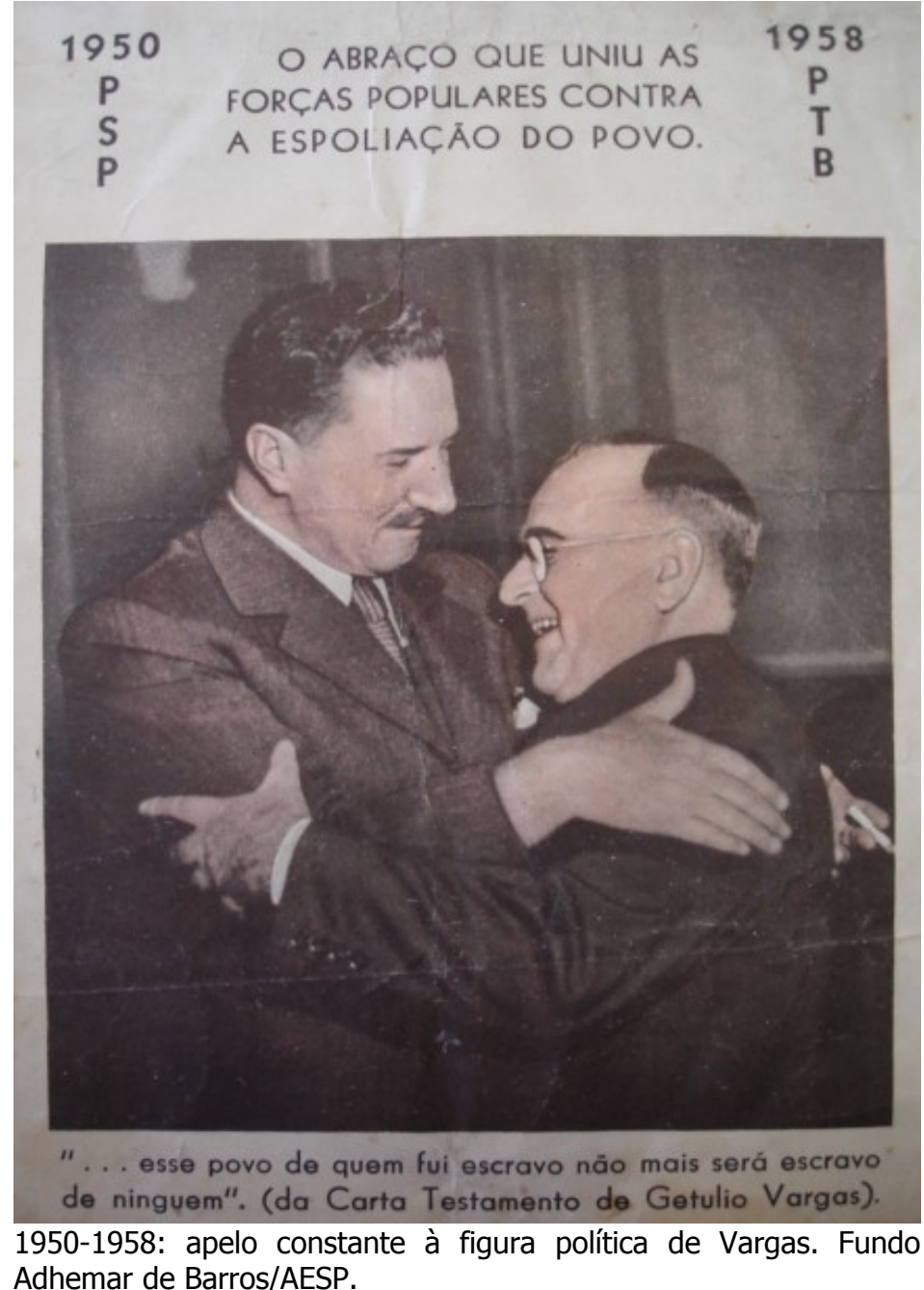

e osso. Nesse sentido, é sintomático que nos BT analisados não encontramos registros de sua voz ou, quando muito, o narrador "fala" por ele. Dado este que nos leva a considerar a opção pela visualidade de um homem moderno proporcionada pelo cinema. Até porque, a sua fala era explorada em outros meios, numa vertente bastante distante do que seria moderno e avançado ${ }^{371}$. Assim sendo, ser progressista transparecia nas várias sutilezas do formato cinematográfico: seu físico avantajado, facilmente notado entre os demais, lhe deu

\footnotetext{
${ }^{368}$ Cf. José Inácio de Melo Souza. O Estado contra os meios de comunicação, op. cit. p. 211.

369 "O abraço que uniu as forças populares contra a espoliação do povo". Panfleto do Partido Social Progressista e Partido Trabalhista Brasileiro. Caixa 638, pasta 03, doc. 001. Fundo Adhemar de Barros/APESP.

${ }^{370}$ Como vimos na primeira parte deste trabalho.

${ }^{371}$ Como as falas do programa radiofônico Palestras ao Pé do Fogo, cuja opção de "falar errado", na língua do povo - como vimos na primeira parte deste trabalho - representa claramente uma estratégia do político cuja formação comportava a fala fluente das línguas inglesa, alemã, francesa e italiana. A esse respeito, cf. Paulo Cannabrava, op. cit., p. 21.
} 
proeminência e destaque no ritual filmado ${ }^{372}$. Gestos firmes e o indefectível cigarro na mão esquerda the deram ares de alguém decidido e moderno ${ }^{373}$. Caminhadas no meio do povo, com as mangas arregaçadas ou com o seu paletó nos braços mostravam alguém sempre disposto ao trabalho ${ }^{374}$ e que por isso era admirado em suas aparições por aqueles e "aquelas" que o cercavam ${ }^{375}$. Detalhes que, a princípio, podem ter pouca importância, mas certamente dizem respeito aos cuidados conscientes da construção de uma visualidade buscada pelo político, que se comportava como um homem moderno e realizador, admirado nos quatro cantos do Brasil, sabedor das dificuldades da população que visitava e "doutor" para os problemas sociais. Enfim, uma autêntica "espontaneidade intencional", pretensa a encarnar a modernidade do seu tempo com um gestual condigno para transmiti-la ao espectador $^{376}$, algo próximo do que fora lembrado acerca da distinção entre a parcela do real e a do imaginário, em que "não existe xamanismo sem uma certa encenação, nem feiticeiro que não seja também ator" ${ }^{377}$.

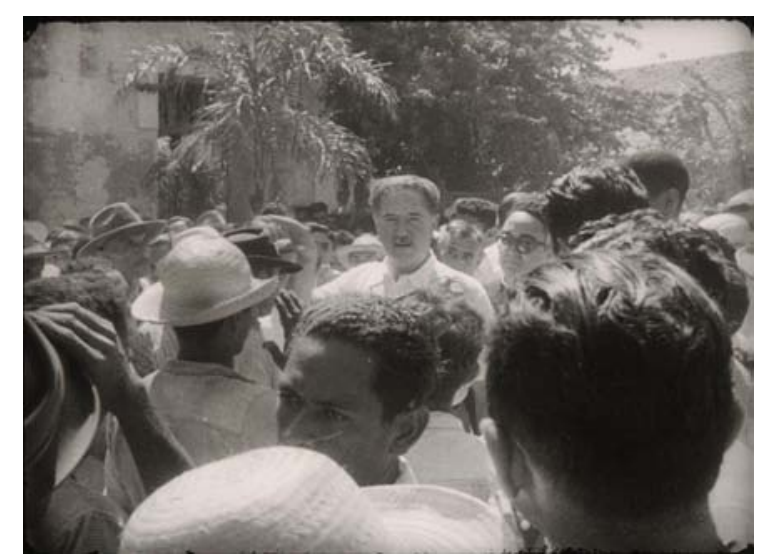

No BT, a presença física de Adhemar era destaque no teatro filmado: num em plano-geral nas ruas de uma cidade do norte do país, pareceu caminhar entre simpatizantes. Bandeirante da Tela no 585, 1954. Acervo Cinemateca Brasileira.

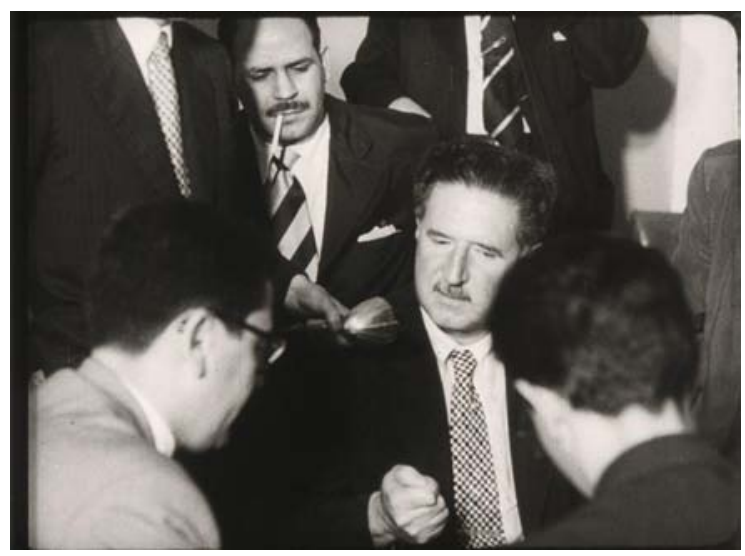

Gestos firmes "confirmam" a convicção de um realizador decidido: Adhemar concede entrevista após uma <viagem de estudos> à Europa. Bandeirante da Tela no 501, 1952. Acervo Cinemateca Brasileira.

${ }^{372}$ Bandeirante da Tela n. 585. São Paulo: Divulgação Cinematográfica Bandeirante, 1954. Fita de vídeo (6min40seg), VHS, sonoro, p\&b, VV00048. Cinemateca Brasileira.

${ }^{373}$ Bandeirante da Tela n. 501. São Paulo: Divulgação Cinematográfica Bandeirante, 1952. Fita de vídeo (7min56seg), VHS, sonoro, p\&b, VV00098. Cinemateca Brasileira; Bandeirante da Tela n. 672. São Paulo: Divulgação Cinematográfica Bandeirante, 1955. Fita de vídeo (6min48seg), VHS, sonoro, p\&b, VV00099. Cinemateca Brasileira; Bandeirante da Tela n. 588. São Paulo: Divulgação Cinematográfica Bandeirante, 1954. Fita de vídeo (6min3seg), VHS, sonoro, p\&b, VV00048. Cinemateca Brasileira.

${ }^{374}$ Bandeirante da Tela n. 678. São Paulo: Divulgação Cinematográfica Bandeirante, 1955. Fita de vídeo (7min17seg), VHS, sonoro, p\&b, VV00099. Cinemateca Brasileira.

${ }^{375}$ Bandeirante da Tela n. 679. São Paulo: Divulgação Cinematográfica Bandeirante, 1955. Fita de vídeo (7min), VHS, mudo, p\&b, VV00099. Cinemateca Brasileira.

376 Tendo em conta a "distinção" como valor inscrito na base das relações sociais, inclusive políticas, como na proposta de Pierre Bourdieu. Cf. O Poder Simbólico, op. cit., pp. 187-8.

${ }^{377}$ Cf. Raoul Girardet, op. cit., p. 72. Grifo nosso. 


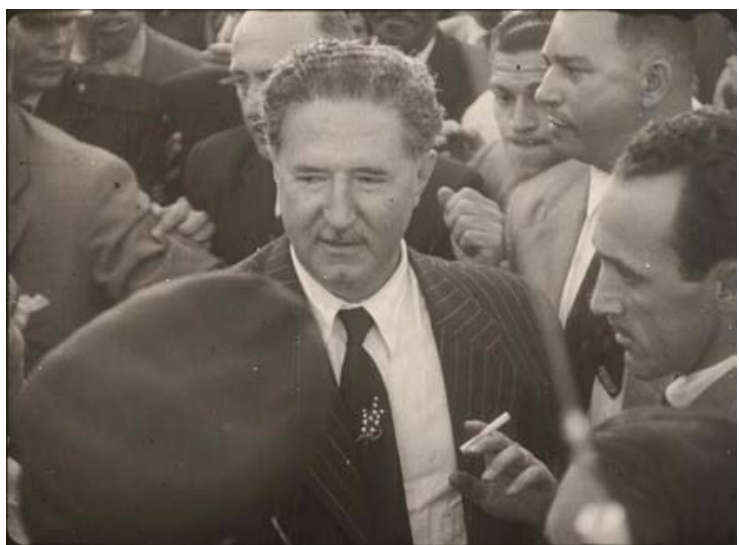

"Momento Político". De volta do Rio, Adhemar não abandona o gestual de um homem moderno, numa expressão bem singular com o seu cigarro na mão esquerda, algo constante no BT. Bandeirante da Tela no 672, 1955. Acervo Cinemateca Brasileira.

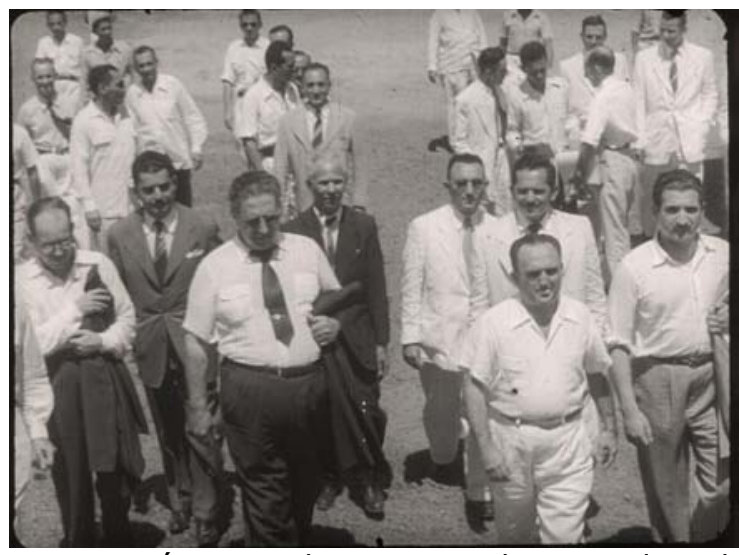

No Amapá, em plena campanha presidencial, Adhemar chega para diagnosticar os problemas daquela região, com a atitude de quem arregaça as mangas e se dispõe a trabalhar. Bandeirante da Tela no 678, 1955. Acervo Cinemateca Brasileira.

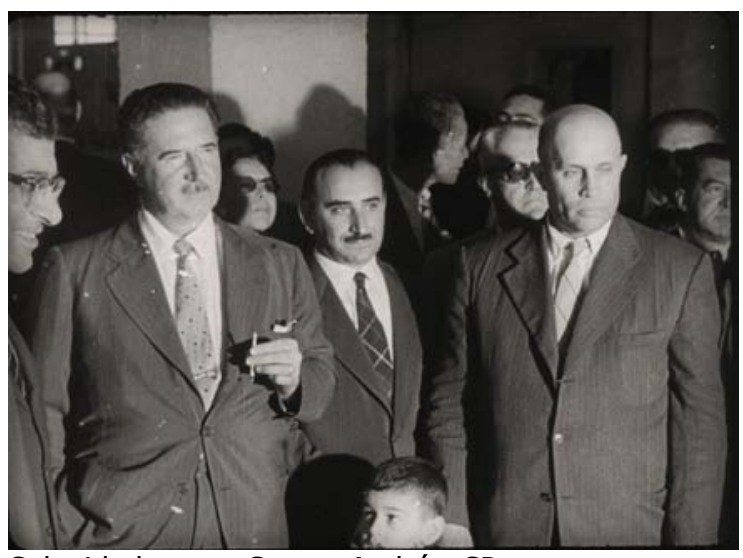

Solenidade em Santo André, SP: postura ereta, cigarro na mão e correligionários ao redor. Uma composição recorrente e que certamente contribuiu para fixar a imagem altiva do político. Bandeirante da Tela no 588, 1954. Acervo Cinemateca Brasileira.

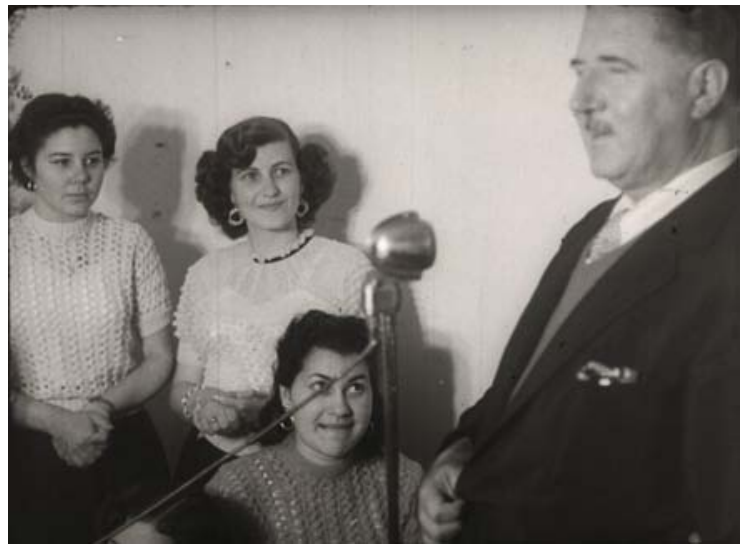

Em São Paulo, a presença de Adhemar é registrada no BT sob os olhares de extrema admiração de um grupo de mulheres. Bandeirante da Tela no 679, 1955. Acervo Cinemateca Brasileira.

Mas o político que conhecia todo o Brasil parece ter enfrentado dificuldades para mostrar nas telas tamanha popularidade. Por mais que visitasse lugares, principalmente entre 1954 e 1955 - nas campanhas para governador e presidente -, um olhar atento aos registros do BT ilumina alguns pontos da construção utilizada para suprir a ausência de uma massa pronta a acompanhá-lo. Por todo o país, Adhemar de Barros era apenas um candidato e precisava convencer milhares de espectadores paulistas com as imagens do seu 
prestígio por onde esteve. Vejamos, por exemplo, o BT $600^{378}$ (1954) com Adhemar de Barros visitando Fortaleza em mais um "Conheça sua Terra". A notícia se inicia com um plano geral de pessoas observando uma aterrissagem. Na cena seguinte, temos o político abrindo a porta do avião (seria o mesmo avião?) e acenando, posicionado ao fundo em relação ao grupo de pessoas ali presente (o mesmo grupo da primeira cena, como podemos notar pelos chapéus e demais vestimentas).

Tal composição, estendendo o espaço em profundidade no enquadramento, cria um campo visual cinematográfico com proporções redimensionadas para enaltecer o momento da chegada de Adhemar de Barros que, assim, é recepcionado por uma "multidão". O que se completa com a informação verbal sobre a <significativa manifestação [que] prestam os habitantes da capital do Ceará, no aeroporto, ao senhor Adhemar de Barros>. Têm-se, dessa forma, a sugestão de que inúmeros cearenses esperavam dar boas-vindas àquele que $<$ recentemente percorreu vários estados do norte e nordeste sendo tão aclamado quanto nos estados sulinos $>$ - não perdendo a oportunidade é claro, com a fala do narrador, de lembrar o público do seu prestígio em todo o país.

O registro segue com um plano médio de Adhemar de Barros andando e acendendo um cigarro num corredor formado por caminhonetes estacionadas e uma aglomeração de pessoas que o observam. A cena não mostra nada além da caminhada do político entre pessoas, no entanto, a esta simples seqüência é creditada uma informação muito distante do que se vê, sobre o quão <impressionante [é] a popularidade de Adhemar, cujas visitas, mesmo destituídas de caráter político, se transformam sempre em grandes demonstrações de apreço $>$. O registro termina num plano geral de vários caminhões com pessoas em suas caçambas, dando a entender que ali estiveram para prestigiar o político que goza de "impressionante" popularidade. Somado a um tema musical alegre - folclórico até - para reforçar a atmosfera amigável pretendida ${ }^{379}$, o registro não conta com mais de quatro seqüências em espaços delimitados para a captação prévia daquelas ações: o avião pousando, o aceno do político que desembarca, a passagem por um grupo de pessoas e caminhões lotados. De qualquer forma, foi esta a solução cinematográfica, neste registro,

\footnotetext{
${ }^{378}$ Bandeirante da Tela n. 600. São Paulo: Divulgação Cinematográfica Bandeirante, 1954. Fita de vídeo (6min47seg), VHS, sonoro, p\&b, VV00048. Cinemateca Brasileira.

${ }^{379}$ Assim como para ajudar na curta continuidade visual do assunto. Cf. Karel Reisz e Gavin Millar, op. cit., p. 191.
} 
para construir a imagem do político que mantém o corpo-a-corpo com as pessoas porque é um homem comum, um amigo por todo o Brasil.

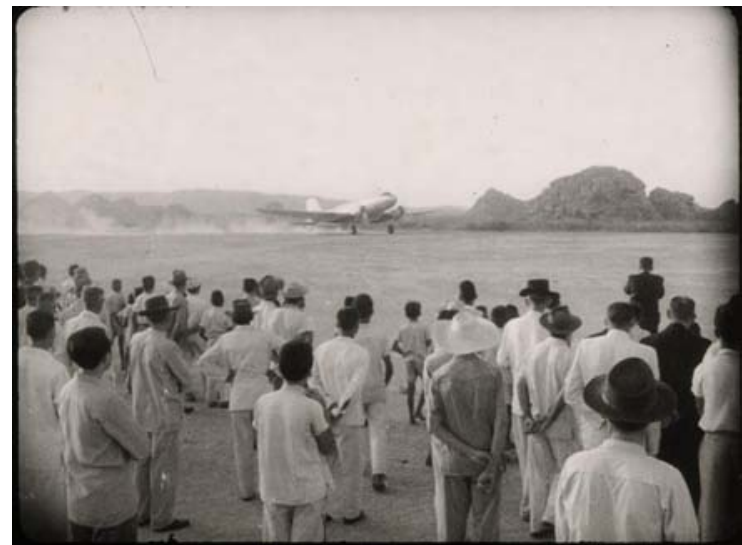

Em Fortaleza, um grupo de pessoas observa a aterrissagem do político progressista que será agraciado...

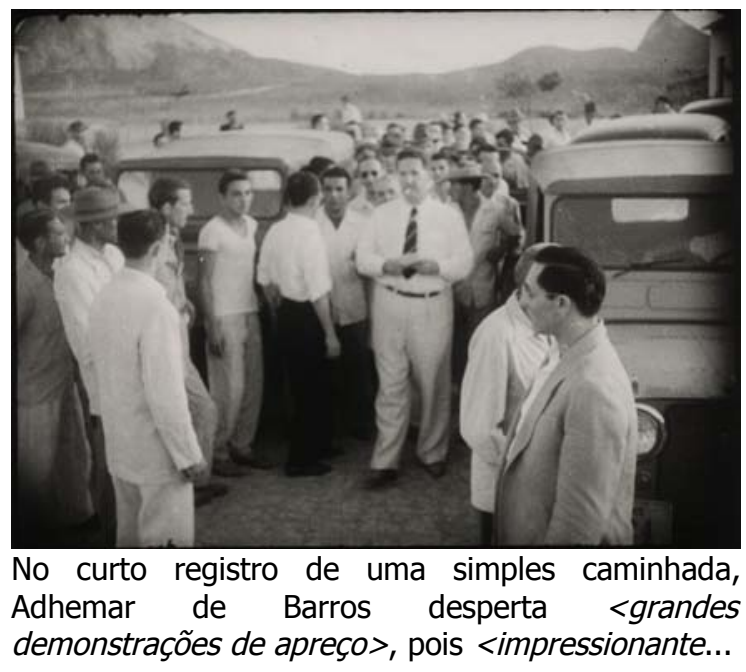

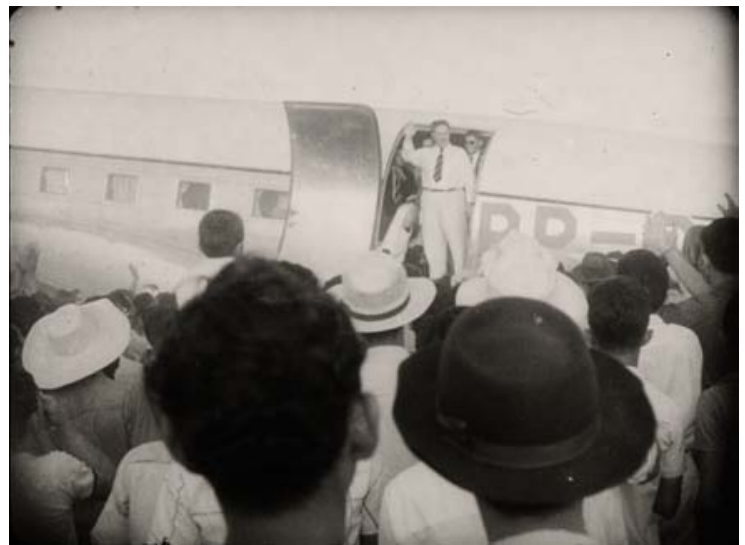

... com uma <significativa manifestação> dos <habitantes da capital do Ceará>. Bandeirante da Tela no 600, 1954. Acervo Cinemateca Brasileira.

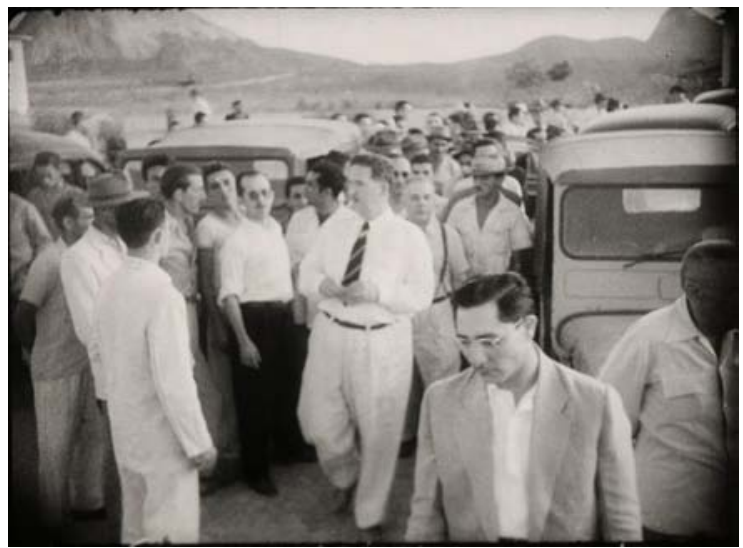

... [é] a popularidade> que goza nos <estados do norte e nordeste> quanto nos <estados sulinos>. Bandeirante da Tela no 600, 1954. Acervo Cinemateca Brasileira.

Em mais dois exemplos, os números $672^{380}$ e $674^{381}$ (ambos de 1955), os indícios da realidade construída para a veiculação no BT ficam evidentes. São registros da passagem de Adhemar de Barros pela capital federal e a chegada em São Paulo onde o corpo-a-corpo com a massa deixa rastros de um teatro ensaiado para as câmeras. No BT 672, a imagem inicial do "Momento Político" apresenta uma rua na capital federal, bastante movimentada, com Adhemar de Barros num carro aberto, acenando, e com a câmera realizando uma

\footnotetext{
${ }^{380}$ Bandeirante da Tela n. 672. São Paulo: Divulgação Cinematográfica Bandeirante, 1955. Fita de vídeo (6min48seg), VHS, sonoro, p\&b, VV00099. Cinemateca Brasileira.

${ }^{381}$ Bandeirante da Tela n. 674. São Paulo: Divulgação Cinematográfica Bandeirante, 1955. Fita de vídeo (5min24seg), VHS, sonoro, p\&b, VV00099. Cinemateca Brasileira.
} 
tomada em plano geral num espaço suficiente para delimitar o cortejo. Em seguida, temos um enquadramento em plano médio de outro espaço, com pessoas segurando faixas, em especial uma que deseja ao político feliz regresso a São Paulo. Após estas duas seqüências, uma terceira segue com Adhemar de Barros, em primeiro plano, no que parece ser uma entrevista, no momento em que o narrador nos informa que a <chegada do senhor Adhemar de Barros à capital da República, de volta da sua viagem da Europa e dos Estados Unidos, foi assinalada por expressivas manifestações por parte dos brasileiros da capital federal>. Com cuidado para não "varrer" o campo visual, e assim garantir a sugestão de um grande número de pessoas ali reunidas, segue-se uma pequena panorâmica sobre um grupo que segura faixas adhemaristas, no mesmo espaço mostrado anteriormente. O registro continua com a chegada do político em sua terra, que <saúda a multidão que o foi esperar no aeroporto de Congonhas>.

Neste aeroporto, um plano geral detém-se sobre um recinto lotado, porém, um olhar detido sobre este mesmo local - certamente difícil para o espectador no momento da projeção - revela enorme semelhança com a arquitetura presente no espaço ocupado por simpatizantes no Rio de Janeiro, mostrado cenas antes. A fachada do prédio no Rio de Janeiro compõe com as colunas do saguão do aeroporto em São Paulo. Nesse sentido, explica-se a "opção" do cinegrafista em deter-se na faixa desejando feliz regresso a São Paulo, como falamos a pouco, dada a necessidade de elementos para corroborar uma grosseira construção se, realmente, tratar-se do mesmo local. E, como em outras vezes verificado no BT, a cena seguinte mostra um plano médio de um trajeto em que o político é auxiliado por correligionários a caminhar no meio de pessoas reunidas naquele recorte visual. A sugestão é clara: Adhemar de Barros tenta "furar" a massa, que assim se comporta devido ao <fruto da experiência e do amadurecimento político do homem comum, [dado] o conceito que hoje goza o senhor Adhemar de Barros $>$. Ou seja, tanto em São Paulo, o seu colégio eleitoral, como na capital federal, Adhemar de Barros é o político - então potencial candidato a presidente - a gozar de extremo carisma, como "atestam" as imagens do seu cinejornal. Mas teria Adhemar de Barros sequer ido ao Rio de Janeiro, para a filmagem deste registro? O seu enquadramento passando em carro aberto num local público bastante movimentado não que dizer que fosse uma rua da capital federal. Soma-se a esta invenção, os curtos movimentos em panorâmica para não "mostrar demais", assim 
como as bandeirinhas do Brasil e do Estado de São Paulo que as pessoas seguram tanto nas ruas da capital federal quanto no aeroporto paulista, como um adereço entregue aos figurantes para enfeitar a mise-en-scène ocorrida num mesmo lugar.

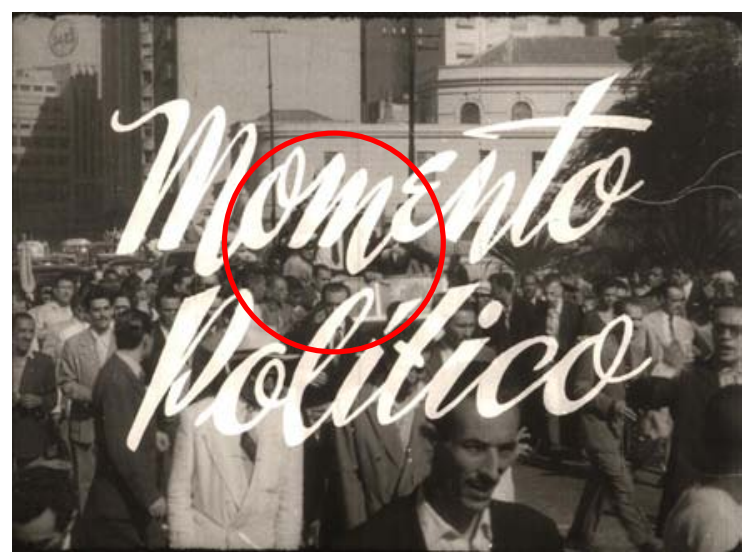

Assistimos Adhemar (atrás do intertítulo) em carro aberto pelo Rio, onde iniciam-se as homenagens do seu retorno ao Brasil...

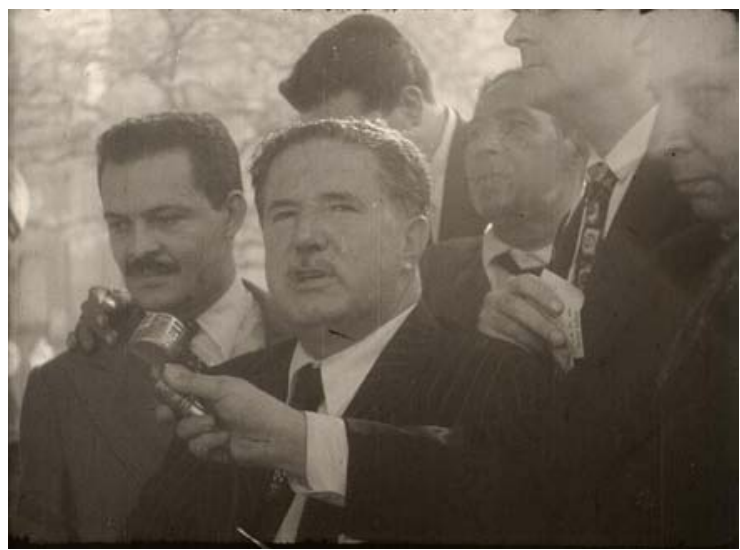

Enquanto concede entrevista, o povo o aclama com faixas nas "ruas da capital federal". Ou seria um espaço inventado? Com pessoas ao lado de fora...

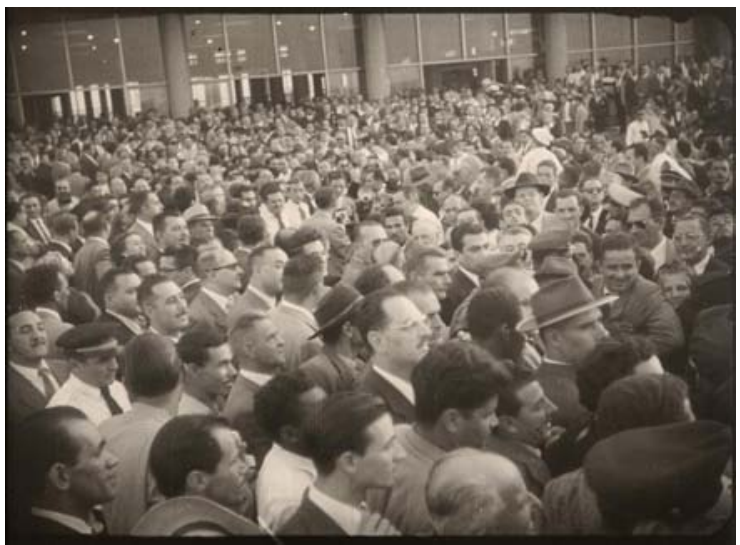

Em São Paulo, Adhemar é esperado por um elevado número de pessoas concentradas no saguão de Congonhas que dificultam a passagem...

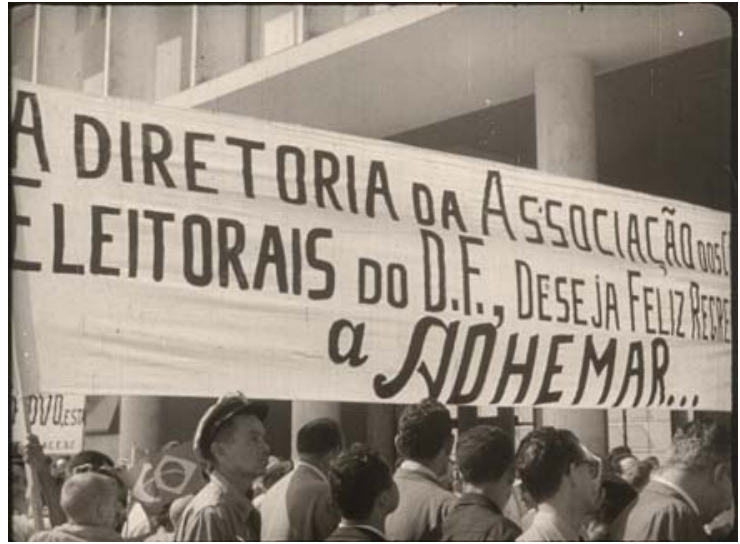

... No detalhe, faixas e bandeirinhas compõe a mise-en-scène. Bandeirante da Tela no 672, 1955. Acervo Cinemateca Brasileira.
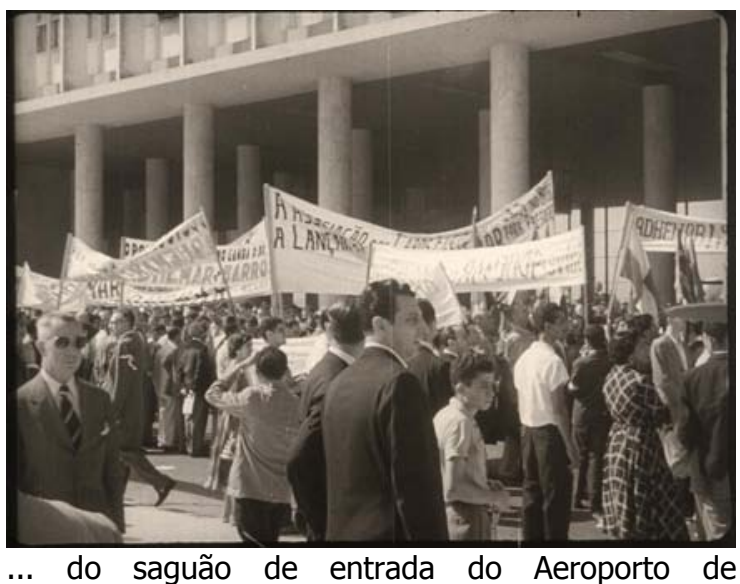
Congonhas?. Bandeirante da Tela no 672, 1955. Acervo Cinemateca Brasileira.

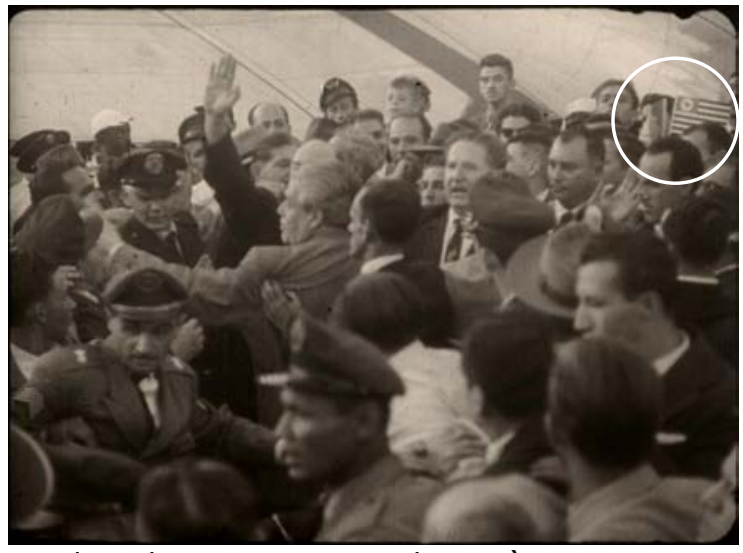

... daquele que sempre desce às massas. No detalhe, mais bandeirinhas. Bandeirante da Tela $n^{\circ}$ 672, 1955. Acervo Cinemateca Brasileira. 
No BT 674 esse teatro adhemarista persiste, também, com outro "Momento Político". As primeiras imagens enquadram, num primeiro plano, bandeiras de vários estados brasileiros, dísticos e cartazes do líder pessepista e o mapa do Brasil ${ }^{382}$. Uma composição que, visualmente, anuncia a notícia a ser transmitida: <o Partido Social Progressista em convenção no Rio de Janeiro homologou a candidatura do senhor Adhemar de Barros à presidência da República>. Após alternâncias entre algumas tomadas em plano geral do recinto com o público presente e os discursos dos componentes da mesa solene montada no local, temos uma cena conhecida: Adhemar de Barros se vê "prensado", agora entre correligionários, na sua caminhada até o palanque, que é registrada num plano médio dentro de um recorte suficiente para reforçar o clima de júbilo pela decisão tomada em convenção nacional. A alternância de planos se dá, daí até o final do registro, entre a fala do homologado candidato e o público que o aplaude com direto a chuva de papel picado, no que foi um discurso < recebido com palmas prolongadas $>$.

Para Adhemar de Barros, estar tomado por pessoas ao redor nos pareceu ser uma regra. Mas é justamente essa regra que desvela o que assistimos nas telas. Não são poucos os registros em que o político se vê envolvido por pessoas, mesmo quando sabemos presentes somente correligionários, como no caso de uma convenção do PSP. Esse componente "sempre presente" no ritual adhemarista, quase idêntico em todas as suas aparições no BT, é esclarecedor de como os correligionários e o líder pessepista estavam aptos a promover esta parte do teatro político. É esse "excesso" quem deixa claro, o exagero da encenação como vimos no BT 501. Não que Adhemar de Barros e seu partido não conseguissem angariar e organizar pessoas para um determinado evento. Nesse particular, vale lembrar que no início dos anos 1950, cerca de quarenta e seis Diretórios Distritais estavam à disposição de Adhemar de Barros e do PSP ${ }^{383}$, além de um "Centro Cívico Adhemar de Barros", localizado no centro da capital paulista, cujo objetivo era “difundir, por todos os meios, os princípios sociais progressistas, prestigiando a obra administrativa do Governador Adhemar de Barros" ${ }^{384}$, e mesmo associações que chegaram

\footnotetext{
${ }^{382}$ Imagens mostradas na página 128 deste trabalho.

383 "Moção de Desconfiança" por (assinatura ilegível) ao sr. Presidente e demais membros do Diretório Nacional do Centro Cívico Adhemar de Barros. São Paulo, julho de 1950. Pront. 105.237 - Centro Cívico Adhemar de Barros. DEOPS-APESP.

384 "Estatutos do Centro Cívico Adhemar de Barros". São Paulo, s/d. Pront. 105.237 - Centro Cívico Adhemar de Barros. DEOPS-APESP.
} 
a promover sessões cinematográficas com até dois mil e quinhentos espectadores ${ }^{385}$. Porém, além de organizar uma massa que creditasse popularidade ao político, foi preciso, por vezes, criar uma com a ajuda do cinema. E considerando a trajetória política de Adhemar de Barros, há um dado que não pode ser esquecido: o início da sua carreira política no PRP. Partido esse que já articulava, na década de 1920, o discurso em cinejornais com governantes paulistas ${ }^{386}$, cujas soluções para compor uma massa de eleitores para os espectadores pareceu ter caminhado numa mesma chave $\mathrm{e}^{387}$.

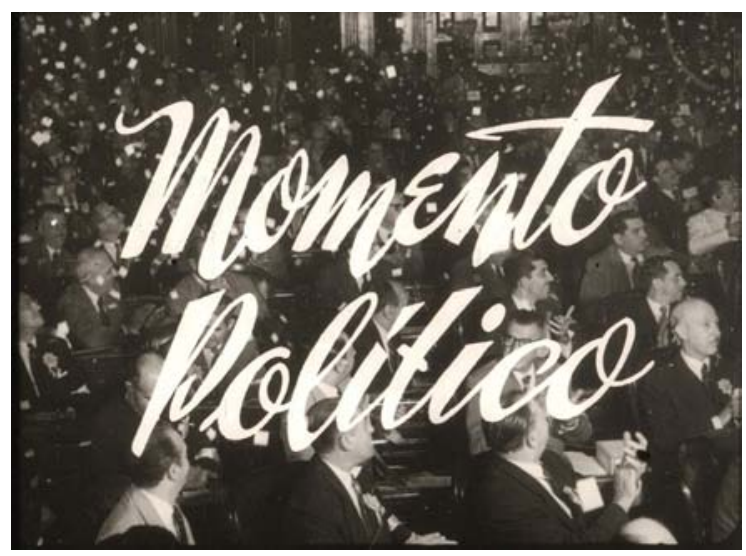

A homologação da candidatura adhemarista no Rio, registrada com festa entre os correligionários...

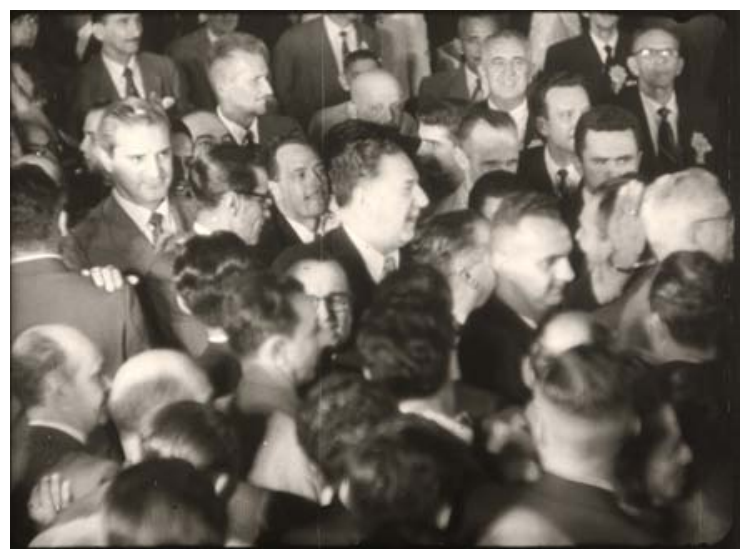

... que envolvem Adhemar de Barros. Bandeirante da Tela no 674, 1954. Acervo Cinemateca Brasileira.

385 Ocasião em que, provavelmente, foram exibidos números do cinejornal adhemarista, dado o caráter panfletário destas sessões ao irradiar pelo alto-falante textos que visavam "prestigiar o nome do Exmo. Snr. Dr. Adhemar Pereira de Barros". Ofício de Nestor Macedo, Representante-geral da Ala Negra Progressista, e José Mazariolli, Presidente da Ala Negra Progressista, a Paulo Rangel, Delegado de Ordem Política e Social. São Paulo, 27 de setembro de 1949. Pront. 101.018 - Ala Negra Progressista. DEOPS-APESP.

${ }^{386}$ A exemplo da Rossi Filmes que consegue "com Washington Luís uma subvenção para fazer um jornal cinematográfico, o Rossi Atualidades, que traz debaixo do título, nos papéis timbrados a especificação Órgão Oficial do Governo do Estado [...] Enquanto o PP [Partido Republicano Paulista] é Governo, a Rossi é a mais importante de nossas produtoras". Cf. José Inácio de Melo Souza, O Estado Contra os Meios de Comunicação, op. cit., p. 30.

387 Como no filme A Era da Renascença Nacional, da produtora Botelho e Neto, em que uma das cartelas diz: "Quando o Dr. Júlio Prestes, Presidente do Estado de São Paulo e candidato à futura Presidência da República, chegou ao Rio para ler a sua plataforma de governo, foi recebido pelo povo carioca com um entusiasmo indescritível". Não existindo, entretanto, cenas desse acontecimento "indescritível”, pois o que segue são tomadas de um banquete onde foi lida a plataforma política do candidato perrepista e detalhes dos “encasacados e suados, pelo calor de dezembro, grandes eleitores de S. Excia”. Cf. José Inácio de Melo Souza. "Eleições e Cinema Brasileiro: Do Fósforo Eleitoral aos Santinhos Eletrônicos”, op. cit., p. 158. 


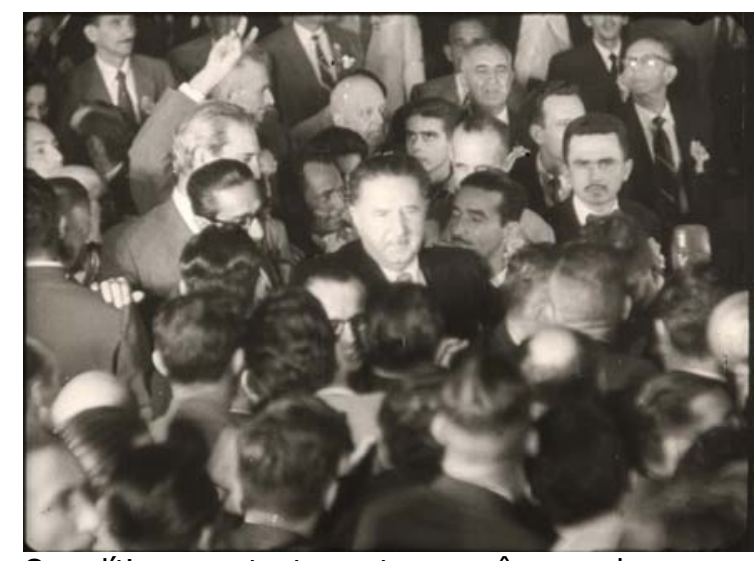

O político constantemente se vê cercado, quase impedido de chegar próximo aos microfones...

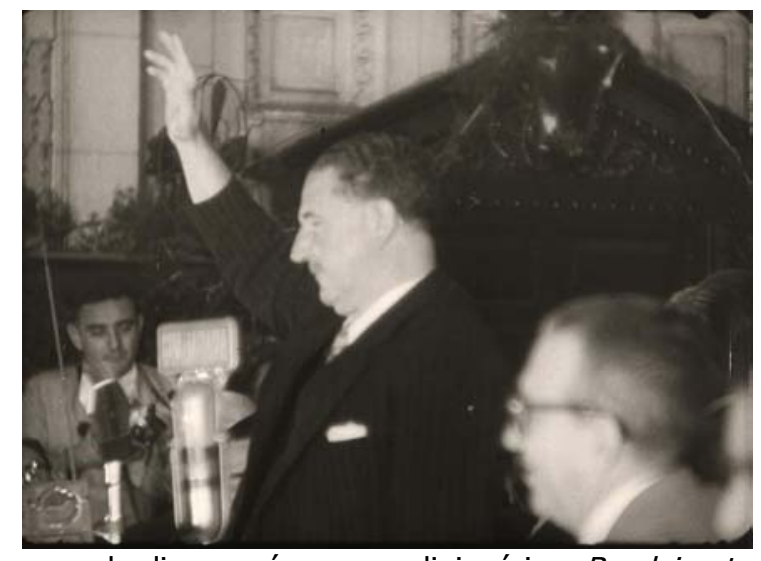

... onde discursará aos correligionários. Bandeirante da Tela no 672, 1954. Acervo Cinemateca Brasileira.

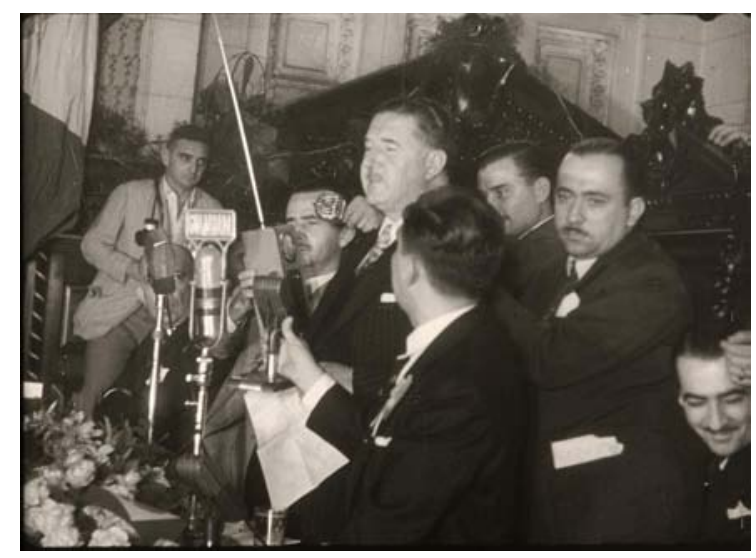

Enquanto profere algumas palavras sobre a sua plataforma de governo...

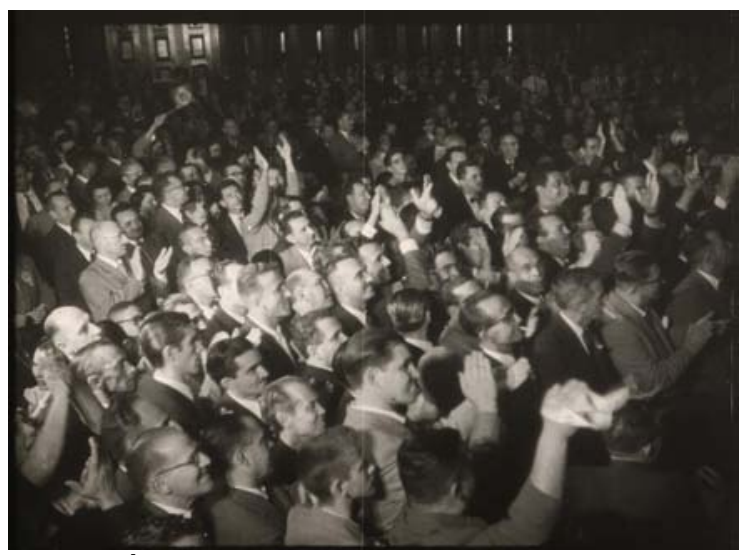

... as câmeras do BT registram os aplausos da claque. Bandeirante da Tela no 674, 1954. Acervo Cinemateca Brasileira.

Entretanto, a imagem do político ilustre nos quatro cantos do país, homem comum e querido pelo povo, assim como a do homem moderno, realizador e doutor para os problemas sociais, encerravam uma lida complexa para conquistar diversos setores da sociedade paulista. Suas vitórias políticas certamente indicaram um grau da apropriação do seu discurso principalmente pelas as camadas médias, ansiosas por um Estado protetor talvez, que lhes garantisse a manutenção de um bem-estar social e a aspiração por algo melhor $^{388}$. Apropriação também ocorrida junto às camadas populares, inseridas que estavam

${ }^{388}$ Como apontado por Francisco C. Weffort, op. cit., p. 33. Porém, nos parece um tanto "esquemático" apontar os interesses econômicos como explicativo das expectativas da classe média. Ainda que ansiosa por 
na mesma coletividade do todo social, vivenciando signos e apelos comuns, reestruturados na fidelidade ao mesmo político ${ }^{389}$. Contudo, o cuidado em representar e "pertencer" a diversos segmentos sociais, mostrar-se um "super-homem [e] ao mesmo tempo realizar o milagre de aparecer como uma pessoa comum" ${ }^{390}$, não aconteceu sem "tensões".

No limite de uma identificação cada vez maior com o eleitorado para vôos mais altos na política, assim como para manter o prestígio conquistado ${ }^{391}$, verificamos de que forma o cinejornal adhemarista se contradiz. Para além da usual ambigüidade do jogo político-partidário, traduzida nas mais díspares alianças políticas ${ }^{392}$, o discurso cinematográfico descortina a dificuldade do adhemarismo em lidar com uma série de valores conflitantes. Nesse sentido, é exemplar um trecho do discurso de Adhemar de Barros - reproduzido pelo narrador, ainda no BT 674 - sobre a sua plataforma de governo para as eleições presidenciais de 1955:

<iremos para luta com um programa popular e nacional, agrupando em nosso lado as forças populares $e$ nacionalistas que, como nós, propugnam uma solução brasileira para os problemas brasileiros, sem chauvinismos nacionais e sem entreguismos mercenários construiremos a felicidade do povo>.

Nas palavras desse vago compromisso político, o seu imbricado conjunto de idéias se desfaz quando questionamos a proposta adhemarista para o cinema. Seja no apelo às "forças populares" que o BT se esforçou em construir - ao menos nos seus números ainda existentes, como na "solução brasileira" para os "problemas brasileiros" num discurso

um Estado protetor, tal expectativa também perpassa valores sobre credibilidade, respeito, passado político, vislumbrados no político que os representa. Nesse quadro complexo, consideramos "classe média" uma denominação irredutível à uma conceituação que a explique por completo. Porém, numa escala sócioeconômica a relação entre "classe média baixa" e uma "classe média alta" é um dado importante para se pensar as "camadas" deste segmento social. E entender, por exemplo, o quão difundido e sociabilizado foi o conjunto de valores partilhado entre uma "camada média baixa" e as camadas populares. Cf. Décio A. M. Saes. "Classe média e política no Brasil: 1930 - 1965" In Ângela Maria de Castro Gomes et. tal. O Brasil republicano, v. 3: sociedade e política (1930 - 1964). Rio de Janeiro: Bertrand Brasil, 2003, (História geral da civilização brasileira; t. 3; v.3), pp. 447-506, 463, 487-8.

${ }^{389}$ Raoul Girardet, op. cit., pp. 95-6.

${ }^{390}$ Theodor W. Adorno, op. cit., p. 176.

${ }^{391}$ Seu "capital político" por assim dizer, “[...] conservado mediante o trabalho constante que é necessário não só para acumular o crédito como também para evitar o descrédito". Pierre Bourdieu. O Poder Simbólico, op. cit., p. 189.

${ }^{392}$ Como, por exemplo, a aliança com Prestes e o PCB nas eleições de 1947, assim como o apoio velado a Jânio Quadros nas eleições para prefeito em 1953, quando Adhemar de Barros rivalizou com o candidato pessepista à prefeitura indicado pelo então governador Lucas Nogueira Garcez. Este episódio foi satiricamente retratado no livro de idiossincrasias de Adhemar, pelo episódio intitulado "Foi a mais bela derrota". Cf. Carlos Laranjeira, op. cit., p. 79. 
daquele que se gabava de visitar o mundo inteiro em viagens de estudos. Mas a questão central, e que engloba todas as outras, permanece em qual foi a promessa de "felicidade" para o povo num discurso que, ele mesmo, não saiu imune aos "chauvinismos" que dizia ir contra.

Vejamos um exemplo do seu cinejornal num ano em que as preocupações eleitoreiras não estavam na ordem do dia, e talvez por isso seja bastante esclarecedor de uma certa distância com as camadas populares. Especialmente um grupo que começava a compor, na década de 1950, uma parcela importante no quadro sócio-cultural da capital paulista, os migrantes ${ }^{393}$. Ao abordar uma cena cotidiana em São Paulo, o BT 549 (1953) trata de famílias nordestinas que chegam "De Todo o Brasil", como anuncia o intertítulo. E com uma música alegre para um clima de boas-vindas aos representantes do norte, a notícia tem início com uma pequena panorâmica em plano médio de um caminhão pau-de-arara estacionado, tendo pessoas descendo da caçamba com seus pertences. O discurso começa estabelecendo um lugar para os "de fora", quando somos informados que $<$ a lavoura paulista precisa de braços $>$. Ou seja, é o que se reserva para estes representantes de um estrato social tido inferior e atrasado, e que chegam na terra paulista onde diariamente $<$ despejam-se levas e levas de patrícios do nordeste>. No BT, não está reservado para estes nordestinos o espaço da cidade, nem o da modernidade - pelo contrário, nota-se um discurso que pretende mantê-los longe dela. E ainda que "patrícios" indique a pretensão de um discurso amigável e cordial, ele não resiste ao que a câmera mostra: mais uma panorâmica (da esquerda para a direita) do mesmo caminhão varrendo topograficamente o espaço $^{394}$ em plano médio, com as famílias desembarcando sob o olhar da Força Pública vigiando crianças, mulheres e homens que <tentam a sorte em regiões onde o clima se mostra mais camarada>. É curioso notar como aquele que chega é um problema, a exemplo da voz em off que ressalva: <enquanto os imigrantes estrangeiros criam casos...>. Subtende-se, assim, que o mesmo deve ser evitado pelo novo contingente de

\footnotetext{
${ }^{393}$ A diminuição da imigração estrangeira até meados dos anos de 1930 gerou a contínua necessidade de mãode-obra em São Paulo, fato que impulsionou a migração de pessoas residentes em outros Estados. A partir de 1935, houve um aumento considerável do movimento migratório, chegando a se aproximar de 250 mil ao ano, entre 1951 e 1952, somente em São Paulo. Cf. SÃO PAULO Outrora e Agora: Informações sobre a população da capital paulista, do século XIX ao século XXI. Jan. 2004. Disponível em $<$ http://www.seade.gov.br/produtos/spoutragora $>$. Acesso em: 23 de ago. 2007, p. 25.

${ }^{394}$ Informando o espectador sobre o espaço e a relação entre o ambiente e os atores numa determinada cena. Cf. Karel Reisz e Gavin Millar, op. cit., p. 233.
} 
nordestinos que deseja aproveitar o "clima camarada" (melhores oportunidades) da terra paulista e que representam, no limite do que o próprio intertítulo sugere, uma "ameaça": eles vêm "De Todo o Brasil", <vendem tudo e trocam a seca pelo tubarão>. Nesse sentido, um clima de vigilância se impõe àquele grupo potencialmente causador de desordem, posto que vieram sem uma segurança econômica sólida, a exemplo das < crianças [que] andaram morrendo pelo caminho> e os < trastes vendidos mal deram para pagar o caminhão>.

Assistimos, durante todo o registro, uma alternância de planos e enquadramentos mostrando o inevitável desconforto daquelas pessoas nas duras condições com que chegam a São Paulo, assim como a incômoda situação em que se encontram. Até mesmo a câmera do BT soa "ameaçadora", dada a pouca receptividade que demonstram ao serem captadas em primeiro plano. Numa panorâmica em plano médio, as pessoas já desceram do caminhão e amontoaram seus pertences na calçada enquanto a Força Pública continua vigiando, pelo que se percebe na varredura de uma pequena panorâmica.

Enquadramentos realizados sobre rostos de mulheres, crianças e velhos, marcam visualmente o semblante cansado daquele grupo que não pertence à cidade grande, mas que dela espera muito, porém, < a cidade grande é uma incógnita>, e nada há para prometer aqueles que sentem <saudades da casa, da terra e da criação>, mas que têm a $<$ esperança de melhores dias $>$. $\mathrm{O}$ assunto termina num enquadramento em plano geral com pessoas encostadas na parede, mais uma vez "escoltadas" pela polícia, com uma música alegre de fundo, quase não identificável no início da notícia. Um misto de saudação e aviso é dito pelo narrador <felicidade amigos, a ordem agora é se virar!>, finalizando o registro daquela cena cotidiana sob um ritmo musical que aos poucos se torna claro, o da "Aquarela do Brasil". Por esta resumida descrição, notamos que o narrador tenta sustentar uma receptividade que inexiste, pelo que se constata nas imagens e no próprio texto narrado. Como vemos, o registro tensiona constantemente e não consegue ocultar uma mensagem nada amigável para com aquelas pessoas: “enquadrem-se”, “comportem-se", “ponham-se no seu lugar", "não causem problemas" e tampouco "desordem”, esta parece ser a verdadeira cordialidade na mensagem de fundo. 


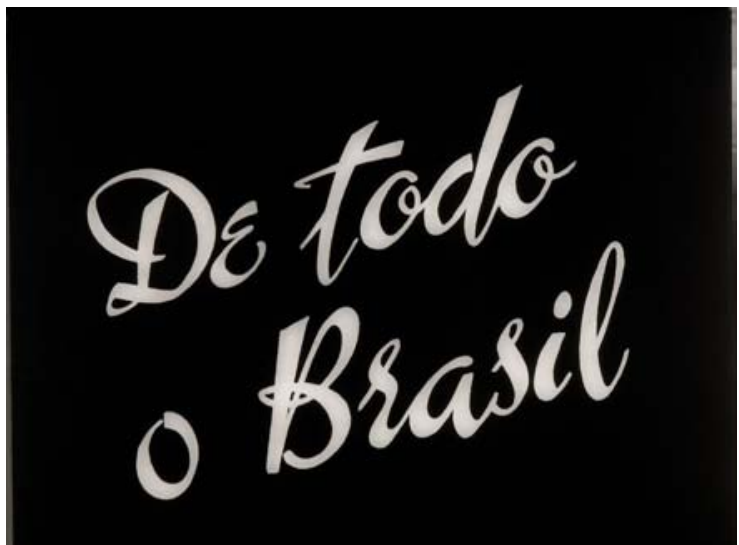

Como indica o intertítulo, "De todo o Brasil" despejam-se levas de nordestinos em São Paulo, esperados para o trabalho ...

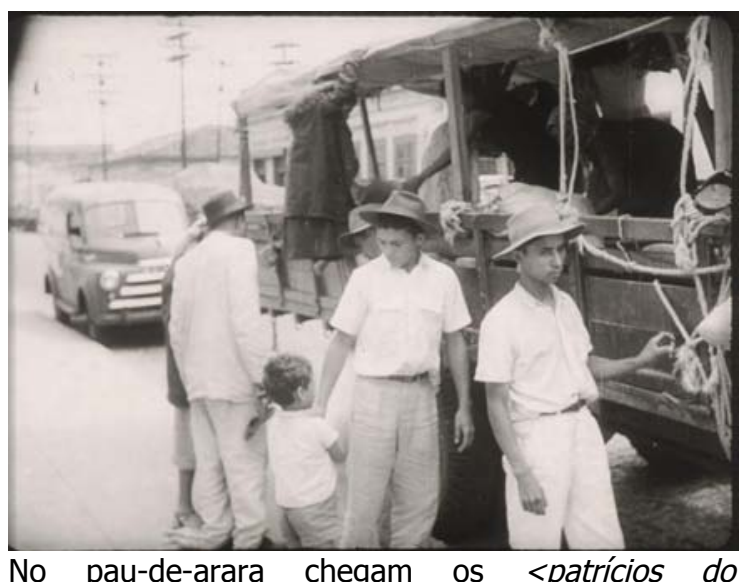

nordeste $>$ que venderam tudo para tentar ganhar a vida na cidade grande...

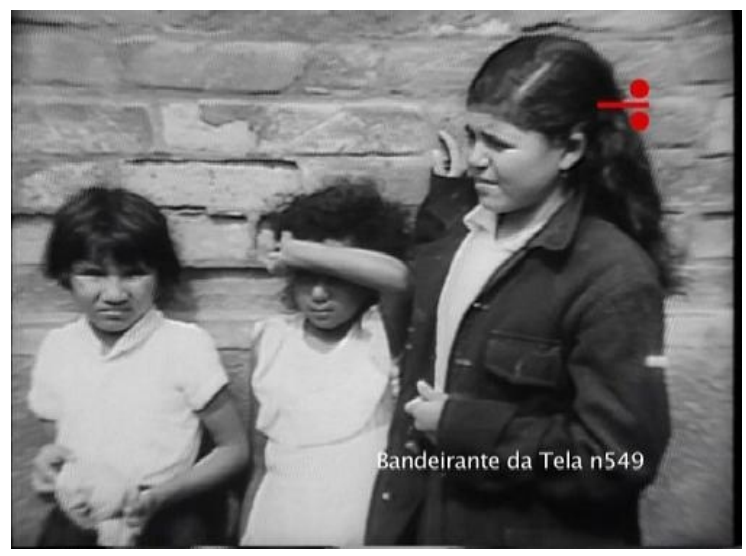

As <crianças andaram morrendo pelo caminho> $e$ os <trastes vendidos mal deram para pagar...

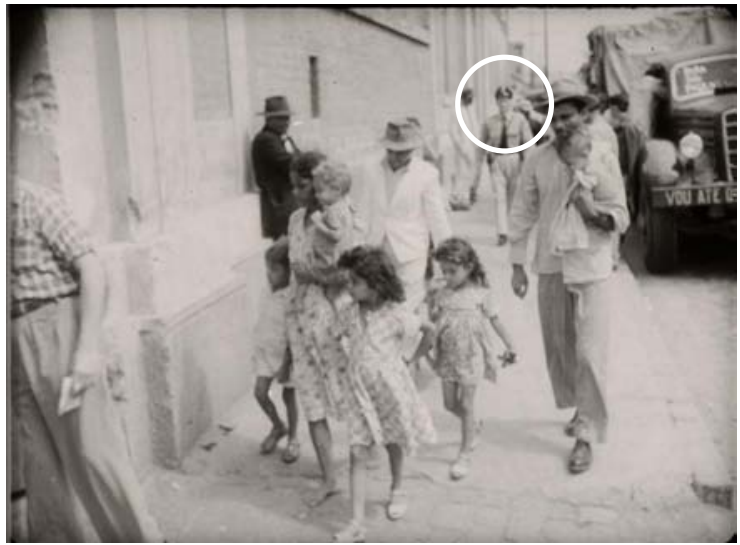

.... na lavoura paulista que <precisa de braços $>$. Ao fundo, policiais "recepcionam" as famílias. Bandeirante da Tela $n^{\circ}$ 549, 1953. Acervo Cinemateca Brasileira.

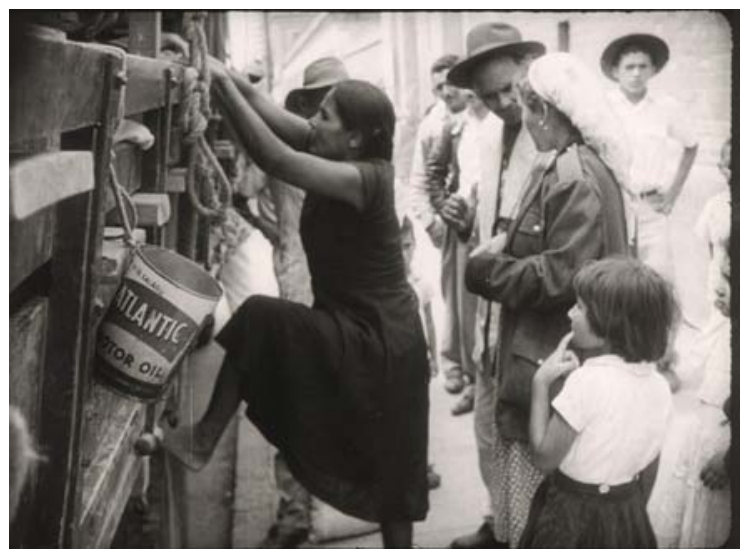

... <onde o clima se mostra mais camarada>. Bandeirante da Tela no 549, 1953. Acervo Cinemateca Brasileira.

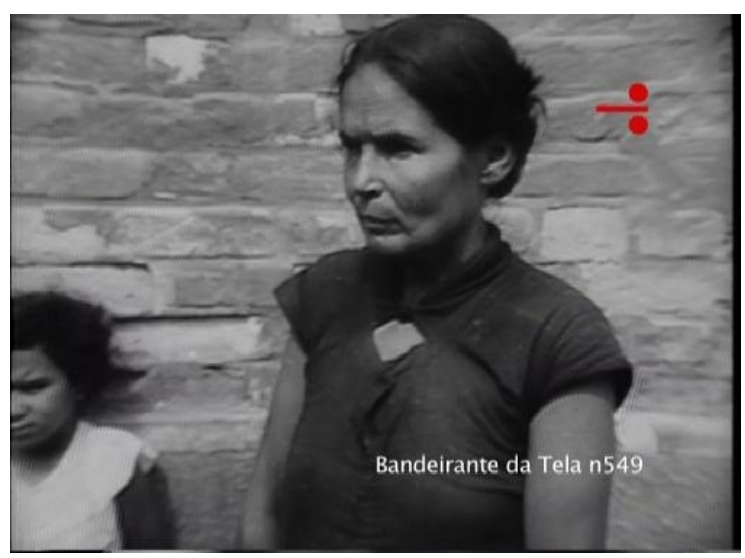

... o caminhão>. Bandeirante da Tela no 549, 1953. Acervo Cinemateca Brasileira 


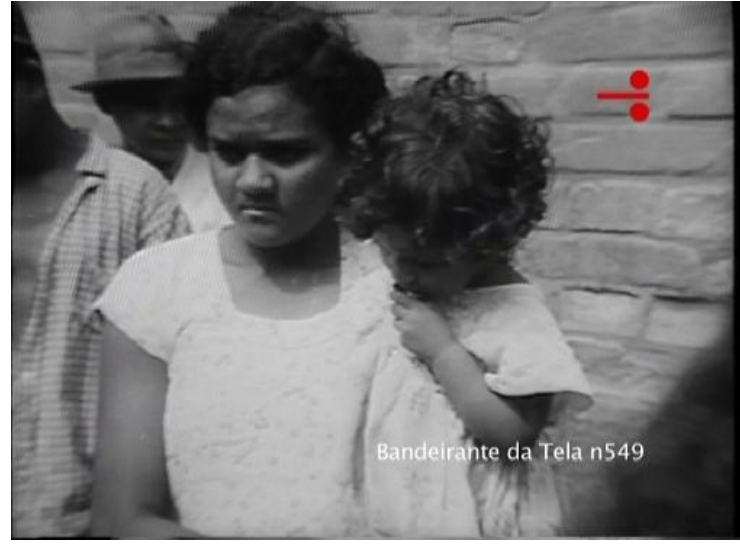

A saudade cede lugar a <esperança de melhores dias $>$, portanto <felicidade amigos...

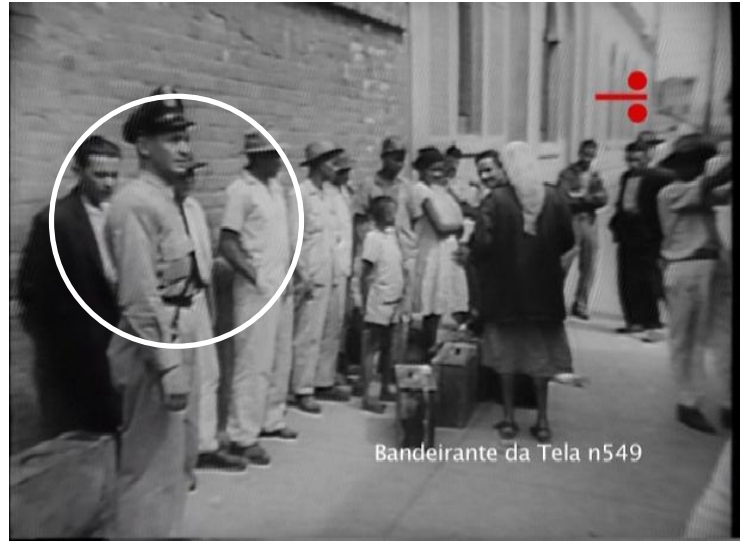

... a ordem agora é se virar!>. Nordestinos "escoltados" pela Força Pública. Bandeirante da Tela no 549, 1953. Acervo Cinemateca Brasileira.

O que está presente neste cinema adhemarista, assim nos parece, é o duplo de uma angústia contida num discurso bastante conservador. Primeiramente, uma "angústia chauvinista" do próprio político que vem à tona com a não aceitação de outros valores para uma São Paulo que, nos anos de 1950, foi se tornando ainda mais heterogênea ${ }^{395}$. Algo traduzido numa espécie de "absorção perversa" somada à "conveniência de explorar" os que vêm de fora, e que resulta numa tolerância repressiva, ou melhor, um pesado clima de vigilância $^{396}$. Existente não só em seu cinejornal, mas em sua prática política, em que Adhemar de Barros pareceu carregar traços de um autoritarismo inspirado na ditadura da qual fez parte, enquanto interventor entre 1938 e 1941. Autoritarismo este manifesto na sua gestão de governador eleito democraticamente, entre 1947 e 1950, em momentos de violência na ocasião da cassação do PCB em 1947, então partido aliado ${ }^{397}$. Ou mesmo

\footnotetext{
${ }^{395}$ Considerando que o contingente migrante tenha se espalhado por todo o estado de São Paulo, a região metropolitana, especificamente a capital, aparecem como grandes áreas de destino dessas pessoas, notadamente após a intensificação da industrialização na década de 1950 adiante. CF. SÃO PAULO Outrora e Agora, op. cit., p. 25.

${ }^{396}$ Sobre este tema, ver Henrique Samet, "A Construção da Brasilidade Excludente” In ARQUIVO PÚBLICO DO ESTADO DO RIO DE JANEIRO. DOPS: a lógica da desconfiança. Rio de Janeiro: Secretaria de Estado de Justiça. Arquivo Público do Estado, 1996, pp. 46-55, 53.

${ }^{397}$ Cf. John French, op. cit, p. 213; E a respeito da repressão política sobre o PCB, ocorrida no governo de Adhemar de Barros, Cf. Eduardo José Afonso. O PCB e o Poder: 1935 o poder pela força, 1945 o poder pelo voto - os comunistas na Assembléia Legislativa (1947-1948). 2004. Dissertação (mestrado em História Social) Faculdade de Filosofia, Letras e Ciências Humanas, USP, São Paulo, p. 92-174.
} 
contra setores organizados das camadas populares, como no episódio em que uma representação contra o governador, assinada por moradores de um bairro paulistano, resultou na prisão de noventa e seis pessoas que pleiteavam mais democracia com a reabertura dos

Comitês Democráticos e Progressistas que não pertencem a nenhum partido, e sim entidades populares que congregam moradores de uma cidade, bairro ou rua, para lutarem por reivindicações mais imediatas. ${ }^{398}$

Algo inadmissível num governo eleito democraticamente, pelo voto direto. E que lançou mão da truculência ao fichar todos os signatários desse documento, homens e mulheres que, pelos nomes e sobrenomes, provavelmente pertenciam às famílias da comunidade local ${ }^{399}$.

Em segundo lugar, parece emergir uma ética coletiva afeita a um conservadorismo disseminado, principalmente, nos setores médios da sociedade paulista, em que o "desejo de preservar" determinados valores participa de um certo projeto de "felicidade" para o estado que se desenvolvia em ritmo acelerado. Porém, embasado num apelo constante a uma certa "ordem" a ser preservada no e para o "progresso". É esta a velha idéia de desenvolvimento excludente que permeia o BT e entrelaça, assim nos parece, os fundamentos morais e religiosos da política adhemarista, convergindo para uma imagem de harmonia, equilíbrio e fusão para a sociedade em questão. Resumindo, propondo uma sociedade "una, indivisível, homogênea, para sempre protegida das perturbações e das discórdias" ${ }^{400}$. Contudo, a linguagem desse imaginário se multiplica, ao circular por todas as camadas da sociedade: "fala à multidão e ela a fala" ${ }^{401}$. E é colhendo o que está no "ver" desse imaginário ${ }^{402}$ que as representações tomam a sua forma: o político progressista, o casal assistencialista, o homem esclarecido, o devoto cristão e o pai de família - todas elas trabalhadas por Adhemar de Barros. E que "autorizam", pelos valores que ostentam, assumir um discurso político com contornos conservadores em prol da melhoria coletiva,

\footnotetext{
${ }^{398}$ Abaixo-assinado, pelos moradores do bairro da Quarta Parada, ao Exmo. Sr. Adhemar Pereira de Barros, governador do Estado de São Paulo. São Paulo, 1947. - Cópia autorizada por Carlos Rubens de Aguiar, Chefe do Arquivo Geral, 16.06.1947. Pront. 081373 - Basílio Maceira. DEOPS-APESP.

399 Sendo que apenas dois prontuários dentre os noventa e seis prontuários, apresentam um conteúdo "subversivo" para além da participação no abaixo-assinado. Todos estão relacionados no final deste trabalho.

${ }^{400}$ Cf. Raoul Girardet, op. cit., pp. 155-56.

${ }^{401}$ Michel de Certeau, op. cit., p. 41.

${ }^{402}$ Ibdem, p. 43.
} 
mesmo quando esbarra agressivamente em signos das camadas mais pobres. Os enquadrando ${ }^{403}$ de forma extremamente preconceituosa, como potenciais representantes da desordem e promotores de um certo "caos" que rivaliza com a harmonia pretendida.

No BT $600^{404}$ (1954), o discurso adhemarista continua esta senda, mesmo tendo em vista a campanha eleitoral para governador. Em "Notícias Diversas", o registro inicia com um plano geral de uma rua em frente à Estação da Luz, em São Paulo, que servirá de palco para uma espécie de denúncia. Nestas primeiras cenas, identificamos barracas de camelôs e, numa tomada em plano médio, o que seriam as mercadorias destes vendedores que < promovem um espetáculo bastante desagradável> aos < <isitantes que desembarcam na conhecida estação ferroviária >. Prosseguem cenas do mesmo local, porém, tomadas em plano geral de pontos distintos, seguindo-se o aviso do narrador que denuncia $<$ vendedores e ambulantes [que] transformam o tradicional Jardim da Luz num verdadeiro mercado>, enfatizando para o espectador que a <desordem, a confusão e a sujeira tomam conta das calçadas e dos canteiros outrora bem tratados $>$.

A "desordem", a "confusão" e a "sujeira" não combinando com os "canteiros outrora bem tratados" certamente fazem alusão à administração adhemarista, quando ainda o governador era quem indicava o chefe do executivo municipal. Porém, por mais eleitoreira que seja a denúncia de que os < dirigentes da São Paulo quadricentenária, negligenciam quanto ao saneamento da cidade de Nóbrega e Anchieta>, uma postura conservadora tensiona signos do cotidiano, tratando grosseiramente as camadas populares ao criticar os vendedores de frutas <cujas cascas se espalham pelo chão>, ou os $<$ refrescos servidos em copos mal lavados, atentatórios à higiene>, mas que são consumidos diariamente por transeuntes de baixa renda, por exemplo. E seguindo a lógica de um ambíguo discurso vigilante ${ }^{405}$, bastante próximo ao que assistimos no BT 549, tal leitura se aplicaria aos mesmos imigrantes estrangeiros, ou seus descendentes, que "criam casos" e, principalmente, aos nordestinos que estariam tentando "se virar". Sejam camelôs, ambulantes, imigrantes ou nordestinos, ainda que na pouca ocorrência desses atores sociais

\footnotetext{
${ }^{403}$ Tomando por empréstimo a idéia de que "indesejabilidade" não está no ato, mas no "enquadramento" de um determinado setor da sociedade. Cf. Henrique Samet, op. cit., p. 51.

${ }^{404}$ Bandeirante da Tela $n$. 600, op. cit.

${ }^{405}$ Em que um "biscateiro, em uma circunstância, era um trabalhador eventual; em outra poderia ser vadio", Henrique Samet, op. cit., p. 52.
} 
verificada no BT, uma aura discriminatória os cerca na medida que são ou representam o porvir de um problema.

Muito embora o BT tenha contribuído para alimentar a "máquina populista" adhemarista, algumas escolhas são claras quanto ao que deveria ser mostrado no cinema. Um exemplo disso é a Ala Negra Progressista que divulgou panfletos informativos, entre 1949 e 1952, vinculando Adhemar de Barros às festas e aos candidatos ligados às comunidades populares em bairros pobres paulistanos ${ }^{406} \mathrm{e}$, sequer, é citada nos números catalogados na Cinemateca Brasileira deste mesmo período. Ainda que existisse, em nome dos "ideais progressistas", uma porta de entrada no jogo político-eleitoral para setores socialmente desfavorecidos, conferindo-lhes certa participação, não foi essa a chave de relacionamento que apareceu nas telas do cinejornal. E sim a do cidadão negro enquanto presença garantida nas filas assistencialistas do teatro adhemarista para o cinema, numa chave bastante marginalizada como vimos anteriormente no BT 415 (1951). Não há registros, por exemplo, da aproximação de Adhemar de Barros aos valores populares como crenças religiosas afro-descendentes ${ }^{407}$, muito embora esse contato existiu, the custando duras críticas por parte da oposição ${ }^{408}$. Nesse caso, a opção de não levar às telas do cinema tal aproximação demonstra um receio em "manchar" a imagem de Adhemar de Barros construída nas sessões cinematográficas.

406 "Alerta - dia 22 de Setembro de 1951". Panfleto da Ala Negra Progressista. São Paulo, setembro de 1951. Pront. 101.018 - Ala Negra Progressista. DEOPS-APESP; "Alerta para os dias 28 e 29 de Junho de 952". Panfleto da Ala Negra Progressista. São Paulo, junho de 1952. Pront. 101.018 - Ala Negra Progressista. DEOPS-APESP; "Alerta! Dias 28 e 29 - Grandiosas Festas da Chita”. Panfleto da Ala Negra Progressista. São Paulo, junho de 1952. Pront. 101.018 - Ala Negra Progressista. DEOPS-APESP; "Alerta! Dia 23 de Setembro". Panfleto da Ala Negra Progressista. São Paulo, s/d. Pront. 101.018 - Ala Negra Progressista. DEOPS-APESP; "Alerta! Dia 7 de Setembro... Dia da Independência do Brasil". Panfleto da Ala Negra Progressista. São Paulo, setembro, s/d. Pront. 101.018 - Ala Negra Progressista. DEOPS-APESP; "Alerta - 2 de Setembro". Panfleto da Ala Negra Progressista. São Paulo, s/d. Pront. 101.018 - Ala Negra Progressista. DEOPS-APESP; "Alerta Povo - 6 de Outubro". Panfleto da Ala Negra Progressista. São Paulo, s/d. Pront. 101.018 - Ala Negra Progressista. DEOPS-APESP.

407 "Brasileiros Alerta - Festa da Mãe Preta". Panfleto da Ala Negra Progressista. São Paulo, dezembro de 1949. Pront. 101.018 - Ala Negra Progressista. DEOPS-APESP.

408 "E agora dizemos: um homem público, tanto quanto qualquer outro tem o direito de possuir sua crença, de filiar-se a um culto, ou de estabelecer sua devoção. Mas não será um traço revelador de mau caráter, o fato de uma pessoa apresentar-se, para efeitos demagógicos, ora espírita, ora católico, e ora praticante de macumba ou baixo espiritismo, sempre de acordo com as conveniências do momento? [...] um governadorsinho de Ubanda (sic)? Um governador que chega a abrir os portões do palácio para que passe no carro oficial, a Maria macumbeira? Que vai ao ponto de iluminar ou escurecer os salões do palácio do governo para invocar os espíritos ou matar galos pretos?". Cf. Francisco Rodrigues Alves Filho. Um Homem Ameaça o Brasil..op. cit., p. 114. 
Contudo, para se comunicar com um povo, que nas falas de correligionários do PSP "não quer palavras, quer ações" 409, através de um veículo inserido semanalmente na nata do divertimento público, o cinejornal se apresentava com um extenso cenário de atualidades atendo-se aos interesses da cavação envolvendo patrocinadores, exibidores e distribuidores $^{410}$ - em que os contrastes sociais, por mais diluídos que fossem, marcaram presença.

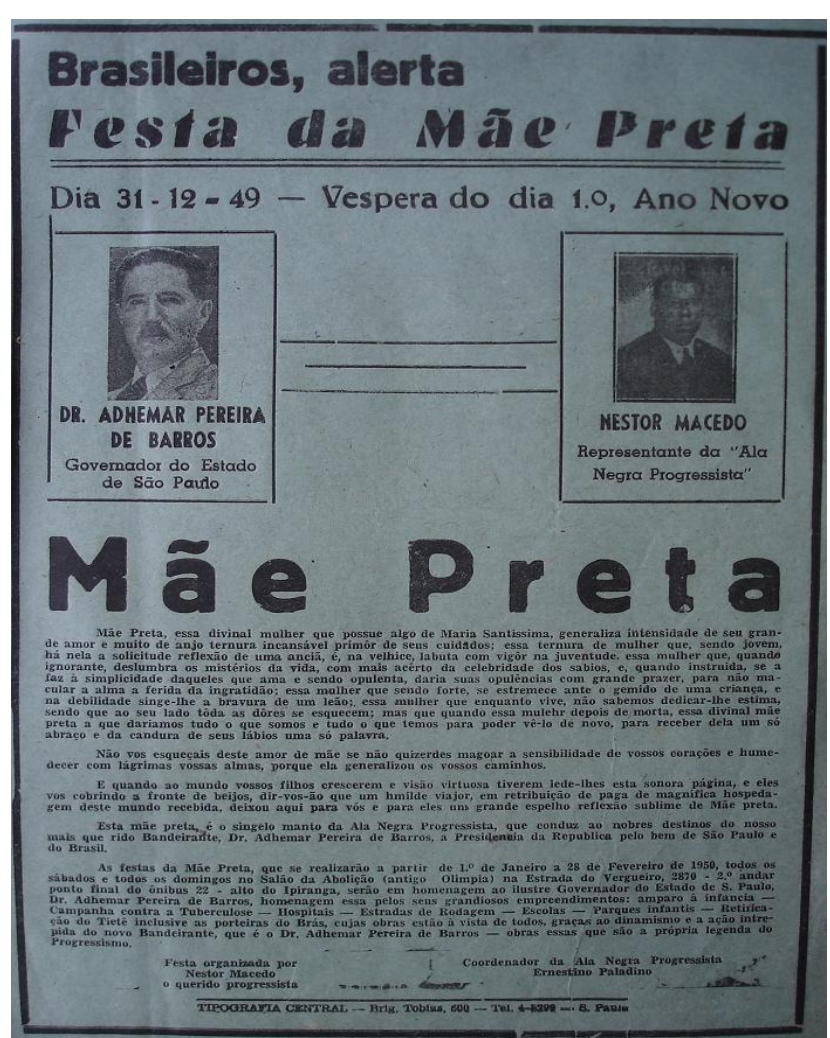

Adhemar de Barros é convidado ilustre na "Festa da Mãe Preta". Evento de caráter religioso organizado pela Ala Negra Progressista. Fundo DEOPS/AESP.

É justamente por mostrar na tela acontecimentos presentes no cotidiano de diferentes camadas sociais que o discurso de Adhemar de Barros se saiu beneficiado. $\mathrm{O}$ cinejornal fez transitar, no espaço contemplativo do seu conteúdo, uma amálgama de valores e angústias daqueles segmentos sociais que o assistiam, propondo, de certa forma, uma nova dimensão de cidadania para $\operatorname{eles}^{411}$. No mosaico de temas e notícias que desfilava

${ }^{409}$ Relatório de Reynaldo Pisapio, Investigador da Seção de Policiamento de Ordem Política, ao Delegado Especializado de Ordem Política, sobre a Sessão Solene de Instalação dos Diretórios Distritais do Partido Social Progressista. São Paulo, 1 de julho de 1946. Pront. 069.506 - Partido Social Progressista. DEOPSAPESP.

${ }^{410}$ Como vimos na segunda parte deste trabalho.

${ }^{411}$ Para esta idéia, compartilhamos de algumas considerações desenvolvidas por Rubens Machado nas primeiras páginas do seu trabalho. A cidade - o "lugar" das representações - vista na tela, e igualmente representada, passa a ser "conhecida" pelo espectador através da massificação do cinema que "transforma a cidade ao filmá-la [e] transforma uma segunda vez ao difundi-la". De maneira que a representação da cidade "passa a fazer parte da imagem que o cidadão tem da própria cidade". E é desta forma, acreditamos, que o discurso cinematográfico leva às telas as representações do cotidiano. Como expõe o autor, o cinema oferece elementos para o cidadão - que sai "da sala escura para as ruas com novas imagens" - somar às suas próprias 
nas sessões cinematográficas, signos críveis $^{412}$ transpostos das experiências concretas das pessoas, resumiam identidades presentes numa sociedade desigual e que, apresentadas pelo cinejornal adhemarista, reforçaram o convite feito ao espectador para participar do seu projeto político. É o que identificamos, por exemplo, ao assistirmos imagens de um clássico futebolístico entre Corinthians e São Paulo ${ }^{413}$, ou Palmeiras e Portuguesa de Desportos $^{414}$, no estádio do Pacaembu - inaugurado em 1940, na interventoria de Adhemar de Barros -, com arquibancadas lotadas e ângulos possíveis de serem vistos e revistos no cinema. Ao passo que esportes como pólo, nada representativos das camadas populares, também figuraram no $\mathrm{BT}^{415}$. Até mesmo como notícia que antecede a chegada de nordestinos ${ }^{416}$, numa das mais claras discrepâncias sociais trazidas à tela.

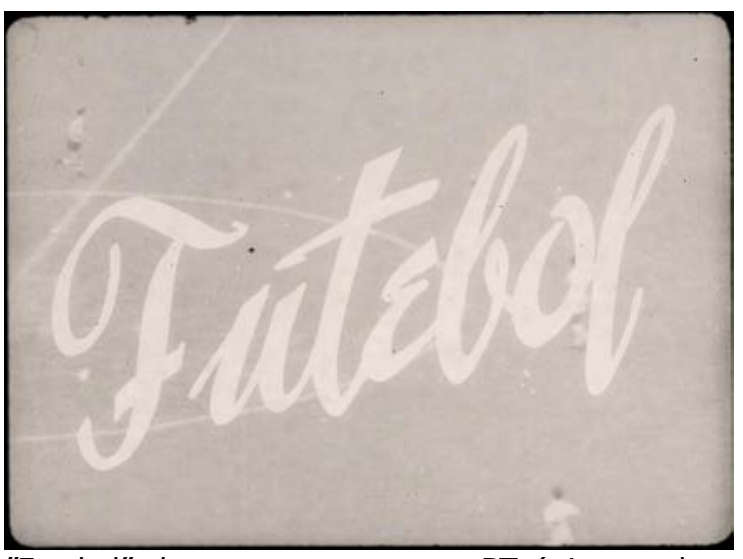

"Futebol": bastante presente no BT (trinta e duas ocorrências ao todo)...

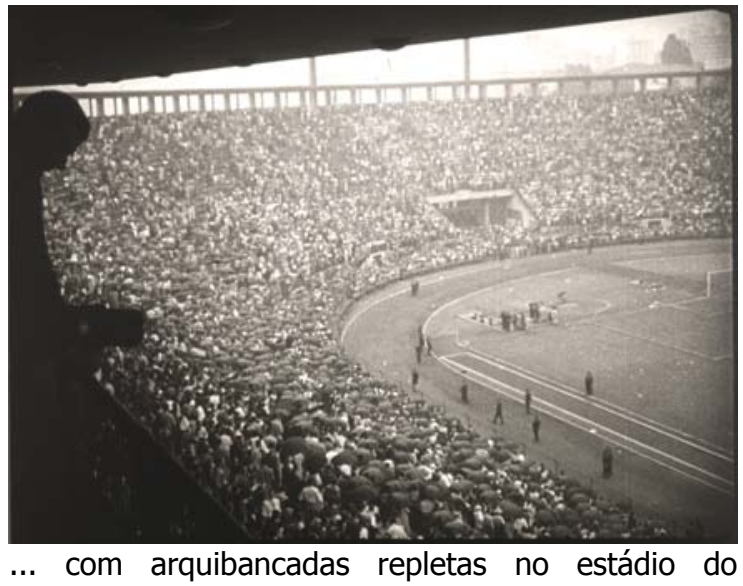
... com arquibo
Pacaembu e...

experiências e assim redimensionar a sua noção de cidadania. Para cada experiência subjetiva - cada cidadão e seus filtros culturais - um caleidoscópio de experiências, umas conhecidas, outras inovadoras, contribui, em última instância, para redefinir o seu sentimento de pertencimento àquilo que assiste. Cf. Rubens Machado, op. cit., pp 1-4.

${ }^{412}$ Cf. Michel De Certeau, op. cit., p. 27.

413 Bandeirante da Tela n. 586. São Paulo: Divulgação Cinematográfica Bandeirante, 1954. Fita de vídeo (5min47seg), VHS, mudo, p\&b, VV00048. Cinemateca Brasileira.

${ }^{414}$ Bandeirante da Tela n. 672. São Paulo: Divulgação Cinematográfica Bandeirante, 1955. Fita de vídeo (6min48seg), VHS, sonoro, p\&b, VV00099. Cinemateca Brasileira.

415 Bandeirante da Tela n. 577. São Paulo: Divulgação Cinematográfica Bandeirante, 1954. Fita de vídeo (6min45seg), VHS, sonoro, p\&b, VV00099. Cinemateca Brasileira.

${ }^{416}$ Bandeirante da Tela n. 549, op. cit. 


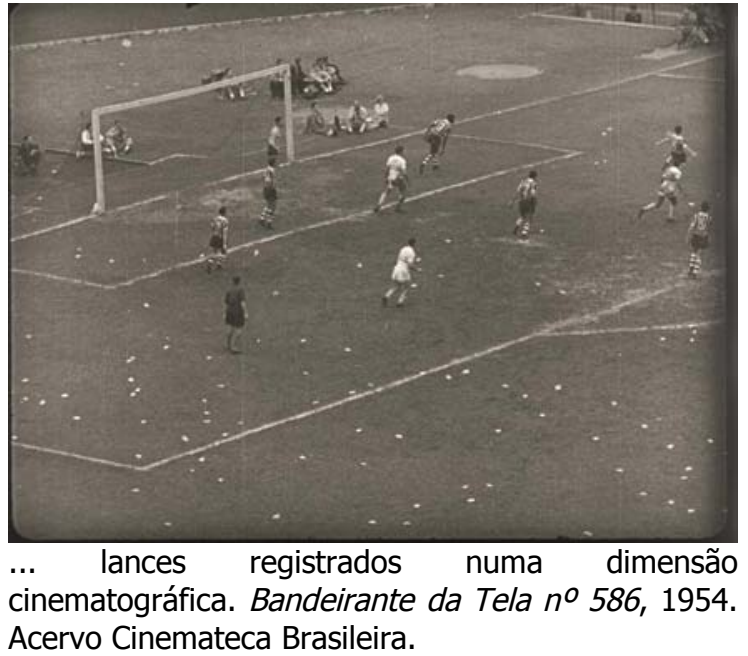

Tantos outros elementos deram um ar de "credibilidade" ao cinejornal porque devolveram ao público uma espécie de espetáculo do real, com eventos do dia-adia. Como nos exemplos das manifestações religiosas ${ }^{417}$ ou comemorações cívicas ${ }^{418}$, as praças, ruas e lugares por onde o espectador eventualmente transitava, ou mesmo tragédias, como nos diversos planos de um prédio em chamas ${ }^{419}$, ou uma ambulância

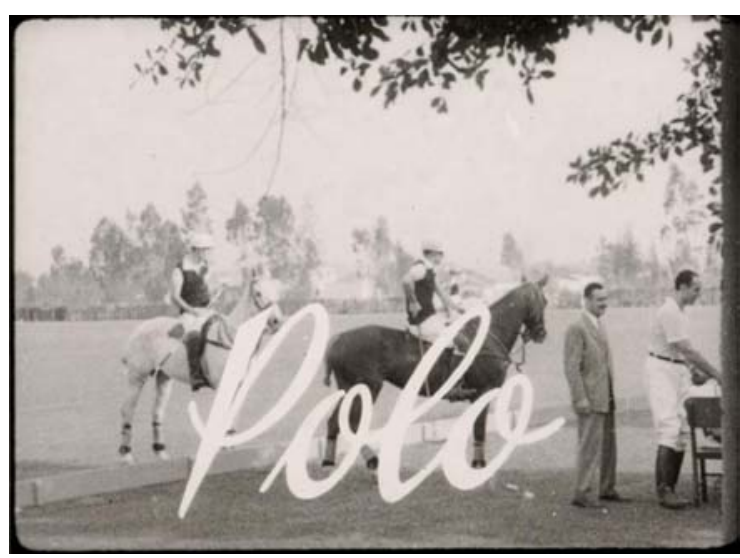

"Pólo": nada representativo das camadas populares, mas com espaço reservado no fragmentado universo do cinejornal adhemarista. Ilustrando, inclusive, as disparidades...

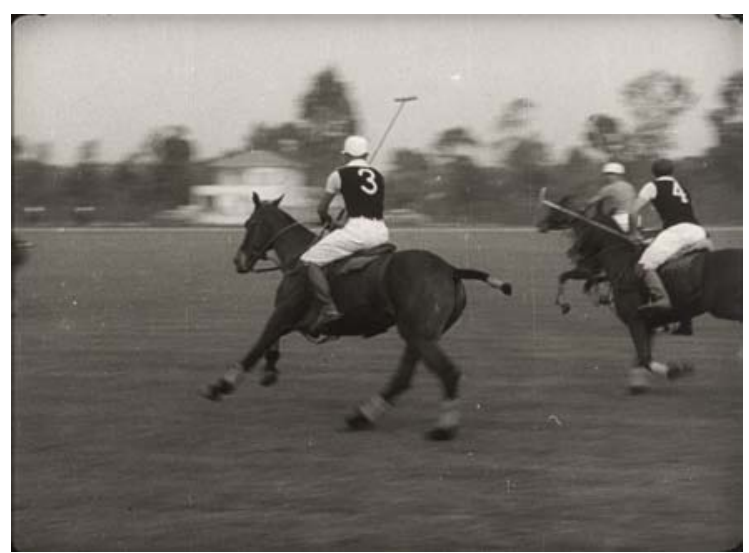

... de uma sociedade desigual, quando tal notícia antecede a chegada de <levas e levas> de nordestinos. Bandeirante da Tela no 549, 1953. Acervo Cinemateca Brasileira.

tombada na rua, num acidente de trânsito ${ }^{420}$, ou ainda uma panorâmica em plano geral de várias pessoas <que permaneceram horas em comentários $>$ à beira de um rio, observando homens do Corpo de Bombeiros na busca por vítimas de afogamento ${ }^{421}-<\ldots$ curiosidade ou manifestação de solidariedade humana?>, pergunta o locutor sobre o comportamento do próprio espectador.

\footnotetext{
${ }^{417}$ Como vimos anteriormente, nos BT 669 e 674, ambos de 1955.

${ }^{418}$ A exemplo das 49 ocorrências para o termo efeméride, constantes entre os 128 cinejornais recuperados pela Cinemateca Brasileira. Cf. CINEMATECA, op. cit.

${ }^{419}$ Bandeirante da Tela $n$. 577, op. cit.

${ }^{420}$ Bandeirante da Tela n. 600, op. cit.

${ }^{421}$ Idem.
} 
E em meio às experiências cotidianas levadas às telas, sinais do conservadorismo e da exaltação de uma São Paulo em desenvolvimento deixaram fortes marcas na representação adhemarista, principalmente ao retratar os estratos sociais mais baixos, como já foi discutido. Nesse sentido, são marcantes as ocasiões em que a câmera do BT tratou das favelas de São Paulo. No BT 591 (1954) este traço conservador é evidente quando, mais uma vez na chave da denúncia da administração janista, contemplam-se as mazelas de uma cidade em seu IV Centenário. Com uma música alegre, quase circense, uma vista aérea "varre" o bairro do Pacaembu, suas casas, prédios e o estádio municipal. A seguir, outra vista aérea sobrevoa o centro mostrando o <dinamismo da metrópole que mais cresce no mundo>. Uma panorâmica em plano médio passa por algumas casas e barracos na favela, contrariando as cenas anteriores do centro com a informação de que há <nos bairros, porém, o realismo que choca $>$. Mas o que vemos, entretanto, não se confirma, pois se trata de uma quase idílica representação de meninos correndo e brincando, numa composição cenográfica marcada por espaços vazios, organizados até, algo bastante distante de um "realismo chocante".

O que segue são algumas tomadas de casas com vigas de madeira escoradas para evitar um eventual desmoronamento, pois, como sentencia o narrador, <mais que o aspecto deselegante, o perigo eminente $>$ cerca tais casas que ficam a $<a$ dez minutos do centro $>$. Ainda sobre as mesmas cenas, o registro finaliza com uma irônica fala de que as <as garotas vizinhas $>$ - as que moram no centro, portanto - <estão proibidas de usar tomaraque-caia $>$, numa alusão às casas que estão quase caindo $^{422}$. Nesta representação, notamos que o espaço da favela, próxima do centro e de um bairro nobre como o Pacaembu, é moldada dentro da ética do progresso e organização da <metrópole que mais cresce $>$. Não se mostra uma versão mais verossímil da dura situação dos espaços reservado aos barracos, como a falta de saneamento, por exemplo. Além da "solução cômica" da fala final, que caminha entre a ironia e o descaso para amenizar a situação. Nada muito profundo aparece sobre as parcelas mais necessitadas de São Paulo para não manchar o "berço esplêndido" do político paulista realizador e moderno que se vale do mesmo cinejornal.

\footnotetext{
${ }^{422}$ Este episódio foi discutido, en passant, por Rubens Machado em "São Paulo e o Seu Cinema: para uma história das manifestações cinematográficas paulistas (1899 - 1954) In Paulo Porta (org.). História da Cidade de São Paulo: a cidade no Império. Vol. 2. São Paulo: Ministério da Cultura / Paz e Terra. 2004, pp. 457-505, 493.
} 


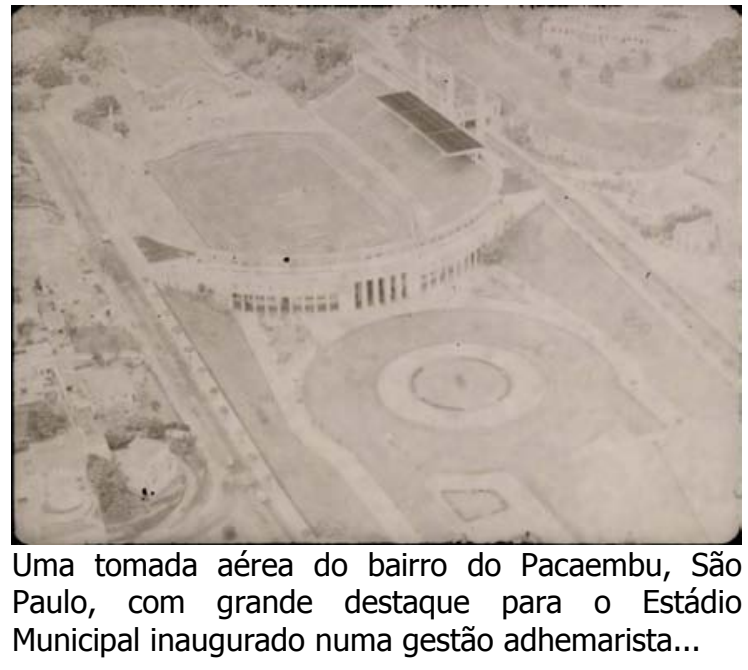

Em mais um exemplo, no BT 696 $(1955)^{423}$, o mesmo acontece. Num ano de eleições presidenciais o discurso adhemarista não escapa ao dilema: denunciar a atual administração para rememorar as realizações de Adhemar de Barros, porém, não mostrar as mazelas ou passar uma imagem muito ruim da terra a qual pertence o político progressista. Em "Registros", mais uma denúncia aborda a questão da baixa

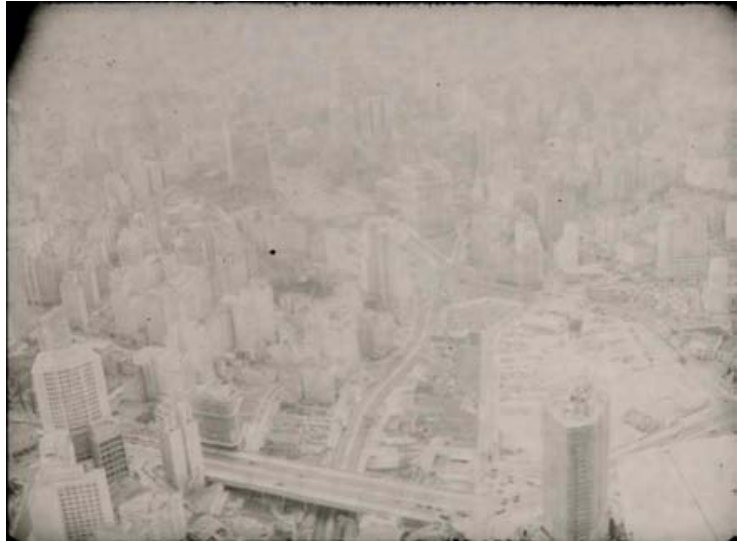

... compondo com o grandioso "berço esplêndido" de uma cidade que, sob a ótica da modernidade e do progresso, não para de crescer...

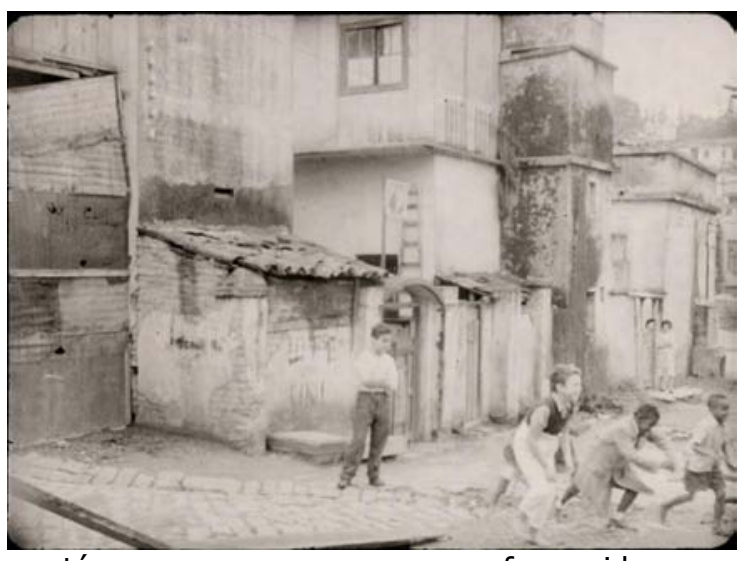

... até mesmos nos espaços menos favorecidos, com barracos organizadas, onde o que "predomina" é a harmonia das crianças que brincam, apesar de viverem numa favela. Bandeirante da Tela no 591, 1954. Acervo Cinemateca Brasileira

moradia. Nas tomadas em plano geral da Avenida Paulista com suas residências, jardins e o transito intenso de carros na rua, constata-se que ela < continua sendo uma das mais finas artérias de São Paulo>. E para mais um plano geral de um prédio em construção na paulista, temos a informação que <ao lado de antigas e belas residências estão sendo construidos luxuosos prédios e apartamentos para moradias de pessoas de largas posses $>$. Feita esta introdução estabelecendo o status dessa "fina artéria" da cidade, vemos alguns planos de uma construção tendo ao lado um conjunto de casas pobres. Logo, somos

${ }^{423}$ Bandeirante da Tela n. 696. São Paulo: Divulgação Cinematográfica Bandeirante, 1955. Fita de vídeo (6min45seg), VHS, sonoro, p\&b, VV00099. Cinemateca Brasileira. 
informados que na Avenida Paulista <vamos encontrar uma favelinha>. E com três tomadas distintas em plano geral de uma mesma viela com casas e barracos, a representação novamente percorre por uma favela quase "ideal”: não há presença de moradores e, ainda que $<$ a miséria e a promiscuidade instalaram-se no reduto da riqueza e do $l u x o>$, o que as câmeras do BT mostram são duas crianças que brincam num espaço de terra batida, compondo um quadro algo bucólico. $<O$ contraste é chocante! Comprometendo a estética urbana e depondo contra os órgãos de assistência social>, porém, o que "choca" é a própria tensão que o registro cinematográfico comporta.

"Miséria" e "promiscuidade" parecem traduzir um preconceito elitista preocupado com uma "estética urbana", cabendo aos "órgãos de assistência social" a tarefa de higienizar a cidade. Por outro lado, as imagens são até mais ousadas que a do BT 591, mas ainda persiste a representação da favela com espaços organizados, com seus entulhos num canteiro, porém recolhidos, e um "quintal” onde as crianças podem brincar livremente. Nesse sentido, a mensagem criada é que em São Paulo também existem favelas, porém organizadas e talvez melhores das que se vê em outros lugares - um discurso cuja provável exibição em outros centros brasileiros o justificasse, na tentativa de produzir uma propaganda positiva do estado paulista ${ }^{424}$.

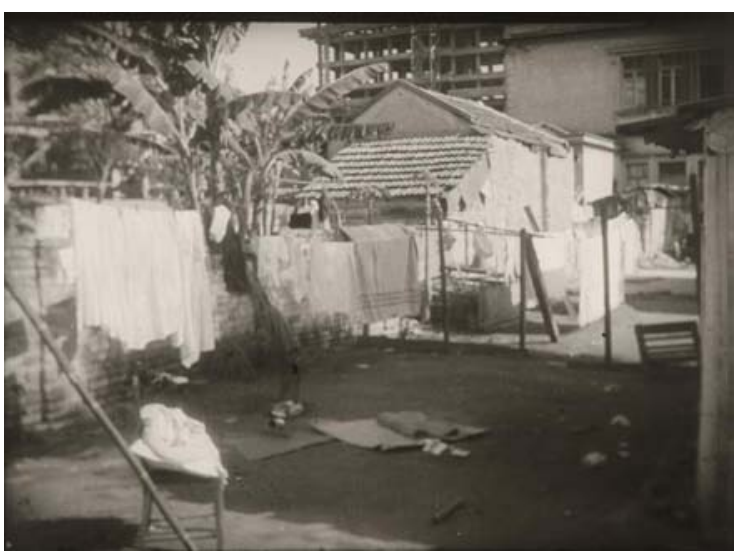

A alternância de tomadas em plano geral do mesmo local com o cuidado em não mostrar ...

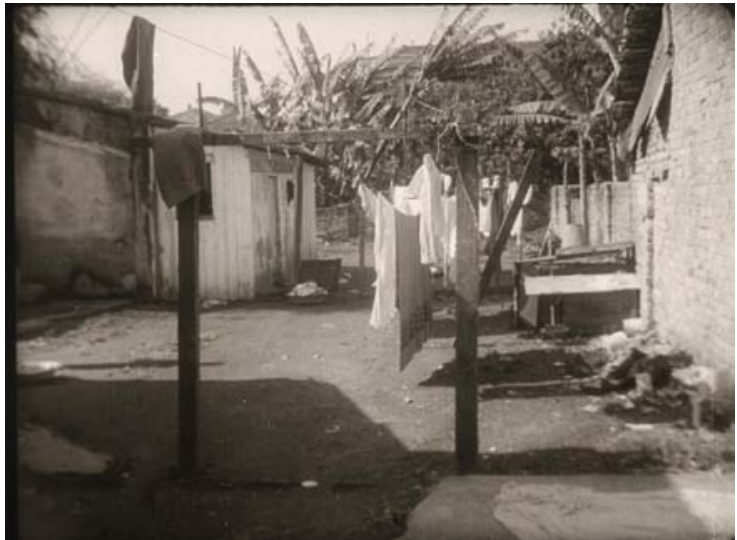

... seus moradores cria um espaço organizado, onde alguns detalhes, como a inserção...

\footnotetext{
${ }^{424}$ Não nos foi possível aferir, com a devida segurança, a efetiva distribuição do BT para outros estados brasileiros. Acreditamos que ela tenha ocorrido, principalmente no ano de 1955, dadas as eleições presidenciais. E, dessa forma, ter composto a estratégia política de propaganda executada pelos diretórios do PSP pelo Brasil.
} 


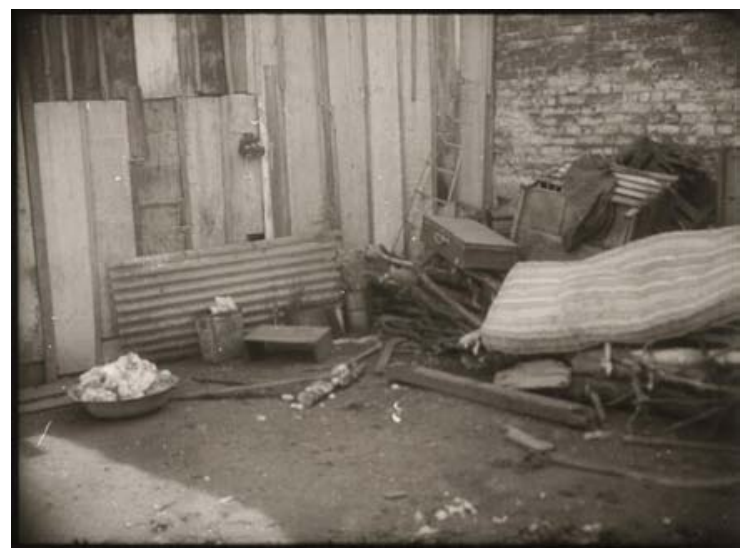

... de um beco com entulhos denunciam o que compromete a <estética urbana>. Porém, numa favela na "cidade que mais cresce" tudo é muito ordenado...

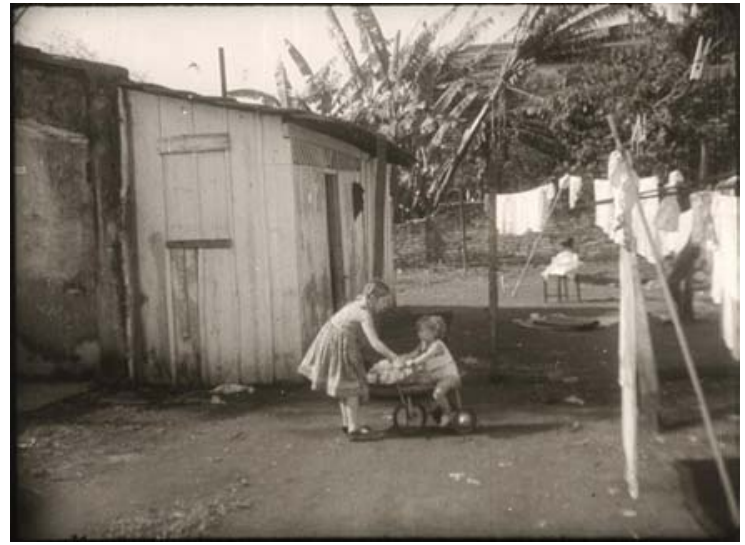

... crianças brincam tranqüilamente, numa clara opção de compor um belo retrato para a favela paulista. Bandeirante da Tela no 696, 1955. Acervo Cinemateca Brasileira.

Em última instância, é o elogio ao "berço esplêndido", a imagem da metrópole que "não pára de crescer" a que se quer passar. E que nas suas exclusões, ainda é capaz de harmonizar diferenças, como no discurso cinematográfico do BT. Também não custa lembrar que esta opção pela exaltação de valores do "reduto da riqueza e do luxo" fica ainda mais evidente quando associado ao histórico do cinejornal adhemarista em noticiar eventos sociais da alta-classe paulistana: das notícias sobre o Aeroporto de Congonhas ${ }^{425}$, símbolo da modernidade e mais uma realização de Adhemar de Barros, passando pelos casamentos e festas beneficentes ${ }^{426}$, até as coberturas do Grande Prêmio do Jóquei Clube de São Paulo, como no BT $577(1954)^{427}$, em que a câmera desfila para o espectador várias tomadas de moças abastadas em trajes finos, que não param de fazer pose para a câmera.

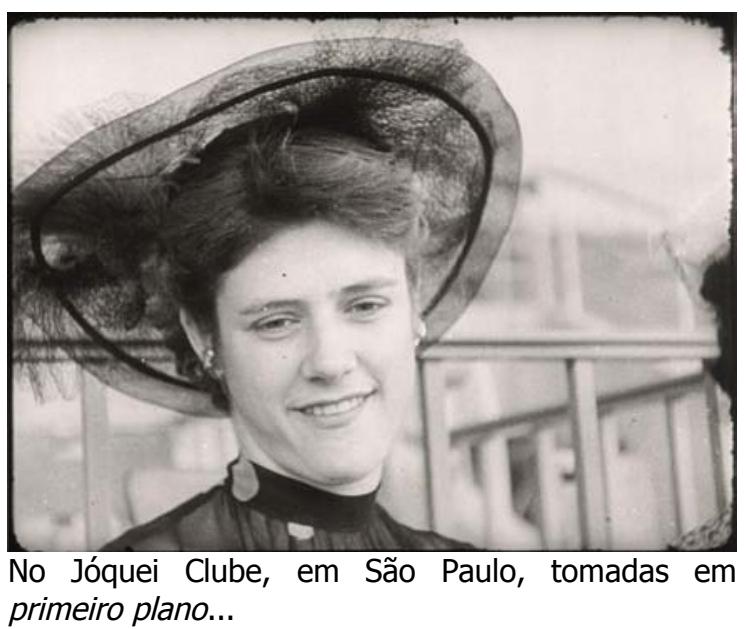

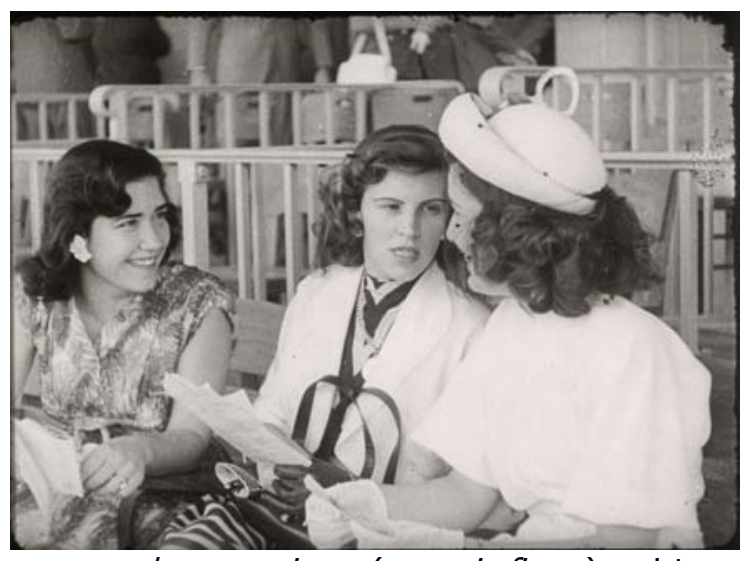

... e em plano americano (ou meia-figura) registram senhoritas...

${ }^{425}$ Bandeirante da Tela $n .678$, op. cit.

${ }^{426}$ Para as notícias de casamento, geralmente noticiando as famílias abastadas, temos 8 ocorrências; e para eventos circundantes às ações filantrópicas, 14 ocorrências. Cf. CINEMATECA, op. cit.

${ }^{427}$ Bandeirante da Tela n. 577, op. cit. 


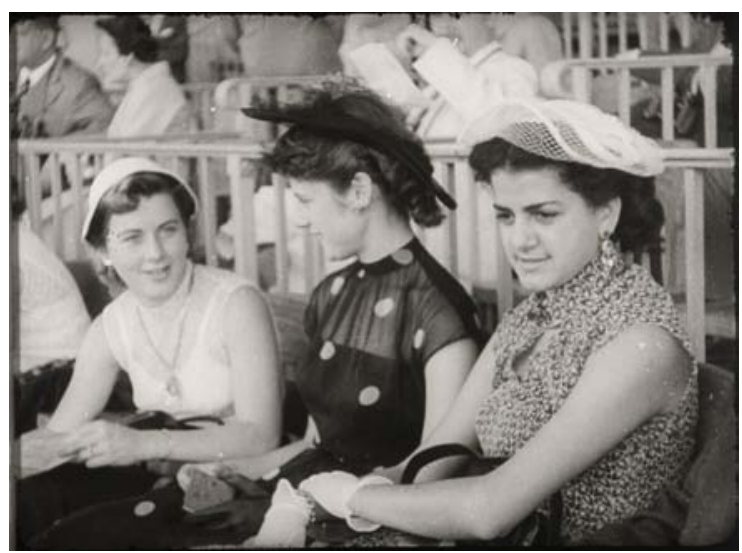

... que exibem para as câmeras a última palavra em moda e...

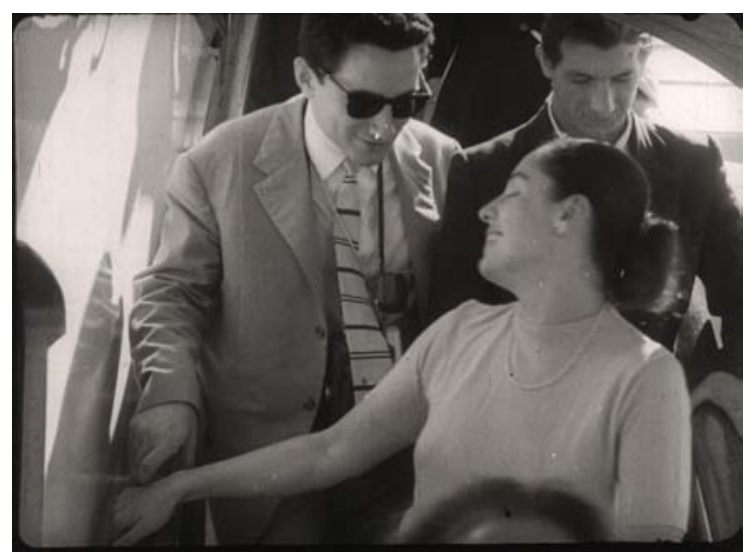

Modernidade e pessoas felizes se combinam no registro das realizações adhemaristas, como por exemplo, os melhoramentos...

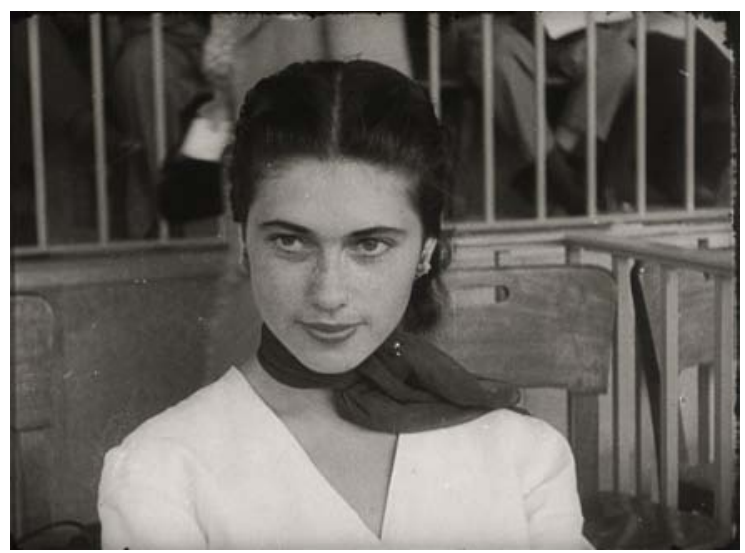

... elegância. Bandeirante da Tela no 577, 1954. Acervo Cinemateca Brasileira.

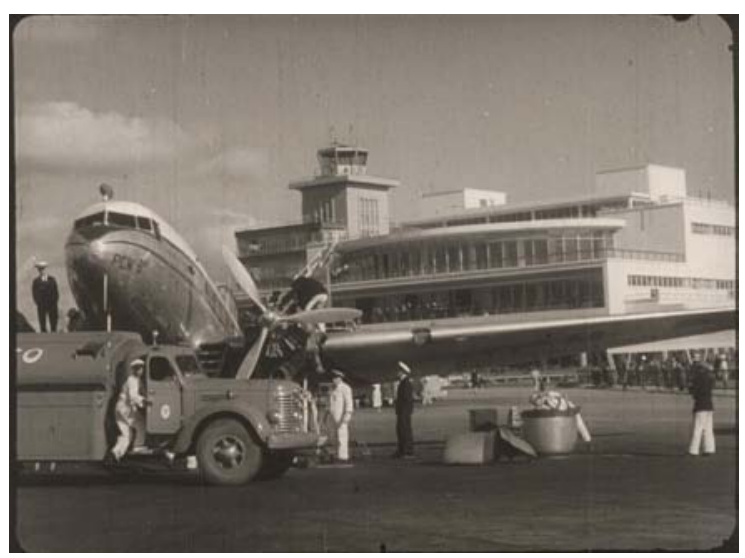

... feitos no Aeroporto de Congonhas, SP. Bandeirante da Tela no 678, 1955. Acervo Cinemateca Brasileira.

Mas ao trazer do cotidiano paulista signos críveis de diferentes camadas sociais, compondo ao mesmo tempo com as necessidades do cinejornal cavado e a propaganda eleitoreira, a credibilidade buscada pelo que se exibia nas telas "colidiu" com a pretensão de naturalidade no discurso adhemarista. Por mais que fossem registrados acontecimentos concretos tirados do dia-a-dia, eles não representaram a realidade em si. Ao contrário, o empreendimento de construir uma realidade para a representação política de Adhemar de Barros é o que a denuncia. Mediante as limitações técnicas - vale lembrar que o BT não era oficial e, com menos recursos porque dependia da cavação, não atingiu o grau de 
sofisticação capaz de lhe oferecer um melhor aprimoramento técnico no seu resultado final - a realidade que vemos na tela apresenta pontos discutíveis de uma desejada veracidade, como já colocamos linhas acima.

A própria linguagem cinematográfica, ao reconstruir um tempo e espaço que lhe são próprios, deixa lapsos que as imagens revelam. E, neste sentido, descortinam uma dimensão social que o discurso político pretendeu ocultar. Por exemplo, os vários enquadramentos de câmera sobre Adhemar de Barros sugerindo uma enormidade de pessoas ao seu redor, sem uma continuidade visual que a comprove (porque talvez não houvesse uma massa) a não ser a fala do narrador que repetidamente acrescenta informações ausentes nas imagens, reforçando o congraçamento com os conhecidos

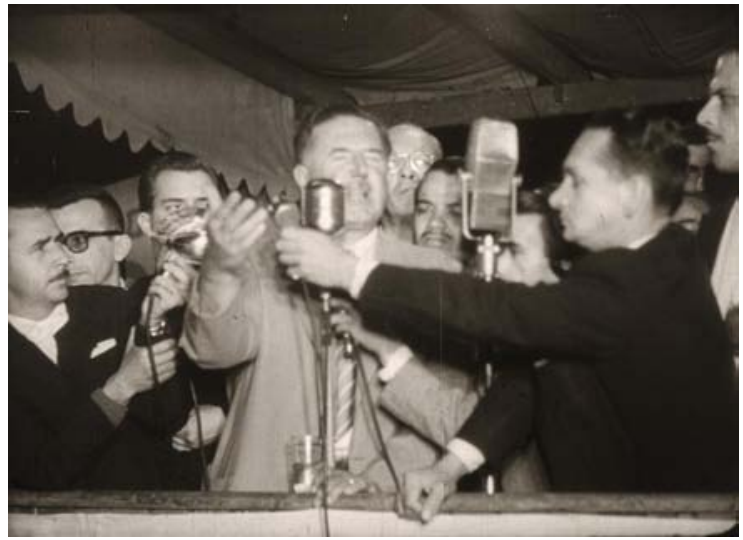

Em Juiz de fora, MG. Adhemar faz seu discurso para presidente num palanque oficial que, em momento algum, segue em continuidade visual (sem cortes)...

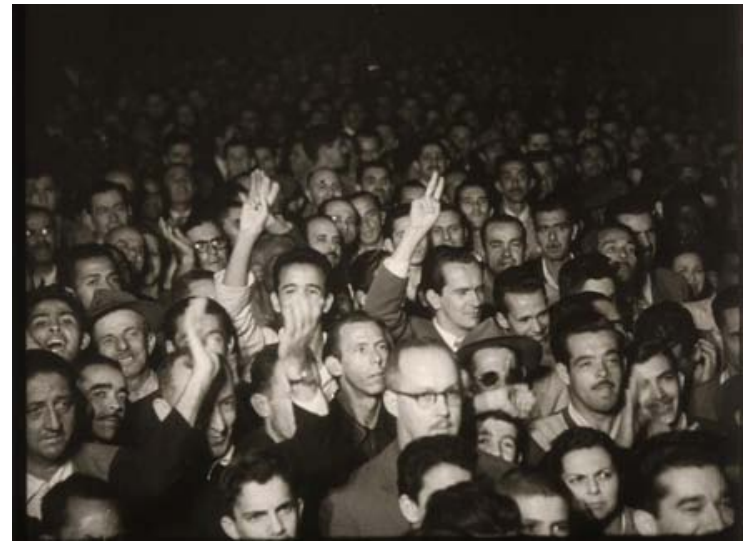

... para uma platéia que aplaude e acena para o cinegrafista. Bandeirante da Tela no 696, 1955. Acervo Cinemateca Brasileira.

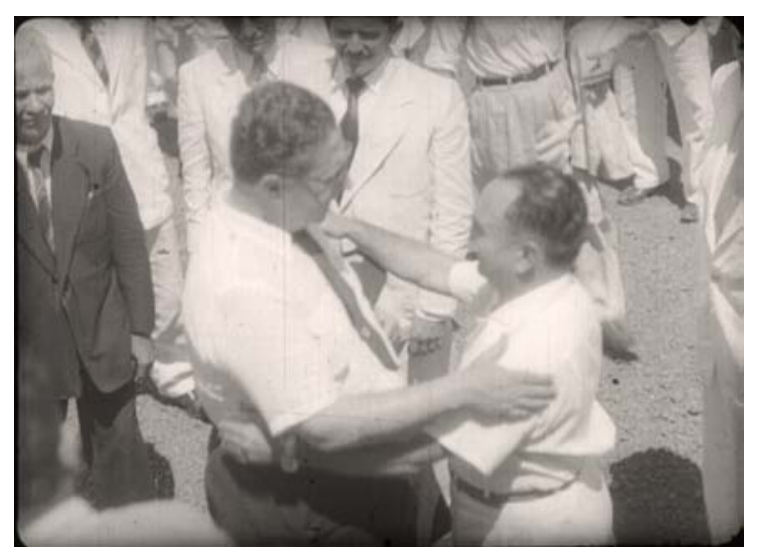

No Amapá, "significativas manifestações prestadas" são registradas com uma simples recepção de Adhemar pelas autoridades locais. Bandeirante da Tela no 678, 1955. Acervo Cinemateca Brasileira. 
vender. Um certo protagonismo das massas ${ }^{428}$ traduzido nos semblantes e nos olhares de insatisfação são reveladores de uma certa violência cometida com as pessoas que não queriam estar ali, naquela condição, ou mesmo diante de um cinegrafista que se sabia estar a serviço de um determinado político.

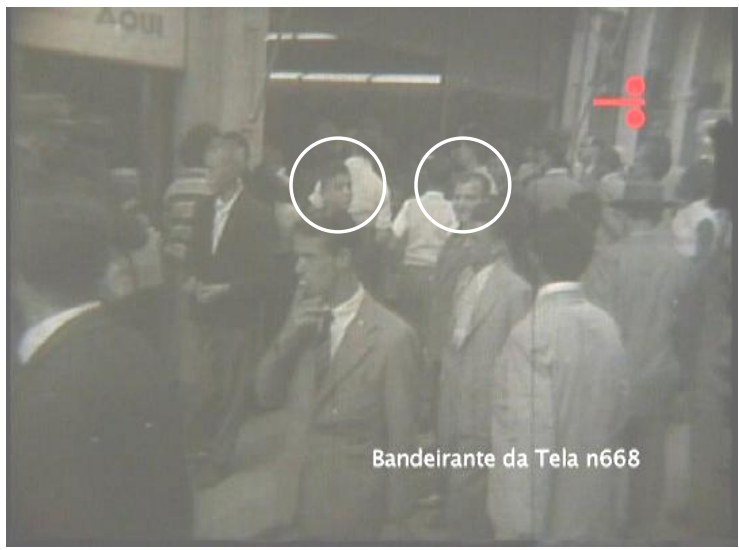

Em São Paulo, pessoas participam de evento olhando para a câmera. Não seria essa a razão de estarem lá? Enquanto nem todos...

Caminhões, ônibus e automóveis enfeitados, ou manifestações de um pequeno grupo de pessoas tomado isoladamente pela câmera, podem sugerir que foram feitos dentro de um roteiro previamente estabelecido para o teatro político. De uma certa forma, todos representam para a câmera ali colocada, seja por um compromisso ideológico ou o desejo de aparecer junto ao "líder populista" ${ }^{429}$, ou porque simplesmente

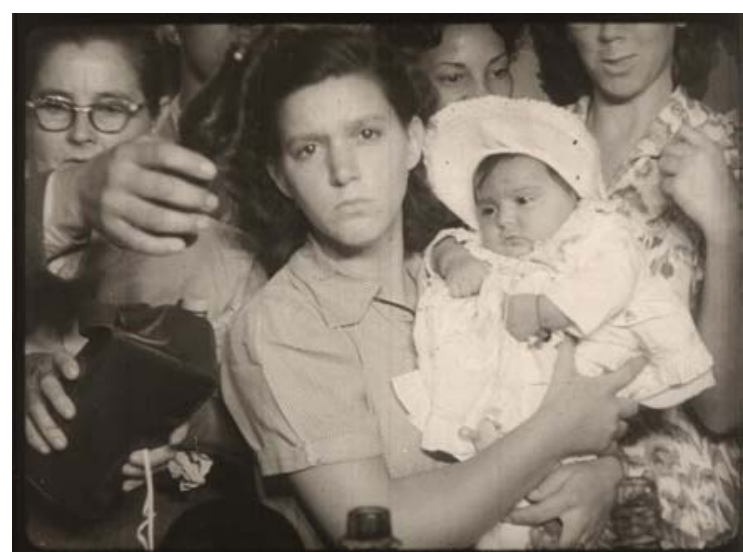

... aceitam participar do teatro político, negando, inclusive, um olhar amigável à câmera. Bandeirante da Tela no 669, 1955. Acervo Cinemateca Brasileira.

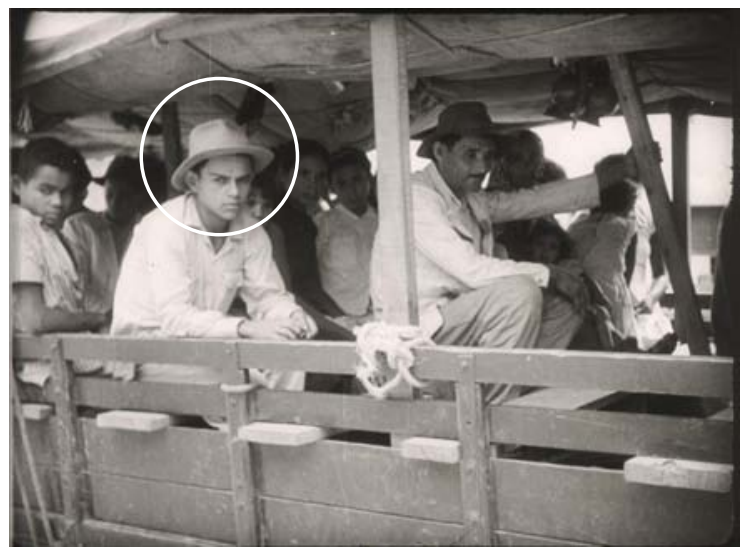

Entre as famílias que chegaram do nordeste, o olhar do rapaz é revelador da "violência" em estarem expostos ao constrangimento. Bandeirante da Tela no 549, 1953. Acervo Cinemateca Brasileira.

\footnotetext{
${ }^{428}$ Não o protagonismo das massas apontado por Vicente Sanchez-Biosca, passivas nos eventos grandiloqüentes de comemorativos, como nas películas de Franco, Cf. NO-DO: el tiempo y la memoria, op. cit., p. 286. Ou como uma "entidade" participativa, segundo as análises de Siegfried Kracauer sobre os cinejornais nazistas. Propomos um certo protagonismo diante do olhar da câmera que desvela a intenção daquele que não está "diluído" em meio a massa. Algo freqüente num cinejornal como o BT que necessita ir até as pessoas por não possuir cenários grandiloqüentes, tampouco o líder que conta com uma massa mobilizada em torno de um projeto nacional, a exemplo dos cinejornais nazistas, com a negação do homem em favor da massa enquanto "entidade". Cf. Siegfried Kracauer, "The Conquest of Europe on the Screen", op. cit., p. 28.

${ }^{429}$ Se sentir algo semelhante, no sentido em que "[...] ao fazer do líder seu ideal, o sujeito ama a si mesmo". Cf. Theodor W. Adorno, op. cit., p. 175.
} 
quisessem se ver, por pura curiosidade ou vontade de participar do espetáculo cinematográfico. E também aqueles que "recusam" a câmera, ou demonstram claramente um outro clima, oposto ao que se pretendia no ápice da preocupação com os pobres: o assistencialismo adhemarista, que fazia questão de registrar tamanha "aceitação" das pessoas na entrega das benesses de dona Leonor. Tais imagens contudo, são reveladoras do cansaço após uma longa fila para receber presentes e do aborrecimento pela exploração da subserviência humana pelas câmeras.

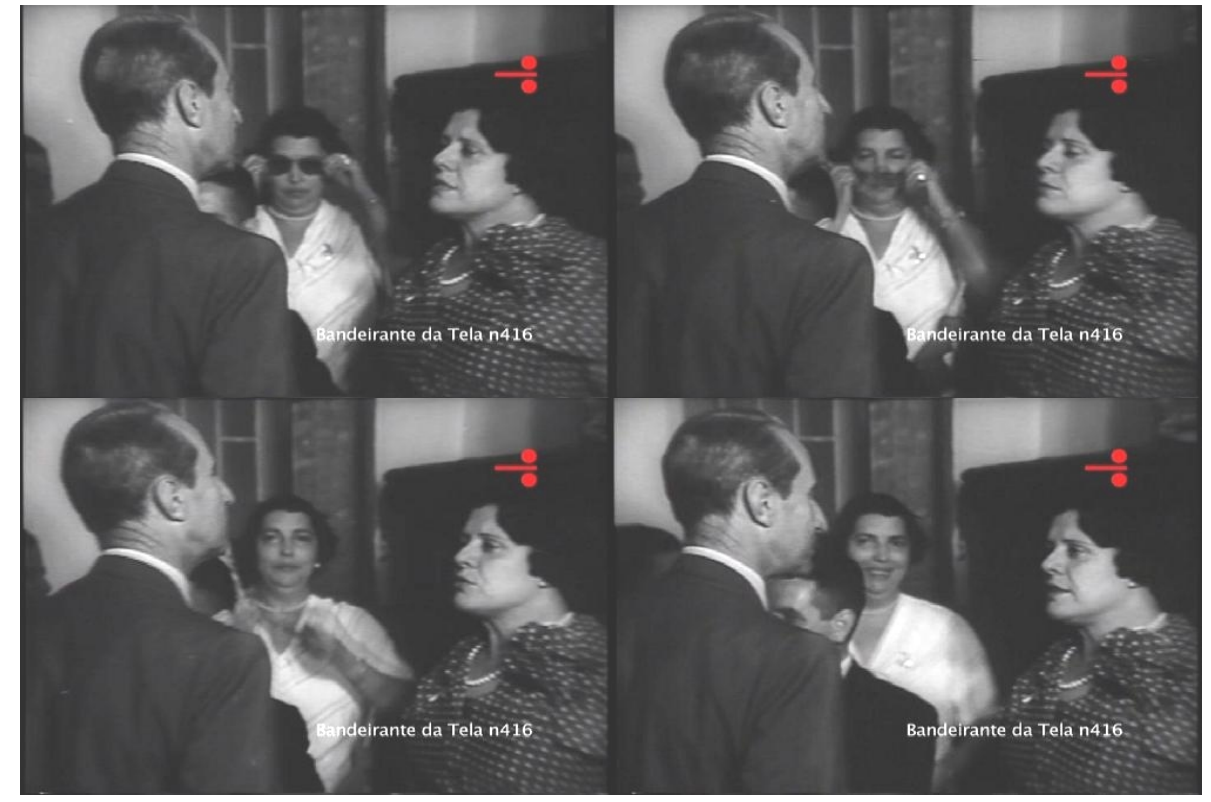

Na reprodução de um simples plano-seqüência, dona Leonor conversa com um dos seus convidados enquanto alguém, ao fundo, se mostra bastante preocu-pada com - público espectador do cinema.

Bandeirante da Tela no 416, 1951. Acervo Cinemateca Brasileira.

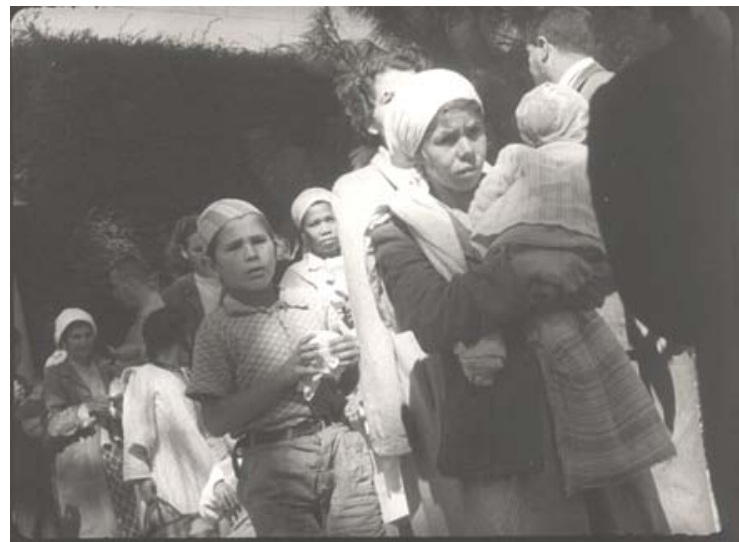

Semblantes cansados revelam a exploração da pobreza pelo teatro assistencialista do político. Bandeirante da Tela $n^{\circ}$ 679, 1955. Acervo Cinemateca Brasileira.

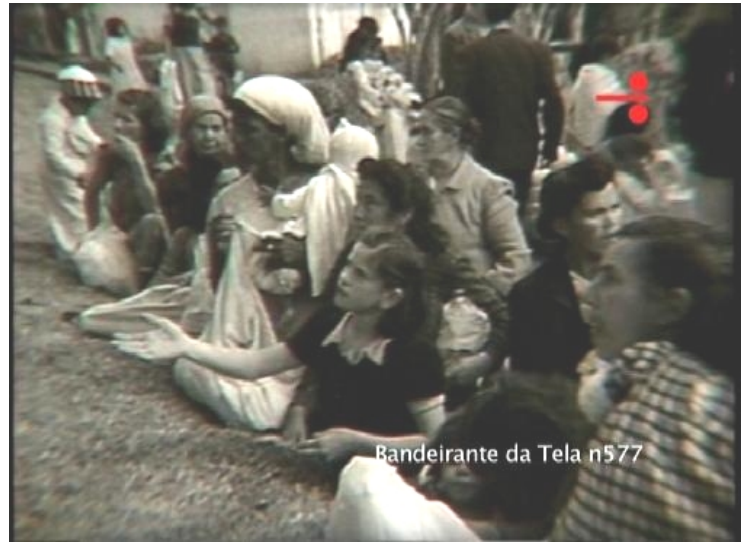

Ainda que hesitante, a menina estende a mão representando, num gesto, um apelo popular bastante explorado pelo cinejornal. Bandeirante da Tela no 577, 1954. Acervo Cinemateca Brasileira. 


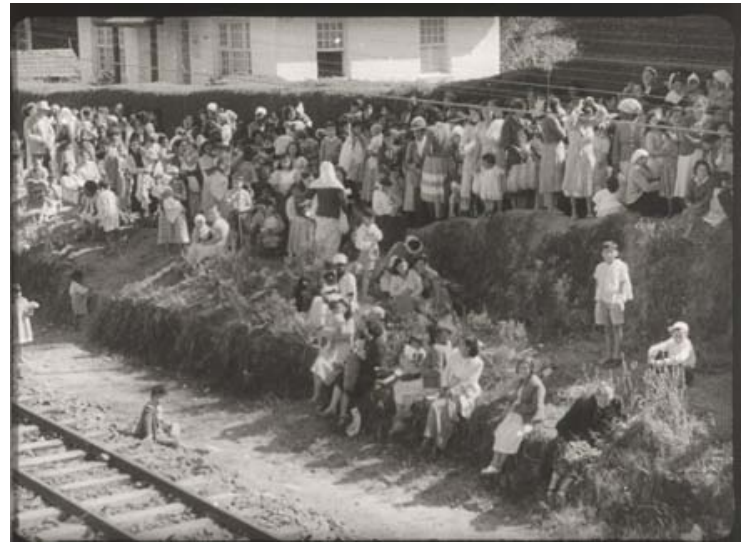

Amontoados num morro ou próximos à linha de trem, a regra é mostrar o maior número de pessoas assistidas, a despeito das condições a que são submetidas para "realizar" o adhemarismo no cinema. Como num desfile de figurantes miseráveis...

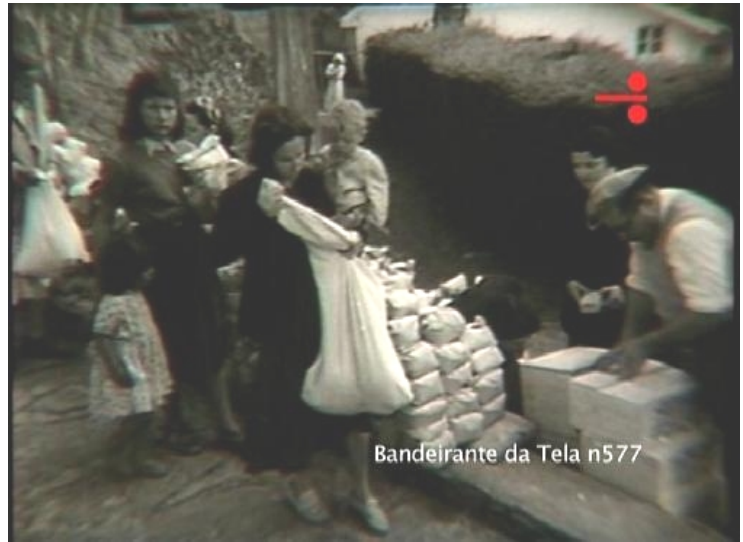

... a exemplo da mulher com crianças, que antes mesmo de entrar no campo visual, já olha para câmera, indicando saber qual o seu papel naquele teatro político. Bandeirante da Tela no 577, 1954. Acervo Cinemateca Brasileira.

A própria linguagem cinematográfica "revela" um discurso que tenta esconder a sua espontaneidade construída. A estratégia populista de Adhemar de Barros criou uma memória política atrelada a uma representação de realizações e amor ao próximo. Mas tal memória através do cinejornal desvela uma visualidade conflitante, inclusive com as representações veiculadas em outros suportes de propaganda. Contudo, caberia perguntar qual o espaço das camadas populares, que eram retratadas de forma tão marginal no BT? Porque não mostrar, por exemplo, as pessoas vivendo nas favelas? A amostragem que ainda resta deste cinejornal revela, no mínimo, uma falta de tato, para não dizer descaso. Nesse sentido, a prometida felicidade no projeto político adhemarista não consegue esconder a desigualdade que lhe é inerente, e o que assistimos, acaba revelando como um populismo é construído, ou melhor, é uma construção tal qual o artefato fílmico. Se para criar uma popularidade para Adhemar de Barros o BT se valeu das angústias e dos valores da sociedade, esta quando observada em detalhes, em filigrana, nos dá um outro recado. Como não considerar, por exemplo, o desdém com as camadas sociais mais baixas (nordestinos, ambulantes, favelados, pessoas nas filas assistencialistas)? Ou passar imune aos detalhes de uma panorâmica em plano geral de famílias que se equilibram à beira de um barranco para serem agraciadas pela demonstração de <solidariedade humana dos bons $>$. Ou a cena pungente de crianças, em especial uma menina, olhando para a câmera que rouba da sua inocência o elemento de credibilidade para um projeto de felicidade que é para poucos. 


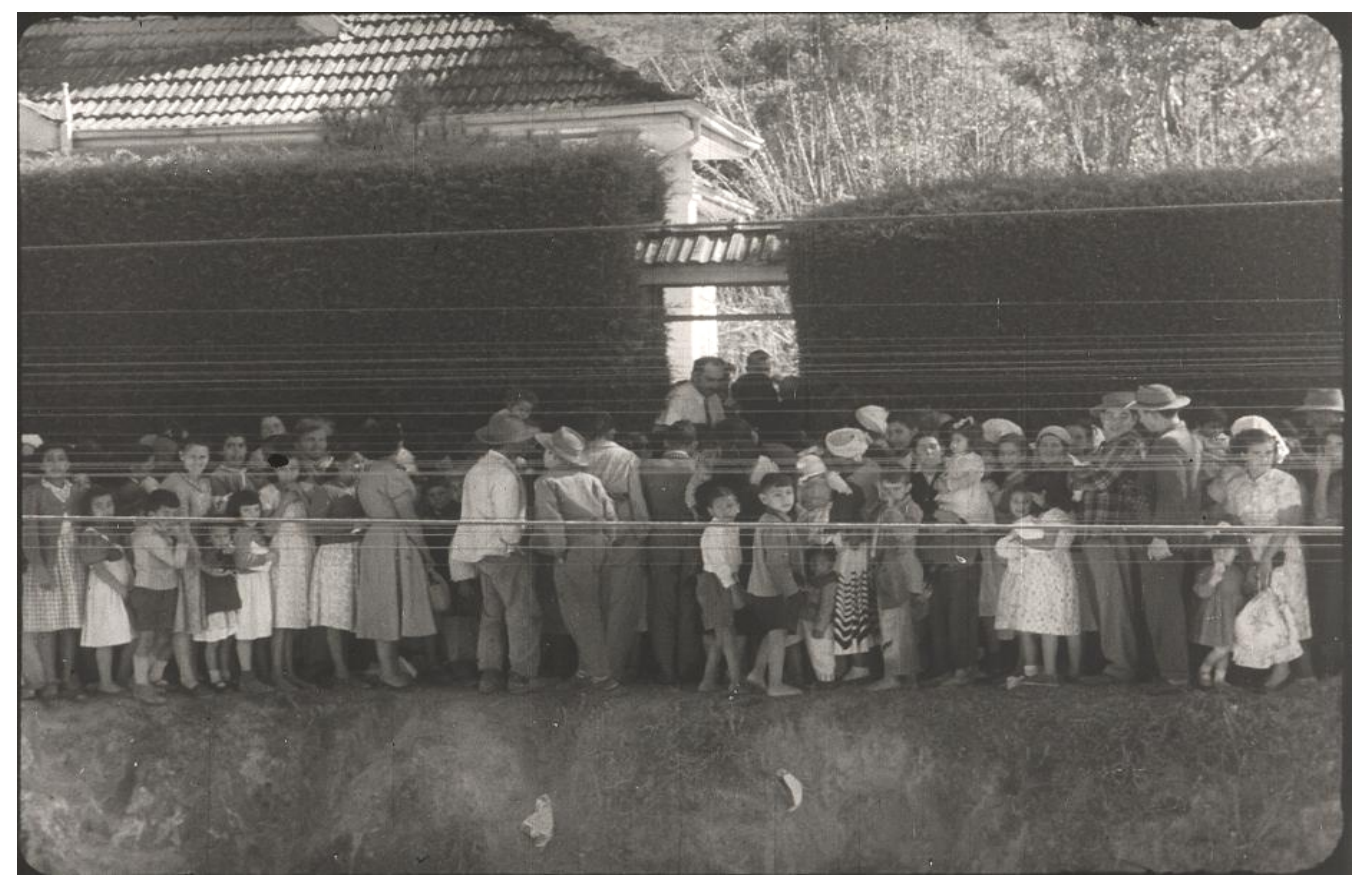

Uma longa panorâmica em plano-geral, da esquerda para a direita, mostra a enorme fila de pessoas (homens, mulheres e crianças, enfim, famílias) esperando pela distribuição das benesses pelo ilustre casal Adhemar e dona Leonor. No momento em que a câmera registra, ela também revela a explo-ração visual de uma situação em que as pessoas, ao mesmo tempo que olham para a câmera, se equilibram num barranco. Bandeirante da Tela $n^{\circ}$ 679, 1955. Acervo Cinemateca Brasileira.

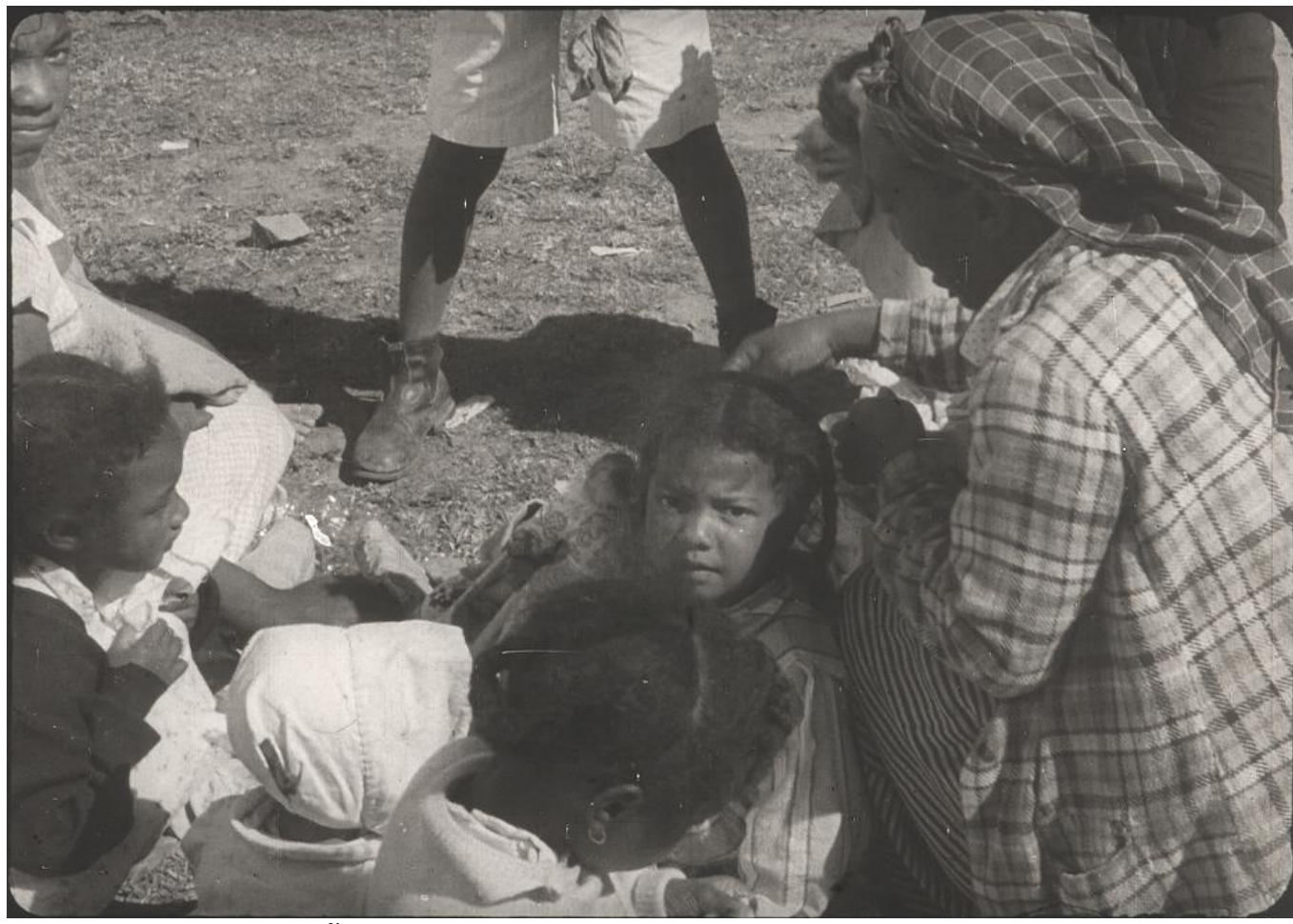

Crianças sentadas no chão de terra abrindo os presentes recebidos de dona Leonor. Momento em que a câmera parece perseguir os olhares que validem a obra social de um projeto político que, no limite, contemple as camadas pobres na chave puramente assistencialista. Bandeirante da Tela no 679, 1955. Acervo Cinemateca Brasileira. 


\section{2 - Um interlocutor para vários desejos: o "Bandeirante" na tela}

Se o discurso de Adhemar de Barros para as telas do cinema não conseguiu esconder uma sociedade desigual, resta saber qual foi o elo encontrado para a representação de um porta-voz do progresso. Ou melhor, como o político progressista manteve - ou tentou manter - a interlocução com diversos tipos de aspirações preservando os predicados do líder populista bastante próximo a um great little $\operatorname{man}^{430}$. No cenário ${ }^{431}$ que mesclou atores e o público na política brasileira que se democratizava e num mosaico de imagens em que transitou a sua proposta política, qual força simbólica foi acionada para anunciar o porvir de um grupo e formalizar, ao espectador, o convite para um mesmo projeto e um mesmo futuro ${ }^{432}$

Para entender a construção de um discurso palatável à sociedade paulista recorremos a um corpus documental composto com outras fontes, para verificar o que foi disseminado na estratégia adhemarista e assim olhar mais a fundo o seu populismo. Nessa busca, é exemplar na retórica de Adhemar de Barros a imagem do bandeirante, corroborando, aliás, com o próprio título do seu cinejornal. Como no exemplo de uma cédula partidária ${ }^{433}$, reproduzida em frente e verso logo abaixo:

\footnotetext{
${ }^{430}$ Uma vez mais, recorrendo à idéia apresentada por Adorno, em que alguém "[...] sugere tanto onipotência quanto a idéia de que é apenas um de nós". Theodor W. Adorno, op. cit., p. 175.

${ }^{431}$ No novo e massificado "palco da vida pública", anunciado principalmente após a Primeira Guerra Mundial com a movimentação ritual envolvendo massa. Cf. Eric J. Hobsbawn. "A produção em massa das tradições: Europa, 1870 a 1914" In Eric J. Hobsbawn e Terence Ranger (org.). A invenção das tradições. Trad. Celina Cardim Cavalcante. Rio de Janeiro: Paz e Terra, 1997, pp. 271.316, 314.

${ }^{432} \mathrm{Ou}$ como formula em poucas linhas Pierre Bourdieu, a respeito do porta-voz de uma mensagem que "[...] anuncia uma vontade, um projeto, uma esperança ou, muito simplesmente, um porvir a um grupo, [...] na medida em que os destinatários se reconhecem nela, conferindo-lhe força simbólica e também material". Pierre Bourdieu, O Poder Simbólico, op. cit., p. 187.

${ }^{433}$ Cédula Partidária do Partido Social Progressista. São Paulo, 1946. Caixa 631, pasta 02, doc. 003. Fundo Adhemar de Barros/APESP.
} 


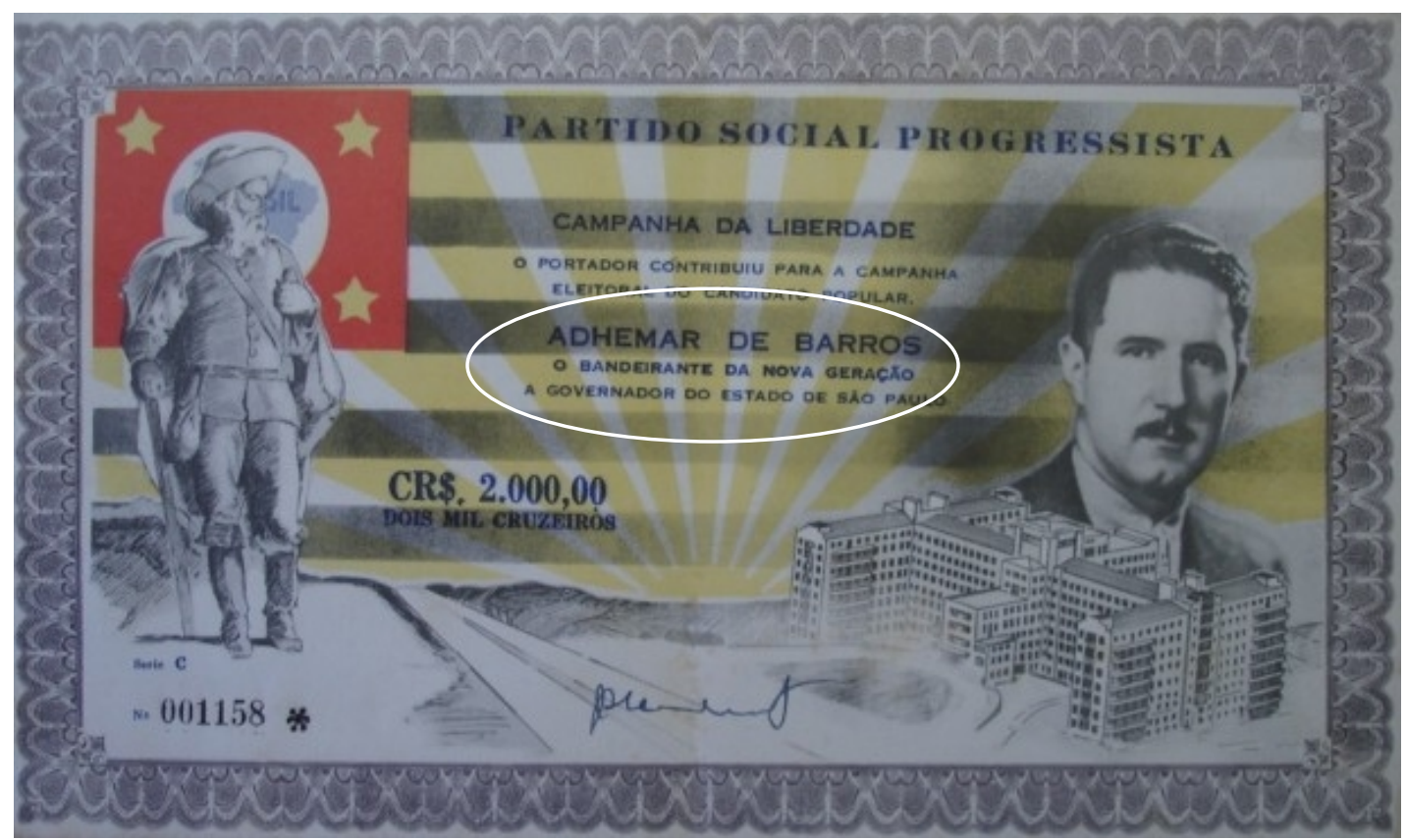

Cédula partidária do PSP para as eleições de governador do estado, em 1947. Seu conteúdo comporta uma série de símbolos que marcariam presença, direta ou indiretamente, no BT. A começar pela iconografia consagrada do bandeirante, à esquerda, que "olha" para o "bandeirante da nova geração" (conforme os dizeres em detalhe) e suas realizações que pairam no horizonte iluminado da terra paulista (representada nos raios de sol e na bandeira do estado ao fundo). O caminho que corta ao meio a composição iconográfica nos remete ao lema "rasgar estradas" e a sua concretização por Adhemar: a Via Anchieta; Assim como não poderia faltar nesta representação outra grande realização do novo bandeirante, o Hospital das Clínicas...

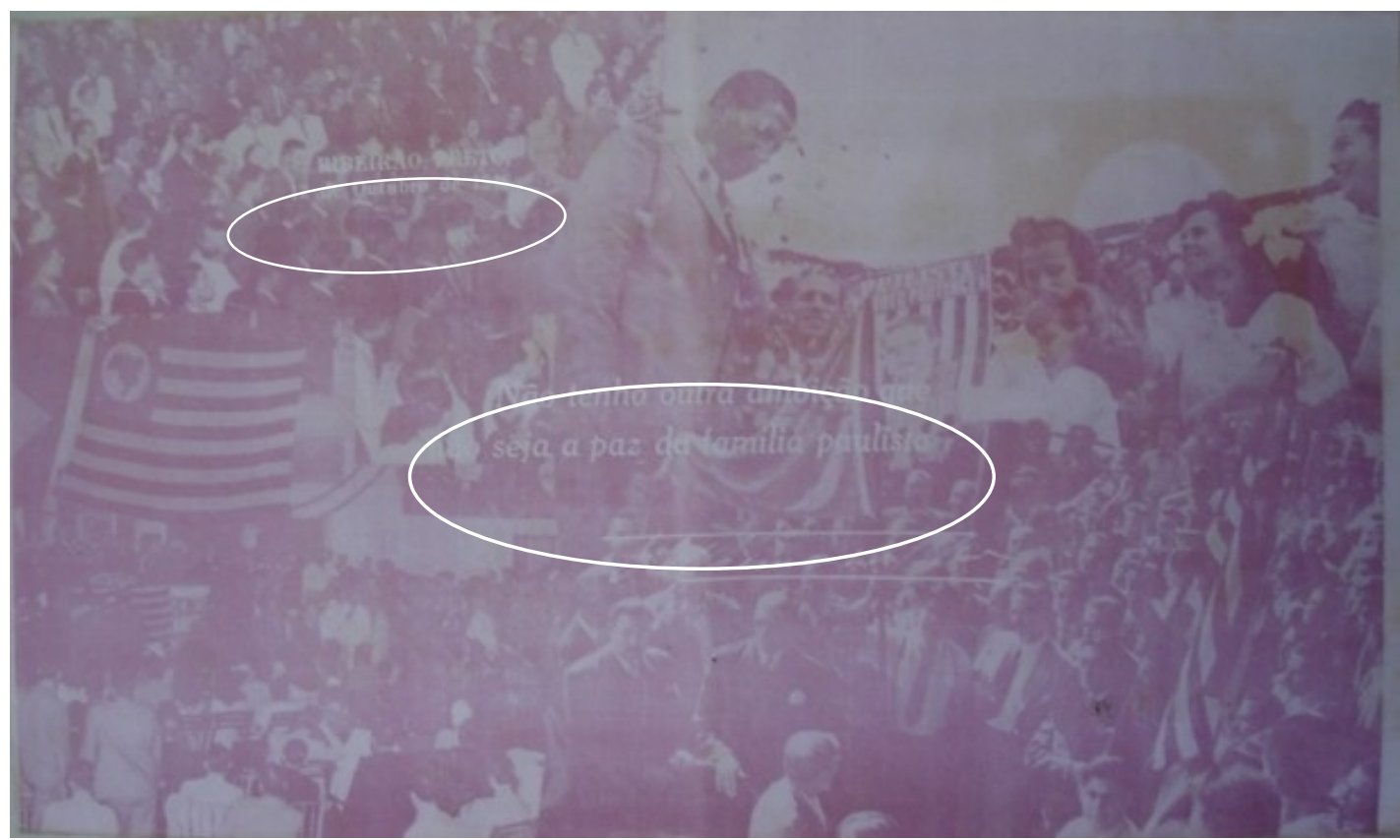

... No verso, imagens monumentais do político envolvido pela massa em comício ocorrido em Ribeirão Preto, em 12 de outubro de 1945 (como constam os dizeres no detalhe). Muitas bandeiras do estado e a frase lapidar de um adhemarismo arraigado ao solo bandeirante: "não tenho outra ambição que não seja a paz da família paulista". Fundo Adhemar de Barros/AESP. 
Há quem diga que o adhemarismo e toda a estrutura que lhe deu apoio - o partido e a forte propaganda - expressaram, desde o início, um fenômeno de "insubordinação paulista" ${ }^{434}$ frente aos partidos nacionalmente estruturados. Nesse sentido, a retomada da simbologia bandeirante, enquanto identidade para todos os paulistas ${ }^{435}$, é sintomática dessa faceta insubordinada de Adhemar de Barros em relação aos partidos como o PTB e o PSD. Curiosamente esse bandeirantismo pareceu ter se baseado, em parte, numa experiência ligada ao Estado Novo, cujos quadros intelectuais se esforçaram em traduzi-lo da Marcha para o Oeste para o sentido de marco fundador do pioneirismo e do progresso vislumbrado no governo varguista ${ }^{436}$. Coube, para isso, até mesmo apostas cinematográficas que tentaram traduzir o potencial iconográfico do tema, a exemplo do filme Os Bandeirantes (1940) de Humberto Mauro, enquanto narrativa monumental de um passado "autêntico" para aquele presente em desenvolvimento ${ }^{437}$.

Provavelmente atento a essa aposta, o então interventor Adhemar de Barros valeu-se deste símbolo, já ensaiado no discurso varguista, para legitimar uma representatividade

${ }^{434}$ Segundo Fernando Henrique Cardoso, o adhemarismo "expressou, desde o início, um fenômeno de 'insubordinação paulista'; o chefe político do grande estado (posto a escanteio no fim do Estado Novo) não quis alinhar-se ao grande partido clientelista estatal, de porte nacional que era o PSD" e acabou montando sua própria máquina partidária. Cf. Fernando Henrique Cardoso. "Partidos e deputados em São Paulo (o voto e a representação)" In Bolívar Lamounier, Fernando Henrique Cardoso (coord.). Os Partidos e as Eleições no Brasil. Rio de Janeiro: Paz e Terra, 1978, pp. 45-75, 50-1.

${ }^{435}$ Foi esse o tema da palestra "Construindo uma identidade paulistana“" pela antropóloga Lilia Moritz Schwarcz, realizada no Centro de Integração Empresa - Escola, em São Paulo, em 05 de ago. 2004. Partindo do contexto da evolução política e econômica do estado de São Paulo na virada do século XIX para o XX, Lilia investigou alguns símbolos pertinentes à busca de uma representação paulista em âmbito nacional. Em que tanto o Instituto Histórico e Geográfico de SP quanto o Museu Paulista fizeram parte de um projeto de construção de uma tradição paulista, tendo o mito do bandeirante - desbravador, branco e europeu traduzindo o preconceito contido no ideal de auto-imagem da elite paulista. De caçador e predador foi transformado em mito sublime, ícone da civilização e do progresso e o oposto do selvagem indígena, compondo, assim, uma narrativa monumental. Contudo, ao longo do tempo, essa mesma narrativa, como nos lembra Elias T. Saliba, parece ter corroborado a função assimiladora do mito, principalmente nos episódios de 1924 e 1932, fazendo com que bandeirante e paulista sejam encarados como termos sinônimos a partir de 1938, ou melhor, como "designações estendidas para todos aqueles que se integrassem na vida paulista, ou seja, que 'trabalhassem para São Paulo crescer”. Cf. Elias T. Saliba, op. cit., p. 575.

${ }^{436}$ Numa chave em que a "Marcha para o Oeste" traduziria a sensação de nação em movimento e o estímulo à participação. Simbolicamente uma conquista, em que "[...] todos se sentissem co-proprietários do território nacional”. Alcir Lenharo. Sacralização da Política. Campinas: Editora da UNICAMP, 1986, p. 15. Nesse sentido, Cassiano Ricardo, um dos intelectuais ligado ao DEIP de São Paulo e autor do livro Marcha para o Oeste (1941) foi quem mais contribuiu à construção desta imagem.

${ }^{437}$ Cf. Eduardo Victorio Morettin, "Quadros em Movimento: o uso das fontes iconográficas no filme Os Bandeirantes (1940), de Humberto Mauro" In Revista Brasileira de História, vol. 8, n.35. Dossiê: Arte e Linguagens. São Paulo: ANPUH/Marco Zero, 1998, pp.105-31.. 
oferecida à sociedade, mas numa chave mais regional: o político autenticamente paulista para as eleições estaduais de 1947. Sendo assim, se o CJB transmitiu um caleidoscópio com imagens das atividades de um Brasil unificado e em marcha, e que no todo formava a bandeira nacional ${ }^{438}$, esta inspiração levada ao BT pode ser traduzida na unidade paulista reinventada para um novo formato no jogo democrático: o bandeirante na tela.

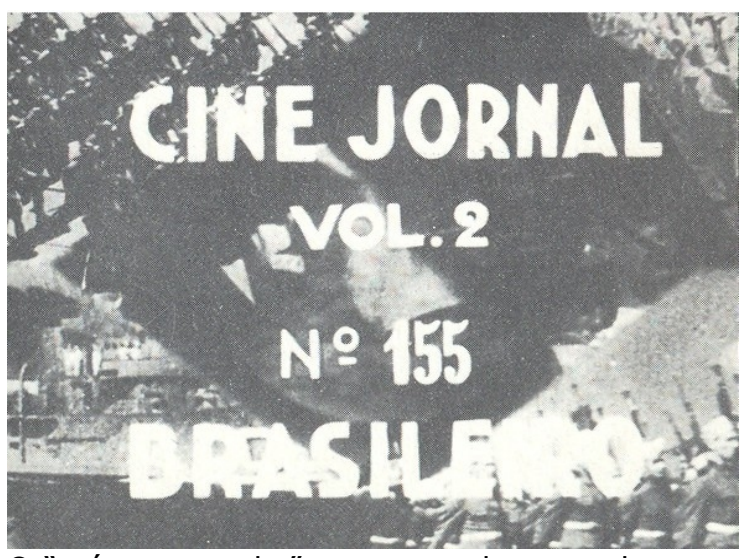

O "país em marcha", representado em cada gomo da bandeira nacional na abertura do CJB. Cine Jornal Brasileiro no 155, 1942. Acervo Cinemateca Brasileira.

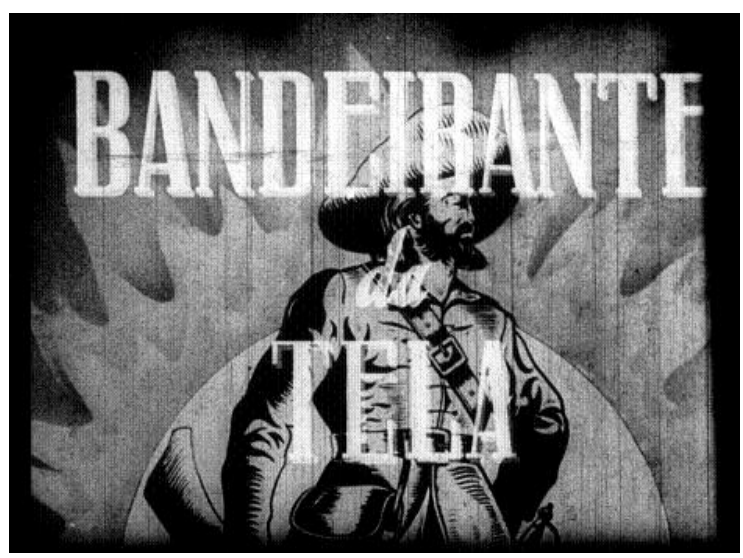

A iconografia bandeirante a serviço do político paulista, na abertura do seu cinejornal. Uma aposta que visitaria as telas a partir de 1947. Bandeirante da Tela no 650, 1955. Acervo Cinemateca Brasileira.

Porém, a retomada de um ícone da tradição, do pioneirismo e do progresso paulista pode refletir matrizes conservadoras mais profundas, manifestas há quase uma década da reabertura democrática e abrigadas no seio do próprio partido de Adhemar de Barros. Em sessão solene de instalação dos diretórios distritais do PSP, Miguel Reale é um dos seus principais oradores $^{439}$. Vice-presidente do PSP e Secretário de Justiça e Negócios Interiores de São Paulo na gestão adhemarista (entre 1947 e 1950) ${ }^{440}$, seu passado como membro da Ação Integralista Brasileira (AIB) é, no mínimo, um indicativo da presença, nas fileiras

\footnotetext{
438 "Sobre cada gomo do losango era exposta uma atividade em marcha no país, com sucessivas aparições de navios de guerra em construção nos estaleiros, colheitas agrícolas abundantes, escolares em marcha, a aviação, formando um caleidoscópio da pujança do Brasil na Era Vargas”. José Inácio de Melo Souza. "Trabalhando com cinejornais: relato de uma experiência", op. cit., p. 50.

${ }^{439}$ Ocorrida no Cine Ritz na avenida São João, em São Paulo. Sala esta que em seguida exibiria em suas sessões o BT, como vimos anteriormente. Relatório de Reynaldo Pisapio, Investigador da Seção de Policiamento de Ordem Política, ao Delegado Especializado de Ordem Política, São Paulo, 1 de julho de 1946. Pront. 069.506 - Partido Social Progressista. DEOPS-APESP.

${ }^{440}$ Cf. Dicionário Histórico-Biográfico Brasileiro, op. cit., p. 4.908.
} 
progressistas, de uma vertente que apregoava o bandeirantismo enquanto ideal de espírito e de $\mathrm{Nação}^{441}$.

Nesse sentido, a propaganda adhemarista parece ressonar - com a encarnação do "bandeirante da nova geração por Adhemar de Barros" - uma "pérola" do próprio Miguel Reale nos seus tempos de AIB, que conclamava "os novos bandeirantes para a conquista da terra de nós mesmos" ${ }^{442}$. Idéia esta que apresenta uma noção de unidade muito mais afeita à idéia de superioridade que o mito do bandeirante comporta ${ }^{443}$ e que, em última instância, arvora a supremacia da "nação" que o abriga mais fortemente: a pátria paulista. Onde já se havia provado a força desta simbologia em momentos de extrema mobilização, quando participou do quadro de valores que compôs o ideário da Revolução de 32. Não custa lembrar, naquele episódio, que o "bandeirante era todo paulista que se dispusesse a partir para a luta" ${ }^{444}$.

Mas essa mesma idéia de superioridade bandeirante, de supremacia de uma nação enfim, cujo passado está fortemente ligado a uma representação elitista ${ }^{445}$, parece não ter se acomodado tão harmonicamente a uma política populista. A apropriação pelo adhemarismo desse baluarte paulista gerou vários enfrentamentos, sobretudo políticos. Durante seu mandato como governador eleito, Adhemar de Barros pareceu incomodar com sua alcunha

441 Nas operações teóricas dos pensadores integralistas, o bandeirante, com outras tantas "palavras encantatórias" é dotado de uma simbologia cuja força pode substituir outros mitos, como o mito da origem européia, por exemplo. Cf. Marilena Chaú, op. cit. Mas como nos lembra Kátia Abud, tal simbologia bandeirante estudada por diferentes autores (M. Chauí, M. H. Capelato e J. Love) converge à procura da "unificação" contida no "bandeirante símbolo" que deriva do "bandeirante histórico", isto é, sobre o que "os estudos de História sobre o movimento bandeirista produziram [enquanto] conhecimento que permitiu que a simbologia fosse criada sobre o pano de fundo da unificação", seja ela racial, territorial, política ou econômica. Cf. Kátia Maria Abud. O Sangue Intimorato e as Nobilíssimas Tradições - a construção de um símbolo paulista: o bandeirante. 1985. Tese (Doutorado em História Social) à Faculdade de Filosofia, Letras e Ciências Humanas da Universidade de São Paulo, p. 9.

${ }_{442}^{4}$ Miguel Reale apud Marilena Chauí, op. cit., p. 41.

${ }^{443} \mathrm{Na}$ medida em que "a noção de unidade presente no conceito de Bandeirismo se alia à noção de 'superioridade' racial, social e psicológica do Bandeirante. O nivelamento da expressão de igualdade e da integração se faz através das qualidades positivas que o bandeirante carrega implícitas, no seu próprio conceito", Kátia Abud, op. cit., p. 09. Grifo nosso.

${ }^{444}$ Compondo o ideário da Revolução de 32, quando "na mobilização ideológica invocou-se a tradição do 'povo paulista', e fez-se reviver o mito das bandeiras em toda a sua plenitude. O bandeirante histórico foi transformado em símbolo do heroísmo e vigor da raça". Maria Helena Capelato. O Movimento de 1932: a causa paulista. $3^{\mathrm{a}}$ ed. São Paulo: Brasiliense, 1981, p. 40.

${ }^{445}$ Que Joseph retrata, inclusive, na chave psicológica de uma elite "quatrocentona" cujos filhos "paulistas educados" alimentam a convicção de uma psicologia coletiva herdada dos bandeirantes, traduzida no seu pioneirismo empreendedor. Cf. A Locomotiva: São Paulo na Federação Brasileira (1889 - 1937). Op cit., p. 107. 
de "bandeirante moderno". Nos livros escritos com intuito de denunciar os desvios financeiros, políticos e morais do líder pessepista, a vergonha e a ira dos que defendiam a "honra e as tradições do povo bandeirante" ${ }^{446}$ estiveram presentes. Assim como panfletos inimigos, em especial um que circulou em 1951, e que colocou o termo "adhemarismo" como sinônimo de "desonestidade, fraude, orgia, corrupção" 447. Insinuando se tratar de um farsante, de um "pseudo-populista" indigno das tradições que dizia ostentar. Um verdadeiro impostor, se comparado com o autor da mensagem: Borba Gato, um legítimo bandeirante. Portanto, é importante ressaltar que o uso desta simbologia, inicialmente

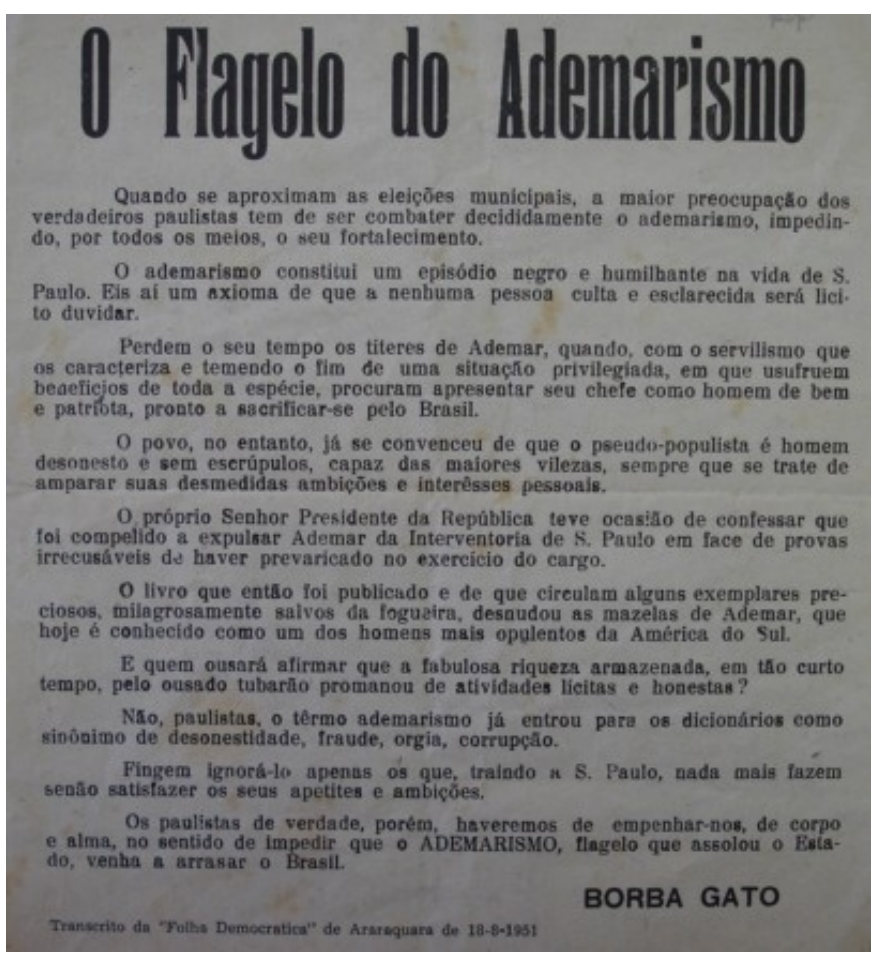

Panfleto cuja mensagem procurou advertir os paulistas contra o que existia de pior: o adhemarismo, comandado por um bandeirante impostor. Fundo Adhemar de Barros/AESP.

ligada ao discurso conservador paulista, pareceu ganhar contornos mais populares na apropriação adhemarista, na medida em que uma estratégia de propaganda pensada para os moldes cinematográficos contribuiu, pelo viés da massificação, à mescla de dois mitos ${ }^{448}$ : 0 bandeirante e o progresso paulista, unificados na imagem de Adhemar de Barros. Denegrindo-os para uns (os defensores da honra e das tradições paulistas) e sendo o convite para outros. Ou melhor, a porta de acesso, pela democracia do voto, à participação de tudo que o estado e a cidade tinham a oferecer num futuro de prosperidade prometido no discurso político progressista. Para a "cidade que mais cresce" ou o estado que é a "locomotiva", a aposta consistiu em levar adiante a idéia de progresso, reinventada no

${ }_{446}$ João Ramalho, A Administração Calamitosa do Snr. Adhemar de Barros em São Paulo, op. cit., p. 272.

${ }^{447}$ O Flagelo do Ademarismo, por Borba Gato. São Paulo, transcrito da "Folha Democrática" de Araraquara. São Paulo, 18 de agosto de 1951. Caixa 631, pasta 02, doc. 012. Fundo Adhemar de Barros/APESP.

${ }^{448}$ Corroborando com a assertiva de Certeau sobre a proliferação das mitologias, sobretudo mediante ao desenvolvimento técnico (aqui entendido como, por exemplo, os avanços dos meios de comunicação) que "transforma as crenças em legendas ainda mais carregadas de sentido". Michel de Certeau, op. cit., p. 41. 
político que se dizia um bandeirante. E que, com igual pioneirismo e vontade, levaria todos a participar de um mesmo projeto, ou melhor, todos que naquele projeto acreditassem e votassem.

Se após a Era Vargas o poder político de São Paulo diante do Brasil foi ofuscado, o significado do "ser bandeirante" fez acentuar ainda mais o seu caráter assimilador pelo viés do desenvolvimento e do progresso econômico ${ }^{449}$. O bandeirante ou o paulista "autêntico" passou a ser todos os que trabalhavam por uma nação paulista próspera, projetada num porvir. Desta forma, tal "identidade" (bandeirante ou paulista) pôde estar de braços dados com a trama daquela sociedade permeada de tensões cotidianas entre o atraso e o progresso. De modo que tal representação pelo adhemarismo, nas eleições de 1947 e 1950, pode ter atendido os anseios de diferentes camadas sociais, tantos os setores médios (ansiosos para se distanciar do pólo inferior da escala social, se identificando com o conservadorismo nas representações adhemaristas); como os mais populares ${ }^{450}$ (identificados com a representação popular de alguém próximo ao povo). Refletindo, pelo voto, a vontade de pertencer à unidade e ser também um bandeirante.

Entretanto, essa unidade pleiteada pelo discurso adhemarista não comportou a sua própria tensão nas pretensões seguintes e a "apaziguadora certeza de uma total reconciliação consigo mesmos" ${ }^{451}$ pareceu não ecoar como antes. Seu rompimento político com o governador Lucas Nogueira Garcez e o surgimento do seu principal opositor, Jânio Quadros, refletiram a própria aposta de Adhemar de Barros num progressismo conservador e, portanto, sem riscos, apresentando-se de maneira paternal, segura, imbuído de valores cristão-católicos da família e mantenedor, em último caso, da ordem. Continuar insistindo num apelo fortemente arraigado na unidade paulista foi o erro de um discurso que se revelava conservador e muito mais distante das camadas populares, sobretudo urbanas ${ }^{452}$.

\footnotetext{
${ }^{449}$ Cf. Elias Thomé Saliba, op. cit., p. 585.

${ }^{450}$ Neste ponto, concordamos com as formulações de Francisco C. Weffort, O Populismo na Política Brasileira. op. cit., ainda que ela não esgote o assunto da receptividade de um eleitorado tão heterogêneo como o paulista. É importante ressaltar, também, que em 1947, a aceitação junto à classe operária pode ter advindo da aproximação de Adhemar de Barros com o PCB; já em 1950, na sucessão com Lucas Nogueira Garcez, o apoio do PTB foi decisivo (que por sua vez obteve a ajuda de Adhemar de Barros em São Paulo à candidatura de Getúlio Vargas, bem com a indicação de João Café Filho, dos quadros do próprio PSP, como vice-presidente).

${ }^{451}$ Raoul Girardet, op. cit. pp. 155-156.

452 O que reflete a investida de Adhemar de Barros tanto nas aproximações como "caboclo franco" nas suas Palestras ao Pé do Fogo, como nas visitações ao interior paulista. Nos registros do BT catalogados pela CB, constam 25 ocorrências de visitas a cidades do interior paulista. Cf. Cinemateca Brasileira, op. cit.
} 
A pátria paulista já não era a do bandeirante, e este não mais aquele a quem recorrer, ela (a pátria) era daqueles que cresciam junto com o seu desenvolvimento, da classe operária urbana. E esta estava muito mais voltada à proposta janista ${ }^{453} \mathrm{ou}$, em último caso, ao trabalhismo que Adhemar de Barros sequer representou, inserido que estava numa prática clientelística que lhe deu aporte ${ }^{454}$. Inversamente, os elogios ao progresso e ao desenvolvimento, como assistimos no BT, deixam claro um certo provincianismo desatento ao que "estava em sua volta" ${ }^{455}$. E que por mais que se diga ${ }^{456}$, não encontrou ecos naquele momento nem regionalmente, muito menos nacionalmente. Esse "melancólico" adhemarismo é notório, no seu limite, pela própria retomada de uma mitologia elitista. Para Adhemar de Barros, que não tinha uma massa sempre o esperando - muito menos por todo o Brasil - como percebemos nas imagens do BT, restava-lhe ostentar, resignadamente, a alcunha de bandeirante completamente "vazia" no momento em que a cidade de São Paulo, em suas comemorações do IV Centenário, estava nas mãos de seus inimigos políticos e o adhemarismo não tinha o que mostrar, a não ser ressentidas denúncias à administração

\footnotetext{
${ }^{453}$ Cf. Francisco C. Weffort, op. cit., pp. 33-36.

${ }^{454} \mathrm{O}$ que o mantinha em voga, "mesmo quando o partido estava alijado da máquina estatal. Nunca se baseou, entretanto, em sindicatos e reivindicações trabalhistas, como o PTB, nem por outro lado confundiu-se inteiramente com setores do aparelho estatal, como o PSD. Ao contrário, organizou-se, utilizando o Estado, mas dele diferenciando-se. Esta estruturação permitiu ao partido e ao ademarismo (sic) sobreviver nos momentos em que o partido perdeu o controle dos postos oficiais". Cf. Fernando Henrique Cardoso, op. cit., pp. 50-1. Mais esclarecedora nesse sentido é a conclusão de Regina Sampaio sobre a máquina partidária, o PSP, que constituiria o "sustentáculo organizacional básico do adhemarismo, sem o qual o apelo populista de Adhemar tenderia a diluir", de modo que este "orienta-se para um apelo populista difuso que é capaz de sensibilizar as massas trabalhadoras sem, contudo, ter condições de enquadrá-las partidariamente". Cf. op. cit., p. 110.

${ }^{455}$ Um provincianismo apontado por Vianna Moog, em que o estado mais "pioneiro" é aquele "que mais cultua o seu paradoxo", ou seja, o bandeirante. Cf. Bandeirantes e Pioneiros: paralelo entre duas culturas. $14^{\mathrm{a}}$ ed.. Rio de Janeiro: Civilização Brasileira, 1983, p.172. Certamente aquele no sentido proposto por Elias Thomé Saliba, ao dizer de uma cidade moderna sob o signo do passado, o bandeirante forte e destemido, op. cit., p. 455.

${ }^{456}$ Concordamos com a crítica de Carlos Davinoff sobre as formulações de Vianna Moog, a respeito do quanto "a imagem do bandeirante foi a representação que afinal se firmou, promovida a símbolo, idealizada e, talvez, a imagem mais cultivada pelo brasileiro, apesar do surgimento dos novos tipos sociais e de seus respectivos símbolos", apud Carlos Davinoff. Bandeirantismo verso e reverso. $8^{\mathrm{a}}$ ed. São Paulo: Brasiliense, 1994, p. 90. Davinoff nos alerta sobre o equívoco em "inverter os sinais do culto do herói bandeirante", ou seja, dotá-lo de "um poder de ubiqüidade e de permanência histórica e que pudesse corporificar e revelar as várias faces do que acreditava serem os males da nacionalidade", pp. 90-91.
} 
municipal e estadual ${ }^{457}$. Assim como a morte de Getúlio, que não pôde ser explorada, posto que naquele momento Adhemar de Barros havia se distanciado do líder trabalhista ${ }^{458}$.

Se o "ritual do poder" pôde ser exercido nas telas durante a ascensão adhemarista (seu mandato e a sucessão), restava-lhe agora o "berço-esplêndido" que traduziria, no limite de sua propaganda, o paradoxo da sua política. Nesse sentido, o BT deixa a ver a não a proposta de um projeto, mas um discurso que, entre o "berço esplendido" e as massas populares, preferiu o primeiro, relegando à segunda um assistencialismo desmistificador de sua própria ação pelas lentes cinematográficas, como vimos anteriormente. Tratou o norte do Brasil como "pitoresco"; clamou pela ordem e denunciou o caos numa cidade que se transformava; alijou-se politicamente do poder regional e nacional; e não ouviu o povo que crescia com a modernidade. Adhemar de Barros e o seu cinejornal não perceberam tudo isso.

Talvez assim fique mais claro porque o adhemarismo não conseguiu alçar vôos mais altos no cenário nacional. Se da sociedade paulista ele tirou a sua força retórica, clamando pioneirismo e progresso, no mesmo "pacote" veio a sua fraqueza. Ao se colocar como mediador para uma série de desejos, tentou mergulhar fundo nos valores e nas tradições de São Paulo, porém não teve fôlego para subir à superfície de um discurso nacionalmente convincente. Ou seja, livrar-se deste enraizamento no solo bandeirante. Por mais que tenha investido em propaganda, Adhemar de Barros não traduziu uma nacionalidade para todo o

${ }^{457} \mathrm{O}$ que talvez explique o fato de não encontrarmos registros do BT dedicados às comemorações do IV Centenário ocorridas em janeiro, no dia do aniversário da cidade. No máximo, o que encontramos é uma edição especial: Bandeirante da Tela, Ed. Especial - Nove de Julho no IV Centenário: Epopéia de Brasilidade. São Paulo: Divulgação Cinematográfica Bandeirante, 1954, Fita de Vídeo (10min54seg), VHS, sonoro, p\&b, VV00206. Cinemateca Brasileira. O que nos remete, provavelmente, ao distanciamento adhemarista dos poderes municipal e estadual que se encarregaram das comemorações oficiais do IV Centenário. Significativa é a escolha do próprio título, em que o Nove de Julho (data da deflagração do movimento revolucionário de 32) sugere a "epopéia de brasilidade" ligada à retórica bandeirante tão participativa neste episódio. Quanto às denúncias de má administração dos dirigentes da São Paulo quadricentenária, ver Bandeirante da Tela $N^{\circ} 591$, op. cit.; Bandeirante da Tela $N^{\circ} 592$, op. cit Bandeirante da Tela $N^{\circ} 600$, op. cit;, Bandeirante da Tela $N^{\circ} 664$, op. cit e Bandeirante da Tela $N^{\circ} 696$, op. cit..

${ }^{458}$ Cf. Bandeirante da Tela s/n (Morte de Getúlio Vargas). São Paulo: Divulgação Cinematográfica Bandeirante, 1954, Fita de Vídeo (6min37seg), VHS, sonoro, p\&b, VV00683. Cinemateca Brasileira. Assim como Rubens Machado, que nos dá uma idéia sobre este episódio retratado pelo BT 632 (1954) - número ao qual não tivemos acesso. Tanto no BT sobre a morte de Vargas, como neste número mencionado pelo autor, o conteúdo parece convergir para o que, resumidamente, coloca Rubens Machado: "apresenta confusamente concentrações de populares no largo de São Francisco e distúrbios com correrias, deslocamento de tropas, bombas, repressão policial [...] e homens de povo empunhando por vezes uma bandeira do Brasil e noutras um pedaço de pau. De tudo isso se extrai naturalmente uma idéia de caos somente superada pela onisciência do locutor que nos assegurava da pronta ação das forças policiais para evitar a baderna". Cf. "São Paulo e o Seu Cinema”, op. cit., p. 493 
território nacional: ele foi, antes, um digno representante da pátria paulista por todo o Brasil.

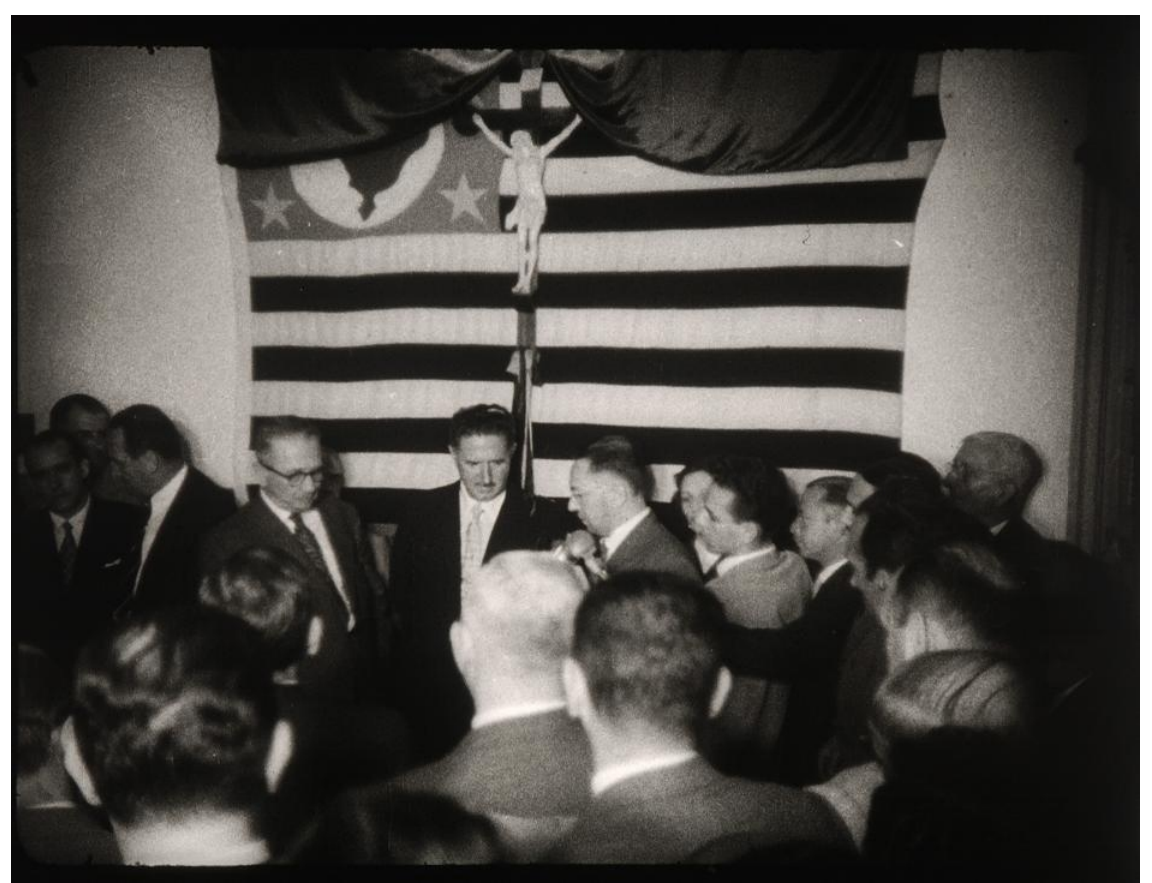

Adhemar de Barros sendo homenageado em seu aniversário. Uma ocasião propícia para o bandeirante expor os valores reiterados em toda a sua retórica: cercado por seus correligionários, a bandeira paulista e a imagem de Jesus Cristo que paira sobre o político indicando, de antemão, os compromissos contidos em seu discurso. Bandeirante da Tela no 546, 1953. Acervo Cinemateca Brasileira. 


\section{Considerações finais}

Como arte, a sétima arte, o cinema também é representação (já dissemos isso). Deste modo, o ritualismo apresentado no BT colheu elementos do já simbolizado e "socializado em cada parte" ${ }^{459}$, seja nas aspirações do momento, seja nos valores tradicionais arraigados no cenário paulista. Assim sendo, a película que analisamos não oferece, simplesmente, fragmentos de um passado, pois em sua superfície também estão vestígios da performance dos entes políticos ${ }^{460}$ cujos traços são evidências do que estava em voga, culturalmente aceitos por assim dizer, e que foram transpostos numa chave envolvendo cinema e política. E foi por esta senda que tentamos seguir por uma História Cultural do Político.

Mais que corroborar um conhecimento já levantado sobre o adhemarismo (e reconhecemos serem os trabalhos de Weffort e Sampaio as melhores contribuições), tentamos compreender em que medida a linguagem do cinema acentuou os traços marcantes de uma autoridade política assim como participou do "fazer política" de um líder populista, trazendo às telas o cotidiano dos espectadores e os representando no que lhes era sensível. Nesse sentido, esperamos contribuir para o entendimento sobre os anos de 1950, tão visitados por uma historiografia que pouco deu passagem para outras manifestações políticas que não o trabalhismo, por exemplo.

Trazer à tona Adhemar de Barros e o seu discurso progressista - inseridos que estavam no ínterim democrático que caracterizou o período de sua ocorrência - pode revelar como um regionalismo travestido de modernidade foi alçado à categoria de projeto para o povo, ao mesmo tempo em que se mostrou excludente quando analisado pelo seu cinema, transpondo para uma chave marginalmente assistida todo o atraso regional representado pelas camadas pobres. De modo que no todo de uma unidade acolhedora, no projeto de futuro de Adhemar de Barros mostrado nas telas, o atraso paulista foi vislumbrado num formato assistencialista afeito ao discurso de uma classe-média conservadora de valores como a família e a religião. E foi nesta toada que o bandeirante moderno "realizava", se apresentava como moderno em outros estados, descia até o povo, sabia buscar lá fora as soluções para a sua terra. Muito embora não realizando, pelo menos

${ }^{459}$ Cf. Jean-Louis Leutrat, op. cit., p. 31.

${ }^{460}$ Raoul Giradet, op. cit., p. 84. 
nas telas, um projeto de felicidade para todos. Ao contrário, acabou se perdendo - e se achando - nos elogios ao "berço esplêndido" paulista e nas manifestações do "ritual do poder" - ocorridas até em sua própria residência. As suas propostas, reclames, obras e realizações, ainda que lembradas fragmentariamente em meio às diversas notícias do cinejornal, e somadas à falta de um maior controle técnico, deixam clara a não aceitação e o descaso com os valores e os signos que não representavam a modernidade. E quando inevitáveis na notícia, eram contemplados na chave da carência, na promessa de olhar pelos pobres protegendo-os, muito embora nada em troca prometendo, como vimos num dos cinejornais analisados: "a cidade grande é uma incógnita, se virem!" - talvez seja esse o recado mais cristalino contido no "compromisso" adhemarista.

O BT repercutiu para o progressismo uma imagem de progresso, obviamente. Porém, um progresso em descompasso com as transformações daquele momento e muito mais ligado à falsa promessa de um futuro promissor, apaziguante e reconciliatório com uma tradição elitista. Algo anunciado na própria ambivalência das imagens registradas, no olhar e nos gestos das pessoas que foram exploradas em suas aparições. Se houve manipulação das massas, houve muito mais uma manipulação das cenas dessa mesma massa. Contudo, o fato de Adhemar de Barros ter voltado para mais um mandato em 1962 e se lembrarmos, inclusive, ter sido essa a fase mais reacionária do adhemarismo - é indicativo da força desse apelo à "ordem" e ao controle do "caos" tão bem representado pela mística adhemarista daquele progresso descompassado das imagens do BT.

Ao fim, resta dizer que tentamos enxergar por detrás da monumentalidade criada para o político Adhemar de Barros. Visitamos uma visualidade do seu cinejornal que se encontra relegada em publicações, documentários institucionais e em sites oficiais na internet porque se trata de uma memória visual que expõe o mito. Mas ainda assim, muito deve ser dito sobre o adhemarismo e o BT que esperam por mais olhares, uma vez que este trabalho nunca teve a pretensão de esgotar o tema. A nossa tentativa se inscreveu na intenção de olhar para o passado com o mesmo cuidado dispensado ao manuseio de uma película antiga, tal qual desenrolando-o no sentido inverso ${ }^{461}$, para reconstituí-lo, melhor entendê-lo, a partir dos vestígios arranhados nos fotogramas ainda disponíveis na CB.

${ }^{461}$ Marc Bloch, op. cit., p. 67. 


\section{FONTES}

\section{Filmografia}

[Adhemar de Barros]. São Paulo: 193?. Fita de vídeo (3min), VHS, mudo, p\&b. VV 01560N. Cinemateca Brasileira.

Bandeirante da Tela, Ed. Especial - Nove de Julho no IV Centenário: Epopéia de Brasilidade. São Paulo: Divulgação Cinematográfica Bandeirante, 1954, Fita de Vídeo (10min54seg), VHS, sonoro, p\&b, VV00206. Cinemateca Brasileira.

Bandeirante da Tela n.372. São Paulo: Divulgação Cinematográfica Bandeirante, 1951. Fita de vídeo (8min55seg), VHS, sonoro, p\&b, VV00098. Cinemateca Brasileira.

Bandeirante da Tela n.415. São Paulo: Divulgação Cinematográfica Bandeirante, 1955. Fita de vídeo (5min40seg), VHS, sonoro, p\&b, VV00098. Cinemateca Brasileira.

Bandeirante da Tela n.416. São Paulo: Divulgação Cinematográfica Bandeirante, 1951. Fita de vídeo (6min47seg), VHS, mudo, p\&b, VV00048. Cinemateca Brasileira.

Bandeirante da Tela n.501. São Paulo: Divulgação Cinematográfica Bandeirante, 1952. Fita de vídeo (7min56seg), VHS, sonoro, p\&b, VV00098. Cinemateca.

Bandeirante da Tela n.521. São Paulo: Divulgação Cinematográfica Bandeirante, 1953. Fita de vídeo (8min), VHS, sonoro, p\&b, VV00098. Cinemateca Brasileira.

Bandeirante da Tela n.546. São Paulo: Divulgação Cinematográfica Bandeirante, 1953. Fita de vídeo (6min50seg), VHS, sonoro, p\&b, VV00048. Cinemateca Brasileira.

Bandeirante da Tela n.549. São Paulo: Divulgação Cinematográfica Bandeirante, 1953. Fita de vídeo (7min59seg), VHS, sonoro, p\&b, VV00048. Cinemateca Brasileira.

Bandeirante da Tela n.577. São Paulo: Divulgação Cinematográfica Bandeirante, 1954. Fita de vídeo (6min45seg), VHS, sonoro, p\&b, VV00099. Cinemateca Brasileira.

Bandeirante da Tela n.585. São Paulo: Divulgação Cinematográfica Bandeirante, 1954. Fita de vídeo (6min40seg), VHS, sonoro, p\&b, VV00048. Cinemateca Brasileira

Bandeirante da Tela n.588. São Paulo: Divulgação Cinematográfica Bandeirante, 1954. Fita de vídeo (6min3seg), VHS, sonoro, p\&b, VV00048. Cinemateca Brasileira.

Bandeirante da Tela n.591. São Paulo: Divulgação Cinematográfica Bandeirante, 1954. Fita de vídeo (6min14seg), VHS, sonoro, p\&b, VV00048. Cinemateca Brasileira. 
Bandeirante da Tela n.685. São Paulo: Divulgação Cinematográfica Bandeirante, 1955. Fita de vídeo (6min40seg), VHS, sonoro, p\&b, VV00048. Cinemateca Brasileira.

Bandeirante da Tela n.650. São Paulo: Divulgação Cinematográfica Bandeirante, 1955. Fita de vídeo (7min36seg), VHS, sonoro, p\&b, VV00098. Cinemateca.

Bandeirante da Tela n.669. São Paulo: Divulgação Cinematográfica Bandeirante, 1955. Fita de vídeo (7min), VHS, sonoro, p\&b, VV00099. Cinemateca Brasileira.

Bandeirante da Tela n.672. São Paulo: Divulgação Cinematográfica Bandeirante, 1955. Fita de vídeo (6min48seg), VHS, sonoro, p\&b, VV00099. Cinemateca Brasileira.

Bandeirante da Tela n.674. São Paulo: Divulgação Cinematográfica Bandeirante, 1955. Fita de vídeo (5min24seg), VHS, sonoro, p\&b, VV00099. Cinemateca Brasileira.

Bandeirante da Tela n.678. São Paulo: Divulgação Cinematográfica Bandeirante, 1955. Fita de vídeo (7min17seg), VHS, sonoro, p\&b, VV00099. Cinemateca Brasileira.

Bandeirante da Tela n.679. São Paulo: Divulgação Cinematográfica Bandeirante, 1955. Fita de vídeo (7min), VHS, mudo, p\&b, VV00099. Cinemateca Brasileira.

Bandeirante da Tela n.696. São Paulo: Divulgação Cinematográfica Bandeirante, 1955. Fita de vídeo (6min45seg), VHS, sonoro, p\&b, VV00099. Cinemateca Brasileira.

Bandeirante da Tela $\mathrm{s} / \mathrm{n}$ (Morte de Getúlio Vargas). São Paulo: Divulgação Cinematográfica Bandeirante, 1954, Fita de Vídeo (6min37seg), VHS, sonoro, p\&b, VV00683. Cinemateca Brasileira.

Cine Jornal Brasileiro vol.1, n.055. Rio de Janeiro: Departamento de Imprensa e Propaganda, 1939. Fita de vídeo (5min88seg), VHS, sonoro, p\&b, VV00047N. Cinemateca Brasileira.

Cine Jornal Brasileiro vol.1, n.083. Rio de Janeiro: Departamento de Imprensa e Propaganda, 1940. Fita de vídeo (6min76seg), VHS, sonoro, p\&b, VV00096M Cinemateca Brasileira.

Cine Jornal Informativo vol. 2, n.52. Rio de Janeiro: Agência Nacional, 1951. Fita de vídeo (9min23seg), VHS, sonoro, p\&b, Arquivo Nacional, Rio de Janeiro - RJ.

Cine Jornal Informativo vol. 3, n.35. Rio de Janeiro: Agência Nacional, 1952. Fita de vídeo (8min40seg), VHS, sonoro, p\&b, Arquivo Nacional, Rio de Janeiro - RJ.

Getúlio Vargas e Adhemar de Barros - visita a Goodyear. São Paulo: Rossi - Rex Film, 1938-1941. Fita de vídeo (6min14seg), VHS, mudo, p\&b. VV01581N.

Primeiro aniversário do Estado Novo. São Paulo: Garnier Film, 1938. Fita de vídeo (6min32seg), VHS, mudo, p\&b. VV00097. Cinemateca Brasileira. 


\section{Fontes orais}

SOUZA, Carlos Roberto de. Entrevista concedida na Cinemateca Brasileira, em São Paulo, em 27 de Outubro de 2004.

SCHWARCZ, Lilia Moritz. Palestra "Construindo uma identidade paulistana“, realizada no Centro de Integração Empresa - Escola, em São Paulo, em 05 de agosto de 2004.

BARRO, Máximo. Entrevista concedida na Biblioteca da Faculdade de Comunicação da FAAP, em São Paulo, em 19 de maio de 2005. Fita cassete (45min).

\section{Artigos e Periódicos}

\section{Hemeroteca - Cinemateca Brasileira}

“Complemento Nacional ou Publicidade?”, A Crítica de São Paulo de 16 a 23 de abril de 1959. Hemeroteca - Cinemateca Brasileira, pasta 995, doc. 2.

"Divulgação Cinematográfica Bandeirante S.A. - relatório da diretoria". Diário Oficial de São Paulo, 23 de fevereiro de 1962. Hemeroteca - Cinemateca Brasileira, pasta 997, doc. 73.

“Os jornais cinematográficos não acompanharam a evolução do cinema”, A Rua, São Paulo, 05 de outubro de 1955. Hemeroteca - Cinemateca Brasileira, pasta 78, doc. 6.

J. Pereira, diretor da Divisão de Diversões Públicas da Secretaria da Segurança de SP, "Justificando o injustificável", O Estado de S. Paulo, 27 de setembro de 1959. Hemeroteca - Cinemateca Brasileira, pasta 995, doc. 4.

"Lei contra nosso cinema". O Cruzeiro, São Paulo, 16 de abril de 1955. Hemeroteca Cinemateca Brasileira, pasta 155-1, doc. 9..

Marcos Maguliés, "Justificando o injustificável", O Estado de S. Paulo, 20 de setembro de 1959. Hemeroteca - Cinemateca Brasileira, pasta 995, doc. 3.

"Nossas homenagens ao governador eleito". Diário de São Paulo, 24.11.1962, p. 5. Hemeroteca - Cinemateca Brasileira, pasta 106, doc.1.

Primo Carbonari, Câmara do Poder. Jornal da Tela, Folha de São Paulo, 29 agosto 1977. pasta 316, doc. 4. Hemeroteca da Cinemateca Brasileira.

Waldemar Paiva, "Cine jornais" O Mundo, 01 de janeiro de 1955. Hemeroteca Cinemateca Brasileira, pasta 78, doc. 7 . 
"Programação do circuito de salas de cinema de São Paulo" Suplemento de Cine Revista, São Paulo, de 13 a 19 de março de 1957, Hemeroteca - Cinemateca Brasileira, documentação diversa 1395, doc. 4 .

Notícias nº 532. São Paulo: Primo Carbonari, 1964. Ficha Cens/I - Cinemateca Brasileira.

Notícias nº 547. São Paulo: Primo Carbonari, 1964. Ficha Cens/I - Cinemateca Brasileira.

\section{Fundo Adhemar de Barros}

Cédula do Partido Social Progressista.São Paulo, 1946. Caixa 631, pasta 02, doc. 003. Fundo Adhemar de Barros/APESP.

Livreto de marchas "Adhemar - Marcha", Clube infantil Adhemar de Barros. São Paulo, S/d. Caixa 631, pasta 02, doc. 006. Fundo Adhemar de Barros/APESP.

Livreto de marchas "O Maior”, Casa Manon S. A., São Paulo, sem data. Caixa 631, pasta 02, doc. 006. Fundo Adhemar de Barros/APESP.

Livreto de marchas "Parada Musical - Adhemar de Barros". Partido Social Progressista, sem data. Caixa 631, pasta 02, doc. 006. Fundo Adhemar de Barros/APESP.

Livreto de músicas "Adhemar de Barros - Bandeirante de uma nova geração", por Jaconias Cristosomo da Silva. São Paulo, s/d. Caixa 631, pasta 02, doc. 016. Fundo Adhemar de Barros/APESP.

Livreto de músicas "Parada Musical" pelo Depto. Musical do Comitê Nacional do Partido Social Progressista. Rio de Janeiro, s/d, Caixa 631, pasta 02, doc. 6. Fundo Adhemar de Barros/APESP.

Livreto de músicas "Patrícios e patrícias, para vocês eu vou contar! Alguns dos crimes, do grande 'líder Adhemar'!!!”. São Paulo, s/d. Caixa 631, pasta 02, doc. 006. Fundo Adhemar de Barros/APESP.

Panfleto "O abraço que uniu as forças populares contra a espoliação do povo", Partido Social Progressista e Partido Trabalhista Brasileiro. São Paulo, 1958. Caixa 638, pasta 03, doc. 001. Fundo Adhemar de Barros/APESP.

Panfleto "O Flagelo do Ademarismo", por Borba Gato. São Paulo, transcrito da "Folha Democrática" de Araraquara. São Paulo, 18 de agosto de 1951. Caixa 631, pasta 02, doc. 012. Fundo Adhemar de Barros/APESP.

Texto de locução para o programa Palestra ao Pé do Fogo. São Paulo, 1955. Caixa 634, pasta 02, doc. 014 - Fundo Adhemar de Barros/APESP. 
Texto de locução para televisão, campanha eleitoral para presidente. São Paulo, 1960. Caixa 634, pasta 002, doc 004 - Fundo Adhemar de Barros/APESP.

\section{Fundo DEOPS/SP (prontuários)}

101.018.- ALA NEGRA PROGRESSISTA.

105.237 - CENTRO CÍVICO ADHEMAR DE BARROS.

069.506 - PARTIDO SOCIAL PROGRESSISTA.

081274 - MANOEL OLIVEIRA.

081275 - MANOEL FRANCISCO DE OLIVEIRA.

081276 - PASCHOAL COSENZO.

081277 - JOSE MARTINS ALVARENGA.

081279 - LIDIA VELASCO.

081284 - ENCARNAÇÃO MILIANO.

081285 - CARMEN MILIANO.

081286 - MARIA P. DE OLIVEIRA.

081287 - PIEDADE CORDEIRO.

081288 - VICTORIA RODRIGUES CONTRARAS.

081289 - ESTHER RODRIGUE CONTRERAS.

081290 - MARIA DUARTE R. CONTRERAS.

081291 - ISABEL MARINO.

081292 - JOANA MARQUES.

081293 - ADELAIDE GETTE.

081294 - AURORA MARIM.

081295 - AVELINO MARCONDES SALES.

081296 - CEZARIO RUIZ MARQUES.

081297 - HENRIQUE FERNANDEZ.

081298 - FRANCISCO LUI.

081299 - RAMON RAMIL MIRANDA.

081300 - ROMILDA BUENO.

081301 - MARIA DE LOURDES MOURA.

081302 - LUIZ CARLOS MOURA BUENO.

081303 - WALDOMIRO GREGORIO.

081304 - FRANCISCO GREGORIO.

081305 - IVONE PAES.

081306 - NELSON PAES.

081307 - MARLENE GREGORIO.

081308 - LUIZA V. GREGORIO. 


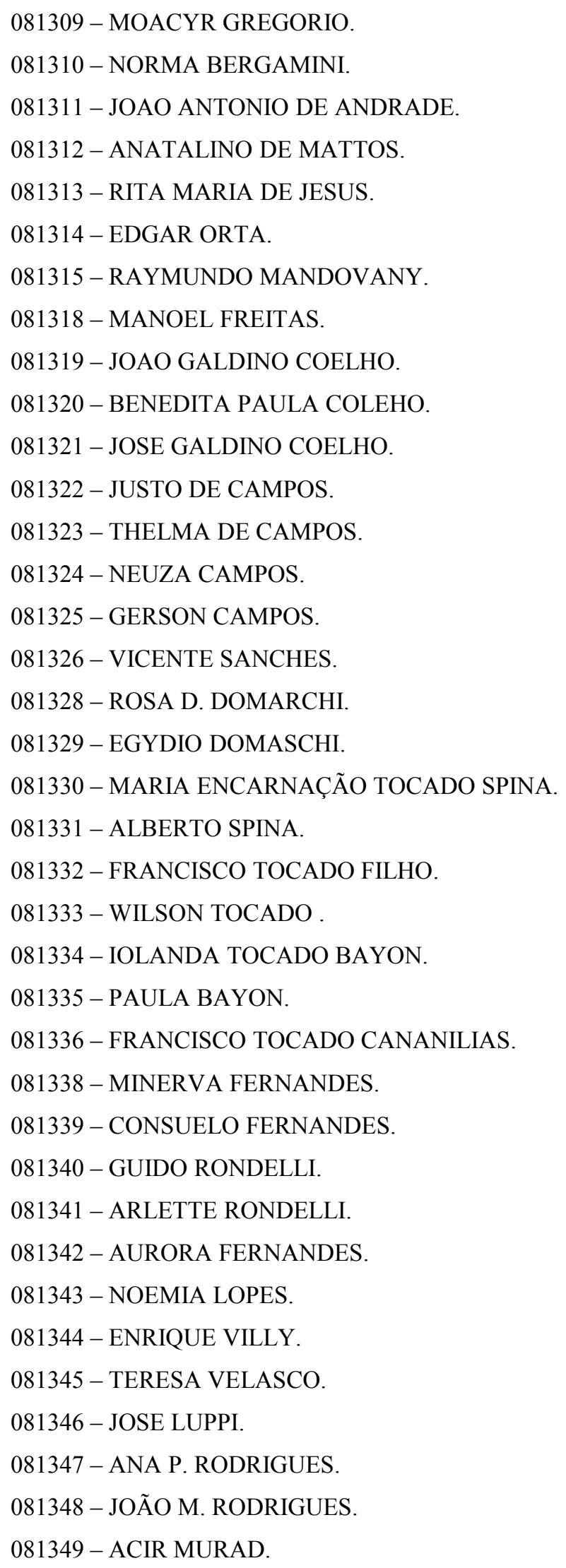




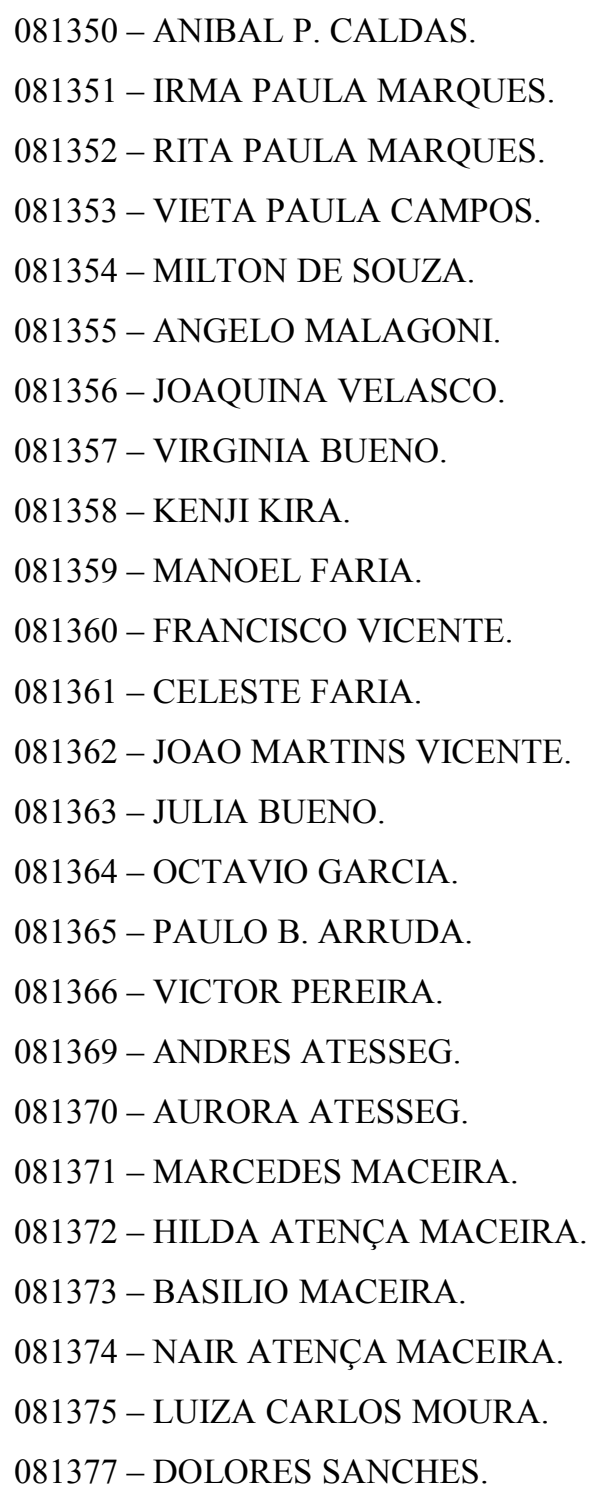

\section{ACERVOS E BIBLIOTECAS}

Arquivo Nacional, Rio de Janeiro - RJ

Arquivo Público do Estado de São Paulo, São Paulo - SP

Cinemateca Brasileira, São Paulo - SP

Escola de Comunicações e Artes - USP

Faculdade de Filosofia, Letras e Ciências Humanas - USP

Instituto de Estudos Brasileiros, São Paulo - SP 


\section{BIBLIOGRAFIA}

Obras

ABUD, Kátia Maria. O Sangue Intimorato e as Nobilíssimas Tradições - a construção de um símbolo paulista: o bandeirante. 1985. Tese (Doutorado em História Social) à Faculdade de Filosofia, Letras e Ciências Humanas da Universidade de São Paulo.

ADORNO. Theodor W.. "A Teoria Freudiana e o Padrão da propaganda Fascista" In Margem Esquerda, n.7. São Paulo: Boitempo, maio de 2006, pp. 164-89.

ALDGATE, Anthony. Cinema and History - British Newsreels and the Spanish Civil War. Lodon: Solar Press, 1979.

ALVES FILHO, Francisco Rodrigues. Um Homem Ameaça o Brasil: A História Secreta e Espantosa da "Caixinha” de Adhemar de Barros. São Paulo: 1954.

BALANDIER, Georges. O Poder em Cena. Brasília: Universidade de Brasília, 1982, p. 21.

BAZIN, André. O Cinema: Ensaios. São Paulo: Brasiliense, 1991.

BENI, Mário. Adhemar. São Paulo: Grafikor, 1973/4

BENJAMIN, Walter. "A Obra de Arte na Época de sua Reprodutibilidade" in Walter Benjamin, Magia e Técnica, Arte e Política. Tradução por Sérgio Paulo Rouanet. São Paulo: Brasiliense, 1985, pp. 165-196. (Obras Escolhidas 1).

BERNARDET, Jean-Claude. Cinema Brasileiro: Propostas para uma História. Rio de Janeiro: Paz e Terra, 1979, p. 27.

. Historiografia Clássica do Cinema Brasileiro. São Paulo: Annablume: Fapesp, 1995.

BETTON, Gerard. Estética do Cinema. São Paulo: Martins Fontes, 1987. (Coleção Opus 86).

BLOCH, Marc. Apologia da História. Rio de Janeiro: Zahar, 2002.

BOURDIEU, Pierre. O Poder Simbólico. Trad. Fernando Tomaz (Portugal). Rio de Janeiro: Bertrand Brasil, 1998.

. Pierre. Coisas Ditas. Tradução: Cássia R. da Silveira e Denise Moreno Pegorim. São Paulo: Brasiliense, 2004.

. Pierre. A Economia das Trocas Simbólicas. Introdução, organização e seleção: Sérgio Miceli, $6^{\text {a }}$ ed. São Paulo: Perspectiva, 2005. (Coleção Estudos). 
CANNABRAVA FILHO, Paulo. Adhemar de Barros: trajetórias e realizações. São Paulo: Terceiro Nome, 2004.

CAPELATO, Maria Helena. O Movimento de 1932: A Causa Paulista. $3^{\text {a }}$ ed. São Paulo: Brasiliense, 1981.

- Multidões em Cena. Propaganda Política no Varguismo e no Peronismo. Campinas: Papirus, 1998.

CARDOSO, Fernando Henrique. "Partidos e deputados em São Paulo (o voto e a representação)" In Bolívar Lamounier, Fernando Henrique Cardoso (coord.). Os Partidos e as Eleições no Brasil. Rio de Janeiro: Paz e Terra, 1978, pp. 45-75.

CENTRO de Documentação e Informação sobre Arte Brasileira Contemporânea. Carlos Ortiz e o Cinema Brasileiro na década de 50. Carlos E. O. Berriel (coord.). São Paulo: Idart, 1981.

CERTEAU, Michel de. A Cultura no Plural. Tradução Enid Abreu Dobránszky. Campinas: Papirus, 1995. (Coleção Travessia do Século).

CHAUÍ, Marilena. "Apontamentos para uma crítica da Ação Integralista Brasileira" In Marilena Chauí e Maria Sylvia Carvalho Franco. Ideologia e Mobilização Popular. Rio de Janeiro: Paz e Terra: Centro de Estudos de Cultura Contemporânea, 1978, pp. 17-149.

CHARTIER, Roger. "O Mundo Como Representação" In Estudos Avançados n $n^{\circ} 11$, vol.5. São Paulo, jan/abr.1991, pp. 173-191.

DAVINOFF, Carlos. Bandeirantismo Verso e Reverso. $8^{\text {a }}$ ed. São Paulo: Brasiliense, 1994.

DEBERT, Guita Grin. Ideologia e Populismo: A. de Barros, M. Arraes, C. Lacerda e L. Brizola. São Paulo: T.A.Queiroz, 1979.

FAUSTO, Boris. A Revolução de 30: História e Historiografia. São Paulo: Brasiliense, 1970.

FERRO, Marc. "O filme: uma contra-análise da sociedade?" In Jacque Le Goff e Pierre Nora (orgs.) História: Novos Objetos. Rio de Janeiro: Francisco Alves, 1976, pp. 202-230.

FONSECA, Pedro César Dutra. Vargas: O Capitalismo em Construção. São Paulo: Brasiliense, 1999.

FOUCAULT, Michel. A Ordem do Discurso - Aula Inaugural no Collége de France, Pronunciada a 2 de Dezembro de 1970; 4 ed.; tradução Laura Fraga de Almeida Sampaio. São Paulo: Edições Loyola, 1998. 
FRANCASTEL, Pierre Francastel, A Realidade Figurativa; tradução: Mary Amazonas Leite de Barros. 2 ed. São Paulo: Perspectiva, 1993. (coleção estudos, 21).

FRANCO, Maria Sylvia Carvalho. "O tempo das ilusões" In Marilena Chaú e Maria Sylvia Carvalho Franco. Ideologia e Mobilização Popular. Rio de Janeiro: Paz e Terra: Centro de Estudos de Cultura Contemporânea, 1978, pp. 151-209.

FRENCH, John. $O A B C$ dos Operários: Conflitos e Alianças de Classe em São Paulo, 1900-1950. São Paulo: São Caetano do Sul: Hucitec, 1995.

FURHAMMAR, Leif e ISAKSSON, Folk. Cinema \& Política. Rio de Janeiro: Paz e Terra, 1976.

GALVÃO, Maria Rita. Crônica do Cinema Paulistano. São Paulo: Ática, 1975. . "O desenvolvimento das idéias sobre cinema independente" In: Cinemateca Brasileira. Trinta Anos de Cinema Paulista: 1950-1980. São Paulo, 1980.

. Burguesia e Cinema: O Caso Vera Cruz. Rio de Janeiro: Civilização Brasileira, 1981.

- e BERNARDET, Jean-Claude. Cinema, Repercussões em Caixa de Eco Ideológica: as idéias de "nacional" e "popular" no pensamento cinematográfico brasileiro. São Paulo: Brasiliense, 1983. (O Nacional e o Popular na Cultura Brasileira, Cinema).

. e SOUZA, Carlos Roberto de. "Cinema Brasileiro: 1930 - 1964” In Boris Fausto (org.). O Brasil Republicano, v. 3: Economia e Cultura (1930-1964). São Paulo: Difel, 1984, pp. 463-500. (História Geral da Civilização Brasileira; t. 3, v. 3.).

GASKELL, Ivan Gaskell. "História das Imagens" In A Escrita da História: Novas Perspectivas. Peter Burke (org.). Tradução Magda Lopes. São Paulo: Editora da Universidade Estadual Paulista, 1992, pp. 199-256.

GIRARDET. Raoul. Mitos e Mitologias Políticas. São Paulo: Cia. das Letras, 1987.

GOMES, Ângela de Castro Gomes. "A política brasileira em busca da modernidade: na fronteira entre o público e o privado" In História da Vida Privada no Brasil: Contrastes da Intimidade Contemporânea. Fernando Novais (coordenador-geral da coleção); Lilia Moritz Schwarcz (organizadora do volume). São Paulo: Cia. das Letras, 1998, pp. 489-558.

. "O populismo e as ciências sociais no Brasil: notas sobre a trajetória de um conceito" In Jorge Ferreira (org.). O Populismo e sua História: Debate e Crítica. Rio de Janeiro: Civilização Brasileira, 2001, pp. 17-57.

GOMES, Paulo Emilio Salles. Entrevista concedida a Carlos Reichenbach, Inácio Araújo e Eder Manzini In Revista Cinema n. 01. Uma publicação do Centro Acadêmico Armando Salles Oliveira. Campos de São Carlos - USP, julho /1974.

. "A arte de não mostrar" In Paulo Emílio Salles Gomes. Crítica de Cinema no Suplemento Literário, vol. 1. Rio de Janeiro: Paz e Terra, 1981, pp. 284-87. 
. “A Expressão Social dos Filmes Documentais no Cinema Mudo Brasileiro (1898 1930)" In Carlos Augusto Calil e Maria Teresa Machado (orgs.). Paulo Emílio: Um Intelectual na Linha de Frente - Coletânea de Textos de Paulo Emilio Salles Gomes. São Paulo: Brasiliense: Rio de Janeiro: Embrafilme, 1986, pp. 323-328.

GOULART, Silvana. Sob a Verdade Oficial - Ideologia, Propaganda e Censura no Estado Novo. São Paulo: Marco Zero, 1990.

HAYASHI, Marli Guimarães. A Gênese do Adhemarismo. 1996. Dissertação (mestrado em História Social) Faculdade de Filosofia, Letras e Ciências Humanas da Universidade de São Paulo.

HISTÓRIA e Multidisciplinaridade: territórios e deslocamentos. Anais do XXIV Simpósio Nacional de História. São Leopoldo, 2007. Associação Nacional de História ANPUH / Unisinos, 2007. 1 CD-Rom.

HOBSBAWN, Eric J. "A produção em massa das tradições: Europa, 1870 a 1914” In Eric J. Hobsbawn e Terence Ranger (org.). A Invenção das Tradições. Trad. Celina Cardim Cavalcante. Rio de Janeiro: Paz e Terra, 1997, pp. 271.316.

IANNI, Octávio. O Populismo na América Latina. Rio de Janeiro: Civilização Brasileira, 1975.

. O Colapso do Populismo no Brasil. Rio de Janeiro: Civilização Brasileira, 1978.

JAGUARIBE, Hélio et. al. "O que é o Adhemarismo?" In Câmara dos Deputados. $O$ Pensamento Nacionalista e os "Cadernos do Nosso Tempo". Seleção e introdução por Simon Schwartzman. Distrito Federal: Universidade de Brasília, 1981, p. 23-30.

JEANNENEY, Jean-Noel. "A Mídia” In René Rémond (org.). Por uma História Política. Trad. Dora Rocha. Rio de Janeiro: FVG, 2003, pp. 213-230.

KOSSOY, Boris. Realidades e Ficções na Trama Fotográfica. São Paulo: Ateliê Editorial, 2000.

"O relógio de Hiroshima: reflexões sobre os diálogos e silêncios das imagens" In Revista Brasileira de História vol. 25, $n^{\circ}$ 49, Dossiê: História e Manifestações Visuais. São Paulo: ANPUH, jan-jun, 2005, pp. 35-42.

KRACAUER, Siegfried. "The Conquest of Europe on the Screen. The Nazi Newsreel (1939-1940)". Nova Iorque, mimeo, 1947.

“O espectador” In Filme e Cultura n. 1, v. 1. São Paulo, out. 1966, pp. 27-38.

. De Caligari a Hitler - Uma História Psicológica do Cinema Alemão. Tradução Tereza Ottoni. Rio de Janeiro: Jorge Zahar Editor, 1988.

LAMOUNIER, Bolívar e CARDOSO, Fernando Henrique (coord.). Os Partidos e as Eleições no Brasil. Rio de Janeiro: Paz e Terra, 1978.

LARANJEIRA, Carlos. Histórias de Adhemar. São Paulo: Carlos Laranjeira, 1990. 
LENHARO, Alcir. Sacralização da Política. Campinas: Editora da UNICAMP, 1986.

LEUTRAT, Jean-Louis. "Uma relação de diversos andares: cinema e história" In Revista Imagens $n^{\circ}$ 5. São Paulo: Campinas: Unicamp, ago/dez. 1995, pp.28-32.

LOVE, Joseph. A Locomotiva: São Paulo na Federação Brasileira (1889 - 1937). Tradução Vera Alice Cardoso da Silva. Rio de Janeiro: Paz e Terra, 1982.

MACHADO JR., Rubens. São Paulo em Movimento - A Representação Cinematográfica da Metrópole nos Anos 20. 1989. Dissertação (Mestrado na área de Artes). Departamento de Cinema, Rádio e Televisão da Escola de Comunicações e Artes da Universidade de São Paulo.

. "São Paulo e o Seu Cinema: para uma história das manifestações cinematográficas paulistas (1899 - 1954) In Paulo Porta (org.). História da Cidade de São Paulo: a Cidade no Império. Vol. 2. São Paulo: Ministério da Cultura / Paz e Terra. 2004, pp. 457-505.

MARX, Karl..O 18 Brumário e Cartas a Kugelmann, 7.ed. Tradução Leandro Konder e Renato Guimarães. Rio de Janeiro: Paz e Terra, 1997.

MERGEL, Thomas. "Algumas Considerações a Favor de Uma História Cultural da Política" In História - Unisinos: Revista do Programa de Pós-Graduação em História da Universidade do Vale do Rio dos Sinos Vol. 7, $N^{o}$ 8. São Leopoldo: 2003, pp. 11-55.

MOOG, Vianna Moog, Bandeirantes e Pioneiros: Paralelo Entre Duas Culturas. $14^{\mathrm{a}}$ ed.. Rio de Janeiro: Civilização Brasileira, 1983.

MORETTIN, Eduardo Victorio. "Quadros em Movimento: o uso das fontes iconográficas no filme Os Bandeirantes (1940), de Humberto Mauro" In Revista Brasileira de História, vol. 8, n.35. Dossiê: Arte e Linguagens. São Paulo: ANPUH / Marco Zero, 1998, pp.105-31.

. "O Cinema Como Fonte Histórica na Obra de Marc Ferro" In História: Questões e Debates, ano 20, n.38. Paraná: Associação Paranaense de História (APAH) / UFPR, jan/jun, 2003. pp. 11-42.

NOVAIS, Fernando e MELLO, João Manuel Cardoso de. "Capitalismo tardio e sociabilidade moderna" In História da Vida Privada no Brasil: Contrastes da Intimidade Contemporânea. Fernando Novais (coordenador-geral da coleção); Lilia Moritz Schwarcz (organizadora do volume). São Paulo: Cia. das Letras, 1998, pp. 559-658.

PESAVENTO, Sandra Jatahy. História e História Cultural, 2 ed. Belo Horizonte: Autêntica, 2005. (História \&... Reflexões). 
PIERCE, Charles Sanders. Semiótica e Filosofia. Octanny Silveira Mota e Leônidas Hegenberg (trad., sel. e org.). São Paulo: Cutrix, 1993.

QUINTILIANO, Marco Fábio. Instituições Oratórias. Tradução por Jerônimo Soares Barbosa. São Paulo: Cultura, 1944. (Clássica Universal).

RAMALHO, João. A Administração Calamitosa do Snr. Adhemar de Barros em SP. Rio de Janeiro: 1941.

REMOND, René. "Uma História Presente" In René Rémond (org.). Por uma História Política. Trad. Dora Rocha. Rio de Janeiro: FVG, 2003, pp. 13-6.

. "As Eleições" In René Rémond.(org.). Por uma História Política. Trad. Dora Rocha. Rio de Janeiro: FVG, 2003, pp. 37-55.

REISZ, Karel e MILLAR, Gavin. A Técnica da Montagem Cinematográfica; Tradução: Marcos Maguliés, apresentação: Alberto Cavalcanti; Rio de Janeiro: Embrafilme / Civilização Brasileira, 1977. (Cinebiblioteca Embrafilme).

REY, Marcos. "O Adhemarista” In Roniwalter Jatobá (org.). Trabalhadores do Brasil: Histórias Cotidianas do Povo Brasileiro. São Paulo: Geração Editorial, 1998, pp. 205-17.

SAES, Décio A. M. “Classe média e política no Brasil: 1930 - 1965” In Ângela Maria de Castro Gomes et. tal. O Brasil Republicano, v. 3: Sociedade e Política (1930 1964). Rio de Janeiro: Bertrand Brasil, 2003, (História geral da civilização brasileira; t. 3; v.3), pp. 447-506.

SALIBA, Elias Thomé. "Histórias, memórias, tramas e dramas da identidade paulistana" In Paulo Porta (org.). História da Cidade de São Paulo: a Cidade na Primeira Metade do Século XX. Vol. 3. São Paulo: Ministério da Cultura / Paz e Terra. 2004, pp. 555-87.

SAMPAIO, Regina. Adhemar de Barros e o PSP. São Paulo: Global, 1982.

SANCHES-BIOSCA, Vicente. Teoria Del Montaje Cinematográfico. Valência: Filmoteca Generalitat Valenciana / IVAECM, 1991. (Coleção Textos).

. Cine de Historia Cine de Memória - La Representación y Sus Límites. Madrid: Cátedra, 2006. (Sigo e Imagem).

SCHAWARZ, Roberto. “Cultura e política, 1964-1969” in Cultura e Política. São Paulo: Paz e Terra, 2005, pp. 7-58.

SIMIS, Anita. Estado e Cinema no Brasil. São Paulo: Annablume/Fapesp, 1996.

SIMÕES, Inimá Ferreira. Salas de Cinema em São Paulo. Col. João Abdalla Saad Neto et. al.. São Paulo: PW/ Sec. Mun. de Cultura/ Sec. Est. da Cultura, 1990. 
SONTAG, Susan. Sobre Fotografia. Tradução Rubens Figueiredo. São Paulo: Cia. das Letras, 2004, p. 96.

SOUZA, Carlos Roberto de. "Newsreels and newsreels cataloguing at the Cinemateca Brasileira" In Roger Smither, Wolfgang Klaue. Newsreels in Film Archive: A Survey Based on the FIAF Newsreels Symposium. Wiltshire: Flicks Books, 1998, pp. 98-105.

SOUZA, José Inácio de Melo. Ação e o Imaginário de uma Ditadura: Controle, Coerção e Propaganda Política nos Meios de Comunicação Durante o Estado Novo. 1990. Dissertação (mestrado em Comunicações) Escola de Comunicações e Artes, USP, São Paulo.

. Filmografia do Cinema Brasileiro: O Estado de São Paulo 1947-1949. São Paulo: Cinemateca Brasileira, 1994.

."Eleições e Cinema Brasileiro: Do Fósforo Eleitoral aos Santinhos Eletrônicos" In Revista da USP $n^{o} 22$ - Dossiê Futebol. São Paulo: USP, jun/jul/ago 1994, pp. 155-65.

. "Trabalhando com Cinejornais: relato de uma experiência" In História: Questões e Debates n. 38, ano 20. Paraná: Associação Paranaense de História / UFPR, jan-jun 2003, pp. 43-62.

- O Estado Contra os Meios de Comunicação (1889 - 1945). São Paulo: Annablumme: Fapesp, 2003.

. "Os Congressos de Cinema" In Congressos, Patriotas e Ilusões e Outros Ensaios de Cinema. São Paulo: Linear B, 2005, pp. 9-121.

. "Eleições e Cinema Brasileiro: Do Fósforo Eleitoral aos Santinhos Eletrônicos" In Congressos, Patriotas e Outros Ensaios de Cinema. São Paulo: Linear B, 2005, pp. 223-41.

TOMAIM, Cássio. "O filme documentário entre a realidade e a ficção: uma proposta de desmistificação" In Revista Olhar, ano 6, n'10-11; jan-jul e ago-dez, 2004, p. 27-47.

TRANCHE, Rafael R. e SANCHES-BIOSCA, Vicente. NO-DO: El Tiempo y La Memoria. Presentación José María Otero. 3. ed. Madrid: Cátedra/Filmoteca Española, 2001.

TUCK, Richard. "História do Pensamento Político" In Peter Burke (org.). A Escrita da História: Novas Perspectivas. Tradução Magda Lopes. São Paulo: Editora da Universidade Estadual Paulista, 1992, pp. 273-89.

VOVELLE, Michel. Imagens e Imaginário da História - fantasmas e certezas nas mentalidades desde a Idade Média até o séc. XX. Trad. Maria Júlia Goldwasser. São Paulo: Ática, 1977.

- Michel. Ideologias e Mentalidades. Trad. Maria Julia Cottvasser. São Paulo: Brasiliense, 2004.

WAINBERG, Jacques A.“A voz de Deus: um estudo da narração de cinejornais em tempos de guerra - a persuasão audiovisual de um povo" In Intercom - Revista Brasileira de Comunicação n. 2, vol. XV. São Paulo: jul/dez, 1992, pp. 144-66. 
WEFFORT, Francisco C. "Razões sociais do populismo em São Paulo" In Revista Civilização Brasileira n. 2. Rio de Janeiro: Civilização Brasileira, 1965, pp. 39-60. . O Populismo na Política Brasileira. Rio de Janeiro: Paz e Terra, 1980, pp.15-44.

WINOCK, Michel. "As Idéias Políticas" In René Rémond (org.). Por uma História Política. Trad. Dora Rocha. Rio de Janeiro: FVG, 2003, pp. 271-94.

XAVIER, Ismail. O Discurso Cinematográfico: a Opacidade e a Transparência. São Paulo: Paz e Terra: 2005.

Obras de referência

CINEMATECA Brasileira. Cine Jornal Brasileiro: Departamento de Imprensa e Propaganda, 1938-1946. São Paulo: Cinemateca Brasileira / Imprensa Oficial do Estado, 1982.

. Bandeirante da Tela. Introdução de Carlos Roberto de Souza; apresentação de José Inácio de Melo Souza. São Paulo: Cinemateca Brasileira / IPHAN, 1991.

DICIONÁRIO HISTÓRICO-BIOGRÁFICO BRASILEIRO PÓS-30. 2. ed. ver. amp. Coordenação: Alzira Alves de Abreu et. al. Rio de Janeiro: FGV; CPDOC, 2001, $5 \mathrm{v}$.

RAMOS, Fernão e MIRANDA, Luiz Felipe (orgs). Enciclopédia do cinema brasileiro. Colaboração de Afrânio Mendes Catani et al. São Paulo: SENAC, 2000. p. 134.

Sites

http://www.cinemateca.com.br.

http://www.adhemar.debarros.nom.br

SÃO PAULO Outrora e Agora: Informações sobre a população da capital paulista, do século XIX ao século XXI. Jan. 2004. Disponível em $<$ http://www.seade.gov.br/produtos/spoutragora $>$. Acesso em: 23 de ago. 2007. 


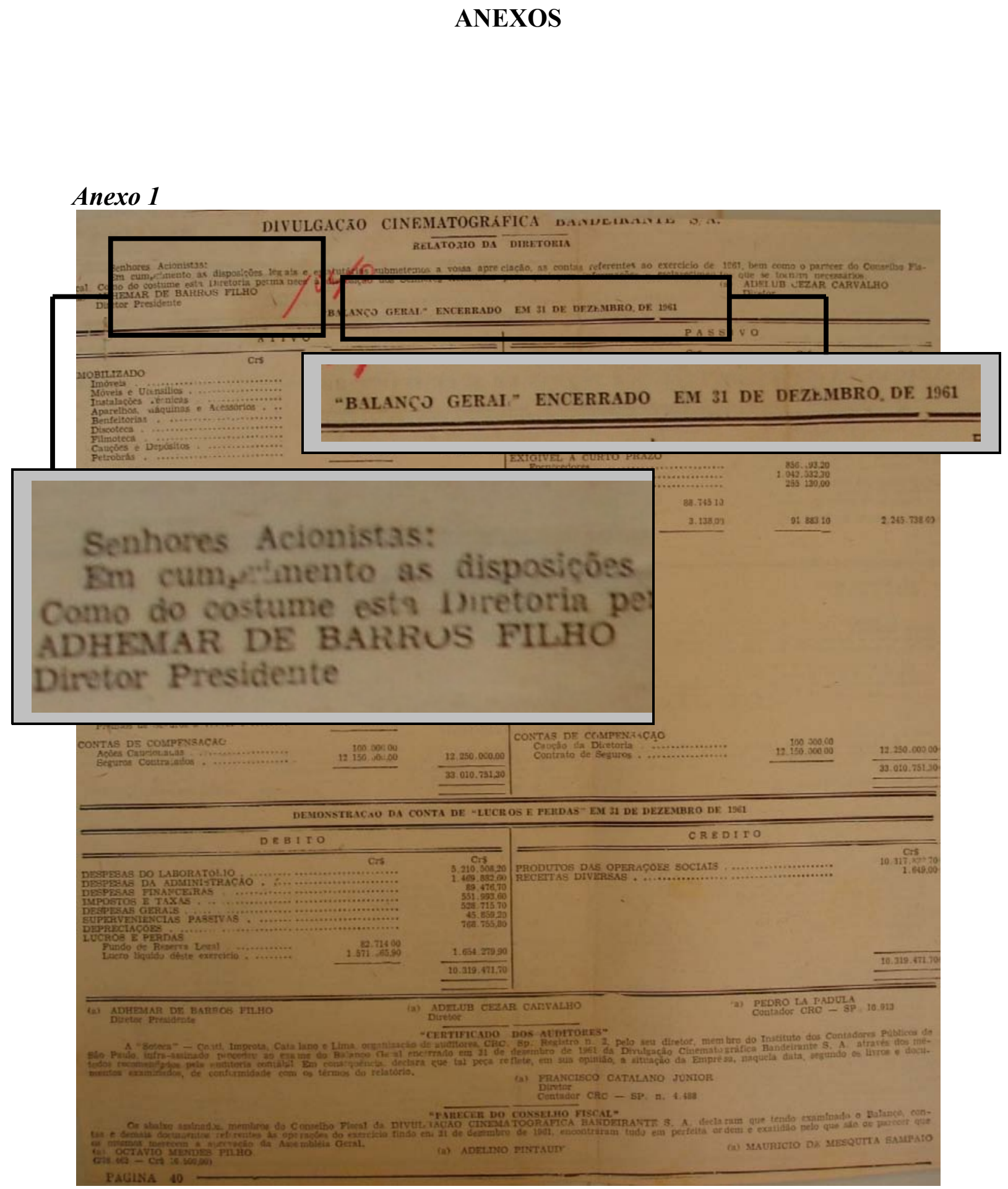

“Divulgação Cinematográfica Bandeirante S.A. - Relatório da Diretoria". Diário Oficial de São Paulo, 23 de fevereiro de 1962. Pasta 997, doc. 73. Hemeroteca Cinemateca Brasileira. 
Anexo 2

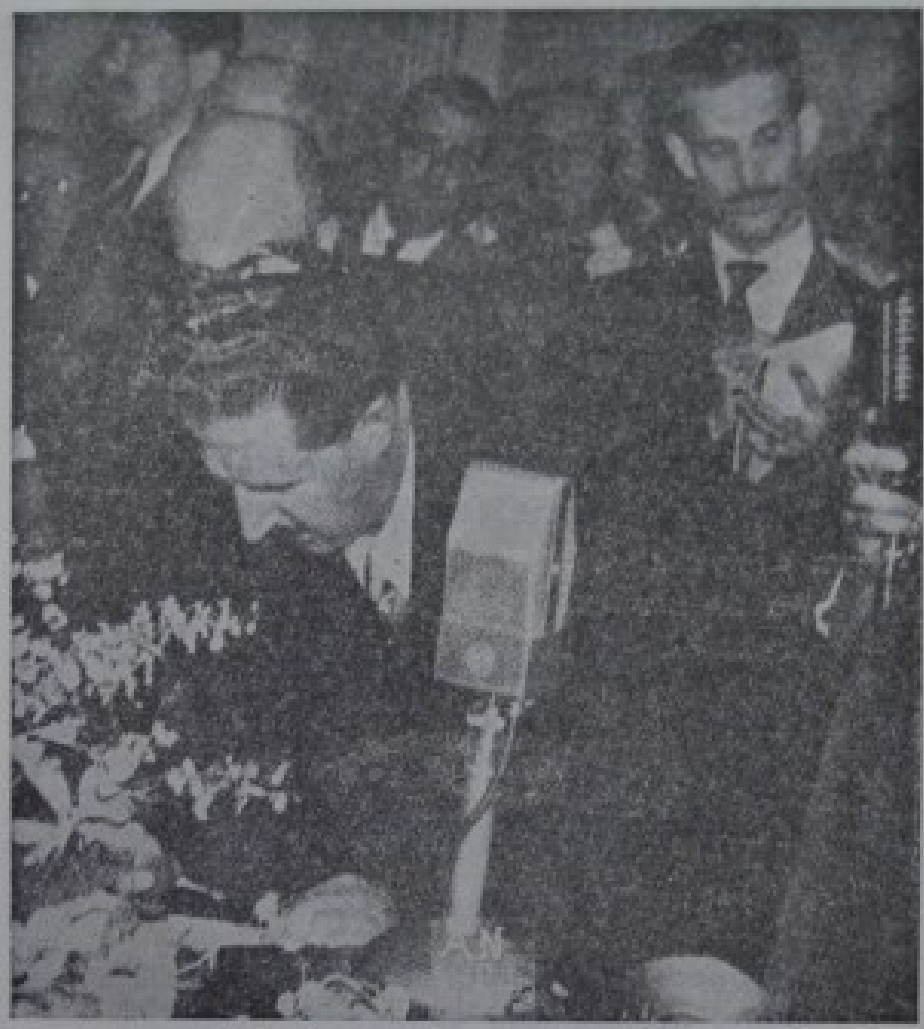

O Governador Bandeirante Assina

- Livro de Posse

菲菲

Patricios e Patricias,

Para vocês vou Contar!

Alguns dos Crimes,

Do Grande "Lider Adhemar"!!!

Livreto de músicas "Patrícios e patrícias, para vocês eu vou contar! Alguns dos crimes, do grande 'líder Adhemar'!!!”. São Paulo, s/d. Caixa 631, pasta 02, doc. 006. Fundo Adhemar de Barros/AESP. 


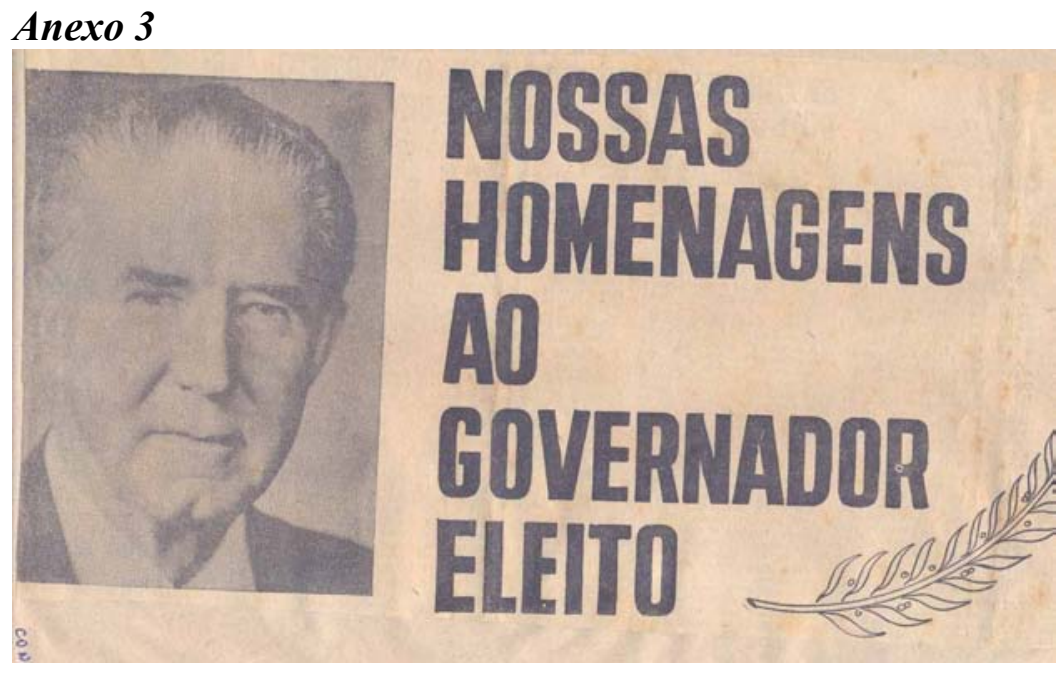

Empresas homenageantes: Empresa Cinematográfica Bandeirante Ltda; Hermantino Coelho - Serviço de Divulgação Cinematográfica; Pelmex Películas Mexicanas do Brasil S.A.; Condor Filmes Ltda.; Empresa Cine Kikkatsu; Empresa Cine Niterói S.A.; Orbis Filmes; Cinedistri Limitada; IRPA Filmes Ltda.; Líder Cinematográfica Ltda.; Jaime Scvartman Rotbart; Cine Marrocos; Paris Filmes Produtora e Distribuidora Cinematográfica Ltda.; PAM Films S.A.; Companhia Primo Carbonari; Companhia Nacional
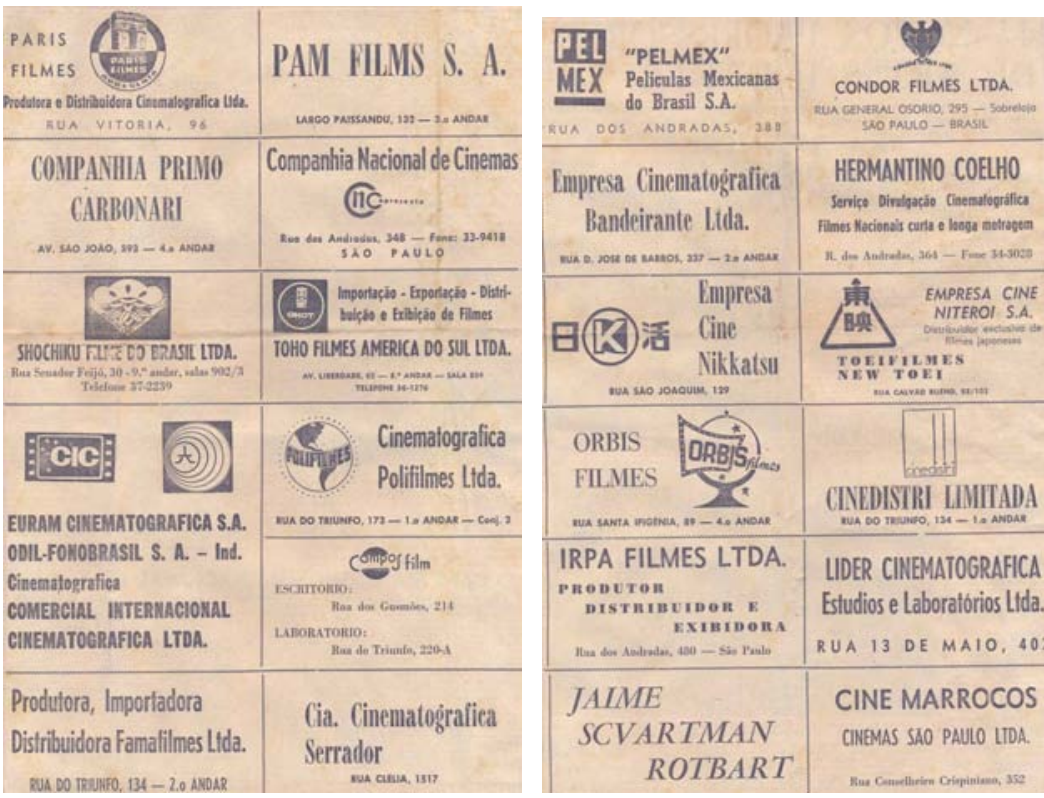
de Cinemas; Shochiku Filme do Brasil Ltda.; Toho Filmes América do Sul Ltda.; Euram Cinematográfica S.A.; OdilFonobrasil S.A.; CIC - Comercial Internacional Cinematográfica Ltda.; Cinematográfica Polifilmes Ltda.; Campos Films; Famafilmes Ltda.; Cia. Cinematográfica Serrador; Empresa de Cinema Rio Ltda.; Empresa de Cinema Jairê Vianna Ltda; Empresa de Cinema Eldorado; Empresa de Cinema Callas e Lucas Ltda; Empresa de Cinema Icaraí Ltda; os diretores: Nadim Callas e Magalhães Rodrigues Lucas; Cine Dom Bosco; Cine Cristal; Cine Itaim; Empreza Lamanna \& Lopes Ltda;

\begin{tabular}{|c|c|c|c|}
\hline 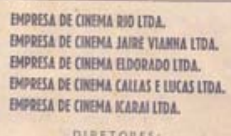 & 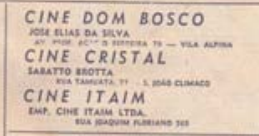 & 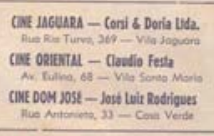 & 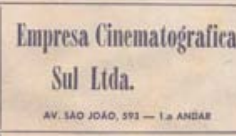 \\
\hline 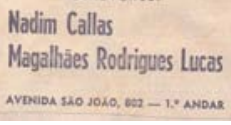 & 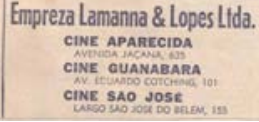 & 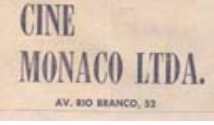 & 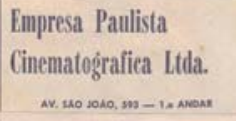 \\
\hline
\end{tabular}
Cine Jaguara; Cine Oriental; Cine Dom José; Empresa Cinematográfica Sul Ltda; Cine Mônaco Ltda; Empresa Paulista Cinematográfica Ltda.

“Nossas homenagens ao governador eleito". Diário de São Paulo, 24.11.1962, p. 5. Pasta 106, doc.1. Hemeroteca - Cinemateca Brasileira. 


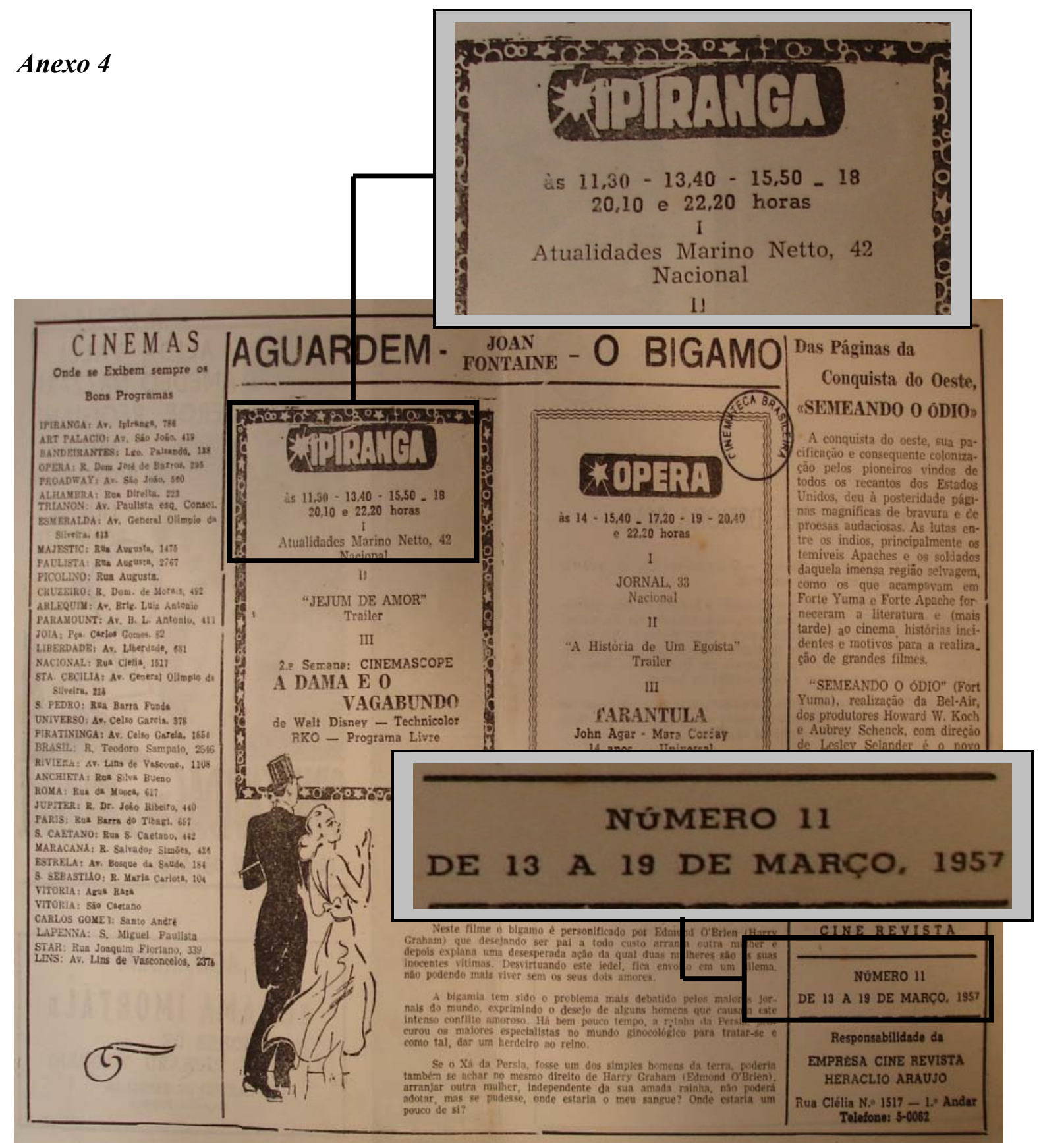

"Programação do circuito de salas de cinema de São Paulo". Suplemento de Cine Revista, São Paulo, de 13 a 19 de março de 1957. Documentação diversa 1395, doc. 4. Hemeroteca - Cinemateca Brasileira 


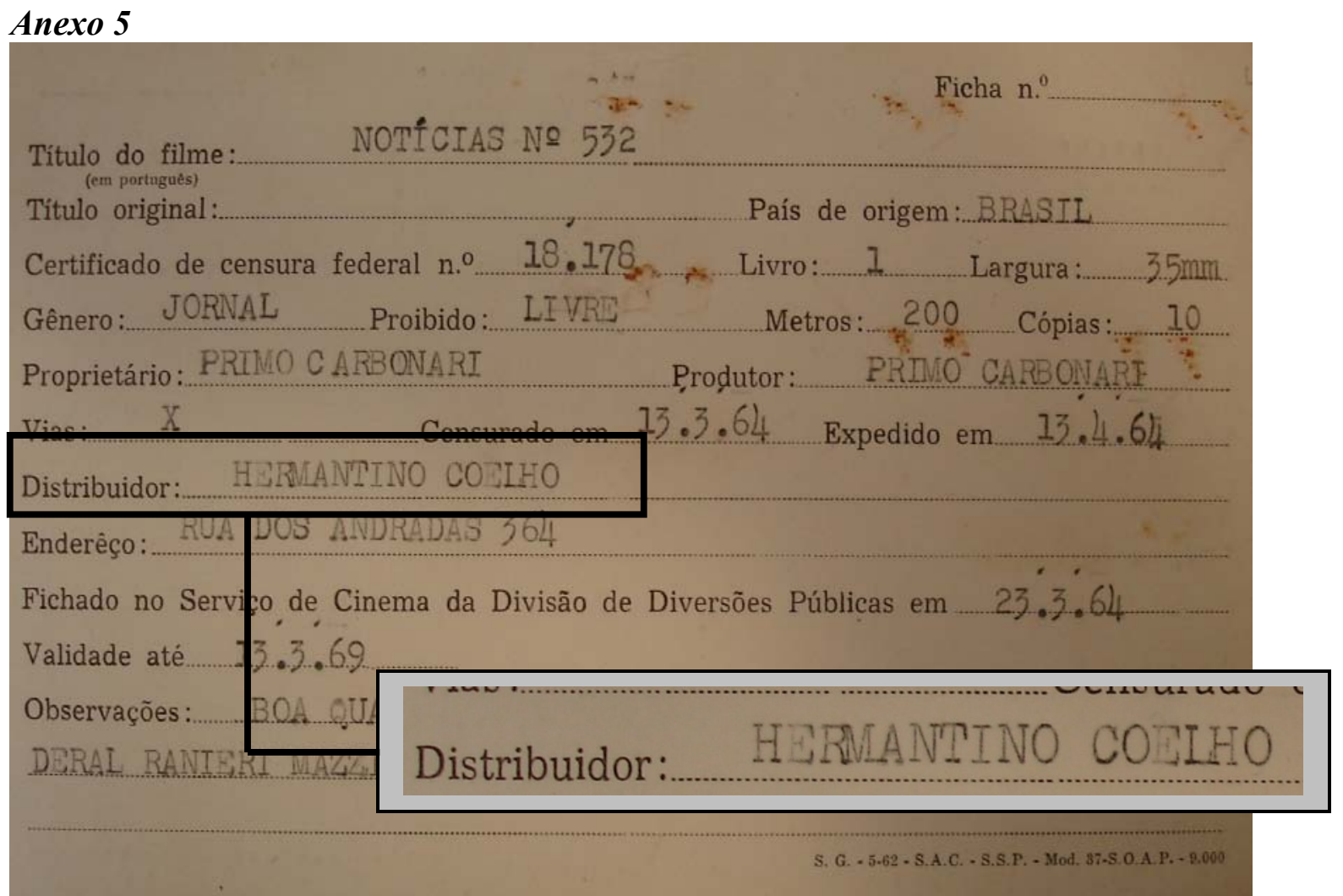

Notícias n 532. São Paulo: Primo Carbonari, 1964. Ficha Cens/I - Cinemateca Brasileira. 


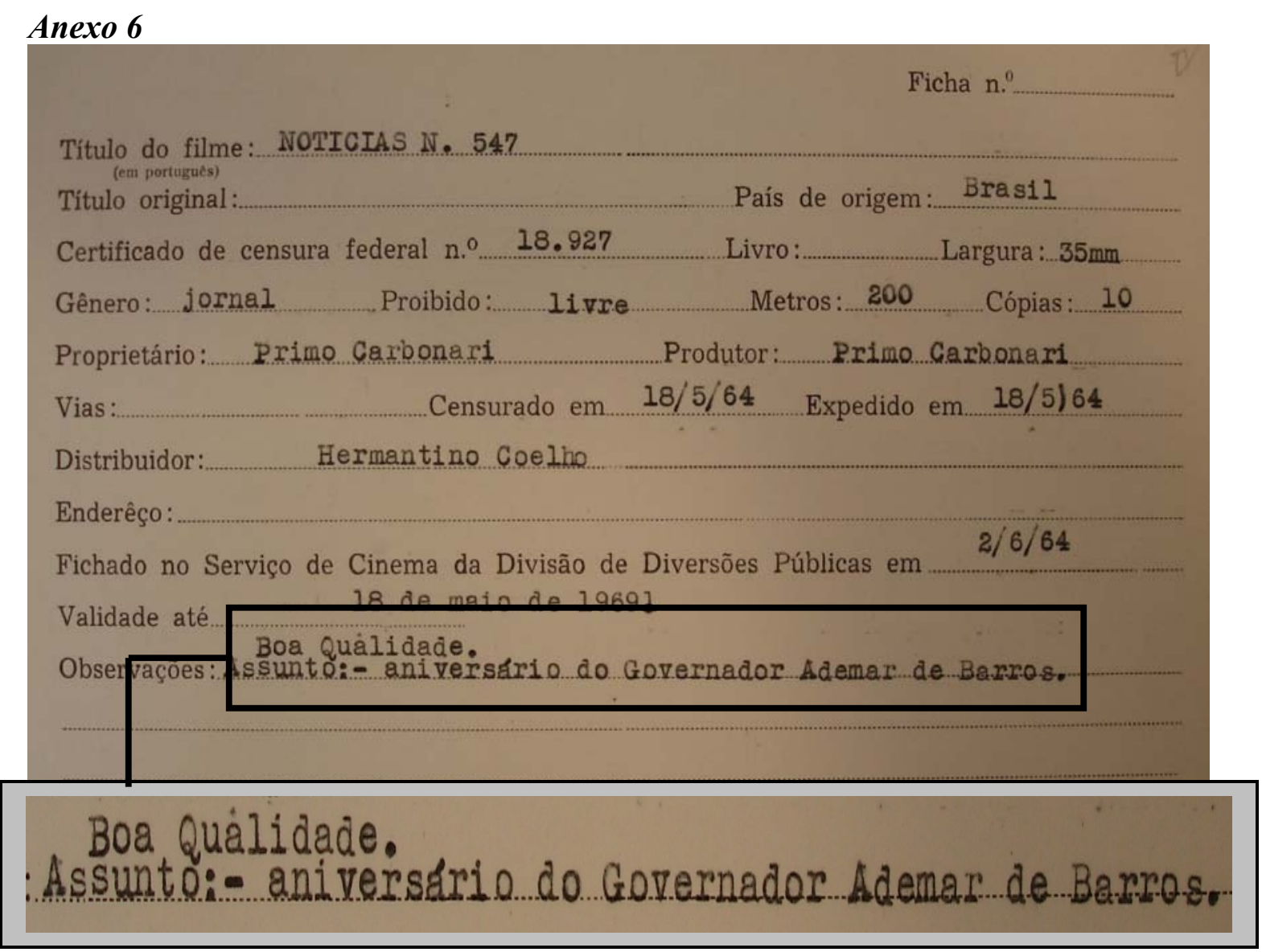

Notícias no 547. São Paulo: Primo Carbonari, 1964. Ficha Cens/I - Cinemateca Brasileira. 


\section{Descrição de imagem e sistematização ${ }^{462}$ do Bandeirante da Tela.}

Abreviaturas dos movimentos e enquadramentos de câmera.

PAN

Panorâmica

PPL

..Primeiríssimo Plano

PP. Primeiro Plano

MF. Meia Figura

PA Plano Americano

PM Plano Médio

PG. Plano Geral

GPG Plongée

Plongée. Plongée

CPlongée Travelling

\footnotetext{
${ }^{462}$ A sistematização aqui adotada segue o padrão utilizado pela CB à indexação da sua base de dados. Assim sendo, as palavras-chave utilizadas em termos descritores tentam abarcar informações num nível mais imediato do assunto apresentado nas imagens. Já em termos livres, procuramos elencar informações peculiares ao registro fílmico, como, por exemplo, nomes próprios de um evento, datas comemorativas; localidades, cidades, clubes ou associações; Ou mesmo nomes de esportes mais específicos, pessoas e lugares que são apenas citados e não aparecem no evento filmado.
} 
Bandeirante da Tela Edição Especial. São Paulo: Divulgação Cinematográfica Bandeirante, 1954. Fita de vídeo (10min54seg), VHS, sonoro, p\&b, VV00206. Cinemateca Brasileira.

\section{Dados técnicos:}

\section{Outros títulos:}

9 DE JULHO EM S. PAULO NO IV CENTENÁRIO EPOPÉIA DE BRASILIDADE

\section{Elenco:}

Loureiro, Paulo Rolim;

Silva, Ademar Ferreira da;

Monteiro, Edmundo;

Marino Neto (narração).

\section{Distribuição:}

Hermantino Coelho.
1) "Divulgação Cinematográfica Bandeirante" /

"Bandeirante da Tela" /

"Edição Especial"..... $. .00: 00-00: 19)$

2) "9 de Julho em São Paulo IV Centenário Epopéia de Brasilidade". .(00:20 - 10:50)

3) "Fim" .$(10: 51-10: 54)$

[1] "Divulgação Cinematográfica Bandeirante" / "Bandeirante da Tela" / "Edição Especial".

[2] "9 de Julho em São Paulo IV Centenário - Epopéia de Brasilidade" / Cplongée em PG de prédios, numa PAN que segue girando e se detém em um deles, descendo verticalmente / PAN que segue registra a concentração de militares na frente do Pátio do colégio / PA músicos batendo tambores na banda militar / Fachada de prédio público / Rápida tomada das autoridades civis e militares chegando no local da solenidade, Garcez passa quase despercebido / PA de autoridades militares / PA de anciã chegando / PM da banda / Tomada da facha de prédio público, a mesma mostrada anteriormente / MF de militar hasteando bandeira nacional / PM da banda / Anciã com "mais de cem anos" hasteia bandeira de São Paulo / Criança hasteia bandeira de São Paulo / PP das bandeiras do Brasil e de São Paulo tremulando / Tomadas em PA da Banda dos Fuzileiros / PM das escadarias da Sé ocupadas por moças militares que carregam bandeiras de São Paulo e do Brasil / Tomadas em diversos planos de meninas vestidas de anjinhos descendo as escadas / Pan em PM do coral / PP de homens (da imprensa?) / PM da imagem de N.S. Aparecida sendo conduzida para missa / PAN em MF de autoridades eclesiásticas acompanha de moça oficial / PG da entrada da catedral da Sé enfeitada de bandeiras paulistas / PAN em PG da concentração de pessoas em frente a catedral / MF de autoridade eclesiástica / PP de crucifixo / MF de autoridade eclesiástica em oração / tomadas em GPG da multidão concentrada / PG da fachada de prédio Faculdade de Direito com o brasão do estado / Cenas do centro da cidade com grande concentração de pessoas / Tomadas em diversos planos do desfile de batedores do Exército e da Força Pública / Diversos planos do desfile das bandas do Distrito Federal, cidades do interior de São Paulo, da Força Pública, entre outras, tendo ao fundo o Viaduto do Chá / PAN de mulheres em PA: "as bandeirantes" / PG de chuva de papel picado / Desfile de estudantes norteamericanos da Miami Jackson High Scool ("trazidos pela rádio Bandeirante") / Planos da performance dos músicos e das balizas / À noite, cplongée do céu e alguns prédios e sinais luminosos / Planos em PG do céu com "chuva de prata" e fogos de artifícios / Av. Nove de Julho, à noite, tomadas em PM e PP do desfile de batedores e da polícia montada / Desfile do Corpo de Bombeiros / Desfile dos ex-combatentes da FEB; representações de escoteiros; banda da Força Pública; militares da aeronáutica; e alegoria e banda dos alunos do colégio Caetano de Campos / Alunos desfilam com bandeira de São Paulo / Atleta Ademar Ferreira da Silva desfila representando o esporte / Alunos, a pé ou em bicicletas, de clubes e associações como o Pinheiros, o Corinthians e o Palmeiras / PAN em GPG do estádio do Pacaembu com suas arquibancadas lotadas e atrações circenses no gramado / PM de palhaços fazendo fanfarrice / Tomadas em PG de trapezistas / PG das arquibancadas lotadas / Ginástica rítmica coordenada, exibição da Escola de Educação Física / Palhaço da perna de pau / PP de garotos na grade do estádio / Tomadas de uma partida de futebol entre palhaços / Tomadas do "Globo da morte" / PG do "circo" montado no gramado do Pacaembu / Diversos planos do céu, à noite, com queima de fogos / Pirotecnia com o emblema da Associação das Rádios de São Paulo / Rápida PAN da cascata de fogos de artifícios / Diversas tomadas da queima de fogos.

г27 "Cim"

Termos descritores: Efeméride; Revolução 32; Cidade; São Paulo - SP; Desfile; Igreja Católica; Universidade; Exército; Polícia; Visita estrangeira - US; Corpo de Bombeiros; Escola; Futebol; Circo; Espetáculo; Rádio.

Termos livres: Força Pública; Caetano de Campos; Av. Nove de Julho, São Paulo - SP; Estádio do Pacaembu, São Paulo - SP; Associação das Rádios de São Paulo; Rádio Bandeirantes; Miami Jackson High Scool; S. E. Palmeiras; S. C. Corinthians; Pinheiros - clube. 
Bandeirante da Tela Edição Especial. São Paulo: Divulgação Cinematográfica Bandeirante, 195-. Fita de vídeo (7min26seg), VHS, sonoro, p\&b, VV00099. Cinemateca Brasileira.

\section{Dados técnicos:}

Outros títulos: O DIA DO TRABALHADOR

Texto: Marino Neto.

Câmera: Jairo Vanco.

Direção: Plínio Garcia Sanchez.

Elenco:

Marino Neto (narração).

Distribuição:

Hermantino Coelho.
1) "Divulgação Cinematográfica Bandeirante" /

"O Dia do Trabalhador" /

"Filme dedicado aos trabalhadores brasileiros por ocasião do $1^{\circ}$ de Maio".........(00:00 - 00:44)

2) [Sem intertítulos]...... (00:45 - 07:14)

3) "Fim" / "Executado nos laboratórios Bandeirantes"... $(07: 15-07: 26)$

[1] "Divulgação Cinematográfica Bandeirante apresenta" / PAN em PG de uma fábrica até o céu onde aparecem os letreiros "O Dia do Trabalhador", "Filme dedicado aos trabalhadores brasileiros por ocasião do $1^{\circ}$ de Maio"; "texto e narração: Marino Neto"; "câmera: Jairo Vanco"; "direção: Plínio Garcia Sanchez".

[2] PAN desce do céu até uma obra em PG (seria uma ponte?) / Sobreposição de imagem (fusão) de cartaz sobre o $1^{\circ}$ de Maio com o plano de multidão e uma escultura (de um homem com duas crianças?) / PG de uma mansão (prédio público?) / Autoridade eclesiástica e outras pessoas em recinto fechado / Estádio arquibancadas em PG e ao céu uma revoada de pássaros / PG da arquibancada com pessoas e um enorme mapa do Brasil / PG em perspectiva de um prédio público com um relógio (Estação da Luz?) com carros passando na rua / Planos das pessoas subindo e descendo escadas, num movimento de uma estação ferroviária / Pessoas saem do trem / PP das rodas do trem que começam a se movimentar sobre os trilhos / PG de chaminé de uma fábrica / PG do portão de uma fábrica com operários entrando para um turno / $O$ mesmo plano, mais fechado / PAN do interior de uma fábrica têxtil / Operário trabalhando / Planos do setor de fundição(?) onde o ferro derretido, líquido, é despejado em outro recipiente / Trabalhadores manuseando material em estado superaquecido / Operário martelando o mesmo material, forjando uma peça / Diversos planos de operários manuseando líquido metálico (o ferro derretido) alimentando forno de alta temperatura / Plano da caçamba sendo retirada após ter despejado o ferro (?) líquido / PP de operário apertando parafuso em trilho / Operário instalando linha ferroviária / PAN em PG que se desloca de operários trabalhando até o topo de um prédio em construção / Funcionários na construção civil / PG de pessoas numa feira-livre (?) / Banca de carnes / Outras bancas / MF de homem montado num cavalo caracterizado como um vaqueiro gaúcho / PG de um "laçada" no gado / Pescadores retirando jangada do mar / Barco chegando na praia / Planos do trabalho dos jangadeiros retirando um cesto (?) do mar, exibindo peixes / Carro acidentado / O mesmo carro visto pelo ângulo de trás / PAN acompanhando uma ambulância até o estacionamento (um hospital?) / Plongée de uma sala de cirurgia com os médicos realizando uma operação / PAN de pessoas no escritório, fecha em um homem que lê jornal, fecha na capa do jornal "Diário Oficial - Diário do Executivo - Governo do Estado" / Professora e aluna escrevendo na lousa / PAN da sala de aula com meninas / PAN de um homem segurando uma escada até o outro, no topo da mesma escada, consertando fios no poste / PAN perseguindo os trabalhadores operando máquinas, guindastes / Container sendo transportado por guindaste / Trabalhador operando guindaste / Guindaste transportando caixas / PG de vários guindastes / Três pessoas numa sala ouvindo rádio / PP do rádio / Pan de homens jogando bocha / Bexigas em PP, seguindo em PAN para um menino / Casal com bebê, no colo da mãe, passeia numa plataforma sobre a água / Menino chega até esse casal / Pessoas passeando de barco / Partida de futebol / PG de estátua em estádio com efeito de transposição (fusão) com outra estátua em outro ponto da cidade, também em PG / PG dessa mesma estátua / PG de prédios em São Paulo / GPG aéreo da cidade à noite.

[3] "Fim" / "Executado nos laboratórios Bandeirante".

Termos descritores: Efeméride; Trabalho; Ferrovia; Igreja Católica; Comércio; Pecuária; Fazenda; Pesca; Medicina; Imprensa; Escola; Indústria; Têxtil; Metalurgia; Rádio; Futebol; Monumento; Engenharia; São Paulo - SP.

Termos livres: Feira-livre; Estação da Luz, São Paulo - SP; Diário Oficial do Estado de São Paulo. 
Bandeirante da Tela n. 074. São Paulo: Divulgação Cinematográfica Bandeirante, 1946-51. Fita de vídeo (11min37seg), VHS, sonoro, p\&b, VV01152. Cinemateca Brasileira.

\section{Dados técnicos:}

Elenco:

Silva, Lisandro Pereira da;

Barros, Adhemar de;

Prestes, Lineu;

Marino Neto (narração).

Distribuição:

Hermantino Coelho.
1) "Serviço de Divulgação Cinematográfica" /

"Divulgação Cinematográfica Bandeirante" /

"N LXXIV Bandeirante da Tela"...(00:00 - 00:20)

2) "Administração Pública"

$(00: 21-11: 33)$

3) "Fim".

$(11: 34-11: 37)$

[1] "Serviço de Divulgação Cinematográfica" / "Divulgação Cinematográfica Bandeirante" / "N LXXIV Bandeirante da Tela".

[2] "Administração Pública" / Seis fotos de pontos distintos da cidade de São Paulo durante um alagamento ocorrido em 1929 / PP de uma imagem de um canal (?) realizado para escoar água / PA de um homem que aponta, num esquema fixo na parede, para as sinuosidades do Rio Tietê e, no mesmo quadro mais abaixo, demonstra como ficará o Rio Tietê depois da sua retificação e da construção de duas marginais que o acompanhará ao logo do seu percurso / GPG aéreo de Osasco / Tomadas em PG e em PAN sobre o Rio Tietê em trechos com margens arborizadas / Mais planos do Tietê / PAN em PG de casas, em Osasco, à beira do rio, a futura Vila Leonor / PG de balsa sobre o rio / PM da mesma balsa com um carro / PA de Adhemar e comitiva observando algo / PAN em PG de estrutura de ferro para construção de ponte por sobre o Tietê / PAN em PG de trabalhadores na construção dos alicerces da ponte, deslocando-se ao fundo onde um trem passa / Mais trecho em retificação / Adhemar e comitiva caminhando por sobre os andaimes / GPS aéreo sobre a Freguesia do Ó e a Lapa / Escavadora extraindo rochas para a retificação do trecho da Lapa / PG da comitiva que observa os trabalhos da escavadora, conforme revela a PAN que se segue em PG/ GPG aéreo sobre o bairro do Limão / GPG aéreo do trecho do Tietê entre Freguesia do Ó e Casa Verde / PG de uma margem do rio / PAN em PG da construção da Ponte do Limão / PAN em PG de homens trabalhando na construção de alicerces para a construção de ponte / Outra tomada em PM do mesmo trabalho / PM de homem martelando a escora do alicerce / PG da comitiva reunida no local da obra, em que técnicos fornecem explicações / PA de Adhemar e comitiva / GPG aéreo do trecho do Tietê onde está sendo construída a ponte da Casa Verde / PAN em PG do rio / PAN da construção da Ponte das Bandeiras / PG em Cplongée de Adhemar e Lineu Prestes que inspecionam a obra / PAN em PG de rua com carros que passam até as obras de construção da ponte / PAN em PG das obras da ponte em construção, com homens trabalhando / GPG aéreo sobre regiões com obras de retificação do rio / PG de homens abrindo canal / PM e PP dos trabalhos do trator removendo terra / PG da draga "Pires do Rio" em funcionamento / Plano mais aberto da draga / PG do prefeito Lineu Prestes e mais dois homens que caminham por ponte flutuante que leva até a draga / PAN acompanha o trabalho de escavadora / PAN em PG de ponte sobre o rio Tietê, tendo duas torres ao fundo (Clube de Regatas Tietê?).

[3] "Divulgação Cinematográfica Bandeirante - Fim - narrador: Marino Neto".

Termos descritores: Desastre natural; Saneamento; Cidade; São Paulo - SP; Rio; Engenharia; Osasco - SP.

Termos livres: Enchente; Rio Tietê, São Paulo - SP; Rio Pinheiros, São Paulo - SP; Freguesia do Ó, São Paulo - SP; Lapa, São Paulo - SP; Casa Verde, São Paulo - SP; Bairro do Limão, São Paulo - SP; Ponte do Limão; Ponte das Bandeiras, São Paulo - SP; Ponte Tietê, São Paulo - SP; Clube de Regatas Tietê. 
Bandeirante da Tela n. 334. São Paulo: Divulgação Cinematográfica Bandeirante, 1951. Fita de vídeo (5min9seg), VHS, sonoro, p\&b, VV00098. Cinemateca Brasileira.

Dados técnicos:

1) "Bandeirante da Tela"

(00:00 - 00:04)

Elenco:

Henreid, Elisabeth; Afonso, Rui; Garcez, Lucas

2) "Crônica Social"

$(00: 05-01: 21)$

Nogueira; Beni, Mário; Almeida, Joaquim Canuto

3) "Comemorações Cívicas"

Herschel V.; Marino Neto (narração).

4) "Visitantes Ilustres"

$(04: 22-05: 05)$

Distribuição:

Hermantino Coelho.

5) "Conheça sua Terra"

(05:06 - 05:09)

[1] "Bandeirantes da Tela".

[2] "Crônica Social" / PG da noiva caminhando de encontro à câmera, sendo acompanhada para o altar, tem à frente dama de honra / PA do noivo recebendo a noiva no altar / PA dos noivos sendo casados pelo padre / PAN vertical sobre o véu da noiva / PA do governador Garcez ao lado de outro homem / PM de mais alguns convidados / MF em perspectiva dos noivos / PG dos convidados / Troca de alianças / PM de Garcez cumprimentando os noivos / PM dos noivos sendo cumprimentados pelos convidados / PP da noiva / PP do noivo / PG dos noivos saindo da Igreja / GPG da saída dos convidados da Igreja / PAN até o alto da catedral.

[3] "Comemorações Cívicas" / PAN de duas mulheres, uma delas carregando a bandeira do Brasil, ao fundo, banda e púbico / PG de enfermeiras (?) desfilando em duas filas paralelas / Autoridades no palanque / Desfile de moças segurando bandeiras / MF de Mário Ferraz (diretor do Depto. Regional do SESI) entre duas mulheres / Moças desfilando uma ao lado da outra formando, com as letras em suas camisetas, a palavra "(?)" / Dois homens no palanque (autoridades?)/ Desfile com moças segurando estandartes e a bandeira de São Paulo / Desfile de carro alegórico com motivos do SESI em homenagem a Roberto Simonsen e Morvan Dias Figueiredo / Garotos vestidos de "operários" desfilam empurrando a "maquete de novas realizações" / Desfile de banda / Três homens (autoridades?) observam do palanque / Homens desfilando com uma bandeira do Brasil / Homem portando a bandeira nacional / Moças e rapazes desfilando com a bandeira nacional e segurando faixas de apoio ao SESI / Garotinho uniformizado desfila como jogador de futebol segurando uma bola e uma bandeirinha do Brasil / PAN da multidão no Anhangabaú observando o desfile, que continua com desfile de outros rapazes (atletas?) / Boxeadores desfilando / Mais moças e carros alegóricos / Carro com motivos do SENAI / Atletas agasalhados desfilando / Carro da rainha dos operários / PP da rainha dos operários / PP de Mariano Ferraz falando ao microfone / Autoridades no palanque aplaudem / PP de uma moça e a bandeira do estado de São Paulo.

[4] "Visitantes Ilustres" / PG de homem que chega e sai de carro oficial, guarda perfilada (dragões?) / PM do embaixador americano e outras autoridades nas escadas do palácio Campos Elíseos / PP do embaixador / No interior do palácio, cumprimentos entre oficialidades / PA de Garcez e o embaixador / PAN da sala com senhoras sentadas, participando da solenidade / PP de duas senhoras no sofá (seria, uma delas, a mulher de Garcez?) / Garcez, o embaixador e outro homem adentram o recinto onde estão as senhoras / Conversam / PP do embaixador / PP de Garcez / Embaixador e Garcez conversam com as senhoras.

「51 "Conhera cı la Terra" / Nãn há imanem rorrecnnnndente

Termos descritores: Casamento; Igreja Católica; Desfile; Indústria; Trabalho; Ensino; Esporte; Diplomacia - US.

Termos livres: Anhangabaú, São Paulo - SP; Primeiro de Maio; SESI - Serviço Social dá Indústria; palácio dos Campos Elíseos, São Paulo - SP. 
Bandeirante da Tela n. 372. São Paulo: Divulgação Cinematográfica Bandeirante, 1951. Fita de vídeo (8min55seg), VHS, sonoro, p\&b, VV00098. Cinemateca Brasileira.

\begin{tabular}{|c|c|}
\hline Dados técnicos: & 1) [Certificado de Censura].............(00:00 - 00:03) \\
\hline $\begin{array}{l}\text { Elenco: } \\
\text { Barros, Adhemar de; } \\
\text { Costa, Lopo Alvares da; } \\
\text { Puch, Juan; } \\
\text { Pereira, Armando de Arruda; } \\
\text { Assunção, Alexandre Zacarias de; } \\
\text { Marino Neto (narração). }\end{array}$ & $\begin{array}{l}\text { 2) "Serviço de Divulgação Cinematográfica" / } \\
\text { "Bandeirante da Tela" / } \\
\text { "372"'......................................(00:04 - 00:34) } \\
\text { 3) "Conheça sua Terra"...................(00:35 - 07:19) } \\
\text { 4) "Noticiário da Agência Nacional" . (07:20 - 08:54) }\end{array}$ \\
\hline $\begin{array}{l}\text { Distribuição: } \\
\text { Hermantino Coelho. }\end{array}$ & 5) "Fim"........................................... $08: 55$ - 08:55) \\
\hline
\end{tabular}

[1] Certificado de Censura / "Serviço de Divulgação Cinematográfica" / "Bandeirante da Tela" / "372".

[2] "Conheça sua Terra" / Adhemar de Barros cercado de autoridades pronto para entrar no carro aberto que levanta a capota / PPL de Adhemar de Barros / Adhemar de Barros e homem entram e sentam no carro / Carro em movimento com Adhemar de Barros e outro homem (prefeito de Belém ou governador do Pará?) / Carro em direção à câmera, precedido de batedor de motocicleta em rua enfeitada e com populares ao redor / Mais populares / Adhemar de barros e o governador Assumpção em pé no carro saúdam os presentes / Mais populares / PAN da praia (Baía do Guajará), com alguns barcos, até a catedral de Belém / PP de uma estátua / PG da mesma estátua numa praça, com a catedral ao fundo / PP de alguns detalhes da igreja / PAN do carro oficial manobrando numa rua da periferia da cidade, ao fundo pessoas andando em direção à câmera / PM e PAN de Adhemar em meio aos populares (praticamente crianças) / PAN dos populares mostrando casas pobres e o carro oficial sendo observado por esses populares / PG de um cais(?) / PG do "Forte do Castelo" / PG de alguns barcos ancorados / Mais barcos ancorados no cais / Mais barcos ancorados / PG das docas com o movimentos de pessoas / PAN do mercado (municipal?) de "Ver o peso", com o movimento de pessoas / PAN da feira próxima de Belém próxima ao cais, com movimento de pessoas / PP d um homem com tabuleiro na cabeça, ao fundo outros homens escolhendo frutas(?) / Pessoas comprando vasos de cerâmica, que estão empilhados / PP dos vasos, ornamentados pelos moradores, que estão à venda / PP de mulher comprando, escolhendo um vaso / Mercadora vendendo macaxeira / PP de vendedor ostentando sua mercadoria: urucum / Mercadora mostra uma garrafa e um ramo de ervas de sua barraca de ervas medicinais, ao fundo pessoas escolhem ervas / PP das ervas e de suas vendedoras com chapéus enormes / PAN do "restaurante" da feira, composto por barracas / PP de mulher preparando o tacacá / Crianças, mulheres e homens comendo o tacacá / "Praça Batista de Campos", diversos planos mostrando o jardim, o coreto da praça, passarela e lagos / GPG da cidade e a caixa d'água central / PAN da cidade e seus prédios e estabelecimentos, caixa d'água presente / Adhemar de Barros despedindo-se de autoridades locais(?) / PP de Adhemar de Barros cumprimentando autoridade eclesiástica(?) / Mais autoridades locais(?) / Planos de avenidas e prédios da cidade.

[3] "Noticiário da Agência Nacional" / Companhia do Batalhão de Guardas, na "Praça San Martin" no Jardim América, presta continência às autoridades: dois homens caminham na frente das tropas / Embaixador argentino acompanhado de oficial / Cumprimentos entre as autoridades militares / Embaixador e militares posam para câmera / Salva de tiro de canhões / Embaixador descerra o busto do Gal. San Martim / PP do busto / PP das escrituras na estátua: "Libertador General José de San Martin" à cidade de São Paulo homenagem da coletividade Argentina 17 de agosto 1954 (?) / PM do busto e do embaixador e outro homem, sob o pedestal / PG das autoridades e o busto ao centro / PP do embaixador discursando / PP Adhemar de Barros entre autoridades civis e militares / Embaixador cumprimenta Adhemar de Barros / Discurso (oração?) do prefeito Armando Arruda Pereira / Autoridades ouvem, entre elas Adhemar de Barros e o embaixador, ambos em destaque / Discurso de autoridade militar / Desfile da Escola Preparatória de Cadetes / PA de Adhemar de Barros e o embaixador entre autoridades.

[4] "Fim".

Termos descritores: Cidade; Belém - PA; Pesca; Igreja Católica; Habitação; Comércio; Alimentação; Abastecimento; Diplomacia - AR; Solenidade; Monumento; Desfile; Exército.

Termos livres: Mercado Municipal "Ver-O-Peso", Belém - PA; Baía do Guajará, Belém - PA; Forte do Castelo, Belém PA; Praça Baptista de Campos, Belém - PA; Praça San Martin, Jardim América, São Paulo - SP; Escola Preparatória de Cadetes. 
Bandeirante da Tela n. 375. São Paulo: Divulgação Cinematográfica Bandeirante, 1951. Fita de vídeo (1min22seg), VHS, sonoro, p\&b, VV01152. Cinemateca Brasileira.

\section{Dados técnicos:}

Elenco:

Garcez, Lucas Nogueira;

Barros, Adhemar de;

Marino Neto (narração).

Distribuição:

Hermantino Coelho.
1) "Divulgação Cinematográfica Bandeirante S/A - Noticiário Semanal Cinematográfico da Sucursal da Agência Nacional em São Paulo". (00:00 - 01:21)

3) [Sem intertítulo] $(01: 22-01: 20)$

2) "Fim". $(01: 21-01: 22)$

[1] "Divulgação Cinematográfica Bandeirante S/A - Noticiário Semanal Cinematográfico da Sucursal da Agência Nacional em São Paulo".

[2] PM de Garcez descendo de um trem e sendo recepcionado por populares e militares em Araraquara-SP, em ocasião do seu $134^{\circ}$ aniversário / PM de Garcez sendo conduzido no meio da multidão / PA do governador e comitiva andando na estação ferroviária e cumprimentando mulheres, crianças que balançam bandeirinhas e oficial que presta continência / PG do governador, comitiva e autoridades locais que posam para uma foto / PP do governador cominando entre a população / Tomada em PM da câmera que capta o governador e sua comitiva que passam diante da câmera, seguidos de Adhemar de Barros / PP de Adhemar e Garcez sentados em carro, alternando tomadas em TRV das ruas da cidade com a população que observa - Adhemar ao centro e Garcez ao lado / PG de palanque montado na cidade, com Adhemar e Garcez ao centro / O mesmo planos, porém mais fechado, de Garcez e Adhemar, este cumprimentando as pessoas que lhe estendem os braços / PG da população reunida em uma praça / PG do palanque com autoridades locais, Adhemar e Garcez que discursa / PA em plongée de Adhemar, no palanque, soltando uma "baforada" de fumaça de cigarro / PA de Adhemar conversando com Garcez, e passando por detrás do governador que é cumprimentado pelos demais no palanque.

[3] "Fim".

Termos descritores: Efeméride; Cidade; Araraquara - SP; Ferrovia.

Termos livres: Aniversário de Araraquara - SP, 134. 
Bandeirante da Tela n. 396. São Paulo: Divulgação Cinematográfica Bandeirante, 1951. Fita de vídeo (8min41seg), VHS, sonoro, p\&b, VV00098. Cinemateca Brasileira.

\section{Dados técnicos:}

Elenco:

Marino Neto (narração).

Distribuição:

Hermantino Coelho.
1) "Serviço de Divulgação Cinematográfica" / "Bandeirante da Tela" / "396".....(00:00 - 00:29)

2) "Brasil x Mortalidade Infantil".....(00:30 - 08:39)

3) "Fim". $(08: 40-08: 41)$

[1] "Serviço de Divulgação Cinematográfica" / "Bandeirante da Tela" / "396".

[2] "Brasil x Mortalidade Infantil" / PAN das chaminés das fábricas ao amanhecer (?) / Portão da fábrica com operárias entrando / MF de mulher trabalhando em maquinário / Vários planos de operárias trabalhando em diversas atividades na fábrica: com embalagens e máquinas / PG da entrada da "Maternidade Condessa Filomena (?) / Entrada da Maternidade São Paulo / Arco da "LBA - Hospital Maternal e da Infância - Leonor Mendes de Barros" / Consultório com médico atendendo uma mulher (mãe?) / Criança sendo vacinada / Enfermeira olhando em microscópio / Nascimento de uma criança, médico corta o cordão umbilical e passa o menino à enfermeira que aplica os procedimentos necessários e enrola a criança na toalha / Mães com crianças entram na maternidade / Crianças no berço / Médico examina neném / Mães dando de comer às crianças / Mães saem da maternidade em direção à câmera, ostentando suas crianças / Mãe entrega sua criança à freira que adentra à creche e coloca-a no berço em ambiente com muitas crianças (bebês) / PP de duas crianças no berço (uma negra e outra branca, "desde pequenas as crianças mostram-se diferentes") / Diversos planos de bebês brincando juntos ou separadamente / PAN do parque onde crianças brincam / Brincadeiras de roda / Balanço / Escorregador / Trepa-trepa / Gira-gira / Crianças brincando, algumas com bambolê / Meninos tomando banho / meninos sentados na fila (?) / Mesa com crianças tomando leite (?) / PAN de sala recreativa, com crianças sentadas em grupos às mesas, praticando atividades como recortar, desenhar e pintar / Montando bloquinhos / Crianças folheando livro com gravuras / Sala de aula com meninas / Menina escrevendo na lousa / Criança sendo examinada / Mulher preparando refeição / Crianças perfiladas entrando em refeitório / Recreio / Fila da merenda / PP de uma menina e um menino, ambos comendo merenda / Crianças sentadas comendo a merenda / Criança em tratamento odontológico / Crianças praticando exercícios físicos, vários planos / Desfile de jovens (moças e rapazes) / carro alegórico com brasão da república.

[3] "Fim".

Termos descritores: Criança; Saúde; Mulher; Trabalho; Criança; Brinquedo; Escola; Medicina; Desfile.

Termos livres: São Paulo - SP; Aleitamento; Maternidade; LBA - Legião Brasileira de Assistência; Maternidade São Paulo; Playground; Hospital Maternal e da Infância Leonor Mendes de Barros; Berçário. 
Bandeirante da Tela n. 415. São Paulo: Divulgação Cinematográfica Bandeirante, 1951. Fita de vídeo (5min40seg), VHS, sonoro, p\&b, VV00098. Cinemateca Brasileira.

\section{Dados técnicos:}

Elenco:

Barros, Leonor Mendes de;

Marino Neto (narração).

Distribuição:

Hermantino Coelho.
1) "415" (00:00 - 00:02)

2) "Natal em São Paulo"

3) "'Notícias Oficiais". (00:03 - 05:34) .$(05: 35-05: 40)$

\section{[1] "415".}

[2] "Natal em São Paulo" / Diversos planos de sinos e bonecos e imagens de Papai-Noel e motivos natalinos / Pessoas andando na rua, vitrines e barracas de vendedores / Fachada de um "parque infantil" com pessoas entrando / Aglomeração de pessoas (à porta do mesmo parque infantil?) / Entrega de cartões, pessoas preenchendo / Dona Leonor entre as pessoas que estão entrando no "parque infantil" / Fachada com uma faixa ostentando os seguintes dizeres: "Pres. Leonor Mendes de Barros - venha buscar o seu cartão neste parque dia 15, dás 8 às 12 horas / D. Leonor distribuindo presentes / PAN da fachada, novamente a faixa com dizeres (legível apenas a primeira linha) "Crianças... Expressão de Assistência Social"/ Fila de pais e crianças para a entrega dos cartões / MF de dona Leonor observando algo / Panorâmica da fila do "parque infantil da prefeitura" / Panorâmica da fachada em GPG / Papai-Noel com crianças / Dona Leonor pega os cartões e entrega presentes com ajuda de outras mulheres que a auxilia / Homem e mulher distribuindo refresco (ou leite) com / Dona Leonor distribuindo presentes e, com o auxílio das ajudantes, apressam as crianças que recebem o embrulho / Pais e crianças com os presentes / Dona Leonor distribuindo presentes para crianças que recebem de suas mãos / Plano de crianças com presentes/ PM de crianças com presentes caminhando em direção à câmera, dona Leonor ao fundo, seguindo uma PAN para à esquerda / Mais crianças recebendo brinquedos / Outro local: fachada com aglomeração de pessoas (pais e crianças) / Dona Leonor entregando presentes em diversos planos / PAN de dona Leonor entregando presentes, e deslocando-se para a multidão que aguarda / PA de duas crianças com presentes: um menino e uma menina, segurando um embrulho grande / Criança pequena tentando abrir embrulho / Planos de crianças e mães sentadas à calçada com presentes / Mãe com duas crianças pequenas sentadas na calçada.

「31 "Notícias Oficiais" / "Aqência Nacional" / Não há imaqens correspondente.

Termos descritores: Natal; Prefeitura; São Paulo - SP; Filantropia; Criança.

Termos livres: Papai-Noel. 
Bandeirante da Tela n. 416. São Paulo: Divulgação Cinematográfica Bandeirante, 1951. Fita de vídeo (6min47seg), VHS, mudo, p\&b, VV00048. Cinemateca Brasileira.

Dados técnicos:

Elenco:

Barros, Adhemar de;

Barros, Leonor Mendes de;

Garcez, Lucas Nogueira;

Câmara, Jaime de Barros;

Salzano, Erlindo;

Marino Neto (narração).

Distribuição:

Hermantino Coelho.
1) $[$ Sem intertítulo].....................(00:00 - 01:41)

2) "Homenagem" $(01: 42-02: 57)$

3) "Natal em São Paulo" $(02: 58-05: 04)$

4) "Notícias Oficiais da Agência Nacional"

5) "Fim". $(06: 45-06: 47)$

[1] [Sem intertítulo] / Senhoras em salão de festas / Convidados entrando, subindo escada (seria uma formatura?) / Convidados à mesa / Mulher ao microfone / Moça vai até mulher e recebe presente / Outra moça é cumprimentada e também recebe presente (?) / O mesmo acontece com outra moça / PAN em PP de moças e rapazes / Moça ao microfone / Moça coloca broche no paletó de rapaz / Outra moça e outro rapaz fazem o mesmo / Banda / Baile / PP de mulher e oficial (?) bailando / Baile.

[2] "Homenagem" / Pessoas na entrada de uma casa (casa de Adhemar de Barros?) / PP de Adhemar cumprimentando convidados / PG dos convidados no interior da casa / PP de Adhemar cumprimentando convidados / Leonor conversando com convidados / Duas moças sentadas conversando / Leonor sentada no canto da tela, e a sua direita uma árvore de Natal ocupando quase todo o enquadramento, câmera em PA se desloca para Leonor, enquadrando-a / Três mulheres sentadas no sofá / PP de moça sentada / Leonor entre convidados, câmera a acompanha e se desloca para cima, onde enquadra uma imagem da Virgem Maria com o menino Jesus (câmera se mantém neste enquadramento por sete segundos).

[3] "Natal em São Paulo" / PAN das famílias / Mães com filhos em fila / Leonor(?) cumprimenta homem e mulher [Imagem muito escura, sem a total identificação] / PAN das pessoas em fila / PG de autoridades com algumas mães e crianças (bem vestidas) / Autoridades caminham em MF para câmera / PAN de algumas mulheres, homens e crianças com Leonor sentada ao meio (parece uma noiva) / Distribuição dos presentes / Menina posa para a câmera com presente nas mãos, sendo acariciada por Leonor, câmera fecha na menina / A mesma seqüência acontece com um menino / PAN das pessoas presentes, mulher puxa um menino com presente para o alcance da câmera / Mulher entrega presentes para uma mulher negra (mãe?) / Homem entrega presente para menino no colo da mãe / Plano mais fechado da mesma cena anterior.

[4] "Notícias Oficiais da Agência Nacional" / Tropa perfilada [Imagem muito escura] / PG das autoridades civis e militares em torno de uma mesa com objeto brilhante (impossível a sua identificação) / MF de oficial com medalhas / PG de Lucas Nogueira Garcez e autoridades civis e militares - dispostas ao fundo e ao seu redor no enquadramento da câmera - durante a execução do hino (?) / Batalhão perfilado / Lucas Nogueira Garcez, cercado por autoridades civis e militares, assina livro / Bandeiras são entregues à tropa por civil e autoridade eclesiástica (?) / Homem cercado de oficiais civis e militares discursa ao microfone / PG da tropa / Oficial cercado de outros oficiais militares e civis discursa ao microfone / Palanque com autoridades civis e militares / Mulheres no palanque observam / Desfile da tropa é aberto por jipe com oficiais.

[5] "Fim".

Termos descritores: Solenidade; Natal; Exército; Filantropia.

Termos livres: São Paulo - SP; Batalhão Tobias de Aguiar. 
Bandeirante da Tela n. 430. São Paulo: Divulgação Cinematográfica Bandeirante, 1952. Fita de vídeo (2min17seg), VHS, mudo, p\&b, VV01152. Cinemateca Brasileira.

\section{Dados técnicos:}

\section{Elenco:}

Garcez, Lucas Nogueira;

Lott, Henrique Teixeira;

Café Filho, João;

Lima, José Geraldo de;

Ferraz, José Mariano;

Costa, Humberto Reis da;

Lima, João Alves Cunha;

Pereira, Armando de Arruda;

Marino Neto (narração).

Distribuição:

Hermantino Coelho.
1) "430"

(00:00 - 00:04)

2) "Notícias Oficiais - Noticiário Semanal da Sucursal da Agência Nacional de São Paulo D.C.B." (00:05 - 00:09)

3) "25 de Janeiro - Fundação de S. Paulo"...... (00:10 - 02:17)

\section{[1] "430".}

[2] "Notícias Oficiais - Noticiário Semanal da Sucursal da Agência Nacional de São Paulo. D.C.B.".

[3] "25 de Janeiro - Fundação de S. Paulo" / PAN em GPG de prédios da cidade / Tomada em GPG de dois prédios na cidade / Tomada em GPG do topo de uma Catedral (Sé?) e uma rua / GPG aéreo de uma avenida (provavelmente a Av. Paulista) cercada por prédios nos dois lados / Tomada em PM de populares / Tomada em PG de populares / PA de dois homens conversando / Os mesmos homens em duas tomadas em PP, cada um / Homens conversam ao lado de um motor de avião / Plongée em PP de homem discursando / PAN em MF de oficiais fardados (seriam pilotos da aeronáutica?) / Diversos planos em PP, mostrando detalhes do motor em funcionamento / Mais detalhes da aeronave / PA do mesmo homem discursando, sendo observado pelos presentes a sua volta / PP do mesmo homem em discurso enfático, com dedo em riste / PP de mapa ilustrando a costa atlântica do Brasil e o caminho a ser percorrido até a costa do continente africano.

Termos descritores: Efeméride; Cidade; São Paulo - SP; Igreja Católica; Solenidade; Aeronáutica.

Termos livres: Avenida Paulista, São Paulo - SP. 
Bandeirante da Tela n. 462. São Paulo: Divulgação Cinematográfica Bandeirante, 1952. Fita de vídeo (10min26seg), VHS, mudo, p\&b, VV00098. Cinemateca Brasileira.

Dados técnicos:

Elenco:

Matos, Lino de;

Toomis, Humphrey;

Correa, Miranda;

Balardia, Jorge Dequeño;

Morais, José Carlos de;

Garcez, Lucas Nogueira;

Calmon, Pedro;

Marino Neto (narração).

Distribuição:

Hermantino Coelho.

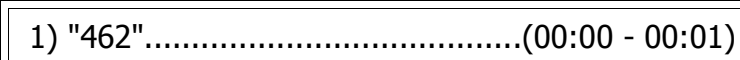

2) "Desastre". $(00: 02-09: 51)$

3) "Notícias Oficiais da Agência Nacional" $(09: 52-10: 23)$

4) "Fim". $(10: 24-10: 26)$

[1] "462".

[2] "Desastre" / Sem descrição correspondente.

[3] "Notícias Oficiais da Agência Nacional" / Lucas Nogueira Garcez recebe pessoas em recinto fechado / PP de Garcez cumprimentando homem / PM de Garcez e os reitores das universidades brasileiras / PP de Garcez conversando com um reitor.

[4] "Fim".

Termos descritores: Acidente; Aeronáutica; Universidade.

Termos livres: São Paulo - SP. 
Bandeirante da Tela n. 501. São Paulo: Divulgação Cinematográfica Bandeirante, 1952. Fita de vídeo (7min56seg), VHS, sonoro, p\&b, VV00098. Cinemateca Brasileira.

Dados técnicos:

Elenco:

Barros, Adhemar de; Garcez, Lucas Nogueira; Barros, Leonor Mendes de; Morais, José Carlos de; Vargas, Getúlio; Forbes, Charles de Souza Dantas; Pópua, Abdon; Costa, Oliveira; Garcez, Maria Carmelita de Oliveira; Marino Neto (narração).

Distribuição: Hermantino Coelho.
1) "Este filme foi submetido à Censura Federal". $(00: 00-00: 07)$

2) "Divulgação Cinematográfica Bandeirante" / "Bandeirante da Tela" / "501"... (00:08 - 00:37)

3) "Homenagem". $(00: 38-06: 17)$

4) "Comemorações Cívicas" $(06: 18-07: 53)$

5) "Fim" $(07: 24-07: 56)$

[1] "Este filme foi submetido à Censura Federal".

[2] "Divulgação Cinematográfica Bandeirante" / "Bandeirante da Tela" / "501".

[3] "Homenagem" / PG de pessoas reunidas em um espaço aberto (estacionamento?) com uma faixa pendurada "O Brasil recebe com alegria o regresso de seu grande filho Adhemar de Barros" / No aeroporto do Rio de Janeiro, Adhemar desembarca sob flashs acenando para as pessoas / Adhemar envolvido pelas pessoas e faixas / Cartazes e flores / Adhemar é "carregado" por pessoas e seguranças (?) / PP de Adhemar envolvido / PM de Adhemar concedendo entrevista / PM de Adhemar com pessoas num salão / Imagens de avião em vôo, tomadas de dentro de outro avião / Dirigível (balão) com nome de "Adhemar" / Caminhão com homens na caçamba segurando faixa "Adhemar - PSP" / Ônibus com faixa de Adhemar, bandeira do Brasil e foto do político / Carro com bandeira do estado de São Paulo / Fila de carros / Trânsito / Faixa na avenida "Com Adhemar lutamos pela grandeza do Brasil" / Viaduto com muitas pessoas / PAN de uma multidão e pessoas por sobre os telhados das casas / Chegada do governador Garcez em meio à multidão / PAN da multidão com faixas e carros / Avião pousa em aeroporto/ pessoas cercam o avião / PPP de Leonor Mendes de Barros em meio à multidão / PG do avião cercado por pessoas / Pessoas correm para cercar Adhemar que é envolvido e levado pela multidão em diversos planos / PP de Adhemar no palanque armado no aeroporto de Congonhas / PAN em PG da multidão com faixas para Adhemar / PP de Adhemar discursando / PG da multidão / PP de Garcez / PG da descida do palanque de Adhemar cercado por seguranças e empurrado pela multidão até a sua entrada no automóvel / Carro parte / Motoqueiros escoltam o carro com Adhemar / Outro local, a casa de Adhemar / Garcez chega / Chega dona Leonor que logo e cumprimentada / Adhemar de Barros no mesmo local, cercado por pessoas / PP de criança recitando saudação para Adhemar / Adhemar e os presentes aplaudem / PP de Adhemar sendo abraçado e beijado no rosto por familiares (seria sua filha com um nenê?) / PP de Leonor sendo cumprimentada / PG das pessoas no exterior da residência de Adhemar / PPP de Adhemar / PPP de Leonor / PM de Adhemar cercado por pessoas e cumprimentando homem / Adhemar segue cumprimentando / MF de Garcez / Adhemar e Leonor na janela (de sua casa?) cumprimentando as pessoas que passam abaixo da sacada / Adhemar recebe uma flâmula e depois um grande cartaz de propaganda.

[4] "Comemorações cívicas" / Getúlio Vargas seguido por Garcez e cercados por pessoas / Chegam ao $2^{\circ}$ Congresso Nacional dos Municípios / PAN de Vargas e Garcez / Outros componentes da mesa / Premiação de Vargas com uma medalha dada pelo presidente do Congresso / PAN dos presentes no auditório / Plano da Mesa / PP de Getúlio e Garcez / PP do secretário da Educação Oliveira Costa falando ao microfone / PG dos políticos presentes / PP de Adhemar e outros componentes da mesa / PP de Adhemar / PP de Garcez ao microfone / PP de Getúlio Vargas sentado / PP de Garcez cumprimentando Getúlio / PG dos presentes na platéia do auditório / MF de Getúlio se levantando e sendo aplaudido por Garcez ao seu lado / PP de Getúlio ao microfone / PG da mesa / Brasão da República na parede do salão.

「51 "Fim".

Termos descritores: Aviação; Efeméride; Cidade; São Paulo - SP; Imprensa; Automóvel; Política; Manifestação; Solenidade; Prêmio.

Termos livres: Rio de Janeiro - DF; São Paulo - SP; Aeroporto de Congonhas, São Paulo - SP; PSP - Partido Social Progressista; Santos - SP. 
Bandeirante da Tela n. 507. São Paulo: Divulgação Cinematográfica Bandeirante, 1952. Fita de vídeo (9min26seg), VHS, sonoro, p\&b, VV00098. Cinemateca Brasileira.

Dados técnicos:

Elenco:

Marino Neto (narração).

Distribuição:

Hermantino Coelho.
1) "Este filme foi submetido à Censura Federal". (00:00 - 00:06)

2) "Serviço de Divulgação Cinematográfica" / "Divulgação Cinematográfica Bandeirante" / "Bandeirante da Tela" / "507".....(00:07 - 00:36)

3) "Brasil - Semana da Asa" / "Rio de Janeiro - Retrospecto"....(00:37 - 01:22)

4) "Rio de Janeiro - Canberras no Brasil". $(01: 23-03: 07)$

5) "Aeronáutica - A Segurança do Vôo"... (03:08 - 09:22)

6) "Fim". (09:23 - 09:26)

[1] "Este filme foi submetido à Censura Federal".

[2] "Serviço de Divulgação Cinematográfica" / "Divulgação Cinematográfica Bandeirante" / "Bandeirante da Tela" / "507".

[3] "Brasil - Semana da Asa" / "Rio de Janeiro - Retrospecto" / PG de uma réplica de uma antigo avião francês (?) em recinto fechado / PAN em PM da mesma réplica / Tomadas em PP e PM de detalhes da réplica / PAN em PP de tela representando aviões antigos e novos, assim como zepelins no céu e pessoas os observando.

[4] "Rio de Janeiro - Canberras no Brasil" / PG dos aviões modelo "canberra" pousando, tomadas de frente e costas / PG de aviões estacionados na pistas / PG de outro avião pousando / PG de mais outro avião pousando / PG de aviões estacionados, com técnicos (?) observando uma aeronave / PG de avião no céu / PG de vôo rasante / PP de dois pilotos conversando / PA de dois oficiais da aeronáutica (?), tendo ao fundo aviões estacionados e demais pessoas (outros oficiais?) / PM do bico da aeronave com mecânicos e oficiais observando danos causados / Planos mais fechado com oficiais observando o bico da aeronave que está danificado / PAN em PM de avião estacionado e oficiais e técnicos que observam tanto o avião como a câmera / PG dos aviões na pista e pessoas reunidas em volta de um deles, ao fundo um avião modelo "presidente" taxia / PP do bico do avião modelo Canberra / PP do emblema da RAF (Real Air Force) no avião / PG de um Canberra parado e outro taxiando.

[5] "Aeronáutica - A Segurança do Vôo" / PG de avião no ar, plano tomado de outro avião / No interior de uma aeronave, PA do comandante passa pelo corredor com passageiros / Passageiro conversa com comandante, outros observam / PP do comandante dando explicações / PP do mesmo passageiro que recebe explicações do comandante / PAN em PG de avião com técnicos que o desmontam uma de suas asas / PM de dois homens que desmontam a hélice de uma turbina / PAM em PM acompanha técnicos desmontando motor / PG do avião desmontado e os técnicos realizando os trabalhos de manutenção / PA de três homens desmontando um motor / PP da desmontagem de motor por técnicos / O mesmo plano para a desmontagem de mais uma peça / PM de técnicos desmontando um "bloco" do motor / PA de dois técnicos desmontando parte do motor com uso de ferramenta específica / PAN em PA acompanha técnico puxando carrinho com as peças do motor / PA de técnico lavando peça / PA de outro técnico "jateando" peça / PAN em PP das peças limpas dispostas numa mesa / PM de trabalhadores retificando peça, em destaque uma máquina fazendo o trabalho de retificação / PP em PAN vertical desta mesma máquina / PP da medição de uma peça / PA de técnico inspecionando peças pequenas / PA de técnico limpando e medindo peças maiores / PP de peça sendo medida com minúcia / PA de técnico medindo (tirando molde?) de peças cilíndricas / PP de peça sendo encaixada no motor / PM de técnicos montando motor / 
PM de técnicos montando motor / PM em plongée de técnico montando motor / PP de técnico repetindo a mesma ação e girando o motor já montado / PM de técnico analisando os ponteiros medidores de um painel / PP de motor em funcionamento / Técnico conserta rádio do avião, segue uma PAN em PM da mesa com as peças do aparelho / PA de técnicos arrumando o trem de pouso / PG de dois técnicos (um em cada lado) montando um motor / PM de técnicos colocando a hélice no mesmo motor / PM de técnico controlando painel / PM do motor em recinto isolado funcionando, com a hélice girando em alta velocidade / Cplongée em PP de motor em funcionamento / Repetem-se os planos iniciais do comandante conversando com o passageiro / PG de avião no ar, plano tomado de outro avião - praticamente o mesmo do início do registro.

[6] "Fim".

Termos descritores: Efeméride; Aeronáutica; Aviação; FR; Visita estrangeira - GB; Engenharia.

Termos livres: São Paulo - SP; Semana da Asa; Canberra - avião; RAF - Real Air Force. 
Bandeirante da Tela n. 510. São Paulo: Divulgação Cinematográfica Bandeirante, 1952. Fita de vídeo (8min), VHS, mudo, p\&b, VV00048. Cinemateca Brasileira.

Dados técnicos:

Elenco:

Vargas, Getúlio;

Eisenhower, Dwight;

Stevenson, Adlai;

Marino Neto (narração).

Distribuição:

Hermantino Coelho.
1) $[$ Sem intertítulo].....................(00:00 - 01:48)

2) "Notícias Esportivas" $(01: 49-02: 46)$

3) "Aviação" $(02: 47-03: 05)$

4) "Assistência à Infância".

5) "Extra - Eisenhower Eleito" $(04: 24-07: 57)$

6) "Fim". (07:58 - 08:00)

[1] [Sem intertítulo] / Banda desfila no centro do estádio / Planos da banda / Arquibancada com pessoas aplaudindo / Desfile de moças (ao fundo, percebe-se que o estádio não está lotado, como se fazia aparecer anteriormente) / Desfile de rapazes em trajes de ginastas / Getúlio Vargas na arquibancada / PG do desfile / Getúlio Vargas na arquibancada / Moças e rapazes apresentam coreografia no centro do campo / Moças e rapazes perfilados no campo / Rapazes fazem exercícios físicos / Getúlio Vargas observa da arquibancada.

[2] "Notícias esportivas" / Casais apresentam numero de patinação sobre rodas / Planos da moça apresentando número individual / Casais fazem carrossel no meio da pista / Mais planos da apresentação dos casais.

[3] "Aviação" / Autoridades e convidados banqueteiam / PP da flâmula da Semana da Asa na mesa / MF de mulher encostada na parede com cartaz "Salve Aviação Brasileira" / Músicos / Baterista / Sanfoneiro / Mais convidados.

[4] "Assistência à Infância" / Planos da fachada (?) com dizeres "Centro de Reabilitação e Educação" / PAN de crianças deficientes brincando no pátio interior do local / PAN em PM de menina em cadeira de rodas / PAN em PM de outra menina em cadeira de rodas / PG de duas crianças se exercitando em barras e uma sentada na colchonete / Criança em exercício na bicicleta ergométrica / Criança se exercitando no remo com ajuda de fisioterapeuta(?) / Menina em cadeira de rodas fazendo bordado / Crianças no tear / Menina tomando instruções no tear / PG dos produtos (produzidos pelas crianças?) na prateleira.

[5] "Extra - Eisenhower Eleito" / PG da Casa Branca(?) com carros estacionados / Eleitores votando / Diversos planos / Eisenhower na fila para votar / Eisenhower votando / Repórteres fotografam Eisenhower assinando o livro de votação / PP de homem / PP da placa de um automóvel com dizeres "Huntsville. Ala. Home of Sem. John Sparkman our next 'Veep"' / Outras autoridades(?) votando / Contagem dos votos / PG do painel com os resultados parciais da eleição nos estados americanos / PG de letreiros luminosos, à noite, noticiando a eleição de Eisenhower / Eisenhower no palanque e o discurso de posse após a votação, ao fundo os letreiros com resultados / Eisenhower e esposa (?) agradecendo ao público / Eisenhower ao microfone / PG do palanque e o público aplaudindo.

Termos descritores: Efeméride; Esporte; Aviação; Criança; Saúde; Deficiente físico; Eleição.

Termos livres: Rio de Janeiro - DF; Estádio das Laranjeiras, Rio de Janeiro - DF; Ginástica; Patinação; Semana da Asa; US; 15 de Novembro. 
Bandeirante da Tela n. 520. São Paulo: Divulgação Cinematográfica Bandeirante, 1952. Fita de vídeo (4min47seg), VHS, mudo, p\&b, VV00048. Cinemateca Brasileira.

Dados técnicos:

Elenco:

Pudelko, Edith;

Marino Neto (narração).

Distribuição:

Hermantino Coelho.

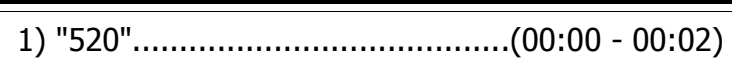

2) "Bailado"...

(00:03-02:23)

3) "Artes Plásticas".

[1] "520".

[2] "Bailado" / Diversos planos de uma moça apresentando coreografia de balé numa praia.

[3] "Artes Plásticas" / Planos de várias esculturas, monumentos e bustos / Estátuas (em bronze ou em pedra?) / PG do Monumento das Bandeiras / PAN e diversos planos do Monumento das Bandeiras.

Termos descritores: Dança; Artes plásticas; Monumento; Praia.

Termos livres: São Paulo - SP; Escultura. 
Bandeirante da Tela n. 525. São Paulo: Divulgação Cinematográfica Bandeirante, 1952. Fita de vídeo (8min31seg), VHS, sonoro, p\&b, VV00098. Cinemateca Brasileira.

Dados técnicos:

\section{Elenco:}

Garcez, Lucas Nogueira; Arantes, Altino; Costa, Canrobert Pereira da; Máximo, Luis Arcângelo; Silva, Leônidas da; Blecaute; Marino Neto (narração).

Distribuição: Hermantino Coelho.
1) "525". (00:00 - 00:01)

2) "Notícias Diversas". $(00: 02-02: 21)$

3) "Notícias Esportivas" $(02: 22-03: 00)$

4) "Carnaval". $(03: 01-08: 28)$

5) "Fim" $(08: 29-08: 31)$

\section{[1] "525".}

[2] "Notícias Diversas" / Motociclistas para o exame de habilitação / TRV dos motociclistas andando em grupo pela rua / PG dos motoqueiros para o teste / Motociclistas fazem "oito" em torno de balizas / Chegada de Lucas Nogueira Garcez e outras autoridades na Biblioteca Municipal / Lucas Nogueira Garcez é cumprimentado por autoridades (?) / PPP de Lucas Nogueira Garcez em frente a casa em homenagem a Euclides da Cunha / GPG da casa, Lucas Nogueira Garcez e da multidão presente / Solenidade no saguão da Biblioteca / Lucas Nogueira Garcez e autoridades inauguram a exposição iconográfica na biblioteca sobre "Os Sertões" / PM de homem que retira a fita de inauguração, Lucas Nogueira Garcez ao centro / Lucas Nogueira Garcez caminha pelo salão / PPP do busto de Euclides da Cunha / Lucas Nogueira Garcez cumprimenta os presentes (autoridades?) / PG da mesa composta por autoridades e Lucas Nogueira Garcez ao centro / PAN da mesma mesa / PP de Altino Pontes lendo discurso / PAN dos presentes / PP do Gal. Canrobert Pereira da Costa lendo discurso / PPP da mesma cena / Presentes aplaudem.

[3] "Notícias Esportivas" / Atletas marcham no treino em estádio de futebol /PG mesmos / PG dos mesmos praticando exercícios / PP de Leônidas da Silva (?) fazendo exercícios / Diversos planos dos jogadores do Corinthians que assistem treino das arquibancadas / PM dos jogadores do Corinthians sentados na arquibancada.

[4] "Carnaval" / GPG em PAN das terras de Jacareí / GPG em PAN das casas em Jacareí / Ponte / Praça / PAN de prédio em construção / Igreja Bom Sucesso / PG de autoridades caminhando sobre via em construção, com tratores trabalhando / PP do prefeito de Jacareí, Luis Arcângelo Máximo conversando com presentes (autoridades?) / TRV da via em construção / Diversos planos dos reservatórios de água na cidade / PAN da parte externa da tecelagem Nossa Senhora da Penha / Planos do interior da fábrica de meias Vitória / GPG do interior da fábrica de fiação de algodão, Fiatex / Planos da fábrica de meias Rubens (?) / PP do brasão e o mapa da cidade pendurado na parede / PG do prefeito sentado à sua mesa / Diversos planos de crianças / PG de letreiro luminoso "Carnaval Ponte Preta" / PG das pessoas entrando na avenida (ou no salão?) / PAN de carro alegórico com o globo da bandeira brasileira / Desfile de rua, pessoas seguram faixa com dizeres: "A Furiosa presta sua (?)" / Desfile da banda / Mais um carro alegórico / Planos da moça neste mesmo carro / Mais planos do desfile / Outro carro alegórico com quatro moças sentadas / Outro carro alegórico com estátua de um índio e moça vestida de índia / Carro alegórico com rei momo / PG da multidão / PP de Blecaute cantando ao microfone / PPL de homem cantando / PPL de mulher / PA do rei momo e o prefeito da cidade cercados de outros rapazes / Prefeito entrega a chave da cidade ao rei momo / PAN de diversos planos do salão com a multidão no baile / PAN dos músicos / No "Trianon Clube" PAN do baile e as pessoas dançando / Diversos planos do baile / PAN de baile em outro local (salão no Ponte Preta?) / PG da ponte em Jacareí.

[5] "Fim".

Termos descritores: Trânsito; Motociclismo; Literatura; Biblioteca; Futebol; Carnaval; Cidade; Jacareí - SP; Indústria Têxtil; Engenharia; Saneamento; Clube; Desfile.

Termos livres: São Paulo - SP; Cunha, Euclides da; Biblioteca Municipal de São Paulo - SP; Fiatex - indústria têxtil; Vitória - fábrica de meias; Ponte Preta - clube; Trianon Clube; Rei Momo; Carro alegórico; S. C. Corinthians. 
Bandeirante da Tela n. 538. São Paulo: Divulgação Cinematográfica Bandeirante, 1953. Fita de vídeo (6min25seg), VHS, mudo, p\&b, VV01125. Cinemateca Brasileira.

Dados técnicos:

Elenco:

Garcez, Lucas Nogueira;

Barros, Adhemar de;

Barros, Leonor Mendes de;

E. C. Corinthians Paulista;

S. E. Palmeiras;

Marino Neto (narração).

Distribuição:

Hermantino Coelho.
1) "Notícias Esportivas"

$(00: 00-02: 06)$

2) "Notícias Diversas".

$(02: 07-04: 02)$

3) "Noticiário Internacional" $(04: 03-06: 25)$

[1] "Notícias Esportivas" / Diversos planos em PG de uma partida de futebol entre Corinthians e São Paulo / Gol do Corinthians / PG da arquibancada "vibrando" / Placar mostrando "Corinthians 1" / Lances da partida / Plongée em PG de policiais escoltam torcedor (detido?) / Lances da partida / PA de homens (autoridades?) confraternizando com o governador Garcez, em recinto que possui ao fundo o retrato pintado de um homem / No mesmo plano homem é cumprimentado pelo governador, detalhe para a bandeira do Corinthians, ao lado esquerdo do retrato, e a bandeira do Palmeiras, ao lado direito / PA de homens (entre eles um jornalista que fala ao microfone) no mesmo enquadramento, tendo ao centro o governador e o homem cumprimentado (homenageado?) sentados cada um em uma poltrona / Pequena PAN em PP do governador Garcez ouvindo dois homens (um em cada lado) / PP de jornalista falando ao microfone / PP de duas mulheres / PAN em PA dos presentes àquela solenidade, tendo o governador Garcez ao centro do enquadramento / PA de jornalista que segura o microfone para o governador, detalhes ao fundo das bandeiras de times paulistanos penduradas na parede, decorando o recinto / PP do governador ao microfone / PAN em PM sobre os presentes que aplaudem.

[2] "Notícias Diversas" / PM de grupo de homens reunidos observando autoridade eclesiástica dando a bênção no local / Mesma tomada em plano um pouco mais fechado de homem recebendo uma urna e dando entrevista / PA da urna sendo passada a outro homem que a deposita numa pequena "cova" / Planos em PA de pessoas cimentando aquela "cova" / PM de autoridades reunidas, posando para a câmera, em solenidade, tendo ao fundo as bandeiras do Brasil e do estado de São Paulo / PAN em PP das autoridades reunidas, partindo do detalhe de uma placa do "Banco do Estado de São Paulo" / Mais planos em PM das autoridades / duas tomadas em PA de dois homens discursando (autoridades?) / PAN dos presentes no recinto / Em outro local planos de pessoas (convidados?) adentrando recinto / PP de moças vestidas para a ocasião de festa, e que se cumprimentam / Mais planos de mulheres / Tomadas em PM de moça (anfitriã?) que serve convidados (todos homens) / Diversos planos de mulheres presentes / PA de homem lendo discurso ao lado da moça que servira anteriormente os convidados / Moça recebe cumprimentos.

[3] "Noticiário Internacional" / PAN de avião na pista de decolagem / Planos de pessoas que chegam para embarcar / Cplongée das pessoas subindo as escadas em entrando no avião / Tomadas em PP de homens e mulheres, passageiros, conversando, entretendo-se e degustando uma bebida sentados nas poltronas da aeronave / PP de aeromoça / Tomadas aéreas de dentro do avião, focalizando a hélice de uma turbina em movimento, as nuvens, e a paisagem terrestre / Tomada rápida do interior do avião no momento da aterrisagem / Passageiros desembarcam / Plongée em PG dos passageiros reunidos após desembarque / PA de militares e civis que se cumprimentam / PA de militares e civis que confraternizam num recinto fechado / Tomadas em PP de homens e mulheres que participam da mesma ocasião / GPG de uma cidade e seus prédios / PAN em PG de monumento eqüestre / A mesma tomada, porém em plano mais fechado / PG de pessoas atravessando a rua / PG de prédio / Planos de um vendedor de objetos (lembranças?) disposto na sua maleta, ambos no banco de uma praça / PP dos objetos ovais e desenhados, trabalhados artesanalmente.

Termos descritores: Solenidade; Futebol; Igreja Católica; Banco; Aviação; Cidade; Montevideo - UY; Artesanato.

Termos livres: São Paulo - SP; S. C. Corinthians; São Paulo F. C.; S. E. Palmeiras; Federação Paulista de Futebol; Banespa - Banco do Estado de São Paulo. 
Bandeirante da Tela n. 539. São Paulo: Divulgação Cinematográfica Bandeirante, 1953. Fita de vídeo (6min25seg), VHS, mudo, p\&b, VV00048. Cinemateca Brasileira.

Dados técnicos:

Elenco:

Garcez, Lucas Nogueira; Morais, José Carlos de; Barros, Adhemar de; Barros, Leonor Mendes de; Carrero, Tonia; Prado, Marisa; Almeida, Abilio Pereira de; Souza, Ruth de; Marino Neto (narração).

Distribuição:

Hermantino Coelho.
1) "539".
$(00: 00-00: 02)$
2) "Desfile de Modas". (00:03 - 01:09)
3) "Notícias Diversas". $(01: 10-02: 05)$
4) "Notícias Sociais". $(02: 06-02: 51)$
5) "Saúde e Beleza". $(02: 52-03: 57)$
6) "Notícias Sociais" $(03: 58-04: 50)$
7) "Artes e Artistas". $(04: 51-06: 47)$

[2] "Desfile de Modas" / Diversos planos das modelos desfilando.

[3] "Noticias Diversas" / PG de algumas casas / PG de Lucas Nogueira Garcez e autoridades civis e militares e algumas moças vestidas para festa de alguma fruta, em Valinhos (a exemplo de um lenço amarrado na cabeça de algumas moças) / PP de moça (rainha da festa?) / Lucas Nogueira Garcez coroa a rainha da festa / Planos de Lucas Nogueira Garcez cumprimentando os presentes e sendo cumprimentado e agraciado com presente / Produtos do Instituto Biológico da Secretaria de Agricultura / PP de alguns figos / PAN do painel da "Escola Superior da Agricultura 'Luiz de Queiroz' - Piracicaba - USP", ao lado maquete da escola (?) / Rainha e princesa (?) da festa / PG da fachada da escola (?) com três pessoas.

[4] "Notícias Sociais" / MF de homem que discursa ao microfone ao lado de mais três homens / MF de Lucas Nogueira Garcez / Presentes no local aplaudem / MF de Lucas Nogueira Garcez discursando ao microfone ao lado de três homens / PP de Lucas Nogueira Garcez ao microfone / Fachada de um clube (?) / Lucas Nogueira Garcez cercado por autoridades e demais pessoas / PAN do publico te Lucas Nogueira Garcez / Homem lê discurso / MF de Lucas Nogueira Garcez observando discurso / PG do interior do clube (?), playground.

[5] "Saúde e Beleza" / PG de pessoas na piscina / Diversos de planos de modelos indo para piscina / Diversos planos de modelos sentadas à beira da piscina.

[6] "Notícias Sociais" / PAN da fachada de igreja / Interior da igreja e os convidados / Noiva entrando na igreja / Leonor e Adhemar de Barros (padrinhos?) e o noivo, Carlito Guimarães / Noivos no altar / PP da noiva / PP do noivo.

[7] "Artes e Artistas" / Artistas chegando para o evento / PP de vários artistas / Aurora Duarte (?) e Tonia Carrero / Banquete com artistas e personalidades / Lucas Nogueira Garcez cumprimenta artistas / PAN de artistas e Lucas Nogueira Garcez em PP / PAN da entrevista coletiva / Diversos planos de personalidades e artistas / Em outro local (?), chegada de carro com atriz (?) / Outra atriz (?).

Termos descritores: Desfile; Moda; Festival; Valinhos - SP; Horticultura; Agricultura; Universidade; Solenidade; Clube; Lazer; Casamento; Arte; Cinema.

Termos livres: Figo; Instituto Biológico da Secretaria de Agricultura de São Paulo; Escola Superior da Agricultura Luiz de Queiroz, Piracicaba - SP; Universidade de São Paulo; Clube Sírio; Piscina. 
Bandeirante da Tela n. 543. São Paulo: Divulgação Cinematográfica Bandeirante, 1953. Fita de vídeo (6min50seg), VHS, mudo, p\&b, VV01152. Cinemateca Brasileira.

Dados técnicos:

Elenco:

E. C. Corinthians Paulista;

Flamengo F. R.;

Ulhoa, Osvaldo;

Rosas, Olavo;

Marino Neto (narração).

Distribuição:

Hermantino Coelho.
1) "543"

(00:00 - 00:01)

2) "Notícias Esportivas"

\section{[1] "543"}

[2] "Notícias Esportivas" / Planos de uma partida de futebol entre p Corinthians e o Flamengo / Gol do Corinthians / Mudança do Placar / Pênalti cobrado pelo Flamengo e o goleiro corintiano defende / PG da arquibancada / PG da arquibancada e do jogo / Jogador do Flamengo sendo carregado do campo / Placar mostra Corinthians 3 e Flamengo 0 / Gol do Corinthians / Placar mostra 4 a 0 para o Corinthians / Gol do Corinthians / Placar mostra 5 a 0 para o Corinthians / Fim de jogo / Placar mostra 6 a zero para 0 Corinthians / PG em PAN do Jóquei Clube da Cidade Jardins / Diversos planos de mulheres elegantemente vestidas / Personalidades / Mais planos de mulheres elegantemente vestidas no jóquei / PG de "Gualixo", cavalo campeão / PG em PAN do público e apostadores / Cavalos entrando, jóquei Olavo Rosas / jóquei Osvaldo Uchoa e o cavalo "Platina" / PAN em PG da prova / Diversos planos do público na arquibancada / cavalos cruzam a linha de chegada / Cavalos saindo da pista / Jóquei no pódio / PP de moças elegantemente vestidas.

Termos descritores: Futebol; Turfe.

Termos livres: S. C. Corinthians; C. R. Flamengo; São Paulo - SP; Jóquei Clube, São Paulo - SP. 
Bandeirante da Tela n. 545. São Paulo: Divulgação Cinematográfica Bandeirante, 1953. Fita de vídeo (7min50seg), VHS, sonoro, p\&b, VV00048. Cinemateca Brasileira.

Dados técnicos:

Elenco:

Garcez, Lucas Nogueira;

Barros, Adhemar de;

Barros, Leonor Mendes de;

Garcez, Maria Carmelita de Oliveira;

Marino Neto (narração).

Distribuição:

Hermantino Coelho.
1) "545" (00:00 - 00:01)

2) [Sem Intertítulo] $(00: 02-00: 45)$

3) "Notícias do Rio" $(00: 46-01: 29)$

4) "Notícias Oficiais". $(01: 30-02: 16)$

5) "Iatismo" $(02: 17-03: 10)$

6) "Conheça sua Terra" $(03: 11-05: 06)$

7) "Notícias Esportivas"

\section{[1] "545".}

[2] [Sem intertítulo] / PA de um homem, de costas para a câmera, pintando uma tela / PP da aquarela (tábua de tintas) sendo pincelada pelo pintor / PP e PA da feitura (pintura) do quadro / Tela escurece, corta para PM de pessoas numa galeria observado quadros expostos / PPP de tela com um barco / PPP de tela com flores / PP de um quadro de uma mulher / PPP do rosto da mulher pintada no quadro / PPP de outra tela com uma caravela / Duas mulheres, inicialmente em PA, se aproximam da câmera - uma delas carrega livros.

[3] "Notícias do Rio" / Três tomadas, em cplongée, em PG, de barracos à beira de um morro / Pequena PAN em GPG de barracos / PG de barracos / PAN e em PG de um morro que segue até o fim do penhasco, cujos barracos estão a beira do seu desfiladeiro / PM de pessoas, um homem e uma mulher, descendo o morro carregando latas d'água na cabeça / PAN em PG do horizonte do morro e seus barracos em contraste com a cidade ao fundo.

[4] "Notícias Oficiais" / PM de um interior de aeronave com sacos e caixas sendo organizadas por um homem / Homem verifica a "firmeza" da corda que amarra os sacos / PA de autoridades se cumprimentando, entre elas o governador Garcez / Mais planos de Garcez conversando com autoridades e acompanhado por uma comitiva (?) / O governador e demais autoridades examinam os sacos no interior da aeronave / PP de oficial da aeronáutica que dá explicações (?) / Homem trava a porta do avião / PM da aeronave da Vasp taxiando para a decolagem.

[5] "Iatismo" / PG de homens puxando os iates para à beira da água (uma praia ou represa?) / PM de mulher, que acena, e uma criança, que puxa uma bandeira, ambos numa torre (guarita) / GPG dos iates no mar (ou represa?) / Tomada em PG dos barcos, partindo de um contra-plano de uma mulher numa lancha / TRV dos iates em disputa / PG dos iates, um deles tombado.

[6] "Conheça sua Terra" / PM de um avião parado enquanto desembarcam dona Leonor e dona Carmelita Garcez / PM de Garcez saindo do avião / PM de Adhemar saindo do avião / PP de Garcez e Adhemar sendo recepcionados pelas autoridades locais / PG em plongée de Adhemar e Garcez andando entre as pessoas que os recepcionam no local / PA de Adhemar, Garcez e demais autoridades - câmera se afasta lentamente / PA de Adhemar e Garcez / Mais uma tomada em PA de Adhemar e Garcez caminhando e sendo cumprimentados / 
Adhemar cumprimenta senhor idoso numa cadeira para deficientes / PAN de crianças (escolares?) que recepcionam os visitantes / PM de Garcez (de chapéu), Adhemar e comitiva caminhando / PA de Garcez cortando uma fita inaugural - tendo ao lado a comitiva que o acompanha e Adhemar de Barros; zoom in em Garcez (e na tesoura cortando a fita) que em seguida cumprimenta Adhemar ao seu lado / Adhemar também corta fita e é cumprimentado / Homem descerra placa "Avenida Vicentezinni" e PAN segue da placa até Garcez que está logo abaixo e cumprimenta homem / Tomada semelhante com Adhemar e Garcez repetindo o gesto / PA de dona Leonor e Carmelita Garcez desatando laço inaugural (de uma escola?), seguido por aplausos / Carmelita Garcez, dona Leonor, Adhemar e Garcez adentram um recinto com demais autoridades / O mesmo acontece em uma sala de aula / PAN em PG da fachada (do grupo escolar?) / Comitiva caminha por entre piscinas públicas / PP de placa "Banhos Públicos - Adhemar de Barros - ao eminente estadista. O povo agradecido" / PM seguido de PP de desenho (uma passagem bíblica?) em azulejo / PG seguido de PM de autoridade discursando em frente a um busto de homem em bronze, estão presentes Adhemar e Garcez / Recinto fechado, mesa com banquete e pessoas aplaudindo / PA de Adhemar e Garcez se abraçando / Garcez em pé discursa / PG do recinto com os convidados que aplaudem.

[7] "Notícias Esportivas" / Diversos lances em PM de uma partida de voleibol masculino / PP de moças que observam / Mais lances da partida / PM e PP de moças assistindo / Tomadas em PM de moças numa disputa de luta livre / Diversos planos dos golpes / Moças se arrumam no ringue / PG do público / PM do ringue, com uma moça num dos cantos / Mesmo enquadramento: luta recomeça, a mulher de preto joga a de branco para fora do ringue / Mais ao centro do ringue, a mulher de branco soca a adversária deitada no tablado, logo em seguida aplica uma pequena "voadora" / Juiz e as lutadoras, vitória da de branco.

Termos descritores: Artes plásticas; Exposição; Aviação; Correio; Habitação; Rio de Janeiro - RJ; Esporte; Embarcação; Solenidade; Escola; Monumento; Mulher.

Termos livres: Pintura; VASP; Iatismo; Porto Ferreira - SP; Voleibol; Luta Livre. 
Bandeirante da Tela n. 546. São Paulo: Divulgação Cinematográfica Bandeirante, 1953. Fita de vídeo (6min50seg), VHS, mudo, p\&b, VV00048. Cinemateca Brasileira.

\begin{tabular}{|c|c|}
\hline Dados técnicos: & 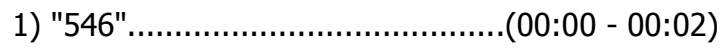 \\
\hline $\begin{array}{l}\text { Elenco: } \\
\text { Barros, Adhemar de; } \\
\text { Garcez, Lucas Nogueira; } \\
\text { Marino Neto (narração). }\end{array}$ & 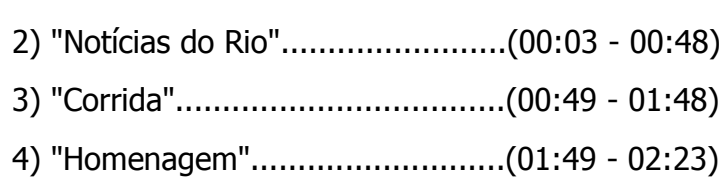 \\
\hline $\begin{array}{l}\text { Distribuição: } \\
\text { Hermantino Coelho. }\end{array}$ & $\begin{array}{l}\text { 5) "Artes e Artistas".......................(02:24 - 03:02) } \\
\text { 6) "Notícias Oficiais".......................(03:03 - 03:56) } \\
\text { 7) "Notícias Diversas".....................(03:57 - 04:48) } \\
\text { 8) [Sem intertítulos].....................(04:49 - 06:48) } \\
\text { 9) "Fim"..................................(06:49 - 06:50) }\end{array}$ \\
\hline
\end{tabular}

[1] "546".

[2] "Notícias do Rio" / Solenidade em que convidados assistem apresentação de meninas / Homem movimenta braço de menina / PA de três moças / Senhoras sentadas à mesa observam/ As três moças fazem poses e ficam paradas como manequins / MF de modelo tendo seu vestido consertado (?) atrás.

[3] "Corrida" / Ciclistas dão a largada / ciclistas correndo e o público observando / Ciclista com a camiseta da Portuguesa de Desportos caminha para a câmera segurando a bicicleta quebrada / Pregos no chão / Ciclistas cruzam a linha de chegada / MF do vencedor com a camiseta da AFE - Araraquara / Vencedor recebe cumprimentos e posa para câmera.

[4] "Homenagem" / PG de Adhemar de Barros e outras pessoas, tendo atrás a bandeira de São Paulo e a imagem de Cristo crucificado / Adhemar de Barros é abraçado / Adhemar de Barros fala ao microfone / PG de Adhemar de Barros envolvido pelos convidados e sendo cumprimentado por alguns deles / Homem discursa (em homenagem a Adhemar de Barros?) / PG dos presentes.

[5] "Artes e Artistas" / Pintor pintando uma tela / Planos de diversas telas: natureza morta, retratos, paisagens / Homem ao lado de seu retrato pintado posam para a câmera (será o pintor o mesmo homem?).

[6] "Notícias Oficiais" / Lucas Nogueira Garcez posa para a câmera / Lucas Nogueira Garcez cercado por pessoas e autoridades, adentra o recinto / Banda de música / No recinto Lucas Nogueira Garcez conversa com os presentes / Diversos planos de Lucas Nogueira Garcez e os presentes / Descerramento de placa / Lucas Nogueira Garcez observa placa / Lucas Nogueira Garcez fala ao microfone / Lucas Nogueira Garcez observa o equipamento (de rádio ou telecomunicação?) / Homem manuseia o equipamento.

[7] "Notícias Diversas" / PAN de carro chegando até a fachada da "Vigorelli" / Lucas Nogueira Garcez e esposa chegam ao local / Esposa de Lucas Nogueira Garcez e outra senhora desatam a faixa de inauguração / Lucas Nogueira Garcez e esposa visitam as instalações do local / TRV das máquinas de costura dispostas no salão / PG da oficina com operários trabalhando / MF de Lucas Nogueira Garcez seguido de sua esposa / PG de Lucas Nogueira Garcez e os presentes brindando.

[8] [Não há intertítulo] / Homem folheia revista tendo à mesa um retrato de mulher / Olha para foto na revista e no retrato / Casal passeia em jardim público / Sentam na grama e se beijam / Homem continua olhando o retrato, olha para o calendário na parede e sai contrariado / O mesmo homem sai de uma loja com um pacote nos braços / Ele chega ao portão de uma casa, toca a campainha e espera / Sai da casa um casal de braços dados e caminham para a rua / Homem olha para o casal e joga o pacote (caixa de bombons) e um ramalhete de flores no chão / Homem vai embora.

[9] "Fim".

Termos descritores: Desfile; Moda; Esporte; Política; Solenidade; Artes-plásticas; Telecomunicação; Governo estadual; São Paulo - SP ; Rio de Janeiro - DF; Indústria; Têxtil; Trabalho; Embarcação; Solenidade; Escola; Monumento; Mulher.

Termos livres: Ciclismo; Portuguesa de Desportos; AFE - Araraquara; Pintura; Rádio; Secretaria Regional do Trabalho do Estado de São Paulo. 
Bandeirante da Tela n. 549. São Paulo: Divulgação Cinematográfica Bandeirante, 1953. Fita de vídeo (7min59seg), VHS, sonoro, p\&b, VV00048. Cinemateca Brasileira.

Dados técnicos:

Elenco:

Reali, Elpídio; Fourneau, William; Moreira, Maria Silvia Godoy; Monteiro, Maria Cecília Barros; Cintra, Isabel; Spalla, Hermínio; Loureiro, Paulo Rolim;

Julianeli, Salvador; Mendes, Murilo; Romero Filho, Pedro; Landi, Chico; Rovai, Alberto; Viana, Godofredo; Vale, Gilberto Pereira do; Cassini, Henrique; Caires, Ciro; Marino Neto (narração).

Distribuição:

Hermantino Coelho.
1) "549" $(00: 00-00: 02)$

2) "Pólo" (00:03 - 01:03)

3) "De Todo o Brasil" $(01: 04-01: 51)$

4) "Notícias Esportivas" $(01: 52-02: 53)$

5) "Notícias Oficiais" $(02: 54-03: 42)$

6) "Notícias Diversas" $(03: 43-05: 52)$

7) "Automobilismo" $(05: 53-07: 56)$

8) "Fim". $(07: 57-07: 59)$

[1] "549".

[2] "Pólo" / PG do desfile de cavaleiros com clarins da força pública / Público / PP da bandeira do Brasil e da Federação Paulista Hípica / PP de oficial / PAN dos jogadores / Diversos planos da partida / MF de duas mulheres elegantes no público.

[3] "De todo o Brasil" / Pau-de-Arara sendo descarregado das bagagens dos nordestinos / Famílias / Planos do Pau-de-Arara com pessoas dentro e desembarcando / PAN e diversos planos das famílias que acabaram de chegar / Crianças / PG do grupo que desembarcou.

[4] "Notícias Esportivas" / Partida de pólo aquático feminino / Competidoras se preparam / PG da partida / Torcida / Diversos planos da partida.

[5] "Notícias Oficiais" / Secretário de Segurança desata fita de inauguração / Autoridades civis e militares e o Secretário de Segurança visitam a exposição permanente / Planos da exposição / PG de equipamento cinematográfico (câmera e rolos) / Secretário de Segurança toma explicações do guia (?) / PG da maquete do prédio (?) / Secretário de Segurança assina livro.

[6] "Notícias Diversas" / PAN dos componentes de uma banca / Músicos tocam partituras / Baile / PP de sanfoneiros / Mais planos em PP dos casais no baile / Músicos / PP de cantora / Músicos / Baile / Boxeador treinando em saco de areia / Vários pugilistas conversam / PP de Hermínio Spalla, veterano boxeador / PAN da de partida de tênis / Moças e rapazes jogando tênis / D. Paulo Rolim Loureiro abençoa a sede do Centro de Negócios Imobiliários / Mulher desta fita de inauguração da exposição / Entre os presentes, bispo e demais autoridades visitam a exposição / Observam quadro / Discurso de Salvador Julianelli / Discurso de Murilo Mendes / PAN da exposição do Depto. de Pesquisa e Estatística / PA dos presentes.

[7] "Automobilismo" / Carros prontos para largada / Largada da corrida em Interlagos, prova "Prefeitura Municipal" / Diversos planos de diferentes pontos do percurso / Arquibancadas / Imagens captadas em primeira pessoa da dianteira do veículo / Uma roda se solta do carro de Pedro Romeno Scarpa / Chico Landi cruza linha de chegada / Cumprimentos ao vencedor.

「81 "Fim".

Termos descritores: Esporte; Comportamento social; Nordeste; Natação; Efeméride; Polícia; Música; Igreja Católica; Automobilismo.

Termos livres: Pólo; Federação Paulista Hípica; Pólo aquático; Mulher; Dia da Polícia; Secretaria de Segurança Pública do Estado de São Paulo; Boxe; Tênis; Autódromo de Interlagos, São Paulo - SP. 
Bandeirante da Tela n. 558. São Paulo: Divulgação Cinematográfica Bandeirante, 1954. Fita de vídeo (7min14seg), VHS, mudo, p\&b, VV00048. Cinemateca Brasileira.

Dados técnicos:

\section{Elenco:}

Gomes, Lauro; Barreto, Lima; Oliveira, Araçary de; Otelo, Grande; Barbosa, Adoniran; Mesquitinha; Loureiro, Paulo Rolim; Carrero, Tonia; Biar, Célia; Cavalcanti, Emiliano Di; Celi, Adolfo; São Paulo F. C.; S. C. Corinthians Paulista; Marino Neto (narração).

Distribuição:

Hermantino Coelho.
1) "558" $(00: 00-00: 02)$
2) "Atletismo" $(00: 03-00: 45)$
3) "Notícias Diversas". $(00: 46-01: 53)$
4) "Desastre". $(01: 54-02: 38)$
5) "Futebol". $(02: 39-05: 27)$
6) "Notícias Sociais" $(05: 28-07: 11)$
7) "Fim" $(07: 12-07: 14)$

\section{[1] "558".}

[2] "Atletismo" / PG dos troféus / Largada para a corrida de revezamento / Autoridades civis e militares assistem / PAN da prova / Troca de bastões / PG da arquibancada / Nova troca de bastões / Equipe do Vasco da Gama posa para a câmera com os troféus.

[3] "Notícias Diversas" / Meninos soltam balão / PP da boca do balão / Homem solta o balão / Balão subindo / Meninos observam / PG do balão subindo e indo embora / PG do balão caindo / Fumaça de incêndio / Corpo de Bombeiros apagando o fogo / PG do fogo / Diversos planos dos bombeiros apagando o incêndio / Incêndio.

[4] "Desastre" / PAN e diversos planos de um incêndio / Durante o dia, PAN de autoridades e meio aos destroços de um avião (?) / Diversos planos dos destroços.

[5] "Futebol" / PG da partida e da arquibancada lotada / PG do jogador do São Paulo caído no chão / Gol do Corinthians (?) / Partida / Falta no jogador do Corinthians / Partida / Arquibancada / Intervalo da partida / Partida / Gol do São Paulo / Placar: São Paulo 1, Corinthians 0 / Gol do Corinthians / Placar mostra empate.

[6] "Notícias Sociais" / PG de Lima Barreto chegando entre o público, vindo em direção à câmera / Mais pessoas chegando / Recinto com convidados, entre eles Grande Otelo e Adoniran Barbosa / Lima Barreto abraça senhora / Personalidades / Convidados / Entrada da noiva (Araçary de Oliveira?) / Lima Barreto e Araçary de Oliveira no altar / PP em PAN em Araçary e Lima Barreto / PP do padre / Noivos no altar / PP do noivo / PP da noiva / Noivos tomam a bênção / Trocam alianças / Noivo beija a noiva / Tonia Carrero e outra atriz(?) entre o presentes / Noivos saem da igreja acompanhados por convidados / PG dos noivos e convidados.

[7] "Fim".

Termos descritores: Esporte; Incêndio; Corpo de Bombeiros; Aviação; Acidente; Futebol; Casamento; Igreja Católica.

Termos livres: Atletismo; C. R. Vasco da Gama; Balão; S. C. Corinthians; São Paulo F. C.; Cinema; São Paulo - SP. 
Bandeirante da Tela n. 576. São Paulo: Divulgação Cinematográfica Bandeirante, 1954. Fita de vídeo (6min8seg), VHS, mudo, p\&b, VV00048. Cinemateca Brasileira.

Dados técnicos:

Elenco:

Garcez, Lucas Nogueira;

Cavalcanti, Alberto;

Souza, Ruth de;

Merinow, Victor;

Prado, Marisa;

Della Costa, Maria;

Marino Neto (narração).

Distribuição:

Hermantino Coelho.
1) "576"
(00:00 - 00:02)
2) [Sem intertítulo]
(00:03 - 00:39)
3) "Saúde e Beleza".
(00:40 - 01:03)
4) "Reportagem da Semana"......
(01:04 - 01:07)
5) "De Todo o Brasil".
6) "Exposição".
7) "Cinema e Teatro"
(02:10 - 02:56)
8) "Notícias Esportivas"
(02:57 - 03:36)
9) "Voleibol"
10) "Luta - Livre"
11) "Corrida". (05:08 - 06:05)
12) "Fim"

[1] "576".

[2] [Sem intertítulo] / PAN em PG de carro chegando com autoridades e público presente / PG da fachada do Paço Municipal com o público presente / PG das autoridades, Lucas Nogueira Garcez e homem lendo discurso / PG de crianças / Desfile de meninas / Tratores / PG da multidão / Noutro local, rapazes perfilados em campo aberto / Autoridade eclesiástica faz oração, presença de Lucas Nogueira Garcez / PG de outro grupo presente, presença da sra. Garcez / Lucas Nogueira Garcez coloca a pedra fundamental / PG de obra / Diversos planos das obras em andamento / Grupo reunido frente a um monumento (?) / Carros das autoridades (?).

[3] "Saúde e Beleza". Moças de maiô numa escada / Diversos planos / Desfile das modelos / PA de três modelos / PP das três.

[4] "Reportagem da Semana" / não há imagem correspondente.

[5] "De todo o Brasil" / GPG de cidade no vale (seria Teresópolis, conforme catálogo?) / PG de prédios, casas e montanhas.

[6] "Exposição" / Homens colocando um container num caminhão estacionado em rua / PG e Travelling do caminhão com container, acompanhado por batedores / Planos do comboio.

[7] "Cinema e Teatro" / Livro sendo folheado / MF de Alberto Cavalcanti ao meio de Ruth de Souza e outra mulher / Planos dos convidados / Alberto Cavalcanti explica o painel com fotografias expostas à uma mulher (seria uma atriz?) / A mesma mulher em MF com outros dois homens / MF de Ruth de Souza e outro homem / Coquetel /Alberto Cavalcanti sendo entrevistado / Dois homens (um deles vestido de mulher) dançam / A "mulher" joga o homem no chão.

[8] "Notícias Esportivas" / PAN de uma partida de tênis / Planos dos dois jogadores / Instrutor ensinando / Câmera lenta de algumas raquetadas do jogador. 
[9] "Voleibol" / Fachada do Clube Tietê / Técnico e suas atletas / PAN da partida de vôlei feminino / Planos das jogadas / Time posa para a câmera.

[10] "Luta Livre" / Homens lutando / Diversos golpes / Público em PG / Outros dois lutadores / Diversos planos dos golpes.

[11] "Corrida" / Motos em posição de largada / Largada / Planos dos motociclistas na corrida / Diversos planos em PG da corrida / Placa com as posições / Corredores cruzam a linha de chegada / Vencedor é abraçado pelos presentes.

[12] "Fim".

Termos descritores: Governo Estadual - SP; Engenharia; Solenidade; Desfile; Escola; Igreja Católica; Monumento; Incêndio; Moda; Mulher; Cidade; Teresópolis - RJ; Artes-plásticas; Transporte de carga; Exposição; Cinema; Esporte; Clube; Motociclismo.

Termos livres: Atletismo; Tênis; Voleibol; Clube Tietê; Luta livre; São Paulo - SP. 
Bandeirante da Tela n. 577. São Paulo: Divulgação Cinematográfica Bandeirante, 1954. Fita de vídeo (6min43seg), VHS, mudo, p\&b, VV00048. Cinemateca Brasileira.

\begin{tabular}{|c|c|}
\hline Dados técnicos: & 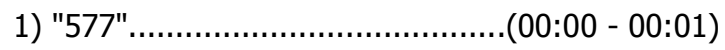 \\
\hline Elenco: & 2) "Pólo".......................................... 00:02 - 00:26) \\
\hline $\begin{array}{l}\text { Prado, Marisa; } \\
\text { Cavalcanti, Alberto; }\end{array}$ & 3) "Vida Militar"................ \\
\hline Souza, Ruth de; & 4) "Desastre"................................... 01:08 - 01:47) \\
\hline $\begin{array}{l}\text { Barros, Leonor Mendes de; } \\
\text { Chateaubriand, Assis; }\end{array}$ & 5) "Notícias Diversas".....................(01:48 - 03:24) \\
\hline $\begin{array}{l}\text { Barros, Adhemar de; } \\
\text { Marino Neto (narração). }\end{array}$ & 6) "Cinema e Teatro"......................(03:25 - 03:48) \\
\hline $\begin{array}{l}\text { Distribuição: } \\
\text { Hermantino Coelho. }\end{array}$ & $\begin{array}{l}\text { 7) "Grande Prêmio Joquei Club"......(03:49 - 04:54) } \\
\text { 8) "Notícias Sociais"........................(04:55 - 06:41) } \\
\text { 9) "Fim".......................................(06:42 - 06:43) }\end{array}$ \\
\hline
\end{tabular}

[1] "577".

[2] "Pólo" / Diversos planos da partida / Moças / Partida / PP de moça / Jogador montado em cplongée / Moças.

[3] "Vida Militar" / Desfile de Atletas militares / Desfile de jipes com "estátuas vivas" representando modalidades esportivas / PG dos militares nas arquibancadas do estádio / Desfile de atletas / PG das arquibancadas com militares / Atletas perfilados no centro do estádio / Arquibancada / Atleta chega em helicóptero com tocha olímpica.

[4] "Desastre" / PG da rua com curiosos / O trabalho dos bombeiros para apagar o incêndio em um prédio / PAN do prédio incendiado / Diversos planos do trabalho dos bombeiros para conter o fogo.

[5] "Notícias Diversas" / PG da multidão e dos eclesiásticos em solenidade religiosa / Avião chega com imagem da Virgem Maria (?) / Multidão / PP da imagem / Imagem segue entre a multidão / [Outro assunto] / Mesa com participantes de uma solenidade / Homens convidados / Banda de música / PG de moças em um jardim com piscina / Moças conversam / Posam para câmera / Diversos planos das moças no jardim / PG das moças e a piscina / Diversos planos.

[6] "Cinema e Teatro" / Reunião com pessoas / Homem manuseando mesa com filmes / Na bilheteria a atriz Ruth de Souza compra uma entrada.

[7] "Grande Prêmio no Jóquei Clube" / PAN das arquibancadas com o público / PP e PG de moças bonitas presentes no local / PG do público / PAN da corrida / PP de homem que observa com binóculos / Cavalos cruzam a linha de chegada / PAN do vencedor (?).

[8] "Notícias Sociais" / PG da fila com pessoas / Leonor de Barros distribui presentes / Diversos planos da entrega / Mães e crianças / Encontro social de Leonor de Barros com outras pessoas / Pessoas chegam ao local / PM de Leonor de Barros sentada numa cadeira cercada pelos participantes da reunião / MF de Leonor de Barros tomando um aperitivo e brindando com os convidados / Diversos PG da instância de férias (Campos do Jordão?) / PP de placa "Pavilhão Adhemar de Barros 21-7-1953" / Mais planos das casas e dos prédios / Pessoas andam a cavalo na rua / Homem pega água na fonte / Pessoas passeiam pelo bosque / casal dança ao som de músicos no bosque / Piquenique / casais dançam / GPG de casa ao topo de uma montanha.

[9] "Fim".

Termos descritores: Esporte; Desfile; Exército; Aviação; Acidente; Incêndio; Corpo de Bombeiros; Igreja Católica; Cinema; Turfe; Filantropia; Campos do Jordão - SP; Lazer; Turismo.

Termos livres: Pólo; Helicóptero; Estádio São Januário, Rio de Janeiro - DF; Rua Xavier de Toledo, São Paulo - SP; N. S. Aparecida; Jóquei Clube de São Paulo. 
Bandeirante da Tela n. 585. São Paulo: Divulgação Cinematográfica Bandeirante, 1954. Fita de vídeo (6min40seg), VHS, mudo, p\&b, VV00048. Cinemateca Brasileira.

Dados técnicos:

Elenco:

Garcez, Lucas Nogueira;

Vargas, Getúlio;

Barros, Adhemar de;

Marino Neto (narração).

Distribuição:

Hermantino Coelho.
1) "585".....
(00:00 - 00:02)
2) "Notícia Diversas".
..(00:03 - 00:34)
3) "Notícias Oficiais"
(00:35 - 01:26)
4) "Notícias Sociais"
(01:27 - 01:58)
5) "Conheça sua Terra"
6) "Vida Industrial"..
7) "Saúde e Beleza".
(04:10 - 04:41)
8) "Norte do Brasil" (04:42 - 06:37)
9) "Notícias do Rio". (00:00 - 00:00)
10) "Fim". (00:00 - 00:00)

\section{[1] "585".}

[2] "Notícias Diversas" / Mesa com participantes de solenidade / Na mesma mesa, homem se levanta e discursa / Presentes / Outro homem discursando / Presentes / PAN em PG da mesa / Presentes / Aplausos / Outro homem discursando / Presentes.

[3] "Notícias Oficiais" / Lucas Nogueira Garcez é recebido por pessoas em aeroporto / GPG da multidão que recebe o governador, faixa "O Povo de Rancharia (?) Os Congressistas" (embaixo da faixa, bandeiras do Brasil, Japão, Inglaterra, Itália, Espanha e o estado de São Paulo) / PM de Lucas Nogueira Garcez e autoridades locais que posam para câmera ao lado de maquetes de alguns prédios / Presentes / GPG de crianças brincando em playground / PG da sacada de um prédio com Lucas Nogueira Garcez e autoridades locais / Desfile em rua de terra / Caminhões desfilam com motivos agrícolas, um deles com a placa "semente de algodão" / Banda de músicos / Esportistas / Moças desfilam portando bandeira dos estados do Brasil / Banquete / Discurso de Lucas Nogueira Garcez / MF de outros participantes.

[4] "Notícias Sociais" / PAN do baile / Diversos planos dos convidados se banqueteando.

[5] "Conheça sua Terra" / No interior do avião, aeromoça distribui almoço (?) / Pessoas conversam / Avião pousa / Pessoas desembarcam (seria uma comitiva?) / Homem sentado conversa com outras pessoas ao seu redor / Discurso / Outro homem discursa / Coquetel / PG de casas e igrejas (de Salvador-BA?) / Prédio Público (?) / Praia com coqueiros / Homem descasca coco / Criança sentada / MF de duas baianas a caráter / Câmera "fecha" em PPL em moça dançando, caracterizada de baiana / Outros planos da mesma moça.

[6] "Vida industrial" / PG da construção de um prédio (apenas os alicerces) / Recinto com pessoas (presentes para solenidade?) / PG do salão / Pessoas se servem do coquetel (?) oferecido / Diversos planos da obra.

[7] "Saúde e Beleza" / Desfile de moças com maiô / Candidatas / modelos posam para jurados / Público / Modelos / Público.

[8] "Norte do Brasil" / Adhemar de Barros caminha entre os populares / PG da multidão presente / PAN dos presentes / PG de barcos e navegando / Barcos no porto / PAN do Barco Flor do Mar / Diversos planos e PAN das ruas da cidade. 
[9] "Notícias do Rio" [conforme o catálogo, pois a imagem ruim não permite confirmação] / PAN em PG do interior de estádio de futebol / Palanque com Getúlio Vargas e outras autoridades / Carro alegórico abre desfile, moças vestidas com roupas gregas / Moça com baliza / Moças na arquibancada / Moças com arcos de flores (representando os anéis olímpicos?) / Moça faz performance com fita / Bloco de moças desfilando com a bandeira dos estados brasileiros / Moça com fita faz performance para o público nas arquibancadas / Moça desfila no topo de um carro alegórico.

[10] "Fim".

Termos descritores: Solenidade; Desfile; Cidade; Rancharia - SP; Agricultura; Imigração - JP - UK - IT - ES; Salvador - BA; Comportamento social; Engenharia; Concurso de beleza; Mulher; Nordeste; Mar; Pesca; Embarcação; Esporte.

Termos livres: Estádio das Laranjeiras, Rio de Janeiro - DF; Carro alegórico. 
Bandeirante da Tela n. 586. São Paulo: Divulgação Cinematográfica Bandeirante, 1954. Fita de vídeo (5min47seg), VHS, mudo, p\&b, VV00048. Cinemateca Brasileira.

\begin{tabular}{|c|c|}
\hline Dados técnicos: & 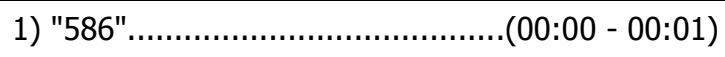 \\
\hline Elenco: & 2) "Vida Militar"................................... $00: 02$ - 00:40) \\
\hline $\begin{array}{l}\text { Carrero, Tonia; } \\
\text { Autran, Paulo; }\end{array}$ & 3) "Luta Livre"..................................(00:41 - \\
\hline Cavalcanti, Emiliano Di; & $01: 14)$ \\
\hline Prado, Marisa; & 4) "Notícias Diversas"......................(01:15 - 01:44) \\
\hline Garcez, Lucas Nogueira; & 5) "Artes e Artistas"... \\
\hline $\begin{array}{l}\text { Gonzaga, Luiz } \\
\text { São Paulo F. C. }\end{array}$ & 6) "Notícias Oficiais".......................(02:50 - 03:46) \\
\hline S. C. Corinthians Paulista; & 7) "Desastre"................................(03:47 - 03:57) \\
\hline Marino Neto (narração) & $\ldots \ldots \ldots \ldots(03: 58-04: 58)$ \\
\hline $\begin{array}{l}\text { Distribuição: } \\
\text { Hermantino Coelho. }\end{array}$ & 9) "Notícias do Rio"........................(04:59 - 05:43) \\
\hline
\end{tabular}

[1] "586".

[2] "Vida Militar" / Público / Espadas sendo entregues / PG da tribuna com autoridades militares / Madrinhas entregam espadas / Aspirantes militares fazem juramento / Desfile dos militares com suas espadas.

[3] "Luta Livre" / Homens lutando / Um dos lutadores é posto para fora do ringue à base de golpes / Público / Luta / Lutador com roupão agradece ao público.

[4] "Notícias Diversas" / Praça com ônibus / Outros pontos com ônibus / Polícia montada / Carros da polícia (?) / Polícia.

[5] "Artes e Artistas" / MF de Paulo Autran e Tônia Carrero / Outros pessoas (artistas?) / Tônia Carrero conversa com mulher / PAN de dois homens se deslocando até Paulo Autran, outro homem e Tônia Carrero / PPL de Tônia Carrero / Mais pessoas (artistas?) / Tônia Carrero / Avião chega em aeroporto / Moça desembarca: Marisa Prado / Moça é recebida / Moça posa para câmera / MF desta mesma moça (Marisa Prado?) conversando com homem / Moça entra em carro / PP da moça dentro do carro.

[6] "Notícias Oficiais" / Desfile de tropas (?) (imagem muito escura) / Oficiais assistem / Plongée de Lucas Nogueira Garcez (costas) com autoridades militares / PP da placa "Tiro de Guerra 298 - São Bernardo do Campo" / Lucas Nogueira Garcez e autoridades civis e militares em frente a bandeira do Brasil que está sendo hasteada / PG dos presentes em frente a escola / Crianças com a bandeira do estado de São Paulo / Outras crianças também seguram a bandeira do Brasil / Trio Nordestino toca para pessoas / Moça entre o bumbo e o sanfonista (Luiz Gonzaga?) / Moças (meninas?) observam de perto o sanfonista / PP do sanfonista (Luiz Gonzaga?).

[7] "Desastre" / Avião caído no mar.

[8] "Futebol" / PG de partida entre o São Paulo e o Corinthians no Pacaembu / Cobrança de falta pelo São Paulo / Placar mostra empate em 0 a 0 / Jogador sai de maca / GPG de torcedores (saindo?) / Gol do São Paulo / GPG do anel superior da arquibancada / Placar mostra 1 a 0 para o São Paulo.

[9] "Notícias do Rio" / Moças disputam campeonato de arco e flecha / Público / PA de arqueira esticando o arco / PP da arqueira / PP do alvo sendo atingido.

[10] "Fim".

Termos descritores: Solenidade; Desfile; Exército; Esporte; Transporte coletivo; São Paulo - SP; Polícia; Arte; Efeméride; São Bernardo do Campo - SP; Música Popular Brasileira; Acidente; Aviação; Futebol; o social; Engenharia; Concurso de beleza; Mulher; Nordeste; Mar; Pesca; Embarcação; Futebol; Esporte.

Termos livres: Luta livre; Ônibus; Teatro; Centenário de São Bernardo do Campo - SP, 4; São Paulo F. C.; S. C. Corinthians; Estádio do Pacaembu, São Paulo - SP; Rio de Janeiro - DF; Arco e flecha. 
Bandeirante da Tela n. 588. São Paulo: Divulgação Cinematográfica Bandeirante, 1954. Fita de vídeo (6min3seg), VHS, mudo, p\&b, VV00048. Cinemateca Brasileira.

Dados técnicos:

Elenco:

Albuquerque, Adalberto Rodrigues de;

Barros, Adhemar de;

Souza, Ruth de;

Gonzaga, Adhemar;

Civelli, Mário;

Somoza, Anastácio;

Marino Neto (narração).

Distribuição:

Hermantino Coelho.
1) "588"
(00:00 - 00:01)
2) "Notícias do Rio".
(00:02 - 00:33)
3) "Notícias Esportivas"
(00:34 - 01:19)
4) "Cinema e Teatro".
(01:20 - 01:47)
5) "Desfile de Modas".
(01:48 - 02:35)
6) [Sem intertítulo].
(02:36 - 04:06)
7) "Visitantes Ilustres".
(02:20 - 04:06)
8) "Momento Político".
(04:07 - 04:31)
9) "Bailado"....
10) "Educação e Ensino".
.(05:29 - 06:02)
11) "Fim".

\section{[1] "588".}

[2] "Notícias do Rio" / MF de dois homens / Homens entrando em recinto / PAN em PA de 4 homens caminhando (para o mesmo local dos outros?), um deles olha para a câmera / No interior do salão PAN das mesmas pessoas para o banquete-almoço / MF de dois homens, o mesmo homem baixo da seqüência anterior sorri para a câmera (seria este o Gal. Adalberto Rodrigues de Albuquerque?) / Banquete / PA dos homens saindo do recinto (o mesmo homem baixo no meio deles.

[3] "Notícias Esportivas" / Desfile de atletas em rua e o público assistindo / Palanque com autoridades civis e militares / Desfile de atletas com bicicletas e mais atrás atletas com faixa sobre Jundiaí / Moças com placas de modalidades esportivas e uniformes do Guarujá-SP / Rapaz e moça em performance com baliza / Menino vestido de bandeirante e atleta com placa de Mogi das Cruzes / Moças / Jipe com moças segurando a bandeira de São Paulo e do Brasil / Atletas com faixa "Sorocaba saúda os esportistas e o povo de Jundiaí" / Atletas de Uberaba.

[4] "Cinema e Teatro" / PAN do interior do auditório / Mesa composta por três homens / Planos dos presentes / Ruth de Souza entre os presentes / Mais presentes (seriam artistas?).

[5] "Desfile de Modas" / Diversos planos das modelos na passarela.

[6] [Sem intertítulo] / PG de grupo de moças perfilado para educação física, ao lado esquerdo, uma fila de rapazes / Em cima de um banco, homem dá instruções àquele grupo de moças / PM do grupo de moças / PG das moças em fila entrando num trailer / Moças sendo orientada por técnico de Raio -X(?) diante de uma máquina (de radiografia?) / MF de outra moça sendo orientada para tirar chapa / MF de perfil da moça diante da máquina / Moça saindo do trailer/ PG da fila de moças.

[7] "Visitantes Ilustres" / PG da guarda perfilada / Guarda (Dragões?) acompanham autoridade militar que passa a tropa em revista (?) / PAN da autoridade que passa a tropa em revista (?) / Coroa de flores / Autoridades militares / Autoridade militar entra em automóvel / Planos das autoridades militares / PG da tropa perfilada (Dragões?) / Noutro local, outras autoridades militares / Militar (Anastácio Somoza?). 
[8] "Momento Político" / Planos de um prédio em obras / Adhemar de Barros cercado de homens (autoridades civis?) / Adhemar de Barros cercado por pessoas (dentro de um prédio?) / MF de Adhemar de Barros e outros dois homens que posam para fotografia / Adhemar de Barros e outros homens, inclusive autoridade eclesiástica / Visita às instalações da obra.

[9] "Bailado" / Meninas fantasiadas apresentam número para o público / Público / Meninas apresentam número de cancã / Menina apresenta número de balé / Público aplaude.

[10] "Educação e Ensino" / Público na arquibancada / Prova de atletismo, corrida / Público / Prova de arremesso de peso / PAN da arquibancada / Prova de salto à distância / PP de moça / Salto em altura / Moças assistem.

[11] "Fim".

Termos descritores: Solenidade; Exército; Esporte; Desfile; Sorocaba - SP; Cinema; Moda; Mulher; Medicina; Diplomacia - NI; Política; Santo André - SP; Dança; Ensino.

Termos livres: Rio de Janeiro - DF; Jogos Abertos do Interior - SP; Jundiaí - SP; Uberaba - SP; Guarujá - SP; Mogi das Cruzes - SP; Raio - X; Cancã; Atletismo; São Paulo - SP. 
Bandeirante da Tela n. 590. São Paulo: Divulgação Cinematográfica Bandeirante, 1954. Fita de vídeo (6min5seg), VHS, mudo, p\&b, VV00048. Cinemateca Brasileira.

Dados técnicos:

Elenco:

Garcez, Lucas Nogueira;

Marino Neto (narração).

Distribuição:

Hermantino Coelho.

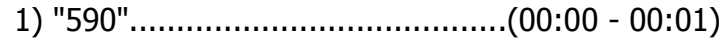

2) "Notícias Diversas"..................(00:02 - 01:08)

3) "Notícias Oficiais".....................(01:09 - 01:37)

4) "Ginástica"...........................(01:38 - 02:33)

5) "Curiosidades".......................(02:34 - 03:16)

6) "De Todo o Mundo"...................(03:17 - 03:59)

7) "Artes Plásticas".....................(04:00 - 04:25)

8) "Notícias do Rio".....................(04:26 - 05:06)

9) "Luta Livre".

05:21)

10) "Atletismo". (05:22 - 06:02)

11) "Fim"

[1] " $590 "$.

[2] "Notícias Diversas" / PG em PAN de obra pública / Plongée em PAN da mesma obra / Homem manuseando o guindaste (?) / PAN em GPG aéreo da obra.

[3] "Notícias Oficiais" / PG de Garcez passando em revista a banda do exército / Banda do exército / PG de Garcez e militares / Garcez na entrada de um prédio com militares / Carros oficiais saem (ou entram) do quartel (?) do exército, enquanto banda toca / PG dos soldados marchando.

[4] "Ginástica" / Panorama do público no palanque / GPG de grupos de moças / Atletas em formação, em espaço aberto / Grupo de moças / Desfile de ginastas / Autoridades civis e militares aplaudem / PG das moças fazendo exercícios / Desfile das atletas do Mackenzie / PG de autoridades civis e militares no palanque / Meninas do Mackenzie desfilam / Moças atletas em PG fazem exercícios / PA de moças perfiladas fazendo exercícios / Cadetes (?) em PG nas arquibancadas aplaudem / Moças fazem exercícios com bambolê / PA de moça fazendo exercício com bambolê / Outros planos das moças fazendo exercícios com bambolê / PG dos cadetes nas arquibancadas que se levantam e aplaudem.

[5] "Curiosidades" / Moça retira caixa de esteira / moças organizam correspondências (?) / Cartas sendo carimbadas-registradas por moça / Cartas são organizadas-separadas / PG do "escaninho" com várias cartas separadas / Rapaz organiza "pacotes" de correspondências.

[6] "De Todo o Mundo" / PG de pessoas e suas bagagens (?) em rua-esquina / PM das mesmas pessoas e suas bancas (?) / Diversos planos de mulheres africanas negras (e filhos) com suas bancas e/ou barracas de produtos à venda ao ar livre.

[7] "Artes Plásticas" / Pessoas visitam exposição / Planos de quadros e artesanato em exposição / Diversos planos e PAN das pessoas presentes no local. 
[8] "Noticias do Rio" / Carro chega em rua com pessoas assistindo gincana (?) / Homem vendado (com saco na cabeça) tenta acertar a moringa pendurada / Homem quebra a moringa com água / Rapazes hasteiam a bandeira do Brasil / Moça corre e entra no carro / Fusca chega, moça e rapaz saem do carro, rapaz dá uma volta ao redor do carro levando a moça num carrinho de pedreiro, depois entram no carro.

[9] "Luta Livre" / Planos dos lutadores no ringue desferindo seus golpes.

[10] "Atletismo" / Moças disputam corrida com barreira / PA de duas atletas / Moças disputam salto à distância / Na arquibancada torcedores do Fluminense / Planos de moças disputando arremesso de peso.

[11] "Fim".

Termos descritores: Engenharia; Energia; Solenidade; Exército; Esporte; Desfile; Correio; Comércio; África; Artesplásticas; Artesanato; Rio de Janeiro - DF; Concurso; Mulher.

Termos livres: Eletricidade; Pedreira, São Paulo - SP; Ginástica; Colégio Mackenzie, São Paulo - SP; Gincana; Luta livre; Atletismo. 
Bandeirante da Tela n. 591. São Paulo: Divulgação Cinematográfica Bandeirante, 1954. Fita de vídeo (6min14seg), VHS, sonoro, p\&b, VV00048. Cinemateca Brasileira.

Dados técnicos:

Elenco:

O'Brien, Michael Patrick;

Marino Neto (narração).

Distribuição:

Hermantino Coelho.
1) "591"..... (00:00 - 00:01)
2) "Ginástica"
(00:02 - 00:38)
3) "Cinema e Teatro".
(00:39 - 01:12)
4) "Saúde e Beleza".....
.(01:13 - 01:56)
5) "Brasil Pitoresco". (01:57 - 03:00)
6) "Futebol". (03:01 - 03:44)
7) "Notícias Diversas".. (03:45 - 04:26)
8) "Desfile de Modas". .(04:27 - 05:26)
9) "Aviação" (05:27 - 06:10)
10) "Fim"... (06:11 - 06:14)

[2] "Ginástica" / Moça pratica exercício de halterofilismo no banco / Moça em pé pratica exercício com pesos / A mesma moça em PP passando batom.

[3] "Cinema e Teatro" / Fachada do cinema com fila de pessoas, anúncio do filme "Veio do Espaço" / PG do cartaz em "3a Dimensão" / PG da fila / Diversos planos das pessoas na fila / Pessoas entregam bilhete na entrada e recebe óculos 3D.

[4] "Saúde e Beleza" / PAN das mães com seus bebês no colo / Diversos planos das crianças / Bebês / Gêmeos / Mães com bebês.

[5] "Brasil Pitoresco" (conforme catálogo da CB) / Praia de Iracema (Ceará) com barcos na areia / Coqueiros / Quiosques / Pescadores preparando suas redes / Pescadores e o trabalho para colocar a jangada no mar / PG de barcos à vela na areia / PAN dos barcos na areia / Pescadores exibem os peixes pescados.

[6] "São Paulo" / Vista aérea do bairro do Pacaembu, suas casas residenciais e o estádio / Vista aérea do centro da cidade / PAN de barraco na periferia, moleques brincando na rua / Diversos planos de casa com vigas de madeira escoradas para evitar o desmoronamento / Vista aérea do Pacaembu e a praça Charles Muller.

[7] "Notícias Diversas" / MF de O'Brien, navegador / O'Brien com sua bagagem passa por passarelas ao desembarcar de navio, seguido de fotógrafos e autoridades policiais / O'Brien cercado por pessoas / PP de O'Brien / PG de O'Brien cercado por jornalistas (?) / Diversos planos de O'Brien e uma comitiva de repórteres e fotógrafos.

[8] "Desfile de Modas" / Diversos planos das modelos na passarela / PA das modelos e seus vestidos.

[9] "Aviação" / PAN de aviões em vôo rasante / PG da banda em marcha / Diversos planos de aviões no céu / Aviões aterrissam.

[10] "Fim".

Termos descritores: Esporte; Mulher; Cinema; Criança; CE; Praia; Pesca; Embarcação; São Paulo - SP; Habitação; Navio; Desfile; Moda; Aviação.

Termos livres: Fisiculturismo; Puericultura; Praia de Iracema - CE; Jangada; Pacaembu, São Paulo - SP; Favela. 
Bandeirante da Tela n. 592. São Paulo: Divulgação Cinematográfica Bandeirante, 1954. Fita de vídeo (6min30seg), VHS, mudo, p\&b, VV00048. Cinemateca Brasileira.

Dados técnicos:

Elenco:

Vargas, Getúlio:

Café Filho, João;

C. R. Flamengo;

C. R. Vasco da Gama;

Marino Neto (narração).

Distribuição:

Hermantino Coelho.
1) "591".
(00:00 - 00:01)
2) "Ginástica"
(00:02 - 00:38)
3) "Cinema e Teatro".
(00:39 - 01:12)
4) "Saúde e Beleza".
(01:13 - 01:56)
5) "Brasil Pitoresco".
6) "Futebol".
(03:01 - 03:44)
7) "Notícias Diversas"
(03:45 - 04:26)
8) "Desfile de Modas".
(04:27 - 05:26)
9) "Aviação".
10) "Fim"

\section{[1] "592".}

[2] "Artes e Artistas" / Equilibrista em apresentação circense / Público / Malabaristas / Diversos planos dos malabaristas em seus números.

[3] "Futebol" / PG da arquibancada / Time do Vasco da Gama posa para as câmeras / Flamengo entra em campo, ao fundo a sua torcida na arquibancada / Time do Flamengo posa para as câmeras / Início da partida / Planos alternados da partida e da arquibancada / Gol do Vasco da Gama / Arquibancada / Fim da partida.

[4] "Cinema e Teatro" / Fachada de um cinema com cartaz "Novidade! Tela Panorâmica" / PAN do público no interior do cinema / Público nas escadas / Anúncio "Lili será o filme de estréia da nova tela panorâmica" / PAN do público presente no interior do cinema.

[5] "Brasil Pitoresco" / Coqueiros / Diversos planos da praia e dos banhistas / Meninos na areia / Diversos planos dos pescadores e uma jangada na areia.

[6] "IV Centenário" / Tomada aérea da cidade de São Paulo / PG de monumento / Fachada de prédio público / PG de terreno abandonado / Planos das casas e estabelecimentos demolidos, destroços e escombros / Tomada aérea da cidade: centro.

[7] "Aviação" / Aviões no céu / PG do palanque montado com autoridades civis e militares, Getúlio Vargas ao centro / Avião aterriza / Getúlio Vargas entre os pilotos, público ao fundo / PG dos aviões, um ao lado do outro / Getúlio Vargas se prepara para voar / PPL de Getúlio Vargas no cockpit do avião / PG do avião com a "tampa" aberta, tendo o piloto na frente e Getúlio Vargas atrás / Getúlio Vargas saindo do avião.

[8] "Desfile de Modas" / Diversos planos das modelos desfilando / MF e PA das modelos.

[9] "Turfe" / Helicóptero pousa no Jóquei Clube / PG da arquibancada / Numa pequena praça, um cavalo é montado / Moças no público / PG dos cavalos chegando / MF de duas moças / PAN em PG do público e a pista com cavalos correndo / Público na arquibancada observa com binóculos / Moças / PAN em PG do público e da pista com cavalos correndo / PG do jóquei e o cavalo vencedor (?).

[10] "Fim".

Termos descritores: Circo; Futebol; Rio de Janeiro - DF; Cinema; CE; Praia; Pesca; Embarcação; São Paulo - SP; Aviação; Efeméride; Desfile; Moda; Turfe.

Termos livres: C. R. Flamengo; C. R. Vasco da Gama; Estádio do Maracanã, Rio de Janeiro - DF; Jóquei Clube de São Paulo; Praia de Iracema - CE; Jangada. 
Bandeirante da Tela n. 600. São Paulo: Divulgação Cinematográfica Bandeirante, 1954. Fita de vídeo (6min47seg), VHS, mudo, p\&b, VV00048. Cinemateca Brasileira.

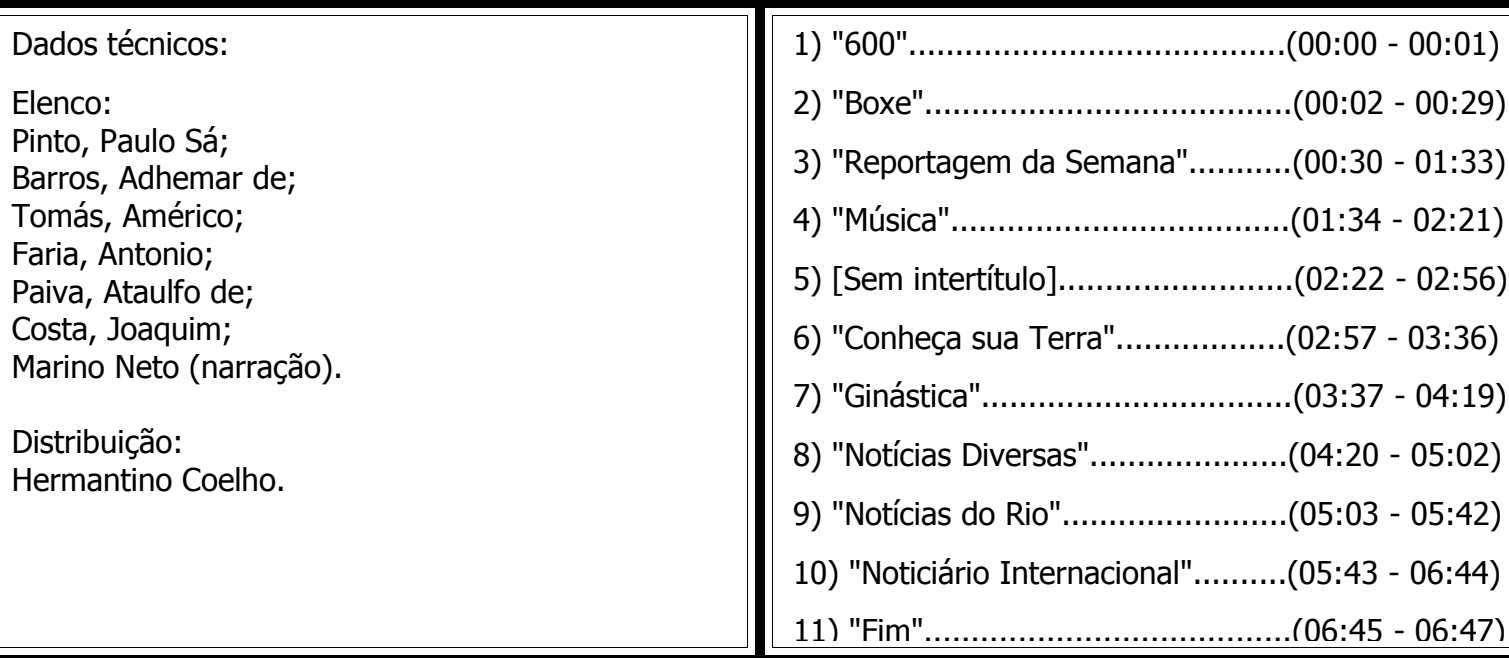

[1] "600".

[2] "Boxe" / Diversos planos em PG de uma luta de boxe.

[3] "Reportagem da Semana" / Diversos planos de uma ambulância tombada na rua / PAN do local com os "curiosos" / Mais planos do carro tomado no local / PG em PAN de um rio, tendo à margem grande número de pessoas / Barco com 3 pessoas / Público na margem do rio / PG de carros de bombeiro e da polícia (?) chegando no local.

[4] "Música" / Diversos planos de moças tocando acordeom / PM das moças dançando-bailando e tocando o instrumento / Mais planos das moças tocando o instrumento / Público aplaude / Menino toca acordeom / Menina baila em torno do menino.

[5] [Sem intertítulo] / Avião aterriza em aeroporto / Pessoas desembarcam / Pessoas cumprimentam homem que desembarca / PM, em direção à câmera, do visitante e das pessoas que o recepcionam.

[6] "Conheça sua Terra" / PAN das pessoas que observam a aterrissagem do avião no aeroporto / PAN em PG do público presente / Adhemar de Barros abre a porta do avião e acena ao público / PAN do público presente / Planos em PG do público presente / PG de Adhemar de Barros - acendendo um cigarro - entre os presentes / PAN em PG de vários caminhões lotados com pessoas em suas caçambas.

[7] "Ginástica" / Homem levanta peso com apenas um braço / PM de moça praticando exercício com peso / A mesma moça, no chão, pratica abdominais / Homem ergue moça como se fosse um peso e pratica exercício com o seu corpo.

[8] "Notícias Diversas" / PG da Estação da Luz e a rua com barracas de camelôs / Planos dos camelôs com suas mercadorias e "sujeira" / Diversos planos (PG e PM) dos camelôs com suas barracas, o público cliente e as ruas sujas.

[9] "Notícias do Rio" / Autoridades se cumprimentam em solenidade / Mesa composta, homem discursa (ministro português?) / MF dos componentes da mesa (?) / Presentes / Moças presentes / Orador / Presentes aplaudem.

[10] "Notícias Internacionais" / PG de palácio/castelo (?) de Notre Dame / Pinturas e livros sendo vendidos na rua / Rio com barco à vapor / Diversos planos em PG da Torre Eifel / GPG aéreo de monumento / PG do museu e outros prédios públicos / PG de barraca de flores.

[11] "Fim".

Termos descritores: Esporte; Acidente; Rio; Dança; Música; Visita estrangeira - FR; Aviação; Fortaleza - CE; Política; Ferrovia; Comércio; Rio de Janeiro - DF; Diplomacia - PT; Paris - FR.

Termos livres: Boxe; Trânsito; Afogamento; Acordeom; Cinema; Fisiculturismo; Estação da Luz, São Paulo - SP; Estádio do Maracanã, Rio de Janeiro - DF. 
Bandeirante da Tela n. 605. São Paulo: Divulgação Cinematográfica Bandeirante, 1954. Fita de vídeo (3min8seg), VHS, mudo, p\&b, VV00048. Cinemateca Brasileira.

Dados técnicos:

Elenco:

Marino Neto (narração).

Distribuição:

Hermantino Coelho.
1) [Sem título e intertítulo].

2) "De Todo o Mundo"

$(00: 00-00: 49)$

$(00: 50-03: 08)$

[1] [Não há título nem intertítulos] / PA de alguns homens falando à imprensa / PG da fachada da Federação Paulista de Futebol com uma multidão de pessoas / Carro do Corpo de Bombeiros com um caixão e bandeira do Estado de São Paulo / Cortejo fúnebre: caminhão de bombeiro andando com batedores e um homem com a bandeira do São Paulo Futebol Clube / Chegada ao cemitério / Planos da chegada ao cemitério e das pessoas em direção à capela (para o velório?) / Bombeiros descem o caixão / PP de imagem de cristo e uma cruz.

[2] "De Todo o Mundo" / Exposição de eletrodomésticos / Forno-fogão que se articula sozinho / Outro fogão / Planos de alguns tipos de televisores / Outro móvel que se articula sozinho (seria um toca discos?) / Crianças brincando-dirigindo "bugs" (carrinhos) e triciclos / Fachada de estabelecimento com dizeres em letreiro: "Paris - Orly" / Avião aterriza / Pessoas desembarcam / PP do comandante (?) / PP de aeromoça / Pessoas descendo a escada de desembarque / PP do comandante (?) que acena / Plongée de dois homens que desembarcam do avião com vestimentas árabes / Locomotivas em exposição / PAN de alguns modelos em miniatura de navios e ferrovias / PG de uma estação ferroviária (seria uma maquete?) / Locomotiva parte / PG de uma estação ferroviária (?).

Termos descritores: Morte; Futebol; Exposição; Eletrodoméstico; Aviação; Modelismo.

Termos livres: Velório; Federação Paulista de Futebol; São Paulo F. C.. 
Bandeirante da Tela n. 611. São Paulo: Divulgação Cinematográfica Bandeirante, 1954. Fita de vídeo (4min48seg), VHS, sonoro, p\&b, VV00048. Cinemateca Brasileira.

Dados técnicos:

\section{Elenco:}

Elíseo, Mário; Machado Neto, Brasílio;

Morais, Manoel Vieira de; Silva, Rivadavia Caetano;

Vidigal, Luis Roberto; Keller, Floriano Peixoto;

Zerbini, Euriale de Jesus; Ararigboia, Armando de

Sousa e Melo; Neiva, Alcides; Centola, Nicolau Mário; Cavalcanti, Alberto; Stroheim, Erich Von; Sevilha, Ninon; Pinheiro, Jaime de Andrade; Hauff, Angélica; Gance, Abel; Fontaine, Joan; Pidgeon, Walter; Fleming, Rhonda; Duarte, Aurora; Flynn, Errol; MacMurray, Fred; Cummings, Robert; Marino Neto (narração).

Distribuição:

Hermantino Coelho.
1) "Número". $(00: 00-00: 01)$

2) "Notícias Esportivas" (00:02 - 01:03)

3) "Vida Industrial". (01:04 - 01:47)

4) "Vida Militar" $(01: 48-02: 28)$

5) "Cinema". $(02: 29-04: 45)$

6) "Fim". $(04: 46-04: 48)$

\section{[1] "611".}

[2] "Notícias Esportivas" / Planos das moças praticando prova de salto em altura no Pacaembu / Homens praticam prova de disco / Atleta do Vasco da Gama / Atleta do Botafogo / PG em PAN da prova de corrida com barreira / Atleta do Vasco da Gama / PAN da prova de corrida / Atleta do Flamengo.

[3] "Vida Industrial" / Homem pescando em rio que passa por debaixo de uma ponte / Planos dos homens pescando / Associação Comercial de Pirassununga / Pessoas reunidas em almoço, homem em pé lendo discurso / PA do homem lendo discurso / Pessoas aplaudem / Outro homem em pé discursa / Presentes à mesa / Outro homem discursa / Presentes à mesa / Outro homem discursa.

[4] "Vida Militar" / PA dos oficiais em solenidade / Civil discursa / O mesmo homem cumprimenta oficiais militares / Homem condecora oficial militar / Condecoração de outro oficial militar / Condecoração do delegado do DOPS / PA dos militares/ PA dos civis.

[5] [Sem intertítulo] / Personalidades do cinema sobem as escadas ao chegarem para o Festival Internacional de Cinema em São Paulo / PA em plongée de duas moças (atrizes?) e o diretor Stroheim / PA e Plongée da Delegação do México / Homem / Atriz (Angélica Hauff?) com a delegação austríaca / Atrizes japonesas, uma delas tropeça na escada / Delegação francesa / Delegação americana / Ator norteamericano Walter Pidgeon cumprimenta crianças / Atriz norte-americana (?) / Público na entrada / Entra Aurora Duarte / Mais atores norte-americanos / Ator norte-americano Robert Cummings (?) /Entrada da delegação italiana / Planos do baile de carnaval no Pacaembu/ Vários atores em MF / PG do baile / Outros artistas em MF.

[6] "Fim".

Termos descritores: Esporte; Solenidade; Comércio; Pirassununga - SP; Exército; Polícia; Festival; Cinema; São Paulo - SP; Carnaval.

Termos livres: Atletismo; Pacaembu, São Paulo - SP; Troféu Brasil de Atletismo; C. R. Flamengo; C. R. Vasco da Gama; Botafogo F. R.; Associação Comercial de Pirassununga; DOPS - Delegacia de Ordem Política e Social; Cine Marrocos, São Paulo - SP; Ginásio do Pacaembu, São Paulo - SP. 
Bandeirante da Tela n. 650. São Paulo: Divulgação Cinematográfica Bandeirante, 1955. Fita de vídeo (7min36seg), VHS, sonoro, p\&b, VV00098. Cinemateca Brasileira.

Dados técnicos:

\section{Elenco:}

Denizard, Antonio; Assis, Plínio de; Paz, Porfírio da; Seyssel, Waldemar; Pimentinha; Arrelia; Amoroso Neto, João; Nunes, José Geraldo Salgado; Oliveira, Francisco José de; Rocha, Marta; Nelly, Carlos J.; Santos, Vanda; Nascimento, Clóvis; Marino Neto (narração).

Distribuição:

Hermantino Coelho.
1) "Guaíba Filmes"......................(00:00 - 00:03)

2) "Divulgação Cinematográfica Bandeirante" / "Bandeirante da Tela" / "650".....(00:04 - 00:30)

3) "Rainha". (00:31 - 01:29)

4) "Vida Militar"..........................(01:30 - 02:11)

5) "Espetáculos".

6) "Saltos Ornamentais". (02:58 - 03:45)

7) "Notícias Sociais". (03:46 - 04:07)

8) "Desfile de Modas". (04:08 - 04:57)

9) "Notícias do Rio". (04:58 - 06:14)

10) "Corrida". $(06: 15-07: 34)$

11) "Fim". (07:35 - 07:36)

[1] "Guaíba Filmes".

[2] "Divulgação Cinematográfica Bandeirante" / "Bandeirante da Tela" / "650".

[3] "Rainha" / PG das pessoas dançando no ginásio do Pacaembu / PG da mesa composta por pessoas (autoridades?) / PP de Antonio Denizard ao microfone / PP de Plínio de Assis no microfone / Outro plano da mesma mesa / PP de Francisco José de Oliveira ao microfone / Desfile das candidatas ao título "Rainha dos Trabalhadores" / Rainha anterior coloca a coroa em sua sucessora / Faixa é entregue pelo prefeito.

[4] "Vida Militar" / Diversos planos do desfile do regimento da Cavalaria da Força Pública / PG das manobras dos cavaleiros / "Carrossel" com os cavalos em apresentação em campo aberto / GPG de diversos exercícios / PP dos cavaleiros com cornetas / Diversos planos da exibição.

[5] "Espetáculos" / Pessoas chegando ao circo / Público com crianças / PA dos palhaços Pimentinha e Arrelia / PG da platéia / Pimentinha e Arrelia brincam com duas crianças no picadeiro / Diversos planos alternando os palhaços e o público / Diversos planos do exterior do circo com pessoas saindo (?) / PG da externa do circo com letreiro TV Record e placa-cartaz Circo Arrelia - Eduardo.

[6] "Saltos Ornamentais" / PAN das atletas correndo com obstáculos na pista do Clube Tietê / PP da vencedora Vanda dos Santos (vestida com a camisa do SPFC) / Planos das arremessadoras de dardos durante as provas / Planos das atletas nas provas de salto em altura / PP do técnico "Kisley" / Atletas na prova dos 100 metros rasos / PP do vencedor Clóvis Nascimento.

[7] "Notícias Sociais" / Homens num recinto / PP de João Amoroso Neto / PG dos presentes no recinto / PP de José Geraldo Salgado Nunes e de João Amoroso Neto / João Amoroso Neto recebe cumprimentos.

[8] "Desfile de Moda" / MF de Tristão de Almeida ao microfone tendo ao seu lado Marta Rocha (que parece estar sentada) / PP de Marta Rocha / Planos das modelos desfilando / Pessoas observam / PP de moça assinando papel / PA de Flavio Rodrigues ao microfone / PP de quatro homens, componentes da mesa. 
[9] "Notícias do Rio" / PP de um camelo / PP de um leão marinho / PG de uma ema / Elefantes / PG de aves / Macacos se balançando / PP de um macaco / PG da Baía de Guanabara (?) / PG das obras do aterro do Flamengo (?) / Caminhões e tratores trabalhando / PAN em PG da obra / PG da "concha" e da cruz construída para o $36^{\circ}$ Congresso Eucarístico Internacional no Rio de Janeiro.

[10] "Corrida" / Diversos planos dos organizadores da corrida de São Silvestre / Diversos planos de atletas / PP do corredor veterano Alfredo Gomes /Planos da corrida / Faixa de chegada / Planos dos vencedores na chegada (cruzando a linha) / Planos do pódio e dos vencedores sendo entrevistados / PP do terceiro e segundo colocados / PG dos vencedores no pódio / Diversos planos dos atletas no pódio.

[11] "Fim".

Termos descritores: Concurso de beleza; Trabalho; Polícia; Circo; Telecomunicação; Esporte; Solenidade; Animal; Moda; Mulher; Rio de Janeiro - DF; Igreja Católica; São Paulo - SP.

Termos livres: Força Pública; TV Record; Televisão; Salto ornamental; Atletismo; Clube Tietê; Dardo; Jardim Zoológico; Morro de Santo Antonio, Rio de Janeiro - DF; Congresso Eucarístico; Corrida de São Silvestre. 
Bandeirante da Tela n. 654. São Paulo: Divulgação Cinematográfica Bandeirante, 1955. Fita de vídeo (7min35seg), VHS, sonoro, p\&b, VV00098. Cinemateca Brasileira.

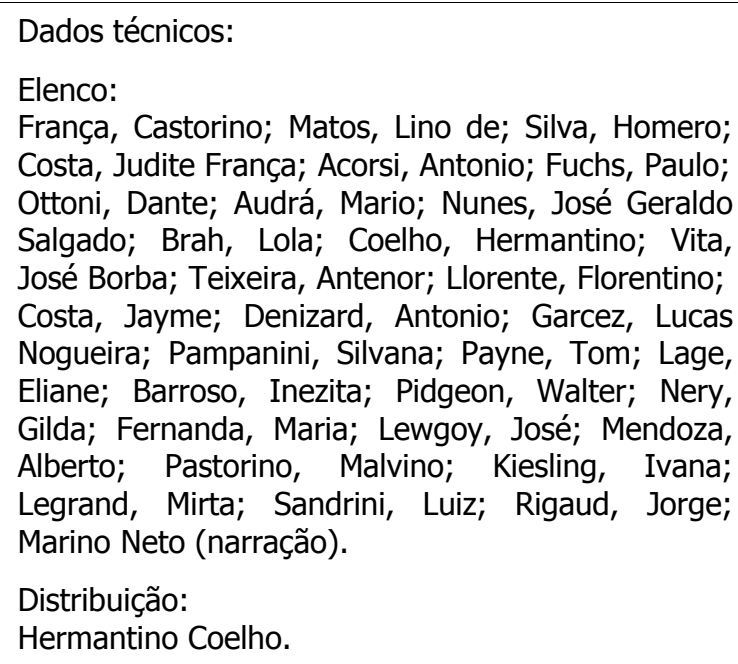

Dados técnicos:

Elenco:

França, Castorino; Matos, Lino de; Silva, Homero; Costa, Judite França; Acorsi, Antonio; Fuchs, Paulo; Ottoni, Dante; Audrá, Mario; Nunes, José Geraldo Salgado; Brah, Lola; Coelho, Hermantino; Vita, José Borba; Teixeira, Antenor; Llorente, Florentino; Costa, Jayme; Denizard, Antonio; Garcez, Lucas Nogueira; Pampanini, Silvana; Payne, Tom; Lage, Eliane; Barroso, Inezita; Pidgeon, Walter; Nery, Gilda; Fernanda, Maria; Lewgoy, José; Mendoza, Alberto; Pastorino, Malvino; Kiesling, Ivana; Legrand, Mirta; Sandrini, Luiz; Rigaud, Jorge; Marino Neto (narração).

Distribuição:

Hermantino Coelho.

1) [Certificado de Censura].

(00:00 - 00:02)

2) "Guaíba Filmes" (00:03 - 00:06)

3) "Divulgação Cinematográfica Bandeirante" / "Bandeirante da Tela" / "654".....(00:07 - 00:35)

4) "Momento Político"... (00:36 - 01:03)

5) "Educação e Ensino". (01:04 - 02:01)

6) "Curiosidades" (02:02 - 02:35)

7) "Homenagem". (02:36 - 03:14)

8) "Turfe". (03:15 - 04:07)

9) "Notícias do Rio". (04:08 - 05:04)

10) "Vida Industrial. (05:05 - 05:35)

11) "Artes e Artistas".....

\section{[1] [Certificado de censura].}

[2] "Guaíba Filmes".

[3] "Divulgação Cinematográfica Bandeirante / "Bandeirante da Tela" / "654".

[4] "Momento político" - Aeroporto de Congonhas, pessoas desembarcando do avião / Planos dos procedimentos aéreos em aviões / Aviões taxiando / Planos internos e externos do aeroporto.

[5] "Educação e Ensino" / Entrega de diplomas aos formandos / Turma de bacharéis de 1954 do ginásio Castro Alves, no Teatro de Cultura Artística / Diversos planos dos formandos recebendo diplomas / Deputado Homero Silva cumprimenta formando / PP da Profa. Judite França Costa / Deputado Homero Silva continua entregando diplomas / Prof. Antonio Acorsi entrega diplomas para turma de contadores / Três alunas tocam o mesmo piano / Maestro rege coro orfeônico.

[6] "Curiosidades" / PG do prédio Martinelli / PP do prédio / PG da coroa de aço no topo do prédio / pessoas andando na rua do prédio / Mão indica na fotografia a localização do prédio / PAN do topo do prédio (objetivando a coroa) até a rua.

[7] "Homenagem" / PA de cinco homens / MF de Paulo Fuchs da Columbia Pictures ao lado de outro homem / PA de quatro homens / PP de Mario Audrá / PA de três homens, entre eles Hermantino Coelho da D.C.B. / MF de José Borba Vita da Republic / MF de Florentino Llorente da Cia. Serrador ao lado de Paulo Fuchs / PP do jornalista Antenor Teixeira / PP do chefe de serviço de cinema / PP de Paulo Fuchs.

[8] "Turfe" / Jóqueis chegando com cavalos / PP de Jaime Costa / PAN da corrida / PA das mulheres nas arquibancadas / Pessoas nas cadeiras / PP de diversas mulheres em trajes de passeio (elegantes). 
[9] "Notícias do Rio" / PG da Cruz e da concha no aterro Sta. Luzia na esplanada do castelo / Planos das pessoas / Fiéis que assistem a missa em céu aberto / Interior da concha e os eclesiásticos / Eclesiásticos participam da missa / Autoridade eclesiástica de joelhos no altar cercada por assistentes / Amanhecer, sol nascendo com barcos no mar / Barcos, vapores transportam em procissão a imagem de N. S. de Fátima / Diversos planos dos barcos e vapores que acompanham o cortejo / Procissão.

[10] "Vida Industrial" / Auditório lotado / Mesa composta com o presidente reeleito Antonio Denizard (FIESP) em pé, discursando ao microfone (Nogueira Garcez sentado ao lado?) / Planos de algumas autoridades civis e militares / Nogueira Garcez fala ao microfone / Pessoas aplaudem em pé.

[11] "Artes e Artistas" / Planos de alguns chalés onde se hospedou Silvana Pampanini em Punta Del Leste / Planos de diversas de pessoas (fãs?) / Fachada do Cine Fragata / Plano dos mastros com bandeiras dos países das delegações presentes ao vento / Noite /Silvana Pampanini chega acompanhada / Tom Payne e Eliane Lage da delegação brasileira / Tom Payne ao microfone / Inezita Barroso tocando violão e cantando / Baile / Maria Fernand e José Lewgoy / Walter Pidgeon dançando com Gilda Néri / Praia da Punta Del Leste / Banhistas em diversos planos / Atores argentinos reunidos na praia em trajes de banho / Dois homens e três mulheres / Os mesmos entram e brincam na água.

Termos descritores: Aviação; Política; Solenidade; Escola; Música; São Paulo - SP; Engenharia; Cinema; Turfe; Efeméride; Cidade; Rio de Janeiro - DF; Igreja Católica; Praia; Embarcação; Indústria; Festival.

Termos livres: Aeroporto de Congonhas, São Paulo - SP; Ginásio Castro Alves, São Paulo - SP; Teatro Cultura Artística, São Paulo - SP; Coro; Prédio Martinelli, Avenida São João, São Paulo - SP; Jóquei Clube de São Paulo; Aniversário do Rio de Janeiro, 390; Punta Del Leste - UY. 
Bandeirante da Tela n. 663. São Paulo: Divulgação Cinematográfica Bandeirante, 1955. Fita de vídeo (9min7seg), VHS, sonoro, p\&b, VV00098. Cinemateca Brasileira.

Dados técnicos:

Elenco:

Silva, Ademar Ferreira da; Barros, Adhemar de; Barros, Leonor Mendes de; Silverman, Murrey; Pinto, Paulo Sá; Ararigbóia, Armando de Sousa e Melo; Tinoco, Tasso de Oliveira; Lima, Stenio Caio de Albuquerque; Alves, Murilo Antunes; Lemos, Túlio de; Morais, Conchita de; Lombardi, Carlos; Feres, Romeu; Silva, Homero; Moura, Maurici; Juliano, Randal; Migliori, Gabriel; Zan, Mário; Durães, Manoel; Cardoso, Elizeth; Carvalho, Paulo Machado de; Benetti, John; Jonnes, Louis; Kelly, John; Davis, Jack; O’Brian, Perry; Marino Neto (narração).

Distribuição:

Hermantino Coelho.
1) [Certificado de Censura].

(00:00 - 00:05)

2) "Divulgação Cinematográfica Bandeirante" /

"Bandeirante da Tela" / "663".....(00:06 - 00:29)

3) "Registros".

$(00: 30-01: 41)$

4) "Iatismo"

(00:55 - 01:41)

5) "Artes e Artistas".

6) "Atletismo"

7) "Coisas do Norte" (03:30 - 04:08)

8) "Luta Livre". 05:02)

9) "Reportagem da Semana". $(05: 03-05: 50)$

10) "Flagrantes". (05:51 - 06:45)

\section{[1] [Certificado de censura].}

[2] "Divulgação Cinematográfica Bandeirante" / "Bandeirante da Tela" / "663".

[3] "Registros" / Desembarque e recepção do atleta Ademar Ferreira da Silva / PP de Ademar com chapéu mexicano / Ademar é carregado / PP de Ademar / Desembarque de Murrey Silverman e esposa, presidente da 20th Century Fox/ Pessoas (oficiais e civis) recepcionando-os, entre eles Paulo Sá Pinto / Coquetel oferecido pelo casal Sá Pinto / Entre os presentes, General Stênio Caio de Albuquerque Lima e esposa, General Tassio de Oliveira Tinoco, Brigadeiro Armando Ararigbóia.

[4] "Iatismo" / Barcos parados sendo preparados para prova (Taça Dark de Matos) / Diversos planos dos barcos em competição.

[5] "Artes e artistas" / Mesa com vários troféus / Murilo Antunes Alves entrega o troféu Roquette Pinto aos premiados / Planos da entrega a vários premiados / Túlio de Lemos / Manuel Durães acompanhando Conchita de Morais / Randal Juliano / Paulo de Carvalho / Carlos Lombardi / Romeu Félix / Homero Silva / Mario Zan / Elizete Cardoso, madrinha de Maurici Moura.

[6] "Atletismo" / Atletas perfilados / Ademar cumprimenta John Benetti, Louis Jonnes e John Kelly (atletas americanos)/ Moças assistem as provas / Jack Davis em prova: corrida com obstáculos / Perry O'Brian em arremesso de disco / John Benetti em salto em altura.

[7] "Coisas do Norte" / Ave no jardim zoológico e botânico "Dois Irmãos" no Recife / Lago e vegetação / Quati / Emas e siriemas / Tapir (parece uma anta) / Peixe-boi.

[8] "Luta-livre" / Mulher de kimono aplicando golpes de judô em um homem.

[9] "Reportagem da semana" / Bomba de gasolina "Texaco" / Tomadas de placas de aluguel e locação de táxi / Taxímetro / Taxistas com seus carros estacionados / Táxi / Lotação capotado, tombado com pessoas ao redor / Diversos planos do local do acidente. 
[10] "Flagrantes" / Boneco do Judas gigante, de quase 10 metros, na Vila Paulicéia / Multidão observa / Pára-quedistas ao céu / Os mesmos pára-quedistas posam para a câmera em frente ao Judas / Ateiam fogo no boneco / Boneco queimando.

[11] "Fatos do momento" / PG aéreos de Belo Horizonte: prédios, igreja, prédios públicos, praça, monumento, ruas, pessoas / Faixa de campanha de Adhemar de Barros pendurada na rua / Aeroporto de Pampulha / Multidão / Chegam: Adhemar e Leonor cercados de autoridades / Recebem cumprimentos / Pessoas com faixas com dizeres e fotos de Adhemar / PAN das pessoas presentes / Convenção do PSP em Minas Gerais / Auditório (local) lotado aplaude / Bancada do Partido com imagens de Adhemar pregado à bandeira do Brasil / Lúcio Bittencourt para governador e Arthur Bernardes Filho para vice / PM da bancada do partido com, no centro, Adhemar de Barros / Adhemar discursa / pessoas assistem e aplaudem / Noite / comício em local aberto / Holofote ilumina multidão / Adhemar de Barros e Leonor no palanque cercado por correligionários / Mulher fala ao microfone / Homens falam ao microfone / Multidão.

Termos descritores: Esporte; Visita estrangeira - US; Cinema; Aviação; Iatismo; Música; Rádio; Prêmio; Recife - PE; Jardim Zoológico; Jardinagem; Comércio; Automóvel; Pára-quedismo; Páscoa; Cidade; Belo Horizonte - MG; Política.

Termos livres: Atletismo; Aeroporto de Congonhas, São Paulo - SP; 20th Century Fox; Taça Dark de Matos; Troféu Roquette Pinto; Jardim Zoológico e Botânico Dois Irmãos, Recife - PE; Luta livre; Posto de gasolina; Táxi; Sábado de Aleluia; Malhação de Judas; Aeroporto da Pampulha, Belo Horizonte - MG; PSP - Partido Social Progressista; Bittencourt, Lúcio; Bernardes Filho, Arthur. 
Bandeirante da Tela n. 664. São Paulo: Divulgação Cinematográfica Bandeirante, 1955. Fita de vídeo (6min47seg), VHS, sonoro, p\&b, VV00098. Cinemateca Brasileira.

Dados técnicos:

Elenco:

Cunha, Olímpio Falconieri da; Ferreira, Procópio; Araújo, Carlos; Cotrim, Carlos; Esmeralda, Ana; Souza, Ruth de; Quintanilha, Rui; Caldeira, Leni; Laranjeira, Elza; Dias, João; Silveira, Heleninha; Alves, Carmélia; Barroso, Inezita; Cury, Ivon; Fraga, Vanda; Farney, Dick; : Jonnes, Louis; O'Brien, Perry; Bennetti, John; Kelly, John; Davis, Jack; Marino Neto (narração).

Distribuição:

Hermantino Coelho.
1) "Divulgação Cinematográfica Bandeirante" / "Bandeirante da Tela" / "664".....(00:00 - 00:25)

2) "Homenagem". (00:26-01:17)

3) "Flagrantes". $(01: 18-01: 48)$

4) "Exposição". $(01: 49-02: 33)$

5) "Cinema e Teatro" (02:34 - 03:04)

6) "Desfile"............................(03:05 - 03:37)

7) "Notícias Esportivas". (03:38 - 04:20)

8) "Coisas do Norte". $(04: 21-05: 15)$

9) "Música". .(05:16 - 06:43)

10) "Fim"... $(06: 44-06: 47)$

[1] "Divulgação Cinematográfica Bandeirante" / "Bandeirante da Tela" / "664".

[2] "Homenagem" / Recinto fechado com pessoas em trajes sociais / PP (perfil) de Olímpio Falconieri da Cunha / Mulheres conversam / Mulheres sentadas no sofá conversam / PP de homem e mulher posando para a câmera / PA de 2 guardas / Mesa composta para autoridades militares / Bandeiras do Brasil e do estado de São Paulo na parede, Falconieri ao centro / Homem em pé, discursa na mesa / MF de Falconieri ao centro, entre dois homens / Plano de senhoras sentadas à mesa / Senhores (entre eles oficiais) sentados à mesa / Gal. Olímpio Falconieri discursa.

[3] "Flagrantes" / Planos aéreos da Estação da Luz em reforma / Planos diversos da obra paralisada.

[4] "Exposição" / Mulher com o cão / PG dos troféus a serem distribuídos / Donos correm com seus cães / PM de mulher com dois cães, posando para a câmera / PP de homem segurando um cão pequenino / Mulher com cão / Homem com dois cães / Mulher posa para a câmera com poodle / PG do poodle / Outros cães / Pessoas na arquibancada.

[5] "Cinema e Teatro" / Procópio Ferreira nas gravações do filme "Quem matou Anabela?" / Procópio Ferreira no set de filmagem, mexendo na câmera / Outros atores, entre eles Paulo Zara / Procópio Ferreira com os outros atores.

[6] "Desfile" / Abrem o desfile cavaleiros fantasiados de mouros / Desfile dos acadêmicos de engenharia / Calouros mostram saco para arrecadar dinheiro / Pessoas desfilando com faixas / Carros são abordados pelos calouros / PG dos calouros.

[7] "Notícias Esportivas" / PG dos atletas/ Atletas americanos recebem medalhas / PAN doa atletas: Louis Jonnes, Perry O'Brien, John Bennetti, John Kelly e Jack Davis / Moças observam das arquibancadas / Louis Jonnes prega apoio para a largada / Atletas correm / Perry O’Brien lança peso / John Bennetti salta / Perry O’Brien arremessa disco. 
[8] "Coisas do Norte" / Planos aéreos de Olinda / Jumentos carregam carga / PG de igrejas com pessoas na rua / PP de uma cruz (monumento?) / GPG do Forte de Olinda / Planos das ruas, casas, monumentos / PP da placa do monumento / Plano das casas e ruas / PM de menino nu / Outras crianças.

[9] "Música" / Cartaz / Placa com dizeres "10 Festival Brasileiro" / Rui Quintanilha desata faixa e inaugura / Abre $\circ 1^{\circ}$ Festival Brasileiro do Disco / Recinto com personalidades / Inezita Barroso, Leni Caldeira, Heleninha Silveira, Elza Laranjeira, todos em PP / MF de João Dias / PP de Neide Fraga / PP de Inezita Barroso / PAN de Carmélia Alves e outras personalidades / PP de disco de vinil, sobreposto pela imagem de Heleninha da Silveira cantando, seguido de MF da mesma cantando.

[10] "Fim".

Termos descritores: Solenidade; Exército; São Paulo - SP; Obra pública; Ferrovia; Concurso; Animal; Cinema; Desfile; Universidade; Engenharia; Visita estrangeira - US; Esporte; Cidade; Olinda - PE; Igreja Católica; Música Popular Brasileira; Rádio.

Termos livres: Estação da Luz, São Paulo - SP; Cachorro; Atletismo; Festival do Disco, 1; Mackenzie, São Paulo - SP. 
Bandeirante da Tela n. 666. São Paulo: Divulgação Cinematográfica Bandeirante, 1955. Fita de vídeo (6min55seg), VHS, sonoro, p\&b, VV00098. Cinemateca Brasileira.

Dados técnicos:

Elenco:

Salem, William;

Prado, Fábio;

Barros, Ulisses Paes de;

Viana, Augusto;

Denizard, Antonio;

Marrey Junior;

Marino Neto (narração).

Distribuição:

Hermantino Coelho.
1) [Certificado de Censura]

$(00: 00-00: 07)$

2) "Divulgação Cinematográfica Bandeirante" /

"Bandeirante da Tela" / "666".....(00:08 - 00:33)

3) "Turfe".

$(00: 34-02: 13)$

4) "Comemorações Cívicas". .$(02: 14-06: 55)$

\section{[1] [Certificado de Censura].}

[2] "Divulgação Cinematográfica Bandeirante" / "Bandeirante da Tela" / "666".

[3] "Turfe" / Mulher posa para câmera / PG de cinco mulheres reunidas, sentadas em torno de uma mesa / Planos de mulheres elegantemente vestidas / Prefeito Willian Salem conversa com mulher / PG do palanque / Tribuna de honra com Fábio Prado, Ulisses Paes de Barros e William Salem / PAN da corrida / PG do cavalo vencedor com o jóquei montado / Solenidade nos salões do Jóquei Clube / Planos dos convidados em trajes de gala, conversando e sentados à mesa com banquete sendo servido / Músicos: guitarrista, violinista e baterista / Baile / Pessoas conversam sentados à mesa para banquete / PAN do baile / Violoncelista ao fundo.

[4] "Comemorações Cívicas" / Crianças desfilando com uniformes da escola / Menina com baliza abre desfile de banda de música composta só por mulheres / Desfile de bailarinas / Crianças com roupas "turcas" (?) seguidas por duas bailarinas que seguram a faixa "Serviço de teatro do SESI Grupo Musicado" / Batedores em desfile / Cavalaria desfila / Banda de Música composta por oficiais seguidos pela ala que representa os trabalhadores que seguram as bandeiras de São Paulo do Brasil / Carro alegórico seguido por moças uniformizadas / Autoridades conversam entre si / Autoridades no palanque / Antonio Denizard, Augusto Viana da Confederação das Indústrias, Adriano Marrey Junior Secretário da Justiça / Desfile de meninas uniformizadas segurando faixa "Cursos Populares do SESI - Vila Guilherme" / Crianças fazendo baliza seguidas da Ala "Grêmios do Sesinho" / Moça com baliza / PP de autoridades no palanque / Ala desfilando com as bandeiras dos estados brasileiros / Palanque com pessoas / Bandeiras do Paraná, Paraíba, Minas / Palanque com pessoas / Moças desfilam abraçadas com camisetas que juntas formam "Centros de Aprendizado Doméstico" / Moças com bastão / Bandeiras dos Estados em desfile / Banda / Moças desfilam com faixa "Saudação do SESI ao Sr. Prefeito Municipal" / Desfile de Meninas / Diversos planos da banda estacionando junto com outras alas / PG das alas "estacionadas" uma ao lado da outra / GPG da concentração das alas (após o desfile?) / PP de moças / Alas perfiladas / Autoridades / Personalidades no palanque, entre elas, moças com faixas de "princesas" / Banda / Menina posa para a câmera segurando uma bandeira do Brasil e outra de São Paulo / Desfile de moças e rapazes fardados / Batedores acompanham atleta com tocha olímpica / Palanque com autoridades / Sob o Viaduto do Chá, atleta acende a pira simbolizando a crença na educação social / Multidão observa / Discurso de autoridade no palanque / Outra autoridade fala ao microfone / Hasteamento da Bandeira Nacional.

Termos descritores: Turfe; Música; Solenidade; Efeméride; São Paulo - SP; Indústria; Esporte.

Termos livres: Jóquei Clube de São Paulo; Primeiro de Maio; SESI - Serviço Social do Comércio; Jogos Desportivos Operários, 8. 
Bandeirante da Tela n. 667. São Paulo: Divulgação Cinematográfica Bandeirante, 1955. Fita de vídeo (6min48seg), VHS, sonoro, p\&b, VV00098. Cinemateca Brasileira.

Dados técnicos:

Elenco:

Assis, Plinio de; Cabral, Carlos Castilho; Zavini, Ângelo; Kovarick, Alexandre; Cabral, Danton Castilho; Crespi, Rodolfo; Figueiredo, Joaquim; Stockler, Darci; Toledo, Álvaro de; Chechia, Renato; Lima, Altimar Ribeiro de; Luz, William Roberto Marcílio; Salem, William; Zagottis, Alberto De; S. C. Corinthians Paulista; Fluminense F. C.; Marino Neto (narração).

Distribuição:

Hermantino Coelho.
1) "Divulgação Cinematográfica Bandeirante" / "Bandeirante da Tela"/ "667"......(00:00 - 00:23)

2) "Notícias Sociais". $(00: 24-01: 10)$

3) "Coisas do Norte". $(01: 11-01: 47)$

4) "Notícias Oficiais" (01:48 - 02:19)

5) "Notícias Esportivas". (02:20 - 02:50)

6) "Futebol". (02:51 - 03:53)

7) "Bailado". (03:54 - 04:20)

8) "Notícias do Rio". (04:21 - 05:06)

9) "Notícias Diversas". (05:07 - 05:56)

10) "Flagrantes". (05:57 - 06:47)

11) "Fim (06:43-06:48)

[1] "Divulgação Cinematográfica Bandeirante" / "Bandeirante da Tela" / "667".

[2] "Notícias Sociais" / PP de moças / PG do baile / Músicos / Mulher cantando ao microfone / Baile / PP de algumas moças / PA de três moças coroadas rainha e princesas / PP da rainha / PA da rainha e as princesas.

[3] "Coisas do Norte" / PG da orla marinha de Salvador, Bahia / Num navio, pessoas observam a praia / PG da igreja de São Francisco / Planos diversos dos detalhes no interior da catedral / Ruas / Prédios históricos.

[4] "Notícias Oficiais" / Carlos Castilho Cabral, Secretários do Trabalho, fala ao microfone em recinto onde estão demais autoridades / Posse do Sr. Plínio de Assis do Departamento de Produção Industrial / PAN dos presentes / Entre os presentes, representantes de secretários de estado / Sr. Danton Castilho Cabral / Ângelo Zavine e representantes do comércio e da indústria / PG de autoridades / PP de Plínio de Assis em discurso / Cumprimentos a Plínio de Assis e os demais presentes.

[5] "Notícias Esportivas" / Cavalo e cavaleiro em provas no concurso hípico do Ibirapuera / PP da mesa com troféus / GPG de cavaleiro e cavalo saltando obstáculos da prova / PP do cavaleiro Rodolfo Crespi / Público observa / Planos das provas / Oficial cumprimenta cavaleiro.

[6] "Futebol" / Jogo entre Corinthians e Fluminense no Maracanã / Gol do Fluminense.

[7] "Bailado" / Renato Chechia e Altimar Ribeiro de Lima, secretário da Educação e Cultura e o secretário de Obras da Prefeitura desatam o laço e re-inauguram a escola de bailado da municipalidade nos baixos do Viaduto do Chá / Menina baila para os presentes / Presentes observam.

Guanabara e do centro do Rio / Vistas do Pão de Açúcar/ GPG da Baía da Guanabara / Pessoas observam a cidade pelo mirante / PAN do bonde de Pão de Açúcar. 
[9] "Notícias Diversas" / Exposição dos funcionários da Light / Diversos planos dos trabalhos em exposição / Quadros, esculturas e plantas / William Roberto Marćílio Luz, Superintendente Geral da Light, abre a exposição / PAN dos presentes / Homens conversam no recinto / Diversos planos da exposição.

[10] "Flagrantes" / William Salem, prefeito, acompanhado dos seus secretários Altimar Ribeiro de Lima e pelo Diretor de Obras Alberto De Zagottis, inauguram a nova linha de bondes / Prefeito e secretários caminham pela rua com demais autoridades civis e oficiais, seguidos pelos populares / PG da população que assiste / PG de igreja / Bonde lotado para viagem inauguração / Multidão no local / Planos da multidão / Palanque montado com prefeito e autoridades / Autoridades discursam / PP de crianças balançando bandeiras de SP e do Brasil. / PG da multidão e do palanque.

[11] "Fim".

Termos descritores: Baile; Cidade; Salvador - BA; Praia; Igreja Católica; Embarcação; Solenidade; Indústria; Esporte; São Paulo - SP; Indústria; Esporte; Futebol; Dança; Escola; Exposição; Trabalho; Transporte coletivo.

Termos livres: Hipismo; Jóquei Clube de São Paulo; São Paulo - SP; Estádio do Maracanã, Rio de Janeiro - DF; S. C. Corinthians; Fluminense F. C.; Light; Bonde. 
Bandeirante da Tela n. 669. São Paulo: Divulgação Cinematográfica Bandeirante, 1955. Fita de vídeo (6min49seg), VHS, sonoro, p\&b, VV00099. Cinemateca Brasileira.

Dados técnicos:

1) [Certificado de Censura]..............(00:00 - 00:01)

Elenco:

2) "Guaíba Filmes Apresenta".

Barros, Adhemar de;

Aurelly, Willy;

3) "669".

Prado, Fábio;

4) "Atualidades".....

(00:08 - 00:42)

Barros, Ulisses Paes de;

Rezende, Póla;

5) "Notícias Diversas"....

.$(00: 43-01: 39)$

Oliveira, Carolina Renó Ribeiro de;

6) "Fatos do Momento".

Lima, Altimar Ribeiro de;

Salem, William;

7) "Turfe".

(03:00 - 03:22)

Lopes, Helvécio Xavier;

8) "Artes e Artistas"....

Vilaverde, Oswaldo;

Marino Neto (narração).

9) "Norte do Brasil".

Distribuição:

10) "Notícias Oficiais".

Hermantino Coelho.

11) "Registros". .(05:43 - 06:49)

[1] [Certificado de Censura].

[2] "Guaíba Filmes".

[3] "669".

[4] "Atualidades" / Adhemar de Barros chega para discurso em Aracajú / Palanque montado com autoridades (?) e microfones / Homem falando ao microfone / PG do público / PA de Adhemar de Barros e outros dois homens no palanque / PG do público que aplaude / PA de Adhemar de Barros falando ao microfone / MF em contra plongée de Adhemar de Barros discursando - enquanto dois homens seguram os microfones, um de cada lado / Público / MF em perfil de Adhemar de Barros discursando com outros dois homens no palanque / Público / Mesma tomada de Adhemar de Barros / PA do palanque com autoridades (?) / Correligionários (?) e Adhemar de Barros no canto direito da tela.

[5] "Notícias Diversas" / Livro sendo assinado sobre a mesa / PG dos presentes / PP de homem / Presentes (associados?) / planos da votação na Associação Paulista de Imprensa / Homem votando (um dos candidatos?) / Mesa de votação e seus presidentes / PM da mesa composta para a votação na Faculdade de Direito do Mackenzie / Planos das pessoas votando / Presentes / Moça votando / Homem votando.

[6] "Fatos do Momento" / PA de mulheres mostram para a câmera imagens religiosas / Três crianças segurando, cada uma, uma garrafinha com a imagem da Nossa Senhora/ Mulheres entrando em recinto / Interior da Rádio Nacional (?)/ PG das pessoas / PA de uma menina segurando garrafinha com a imagem da santa / PG das pessoas em frente à mesa para receber as garrafinhas com a imagem religiosa / Mulher segurando bebê / PP da Mão mostrando a pequena imagem da Santa / PM das pessoas andando na rua, em frente ao recinto onde se distribui a imagem, nota-se uma fila de pessoas entrando/ Outro plano, no interior do recinto / Homem distribui imagens para as pessoas, entre elas uma mulher que beija a imagem / PG do local, no interior/ PP de uma caixa com as imagens / PP das pessoas que passam e recebem a imagem, mulheres em sua maioria, mas há homens e até oficiais / Mulher distribui / PG das pessoas na entrada do recinto / PP de uma mulher que conversa com quem lhe entrega a imagem/ Outra mulher recebe / PP de uma mulher que conversa com a pessoa que lhe entrega a imagem / PG das pessoas em fila recebendo a imagem / Três mulheres seguidas por homens na fila.

[7] "Turfe" / PA de Fábio Prado e Ulisses Paes de Barros e uma mulher o centro / PAN da corrida / Cavalo vencedor / PA do público na arquibancada. 
[8] "Artes e Artistas" / Planos de esculturas de Cristo / Mulher / Busto de mulher / Duas cabeças / Escultura em diversos planos / PA da exposição / PA de um homem e duas mulheres / MF de um senhor e duas senhoras / Duas mulheres.

[9] "Norte do Brasil" / PG de barcos no rio / Santarém, AM / GPG do rio e a cidade / Diversos planos dos barcos e canoas / Diversos planos do rio - trechos do mesmo / Planos da vegetação e dos trechos dos rios / Queda d'água / Planos do porto?

[10] "Notícias Oficiais" / PAN do local a ser inaugurado / Senhora e homem, juntos a autoridades e demais presentes, desfazem o laço da fita inaugural, abrindo os portões / PG dos presentes hasteando a bandeira nacional / PAN dos presentes.

[11] "Registros" / Planos do prédio do Hospital do IAPETC / Planos de homens conversando em PA e MF / Homens chegam ao recinto, saem do carro / PP de homem (Helvécio Xavier Lopes) / PP de Oswaldo Vilaverde - diretor de arrecadação / PP de outro diretor / Descerramento da placa de inauguração / Padre reza missa solene / Pessoas visitam as dependências do hospital / PG da mesa para cerimônia inaugural / Quatro componentes, entre civis e militares / Plano do público presente / Homem lê discurso / Outro homem lê discurso / PG dos presentes / Outros dois homens discursam / Presidente do recinto / Público aplaude / PG do hospital / Mulher preparando refeição / Crianças perfiladas entrando no recinto / Recreio / Fila da merenda / PP de menina e menino comendo a merenda / Crianças sentadas comendo a merenda / Criança em tratamento odontológico / Crianças praticando exercícios físicos/ Desfile de jovens (moças e rapazes) / Diversos planos de carro alegórico com Brasão da República.

Termos descritores: Política; Aracaju - SE; Solenidade; Igreja Católica; Efeméride; São Paulo - SP; Rádio; Turfe; Artesplásticas; Rio; Amazônia; Santarém - AM; Embarcação; Vegetação; Parque; Criança; Hospital.

Termos livres: Associação Paulista de Imprensa; Mackenzie, São Paulo - SP; N. S. Aparecida; Padre Lima; Jóquei Clube de São Paulo; Escultura; Cachoeira; Parque Infantil Edu Chaves, São Paulo - SP; Hospital do IAPETC. 
Bandeirante da Tela n. 672. São Paulo: Divulgação Cinematográfica Bandeirante, 1955. Fita de vídeo (6min48seg), VHS, sonoro, p\&b, VV00099. Cinemateca Brasileira.

Dados técnicos:

1) [Certificado de Censura].............(00:00 - 00:01)

Elenco:

Barros, Adhemar de; Esmeralda, Ana; Audrá, Mário; Lima, Altimar Ribeiro de; Salem, William;

Pegato, William; Fonseca, Cássio; Rondon, Candido; Pinto, Paulo Sá; Aurelly, Willy; Barros, Ulisses Paes de; Zagottis, Alberto De; Portuguesa de Desportos; S. E. Palmeiras; Marino Neto (narração).

Distribuição:

Hermantino Coelho.

2) "Bandeirante da Tela" / "672".....(00:02 - 00:07)

3) "Momento Político".

4) "Cinema e Teatro".

(00:49 - 01:22)

5) "Notícias Diversas"....

.(01:23 - 02:02)

6) "Notícias Sociais".....

7) "Homenagem". (03:39 - 04:21)

8) "Turfe"..... (04:22 - 04:43)

9) "Obra Pública".

10) "Futebol". (05:06 - 06:47)

11) "Fim". $(\cap 6: 48-06: 48)$

[1] [Certificado de censura].

[2] "Bandeirante da Tela" / "672".

[3] "Momento Político" / Adhemar de Barros nas ruas do Rio de Janeiro em carros aberto com seus correligionários (?) e autoridades / Faixas desejando feliz regresso a Adhemar de Barros / PP de Adhemar de Barros em entrevista / PAN da rua com pessoas e faixas de apoio a Adhemar / PG da multidão no aeroporto de Congonhas / Avião taxiando em sua chegada / Adhemar sai do avião e acena para as pessoas / PG da multidão no aeroporto / Adhemar descendo escada / PG de Adhemar desembarcando / Adhemar cercado pelas pessoas / MF de Adhemar cercado.

[4] "Cinema e teatro" / Fachada do cine República / Cartaz do filme "O Mundo da Fantasia" / Plano em placa com dizeres "Importante: Embora reabrindo, este cinema continua com os preparativos e obras, a fim de que dentro e breve, possa dar a São Paulo a maior tela do mundo!" / Letreiro "República" / Fachada do cinema.

[5] "Notícias Diversas" / Homens - time dos casados - posam para câmera / Homens e uma mulher - time dos solteiros - posam para a câmera / Atriz dá o pontapé inicial / A mesma atriz entrega troféu para os vencedores e cumprimenta os participantes da pelada/ Pessoas bebendo / PA dos participantes bebendo e a atriz, ao centro dos homens, bebe no troféu / PA dos participantes se confraternizando, posando para a câmera / Crianças montadas num burro.

[6] "Notícias Sociais" / Pessoas reunidas, sentadas à mesa, comemoram aniversário de Altimar Ribeiro de Lima / PAN dos presentes / Planos dos presentes / Entre eles o prefeito Willian Salem / Diversos planos dos presentes em pé, sentados na sala e à mesa / Noiva sai do carro/ Noiva caminha para o altar / Noivos no altar / Troca de alianças / Convidados / Noiva assina livro / Noivos e padrinhos posam para a câmera / Padrinhos / Noivos chegam a outro recinto, saindo do carro (?) / PAN de recinto com convidados / Noiva corta o bolo / Convidados / Noivos se beijam.

[7] "Homenagem" / Cine Normandie / Público e banda / Marechal Rondon chega para ser homenageado / PA do marechal cercado por oficial e civil (?) / PP de Paulo de Sá Pinto / Paulo de Sá cumprimenta Rondon / Público / Marechal é cortejado / O sertanista Willy Aurelly (?) ao microfone / Marechal Rondon em PA é conduzido por oficiais e civis / marechal sentado na poltrona do cinema / Planos dos convidados sentados para assistir o filme / Planos dos presentes. 
[8] "Turfe" / PAN do público nas arquibancadas / PAN da corrida / Público / Corrida / PG da torre da comissão de corridas / Cavalo vencedor (?).

[9] "Obra Pública" / PG em cplongée de prédios / Prefeito Willian Salem e repórteres (?)/ Autoridades / Público / Pessoas utilizando a escada rolante / Inauguração da escada rolante no Anhangabaú / Pessoas (autoridades) andam na escada em sua inauguração.

[10] "Futebol" / Times entram em campo para disputar a partida pelo torneio "Roberto Gomes Pedrosa" / Palmeiras e Portuguesa (final do torneio) / Planos da partida / Gols dos times / PG da arquibancada / Times entram em campo / Planos da partida e das arquibancadas / Gols da Portuguesa / Arquibancada.

[11] "Fim".

Termos descritores: Política; Rio de Janeiro - DF; São Paulo - SP; Aviação; Cinema; Futebol; Lazer; Solenidade; Turfe; Urbanismo; Futebol.

Termos livres: Aeroporto de Congonhas, São Paulo - SP; Cine República, São Paulo - SP; Cine Normandie, São Paulo SP; Companhia Cinematográfica Maristela; Jóquei Clube de São Paulo; Escada rolante; Anhangabaú, São Paulo - SP; S. E. Palmeiras; Portuguesa de Desportos; Taça Roberto Gomes Pedrosa; Pacaembu, São Paulo - SP. 
Bandeirante da Tela n. 674. São Paulo: Divulgação Cinematográfica Bandeirante, 1955. Fita de vídeo (6min55seg), VHS, sonoro, p\&b, VV00098. Cinemateca Brasileira.

\begin{tabular}{|c|c|}
\hline Dados técnicos: & 1) "Certificado de Censura".............(00:00 - 00:04) \\
\hline $\begin{array}{l}\text { Elenco: } \\
\text { Costa, Carlos Casimiro da; } \\
\text { Navajas, Carlos; } \\
\text { Nunes, José Geraldo Salgado; } \\
\text { Barros, Adhemar de; } \\
\text { Morais, José Carlos de; } \\
\text { Quadros, Jânio da Silva; } \\
\text { Motta, Carlos Carmelo de Vasconcellos; } \\
\text { Marino Neto (narração). }\end{array}$ & 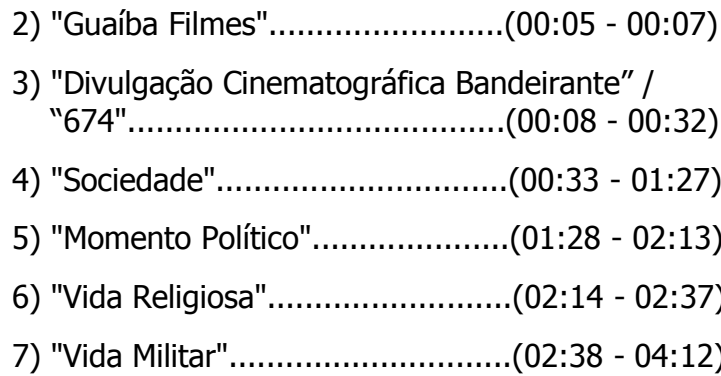 \\
\hline $\begin{array}{l}\text { Distribuição: } \\
\text { Hermantino Coelho. }\end{array}$ & 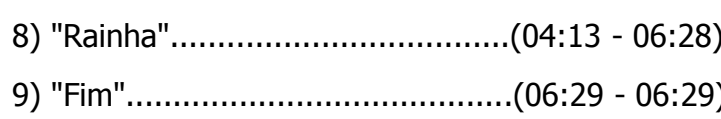 \\
\hline
\end{tabular}

[1] [Certificado de censura].

[2] "Guaíba Filmes".

[3] "Divulgação Cinematográfica Bandeirante" / "674".

[4] "Sociedade" / pessoas no recinto, senhoras da alta sociedade, membros do Lions Club (na $2^{\mathrm{a}}$ convenção nacional desta instituição) / Vários planos em MF de alguns convidados - homens e mulheres / PG da mesa para banquete / Diversos planos dos membros do Lions Club em MF e PP / Alguns PG das mesas com convidados banqueteando / PA da condecoração de dois homens / Convidados em pé aplaudindo / Diversos planos do baile.

[5] "Momento político" / PG dos presentes (em auditório ou espaço aberto?) aplaudindo sob chuva de papel picado / PM de arranjo com foto de Adhemar, cartazes, bandeiras estaduais e o mapa do Brasil / PA em perspectiva da mesa composta por correligionários, em pé, lendo discurso / Plano mais fechado da tomada anterior / PG dos presentes / MF de correligionários discursando / PG dos presentes que aplaudem / PG de Adhemar chegando (?) cercado pelos presentes / Adhemar acena, em pé, e em frente ao microfone / PG do público que aplaude / PM da mesa / MF de Adhemar cercado por repórteres, discursando em frente aos microfones / Público aplaude.

[6] "Vida Religiosa" / PG de muitas pessoas reunidas em espaço aberto / PA de grupo de pessoas (praticamente mulheres e crianças) / PP de imagem de N.S. Aparecida / Pessoas saem da casa (local onde se encontra a imagem (?) / Mulher é amparada por homem / Parede com velas acesas / PP da imagem da padroeira que é tocada por uma mão.

[7] "Vida Militar" / GPG das tropas perfiladas e formadas / PM de oficial hasteando a bandeira nacional / PA distante de Jânio Quadros com a mão no peito e quase atrás do mastro da bandeira que está sendo hasteada, apesar do mesmo estar no centro do enquadramento com um oficial ao lado, crianças e soldados em continência ao fundo / MF do oficial hasteando a bandeira / PG da banda formada / PG da entrada / Fachada / Escadarias da catedral da Sé onde está montado um altar / Pessoas nas escadarias / PM de três autoridades eclesiásticas em frente ao altar / Planos das pessoas rezando / PG de oficiais perfilados / PG de outros oficiais também perfilados (seriam da Marinha?) / PA de autoridades eclesiásticas / GPG das tropas formadas / PM dos eclesiásticos ajoelhados no altar, enquanto um deles ergue o ostensório / PG das tropas 
dispostas na Praça da Sé em forma de cruz / Planos dos oficiais em disposição / Autoridades eclesiásticas e coroinhas descem as escadas com hóstias (?) / PAN de alguns presentes e representantes de outras associações / Planos da distribuição das hóstias / GPG em PAN da Praça da Sé totalmente ocupada / PG da soltura de pombos / Pombos no céu.

[8] "Rainha" / Planos das mesas com convidados / Homem entrevista miss São Paulo / MF da miss São Paulo / Convidados / Desfile da miss São Paulo / Desfile da miss Ceará / Moça - convidada - observa / Desfile da miss Distrito Federal / Mulher - convidada - sorri / Miss Rio de Janeiro / Convidadas / Miss Espírito Santo / Desfile da miss Santa Catarina / Convidados / Miss Maranhão desfila / Desfile da miss Matogrosso / Desfile da miss Rio Grande do Norte / Convidados / PA em PAN das misses / PG das misses / PM das misses / Outros planos das misses.

[9] "Fim".

Termos descritores: Filantropia; Solenidade; Política; Partido Político; Rio de Janeiro - DF; Igreja Católica; São Paulo SP; Páscoa; Exército; Marinha; Aeronáutica; Concurso de beleza; Mulher.

Termos livres: Lions Club; Praça da Sé, São Paulo - SP; N. S. Aparecida; Miss Brasil. 
Bandeirante da Tela n. 678. São Paulo: Divulgação Cinematográfica Bandeirante, 1955. Fita de vídeo (7min17seg), VHS, sonoro, p\&b, VV00099. Cinemateca Brasileira.

Dados técnicos:

Elenco:

Lombardi, Carlos;

Barros, Adhemar de;

Nunes, Janari Gentil;

Marino Neto (narração).

Distribuição:

Hermantino Coelho.
1) [Certificado de Censura].............(00:00 - 00:01)

2) "Divulgação Cinematográfica Bandeirante" /

"Bandeirante da Tela" / "678".....(00:02 - 00:25)

3) "Cinema e Teatro"

(00:26 - 00:54)

4) "Música"..................................(00:55 - 02:34)

5) "Flagrantes".

6) "Homenagem". (03:41 - 04:17)

7) "Santos"..... (04:18 - 05:01)

8) "Conheça sua Terra"

9) "Momento Político". (06:50 - 07:16)

10) "Fim" $(07: 17-07: 17)$

[1] [Certificado de censura].

[2] "Divulgação Cinematográfica Bandeirante" / "Bandeirante da Tela" / "678".

[3] "Cinema e Teatro" / Ônibus chega / Pessoas descem do mesmo / Diversas pessoas no local onde pessoas chegam / Palanque montado onde homem fala para os presentes / Outro homem fala / PAN das pessoas que aplaudem e começam a andar, enquanto um homem acena para a câmera.

[4] "Música" / PG do estúdio com orquestra / Público no auditório / PM de Carlos Lombardi e orquestra / PP de Carlos Lombardi cantando / Público / PM do cantor e orquestra / Orquestra - violinistas / PP do cantor / Público / PM do cantor e orquestra / Orquestra - acordeons / PM do Cantor / PP do cantor / PM do cantor e orquestra / PP do cantor / PM do cantor e orquestra / Público aplaude / MF do cantor e apresentador.

[5] "Flagrantes" / Travelling da orla da praia de Santos / Entrada (ou saída ?) da balsa / Diversos planos dos banhistas na areia / Lancha corre na praia / Veleiro / Homem pratica esqui aquático / Banhistas.

[6] "Homenagem" / PA de homem que lê discurso cercado por outros homens, ao fundo uma bandeira do CASS (Clube Amigos do Sesc e do Senac) / Homem corre ao lado / Descerramento de retrato de Luís Roberto de Carvalho Vidgal - presidente do conselho do Sesc e Senac / Diversos planos dos presentes e do baile.

[7] "Santos" / cplongée de navio (no porto?) / MF de pessoas que acenam para o público / Grupo de pessoas da companhia teatral européia / MF em cplongée de dois integrantes do grupo / Diversos planos dos artistas / Integrantes descem as escadas do navio, desembarcando. 
[8] "Conheça sua terra" / Adhemar chega ao local acompanhado por várias pessoas, entre elas, o governador do Amapá / PG do forte da cidade / PP de canhão sendo carregado com munição / Soldado acende o canhão / Canhão dispara / Planos da fachada e paredes do forte / PG do forte / Planos dos detalhes da arquitetura do forte / PG dos canhões / PAN do morro com vegetação / PG da vila com barcos / Diversos planos dos barcos / Diversos planos dos pescadores e seus peixes / Planos do porto / PG da vil com pessoas andando na rua ("cidade velha") / Fachada de um prédio (público?) moderno / Adhemar chega com o governador e outras pessoas / Adhemar cumprimenta governador do Amapá.

[9] "Momento político" / Aeroporto de Congonhas com pessoas desembarcando de avião / Avião taxiando na pista / Avião é abastecido (?) ou em manutenção (?) / Diversos planos da fachada do aeroporto.

[10] "Fim".

Termos descritores: Cinema; Rádio; Música popular brasileira; Cidade; Praia; Santos - SP; Guarujá - SP; Solenidade; Comércio; Efeméride; Teatro; Visita estrangeira - IT; Cidade; Macapá - AP; Política; Pesca; Embarcação; Aviação.

Termos livres: Rádio Bandeirantes; SESC - Serviço Social do Comércio; SENAC - Serviço Nacional de Aprendizagem Comercial; Dia do Comerciante; Aeroporto de Congonhas, São Paulo - SP. 
Bandeirante da Tela n. 679. São Paulo: Divulgação Cinematográfica Bandeirante, 1955. Fita de vídeo (7min2seg), VHS, sonoro, p\&b, VV00099. Cinemateca Brasileira.

Dados técnicos:

1) [Certificado de Censura]..............(00:00 - 00:01)

Elenco:

Motta, Carlos Carmelo de Vasconcellos;

Cerejeira, Manuel;

Lima, Altimar Ribeiro de;

Salem, William;

Sanchez Filho, Benito;

Barros, Adhemar de;

2) "Guaíba Filmes"

(00:02 - 00:05)

3) Divulgação Cinematográfica Bandeirante" / "Bandeirante da Tela" / "679".....(00:06 - 00:30)

Barros, Leonor Mendes de;

Marino Neto (narração).

4) "Vida Religiosa".........................(00:31 - 02:42)

5) "Registros"

6) "Manifestações"

(03:14 - 04:11)

Distribuição:

Hermantino Coelho.

7) "Boxe"

8) "Notícias Sociais".

9) "Fim"..... (07:01 - 07:02)

[1] [Certificado de censura].

[2] "Guaíba Filmes"

[3] "Divulgação Cinematográfica Bandeirante" / "Bandeirante da Tela" / "679".

[4] "Vida Religiosa" / PG de multidão na rua / PG em cplongée de um prédio com relógio, desce em PAN até a Praça Pedro II no Rio de Janeiro, com muitas pessoas / Trem chega na estação com a imagem da N. S. Aparecida, na sua dianteira um desenho da imagem / Plongée das pessoas aglomeradas na porta do trem de onde sai a imagem da santa / Imagem, em invólucro de vidro, sendo conduzida pela estação por autoridades eclesiásticas, erguida sobre a multidão / Pessoas / PG do público que aplaude / PG da rua lotada de pessoas e carros seguindo a procissão / Guardas abrem a procissão / Imagem é levada em "carruagem suspensa" em meio a multidão / PG da multidão na rua acompanhando a procissão / Tomada aérea em GPG da multidão nas ruas / PAN em PP do cordão de isolamento feito por guardas / Autoridades eclesiásticas em procissão / PAN da imagem sendo carregada por marinheiros em procissão / Crianças com as mães assistem procissão / PAN da imagem em procissão / PG da imagem em procissão / PAN do cordão de isolamento / PG das autoridades eclesiásticas / Pessoas e a imagem em procissão / PAN do público em PA / PAN da imagem em procissão.

[5] "Registros" / Planos de um local com convidados sentados à mesa para banquete / Homem discursa / Planos dos convidados sendo servidos / William Salem (ex-prefeito) discursa / Planos dos convidados.

[6] "Manifestações" / PAN em GPG da cidade de Bauru / Fachada da Escola Prática de Agricultura Gustavo Capanema / Planos do prédio / PAN em PG do pátio interno / Pessoas e o público / Diversos homens que discursam, em PP de perfil / [cenas muito escuras, apenas reconhecemos algumas labaredas, como se houvesse um incêndio, locução diz "Bauru realizou a queima simbólica do presídio"].

[7] "Boxe" / Juiz conversa com os pugilistas / Diversas tomadas da luta / Lutador é dado como campeão e abraça o adversário / Público / Juiz conversa com lutadores - outra luta / Diversas tomadas da luta / Lutador vai à nocaute / Tomadas da luta / Lutadores cumprimentam-se. 
[8] "Notícias Sociais" / Local com muitas senhoras / PA de Leonor recebendo flores pelo seu aniversário, Adhemar ao lado, mulheres cantam / Adhemar em MF, no canto direito da tela discursa, com mulheres que o observam / MF de Adhemar e Leonor / Adhemar discursando é aplaudido, segue PAN à esquerda, mostrando algumas mulheres presentes / PM de Leonor e demais pessoas seguindo por um corredor, em direção à câmera / Adhemar e outras pessoas entram em quarto do hospital / PA de Leonor no quarto / PA de Adhemar e Leonor, e entre eles uma paciente deitada em uma maca / MF de Adhemar e Leonor entre a mesma paciente / Leonor conversa com outra paciente na cama / Cplongée de Leonor em PA, saindo do local seguida por pessoas / PAN da fila de pessoas para receber presentes / Fachada/ Portal com pessoas saindo com seus presentes / Planos das pessoas nas filas / Homem distribui presente / Adhemar em cplongée ajuda a distribuir os presentes / Planos de mulheres distribuindo presentes / Pessoas com presentes / Homens distribuem cobertores e bonecas / Menina com boneca / Senhoras recebendo presentes / Duas tomadas de homem ajudando a distribuir presentes (será William Salem?) / PM de pessoas recebendo presente / Planos de crianças com presentes e algumas mães.

[9] "Fim".

Termos descritores: Igreja Católica; Rio de Janeiro - DF; Ferrovia; Marinha; Solenidade; Governo Estadual - SP; Manifestação; Escola; Agricultura; Presídio; Bauru - SP; Esporte; Hospital; Filantropia; Campos de Jordão - SP.

Termos livres: Procissão; N. S. de Fátima; Congresso Eucarístico Internacional, 36; Praça Pedro II, Rio de Janeiro - DF; Escola Prática de Agricultura Gustavo Capanema, Bauru - SP; São Paulo - SP. 
Bandeirante da Tela n. 680. São Paulo: Divulgação Cinematográfica Bandeirante, 1955. Fita de vídeo (7min24seg), VHS, sonoro, p\&b, VV00099. Cinemateca Brasileira.

Dados técnicos:

Elenco:

Botelho, Julinho; Campanella, Anacleto; Lorenzini, Jacó; Montanaro, Olga; Garcia, Lafaiete Belfort; Matos, Lino de; Vidigal, Luis Roberto; Azenha, Candido Pedro; Medeiros, Sabóia de; Paz, Porfírio da; Marino Neto (narração).

Distribuição:

Hermantino Coelho.
1) [Certificado de Censura].

(00:00 - 00:03)

2) "Divulgação Cinematográfica Bandeirante" / "Bandeirante da Tela" / "680".....(00:04 - 00:27)

3) "Notícias Esportivas"... (00:28 - 01:09)

4) "Conheça sua Terra" (01:10 - 02:30)

5) "Educação e Ensino" $(02: 31-03: 17)$

6) "Homenagem". (03:18 - 04:11)

7) "Cinema e Teatro". (04:12 - 04:44)

8) "Reportagem da Semana". (04:45 - 06:55)

9) "Momento Político". (06:56 - 07:24)

[1] [Certificado de censura].

[2] "Divulgação Cinematográfica Bandeirante" / "Bandeirante da Tela" / "680".

[3] "Notícias Esportivas" / Pessoas reunidas / MF do jogador Julinho Botelho e mais outros dois homens / Julinho e amigos (?) / PP da esposa do jogador / Julinho segura seu filho para a câmera / Julinho e seus familiares posam para a câmera / Julinho abraça seus pais (?), recebe um beijo (de sua mãe?) / PG de Julinho e várias pessoas / Julinho embarca em avião, antes acena para o público e para a câmera / Avião parte.

[4] "Conheça sua Terra" / Planos de São Caetano do Sul / PG do Viaduto dos Automobilistas / Trem chegando numa tomada em perspectiva diante da câmera / PAN do jardim público / Diversos planos do Jardim Público / Diversas tomadas externas da fachada do grupo escolar, com comitiva formada pelo prefeito Anacleto Campanela, o vice e uma vereadora / PG de campo aberto / Estrada asfaltada que liga São Bernardo a São Caetano / Segue PAN para o local dos caminhões / Estádio Anacleto Campanela fachada / Arquibancada / Jogo entre Palmeiras e São Bento - time local / Pessoas deixam o local (seria a comitiva?).

[5] "Educação e ensino" / PG de alguns painéis em exposição organizada pelo Serviço Nacional de Aprendizagem Comercial / Homem discursa / Presentes no recinto / PG dos presentes à mesa, um homem discursa em pé / Outro homem lê discurso / Presentes / Mesa / PG dos presentes / Outro homem discursa / Presentes à mesa / homem continua discursando / PG dos presentes no local / Pessoas apreciam a exposição de painéis do SENAC - diversas tomadas alternadas / Faixa: "O SENAC - Departamento Regional de São Paulo - saúda os congressistas" PG dos painéis.

[6] "Homenagem" / Fachada de igreja em cplongée / Pessoas adentram o recinto / Tomada externa / PG das pessoas no velório de autoridade eclesiástica / Caixão cercado por pessoas, diversos planos / Cortejo fúnebre, transporte das coroas de flores / Coroinhas / Caixão é conduzido por homens, entre eles Lucas Nogueira Garcez / Planos em PG dos presentes / Cortejo fúnebre pela rua, diversos planos em PG / PAN que termina numa cruz.

[7] "Cinema e Teatro" / Homens reunidos em recinto / No mesmo local, entrevista acontece / Planos diversos / Atores da Companhia de teatro Italiana / Diversos planos em MF dos atores e convidados. 
[8] "Reportagem da Semana" / PG de trecho da Via Anchieta / PAN acompanha ônibus / A mesma tomada em PAN com uma visão traseira do veículo / PP de placa de trânsito / Outra placa / MF de policial rodoviário / PP de placa de trânsito / PG de outro trecho / Diversos planos de placa de trânsito / PG de um trecho com ponte / Planos de placas / PAN de caminhão na pista / Outra plongée em MF de policial com moto / Travelling avança em $1^{\text {a }}$ pessoa na pista / Planos do motoqueiro / Policial na pista / Motoqueiro pára carro / Guarda aplica multa em motorista / GPG dos trechos com pontes / GPG aéreo de trechos / PA de motoqueiro / Policial noutra moto / PAN de carros na pista / PP de motorista acenando para motoqueiro / Vigilante rodoviário, em PA, responde acenando também / PG de trecho com caminhão indo embora / PG de monumento.

[9] "Momento Político" (o mesmo material sobre o Aeroporto de Congonhas, verificado no BT - 678).

Termos descritores: Futebol; Aviação; Cidade; Santo André - SP; Congresso; Exposição; Ensino; Igreja Católica; Morte; Visita estrangeira - IT; Teatro; Rodovia; Polícia; Política; Monumento; Aviação.

Termos livres: Viaduto dos Automobilistas, Santo André - SP; Estádio Anacleto Campanela, Santo André - SP; S. E. Palmeiras; São Bento F. C.; SENAC - Serviço Nacional de Aprendizagem Comercial; Congresso de Ensino Comercial, 1; Rodovia Anchieta - SP; Aeroporto de Congonha, São Paulo - SP. 
Bandeirante da Tela n. 684. São Paulo: Divulgação Cinematográfica Bandeirante, 1955. Fita de vídeo (5min24seg), VHS, sonoro, p\&b, VV00099. Cinemateca Brasileira.

Dados técnicos:

1) [Certificado de Censura]..............(00:00 - 00:00)

Elenco:

Vidigal, Luis Roberto; Pidgeon, Walter; Lott, Henrique Teixeira; Paz, Porfírio da; Matos, Lino de; Mojica, José; Forster, Walter; Costa, Pedro Geraldo; Villaveces, Carlos; Mejias, Manoel; Marino Neto (narração).

Distribuição:

Hermantino Coelho.

2) "Guaíba Filmes"

(00:01 - 00:04)

3) "Divulgação Cinematográfica Bandeirante" /

"Bandeirante da Tela" / "684".....(00:05 - 00:29)

4 ")Homenagem".

..(00:30 - 01:04)

5) "Cinema e Teatro"......................(01:05 - 01:52)

6) "Vida Militar".

(01:53 - 03:21)

7) "Cinema e Teatro".

8) "Visitantes Ilustres".

9) "Notícias Esportivas".

(04:49 - 05:24)

[1] [Certificado de Censura].

[2] "Guaíba Filmes".

[3] "Divulgação Cinematográfica Bandeirante" / "Bandeirante da Tela" / "684".

[4] "Homenagem" / Local com pessoas (auditório?) / PAN de quadro na parede até a mesa dos participantes do $1^{\circ}$ Congresso Brasileiro de Ensino Comercial / Público presente / Vários planos em MF de alguns componentes da mesa / Homem discursa / Pessoas aplaudem / Outro homem discursa / Tomadas dos presentes.

[5] "Cinema e teatro" / PG do avião (taxiando ou chegando) no aeroporto / pessoas desembarcam do avião / Planos das pessoas que desembarcam e das que já desembarcaram / Diversas tomadas em MF das dançarinas da companhia francesa / Pessoas saem / Walter Pidgeon (?) acompanhado por pessoas.

[6] "Vida Militar" / PA de oficial em continência, ao lado um civil com a mão no peito, ao fundo, outros oficiais em continência / PAN da arquibancada lotada no Pacaembu / PAN em PP de oficiais e civis / Desfile e banda / PA de autoridades oficiais e civis / Desfile da tropa, detalhe em PP do rosto em perfil de soldado / PG de autoridades civis e militares tendo mais a frente, em PA, dois soldados / Hasteamento da bandeira, arquibancada lotada ao fundo / Oficial hasteia a bandeira / PP da bandeira nacional ao vento, já hasteada / Oficial entrega faixa a formando / MF de madrinha com a espada / Formando recebe bandeira das mãos de oficial / PG das madrinhas com as espadas, na arquibancada / Juramento solene / Madrinhas / Oficial conduz juramento / Madrinhas entram com as espadas / Madrinhas e formandos se abraçam / Formandos desfilam.

[7] "Cinema e Teatro" / PM de Frei José de Guadalupe ao microfone, cantando ? Público / Frei cantando / Público / Cantor / Público aplaude / Senhora cumprimenta cantor / A mesma senhora é conduzida ao sair / PP de moça no auditório / cantor com motivos do México / Aplausos do público / O frei mais o outro cantor com motivos do México, ambos no microfone / Público/ O cantor e o frei ao microfone, ambos em MF. 
[8] "Visitantes Ilustres" / Pessoas desembarcam de avião / PG das autoridades presentes para a recepção / Ministro da Fazenda da Colômbia é cumprimentado pelas autoridades / PG dos presentes, algumas tomadas / Autoridades e os demais presentes descem as escadas / PG das tropas / O ministro em PAN passa em revista a tropa.

[9] "Notícias Esportivas" / Ciclistas conversam / PG do início da corrida / Travelling dos ciclistas - corrida / Saída do túnel Nove de Julho / PG do público presente / Ciclistas chegam acompanhados por batedores / Ciclistas da Portuguesa é cumprimentado em PP / Outro ciclista chega / PP da bandeira de chegada / MF do ciclista do Palmeiras que chegou em segundo lugar.

Termos descritores: Congresso; Ensino; Comércio; Visita estrangeira - FR; Cinema; Solenidade; Exército; Igreja Católica; Telecomunicação; Diplomacia - CO; Esporte.

Termos livres: SENAC - Serviço Nacional de Aprendizagem Comercial; Congresso de Ensino Comercial, 1; Aeroporto de Congonha, São Paulo - SP; Estádio do Pacaembu, São Paulo - SP; TV Tupi; Ciclismo; Portuguesa de Desportos; S. E. Palmeiras; Prova Ciclística São Roque - São Paulo. 
Bandeirante da Tela n. 687. São Paulo: Divulgação Cinematográfica Bandeirante, 1955. Fita de vídeo (4min41seg), VHS, sonoro, p\&b, VV00099. Cinemateca Brasileira.

Dados técnicos:

Elenco:

Moses, Herbert;

Butler, Richard;

Pupo Neto, Trajano;

Paz, Porfírio da;

Almeida, Abilio Pereira de;

Souza, Ruth de;

Barreto, Lima;

Oliveira, Araçary de;

Brah, Lola;

Marino Neto (narração).

Distribuição:

Hermantino Coelho.
1) [Certificado de Censura]............(00:00 - 00:03)

2) "Guaíba Filmes"

(00:04 - 00:08)

3) "Divulgação Cinematográfica Bandeirante" /

"Bandeirante da Tela" / "684".....(00:09 - 00:33)

4) "Música".

(00:34 - 01:05)

5) "Artes Plásticas".

6) [Sem Intertítulo]

7) "Trânsito".

8) "Notícias Esportivas"

9) "Cinema e Teatro"

10) "Fim"

[1] [Certificado de Censura].

[2] "Guaíba Filmes"

[3] "Divulgação Cinematográfica Bandeirante" / "Bandeirante da Tela" / "687".

[4] "Música" / PG de homem e alguns cartazes e esquemas explicativos sobre a "polissom" / PA em perfil do mesmo homem explicando as escalas do instrumento / PAN do cartaz até o homem / Moças observam cartazes / Público do recinto / Tomadas alternando as mãos no teclado e a escala / Medidor do polissom.

[5] "Artes Plásticas" / Homem desata fita de inauguração no mesmo quadro homens e mulheres em PA / Pessoas observam quadros expostos / presentes / Escultura e a moça que a observa / Dois homens observam escultura / PP da escultura.

[6] [Sem intertítulo] / Fachada de uma mansão (Casa Roosevelt?) / Comitivas sobe as escadas / Homens conversam / Numa biblioteca (?) homens conversam / MF dos mesmos homens conversando no mesmo local / Homens andam por uma sala de leitura com pessoas (estudantes?) / sentadas às mesas / Plongée de estudantes lendo / MF de homem mostrando papel para outro homem, ao fundo mulher observa.

[7] Trânsito / PAN de local com caminhões passando por uma entrada semelhante a uma passagem por debaixo de uma ponte / PG de outro lado dessa passagem com caminhões saindo por ela / PG de linha de trem / PAN de obra sendo realizada em estação ferroviária / PG de trem chegando e se aproximando da câmera / PG do viaduto com carros e ônibus passando por cima da linha ferroviária com trem passando / PAN do mesmo viaduto e linha ferroviária com trem passando / Outros planos alternando o mesmo viaduto e a linha do trem / PAN de fachada de estabelecimento com guarda (de trânsito?) ao lado de poste. 
[8] "Notícias Esportivas" / Diversos planos de homens jogando boliche, das bolas sendo repostas, das garrafas sendo derrubadas e de homens marcando os pontos na lousa / Diversos planos de homens bebendo num barzinho.

[9] "Cinema e Teatro" / Homem ao microfone discursando, bandeira de São Paulo na parede / PG da mesa composta com homem em pé discursando ao microfone / PAN do público presente / MF de homem e mulher no público / PAN do público que aplaude / Discurso de homem em MF / PP do presidente da Associação Profissional da Indústria Cinematográfica / Público aplaude / PAN da mesa / MF de homem / PAN em MF de uma fileira do público / MF de moça no público (uma atriz?) / Diversos planos em PAN do público presente com vários atores, entre eles Ruth de Souza / Representante da Divulgação Cinematográfica Bandeirante assina documento (Marino Neto?).

[10] "Fim".

Termos descritores: Música; Artes-plásticas; Exposição; Diplomacia - US; Biblioteca; Ferrovia; Trânsito; Rodovia; Esporte; Cinema; Sindicato; Solenidade.

Termos livres: Polissom - instrumento musical; Pintura; Salão de Arte Moderna; Pintura; Escultura; União Cultural Brasil-Estados Unidos; Lapa, São Paulo - SP; Rodovia Anhanguera - SP; Boliche; Associação Profissional da Indústria Cinematográfica. 
Bandeirante da Tela n. 689. São Paulo: Divulgação Cinematográfica Bandeirante, 1955. Fita de vídeo (5min32seg), VHS, sonoro, p\&b, VV00099. Cinemateca Brasileira.

Dados técnicos:

Elenco:

Lott, Henrique Teixeira;

Café Filho, João;

Boto, Pena;

Carvalho, Paulo Machado de;

Marino Neto (narração).

Distribuição:

Hermantino Coelho.
1) [Certificado de Censura]............(00:00 - 00:03)

2) "Divulgação Cinematográfica Bandeirante" /

"Bandeirante da Tela" / "689".....(00:04 - 00:28)

3) "Vida Militar"

4) "Fatos do Momento".

5) "Registros".

6) "Notícias Esportivas"

[1] [Certificado de Censura].

[2] "Divulgação Cinematográfica Bandeirante" / "Bandeirante da Tela" / "689".

[3] "Vida Militar" / PG da banda militar / Presidente da República acena para o público, acompanhado por militares / PG da banda / Tropa formada / PG do presidente e dos militares / MF em perfil dos militares e presidente da República / PG da tropa formada / MF do General Teixeira Lott lendo discurso ao microfone / Presidente coloca condecoração na bandeira brasileira / Presidente desce escada (se retirando?) / Tropa / Veterano de guerra (?) e militares / Desfile de tropa / Plano do povo assistindo / PG das tropas formadas e ao meio delas uma bandeira nacional hasteada / PA do presidente ao lado de um militar e um civil / GPG da mesma cena aparecendo outros militares / Público assume de um patamar acima / PG da tropa montada / Monumento eqüestre de Duque de Caxias em PG / Tropa montada portando bandeira / Autoridade militar condecora militares / PAN do local onde ocorrem as condecorações e onde está montado o palanque com microfone / Segue PAN até o patamar acima onde se encontram outras pessoas (autoridades?) e mais acima a estátua do marechal / PG da estátua eqüestre do marechal / Desfile militar / PG da banda em desfile / Desfile da tropa / PM do presidente e militares que prestam continência / Desfile da tropa montada PM do presidente e militares que prestam continência / Militar condecora homem / Militares (veteranos?) a postos / Homem cumprimenta militar / desfile da banda / Desfile da tropa (Marinha?) / Desfile da tropa (Exército?) / PG do local onde se encontram autoridades civis e militares tendo ao alto a estátua eqüestre de Caxias / PP da bandeira nacional ao vento.

[4] "Fatos do Momento" / Homem discursa ao microfone / Homens sentados - público aplaude / Público no salão nobre do Ministério da Fazenda / Tomadas de alguns homens - representantes de países latinoamericanos / PAN do público presente, que aplaude / PP da insígnia com os dizeres: "Cruzada brasileira anti-comunista, cruz da ordem do mérito, 1955".

[5] "Registros" / GPG de prédio / PAN em vertical do novo prédio do Palácio da fazenda / GPG de prédio / Tomada aérea em GPG do alto do prédio recém construído / PAN desta mesma tomada aérea em GPG / PAN partindo de um "trenzinho" até um bosque (?) com pessoas andando / PAN do lago / Vários planos em MF de moças e rapazes bem vestidos onde, por vezes, aparecem alguns carros, sempre destacando a beleza das moças / Grupos de pessoas caminhando, em destaque três moças bem vestidas e bonitas.

[6] "Notícias Esportivas" / Avião taxiando na pista / Atletas desembarcam, em primeiro lugar o goleiro Gilmar / PA de Pessoas que aguardam os atletas, em destaque um repórter que fala num aparelho / Atletas são abraçados ainda nas escadas de desembarque / Garotos observam pela vitrine / Atletas continuam desembarcando e sendo entrevistados por repórteres / Atletas sendo recepcionados / Pessoas observam pela vitrine do aeroporto / Menino (?) observa com a cara "colada" no vidro / PM dos atletas descendo as escadas e sendo cumprimentados pelos presentes / Técnico (?) desce escada com troféu / PP de jogador (?) que fala o microfone / PM onde se observa a grande quantidade de pessoas que recepcionam os jogadores que ainda descem do avião / PAN em PA de pessoas (comissão técnica?) segurando troféu / MF de homem alto dando entrevista a repórter.

Termos descritores: Efeméride; Desfile; Militar; Monumento; Marinha; Congresso; Comunismo; Engenharia; Governo Estadual - SP; Pólo; Aviação; Futebol.

Termos livres: Rio de Janeiro - DF; Dia de Duque de Caxias; Congresso Anticomunista da América Latina, 2; Cruzada Brasileira Anti-comunista; Sociedade Hípica Paulista; Secretaria da Fazenda; Seleção Brasileira de Futebol. 
Bandeirante da Tela n. 692. São Paulo: Divulgação Cinematográfica Bandeirante, 1955. Fita de vídeo (6min55seg), VHS, sonoro, p\&b, VV00099. Cinemateca Brasileira.

Dados técnicos:

1) [Certificado de Censura]

(00:00 - 00:03)

Elenco:

Brandão, Maria Carmen; Almeida, Aracy de; Silveira, Heleninha; Bandolim, Jacob do; Blecaute; Mazzuca, Silvio; Barroso, Inezita; Santos F. C.;

S. C. Corinthians Paulista; Marino Neto (narração).

2) "Bandeirante da Tela" / "692".

(00:04 - 00:11)

3) "Conheça sua Terra"......

4) "Bailado".....

5) "Turfe". (01:32 - 02:17)

Distribuição:

Hermantino Coelho.

6) "Futebol"......

7) "Artes".

8) "Boxe".

9) "Fatos do Momento" .(06:00 - 06:55)

[1] [Certificado de Censura].

[2] "Bandeirante da Tela" / "692".

[3] "Conheça sua Terra" / PAN partindo de vegetação até o prédio / Fachada de uma maternidade / PAN de outro lado da fachada / PG da entrada com um carro saindo / PG de meninos colocando uma jangada no mar / PG da baía com alguns barcos / Cplongée de estátua / PG de estátua e a ponte Hercílio Luz.

[4] "Bailado" / Diversos planos da apresentação de uma bailarina / Planos de outra bailarina / Quatro moças / Bailarinas em cantiga de roda / Duas pessoas se apresentam com roupas de caveira.

[5] "Turfe" / MF de duas moças na arquibancada / MF de moça e rapaz / Planos do público, enfoque nas mulheres / GPG do púbico andando pelo Jóquei Clube / Moças na arquibancada / PAN em PG da corrida / PM dos cavalos vencedores / PAN do cavalo e do jóquei (vencedores?).

[6] "Futebol" / PAN da arquibancada / Diversos planos da partida entre Santos e Corinthians / PA do goleiro do Corinthians (Gilmar?) e outro jogador / PA de três jogadores do Corinthians / Jogador do Corinthians agachado posando para a câmera / Outro jogador também agachado / PM do time do Santos que posa para a câmera / Jogador do Santos se aquece / Outro jogador dos Santos.

[7] "Artes" / Homem em MF ao microfone / Pianista / Público aplaude / PAN de maestro e orquestra / Heleninha Silveira, cantora, fala ao microfone /Público / PA de Aracy de Almeida ao microfone / Público / PP de Aracy / Público aplaude / MF de Aracy recebendo flores / Público aplaude / PA de Aracy e locutor de rádio / MF de Jacó do Bandolim / PA de Jacó do Bandolim recebendo prêmio / PAN do público que aplaude / PA de Blecaute cantando / Moças do público / PAN do público aplaudindo / PA de Blecaute recebendo prêmio / PAN do público aplaudindo / Planos dos músicos: saxofonistas, xalingo, percussionista e pandeiro / MF de Inezita Barroso cantando com violão / PAN de Inezita com violão cantando / PAN do público que aplaude. 
[8] "Boxe" / Diversos planos em PM da luta / PG do ringue e do público / Lutadores e juiz se cumprimentam.

[9] "Fatos do Momento" / PG de prédio em cplongée / PG do mesmo prédio, mas com rua, carros e pessoas passando / Entrada da biblioteca / PAN da fila de pessoas para entrar na biblioteca / PM de pessoas consultando (ou sendo atendidas) / Moça consultando livro na estante / Moças estudantes consultam índices (?) / PA de moça lendo livro / Moças consultando fichas / Planos dos consulentes lendo nas mesas / Homem coloca livro na estante.

Termos descritores: Cidade; Florianóplis - SC; Embarcação; Engenharia; Mar; Dança; Teatro; Turfe; Futebol; Esporte; Música Popular Brasileira; Biblioteca.

Termos livres: Ponte Herćlio Luz, Florianópolis - SC; Jóquei Clube de São Paulo; S. C. Corinthians; Santos F. C.; Festival Brasileiro do Disco no Paramount, 1; Esádio do Pacaembu, São Paulo - SP; Boxe; Biblioteca Municipal de São Paulo - SP. 
Bandeirante da Tela n. 694. São Paulo: Divulgação Cinematográfica Bandeirante, 1955. Fita de vídeo (6min42seg), VHS, mudo, p\&b, VV00048. Cinemateca Brasileira.

Dados técnicos:

Elenco:

Barros, Adhemar de;

Cole;

Marino Neto (narração).

Distribuição:

Hermantino Coelho.
1) "694". (00:00 - 00:01)
2) "Comemorações Cívicas"
(00:02 - 01:02)
3) "Curitiba"......
(01:03-01:52)
4) "Notícias Esportivas".
(01:53 - 02:51)
5) "Rainha".
6) "Corrida"
7) "Tênis".
(04:43 - 05:30)
8) "De Todo o Brasil"
9) "Cinema e Teatro"
10) "Fim". (06:41 - 06:42)

[1] "694".

[2] "Comemorações Cívicas" / PG em PAN dos atletas fazendo ginástica no Pacaembu / Diversos planos em PG dos atletas praticando exercícios físicos / PG em PAN dos atletas em exercícios.

[3] "Curitiba" / Crianças seguem em fila para o banho / Crianças pequenas / PAN do refeitório com crianças comendo à mesa e em cadeiras para bebês / PP de várias crianças comendo / Berçário.

[4] "Notícias Esportivas" / PAN do público presente em campo aberto / PAN dos lutadores / Público / Luta de sumo entre japoneses / Público / Luta / Diversos planos de outras lutas / Lutadores no palanque, segue PAN até o público.

[5] "Rainha" / PG da bandeira da Associação de Imprensa (?) / Planos de pintura de caipiras e casais de caipiras na parede / Baile / Mais pinturas na parede / Baile / MF de moças / Desfile das concorrentes (?) / Mais pinturas na parede / Casais no baile / Pinturas na parede / Baile.

[6] "Corrida" / PAN dos presentes na rua / [imagem sem identificação] / Público / Carroças disputam corrida / Diversos planos da prova / Público.

[7] "Tênis" / Público / Atletas (moças e rapazes) sentados / Planos dos atletas sentados / Presentes / PA das atletas tenistas que posam para câmera / MF das tenistas / Partida de tênis / PP da tenista.

[8] "De Todo o Brasil" / Público / Adhemar de Barros no meio do público discursa / Diversos planos dos presentes / Adhemar de Barros recebe coroa de flores / Tomadas em diversos planos do público presente.

[9] "Cinema e Teatro" / PA de três moças (dançarinas?) em fantasias de carnaval (?) / PP de cinco moças (uma por vez) / MF de moça fantasiada que posa para câmera / PM de apresentador e dançarina (apresentadora?) / Dois homens e uma moça dançando / Planos de uma apresentação (peça teatral?) / MF de moça com um biquíni muito curto, antecedida pela claquete da "Golpe Filmes".

[10] "Fim".

Termos descritores: Efeméride; Ginástica; Criança; Curitiba - PR; Imigração - JP; Esporte; Concurso de beleza; Jogo; Esporte; Política; Cinema; Teatro.

Termos livres: Semana da Pátria; Estádio do Pacaembu, São Paulo - SP; Sumô; Miss Objetiva; Gincana; Tênis. 
Bandeirante da Tela n. 696. São Paulo: Divulgação Cinematográfica Bandeirante, 1955. Fita de vídeo (6min45seg), VHS, sonoro, p\&b, VV00099. Cinemateca Brasileira.

Dados técnicos:

1) [Certificado de Censura] .$(00: 00-00: 06)$

Elenco:

Matos, Lino de;

Quadros, Jânio da Silva;

2) "Bandeirante da Tela" / "692".....(00:07 - 00:19)

Barros, Adhemar de;

3) "Notícias Esportivas"...................(00:20 - 00:52)

Bittencourt, Lúcio;

Marino Neto (narração).

4) "Sociedade".

5) "Natação".

$(02: 18-02: 47)$

Distribuição:

6) "Registros"

Hermantino Coelho.

7) "Notícias do Rio".

8) "Comemorações Cívicas".

9) "De Todo o Brasil".

10) "Fim"......

[1] [Certificado de censura].

[2] "'Bandeirante da Tela" / "696".

[3] "Notícias Esportivas" / Planos de atletas em prova de atletismo: corrida / Atleta do São Paulo Futebol Clube cruza a faixa de chegada / MF do atleta vencedor do São Paulo Futebol Clube.

[4] "Sociedade" / Planos das modelos desfilando / Convidados à mesa observam desfile / Planos alternados das modelos desfilando / Planos em PA, MF e PP das modelos desfilando / Modelos / Diversos planos dos convidados / Baile.

[5] "Natação" / Arquibancada cheia no clube do Fluminense / PG das Atletas em posição de largada, dentro da água / Nadadoras iniciam a prova / Homem cronometra / Prova na piscina / Arquibancada / Piscina e as nadadoras chegando / Arquibancada / PM de duas atletas (campeãs?) sentadas em um patamar de largada.

[6] "Registros" / Planos da Avenida Paulista com suas residências de luxo e o movimento dos carros na rua / PG de um prédio em construção na Avenida Paulista / Planos de uma construção, tendo ao lado um conjunto de casas humildes - "favelinha" - com varal portando roupas penduradas / Planos das casas e as péssimas condições de moradia, com colchão e outros objetos jogados no chão / Mulher entra as roupas no varal / Crianças brincando no chão de terra batida.

[7] "Notícias do Rio" / MF de dois homens conversando com pessoas ao redor / PP dos dois homens / Homem - o jejuador - brinda / Homem é ajudado a subir numa escada e entrar numa cama (?) / Homem deitado. 
[8] "Comemorações Cívicas" / Prefeito Lino de Matos no palanque / PG do palanque com o prefeito, o governador Jânio Quadros e outras autoridades civis e militares / Desfile de civis e militares, diversos planos / Desfile de Tropa com cães / PG e GPG aéreo do Anhangabaú com desfile / PG da população que assiste do viaduto / GPG do desfile de carros militares / Diversos planos do desfile de carros militares / Tropa montada / MF de Jânio Quadros / Planos do desfile da tropa montada.

[9] "De todo o Brasil" / Diversos planos aéreos em GPG de Juiz de fora / PG de monumento / PG de lago / Três patos na lagoa / Cisne na lagoa / Diversos planos de patos na lagoa / Diversos planos em PG de igrejas / GPG do prédio da prefeitura / Planos de "casas modernas residenciais" / PG da população presente em comício / MF de homem em perfil, ao microfone / Público acena / MF em perfil de mulher ao microfone / Público / MF em perfil de homem ao microfone / PAN do público presente / MF em perfil de homem - Senador Lúcio Bittencourt (?) - discursando / Público acena / Palanque com vários homens tendo ao centro Adhemar de Barros discursando diante de vários microfones / Abaixo do palanque, faixa: "Frente Popular Nacionalista" (?) / PA de Adhemar ao microfone cercado por outros homens / Diversos planos em PG do público que aplaude.

[10] "Fim".

Termos descritores: Esporte; Clube; feméride; Ginástica; Baile; Desfile; Moda; Filantropia; Habitação; São Paulo - SP; Urbanismo; Circo; Efeméride; Cidade; Juiz de Fora - MG; Política.

Termos livres: Atletismo; São Paulo F. C.; S. E. Palmeiras; Associação Paulista de Combate ao Câncer; Natação; Flumense F. C.; Avenida Paulista, São Paulo - SP; Favela; Rio de Janeiro - DF; Sete de Setembro; Anhangabaú, São Paulo - SP. 
Bandeirante da Tela SN. São Paulo: Divulgação Cinematográfica Bandeirante, 1951. Fita de vídeo (9min), VHS, sonoro, p\&b, VV01152. Cinemateca Brasileira.

Dados técnicos:

1) "Momento Político". .$(00: 00-08: 57)$

Outros títulos:

POSSES DE GETÚLIO E DE GARCEZ

2) "Fim"

Elenco:

Garcez, Lucas Nogueira; Machado Neto, Brasilio; Lima, Vicente de Paula; Barros, Adhemar de; Vargas, Getúlio; Fontes, Lourival; Rockfeller, Nelson; Salzano, Erlindo; Morais, José Carlos de; Barros, Leonor Mendes de; Marino Neto (narração).

Distribuição:

Hermantino Coelho.

[1] "Momento Político" / PG de autoridades civis, em fraque e cartola, e militares cumprimentando Getúlio Vargas / PAN em MF das mesmas autoridades que caminham para a câmera / PAN curtas em PM sobre as autoridades que sobem as escadarias do Palácio Tiradentes / PAN em PG do interior do palácio com as autoridades sentadas e outras adentrando o recinto / PAN em PM, onde a câmera se demora em três autoridades que cumprimentam a câmera / PA em perfil de Vargas em pé, com autoridades ao redor, na sessão solene de posse/ Tomadas em PP de autoridades civis e militares / PP de Vargas assinando livro de posse / Mais tomadas em PP de autoridades / PP da assinatura da posse / Mais tomadas em PP e PG de autoridades civis e militares presentes no recinto / PP em perfil de Vargas / PAN em PG do recinto com autoridades / Alternando PP de mais autoridades presentes / PG demorado em Vargas ao centro da mesa solene / PP de políticos (?) presentes à solenidade / PG, do recinto lotado com os presentes aplaudindo, que se desloca em PAN para o teto do local / Plano em PM e PG de populares que acenam para a câmera / PG de uma sacada (?) ou espaço coberto e reservado de onde Vargas irá realizar pronunciamento / PP de Vargas lendo discurso / PG de tropa (soldados?) parada com faixas de Vargas / PAN em PG do Palácio Nove de Julho que se desloca levemente (para baixo) / PG em perspectiva dos batedores (motos) chegando e logo atrás os carros oficiais, tendo nas laterais da rua tropas postadas e poucos populares / PA de Garcez e E. Salzano na frente do palácio, ao fundo autoridades, repórteres e militares / PG da mesa solene com o governado eleito / PA de Garcez discursando, sob flashs / Mesmo plano com E. Salzano / Mesmo plano com Vicente Paula Lima, secretário da mesa, que lê o termo de posse assinado por Garcez / Pan em PM de alguns presentes / PA de Garcez e outros componentes da mesa que parecem posar para a câmera e em seguida se cumprimentam / PAN em PG (que se desloca em vertical de cima para baixo) da fachada do Palácio dos Campos Elíseos, com pessoas que aguardam / PM de Garcez e comitiva (saindo do Palácio Nove de Julho?) / PM de um batalhão de guardas que empunham suas armas em sinal de continência / Garcez entrando em carro oficial / PG da cavalaria montada abrindo caminho para o carro oficial do governador empossado / PM de rua com pessoas na calçada / Carro oficial completamente cercado e tendo Garcez na porta também cercado (tentando chegar ou sair?) / Plongée em PM de Adhemar chegando e sendo aplaudido e cumprimentado pelos presentes que o cercam, tendo logo em seguida Garcez que o acompanha / PP de Adhemar (à direita da tela) discursando ao microfone e Garcez (à esquerda) que escuta / Plongée em PM de Garcez que lê discurso acompanhado de Adhemar e os demais presentes / Plongée em PP da mesma ação / PAN em PM por sobre alguns presentes no interior do palácio / PP de Garcez caminhando entre os presentes, jornalistas que lhe pedem uma fala ao microfone / PP de E. Salzano / PP de Adhemar / PP de Salzano sendo cumprimentado por Adhemar e Garcez / Pequena PAN em PM de carros oficiais que tentam se deslocar, com dificuldade, entre as pessoas presentes / PG da mesma ação / PG da Rua Albuquerque Lins com batedores oficiais que abrem caminho para comitiva de carros oficiais que trazem o ex-governador Adhemar de Barros / PM do carro que estaciona na entrada da residência de Adhemar, com pessoas que aglomeram o local / PG da Rua Albuquerque Lins com muitos carros / Tomadas em PP de Adhemar em sua residência sendo cumprimentado por várias pessoas.

[2] "Fim".

Termos descritores: Solenidade; Política; São Paulo - SP; Rio de Janeiro - DF; Imprensa; Exército; Polícia; Desfile; Manifestação.

Termos livres: Palácio Tiradentes, Rio de Janeiro - DF; Palácio Nove de Julho, São Paulo - DF; Palácio doa Campos Elíseos, São Paulo - SP. 
Bandeirante da Tela SN. São Paulo: Divulgação Cinematográfica Bandeirante, 1954. Fita de vídeo (4min24seg), VHS, sonoro, p\&b, VV00099. Cinemateca Brasileira.

\section{Dados técnicos:}

Outros títulos: UM HOMEM CAPAZ

Elenco:

Barros, Adhemar de;

Garcez, Lucas Nogueira;

Salzano, Erlindo;

Marino Neto (narração).

Distribuição:

Hermantino Coelho.
1) "Um Homem Capaz"...

2) [O filme].

3) "Com Adhemar - Salzano e Lino de Mattos votem na legenda P.S.P.". ...(00:00 - 00:06)

(00:07 - 04:09) ... (04:10 - 04:24)

[1] "Um Homem Capaz".

[2] Diversos planos em PG de pontos da cidade de São Paulo / PG de Adhemar acenando entre a multidão que o acompanha / PG de multidão concentrada com faixas de apoio a Adhemar / PAN em PA de Adhemar de Barros saindo de helicóptero e acenando, após tirar cigarro da boca / MF de Lucas Nogueira Garcez falando para a câmera / PG da externa de uma escola (?) com multidão / PA de Adhemar cortando fita inaugural / Adhemar visita sala de aula / Adhemar e comitiva / Planos de prédios públicos (realizações de Adhemar?) / Planos de crianças em ciranda e brincando em playground / PG de Adhemar descendo rua acompanhado por pessoas / Adhemar inspeciona casas recém-construídas / Adhemar coloca uma telha na casa ao lado de Erilindo Salzano / MF de E. Salzano em depoimento para a câmera / PAN externa de hospital com multidão / Adhemar, Leonor e autoridades eclesiásticas percorrem o interior de hospital / Planos das instalações do hospital - entre estes planos, PP da inscrição "Sanatório Adhemar de Barros" / PAN da externa de um hospital / Trem partindo com bandeira de Adhemar / Homens conversando, entre eles Adhemar / Planos de crianças sendo vacinadas e pessoas tirando radiografia / Adhemar em solenidade de inauguração / Diversos planos de obras para saneamento e canalização da água / Maquete do aeroporto de Congonhas / Trator em PP / Adhemar e autoridade militar / Adhemar passa em meio de multidão / Diversos planos da Via Anchieta / Adhemar chega em carro oficial para inauguração (?), sendo recebido por outras pessoas com guarda-chuva / Descerramento do busto de Adhemar / Travelling da pista Anchieta / Plongée de Adhemar e os jogadores da seleção brasileira / Jogadores entram em campo / Adhemar na multidão (que assiste o jogo?) / PP de avião com dizeres "Cidade de Belém - Aerovias" / Pára-quedistas no interior do avião / Planos aéreo da mata / Pára-quedistas saltam / Destroços de um avião / Planos de pessoas do campo (?) / PG de multidão que aplaude / Adhemar ao microfone / Multidão.

[3] "Com Adhemar - Salzano e Lino de Matos - votem na legenda do PSP".

Termos descritores: Política; Cidade; São Paulo - SP; Aviação; Desfile; Solenidade; Escola; Hospital; Saneamento; Ferrovia; Pára-quedismo; Rodovia; Engenharia; Futebol; Acidente; Política.

Termos livres: Helicóptero; Aeroporto de Congonhas, São Paulo - SP; Raio-X; Sanatório Adhemar de Barros; Rodovia Anchieta - SP; Seleção Brasileira de Futebol; PSP - Partido Social Progressista. 
Bandeirante da Tela SN (632). São Paulo: Divulgação Cinematográfica Bandeirante, 1954. Fita de vídeo (6min37seg), VHS, sonoro, p\&b, VV00683. Cinemateca Brasileira.

Dados técnicos:

Outros títulos:

REPERCUSSÕES DA MORTE DE GETÚLIO; BANDEIRANTE DA TELA SN (MORTE DE GETÚLIO VARGAS)

Elenco:

Marino Neto (narração).

Distribuição:

Hermantino Coelho.
1) "Reportagem da Semana". (00:00 - 06:33)

2) "Fim". $(06: 34-06: 37)$

[1] "Reportagem da Semana" / Cidadão encostado junto ao poste seguido de PAN focando alguns populares numa rua (provavelmente na zona central) de São Paulo / PAN em PG de uma passeata na rua (provavelmente na zona central) com pessoas e dois carros de som ao meio / Alternâncias de PG e PM do evento, com tomadas de pessoas segurando faixas com o rosto de Getúlio e a bandeira nacional / Tomadas de pessoas descendo de bonde ainda em movimento / Tomadas rápidas (PG e PAN em PG) de pessoas correndo, carro com vidro quebrado, bombas de gás lacrimogêneo sendo lançadas (em frente ao Palácio Nove de Julho?), pessoas sendo detidas pela polícia, pessoas correndo, soldados (ou policiais?) / Corta para o Rio de Janeiro, diversas tomadas de soldados, policiais, etc. perfilados ou fazendo paredão para conter populares, manutenção da ordem / Mais cenas em PG de bombas de gás lacrimogêneo, pessoas e soldados correndo, seqüência de cenas sugerindo uma atuação das forças armadas, PAN em PM de carro de bombeiro, pessoa sendo carregada de maca, PM de tanques do exército, PG da polícia montada / Rio Grande do Sul, PP de um jornal aberto ("Folha da Tarde - a morte do presidente emocionou todo o país", mais abaixo, ainda na primeira página, "o povo carioca chora nas ruas"), sendo lido por um popular / populares na rua se aproximam da câmera (de PM a PA) posando sorridentes (!) e agitando bandeiras, corta para MF do mesmo rapaz ao centro da cena anterior caminhando em perfil carregando mastro com a bandeira nacional, PP do caminhar de um homem segurando em cada mão o que parece ser uma bandeira enrolada, PP de um rapaz negro caminhando para câmera com uma bandeira enrolada no ombro./ PAN em PA de soldados dispostos na "Avenida Farrapos" em meio a populares, PP de homem protestando, PG da fachada de um prédio incendiando ou sob ataque de protestos (talvez sede da prefeitura ou algum prédio público ligado a administração do prefeito Meneghetti, ligado a UND e PSD, adversários de Getúlio) / PG de pessoas reunidas numa praça protestando / Mais tomadas em PG das pessoas nas ruas / PM de um coletivo (ônibus?) parado e cercado por alguns poucos populares, PP do capô aberto, sugerindo um estrago ocasionado pelo protesto / Carro de bombeiro se aproxima em PAN com homens em cima / Tomada da escada de bombeiro içada (cplongée) com mangueira lançando água, que se desloca em PAN até "fechar" em dois oficiais bombeiros em PA / Bombeiros escalando edifício vizinho / homem atira móvel da janela localizada num andar com fumaça e acena pra multidão que aparece, após uma PAN que desloca até ao nível da rua, num plano mais visível em que os móveis já estão no chão (possivelmente atirados) / PAN da fachada do prédio do jornal Diário de Notícias em chamas / Bombeiro e populares / PAN em PG de multidão reunida na rua, em frente a cinzas (papéis queimados) / Mais um movimento em PAN, fechado (PP) numa fogueira e percorrendo abrindo à multidão nas calçadas, em PG / Tomada da multidão em PG / tomadas em PP dos "passos" de pedestres pisando numa bandeira de Meneguethi / PP de pessoa discursando com microfone à mão / PAN em PG das pessoas assistindo / PP do mesmo orador / Mais PAN em PG da multidão assistindo / PAN em vertical de um prédio com fumaça (gabinete de um deputado "das ideologias da esquerda") / Tomada em PG da multidão sob chuva de papel picado (?) / Chegada de carro de bombeiros / PP de móvel sendo jogado pela janela, seguido pela câmera até o chão, onde se encontram mais móveis estilhaçados. Diversas tomadas em PM / GPG de pessoas a frente de estabelecimento sendo molhado por mangueira (consulado norte-americano?) / Duas seqüências em PAN vertical dos estragos causados / 
Populares em PA / Bombeiro no combate ao fogo / PG em PM de um cordão de isolamento pelo exército contra a população / Diversas tomadas em PAN do trabalho dos bombeiros no combate o fogo e dos estragos causados / PAN em PG da fachada da "Importadora Americana" que se desloca em PG até a multidão presente no local / Tomadas em PM dos estragos causados / PP de cartaz gigante de Vargas (estilo daqueles utilizados em desfiles) / PAN em PA de populares com bandeira nacional e retrato de Vargas / A mesma seqüência, se fechando em MF e PP, com populares segurando motivos e retratos de Vargas e acenando para câmera, plano termina fechando em quadro de Vargas / Tomadas em PM de oficiais dispersando manifestantes / Pessoas protestando / Popular em perfil passa em PP na frente da câmera com a testa sangrando / Soldado chuta e derruba manifestante com cartaz de Vargas / Tomadas em PAN rápidas do movimento dos manifestantes, por vezes cercados pelos oficiais, na rua / PAN em PP dos escritos "... National City Bank of New York" / PM de quatro homens limpando a entrada de um prédio / PP dos entulhos recolhidos / PM de carro que parte da cena dos entulhos / PP de homem deitado em leito de hospital, levantando braço esquerdo ferido no tríceps / PPL do curativo no braço levantado / Tomadas PP e PG de cortejo fúnebre / PAN em PM das pessoas e soldados nas ruas / PP de bandeira nacional ao vento, içada na fachada de um prédio / PAN em PM de populares e tanque (dois) / Três tomadas do tanque em movimento, com a última em PAN curta em PP do veículo por entre a multidão.

[2] "Fim".

Termos descritores: Morte; Vargas, Getúlio; Manifestação; Transporte coletivo; Polícia; Exército; Imprensa; Política; Incêndio; Diplomacia - US; Hospital.

Termos livres: Força Pública; São Paulo - SP; Rio de Janeiro - DF; Porto Alegre - RS; UDN - União Democrática Nacional; PSD - Partido Social Democrático; Folha da Tarde - jornal; Corpo de Bombeiros; Diário de Notícias - jornal. 


\section{ERRATA}

Página 64: imagens invertidas.

Página 89: onde se lê "No que os diretórios distritais, veiculação em programas radiofônicos e o cinema", leia-se "No que os diretórios distritais, a veiculação em jornais, em programas radiofônicos e no cinema". E onde se lê "Vale lembrar que a maioria dos números disponíveis do BT é do período em que Adhemar de Barros governa", leia-se "Vale lembrar que a maioria dos números disponíveis do BT não é do período em que Adhemar de Barros governa”.

Página 121, nota 349: onde se lê "Jânio Quadros que aparece uma única vez em nossas sistematizações (no BT 674 de 1955)", leia-se "Jânio Quadros que aparece duas vezes em nossas sistematizações (no BT 674 e 696, ambos de 1955)". E onde se lê "Veja imagem na página 93", leia-se "Veja imagem na página 94". 